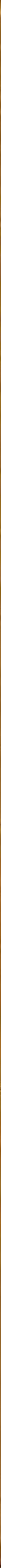




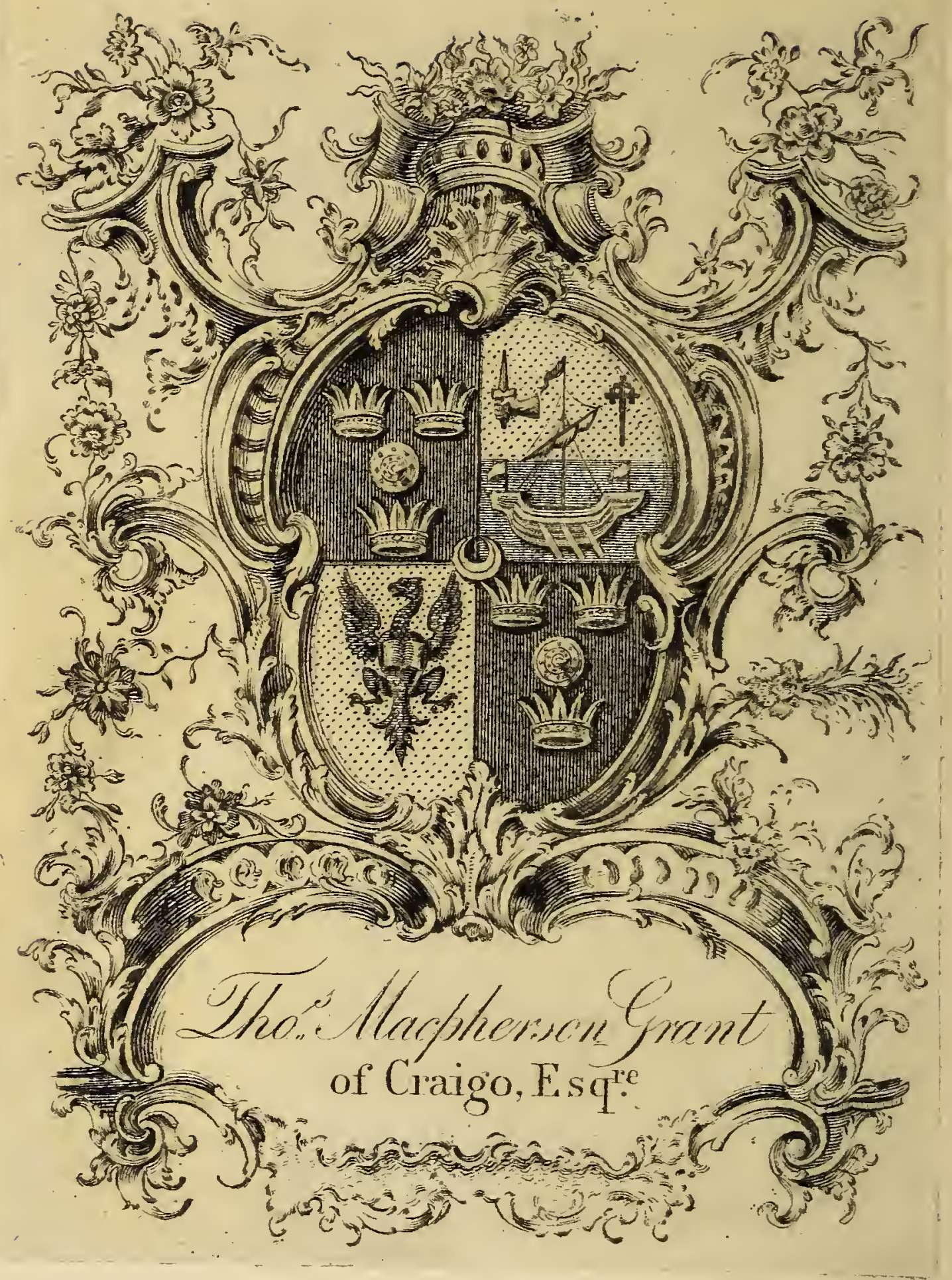




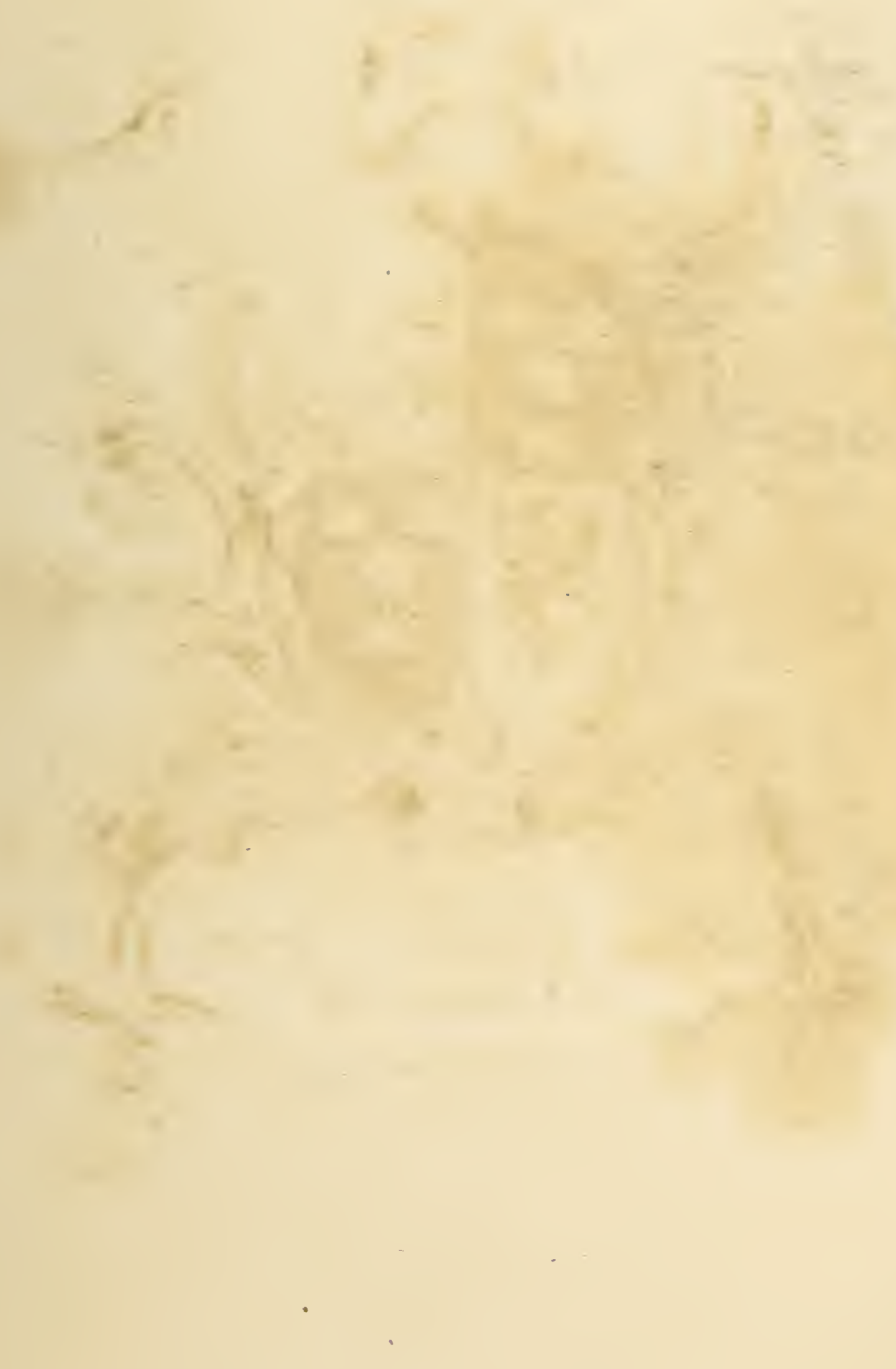



Digitized by the Internet Archive in 2018 with funding from University of Toronto 


\title{
ASPECTS OF NATURE,
}

IX

\section{DIFFERENT LANDS AND DIFFERENT CLIMATES;}

\author{
WITH
}

\section{Srientitic 五lucioations.}

\section{ALEXANDER VON HUMBOLDT.}

\author{
TRANSILATED BY MRS. SABINE.
}

IN TWO VOLUMES.

$$
\text { VOI. I. }
$$

\section{LONDON:}

PRIXTED FOR

LONGMAN, BROWN, GREEN, AND LONGMANS,

PATERYOSTER ROT; AND

JOHN MURRAY, ALBEMARLE STREET.

1849. 



\section{AUTHOR'S PREFACE}

TO THE

\section{FIRST EDITION.}

IT is not without diffidence that I present to the public a series of papers which took their origin in the presence of natural scenes of grandeur or of beanty, - on the Ocean, in the forests of the Orinoco, in the Steppes of Venezuela, and in the mountain wildernesses of Peru and Mexico. Detached fragments were written down on the spot and at the moment, and were afterwards moulded into a whole. The view of Nature on an enlarged scale, the display of the concurrent action of various forces or powers, and the renewal of the enjoyment which the immediate prospect of tropical scenery affords to sensitive minds, are the objects which I have proposed to myself. According to the design of my work, whilst each of the treatises of which it consists should form a whole complete in itself, one common tendency should pervade them all. Such an artistic and TOL. I. 
literary treatment of subjects of natural history is liable to difficulties of composition, notwithstanding the aid which it derives from the power and flexibility of our noble language. The unbounded riches of Nature occasion an accumulation of separate images; and accumulation disturbs the repose and the unity of impression which should belong to the picture. Moreover, when addressing the feelings and imagination, a firm hand is needed to guard the style from degenerating into an undesirable species of poetic prose. But I need not here describe more fully dangers which I fear the following pages will shew I have not always succeeded in avoiding.

Nevertheless, notwithstanding faults which I can more easily perceive than amend, I venture to hope that these descriptions of the varied Aspects which Nature assumes in distant lands, may impart to the reader a portion of that enjoyment which is derived from their immediate contemplation by a mind susceptible of such impressions. As this enjoyment is enhanced by insight into the more hidden connection of the different powers and forces of nature, I have subjoined to each treatise scientific elucidations and additions. 
Throughout the entire rork I have sought to indicate the unfailing influence of external nature on the feelings, the moral dispositions, and the destinies of man. To minds oppressed with the cares or the sorrows of life, the soothing influence of the contemplation of nature is peculiarly precious; and to such these pages are more especially dedicated. May they, "escaping from the stormy waves of life," follow me in spirit with willing steps to the recesses of the primeval forests, over the boundless surface of the Steppe, and to the higher ridges of the Auides. To them is addressed the poet's voice, in the sentence of the Chorus -

"Auf den Bergen ist Freiheit! Der Hauch der Grüfte Steigt nicht hinauf in die reinen Lüfte;

Die Welt ist vollkommen überall, Wo der Mensch nicht hinkommt mit seiner Qual." 



\section{A UTHOR'S PREFACE}

TO THE

\section{SECOND AND THIRD EDITIONS.}

THE twofold aim of the present work (a carefully prepared and executed attempt to enhance the enjoyment of Nature by animated description, and at the same time to increase in proportion to the state of knowledge at the time the reader's insight into the harmonious and concurrent action of different powers and forces of Nature) was pointed out by me nearly half a century ago in the Preface to the First Edition. In so doing, I alluded to the various obstacles which oppose a successful treatment of the subject in the manner designed. The combination of a literary and of a purely scientific object,-the endeavour at once to interest and occupy the imagination, and to enrich the mind with new ideas by the augmentation of knowledge,-renders the due arrangement of the separate parts, and the desired unity of composition, difficult of attainment. Yet, notwithstanding these dis- 
advantages, the public have long regarded my imperfectly executed undertaking with friendly partiality.

The second edition of the "Ansichten der Natur" was prepared by me in Paris in 1826; and at the same time two fresh treatises were added,- - one an Essay on the Structure and mode of Action of Volcanoes in different regions of the earth; and the other on the "Vital Power," bearing the title "Lebenskraft, oder der rhodische Genius." During my long stay at Jena, Schiller, in the recollection of his youthful medical studies, loved to converse with me on physiological subjects; and the considerations in which I was then engaged on the muscular and nervous fibres when excited by contact with chemically different substances, often gave a more specific and graver turn to our discourse. The "Rhodian Genius" was written at this time: it appeared first in Schiller's "Horen," a periodical journal; and it was his partiality for this little work which encouraged me to allow it to be reprinted. My brother, in a letter forming part of a collection which has recently been given to the public (Wilhelm von Humboldt's Briefe an eine Freundin, Th. ii. S. 39), touches tenderly on the subject of the memoir in question, but adds at the same time a very just remark : 
"The development of a physiological idea is the object of the entire treatise; men were fonder at that time than they would now be of such semi-poetic clothing of severe scientific truths."

In my eightieth year, I am still enabled to enjoy the satisfaction of completing a third edition of my work, remoulding it entirely afresh to meet the requirements of the present time. Almost all the scientific Elucidations or Annotations have been either enlarged or replaced by new and more comprehensire ones. I have hoped that these volumes might tend to inspire and cherish a lore for the study of Nature, by bringing together in a small space the results of careful observation on the most varied subjects; by showing the importance of exact numerical data, and the use to be made of them by well-considered arrangement and comparison; and by opposing the dogmatic half-knowledge and arrogant scepticism which have long too much prevailed in what are called the higher circles of society.

The expedition made by Ehrenberg, Gustar Rose, and myself, by the command of the Emperor of Russia, in 1829, to Northern Asia (in the Ural and Altai mountains, and on 
xiv PREFACE TO THE SECOND AND THIRD EDITIONS.

the shores of the Caspian Sea), falls between the period of publication of the second and third editions. This expedition has contributed materially to the enlargement of my views in all that regards the form of the surface of the earth, the direction of mountain-chains, the connection of steppes and deserts with each other, and the geographical distribution of plants in relation to ascertained conditions of temperature. The long subsisting want of any accurate knowledge on the subject of the great snow-covered mountain-chains which are situated between the Altai and the Himalaya (i.e. the Thian-schan and the Kuen-lün), and the ill-judged neglect of Chinese authorities, have thrown great obscurity around the geography of Central Asia, and have allowed imagination to be substituted for the results of observation in works which have obtained extensive circulation. In the course of the last few months the hypsometrical comparison of the culminating summits of the two continents has almost unexpectedly received important corrections and additions, of which I hasten to avail myself. (Vol. i. pp.57-58, and 92-93.) The determinations of the heights of two mountains in the eastern chain of the Andes of Bolivia, the Sorata and the Illimani, have been freed from the errors which had placed those mountains above the Chimborazo, but without as yet 
altogether restcring to the latter with certainty its ancient pre-eminence among the snory summits of the New World. In the Himalaya the recently executed trigonometrical measurement of the Kinchinjinga (28178 English feet) places it next in altitude to the Dhawalagiri, a new and more exact trigonometrical measurement of which has also been recently made.

For the sake of uniformity with the two previous editions of the "Ansichten der Natur," I have given the degrees of temperature in the present work (unless where expressly stated otherwise) in degrees of Reaumur's scale. The linear measures are the old French, in which the toise equals six Parisian feet. The miles are gengraphical, fifteen to a degree of the equator. The longitudes are reckoned from the Observatory at Paris as a first meridian.

BERLIN, 1849. 



\section{NOTE BI THE TRANSLATOR.}

Is the translation the temperatures are given in degrees of Fahrenheit, retaining at the same time the original figures in Reaumur's scale. In the same manner the measures are given in English feet, generally retaining at the same time the original statements in Parisian or French feet or toises, a desirable precaution where accuracy is important. The miles are given in geographical miles, 60 to a degree, but in this case the original figures have usually been omitted, the conversion being so simple as to render the introduction of error very improbable. In a very few instances "English miles" appear without any farther epithet or explanation; these have been taken by the author from English sources, and may probably signify statute miles. The longitudes from Greenwich are substituted for those from Paris, retaining in addition the original statement in particular cases. 



\section{CONTENTS.}

PAGE

Author's Preface to the First Edition . . . . vii

Author's Preface to the Second and Third Editions . Ii

Note bi the Tratsiator . . . . . . xfï

Steppes AND Deserts . . . . . . . 1

Annotations and Additions . . . . . 27

Cataracts of the Orinoco . . . . . . $20 \%$

Annotations and Additions . . . . . 233

Nocturnat Life of Axtmals in the Primeval Forest 257

Annotations and Additions . . . . 273

HrPSOMETRIC ADDENDA . . . . . . . 277

* For General Summary of the Contexts of the First Volume, see page 289. 



\section{STEPPES AND DESERTS.}





\section{ASPECTS OF NATURE}

IN

\section{DIFFERENT LANDS AND DIFFERENT CLIMATES.}

\section{STEPPES AND DESERTS.}

A WIDELY extended and apparently interminable plain stretches from the southern base of the lofty granitic crest, which, in the youth of our planet, when the Caribbean gulf was formed, braved the invasion of the waters. On quitting the mountain valleys of Caraccas, and the island-studded lake of Tacarigua (1) whose surface reflects the stems of plantains and bananas, and on leaving behind him meads adorned with the bright and tender green of the Tahitian sugar cane or the darker verdure of the Cacao groves, the traveller, looking southward, sees unroll before him Steppes receding until they vanish in the far horizon.

Fresh from the richest luxuriance of organic life, he treads at once the desolate margin of a treeless desert. Neither hill nor cliff rises, like an island in the ocean, to break the uniformity of the boundless plain; only here and there 
broken strata of limestone, several hundred square miles in extent, appear sensibly higher than the adjoining parts. "Banks" (2) is the name given to them by the natives; as if language instinctively recalled the more ancient condition of the globe, when those elevations were shoals, and the Steppes themselves were the bottom of a great Mediterranean sea.

Even at the present time nocturnal illusion still recalls these images of the past. When the rapidly rising and descending constellations illumine the margin of the plain, or when their trembling image is repeated in the lower stratum of undulating vapour, we seem to see before us a shoreless ocean. ( $\left.{ }^{3}\right)$ Like the ocean, the Steppe fills the mind with the feeling of infinity; and thought, escaping from the visible impressions of space, rises to contemplations of a higher order. Yet the aspect of the clear transparent mirror of the ocean, with its light, curling, gently foaming, sportive waves, cheers the heart like that of a friend; but the Steppe lies stretched before us dead and rigid, like the stony crust ( ${ }^{4}$ ) of a desolated planet.

In every zone nature presents the phenomena of these great plains : in each they have a peculiar physiognomy, determined by diversity of soil, by climate, and by elevation above the level of the sea.

In northern Europe, the Heaths, which, covered with a single race of plants repelling all others, extend from the point of Jutland to the mouth of the Scheldt, may be regarded as true Steppes,-but Steppes of small extent and hilly surface, if compared with the Llanos and Pampas of 
South America, or even with the Prairies of the Missouri (5) and the Barrens of the Coppermine river, where range countless herds of the shaggy buffalo and musk ox.

A grander and severer aspect characterises the plains of the interior of Africa. Like the wide expanse of the Pacific Ocean, it is only in recent times that attempts have been made to explore them thoroughly. They are parts of a sea of sand, which, stretching eastward, separates fruitful regions from each other, or encloses them like islands; as where the Desert, near the basaltic mountains of Harudsh, $\left({ }^{6}\right)$ surrounds the Oasis of Siwah rich in date trees, and in which the ruins of the temple of Ammon mark the venerable site of an ancient civilisation. Neither dew nor rain bathe these desolate plains, or develope on their glowing surface the germs of vegetable life; for heated columns of air, every where ascending, dissolve the vapours, and disperse each swiftly vanishing cloud.

Where the Desert approaches the Atlantic Ocean, as between the Wadi Nun and Cape Blanco, the moist sea air pours in to supply the void left by these upward currents. The mariner, steering towards the mouth of the Gambia through a sea covered with weed, when suddenly deserted by the east trade wind of the tropics, $\left({ }^{7}\right)$ infers the vicinity of the widely extended heat-radiating desert. Herds of antelopes and swift-footed ostriches roam through these vast regions; but, with the exception of the watered Oases or islands in the sea of sand, some groups of which have recently been discovered, and whose verdant shores are frequented by nomade Tibbos and Tuaricks, $\left(^{8}\right)$ the African 
Desert must be regarded as nninhabitable by man. The more civilised nations who dwell on its borders only venture to enter it periodically. By trading routes, which have remained unaltered for thousands of years, caravans traverse the long distance from Tafilet to Timbuctoo, and from Moorzouk to Bornou; adventurous undertakings, the possibility of which depends upon the existence of the camel, the "ship of the desert," (9) as it is called in the traditionary language of the eastern world.

These African plains occupy an extent nearly three times as great as that of the neighbouring Mediterranean sea. They are situated partly within, and partly in the vicinity of the tropics; and on this situation their peculiar character depends. In the eastern part of the old continent, the same geognostic phenomenon occurs in the temperate zone. On the plateaux of central Asia, between the gold mountains or the Altai and the Kuen-lun, (10) from the Chinese wall to beyond the Celestial mountains, and towards the sea of Aral, there extend, through a length of many thousand miles, the most vast, if not the most elevated, Steppes on the surface of the globe. I have myself had the opportunity, fully thirty years after my South American journey, of visiting a portion of them; namely, the Calmuck Kirghis Steppes between the Don, the Volga, the Caspian, and the Chinese lake Dsaisang, being an extent of almost 2800 geographical miles.

These Asiatic Steppes, which are sometimes hilly and sometimes interrupted by pine forests, possess (dispersed over them in groups) a far more varied vegetation than that 
of the Llanos and Pampas of Caraccas and Buenos Ayres. The finest part of these plains, which is inhabited by Asiatic pastoral tribes, is adorned with low bushes of luxuriant white-blossomed Rosacex, and with Fritillarias, Tulips, and Cypripedias.

As the torrid zone is characterised on the whole by a disposition in all' regetation to become arborescent, so some of the Asiatic Steppes in the temperate zone are characterised by the great height attained by flowering herbaceous plants, Saussureas and other Synantheræ, and Papilionaceæ especially a host of species of Astragalus. In traversing pathless portions of these Steppes, the traveiler, seated in the low Tartar carriages, sees the thickly crowded plants bend beneath the wheels, but without rising up camnot look around him to see the direction in which he is moving. Some of the Asiatic Steppes are grassy plains; others are covered with succulent, evergreen, articulated soda plants: many glisten from a distance with flakes of exuded salt which cover the clayey soil, not unlike in appearance to fresh fallen snow.

These Mongolian and Tartarian Steppes, interrupted frequently by mountainous features, divide the very ancient civilisation of Thibet and Hindostan from the rude nations of Northern Asia. They have in various ways exercised an important influence on the changeful destinies of man. They have compressed the population torrards the south, and have tended, more than the Himalaya, or than the snowy mountains of Srinagur and Ghorka, to impede the intercourse of nations, and to place permanent limits to the extension 
of milder manners, and of artistic and intellectual cultivation in northern Asia.

But, in the history of the past, it is not alone as an opposing barrier that we must regard the plains of Central Asia: more than once they have proved the source from whence devastation has spread over distant lands. The pastoral nations of these Steppes,-Moguls, Getæ, Alani, and Usuni,-have shaken the world. As in the course of past ages, early intellectual culture has come like the cheering light of the sun from the East, so, at a later period, from the same direction barbaric ruderiess has threatened to overspread and involve Europe in darkness. A brown pastoral race, $\left({ }^{11}\right)$ of Tukiuish or Turkish descent, the Hiongnu, dwelling in tents of skins, inhabited the elevated Steppe of Gobi. Long terrible to the Chinese power, a part of this tribe was driven back into Central Asia. The shock or im. pulse thus given passed from nation to nation, until it reached the ancient land of the Finns, near the Ural mountains. From thence, Huns, Avari, Ghazarés, and various admixtures of Asiatic races, broke forth. Armies of Huns appeared successively on the Volga, in Pannonia, on the Marne, and on the Po, desolating those fair and fertile fields which, since the time of Antenor, civilised man had adorned with monument after monument. Thus went forth from the Mongolian deserts a deadly blast, which withered on Cisalpine ground the tender long-cherished flower of art.

From the salt Steppes of Asia, from the European Heaths smiling in summer with their purple blossoms rich in honey, 
and from the arid Deserts of Africa devoid of all vegetation, let us now return to those South American plains of which I have already began to trace the picture, albeit in rude outlines.

The interest which this picture can offer to the beholder is, however, exclusively that of pure nature. Here no Oasis recalls the memory of earlicr inhabitants; no carved stone, (12) no ruined building, no fruit tree once the care of the cultivator but now wild, speaks of the art or industry of former generations. As if estranged from the destinies of mankind, and riveting attention solely to the present moment, this corner of the earth appears as a wild theatre for the free development of animal and vegetable life.

The Steppe extends from the Caraccas coast chain to the forests of Guiana, and from the snowy mountains of Merida (on the slope of which the Natron Lake Urao is an object of superstitious veneration to the natives,) to the great delta formed by the Orinoco at its mouth. To the south-west a branch is prolonged, like an arm of the sea, (13) beyond the banks of the Meta and Vichada to the unvisited sources of the Guaviare, and to the lonely mountain to which the excited fancy of the Spanish soldiery gave the name of Paramo de la Suma Paz-the seat of perfect peace.

This Steppe occupies a space of 16,000 (256,000 English) square miles. It has often been erroneously described as running uninterruptedly, and with an equal breadth, to the straits of Magellan, forgetting the forest-covered plain of the Amazons which intervenes between the grassy Steppes of the Apure and those of the river Plate. The Andes of 
Cochabamba, and the Brazilian group of mountains, send forth, between the province of Chiquitos and the isthmus of Villabella, some detached spurs, which advance, as it were, to meet each other. (14) A narrow plain connects the forest lands of the Amazons with the Pampas of Buenos Ayres. The latter far surpass the Llanos of Venezuela in area; and their extent is so great that while their northern margin is bordered by palm trees, their southern extremity is almost continually covered with ice.

The Tuyu, which resembles the Cassowary (the Struthio rhea), is peculiar to these Pampas, which are also the haunt of troops of dogs ( ${ }^{15}$ ) descended from those introduced by the colonists, but which have become completely wild, dwelling together in subterranean hollows, and often attacking with blood-thirsty rage the human race whom their progenitors served and defended.

Like the greater portion of the desert of Sahara, (16) the northernmost of the South American plains, the Llanos, are in the torrid zone: during one half of the year they are desolate, like the Lybian sandy waste; during the other, they appear as a grassy plain, resembling many of the Steppes of Central Asia. (17)

It is a highly interesting though difficult task of general geography to compare the natural conditions of distant regions, and to represent by a few traits the results of this comparison. The causes which lessen both heat and dryness in the New World (18) are manifold, and in sorne respects as yet only partially understood. Amongst these may be classed the narrowness and deep indentation of the 
American land in the northern part of the torrid zone, where consequently the atmosphere, resting on a liquid base, does not present so heated an ascending current; - the extension of the continent towards the poles; - the expanse of ocean over which the trade-winds sweep freely, acquiring thereby a cooler temperature; - the flatness of the eastern coasts; currents of cold sea-water from the antarctic regions, which, coming from the south-west to the north.east, first strike the coast of Chili in the parallel of $35^{\circ}$ south latitude, and advance along the coast of Peru as far north as Cape Parina, and then turn suddenly to the west; - the numerous lofty mountain chains rich in springs, and whose snow-clad summits, rising high above all the strata of clouds, cause descending currents of cold air to roll down their declivities; -the abundance of rivers of enormous breadth, which, after many windings, seek the most distant coast;-Steppes which from not being sandy are less susceptible of acquiring a high degree of heat,-impenetrable forests occupying the alluvial plains situated immediately beneath the equator, protecting with their shade the soil beneath from the direct influence of the sunbeams, and exhaling in the interior of the country at a great distance from the mountains and from the ocean vast quantities of moisture, partly imbibed and partly elaborated:-all these circumstances afford to the flat part of America a climate which by its humidity and coolness contrasts wonderfully with that of Africa. It is to the same causes that we are to attribute the luxuriant vegetation, the magnificent forests, and that abundant leafiness by which the new continent is peculiarly characterised. 
If, therefore, one side of our planet has a moister atmosphere than the other, the consideration of the present condition of things is amply sufficient to explain the problem presented by this inequality. The physical inquirer needs not to clothe the explanation of these phenomena in a mantle of geological myths. He needs not to assume that on our planet the harmonious reconciliation of the destructive conflict of the elements took place at different epochs in the eastern and the western hemispheres; or that America emerged later than the other parts of the globe from the chaotic watery covering, (19) as an island of swamps and marshes tenanted by alligators and serpents.

There is, indeed, a striking similarity between South America and the southern peninsula of the old continent in the form of the outline and in the direction of the coasts; but the nature of the soil, and the relative position of the neighbouring masses of land, produce in Africa that extraordinary aridity which over an immense area checks the development of organic life. Four-fifths of South America are situated on the southern side of the equator; or in a hemisphere which from the greater proportion of sea and from other causes is cooler and moister than our northern half of the globe, $\left({ }^{20}\right)$ to which the larger part of Africa belongs. The breadth of the South American Steppe, measured from east to west, is only a third of that of the African Desert. The Llanos receive the influence of the tropical sea wind, while the African Deserts, being situated in the same zone of latitude as Arabia and the south of Persia, are in contact with strata of air which have blown 
over warm heat-radiating continents. The venerable and only lately appreciated father of history, Herodotus, in tne true spirit of an enlarged view of nature, described the Deserts of northern Africa, of Yemen, of Kerman and Mekran (the Gedrosia of the Greeks), and even as far as Moultan, as forming a single connected sea of sand. ( $\left.{ }^{21}\right)$

In addition to the action of these hot winds, there is (so far as we know) an absence or comparative paucity in Africa of large rivers, of widely extended forests producing coólness and exhaling moisture, and of lofty mountains. Of mountains covered with perpetual snow, we know only the western part of the Atlas, $\left({ }^{22}\right)$ whose narrow range, seen in profile from the Atlantic, appeared to the ancient navigators when sailing along the coast as a single detached lofty sky-supporting mount. The eastern prolongration of the chain extends nearly to Dakul, where Carthage, once mistress of the seas, now lies in mouldering ruins. As forming a long extended coast-chain, or Gætulian rampart, the effect of the Atlas range is to intercept the cool north breezes, and the vapours which ascend from the Mediterranean.

The Mountains of the Moon, Djebel-al-Komr, (23) (fabulously represented as forming part of a mountainous parallel extending from the high plateaux of Habesh, an African Quito, to the sources of the Senegal), were supposed to rise above the limit of perpetual snow. The Cordillera of Lupata, which extends along the eastern coast of Mozambique and Monomotapa, as the Andes along the 
western coast of Peru, is believed to be covered with perpetual snow in the gold districts of Machinga and Mocanga. But all these mountains, with the abundant waters to which they give rise, are far remote from the immense Desert which stretches from the southern declivity of the Atlas to the Niger.

Possibly, however, all the causes of heat and dryness which have been enumerated may have been insufficient to transform such considerable parts of the African plains into a. dreadful desert, without the concurrence of some revolution of nature,-such, for instance, as an irruption of the ocean, whereby these flat regions may have been despoiled of their coating of vegetable soil, as well as of the plants which it nourished. Profound obscurity veils the period of such an event, and the force which determined the irruption. Perhaps it may have been caused by the great "rotatory current" ${ }^{24}$ ) which sends the warmer water of the Mexican gulf over the banks of Newfoundland and to the shores of the old continent, and causes West India cocoa-nuts and other tropical fruits to reach the coasts of Ireland and Norway. There is still at least at the present time, an arm of this current directed from the Azores to the south-east, which sometimes produces disasters by carrying ships upon the west coast of Africa, which it strikes at a part lined by sand-hills. Other sea coasts (I particularly recall that of Peru between Amotape and Coquimbo) shew that in these hot regions of the earth, where rain never falls and where neither Lecideas nor other Lichens $\left({ }^{25}\right)$ germinate, centuries 
and perhaps thousands of years may elapse before the moveable sand can afford to the roots of plants a secure. holding place.

These considerations are sufficient to explain why, with an external similarity of form, Africa and South America present so marked a difference of character both in respect to climate and to regetation. But although the South American Steppe is covered with a thin coating of mould or fertile earth, and although it is periodically bathed by rains, and becomes covered at such seasons with luxuriantly sprouting herbage, yet it never could attract the surrounding nations or tribes to forsake the beautiful mountain valleys of Caraccas, the margin of the sea, or the wooded banks of the Orinoco, for the treeless and springless wilderness; and thus, previous to the arrival of European and African settlers, the Steppe was almost entirely devoid of human inhabitants.

The Llanos are, indeed, well suited to the rearing of cattle, but the care of animals yielding milk (26) was almost unknown to the original inhabitants of the $\mathrm{New}$ Continent. Hardly any of the American tribes have ever availed themselves of the advantages which nature offered them in this respect. The American race (which, with the exception of the Esquimaux, is one and the same from $65^{\circ}$ North to $55^{\circ}$ South latitude), has not passed from the state of hunters to that of cultivators of the soil through the intermediate stage of a pastoral life. Two kinds of native cattle (the Buffalo and the Musk $\mathrm{Ox}$ ) feed in the northern prairies of western Canada and the plains of arctic America, in Quivira, and 
around the colossal ruins of the Aztec fortress which rises in the wilderness, like an American Palmyra, on the solitary banks of the Gila. The long-horned Rocky Mountain Sheep abounds on the aridlimestone rocks of California. The Vicunas, Huanacos, Alpacas, and Lamas, belong to South America; but the two first named of all these useful animals, i.e., the Buffalo and the Musk Ox, have retained their natural freedom for two thousand years, and the use of milk and cheese, like the possession and cultivation of farinaceous grasses, (27) has remained a distinguishing characteristic of the nations of the old world.

If some of the latter have crossed from northern Asia to the west coast of America, and if, keeping by preference to the cooler mountain regions, $\left({ }^{28}\right)$ they have followed the lofty ridge of the Andes towards the south, their migration must have taken place by ways in which they could not be accompanied by their flocks and herds, or bring with them the cultivation of corn. When the long shaken empire of the Hiongnu fell, may we conjecture that the movement of this powerful tribe may also have occasioned in the north-east of China and in Corea a shock and an impulse which may have caused civilized Asiatics to pass over into the new continent? If such a migration had consisted of inhabitants of the Steppes in which agriculture was not pursued, this hazardous hypothesis (which has hitherto been but little favoured by the comparison of languages) would at least explain the striking absence of the Cereals in America. Possibly one of those Asiatic priestly colonies whom mystic dreams sometimes impelled to embark in long voyages, (of which 
the history of the peopling of Japan (29) in the time of Thsinchi-huang-ti offers a memorable example), may have been driven by storms to the coasts of New California.

If, then, pastoral life, that beneficent middle stage which attaches nomadic hunting hordes to desirable pastures and prepares them, as it were, for agriculture, has remained unknown to the aboriginal nations of America, this circum. stance sufficiently explains the absence of human inhabitants in the South American Steppes. This absence has allowed the freest scope for the abundant development of the most varied forms of animal life; a development limited only by their mutual pressure, and similar to that of vegetable life in the forests of the Orinoco, where the Hymenæa and the gigantic laurel are never exposed to the destructive hand of man, but only to the pressure of the luxuriant climbers which twine around their massive trmnks. Agoutis, small spotted antelopes, cuirassed armadilloes, which, like rats, startle the hare in its subterramean holes, herds of lazy chiguires, beautifully striped viverræ which poison the air with their odour, the large maneless lion, spotted jaguars (often called tigers) strong enough to drag away a young bull after killing him; - these and many other forms of animal life $\left({ }^{30}\right)$ wander through the treeless plain.

Thus almost exclusively inhabited by these wild animals, the Steppe would offer little attraction or means of subsistence to those nomadic native hordes, who, like the Asiatics of Hindostan, prefer vegetable nutriment, if it were not for the occasional presence of single individuals of the fan palm, the Mauritia. The benefits of this life-supporting 
tree are widely celebrated; it alone, from the mouth of the Orinoco to north of the Sierra de Imataca, feeds the unsubdued nation of the Guaranis. ( ${ }^{31}$ ) When this people were more numerous and lived in closer contiguity, not only did they support their huts on the cut trunks of palm trees as pillars on which rested a scaffolding forming the floor, but they also, it is said, twined from the leaf-stalks of the Mauritia cords and mats, which, skilfully interwoven and suspended from stem to stem, enabled them in the rainy season, when the Delta is overflowed, to live in the trees like the apes. The floor of these raised cottages is partly covered with a coating of damp clay, on which the women make fires for household purposes, - the flames appearing at night from the river to be suspended high in air. The Guaranis still owe the preservation of their physical, and perhaps also their moral, independence, to the half-submerged, marshy soil over which they move with a light and rapid step, and to their elevated dwellings in the trees, - a habitation never likely to be chosen from motives of religious enthusiasm by an American Stylites. (32) But the Mauritia affords to the Guaranis not merely a secure dwelling-place, but also various kinds of food. Before the flower of the male palm tree breaks through its tender sheath, and only at that period of vegetable metamorphosis, the pith of the stem of the tree contains a meal resembling sago, which, like the farina of the jatropha root, is dried in thin bread. like slices. The fermented juice of the tree forms the sweet intoxicating palm wine of the Guaranis. The scaly fruits, which resemble in their appearance reddish fir cones, afford, 
like the plaintain and almost all tropical fruits, a different kind of nutriment, according as they are eaten after their saccharine substance is fully developed, or in their earlier or more farinaceous state. Thus in the lowest stage of man's intellectual development, we find the existence of an entire people bound up with that of a single tree; like the insect which lives exclusively on a single part of a particular flower.

Since the discovery of the New Continent, the Llanos have become habitable to men. In order to facilitate communication between the Orinoco country and the coasts, towns have been brilt here and there on the banks of the streams which flow through the Steppes. (33) The rearing of cattle has began orer all parts of these vast regions. Huts, formed of reeds tied together with thongs and corered with skins, are placed at distances of a day's journey from each other; numberless herds of oxen, horses, and mules, estimated at the peaceful epoch of my journey at a million and a half, roam orer the Steppe. The immense multiplica. tion of these animals, originally brought by man from the Old Continent, is the more remarkable from the number of dangers with which they have to contend.

When, under the vertical rays of the never-clouded sun, the carbonized turfy covering falls into dust, the indurated soil cracks asunder as if from the shock of an earthquake. If at such times two opposing currents of air, whose conflict produces a rotatory motion, come in contact with the soil, the plain assumes a strange and singular aspect. Like conical-shaped clouds ${ }^{34}$ ) the points of which descend

TOL. I. 
to the earth, the sand rises through the rarified air in the electrically charged centre of the whirling current; resembling the loud waterspout dreaded by the experienced mariner. The lowering sky sheds a dim, almost strawcoloured light on the desolate plain. The horizon draws suddenly nearer ; the Steppe seems to contract, and with it the heart of the wanderer. The hot dusty particles which fill the air increase its suffocating heat, ( ${ }^{35}$ ) and the east wind, blowing over the long-heated soil, brings with it no refreshment, but rather a still more burning glow. The pools which the yellow fading branches of the fan palm had protected from evaporation now gradually disappear. As in the icy north the animals become torpid with cold, so here, under the influence of the parching drought, the crocodile and the boa become motionless and fall asleep, deeply buried in the dry mud. Every where the death-threatening drought prevails, and yet, by the play of the refracted rays of light producing the phenomenon of the mirage, the thirsty traveller is every where pursued by the illusive image of a cool rippling watery mirror. ${ }^{36}$ ) The distant palm bush apparently raised by the influence of the contact of unequally heated and therefore unequally dense strata of air, hovers above the ground, from which it is separated by a narrow intervening margin. Half concealed by the dark clouds of dust, restless with the pain of thirst and hunger, the horses and cattle roam around, the cattle lowing dismally, and the horses stretching out their long necks and snuffing the wind, if haply a moister current may betray the neighbourhood of a not wholly dried up pool. More saga- 
cious and cunning, the mule seeks a different mode of alleviating his thirst. The ribbed and spherical meloncactus $\left({ }^{37}\right)$ conceals under its prickly envelope a watery pith. The mule first strikes the prickles aside with his fore feet, and then ventures warily to approach his lips to the plant and drink the cool juice. But resort to this regetable fountain is not always without danger, and one sees many animals that have been lamed by the prickles of the cactus.

When the burning heat of the day is followed by the coolness of the night, which in these latitudes is always of the same length, even then the horses and cattle cannot enjoy repose. Enormous bats suck their blood like vampires during their sleep, or attach themselves to their backs, causing festering wounds, in which musquitoes, hippobosces, and $a$ host of stinging insects, niche themselves. Thus the animals lead a painful life during the season when, under the fierce glow of the sun, the soil is deprived of its moisture. At length, after the long drought, the welcome season of the rain arrives; and then how suddenly is the scene changed! (38) The deep blue of the hitherto perpetually cloudless sky becomes lighter; at night the dark space in the constellation of the Southern Cross is hardly distinguishable; the soft phosphorescent light of the Magellanic clouds fades away; even the stars in Aquila and Ophiucus in the zenith shine with a trembling and less planetary light. A single cloud appears in the south, like a distant mountain, rising perpendicularly from the horizon. Gradually the increasing vapours spread like mist over the sky, and now the distant thunder ushers in the life-restoring 
rain. Hardly has the surface of the earth received the refreshing moisture, before the previously barren Steppe begins to exhale sweet odours, and to clothe itself with Kyllingias, the many panicules of the Paspalum, and a variety of grasses. The herbaceous mimosas, with renewed sensibility to the infiuence of light, unfold their drooping slumbering leaves to greet the rising sun; and the early song of birds, and the opening blossoms of the water plants, join to salute the morning. The horses and cattle now graze in full enjoyment of life. The tall springing grass hides the beautifully spotted jaguar, who lurking in safe concealment, and measuring carefully the distance of a single bound, springs, cat-like, as the Asiatic tiger, on his passing prey.

Sometimes, (so the Aborigines relate), on the margin of the swamps the moistened clay is seen to blister and rise slowly in a kind of mourd; then with a violent noise, like the outbreak of a small mud volcano, the heaped-up earth is cast high into the air. The beholder acquainted with the meaning of this spectacle flies, for he knows there will issue forth a gigantic water-snake or a scaly crocodile, awakened from a torpid state (39) by the first fall of rain.

The rivers which bound the plain to the south, the Arauca, Apure, and Payara, become gradually swollen; and now nature constrains the same animals, who in the first half of the year panted with thirst on the dry and dusty soil, to adopt an amphibious life. A portion of the Steppe now presents the aspect of a vast inland sea. $\left({ }^{40}\right)$ The brood mares retire with their foals to the higher banks, which stand like islands above the surface of the lake. 
Every day the space remaining dry becomes smaller. The animals, crowded together, swim about for hours in search of other pasture, and feed sparingly on the tops of the flowering grasses rising above the seething surface of the dark-coloured water. Many foals are dromned, and many are surprised by the crocodiles, killed by a stroke of their powerful notched tails, and devoured. It is not a rare thing to see the marks of the pointed teeth of these monsters on the legs of the horses and cattle who have narrowly escaped from their blood-thirsty jaws. Such a sight reminds the thoughtful observer involuntarily of the capability of conforming to the most varied circumstances, with which the all-providing Author of Nature has endowed certain animals and plants.

The ox and the horse, like the farinaceous cerealia, have followed man over the whole surface of the globe, from India to Northern Siberia, from the Ganges to the River Plate, from the African sea shore to the mountain plateau of Antisana, ( $\left.{ }^{41}\right)$ which is higher than the summit of the Peak of Teneriffe. The ox wearied from the plough reposes, sheltered from the noontide sun in one country by the quivering shadow of the northern birch, and in another by the date palm. The same species which, in the east of Europe, has to encounter the attacks of bears and wolves, is exposed in other regions to the assaults of tigers and crocodiles.

But the crocodile and jaguar are not the only assailants of the South American horses; they have also a dangerous enemy among fishes. The marshy waters of Bera and 
Rastro $\left({ }^{42}\right)$ are filled with numberless electric eels, which can at pleasure send a powerful discharge from any part of their slimy yellow spotted bodies. These gymnoti are from five to six feet in léngth, and are powerful enough to kill the largest animals when they discharge their nervous organs at once in a favourable direction.

The route from Uritucu through the Steppe was formerly obliged to be changed, because the gymnoti had increased to such numbers in a small stream that in crossing it many horses were drowned every year, either from the effects of the shocks they received, or from fright. All other fishes fly the vicinity of these formidable eels. Even the fisherman angling from the high bank fears lest the damp line should convey the shock to him from a distance. Thus, in these regions, electric fire breaks forth from the bosom of the waters.

The capture of the gymnoti affords a picturesque spectacle. Mules and horses are driven into a marsh which is closely surrounded by Indians, until the unwonted noise and disturbance induce the pugnacious fish to begin an attack. One sees them swimming about like serpents, and trying cunningly to glide under the bellies of the horses. Many of these are stunned by the force of the invisible blows; others, with manes standing on end, foaming and with wild terror sparkling in their eyes, try to fly from the raging tempest. But the Indians, armed with long poles of bamboo, drive them back into the middle of the pool. Gradually the fury of the unequal strife begins to slacken. Like clouds which have discharged their electricity, the 
wearied fish begin to disperse; long repose and abundant food are required to replace the galvanic force which they have expended. Their shocks become gradually weaker and weaker. Terrified by the noise of the trampling horses, they timidly approach the bank, where they are wounded by harpoons, and cautiously dramn on shore by non-conducting pieces of dry wood.

Such is the extraordinary battle between horses and fish. That which forms the invisible but living weapon of this electric eel; - - that which, awakened by the contact of moist dissimilar particles, ${ }^{43}$ ) circulates through all the organs of plants and animals; - that which, flashing from the thunder cloud, illumines the wide skyey canopy; - that which draws iron to iron and directs the silent recurring march of the guiding needle;-all, like the several hues of the divided ray of light, flow from one source; and all blend again together in one perpetually, every where diffused, force or power.

I might here close the liazardous attempt to trace a picture of nature such as she shows herself in the Steppes. But as on the ocean fancy not unwillingly dwells awhile on the image of its distant shores, so, before the wide plain disappears from our view, let us cast a rapid glance at the regions by which the Steppes are bounded.

The Northern Desert of Africa divides two races of men who belong originally to the same part of the globe, and whose unreconciled discord appears as ancient as the mythus of Osiris and Typhon. $\left(^{44}\right)$ North of the Atlas there dwell nations with long and straight hair, of sallow complexion and 
Caucasian features. On the south of the Senegal, towards Soudan, live hordes of negroes in many different stages of civilization. In Central Asia, the Mongolian Steppe divides Siberian barbarism from the ancient civilisation of the peninsula of India.

The South American Steppes form the boundary of a partial European cultivation. (45) To the north, between the mountains of Venezuela and the Caribbean sea, we find commercial cities, neat villages, and carefully cultivated fields. Even the love of art and scientific culture, together with the noble desire of civil freedom, have long been awakened there. Towards the south the Steppe terminates in a savage wilderness. Forests, the growth of thousands of years, fill with their impenetrable fastnesses the humid regions between the Orinuco and the Amazons. Massive leaden-coloured granite rocks ${ }^{46}$ ) narrow the bed of the foaming rivers. Mountains and forests resound with the thunder of the falling waters, with the roar of the tiger-like jaguar, and with the melancholy rain-announcing howlings of the bearded apes. ( $\left.{ }^{47}\right)$

Where a sand-bank is left dry by the shallow current, the unwieldly crocodiles lie, with open jaws, as motionless as pieces of rock and often covered with birds. (48) The boa serpent, his body marked like a chess-board, coiled up, his tail wound round the branch of a tree, lies lurking on the bank secure of his prey; he marks the young bull or some feebler inhabitant of the forest as it fords the stream, and swiftly uncoiling seizes the victim, and covering it with mucus forces it laboriously down his swelling throat. (49) 
In the midst of this grand and savage nature live many tribes of men, isolated from each other by the extraordinary diversity of their languages: some are nomadic, wholly unacquainted with agriculture, and using ants, gums, and earth as food (50); these, as the Otomacs and Jarures, seem a kind of outcasts from humanity : others, like the Maquiritares and Macos, are settled, more intelligent and of milder manners, and live on fruits which they have themselves reared.

Large spaces between the Cassiquiare and the Atabapo are only inhabited by the tapir and the social apes, and are wholly destitute of human beings. Figures graven on the rocks ( ${ }^{51}$ ) shew that even these deserts were once the seat of some degree of intellectual cultivation. They bear witness to the changeful destinies of man, as do the unequally developed flexible languages; which latter belong to the oldest and most imperishable class of historic memorials.

But as in the Steppe tigers and crocodiles fight with horses and cattle, so in the forests on its borders, in the wildernesses of Guiana, man is ever armed against man. Some tribes drink with unnatural thirst the blood of their enemies; others apparently weaponless and yet prepared for murder $\left({ }^{52}\right)$ kill with a poisoned thumb-nail. The weaker hordes, when they have to pass along the sandy margin of the rivers, carefully efface with their hands the traces of their timid footsteps. Thus man in the lowest stage of almost animal rudeness, as well as amidst the apparent brilliancy of our higher cultivation, prepares for himself and his fellow 
men increased toil and danger. The traveller wandering over the wide globe by sea and land, as well as the historic inquirer searching the records of past ages, finds every where the uniform and saddening spectacle of man at variance with man.

He, therefore, who, amidst the unreconciled discord of nations, seeks for intellectual calm, gladly turns to contemplate the silent life of vegetation, and the hidden activities of forces and powers operating in the sanctuaries of nature; or, obedient to the inborn impulse which for thousands of years has glowed in the human breast, gazes upwards in meditative contemplation on those celestial orbs, which are ever pursuing in undisturbed harmony their ancient and unchanging course. 


\section{ANNOTATIONS AND ADDITIONS.}

\section{(1) p. 1.- "The Lake of Tacarigua."}

In proceeding through the interior of South America from the Caraccas or Venezuela shore towards the boundary of Brazil, from the 10th degree of North latitude to the Equator, the traveller crosses first an elevated mountainchain running in an east and west direction, next rast treeless Steppes or Plains (los Llanos), which stretch from the foot of the above-named mountains (the coast chain of Caraccas) to the left bank of the Orinoco, and lastly the range which occasions the Cataracts of Atures and Maypure. This latter range of mountains, to which I have given the name of the Sierra Parime, runs in an easterly direction from the Cataracts to Dutch and French Guiana. It is a mass of mountains divided into many parallel ridges, and is the site of the fabled Dorado. It is bordered on the south by the forest plain, through which the river of the Amazons and the Pio Negro have formed the channels in which their waters flow. Those who desire a fuller acquaintance with the geography of these regions will do well to consult and compare the great map of La Cruz-Olmedilla, bearing date 1775 , (from which almost ail the more recent maps of South America have been formed,) and the map of Columbia 
constructed by me from my own astronomical determinations of geographical positions, and published in 1825 .

The coast chain of Venezuela, geographically considered, is a part of the chain of the Andes of Peru. The chain of the Andes divides itself, at the great mountain junction at the sources of the Magdalena, south of Popayan, (between $1^{\circ} 55^{\prime}$ and $2^{\circ} 20^{\prime}$ latitude), into three chains, the easternmost of which terminates in the snow-covered mountains of Merida. These mountains sink down towards the Paramo de las Rosas into the hilly land of Quibor and Tocuyo, which connects the coast chain of Venezuela with the Cordilleras of Cundinamarca. The coast chain forms an unbroken rampart from Porto Cabello to the promontory of Paria. Its mean height hardly equals 750 toises or 4795 English feet; yet single summits, like the Silla de Caracas (also called Cerro de Avila), decked with the purple-flowering Befaria the American Rose of the Alps, rise 1350 toises or 8630 English feet above the level of the sea. The coast of Terra Tirma bears traces of devastation. We recognise everywhere the action of the great current which, sweeping from east to west, formed by disruption the West Indian Islands, and hollowed out the Caribbean gulf. The projecting tongues of land of Araja and Chuparipari, and especially the coast of $\mathrm{Cu}$ mana and New Barcelona, offer a remarkable spectacle to the geologist. The precipitous Islands of Boracha, Caracas, and Chimanas, rise like towers from the sea, and bear witness to the terrible pressure of the waters against the mountain chain when it was broken by their irruption. Perhaps, like the Mediterranean, the Antillean gulf was once an inland 
sea, which became suddenly connected with the ocean. The islands of Cuba, Harti, and Jamaica, still contain the remmants of the lofty mountains of mica slate which bounded this sea to the north. It is remarkable that where these three islands approach each other most nearly the highest summits are found; and we may conjecture that the highest part of this Antillean chain was situated between Cape Tiburon and Point Morant. The Copper Mountains (Montañas de Cobre) near Santiago de Cuba hare not yet been measured, but their elevation is probably greater than that of the Blue Mountains of Jamaica, (1138 toises, 7277 English feet,) which somemhat exceeds the height of the St. Gothard Pass. My conjectures on the valley-form of the Atlantic Ocean, and on the ancient comnection of the continents, were given more in detail in a memoir witten in Cumana, entitled Fragment d'un 'Tableau Géologique de l'Amerique Meridionale (Journal de Physique, Messidor, An. IX.) It is worthy of remark, that Columbus himself, in his Official Reports, called attention to the comnection between the direction of the equatorial current and the form of the coast line of the larger Antilles. (Examen critique de l'hist. de la Géographie, p. 104-108.)

The northerm and most cultivated part of the province of Caraccas is a country of mountains. The coast chain is divided like the Swiss Alps into sereral subordinate chains enclosing longitudinal valleys. The most celebrated of these is the pleasant valley of Aragua, which produces a great quantity of indigo, sugar, cotton, and, what is most re- 
markable, European wheat. The southern margin of this valley adjoins the beautiful lake of Valencia, whose old Indian name is Tacarigua. The contrast between its opposite shores gives it a striking resemblance to the Lake of Geneva. It is true that the bare mountains of Guigue and Guiripa have less grandeur of character than the Savoy Alps; but, on the other hand, the opposite bank of the Tacarigua lake, which is thickly clothed with plantains, mimosas, and triplaris, far surpasses in picturesque beauty the vineyards of the Pays de Vaud. The lake is about thirty geographical miles in length, and is full of small islands, which, as the loss of water by evaporation exceeds the influx, are increasing in size. Within some years sandbanks have even become real islands, and have received the significant name of the "Newly Appeared," Las Aparecidas. On the island of Cura the remarkable species of Solanum is cultivated which has edible fruit, and which Wildenow has described in the Hortus Berolinensis (1816, Tab. xxvii.) The height of the Lake of Tacarigua above the sea is almost 1400 French feet, (according to my measurement exactly 230 toises, or 1470 English feet,) less than the mean height of the valley of Caraccas. The lake has several kinds of fish (see my Observations de Zoologie et d'Anatomie comparée, T. ii p. 179-181), and is one of the most pleasing natural scenes which $I$ know in any part of the globe. In bathing, Bonpland and myself were often alarmed by the appearance of the Bava, an undescribed crocodile-like lizard, three or four feet in length, of repulsive aspect, but harmless to men. We found in the lake a 
Typha (Cats-tail), identical with the European Typha angustifoila; a singular fact, and important in reference to the geography of plants.

Two varieties of sugar-cane are cultivated near the lake, in the valleys of Aragua: the common sugar-cane of the West Indies, Caña criolla; and the cane recently introduced from the Pacific, Caña de Otaheiti. The verdure of the Tahitian cane is of a much lighter and more agreeable tint, and a field of it can readily be distinguished at a great distance from a field of the common cane. The sugar-cane of Tahiti was first described by Cook and George Forster, who appear, howerer, from the excellent memoir of the latter upon the edible plants of the islands of the Pacific, to have been but little acquainted with its valuable qualities. Bougainville brought it to the Isle of France, from whence it was conveyed to Cayenne, and since 1792 it has been taken to Martinique, Hayti, and several of the smaller West Indian Islands. It was carried with the bread-fruit tree to Jamaica by the brave but unfortunate Captain Bligh, and was introduced from the Island of Trinidad to the neighbouring coast of Caraccas, where it became a more important acquisition than the bread-fruit, which is never likely to supersede a plant so valuable and affording so large an amount of sustenance as the plantain. The Tahitian sugar-cane is much richer in juice than the common cane, said to be originally a native of the east of Asia. On an equal surface of ground it yields a third more sugar than the caña criolla, which has a thinner stalk and smaller joints. As, moreover, the Tiest India islands begin to suffer great want of fuel, (in Cuba 
the wood of the orange tree is used for sugar boiling, the thicker and more woody stalk of the Tahitian cane is an important advantage. If the introduction of this plant had not taken place almost at the same time as the commencement of the bloody negro war in St. Domingo, the prices of sugar in Europe would have risen still higher than they did, in consequence of the ruinous effects of those troubles on agriculture and trade. It was an important question, whether the cane of the Pacific, when removed from its native soil, would gradually degenerate and become the same as the common cane. Experience hitherto has decided against any such degeneration. In Cuba a caballeria (nearly 33 English acres) planted with Tahitian sugar-cane produces 870 hundred weight of sugar. It is singular that this important production of the islands of the Pacific is only cultivated in those parts of the Spanish colonies which are farthest from the Pacific. The Peruvian coast is only twenty-five days' sail from Tahiti, and yet, at the period of my travels in Peru and Chili, the Tahitian cane was unknown there. The inhabitants of Easter Island, who suffer much from deficiency of fresh water, drink the juice of the sugarcane, and (a very remarkable physiological fact) also sea water. In the Society, Friendly, and Sandwich Islands, the light green, thick-stalked sugar-cane is always the one cultivated.

Besides the Caña de Otaheiti and the Caña Criolla, a reddish African variety, called Caña de Guinea, is cultivated in the West Indies: its juice is less in quantity than that of the common Asiatic cane, but is said to be better suited for making rum. 
In the province of Caraccas the dark shade of the cacao plantations contrasts beautifully with the light green of the Tahitian sugar cane. Few tropical trees have such thick foliage as the Theobroma cacao. It loves hot and humid valleys : great fertility of soil and insalubrity of atmosphere are inseparable from each other in South America as well as in Asia; and it has even been remarked that as increasing cultivation lessens the extent of the forests, and renders the soil and climate less humid, the cacao plantations become less flourishing. For these reasons these plantations are diminishing in number and extent in the province of Caraccas, and increasing rapidly in the more eastern provinces of New Barcelona and Cumana, and particularly in the moist woody district between Cariaco and the Golfo Triste.

(') p. 2.-"Banks' is the name given by the natives to this phenomenon."

The Llanos of Caraccas are occupied by a great and widely extended formation of conglomerate of an early period. In descending from the vallies of Aragua, and crossing orer the most southern ridge of the coast chain of Guigue and Villa de Cura towards Parapara, one finds successively, gneiss and mica slate;-a probably silurian formation of clay slate and black limestone;-serpentine and greenstone in detached spheroidal masses; -and, lastly, close to the margin of the great plain, small hills of augitic amygdaloid and porphyritic slate. These hills between Parapara and Ortiz appear to me like volcanic eruptions on FOI. I. 
the ancient sea-shore of the Llanos. Farther to the north are the celebrated grotesque-shaped cavernous rocks of Morros de San Juan; they form a kind of rampart, have a crystalline grain like upheaved dolomite, and are rather to be regarded as parts of the shore of the ancient gulf than as islands. I term the Llanos a gulf, for when we consider their small elevation above the present sea level, their form open as it were to the equatorial current sweeping from east to west, and the lowness of the eastern coast between the mouth of the Orinoco and the Essequibo, we can scarcely doubt that the sea once overflowed the whole basin between the coast chain of Caraccas and the Sierra de la Parime, and beat against the mountains of Merida and Pamplona; (as it is supposed to have overflowed the plains of Lombardy, and beat against the Cottian and Pennine Alps). The strike or inclination of the American Llanos is also directed from west to east. Their height at Calabozo, 400 geographical miles from the sea, is barely 30 toises (192 English feet); being 15 toises (96 English feet) less than that of Pavia, and 45 toises (288 English feet) less than that of Milan, in the plains of Lombardy between the Alps and Apemines. The form of the surface of this part of the globe reminds one of Claudian's expression, "curvata tumore parvo planities." The horizontality of the Llanos is so perfect that in many portions of them no part of an area of more than 480 square miles appears to be a foot higher than the rest. If, in addition to this, we imagine to ourselves the absence of all bushes, and even in the Mesa de Parones the absence of any isolated palm-trees, it will afford some idea of the 
singular aspect of this sea-like desert plam. As far as the eye can reach, it can hardly rest on a single object a few inches high. If it were not that the state of the lowest strata of the atmosphere, and the consequent changes of refraction, render the horizon continually indeterminate and undulating, altitudes of the sun might be taken with the sextant from the margin of the plain as well as from the horizon at sea. This great horizontality of the former sea bottom makes the "banks" more striking. They are broken strata which rise abruptly from two to three feet above the surrounding rock, and extend uniformly over a length of from 40 to 48 English geographical miles. The small streams of the Steppes take their rise on these banks.

In passing through the Llanos of Barcelona, on our return from the Rio Negro, we found frequent traces of earthquakes. Instead of the banks standing higher than the surrounding rock, we found here solitary strata of gypsum from 3 to 4 toises (19 to 25 English feet) lower. Farther to the west, near the junction of the Caura with the Orinoco, and to the east of the mission of S. Pedro de Alcantara, an extensive tract of dense forest sank down in an earthquake in 1790, and a lake was formed of more than 300 toises (1918 English feet) diameter. The tall trees (Desmanthus, Hymenæas, and Malpighias) long retained their foliage and rerciure under the water.

(3) p. 2.-"We seem to see before us a shoreless ocean."

The prospect of the distant Steppe is still more striking, when the spectator has been long accustomed in the dense 
forests both to a very restricted field of view, and to the aspect of a rich and highly luxuriant vegetation. Ineffaceable is the impression which I received on our return from the Upper Orinoco, when, from the Hato del Capuchino, on a mountain opposite to the mouth of the Rio Apure, we first saw again the distant Steppe. The sun had just set; the Steppe appeared to rise like a hemisphere; and the light of the rising stars was refracted in the lowest stratum of air. The excessive heating of the plain by the vertical rays of the sun causes the variations of refraction,-occasioned by the effects of radiation, of the ascending current, and of the contact of strata of air of unequal density, - to continue through the entire night.

\section{(4) p. 2.-"The naked stony crust."}

Immense tracts of flat bare rock form peculiar and characteristic features in the Deserts both of Africa and Asia. In the Schamo, which separates Mongolia and the mountain chains of Ulangom and Malakha-Oola from the north-west part of China, these banks of rock are called Tsy. They are also found in the forest-covered plains of the Orinoco, surrounded by the most luxuriant vegetation (Relation Hist. t. ii. p. 279). In the middle of these flat tabular masses of granite and syenite of some thousand feet diameter, denuded of all vegetation save a few scantily distributed lichens, we find small islands of soil, covered with low and always flowering plants which give them the appearance of little gardens. The monks of the Upper Orinoco regard these bare and perfectly level surfaces of rock, when 
they are of considerable extent, as peculiarly apt to cause fevers and other illnesses. Several missionary villages have been deserted or removed elsewhere in consequence of this opinion, which is very widely diffused. Supposing the opinion correct, is such an influence of these flat rocks or laxas to be attributed to a chemical action on the atmosphere, or merely to the effect of increased radiation?

${ }^{5}$ ) p. 2.- "The Llanos and Pampas of South America, and the Prairies of the Missouri."

The physical and geognostical views entertained respecting the western part of North America have been rectified in many respects by the adventurous journey of Major Long, the excellent writings of his companion Edwin James, and more especially by the comprehensive observations of Captain Frémont. These, and all other recent accounts, now place in a clear light what, in my work on New Spain, I could only put forward as conjecture, on the subject of the mountain ridges and plains to the north. In the description of nature as well as in historical inquiries, facts long remain isolated, until by laborious investigation they are brought into connection with each other.

The east coast of the United States of North America runs from south-west to north-east, in the same direction as that followed in the southern hemisphere by the Brazilian coast from the river Plate to Olinda. In the two hemispheres two ranges of mountains exist at a short distance from the eastern coast; they are more nearly parallel to 
each other than they are to the more westerly chain, called in South America the Cordilleras of Peru and Chili, and in North America the Rocky Mountains. The Brazilian system of mountains forms an isolated group, of which the lighest summits (the Itacolumi and Itambe) do not rise above the height of 900 toises (5755 English feet). The most easterly ridges, which are nearest to the Atlantic, follow a uniform direction from SSW. to NNE.; more to the west the group becomes broader, but diminishes considerably in height. The Parecis hills approach the rivers Itenes and Guaporé, and the mountains of Aguapelii (to the south of Villabella) approach the lofty Andes of Cochabamba and Santa Cruz de la Sierra.

There is no immediate connection between the eastern and western chains, - the Brazilian mountains, and the Cordilleras of Peru,-for the low province of Chiquitos, which is a longitudinal valley running from north to south, and opening into the plains both of the Amazons and of the river Plate, separates Brazil on the east from the Alto Peru on the west. Here, as in Poland and Russia, an often almost imperceptible rise of ground (called, in Slavonian, Uwaly) forms the separating water-line between the Pilcomayo and the Madeira, between the Aguapehi and the Guaporé, and between the Paraguay and the Rio Topayos. The swell of the ground runs to the south-east from Chayanta and Pomabamba (lat. $19^{\circ}-20^{\circ}$ ), traverses the province of Chiquitos, which, since the expulsion of the Jesuits, has again become almost a terra incognita, and forms, to the north-east, where there are only detached mountains, the "divortia 
aquarum" at the sources of the Batres and near Villabella, lat. $15^{\circ}-17^{\circ}$.

This line of separation of the waters is important in relation to facilities of intercourse, and to the increase of cultivation and civilisation: more to the north $\left(2^{\circ}-3^{\circ} \mathrm{N}\right.$. lat. $)$, a similar line divides the basin of the Orinoco from that of the Amazons and the Rio Negro. These risings or swellings in the plains (called, by Frontin, terræ tumores) might be regarded as undereloped systems of mountains, which would have connected two apparently isolated groups (the Sierra Parime and the Brazilian mountains) with the Andes of Timana and Cochabamba. These relations, which have been hitherto but little attended to, are the ground of the division which I have made of South America into three basins; viz. those of the lower Orinoco, of the Amazons, and of the Rio de la Plata. The first and last of these are steppes or prairies; the middle basin, that of the Amazons, between the Sierra Parime and the Brazilian group of mountains, is a forestcovered plain or Hylea.

If we wish to trace, in equally few lines, a sketch of the natural features of North America, let us cast our eyes first on the mountain chain which, running from south-east to north-west, at first low and narrow, and increasing both in breadth and height from Panama to Veragua, Guatimala, and Mexico (where it was the seat of a civilisation which preceded the arrival of Europeans), arrests the general equatorial current of the waters of the ocean, and opposes a barrier to the more rapid commercial intercourse of Europe and Western Africa with the eastern parts of Asia. North 
of the 17th degree of latitude and the celebrated isthmus of Tehuantepec, the mountains, quitting the coast of the Pacific, and following a more direct northerly course, become an inland Cordillera. In North Mexico, the "Crane Mountains" (Sierra de las Grullas) form part of the Rocky Mountain chain. Here rise, to the west, the Columbia and the Rio Colorado of California ; and, to the east, the Rio Roxo de Natchitoches, the Candian, the Arkansas, and the Platte or shallow river, a name which has latterly been ignorantly transformed into that of a silver-promising river Plate. Between the sources of these rivers (from N. lat. $37^{\circ} 20^{\prime}$ to $40^{\circ} 13^{\prime}$ ) rise three lofty summits (formed of a granite containing much hornblende and little mica), called Spanish Peak, James's or Pike's Peak, and Big Horn or Long's Peak. (See my Essai Politique sur la Nouvelle Espagne, 2me édit. t. i. pp. 82 and 109.) The elevation of these peaks exceeds that of any of the summits of the Andes of North Mexico, which, indeed, from the 18th and 19th parallels of latitude, or from the group of Orizaba and Popocatepetl (respectively 2717 toises or 17374 English feet, and 2771 toises or 17720 English feet,) to Santa Fé and Taos, never reach the limits of perpetual snow. James Peak, in lat. $38^{\circ} 40^{\prime}$, is supposed to be 1798 toises, or 11497 English feet; but of this elevation only 1335 toises (8537 English feet) has been measured trigonometrically, the remaining 463 toises, or 2960 English feet, being dependent, in the absence of barometrical observations, on uncertain estimations of the declivity of streams. As a trigonometrical measurement can hardly ever be undertaken 
from the level of the sea, measurements of inaccessible heights must generally be partly trigonometrical, and partly barometrical. Estimations of the fall of rivers, of their rapidity and of the length of their course, are so deceptive, that the plain at the foot of the Rocky Mountains, nearest to the summits above spoken of, was estimated, previous to the important expedition of Capt. Frémont, sometimes at 8000 , and sometimes at 3000 feet. (Long's Expedition, vol. ii. pp. 36, 362, 382, App. p. xxxvii.) It was from a similar deficiency of barometrical measurements that the true elevation of the Himalaya continued so long uncertain: but now the resources which belong to the cultivation of science have increased in India to such a degree, that Captain Gerard, when on the Tarhigang, near the Sutlej, north of Shipke, at an elevation of 19411 English feet, after breaking three barometers, had still four equally correct ones remaining. (Critical Researches on Philology and Geography, 1824, p. 144.)

Frémont, in the expedition which he made in the years 1842 - 1844 by order of the Government of the United States, found the highest summit of the whole chain of the Rocky Mountains to the north north-west of Spanish, James's, Long's, and Laramie Peaks. This snowy summit, of which he measured the elevation barometrically, belongs to the group of the Wind River mountains. It bears on the large map, edited by Colonel Abert, Chief of the Topographical Office at Washington, the name of Frémont's Peak, and is situated in $43^{\circ} 10^{\prime}$ lat. and $110^{\circ} 13^{\prime} \mathrm{W}$. long. from Greenwich, almost $5 \frac{1}{2}^{\circ}$ north of Spanish Peak. Its height, 
by direct measurement, is 12730 French, or 13568 English feet. This would make Frémont's Peak 324 toises (or 2072 English feet) higher than the elevation assigned by Long to James's Peak, which, according to its position, appears to be identical with Pike's Peak in the map above referred to. The Wind River mountains form the divortia aquarum, or division between the waters flowing towards either ocean. Captain Frémont (in his Official Report of the Exploring Expedition to the Rocky Mountains in the year 1842, and to Oregon and North California in the years 1843-44, p. 70,) says, "We saw, on one side, countless mountain lakes, and the sources of the Rio Colorado which carries its waters through the gulf of California to the Pacific; and, on the other side, the deep valley of the Wind river, where are situated the sources of the Yellowstone river, one of the principal branches of the Missouri which unites with the Mississippi at St. Louis. To the northwest, rise, covered with perpetual snow, the summits called the Trois Tetons, where the true source of the Missouri itself is situated, not far from that of the head water of the Oregon or Columbia, or the source of that branch of it called Snake River or Lewis Fork." To the astonishment of the adventurous travellers, they found the top of Frémont's Peak visited by bees : perhaps, like the butterflies seen by me, also among perpetual snow but in much more elevated regions in the Andes of Peru, they had been carried thither involuntarily by ascending currents of air. I have seen in the Pacific, at a great distance from the coast, large winged lepidopterous insects fall on the deck of the ship, 
having, no doubt, been carried far out to sea by land winds.

Frémont's map and greographical investigations comprehend the extensive region from the junction of the Kanzas river with the Missouri, to the falls of the Columbia and to the missions of Santa Barbara and Pueblo de los Angeles in New California; or a space of 28 degrees of longitude, and from the 34th to the 45 th parallel of latitude. Four hundred points have been determined hypsometrically by barometric observations, and, for the most part, geographically by astronomical observations; so that a district which, with the windings of the route, amounts to 3600 geogra. phical miles, from the mouth of the Kanzas to Fort Vancouver and the shores of the Pacific (almost 720 miles more than the distance from Madrid to Tobolsk), has been represented in profile, shewing the relative heights above the level of the sea. As I was, I believe, the first person who under. took to represent, in geognostic profile, the form of entire countries, - such as the Iberian peninsula, the highlands of Mexico, and the cordilleras of South America, (the semiperspective projections of a Siberian traveller, the Abbé Chappe, were founded on mere and generally ill-judged estimations of the fall of rivers), -it has given me peculiar pleasure to see the graphical method of representing the form of the earth in a vertical direction, or the elevation of the solid portions of our planet above its watery covering, applied on so grand a scale as has been done in Frémont's map. In the middle latitudes of $37^{\circ}$ to $43^{\circ}$, the Rocky Mountains present, besides the higher snowy summits 
comparable with the Peak of Teneriffe in elevation, Iofty plains of an extent hardly met with elsewhere on the surface of the earth, and almost twice as extensive in an east and west direction as that of the Mexican plateaux. From the group of mountains, which commences a little to the west of Fort Laramie to beyond the Wahsatch mountains, there is an uninterrupted swelling of the ground from 5300 to 7400 English feet above the level of the sea. A similar elevation may even be said to occupy the whole space from $34^{\circ}$ to $45^{\circ}$ between the Rocky Mountains proper and the Californian snowy coast chain. This space, a kind of broad longitudinal valley like that of the lake of Titiaca, has been called, by Joseph Walker, a traveller well acquainted with these western regions, and by Captain Frémont, "The Great Basin." It is a terra incognita of at least 128000 square miles in extent, arid, almost entirely without human inhabitants, and full of salt. lakes, the largest of which is 4200 English feet above the level of the sea, and is connected with the narrow lake of Utah. (Frémont, Report of the Exploring Expedition, pp. 154 and 273-276.) The last-mentioned lake receives the abundant waters of the "Rock River;" Timpan Ogo, in the Utah language. Father Escalante, in journeying, in 1776, from Santa Fé del Nuevo Mexico to Monterey in New California, discovered Frémont's "Great Salt Lake," and, confounding lake and river, gave it the name of Laguna de Timpanogo. As such I inserted it in my map of Mexico; and this has given rise to much uncritical discussion on the assumed non-existence of a great 
inland salt lake in North America,-a question previously raised by the well-informed American geographer, Tanner. (Humboldt, Atlas Mexicain, planche 2; Essai Politique sur la Nourelle Espagne, T. i. p. 231, T. ii. pp. 243, 313, and 420 ; Frémont, Upper California, 1848, p. 9 ; and, also, Duflot de Mofras, Exploration de l'Oregon, 1844, T. ii. p. 40.) Gallatin says expressly, in the Memoir on the Aboriginal Races in the Archæologia Americana, vol. ii. p. 140, "General Ashley and Mr. J. S. Smith have found the lake Timpanogo in the same latitude and longitude nearly as had been assigned to it in Humboldt's Atlas of Mesico."

I have dwelt on the remarkable swelling of the ground in the region of the Rocky Mountains, because, doubtless, by its elevation and extent, it exercises an influence hitherto but little considered, on the climate of the whole continent of North America, to the south and east. In the extensive continuous plateau, Frémont saw the waters covered with ice every night in the month of August. Nor is the elevation of this region less important as respects the social state and progress of the great United States of North America. Although the elevation of the line of the separation of the waters nearly equals that of the passes of the Simplon (6170 French, or 6576 English feet), of the St. Gothard (6440 French, or 6865 English feet), and of the St. Bernard (7476 French, or 7969 English feet), yet the ascent is so gradual, as to offer no obstacle to the use of wheel carriages of all kinds in the communication between the basins of the Missouri and the Oregon; in other words, 
between the states on the Atlantic Sea Board opposite Europe, and the new settlements on the Oregon and Columbia opposite China. The itinerary distance from Boston to Astoria on the Pacific at the mouth of the Columbia, is, according to the difference of longitude, 2200 geographicai miles, or about one-sixth less than the distance of Lisbon from the Ural near Katharinenburg. From the gentleness of the ascent of the high plateau which leads from the Missouri to California and to the basin of the Oregon,-(from the River and Fort Laramie, on the northern branch of the Platte River, to Fort Hall on the Lewis Fork of the Columbia, all the camping places of which the height was measured were from upwards of five to seven thousand, and at Old Park even $9 \% 60$ French, or 10,403 English feet); -it has not been easy to determine the situation of the culminating point, or "divortia aquarum." It is south of the Wind River mountains, nearly midway between the Mississipi and the coast of the Pacific, at an elevation of 7027 French, or 7490 English feet; therefore only 450 French, or 480 English, feet lower than the Pass of the great St. Bernard. The immigrants call this point "the South Pass." (Frémont's Report, pp. 3, 60, 70, 100, 129). It is situated in a pleasant district, in which the mica slate and gneiss rock are found covered with many species of Artemisia, particularly Artemisia tridentata (Nuttall), asters, and cactuses. Astronomical determinations give the latitude $42^{\circ} 24^{\prime}$, and the longitude $109^{\circ} 24^{\prime} \mathrm{W}$. from Greenwich. Adolph Erman has already called attention to the circumstance that the 
direction of the great chain of the Aldan mountains in the east of Asia, which divides the streams flowing into the Lena from those which flow towards the Pacific, if prolonged on the surface of the globe in the direction of a great circle, passes through several summits of the Rocky Mountains, between the parallels of $40^{\circ}$ and $55^{\circ}$ "Thus an American and an Asiatic chain of mountains appear to belong to one great fissure, following the direction of a great circle, or the shortest course from point to point." (Compare Erman's Reise um die Erde, Abth. I. Bd. iii. S. 8, Abth. II. Bd. i. S. 386, with his Archiv für wissenschaftliche Kunde von Russland, Bd. vi. S. 671).

The Rocky Mountains which sink down towards the Mackenzie River which is corered a large portion of the year with ice, and the highlands from which single snow-clad summits rise, are altogether distinct from the more westerly and higher mountains of the coast, or the chain of the Californian Maritime Alps, the Sierra Nevada de California. However ill selected the now generally used name of the Rocky Mountains, to designate the most northerly continuation of the Mexican Central Chain, it does not appear to me desirable to change it, as has been often proposed, for that of the Oregon Chain. Although these mountains do indeed contain the sources of Lewis's, Clark's, and North Fork, the three chief branches which form the mighty Oregon, or Columbia River, yet this river also breaks through the Californian chain of snow-clad Maritime Alps. The name of Oregon District is also employed politically and officially for the smaller territory west of the 
Coast Chain, where Fort Vancouver and the Ninlahmutti settlements are situated, and therefore it is the more desirable not to give the name of Oregon either to the Central or the Coast Chain. This name is connected with a most singular mistake of an eminent geographer, $\mathrm{M}$. Malte Brun: reading on an old Spanish map, "And it is not yet known, ( $y$ aun se ignora) where the source of this river" (the river now called the Columbia) "is situated," he thought he recognised in the word ignora the name of Oregon. (See my Essai politique sur 1a Nouvelle Espagne, T. ii. p. 314).

The rocks which, where the Columbia breaks through the Chain, form the Cataracts, mark the continuation of the Sierra Nevada de California from the 44th to the 47th degree of latitude. (Frémont, Geographical Memoir upon Upper California, 1848, p. 6.) This northern continuation comprises the three colossal summits of Mount Jefferson, Mount Hood, and Mount St. Helen's, which rise more than 14540 French or 15500 English feet above the level of the sea. The height of this Coast Chain, or Range, far exceeds, therefore, that of the Rocky Mountains. "During a journey of eight months' duration which was made along the Maritime Alps," says Captain Frémont, in his Report, p. 274, "we had snowy peaks always in view; we had surmounted the Rocky Mountains by the South Pass at an elevation of 7027 (74.90 E.) feet, but we found the passes of the Maritime Alps, which are divided into several parallel ranges, more than 2000 feet higher ;" therefore, only about 1170 feet $1247 \mathrm{E}$.) below the summit of Etna. It is extremely 
remarkable, and reminds us of the difference between the eastern and western cordilleras of Chili, that it is only the chain of mountains nearest to the sea (the Californian range), which has still active volcanoes. The conical mountains of Regnier and St. Helen's are seen to emit smoke almost constantly, and on the 23rd of Norember 1843, Mount St. Helen's sent forth a quantity of ashes which covered the banks of the Columbia for forty miles like snow. To the rolcanic Coast Range also belong, (in Russian America in the high north), Mount St. Elias (1980 toises high, according to La Perouse, and 2792 toises, according to Malaspina (12660 and 17850 E. feet), and Mount Fair Weather, (Cerro de Buen Tempo) 2304 toises, or 14732 E. feet high. Both these mountains are supposed to be still active volcanoes. Frémont's expedition, (which was important alike for its botanical and geological results), collected volcanic products, such as scoriaceous basalt, trachyte, and even obsidian, in the Rocky Mountains, and found an extinct volcanic crater a little to the east of Fort Hall, (lat. $43^{\circ} 2^{\prime}$, long. $\left.112^{\circ} 28 \mathrm{~W}.\right)$; but there are no signs of volcanoes still active, that is to say, emitting at times lava or ashes. We are not to confound with such activity the still imperfectly explained phenomenon of "smoking hills ;" "côtes brûlées," or "terrains ardens," as they are called by the English settlers, and by natives speaking French. An accurate observer, M. Nicollet, sars, "ranges of low conical hills are covered with a thick black smoke almost periodically, and often for two or three years together. No flames are seen." This phenomenon 
shews itself principally in the district of the Upper Missouri, and still nearer to the eastern declivity of the Rocky Mountains, where a river bears the native name of MankizitahWatpa, or the "river of the smoking earth." Scoriacous pseudo-volcanic products, such as a kind of porcelain jasper, are found in the vicinity of the "smoking hills." Since the expedition of Lewis and Clark an opinion has become prevalent that the Missouri deposits real pumice on its banks. Fine cellular whitish masses have been confounded with pumice. Professor Ducatel was disposed to ascribe this appearance, which was principally observed in the chalk formation, to a "decomposition of water by sulphuric pyrites, and to a reaction on beds of lignite." (Compare Trémont's Report, p. 164, 184, 187, 193, and 299, with Nicollet's Illustration of the Hydrographical Basin of the Upper Mississipi River, 1843, p. 39-41.)

If, in concluding these few general considerations on the physical geography of North America, we once more turn our attention to the spaces which separate the two diverging coast chains from the central chain, we find, in striking contrast, on the one hand, the arid uninhabited plateau of above five or six thousand feet elevation, which in the west intervenes between the central chain and the Californian Maritime Alps which skirt the Pacific; and on the eastern side of the Rocky Mountains, between them and the Alleghanies, (the highest summits of which, Mount Washington and Mount Marcy, are, according to Iuyell, 6240 and 5066 French, or 6652 and 5400 English feet above the level of the sea, the vast, well-watered, and fertile 
low plain or basin of the Mississipi, the greater part of which is from 400 to 600 French feet above the level of the sea, or about twice the elevation of the plains of Lombardy. The hypsometric conformation of this eastern region, $i . e$. the altitude of its several parts above the sea, has been elucidated by the valuable labours of the highly-talented French astronomer, Nicollet, of whom science has been deprived by a too early death. His large and excellent map of the Upper Mississipi, constructed in the years 1836-1840, is based on 240 astronomically determined latitudes, and 170 barometric measurements of elevation. The plain which contains the basin of the Mississipi is one with the Northern Canadian plain, so that one low region extends from the Gulf of Mexico to the Arctic Sea. (Compare my Rélation Historique T. iii. p. 234, and Nicollet's Report to the Senate of the United States, 1843, p. 7 and 5\%.) Where the plain is undulating, and where, between $47^{\circ}$ and $48^{\circ}$ of latitude, low hills (côteaux des prairies, and côteaux des bois, in the still un-English nomenclature of the natives) occur in connected ranges, these ranges and gentle swellings of the ground divide the waters which flow towards Hudson's Bay from those which seek the Gulf of Mexico. Such a dividing line is formed north of Lake Superior by the Missabay Heights, and more to the west by the "Hauteurs des Terres," in which were first discovered, in 1832, the true sources of the Mississipi, one of the largest rivers in the world. The highest of these ranges of hills hardly attains an elevation of 1400 to 1500 (1492 to 1599 English) feet. From St. Louis, a little to the soutb of the junction of the Mis- 
souri and the Mississipi, to the mouth of the latter river at Old French Balize, it has only a fall of 357 (380 English) feet in an itinerary distance of more than 1280 geographical miles The surface of Lake Superior is 580 (618 English) feet above the level of the sea, and its depth near Magdalen Island is 742 (791 English) feet; its bottom, therefore, is 162 (173 English) feet below the surface of the ocean: (Nicollet, p. 99, 125, and 128.)

Beltrami, who separated himself from Major Long's expedition in 1825, boasted of having discovered the source of the Mississipi in Lake Cass. The river in the upper part of its course passes through four lakes, of which Lake Cass is the second. The uppermost is the Istaca Lake (in lat. $47^{\circ}$ $13^{\prime}$ and long. $95^{\circ} 0^{\prime}$ ), and was first recognised as the true source of the Mississipi in the expedition of Schoolcraft and Allen in 1832. This afterwards mighty river is only 17 feet wide and 15 inches deep when it issues from the singular horse-shoe-shaped Lake of Istaca. Itwas not until the scientific expedition of Nicollet, in 1836, that a clear knowledge of the localities was obtained and rendered definite by astronomically determined positions. The height of the sources of the Mississipi, viz. of the remotest affluent received by the Lake of Istaca from the dividing ridge or "Hauteur de Terre," is 1575 (1680 English) feet above the level of the sea. In the immediate vicinity, and indeed on the southern slope of the same dividing ridge, is Elbow Lake, in which the smaller Red River of the North, which after many windings flows into Hudson's Bay, has its origin. The Carpathian mountains present similar circumstances in the 
proximity and relative positions of the sources of rivers which send their waters respectively to the Black Sea and to the Baltic. Twenty small lakes, forming narrow groups to the south and west of Lake Istaca, have received from $M$. Nicollet the names of distinguished European astronomers, adversaries as well as friends. The map thus becomes a kind of geographical album, reminding one of the botanical album of Ruiz and Pavon's Flora Peruviana, in which the names of new genera of plants were adapted to the Court Calendar, and to the various changes taking place in the Oficiales de la Secretaria.

To the east of the Mississipi dense forests still partially prevail; but to the west of the river there are only Prairies, in which the buffalo (Bos americanus), and the musk ox (Bos moschatus), feed in large herds. Both these animals, (the largest of the New World) serve the wandering Indians, the Apaches Llaneros and the Apaches Lipanos, for food. The Assiniboins sometimes kill in a few days from seven to eight hundred bisons in what are called "bison parks," artificial enclosures into which the wild herds are driven. (Maximilian, Prinz zu Wied, Reise in das innere Nord-America, Bd.i.1839, S.443.) The American bison, or buffalo, called by the Mexicans Cibolo, which is frequently killed merely for the sake of the tongue a much-prized dainty, is by no means a mere variety of the Aurochs of the Old Continent; although some other kinds of animals, as the elk (Cerrus alces) and the reindeer (Cervus tarandus), and even, in the human race, the short-statured polar man, are common to the northern parts of both continents, evidencing 
their former long continued connection. The Mexicans call the European ox in the Aztec dialect "quaquahue," a horned animal, from quaquahuitl, a horn. Some very large horns of cattle found in the ancient Mexican buildings not far from Cuernavaca, to the south-west of the city of Mexico, appear to me to have belonged to the musk ox. The Canadian bison can be tamed to agricultural labour. It breeds with the European cattle, but it was long uncertain whether the hybrid was fruitful. Albert Gallatin, who, before he appeared in Europe as a distinguished diplomatist, had obtained by personal inspection great knowledge of the uncultivated parts of the United States, assures us that "the mixed breed was quite common fifty years ago in some of the north-western counties of Virginia; and the cows, the issue of that mixture, propagated like all others." "I do not remember," he adds, "the grown bison being tamed, but sometimes young bison calves were caught by dogs, and were brought up and driven out with the European cows." At Monongahela all the cattle were for a long time of this mixed breed : but complaints were made that they gave very little milk. The favourite food of the bison or buffalo is Tripsacum dactyloides (called buffalo grass in North Carolina), and an undescribed species of clover nearly allied to Trifolium repens, and designated by Barton as Trifolium bisonicum.

I have already called attention elsewhere (Cosmos, vol. ii. note 455, English ed.) to the circumstance that, according to a statement of the trustworthy Gomara, (Historia General de las Indias, cap. 214) there was still living in the six- 
teenth century, in the north-west of Mexico, in $40^{\circ}$ latitude, an Indian tribe, whose principal riches consisted in herds of tame bisons (bueyes con una giba). But notwithstanding the possibility of taming the bison, notwithstanding the quantity of milk it yields, and notwithstanding the herds of lamas in the Cordilleras of Peru, no pastoral life or pastoral people were found when America was discovered, and there is no historical evidence of this intermediate stage in the life of nations ever having existed there. It is worthy of remark that the American buffalo or bison has exerted an influence on the progress of geography in trackless mountainous regions. These animals wander in the winter, in search of a milder climate, in herds of several thousands to the south of the Arkansas River. In these migrations their size and unwieldiness make it difficult for them to pass over high mountains. When, therefore, a well-trodden buffialo path is met with, it is advisable to follow it, as being sure to conduct to the most convenient pass across the mountains. The best routes through the Cumberland Mountains, in the south-west parts of Virginia and Kentucky, in the Rocky Mountains between the sources of the Yellow Stone and the Platte, and between the southern branch of the Columbia and the Rio Colorado of California, were thus marked out beforehand by buffalo paths. The advance of settlement and cultivation has gradually driven the buffalo from all the Eastern states: they formerly roamed on the banks of the Mississipi and of the Ohio far beyond Pittsburg. (Archæologia Americana, vol. ii., 1836, p. 139.) 
From the granitic cliffs of Diego Ramirez,-in the deeply indented and intersected Tierra del Fuego, which contains on the east silurian schists and on the west the same schists altered by the metamorphic action of subterranean fire, (Darwin's Journal of Researches into the Geology and Natural History of the Countries visited in 1832-1836 by the Ships Adventure and Beagle, p. 266), - to the North Polar Sea, the Cordilleras extend in length more than 8000 geographical miles. They are the longest though not the loftiest chain on our planet; being raised from a cleft running in the direction of a meridian from pole to pole, and exceeding in linear distance the interval which in the Old Continent separates the Pillars of Hercules from the Icy Cape of the Tchuktches in the north-east of Asia. Where the Andes divide into several parallel chains, it is remarked that the ranges nearest the sea are usually those which exhibit most volcanic activity; but it has also been observed repeatedly, that when the phenomena of still active subterranean fire disappear in one chain, they break out in another chain running parallel to it. Generally speaking, the volcanic cones are found in a direction corresponding with that of the axis of direction of the entire chain; but in the elevated highlands of Mexico the active volcanoes are placed along a transverse cleft running from sea to sea in the east and west direction. (Humboldt, Essai Politique, T. ii. p. 173.) Where, by the elevation of mountain masses in the ancient corrugation or folding of the crust of the earth, access has been opened to the molten interior, that interior continues to act, through the medium of the cleft, 
upon the upheared wall-like mass. That whicn we now call a mountain chain has not arrived at once at its present state: rocks, very different in the order of succession in reference to age, are found superimposed upon each other, and have penetrated to the surface by early formed channels. The various nature of the formations is due to the outpouring and elevation of eruptive rocks, as well as to the slow and complicated process of metamorphic action taking place in clefts filled with vapours and favourable to the conduction of heat.

For a long time past, from 1830 to 1848 , the following have been regarded as the culminating or highest points of the Cordilleras of the New Continent.

The Nevado de Sorata, also called Ancohuma or Tusubaya, (S. lat. $15^{\circ} 52^{\prime}$ ) a little to the south of the village of Sorata or Esquibel, in the eastern Bolivia Range: elevation 3949 toises, or 23692 Parisian, or 25250 English feet.

The Nevado de Illimani, west of the Mission of Yrupana (S. lat. $16^{\circ} 38^{\prime}$ ) in the same mountain range as Sorata: elevation 3753 toises, or 22518 Parisian, or 24000 English feet.

The Chimborazo (S. lat. $1^{\circ} 27^{\prime}$ ) in the province of Quito: elevation 3950 toises, or 20100 Parisian, or 21423 English feet.

The Sorata and Illimani were first measured by a distinguished geologist, Mr. Pentland, in 1827, and also in 1838. Since the publication, in June 1848, of his great map of the basin of the lake of Titiaaca, we know that the above-mentioned elevations of these two mountains are 
respectively 3960 and 2851 English feet, too great. The map gives to the Sorata 21286, and to the Illimani 21149 English feet. A more exact calculation of the trigonometrical operations of 1838 has led Mr. Pentland to these new results. There are, according to him, in the western Cordillera four peaks of from 21700 to 22350 English feet. The highest of these, the peak of Sahama, would thus be 926 English feet higher than the Chimborazo, and but 850 English feet lower than the Volcano of Acongagua, measured by the expedition of the Beagle (Fitz Roy's Narrative, Vol. ii. p. 481.)

\section{${ }^{6}$ ) p. 3.- "The Desert near the basaltic mountains of Harudsh."}

Near the Egyptian-Natron Lakes, (which in the time of Strabo had not yet been divided into six reservoirs), there is a range of hills which rises steeply on the northern side, and runs from east to west past Fezzan, where it finally appears to join the chain of the Atlas. It divides in north-eastern Africa, as the Atlas does in north-western Africa, the inhabited maritime Lybia of Herodotus from the land of the Berbers, or Biledulgerid, abounding in wild animals. From the limits of Middle Egypt the whole region south of the 30th degree of North latitude is a sea of sand, in which are dispersed islands, or Oases, containing springs of water and a flourishing vegetation. The number of these Oases, of which the ancients only reckoned three, and which Strabo compared to the spots on a panther's skin, has been considerably augmented by the discoveries of modern travellers. The third Oasis of the ancients, now called 
Siwah, was the Nomos of Ammon; a residence of priests, a resting place for caravans, and the site of the temple of the horned Ammon and the supposed periodically cool fountain of the Sun. The ruins of Ummibida, (OmmBeydah), belong incontestibly to the fortified caravanserai at the temple of Ammon, and therefore to the most ancient monuments which have come down to us from the early dawn of civilization. (Caillaud, Voyage à Syouah, p. 14; Ideler in den Fundgruben des Orients, Bd. iv. S. 399. 411).

The word Oasis is Egyptian, and synonymous with Auasis and Hyasis (Strabo, lib. ii. p. 130, lib. xvii. p. 813, Cas.; Herod. lib. iii. cap. 26, p. 207, Wessel). Abulfeda calls the Oases, el-Wah. In the later times of the Cæsars, malefactors were sent to the Uases; being banished to these islands in the sea of sand, as the Spaniards and the English have sent criminals to the Falklands or to New Holland. Escape by the ocean is almost easier than through the desert. The fertility of the Oases is subject to diminution by the invasion of sand.

The small mountain-range of Harudsh is said to consist of basaltic hills of grotesque form (Ritter's Afrika, 1822, S. 885, 988, 993, and 1003). It is the Mons Ater of Pling; and its western extremity or continuation, called the Soudah mountains, has been explored by my unfortunate friend, the adventurous traveller Ritchie. This eruption of basalt in tertiary limestone, rows of hills rising abruptly from dike-like fissures, appears to be analogous to the outbreak of basalt in the Vicentine territory. Nature often repeats the same phenomena in the most distant 
parts of the earth. In the limestone formations of the "white Harudsh" (Harudje el-Abiad), which perhaps belong to the old chalk, Hornemann found an immense number of fossil heads of fish. Ritchie and Lyon remarked that the basalt of the Soudah mountains, like that of the Monte Berico, was in many places intimately mixed with carbonate of lime,-a phenomenon probably connected with eruption through limestone strata. Lyon's map even mentions dolomite in the neighbourhood. Modern mineralogists have found syenite and greenstone in Egypt, but not basalt. Possibly the material of some of the ancient Egyptian vases, which are occasionally found of true basalt, may have been taken from these western mountains. May "Obsidius lapis" also have been found there? or are basalt and obsidian to be sought for near the Red Sea? The strip of volcanic or eruptive formations of the Harudsh, on the margin of the African desert, reminds the geologist of the augitic vesicular amygdaloid, phonolite, and greenstone porpyhry, which are only found at the northern and western boundaries of the Steppes of Venezuela and of the plains of the Arkansas, as it were on the hills of the ancient coast line. (Humboldt, Relation Historique, tom. ii. p. 142 ; Long's Expedition to the Rocky Mountains, vol. ii. pp. 91 and 405.)

(7) p. 3.- "When suddenly deserted by the east wind of the tropics in a sea covered with weed."

It is a remarkable phenomenon, well known among sailors, that in the vicinity of the African coast (between the Canaries and the Cape de Verde Islands, and particularly between Cape Bojador and the mouth of the Senegal), 
a west wind often takes the place of the general east or trade-wind of the tropics. It is the wide expanse of the desert of Sahara which causes this westerly wind. The air orer the heated sandy plain becomes rarefied and ascends, the air from the sea rushes in to supply the roid so formed, and thus there sometimes arises a west wind, adverse to ships bound to the American coast, which are made in this manner to feel the vicinity of the heat-radiating desert without even seeing the continent to which it belongs. The changes of land and sea breezes, which blow alternately at certain hours of the day or night on all coasts, are due to the same causes.

The accumulation of sea-weed in the neighbourhood of the African coast has been often spoken of by ancient writers. The locality of this accumulation is a problem which is intimately connected with our conjectures respecting the extent of Phonician navigation. The Periplus, which has been ascribed to Scylas of Caryanda, and which, according to the researches of Niebuhr and Letronne, was very probably compiled in the time of Philip of Macedon, describes beyond Cerne a quantity of fucus forming a weedcorered sea-a kind of "Mar de Sargasso ;" but the locality indicated appear's to me to differ very much from that assigned in the work entitled "De Mirabilibus Auscultationibus," which long bore, unduly, the great name of Aristotle. (Compare Scyl. Caryand. Peripl. in Hudson, vol. ii. p. 5̌B, with Aristot. de Mirab. Auscult. in opp. omnia ex. rec. Bekkeri, p. 844, § 136.) The pseudo-Aristotle says, "Phœnician mariners, driven by the east wind, came in four days' sail from Gades to a nart where they found the sea 


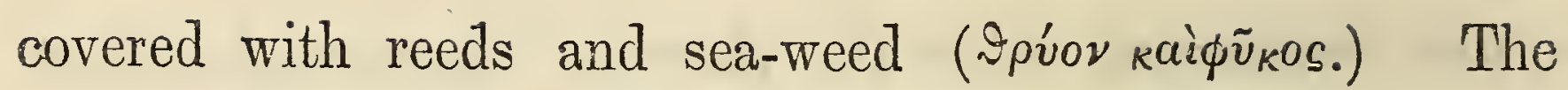
sea-weed is uncovered at ebb and covered at flood tide." Is he not here speaking of a shallow place between the $34^{\circ}$ and $36^{\circ}$ of latitude? Has a shoal dissappeared in consequence of volcanic eruption? Vobonne speaks of rocks north of Madeira. (Compare also Edrisi, Geog. Nub., 1619, p. 15\%.) In Scylax it is said, "The sea beyond Cerne is unnavigable on account of its great shallowness, its muddiness, and the great quantity of sea grasses. The sea grass lies a span thick, and is full of points at the top, so that it pricks." The sea-weed found between Cerne,(the Phœnician station for laden vessels, Gaulea, or, according to Gosselin, the small island of Fedallah, on the north. western coast of Mauritania), - and Cape de Verde, does not now by any means form a great sea meadow, or connected tract of fucus, a "mare herbidum," such as exists beyond the Azores. In the poetic description of the coast by Festus Avienus, (Ora Maritima, v. 109, 122, 388, and 408), in the composition of which, as Avienus himself says, (v. 412) he availed himself of the journals of Phœnician ships, the obstacle presented by the sea-weed is referred to in a very circumstantial manner; but its site is placed much farther north, towards Ierne, the "Sacred Island."

Sic nulla late flabra propellunt ratem, Sic segnis humor æquoris pigri stupet. Adjicit et illud, plurimum inter gurgites

Exstare fucum, et sæpe virgulti vice

Retinere puppim

Hæc inter undas multa cæspitem jacet,

Eamque late gens Hibernorum colit. 
In remarking that the fucus and the mud or mire, ( $\pi \eta \lambda$ ós , the shallowness of the sea, and the perpetual calms, are always spoken of by the ancients as characteristics of the western ocean beyond the Pillars of Hercules, one is disposed, more particularly on account of the mention of the calms, to ascribe something to Punic artifice,- - to the desire of a great trading people to deter others, by the apprehension of dangers and diffculties, from entering into competition with them in western narigation and commerce. But even in the genuine writing's of Aristotle (Meteorol. ii. p. 1, 14, he maintains this same opinion of the absence of wind in those regions, and seeks the explanation of what he erroneously supposes to be a fact of observation, but which is more properly a fabulous mariner's tale, in an hypothesis concerning the depth of the sea. In reality, the stormy sea between Gades and the islands of the Blest or Fortunate Islands, (between Cadix and the Canaries), is rery unlike the sea farther to the south between the tropics, where the gentle trade winds blow, and which is called very characteristically by the Spaniards, el Golfo de las Damas, the Ladies' Gulf. (Acosta Historia natural y moral de las Indias, lib. iii. cap. 4.)

From very careful researches by myself, and. from the comparison of the logs or journals of many English and French vessels, I infer that the old and indefinite expression, Mar de Sargasso, includes two banks of fucus, of which the greater and eastermmost one, of a lengthened shape, is situated between the parallels of $19^{\circ}$ and $34^{\circ} \mathrm{N}$. lat., in a meridian of 7 degrees to the west of the Fsland of 
Corvo, one of the Azores; while the lesser and westernmost bank, of a roundish form, is situated between the

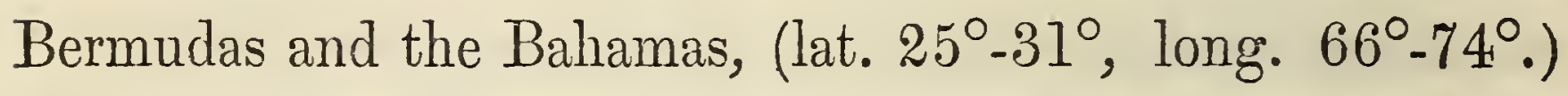
The longer axis of the small bank which is crossed by ships going from Baxo de Plata (Caye d'Argent, Silver Cay) on the north of St. Domingo, to the Bermudas, appears to have a N. $60^{\circ} \mathrm{E}$. direction. A transverse band of Fucus natans, running in an East and West direction between the parallels of $25^{\circ}$ and $30^{\circ}$, connects the greater and lesser banks. I have had the gratification of seeing these inferences approved by my honoured friend Major Rennell, and adopted by him in his great work on Currents, where he has further supported and confirmed them by many new and additional observations. (Compare Humboldt, Relation Historique, tom. i. p. 202, and Examen critique, tom. iii. p. 68-99, with Rennell's Investigation of the Currents of the Atlantic Ocean, 1832, p. 184.) The two groups of sea-weed, included together with the transverse connecting band under the old general name of the Sargasso Sea, occupy altogether a space exceeding six or seven times the area of Germany.

Thus it is the vegetation of the ocean which offers the most remarkable example of an assemblage of "social plants" of a single species. On terra firma, the savannahs or prairies, or grassy plains of America, the heaths (ericeta), and the forests of the North of Europe and Asia, consisting of coniferous trees, birches, and willows, offer a less degree of uniformity than do those thalassophytes. Our heaths show, in the north, in addition to the prevailing Calluna 
vulgaris, Erica tetralis, E. ciliaris, and E. cinerea; and in the south, Erica arborea, E. scoparia, and E. meditterranea. The uniformity of the aspect offered by the Fucus natans is greater than that of any other assemblage or association of plants. Oviedo calls the fucus banks "meadors," praderias de yerva. Considering that the island of Flores was discovered in 1452, by Pedro Velasco, a native of the Spanish port of Palos, by following the flight of certain birds from the island of Fayal, it seems almost impossible, seeing the proximity of the great fucus bank of Corro and Flores, that a part of these oceanic meadows should not have been seen before Columbus, by Portuguese ships driven by storms to the westward. Yet the astonishment of the companions of Columbus in 1492, when surrounded by sea-weed uninterruptedly from the 16 th of September to the Sth of October, sherrs that the magnitude of the phenomenon at least was previously unknown to the sailors. The anxieties excited by the accumulation of sea-weed, and the murmurs of his companions in reference thereto, are not indeed mentioned by Cotumbus in the extracts from the ship's journal given by Las Casas. $\mathrm{He}$ merely speaks of the complaints and murmurs respecting the danger to be feared from the weak but constant East winds. It is only the son, Femando Colon, who, in writing his father's life, endearoured to depict the fears of the sailors in a dramatic manner.

According to my researches, Columbus crossed the great fucus bank in 1492 , in lat. $28 \frac{1}{3}^{\circ}$, and in 1493 , in lat. $37^{\circ}$, both times in the long. of from $38^{\circ}$ to $47^{\circ} \mathrm{W}$. This is 
deducible with tolerable certainty from Columbus's recorded estimation of the ship's rate, and the "distance daily sailed over ;" derived indeed, not from casting the log, but from data afforded by the running out of half-hour sandglasses (ampolletas). The first certain and definite mention of a log (catena della poppa) which I have been able to discover, is in the year 1521, in Pigafetta's journal of Magellan's Voyage round the World. (Cosmos, vol. ii. p. 259, and Note 405, English ed.) The determination of the ship's place, while Columbus was engaged in traversing the great meadows of sea-weed, is the more important, because we learn from it that for three centuries and a half the situation of this great accumulation of thalassophytes, whether resulting from the local character of the bottom of the sea, or from the direction of the Gulf stream, has remained the same. Such evidences of the permanency of great natural phenomena arrest the attention of the physical inquirer with double force, when they present themselves in the evermoving oceanic element. Although the limits of the fucus banks oscillate considerably, in correspondence with the variations of the strength and direction of the prevailing winds, yet we may still in the middle of the 19th century take the meridian of $41^{\circ} \mathrm{W}$. from Paris $\left(38^{\circ} 38^{\prime} \mathrm{W}\right.$. from Greenwich) as the principal axis of the "great bank." In the vivid imagination of Columbus, the idea of the position of this bank was intimately connected with the great physical line of demarcation, which, according to him, divided the globe into two parts, with the changes of magnetic variation, and with climatic relations. Columbus, 
when uncertain respecting his longitude, (February 1493), directed himself by the appearance of the first floating streamers of weed (de la primera yerva) on the eastern margin of the great Corro bank. The physical line of demarcation was, by the powerful influence of the Admiral, converted on the 4th of May, 1493, into a political line, being made the celebrated "line of demarcation" between the Spanish and Portuguese rights of possession. (Compare my Examen Critique, tom. iil. p. 64-99, and Cosmos, English ed. vol. ii. p. 279-280.)

(8) p. 3.- "The Nomadic Tibbos and Tuaricks."

These two nations inhabit the deserts between Bornou, Fezzan, and Lower Egypt. They were first made known to us with some exactness by Hornemann's and Lyon's travels. The Tibbos or Tibbous roam through the eastern, and the Tuaticks (Tuereg's) through the western, parts of the great desert. The first are called by the other tribes, from being in continual morement, "birds." The Tuaricks are distinguished into those of Aghadez and those of Tagazi. They are often engaged as conductors of caravans, and in trade. Their langrage is the same as that of the Berbers; and they belong unquestionably to the number of the primitive Lybian nations. The Tuaricks present a remarkable physiological phenomenon. Different tribes among them are, according to the climate, white, yellowish, and eren almost black; but all are without woolly hair or Negro features. (Exploration scientifique de l'Alg'érie, T. ii. p. 343.) 


\section{(9) p. 4.-" The Ship of the Desert."}

In oriental poems, the camel is called the land-ship, or the ship of the Desert (Sefynet-el-badyet); Chardin, Voyages, nouv. éd. par Langlès, 1811, T. iii. p. 376.

But the camel is not merely the carrier of the desert, and the link which, rendering communication between different countries possible; connects them with each other: he is also, as Carl Ritter has shewn in his excellent memoir on the sphere of diffusion of these animals, the principal and essential condition of the nomadic life of nations in the patriarchal stage of national development, in the hot parts of our planet where rain is either altogether wanting or very infrequent. No animal's life is so closely associated by natural bonds with a particular stage of the developement of the life of man,-a connection historically established for several thousand years, —as the life of the camel among the Bedouin tribes" (Asien, Bd. viii. Abth. i. 1847, S. 610 und 758). "The camel was entirely unknown to the cultivated Carthaginian nation through all the centuries of their flourishing existence, until the destruction of their city. The Marusians first brought it into military use, in the train of armies, in Western Lybia, in the times of the Cæsars; perhaps in consequence of its employment in commercial operations in the valley of the Nile by the Ptolemies. The Guanches, the inhabitants of the Canary Islands and probably related to the Berber race, were not acquainted with the camel before the 15 th century, 
when it was introduced by Norman conquerors and settlers. In the probably very limited communication of the Guanches with the Coast of Africa, the small size of the boats would prevent the transport of large animals. The true Berber race, diffused throughout the interior of Northern Africa, and to which the Tibbos and Tuaricks, as already mentioned, belong, owes doubtless to the use of the camel throughout the Lybian desert and its Oases, not only the advantages of intercommunication, but also the preservation of its national existence to the present day. On the other hand, the negro races never, of their own accord, made any use of the camel ; it was only in company with the conquering expeditions and proselyting missions of the Bedouins, carrying their prophet's doctrines over the whole of Northern Africa, that the useful animal of the Nedjid, of the Nabatheans, and of all the countries inhabited by Aramean races, spread to the westward and was introduced among the black popu lation. The Goths took camels as early as the fourth century to the Lower Istros (the Danube), and the Ghaznevides conveyed them in much larger numbers as far as India and the banks of the Ganges." We must distinguish two epochs in the diffusion of the camel throughout the northern part of the African continent; one under the Ptolemies, operating through Cyrene on the whole of the north-west of Africa; and the Mohammedan epoch of the conquering Arabs.

It has long been a question, whether those domestic animals which have been the earliest companions of mankindoxen, sheep, dogs, and camels -are still to be metwith in a 
state of original wildness. The Hiongnu, in Eastern Asia, belong to the nations who earliest tamed and trained wild camels as domestic animals. The compiler of the great Chinese work, Si-yu-wen-kien-lo, (Historia Regionum occidentalium, quæ Si-yu vocantur, visu et auditu cognitarum,) affirms that in the middle of the 18th century wild camels, as well as wild horses and wild asses, still wandered in East Turkestan. Hadji Chalfa, in his Turkish Geography, written in the 17th century, speaks of the frequent chase of the wild camel in the high plains of Kashgar, Turfan, and Khotan. Schott translates, from a Chinese author, Ma-dschi, that wild camels are to be found in the countries to the north of China and west of the Hoang-ho, in Ho-si or Tangut. Cuvier alone (Règne Animal, T. i. p. 257), doubts the present existence of wild camels in the interior of Asia. He believes they have merely "become wild;" because Calmucks, and others having Buddhistic religious affinities with them, set camels and other animals at liberty, in order " to acquire to themselves merit for the other world." According to Greek witnesses of the times of Artemidorus and Agatharchides of Cnidus, the Ailanitic Gulf of the Nabatheans was the home of the wild Arabian camel. (Ritter's Asien, Bd. viii. s. 670, 672, and 746.) The discovery of fossil camel bones of the ancient world by Captain Cautley and Doctor Falconer, in 1834, in the subHimalaya range of the Sewalik hills, is peculiarly deserving of notice. These bones were found with other ancient bones of mastodons, of true elephants, of giraffes, and of a gigantic land tortoise (Colossochelys), twelve feet in length 
and six feet in height. (Humboldt, Cosmos, Engl. ed. vol. i. p. 268.) This camel of the Ancient World has received the name of Camelus sivalensis, but does not show any considerable difference from the still living Egyptian and Bactrian camels with one and two humps. Forty camels have very recentì been introduced into Java, having been brought there from Teneriffe. (Singapore Journal. of the Indian Archipelago, 1847, p. 206.) The first experiment has been made in Samarang. In like manner, reindeer have only been introduced into Iceland from Norway in the course of the last century. They were not found there when the island was settled, notwithstanding the proximity to East Greenland, and the existence of floating masses of ice. (Sartorius von Waltershausen physisch-geographische Skizze von Island, 1847, S. 41.)

(10) p. 4.)-"Between the Altai and the Kuen-liun."

The great highland, or, as it is commonly called, the mountain plateau of Asia, which includes the lesser Bucharia, Songarei, Thibet, Tangut, and the Mogul country of the Chalcas and Olotes, is situated between the 36th and 48th degrees of latitude, and the meridians of $81^{\circ}$ and $118^{\circ} \mathrm{E}$. long. It is an erroneous view to represent this part of the interior of Asia as a single undivided mountainous gibbosity, continuous like the elevated plains of Quito and Mexico, and elevated from seven to nine thousand feet above the level of the sea. That there is not in this sense any undivided mountain plateau in the interior of Asia, has already been shewn by me in my "Researches respecting the Mountains of Northern India." 
(Humboldt, Premier Mémoire sur les Montagnes de l'Inde, in the Annales de Chimie et de Physique, T. iii. 1816, p. 303 ; Second Mérnoire, T. xiv. 1820, p. 5-55.)

My views concerning the geographical range of plants, and the mean degree of temperature requisite for certain kinds of cultivation, had early led me to entertain considerable doubts as to the continuity of a great Tartarian plateau between the Himalaya and the Altai. Writers continued to characterise this platean as it had been described by Hippocrates (De Fire et Aquis, § xcvi. p. 74), as "the high and naked plains of Scythia, which, without being crowned with mountains, rise and extend to beneath the constellation of the Bear." Klaproth has the undeniable merit of having been the first to make us acquainted with the true position, extent, and direction of two great and entirely distinct chains of mountains - the Kuen-luin and the Thianschan, in a part of Asia which is better entitled to the name of "central" than Kashmeer, Baltistan, and the Sacred Lakes of Thibet, (the Manasa and the Ravanahrada). The importance of the Celestial Mountains, the Thian-schan, had indeed been already surmised by Pallas, without his being aware of their volcanic nature; but this highly-gifted investigator of nature, hampered by the then prevailing hypothesis of a dogmatic and fantastic geology, firmly believing in "chains of mountains radiating from a centre," saw in the Bogdo Oola (the Mons Augustus, or culminating point of the Thian-schan) such a "central node, from whence all the Asiatic mountain chains diverge in rays, and which dominates over all the rest of the continent!" 
The erroneous idea of a single vast elevated plain occupying the whole of central Asia, the "Plateau de la Tartarie," took its rise in France, in the latter half of the 18th century. It was the result of historical combinations, and of a not sufficiently attentive study of the writings of the celebrated Venetian traveller, as well as of the naive relations of those diplomatic monks who, in the 13th and 14th centuries, (thanks to the unity and extent of the Mogul empire at that time) were able to traverse almost the whole of the interior of the continent, from the ports of Syria and of the Caspian Sea to the shores of the Pacific on the east coast of China. If a more exact acquaintance with the language and ancient literature of India had dated farther back among us than half a century, the hypothesis of this central plateau, occupying the wide space between the Himalaya and the south of Siberia, would no doubt have had adduced in its support an ancient and venerable authority from that source. The poem of the Mahabharata appears, in the geographical fragment Bhischmakanda, to describe "Meru" not so much as a mountain as an enormous elevation of the land, which supplies with water at once the sources of the Ganges, those of the Bhadrasoma (Irtysh), and those of the forked Oxus. These physico-geographical views were intermingled in Europe with ideas of other kinds, and with mythical reveries relating to the origin of mankind. It was said that the elevated regions from which the waters first retreated, (geologists in general were long averse to the theory of elevation), must also have received the first germs of civilisation. Hebraizing systems of geology, and views connected with the Deluge 
and supported by local traditions, favoured these assumptions. The intimate connection between time and space, between the beginnings of social order and the plastic character of the surface of the earth, lent to the supposed " uninterrupted Plateau of Tartary" a peculiar importance, and an almost moral interest. Acquisitions of positive knowledge, the late matured fruit of scientific travels and direct measurements, as well as of a fundamental study of Asiatic languages and literature especially those of China, have gradually demonstrated the inaccuracies and exaggerations of those wild hypotheses. The mountain plains (óporédıa) of Central Asia are no longer regarded as the cradle of civilization and the primitive seat of all arts and sciences. The ancient nation of Bailly's Atlantis, happily described by d'Alembert as "having taught us everything but their own name and existence," has vanished. The supposed inhabitants of the Oceanic Atlantis had already been treated, in the time of Posidonius, in a no less derisive manner. (Strabo, lib. ii. p. 102 ; and lib. xiii. p. 598, Casaub.)

A plateau of considerable but very unequal elevation, having the names of Gobi, Scha-mo (sand desert), Scha-ho (sand river), and Hanhai, runs in a SSW.-NNE. direction, with little interruption, from Eastern Thibet towards the mountain knot of Kentei south of Lake Baikal. This swelling of the ground is probably anterior to the elevation of the mountain chains by which it is intersected; it is situated, as already remarked, between $79^{\circ}$ and $116^{\circ}$ long. from Paris, $\left(81^{\circ}\right.$ and $118^{\circ} \mathrm{E}$. from Greenwich). Measured at right angles to its longitudinal axis, its breadth 
is, in the south between Ladak, Gertop, and H'lassa, (the seat of the great Tama,) 720 geographical miles; between Hami in the Celestial Mountains, and the great bend of the Hoang-ho near the In-schan chain, hardly 4.80 ; and in the north, between the Khanggai, where the great city of Karakhorum once stood, and the chain of Khin-gan-Petscha, which runs north and south (in the part of the Gobi traversed in travelling from Kiachta by Urga to Pekin) 760 geographical miles. The whole extent of this swelling ground, which must be carefully distinguished from the far more elevated mountain range to the east, may be approximately estimated, taking its inflections into account, at about three times the area of France. The map of the mountain ranges and volcanoes of Central Asia (Carte der Bergketten und Vulkane ron Central-Asien), constructed by me in 1839, but not published until 1843, shows in the clearest manner the hypsometric relations between the mountain ranges and the Gobi plateau. It was founded on the critical employment of all the astronomical determinations accessible to me, and on a vast amount of orographic description, in which Chinese literature is beyond measure rich, examined at my request by Klaproth and Stanislas Julien. My map marks the mean direction and the height of the mountain chains, and represents the leading features of the interior of the continent of Asia, from $30^{\circ}$ to $60^{\circ}$ degrees of north latitude, and between the meridians of Kherson and Pekin. It differs materially from any previously published map.

The Chinese have enjoyed a threefold advantage towards 
the collection of so great an amount of orographic data in the highlands of Asia, and more especially in the regions (hitherto so little known in the west), north and south of the Celestial mountains, between the In-schan, the mountain lake Khuku-noor, and the banks of the Ili and the Tarim. The three advantages I allude to are,- the military expeditions towards the west, (under the dynasties of Han and Thang 122 years before our era, and again in the ninth century when conquerors advanced as far as Ferghana and to the borders of the Caspian), together with the more peaceful conquests of Buddhistic pilgrims; - the religious interest attaching to certain lofty mountain summits on account of sacrifices to be periodically offered there;-and the early and general use of the compass in giving the directions of mountains and of rivers. The knowledge and use of the "South pointing" of the magnetic needle twelve centuries before our era, has given to the orographic and hydrographic descriptions of countries by the Chinese, a great superiority over the descriptions of the same kind which Greek or Roman writers have bequeathed to us, and which are besides extremely few. The acute and sagacious Strabo, was alike imperfectly acquainted with the direction of the Pyrenees, and with those of the Alps and of the Appennines. (Compare Strabo, lib. ii. p. 71 and 128 ; lib. iii. p. 137 ; lib.iv. p. 199 and 202 ; lib. v. p. 211, Casaub.)

To the lowlands belong almost the whole of Northern Asia to the north-west of the volcanic chain of the Thian-schan;the Steppes to the north of the Altai and of the Sayan chain; - the countries which extend from the mountains of 
Bolor, or Bulyt-Tagh, ("cloud mountains" in the Uigurian dialect) which follow a north and south direction, and from the upper Oxus, (whose sources were found by the Buddhistic pilgrims Hiuen-thsang and Song-yun in 518 and 629, by Marco Polo in 1277, and by Lieutenant Wood in 1838, in the Pamer Lake, Sir-i-kol, Lake Victoria), towards the Caspian; and from Tenghir or the Balkhash Lake through the Kirghis Steppe, towards the sea of Aral and the southern extremity of the Ural mountains. As compared with high plains of 6,000 to 10,000 feet above the level of the sea, it may well be permitted to use the expression of "lowlands" for flats of little more than 200 to 1200 feet of elevation. The lowest of the last two numbers corresponds nearly to the altitude of the town of Mannheim, and the highest to that of Geneva and Tubingen. If the word plateau, so often misemployed in modern works on geography, is to have its use extended to elevations which hardly present any sensible difference in climate and regetation, the indefiniteness of the expressions "highlands and lowlands," which are only relative terms, will deprive physical geography of the means of expressing the idea of the connection between elevation and climate, between the profile or relief of the ground and the decrease of temperature. When $\mathrm{I}$ found myself in Chinese Dzungarei, between the boundary of Siberia and Lake Dsaisang, at an equal distance from the Icy Sea and from the mouth of the Ganges, I might well consider myself in Central Asia. The barometer, however, soon taught me that the plains through which the Upper Irtysh flows, between Ustkamenogorsk and the Chinese 
Dzungarian Post, Chonimailachu, (sheep-bleating,) are scarcely raised 850 , or at the most 1170 , feet above the level of the sea. Pansner's older barometric measurements (which, however, were not published until after my expedition), are confirmed by mine. Both refute the hypothesis of Chappe, relative to the supposed high elevation of the banks of the Irtysh, in Southern Siberia; an hypothesis based on estimations of river declivities. Even further to the East, Lake Baikal is only 222 toises, or 1420 English feet, above the level of the sea.

In order to connect the idea of the relation of the terms lowlands and highlands and of the various gradations in the height of elevated plains or undulating grounds, with actual examples ascertained by measurement, I have subjoined a table, forming an ascending scale of such districts in different parts of the Globe. What I have said above respecting the mean height of those Asiatic $\mathrm{p}$ ains, which I have termed lowlands, may be compared with the following numbers:-

Toises. English feet.

Plateau of Auvergne . . . . . . . . 170

1087

" of Bavaria ........... 260

1663

" of Castille ........... 350

2239

" of Mysore ............ 460

2942

" of Caraccas............. 480

3070

" of Popayan ............. 900

5756

“ round Lake Tzana (in Abyssinia) ... 950

6076

" of the Orange River (in South Africa) 1000

6395

" of Axum (in Abyssinia) . . . . . 1100

7034

" of Mexico ............ 1170

7483

" of Quito ............. 1490

9528

" of the Province de los Pastos . . . . 1600

10231

66

round Lake Titiaca . . . . . . . . . 2010

12853 
No portion of the so-called Desert of Gobi (parts of which contain fine pastures) has been so thoroughly explored in respect to the differences of elevation as the zone, of nearly 600 geographical miles in breadth, between the sources of the Selenga and the great Wall of China. A very exact series of barometric levellings was executed under the auspices of the Academy of St. Petersburgh by tro distinguished Savans, the astronomer George Fuss, and the botanist Bunge. In the year 1832 they accompanied the mission of Greek monks to Pekin, to establish there one of the magnetic stations recommended by me. The mean height of this part of Gobi does not amount, as had been too hastily inferred from the measurement of neighbouring summits by the Jesuits Gerbillon and Verbiest to from 7500 to 8000 French ( 8000 to 8500 English) feet, but only to little more than half that height, or barely 4000 French or 4264 English feet. Between Erghi, Durma, and Scharaburguna, the ground is only 2400 French, or 2558 English, feet above the level of the sea, or hardly 300 French (320 English) feet higher than the plateau of Madrid. Erghi is situated midway, in lat. $45^{\circ} 31^{\prime}$, long. $111^{\circ} 26^{\prime}$ E. from Greenwich. There is here a depression of more than 240 miles in breadth, in a STT. and NE. direction. An ancient Mogul tradition marks it as the bottom of a former inland sea. There are found in it reeds and saline plants, mostly of the same kinds as those on the low shores of the Caspian. In this central part of the desert there are small salt lakes, from which salt is carried to China. According to a singular opinion rery 
prevalent among the Moguls, the ocean will one day return and establish its empire anew in Gobi. One is remirded of the Chinese tradition of the bitter lake, in the interior of Siberia, mentioned by me in another work. (Humboldt, Asie Centrale, tom. ii. p. 141; Klaproth, Asia Polyglotta, p. 232.) The valley or basin of Kashmeer, so enthusiastically extolled by Bernier, and but too moderately praised by Victor Jacquemont, has also given occasion to great hypsometric exaggerations. By a careful barometrical measurement, Jacquemont found the height of the Wulur Lake in the valley of Kashmeer, not far from the chief city Sirinagur, 836 toises, or 5346 English feet. Uncertain determinations by the boiling point of water gave Baron Carl von Hügel a result of 910, and Lieutenant Cunningham only 790 toises. (Compare my Asie Centrale, tom. iii. p. 310, with the Journal of the Asiatic Society of Bengal, vol. x. 1841,p. 114.) Kashmeer,-respecting which, in Germany particularly, so much interest has been felt, but the delightfulness of whose climate is considerably. impaired by four months of winter snow in the streets of Sirinagur (Carl von Hügel, Kaschmir, Bd. ii. S. 196), -is not situated, as is often supposed, upon the ridge of the Himalaya, but is a true cauldron-shaped valley (Kesselthal, Caldera,) on the southern declivity of those mountains. On the southwest, where the rampart-like elevation of the Pir Panjal separates it from the Punjaub, the snow-covered summits are crowned, according to Vigne, with formations of basalt and amygdaloid. The latter formation has received from the natives the characteristic name of "schischak 
deyu," marked by the devil's small-pox. (Vigne, Travels in Kashmeer, 1842, vol. i. p. 237-293.) The beauty of its vegetation has from the earliest times been very differently described, according as the visitor came from the rich and luxuriant vegetation of India, or from the northern regions of Turkestan, Samarcand, and Ferghana.

It is also only very recently that clearer views have been obtained respecting the elevation of Thibet; the level of the plateau having long been most uncritically confounded with the summits which rise from it. Thibet occupies the interval between the two great chains of the Himalaya and the Kuen-luin, forming the raised ground of the valley between them. It is divided from east to west, both by the natives and by Chinese geographers, into three portions. Upper Thibet, with its capital city H'lassa, probably 1500 toises (9590 English feet) above the level of the sea;Middle Thibet, with the town of Leh or Ladak (1563 toises, or 9995 English feet); -and Little Thibet, or Baltistan, called the Thibet of Apricots, (Sari Boutan), in which are situated Iskardo (985 toises, or 6300 English feet), Gilgit, and south of Iskardo but on the left bank of the Indus, the plateau of Deotsuh, measured by Vigne, and found to be 1873 toises, or 11,977 English feet. On examining all the notices that we possess respecting the three Thibets, (and which will have received in the present year a rich augmentation by the boundary expedition under the auspices of the governor-general, Lord Dalhousie), we soon become convinced that the region between the Himalaya and the Kuenlün is no unbroken plain or table land, but that it is interVOL. I. 
sected by mountain groups, undoubtedly belonging to wholly distinct systems of elevation. There are, properly speaking, very few plains; the most considerable are those between Gertop, Daba, Schang-thung (Shepherd's Plain) the native country of the Shawl-goat, and Schipke (1634 toises, 10,450 English feet); - those round Ladak, which have an elevation of 2100 toises, or 13450 English feet, and must not be confounded with the depression in which the town is situated;-and lastly, the plateau of the Sacred Lakes Manasa and Ravanahrada (probably 2345 toises), which was visited so early as 1625 by Pater Antonio de Andrada. Other parts are entirely filled with crowded mountainous elevations, "rising," as a recent traveller expresses it, "like the waves of a vast ocean." Along the rivers, the Indus, the Sutlej, and the Yaru-dzangbo-tschu which was formerly regarded as identical with the Brahma-putra, points have been measured which are only between 1050 and 1400 toises (671. and 8952 English feet) above the level of the sea; so also with respect to the Thibetian villages of Pangi, Kunawur, Kelu, and Murung. (Humboldt, Asie Centrale, T. iii. p. 281-325.) From many carefully collected measurements of elevation I think I may conclude that the plateau of Thibet, between $73^{\circ}$ and $85^{\circ} \mathrm{E}$. long., does not reach a mean height of 1800 toises (11510 English feet); this is hardly equal to the height of the fertile plain of Caxamarca in Peru, and is 211 and 337 toises (1350 and 2154 English feet) less than the height of the plateau of Titicaca, and the street pavement of the Upper Town of Potosi (2137 toises, 13,665 English feet). 
That outside of the Thibetian highlands and of the Gobi, the boundaries of which have been defined above, there are in Asia, between the parallels of $37^{\circ}$ and $48^{\circ}$, considerable depressions and even true lowlands, where one boundless uninterrupted plateau was formerly imagined to exist, is shewn by the cultivation of plants which cannot thrive without a certain degree of heat. An attentive study of the travels of Marco Polo, in which the cultivation of the vine and the production of cotton in northern latitudes are spoken of, had long called the attention of the acute Klaproth to this point. In a Chinese work, entitled "Information respecting the recently-subdued Barbarians (Sin-kiang-waitan-ki-lio)," it is said, "the country of Aksu, somewhat to the south of the Celestial Mountains (the Thian-schan), near the rivers which form the great Tarim-gol, produces grapes, pomegranates, and numberless other excellent fruits; also cotton (Gossypium religiosum), which covers the fields like yellow clouds. In the summer the heat is exceedingly great, and in winter there is here, as at Turfan, neither severe cold nor heary snow." The district round Khotan, Kashgar, and Yarkand, still pass its tribute in home-grctm cotton as it did in the time of Marco Polo. (Il Milione di Marco Polo, pubbl. dal Conte Baldelli, T. i. p. 32 and 8\%.) In the Oasis of Hami (Khamil), above 200 miles east of Aksu, orange trees, pomegranates, and vines whose fruit is of a superior quality, grow and flourish.

The products of cultivation which are thus noticed imply the existence of only a small degree of elevation, and that over extensive districts. At so great a distance from 
any coast, and in those easterly meridians where the cold of winter is known to exceed that of corresponding latitudes nearer our own part of the world, a plateau which should be as high as Madrid or Munich might indeed have very hot summers, but would hardly have, in $43^{\circ}$ and $44^{\circ}$ latitude, extremely mild winters with scarcely any snow. Near the Caspian, 83 English feet below the level of the Black Sea, at Astrachan in $46^{\circ} 21^{\prime}$ lat., I saw the cultivation of the vine greatly favoured by a high degree of summer heat; but the winter cold is there from $-20^{\circ}$ to $-25^{\circ}$ Cent. $\left(-4^{\circ}\right.$ to $-13^{\circ}$ Fahr.) It is therefore necessary to protect the vines after November, by sinking them deep in the earth. Plants which live, as. we may say, only in the summer, as the vine, the cotton bush, rice, and melons, may indeed be cultivated with success between the latitudes of $40^{\circ}$ and $44^{\circ}$ on plains of more than 500 toises (3197 English feet) elevation, being favoured by the powerful radiant heat; but how could the pomegranate trees of $\mathrm{Aksu}$, and the orange trees of Harni, whose fruit Père Grosier extolled as distinguished for its goodness, bear the cold of the loug and severe winter which would be the necessary consequence of a considerable elevation of the land? (Asie Centrale, T. ii. p. 48-52; and 429.) Carl Zimmerman (in the learned Analysis of his "Karte von Inner Asien," 1841, S. 99) has made it appear extremely probable that the Tarim depression, $i . e$. the desert between the mountain chains of the Thian-schan and the Kuen-liin, where the Steppe river Tarim-gol empties itself into the Lake of Lop, which used to be described as an alpine lake, is hardly 1200 (1279 English) feet above the level of the sea, or only twice 
the height of Prague. Sir Alexander Burnes also assigns to that of Bokhara only an elevation of 1190 English feet. It is earnestly to be desired, that all doubt respecting the elevation of the plateaur of middle Asia, south of $45^{\circ}$ of latitude, should finally be set at rest by direct barometric measurements, or by determinations of the boiling point of water made with more care than is usually given to them. All our calculations respecting the difference between the limits of perpetual snow, and the maximum elevation of vine cultivation in different climates, rest at present on too complex and uncertain elements.

In order to rectify in the smallest space that which was said in the last edition of the present work, relatively to the great mountain systems which intersect the interior of Asia, I subjoin the following general review. We begin with the four parallel chains, which follow with tolerable regularity an east and west direction, and are connected with each other at a few detached points by trausverse elevations. Differences of direction indicate, as in the Alps of western Europe, a difference in the epoch of elevation. After the four parallel chains (the Altai, the Thianschan, the Kuen-lün, and the Himalaya), we have to notice chains following the direction of meridians, viz. the Ural, the Bolor, the Khingan, and the Chinese chains, which, with the great bend of the Thibetian and AssamoBermese Dzangbo-tschu, run north and south. The Ural divides a part of Europe but little elevated abore the level of the sea from a part of Asia similarly circumstanced. The latter was called by Herodotus, (ed. Schweig- 
haüser, T. v. p. 204) and even as early as Pherecydes of Syros, a Scythian or Siberian Europe, including all the countries to the north of the Caspian and of the Iaxartes; in this view it would be a continuation of Europe "prolonged to the north of Asia."

1. The great mountain system of the Altai, (the "gold mountains" of Menander of Byzantium, an historical writer who lived as early as the 7th century, the Altaï-alin of the Moguls, and the Kin-schan of the Chinese), forms the southern boundary of the great Siberian lowlands; and running between $50^{\circ}$ and $52 \frac{1}{2}^{\circ}$ of north latitude, extends from the rich silver mines of the SnakeMountains, and the confluence of the Uba and the Irtysh, to the meridian of Lake Baikal. The divisions and names of the "Great" and the "Little Altai," taken from an obscure passage of Abulghasì, are to be altogether avoided. (Asie Centrale, T. i. p. 247.) The mountain system of the Altai comprehends (a) the Altai proper, or Kolywanski Altai, the whole of which is under the Russian sceptre; it is west of the transverse opening of the Telezki Lake, which follows the direction of the meridian; and in ante-historic times probably formed the eastern shore of the great arm of the sea, by which, in the direction of the still existing groups of lakes, Aksakal-Barbi and Sary-Kupa (Asie Centrale, T. ii. p. 138), the Aralo-Caspian basin was connected with the Icy sea:-(b) East of the Telezki chain which follows the direction of the meridian, the Sayani, Tangnu, and Ulangom or Malakha chains, all running tolerably parallel with each other and in an east and west direction. The Tangnu, which sinks down and terminates 
in the basin of the Selenga, has from very ancient times formed a boundary between the Turkish race to the south and the Kirghis (Hakas, identical with $\Sigma$ áral) in the north. (Jacob Grimm, Gesch. der deutschen Sprache, 1848, Th. i. S. 227.) It is the original seat of the Samoieds or Soyotes, who wandered as far as the Icy Sea, and who were long regarded in Europe as a nation belonging exclusively to the coasts of the Polar Sea. The highest snow-clad summits of the Altai of Kolywan are the Bielucha and the KatuniaPillars. The height of the latter is about that of Etna. The Daurian highland, to which the mountain knot of Kemtei belongs, and on the eastern side of which is the Jablonoi Chrebet, divides the depressions of the Baikal and the Amur.

2. The mountain system of the Thian-schan, or Celestial Mountains, the Tengri-tagh of the Turks (Tukiu) and of the kindred race of the Hiongnu, is eight times as long, in an east and west direction, as the Pyrenees. Beyond,-i.e. west of its intersection with the transverse or north and south chain of the Bolor and Kosuyrt, the Thian-schan bears the names of Asferah and Aktagh, is rich in metals, and has open fissures, which emit hot vapours, luminous at night, and which are used for obtaining sal-ammoniac. (Asie Centrale, T. ii. p. 18-20.) East of the transverse Bolor and Kosyurt chain, there follow successively in theThian-schan,the Kashgar Pass (Kaschgar-dawan); the Glacier Pass of Djeparle, which leads to Kutch and Aksu in the Tarim basin; the volcano of Pe-schan, which sent forth fire and streams of lava at least as late as the middle of the serenth century; the 
great snow-covered massive elevation Bogdo-Oola; the Solfatara of Urumsti, which furnishes sulphur and sal-ammoniac (nao-scha), and is situated in a coal district; the still active volcano of Turfan (or volcano of Ho-tscheu or Bischbalik), almost midway between the meridians of Turfan (Kune-. Turpan), and of Pidjan. The volcanic eruptions of the Thian-schan chain, recorded by Chinese historians, reach as far back as the year 89, A.D., when the Hiongnu of the sources of the Irtysh were pursued by the Chinese army as far as Kutch and Kharaschar (Klaproth, Tableau hist. de l'Asie, p. 108). The Chinese General, Teu-hian, surmounted the Thian-schan, and saw "the Fire Mountains which send out masses of molten rock that flow for many Li."

The great distance from the sea of the volcanoes of the interior of Asia is a remarkable and solitary phenomenon. Abel Rémusat, in a letter to Cordier (Annales des Mines, $\mathrm{T}$. v. 1820, p. 137), first directed the attention of geologists to this fact. The distance, for example, in the case of the volcano of Pe-schan, to the north, or to the Icy Sea at the mouth of the Obi, is 1528 geographical miles; to the south, or to the mouths of the Indus and the Ganges, 1512 geographical miles; to the west, 1360 geographical miles to the Caspian in the Gulf of Karaboghaz; and to the east, 1020 geographical miles to the shores of the sea of Aral. The active volcanoes of the New World were previously supposed to offer the most remarkable instances of such phenomena at a great distance from the sea ; their distance, however, is only 132 geographical miles in the case of the volcano of Popo- 
catepetl in Mexico, and only 92, 104, and 156 geographical miles in those of the South American volcanoes Sangai, Tolima, and de la Fragua, respectively. I exclude from these statements all extinct volcanoes, and all trachytic mountains which have no permanent connection with the interior of the earth. (Asie Centrale, T. ii. p. 16-55, 69-7\%, and 341356.) East of the volcano of Turfan, and of the fertile Oasis of Hami rich in fine fruit, the chain of the Thianschan gives place to the great elevated tract of Gobi which follows a S.W. and N.E. direction. This interruption of the mountain chain, caused by the transverse intersection of the Gobi, continues for more than $9 \frac{1}{2}$ degrees of longitude; but beyond it the mountains recommence in the somewhat more southerly chain of the In-schan, or the Silver Mountains, running (north of the Pe-tscheli) from west to east almost to the shores of the Pacific near Pekin, and forming a continuation of the Thian-schan. As I have viewed the - In-schan as an easterly prolongation (beyond the interruption of the Gobi) of the cleft above which theThian-schan stands,so one might possibly view the Caucasus as a westerly prolongation of the same, beyond the great basin of the Aral and Caspian Seas or the depression of Turan. The mean parallel of latitude or axis of elevation of the Thian-schan oscillates between $40 \frac{2}{3}^{\circ}$ and $43^{\circ} \mathrm{N}$. lat. ; that of the Caucasus, according to the map of the Russian Etat-Major (running rather E.S.E. and W.N.W.), is between $41^{\circ}$ and $44^{\circ} \mathrm{N}$. lat. (Baron von Meyendorff, in the Bulletin de la Societé géologique de France, T. ix. 1837-1838, p. 230.) Of the four parallel chains which traverse Asia from east to west, the Thian- 
schan is the only one in which no summits have yet had their elevation above the sea determined by measurement.

3. The mountain system of the Kuen-lün (Kurkun or Kulkun), if we include in it the Hindu-Coosh and its western prolongation in the Persian Elbourz and Demavend, is, next to the American Cordillera of the Andes, the longest line of elevation on the surface of our planet. Where the northand-south chain of Bolor intersects the Kuen-lün at right angles, the latter takes the name of the Thsung-ling (Onion Mountains), which is also given to a part of the Bolor at the eastern angle of intersection. The Kuen-lün, forming the northern boundary of Thibet, runs very regularly in an east and west direction, in the latitude of $36^{\circ}$. In the meridian of H'lassa an interruption takes place from the great mountain knot which surrounds the alpine lake of Khuku-noor, the Sing-so-hai, or Starry Sea, so celebrated in the mythical geography of the Chinese. The somewhat more northerly chains of Nan-schan and Kilian-schan may almost be regarded as an easterly prolongation of the Thian-schan. They extend to the Chinese wall near Liang-tscheu. West of the intersection of the Bolor and Kuen-lün (the Thsungling) I think I have been the first to shew (Asie Centrale, T. i. p. 23, and 118-159; T. ii. p. 431-434 and 465) that the corresponding direction of the axes of the Kuen-lün and the Hindu-Coosh (both being east and west, whereas the Himalaya is south-east and north-west) makes it reasunable to regard the Hindu-Coosh as a continuation, not of the Himalaya, but of the Kuen-lïn. From the Taurus in Lycia to Kafiristan, through an extent of 45 degrees of longitude, 
this chain follows the parallel of Rhodes, or the diaphragm of Dicearchus. The grand geognostical view of Errastosthenes (Strabo, Lib. ii. p. 68 ; Lib. xi. p. 490 and 511 ; and Lib. xv. p. 689), which is farther developed by Marinus of Tyre, and Ptolemy, and according to which " the continuation of the Taurus in Lycia extends across the whole of Asia to India, in one and the same direction," appears to have been partly founded on statements which reached the Persians and Indians from the Punjaub. "The Brahmins affirm," says Cosmas Indicopleustes, in his Christian Topography, (Mountfauçon, Collectio nova Patrum, T. ii. p. 137) "that a line drawn from Tzinitza (Thinæ) across Persia and Romania, exactly cuts the middle of the inhabited earth." It is deserving of notice that Eratosthenes had so early remarked that this longest axis of elevation in the Old Continent, in the parallels of $35 \frac{1}{2}^{\circ}$ and $36^{\circ}$, points directly through the basin (or depression) of the Mediterranean to the Pillars of Hercules. (Compare Asie Centrale, T. i. p. 23 and 122138; T. ii. p. 430-434, with Kosmos, Bd. ii. S. 222 and 438, p. 188, and note 292, Engl. ed.) The easternmost part of the Hindu-Coosh is the Paropanisus of the ancients, the Indian Caucasus of the companions of Alexander. The now generally used term of Hindu-Coosh, belongs, as may be seen from the Travels of the Arab Ibn Batuta (English version, p. 97), to a single mountain pass on which many Indian slaves often perished from cold. The Kuen-liun, like the Thian-schan, shews igneous outbreaks or eruptions at many hundred miles from the sea. Flames, visible at a great distance, issue from a avcity in the Schin-khieu Mountain. 
(Asie Centrale, T. ii. p. 427 and 483, where I have followed the text of Yuen-thong-ki, translated by my friend Stanislas Julien.) The highest summit measured in the HinduCoosh, north-west of Jellalabad, is 3164 toises above the sea (20132 English feet); to the west, towards Herat, the chain sinks to 400 toises (2558 English feet), until, north of Teheran, it rises again to a height of 2295 toises (14675 English feet) in the volcano of Demavend.

4. The mountain system of the Himalaya. The normal direction of this system is east and west when followed from $81^{\circ}$ to $97^{\circ} \mathrm{E}$. long. from Greenwich, or through more than fifteen degrees of longitude from the colossal Dhawalagiri (4390 toises, 28071 English feet) to the breaking through of the long-problematical Dzangbo-tschu river (the Irawaddy, according to Dalrymple and Klaproth), and to the chains running north and south which cover the whole of Western China, and in the provinces of Sse-tschuan, Hu-kuang, and Kuang-si form the great mountain group of the sources of the Kiang. The next highest culminating point to the Dhawalagiri, of this east and west part of the Himalaya, is not, as has been hitherto supposed, the eastern peak of the Schamalari, but the Kinchinjinga. This mountain is situated in the meridian of Sikhim, between Bootan and Nepaul, and between the Schamalari (3750? toises, 23980 English feet) and the Dhawalagiri : its height is 44.06 toises, or 26438 Parisian, or 28174. English feet. It was first measured accurately by trigonometrical operations in the present year, and as the account of this measurement received by me from India says decidedly, "that a new determination 
of the Dhawalagiri leaves to the latter the first rank among all the snor-capped mountains of the Himalaya," the height of the Dhawalagiri must necessarily be greater than that of 4390 toises, or 26340 Parisian, 28071 English feet, hitherto ascribed to it. (Letter of the accomplished botanist of Sir James Ross's Antarctic Expedition, Dr. Juseph Hooker, written from Dorjling, July 25, 1848.) The turning point in the direction of the axis of the Himalaya range is not far from the Dhawalagiri, in $79^{\circ} \mathrm{E}$. long. from Paris ( $81^{\circ} 22^{\prime}$ Greenwich). From thence to the westward the Himalaya no longer runs east and west, but from S: to NW., connecting itself, as a great cross vein, between Mozuffer-abad and Gilgit south of Kafiristan, with a part of the Hindu-Coosh. Such a bend or change in the direction or strike of the axis of elevation of the Himalaya (from E-W. to SE-NW.), doubtless points, as in the western part of our European Alps, to a difference in the age or epoch of elevation. The course of the Upper Indus, from the sacred lakes Manasa and Ravana-hrada (at an elevation of 2345 toises, 14995 English feet) in the vicinity of which the great river rises, to Iskardo and to the plateau of Deo-tsuh, (at an elevation of 2032 toises, 12993 English feet) measured by Vigne, follows in the Thibetian highlands the same north-westerly direction as the Himalaya. Here is the summit of the Djawahir, long since well measured and known to be 4027 toises (25750 English feet) in elevation, and the valley of Kashmeer, where at an elevation of only 8:36 toises, (5346 English feet), the Wulur Lake freezes every winter, and, from the perpetual calm, no wave ever curls its surface. 
Having thus described the four great mountain systems of Asia, which in their normal geognostic character are chains coinciding with parallels of latitude, I have next to speak of the series of elevations coinciding nearly with meridians, (or more precisely, having a SSE.-NNW. direction), which, from Cape Comorin opposite to the Island of Ceylon to the Icy Sea, alternate between the meridians of $66^{\circ}$ and $77^{\circ} \mathrm{E}$. long. from Greenwich. To this system, of which the alternations remind us of faults in veins, belong the Ghauts, the Soliman chain, the Paralasa, the Bolor, and the Ural. The interruptions of the series of elevations are so arranged that, beside their alternate position in respect to longitude, each new chain begins in a degree of latitude to which the preceding chain had not quite reached. The importance which the Greeks (although probably not before the second century) attached to these chains induced Agathodemon and Ptolemy (Tab. vii. and viii.) to represent to themselves the Bolor, under the name of Imaus, as an axis of elevation extending as far as $62^{\circ} \mathrm{N}$. lat. into the low basin of the Lower Irtisch and the Obi. (Asie Centrale, T. i. p. 138, 154, and 198 ; T. ii. p. 367.)

As the perpendicular elevation of mountain summits above the level of the sea (unimportant as in the eyes of the geologist the circumstance of the greater or lesser corrugation of the crust of the earth may be), is still, like all that is difficult of attainment, an object of popular curiosity, the following historical notice of the gradual progress of hypsometric knowledge may here find a suitable place. When I returned to Europe in 1804 after a four years' absence, not a single Asiatic snowy summit either in the Himalaya, the 
Hindu-Coosh, or the Caucasus, had been measured with any exactness; and I could not therefore compare my determinations of the height of perpetual snow in the Cordilleras of Quito, or the mountains of Mexico, with any corresponding determinations in the East. The important journey of Turner, Davis, and Saunders, to the highlands of Thibet, does indeed belong to the year 1783, but Colebrooke justly remarks, that the elevation given by Turner to the Schamalari (lat. $28^{\circ} 5^{\prime}$, long. $89^{\circ} 30^{\prime}$, a little to the north of Tassisudan) rests on foundations as slight as those of the so-called measurements of the heights seen from Patna and the Kafiristan by Colonel Crawford and Lieutenant Macartney. (Compare Turner, in the Asiatic Researches, vol. xii. p. 234, with Elphinstone's Account of the Kingdom of Caubul, 1815, p. 95, and Francis Hamilton, Accoint of Nepal, 1819, p. 92.) The excellent observations and writings of Webb, Hodgson, Herbert, and the brothers Gerard, have thrown great and certain light on the elevation of the colossal summits of the Himalaya; yet, in 1808, the hypsometric knowledge of this great Indian chain was still so uncertain that Webb wrote to Colebrooke: "The height of the Himalaya still remains a problem. I find, indeed, that the summits visible from the high plain of Rohilcund are 21000 English feet above that plain, but we do not know the absolute height above the sea."

It was not until the beginning of the year 1820 that it began to be reported in Europe, that not only were there in the Himalaya, summits much higher than those of the Cordilleras, but also that Webb had seen in the Pass of Niti, 
and Moorcroft in the Thibetian plateau of Daba and the Sacred Lakes, fine pastures and flourishing fields of corn; at altitudes far exceeding the height of Mont Blanc. These accounts were received in England with much incredulity, and were met by doubts respecting the influence of refraction. I have shown the groundlessness of these doubts in two memoirs (Sur les Montagnes de l'Inde), printed in the Annales de Chimie et de Physique. The Tyrolese jesuit, P. Tiefenthaler, who in 1766 penetrated into the provinces of Kemaun and Nepal, had already divined the importance of the Dhawalagiri. We read on his map, "Montes Albi, qui Indis Dolaghir, nive obsiti." Captain Webb always uses the same name. Until the measurements of the Djawahir (lat. $30^{\circ} 22^{\prime}$, long. $79^{\circ} 58^{\prime}$, altitude 4027 toises, or 25750 English feet) and of the Dhawalagiri (lat. $28^{\circ} 40^{\prime}$, long. $83^{\circ}$ $21^{\prime}$, altitude 4390 ? toises, 28072 English feet) were made known in Europe, the Chimborazo (3350 toises, or 21421 English feet), according to my trigonometric measurement, (Recueil d'Observations astronomiques, T. i. p. 73) was still everywhere regarded as the highest summit on the surface of the earth. The Himalaya now appeared, according as the comparison was made with the Djawahir or the Dhawalagiri, 676 toises (4323 English feet), or 1040 toises (6650 English feet), higher than the Chimborazo. Pentland's South American travels, in the years 1827 and 1838, fixed attention (Annuaire du Bureau des Longitudes, 1830, p. 320 and 323) on two snowy summits of Upper Peru, east of the Lake of Titicaca, which were supposed to surpass the height of the Chimborazo respectively by 598 and 403 
toises, (3824 and 2577 English feet.) I have remarked above, pp. 53-54, that the latest calculation of the measurements of the Sorata and Illimani shews this view to be incorrect. The Dhawalagiri (on the declivity of which, in the valley of the Ghandaki, the Salagrana Ammonites, so celebrated among the Brahmins as symbols of one of the incarnations of Vishnu, are collected) therefore still shews a difference between the culminating points of the Old and the New Continents of more than 6200 Parisian, or 6608 English feet.

The question has been raised, whether there may not exist behind the southernmost more or less perfectly measured chain, other still greater elevations. Colonel George Lloyd, who in 1840 edited the important observations of Captain Alexander Gerard and his brother, entertains an opinion that in the part of the Himalaya which he calls somewhat vaguely "the Tartaric chain," (meaning therefore in north Thibet towards the Kuen-lïn, and perhaps in Kailasa of the sacred lakes, or beyond Leh) there are summits of from 29000 to 30000 English feet,-one or two thousand feet higher therefore than the Dawalagiri. (Lloyd and Gerard, Tour in the Himalaya, 1840, vol. i. p. 143 and 812 ; Asie Centrale, T. iil. p. 324.) So long as actual measurements are wanting, one cannot decide respecting such possibilities; as the indication, from which the natives of Quito, long before the arrival of Bouguer and La Condamine, recognised the superior altitude of the Chimborazo (namely, from the portion of its height above the region of perpetual snow being greater than in any of the other mountains), might YOL. I. 
prove very deceptive in the temperate zone of Thibet, where radiation is so active in the table-land, and where the lower limit of perpetual snow does not form a regular line at an equal elevation, as it does in the tropics. The greatest elevation above the level of the sea ever attained by human beings on the declivity of the Himalaya, is 3035 toises, or 18210 Parisian, or 19409 English feet, reached by Captain Gerard, with seven barometers, on the mountain of Tarhigang, a little to the north-west of Schipke. (Colebrooke, in the Transactions of the Geological Society, vol. vi. p. 411.) This happens to be exactly the same height as that reached by myself on the 23rd of June, 1802, and thirty years later by my friend Boussingault, on the 16th of December, 1831, on the declivity of the Chimborazo. The unattained summit of. the Tarhigang is, however, 197 toises, or 1260 English feet, higher than that of the Chimborazo.

The passes across the Himalaya, leading from Hindostan into Chinese Tartary, or rather into Western Thibet, more particularly between the rivers of Buspa and Schipke or Langzing Khampa, are from 2400 to 2900 toises, or 15346 to 18544 English feet. In the chain of the Andes I found the pass of Assuay, between Quito and Cuenca on the Ladera de Cadlud, having a similar elevation, being 2428 toises, or 15526 English feet, high. A great part of the mountain plains of the interior of Asia would be buried throughout the year in perpetual snow and ice, if it were not, that by the great radiation of heat from the Thibetian plateau, by the constant serenity of the sky, by the rarity of the formation of snow in the dry atmosphere, and by the pow - 
erful solar heat peculiar to the eastern continental climate, the limit of perpetual snow is wonderfully raised on the northern slope of the Himalaya,-perhaps to 2600 toises, or 16625 English feet above the level of the sea. Fields of barley (Hordeum hexastichon) are seen in Kunawur up to 2300 toises, or 14707 English feet; and another variety of barley called Ooa, and allied to Hordeum cœleste, even much higher. Wheat succeeds extremely well in the Thibetian highlands up to 1880 toises, or 12022 English feet. On the northern declivity of the Himalaya, Captain Gerard found the upper limit of the higher birch woods ascend to 2200 toises, 14068 English feet; and small bushes which scrve the inhabitants for fuel to warm their huts, attain, in the latitude of $30 \frac{3}{4}^{\circ}$ and $31^{\circ}$ of north latitude, a height of 2650 toises (16945 English feet), or almost 200 toises (1279 English feet) higher than the limit of perpetual suow under the equator. From the data hitherto collected it would follow, that we may take the lower limit of perpetual snow on the northern side of the Himalaya, on the average, and in round numbers, at 2600 toises, or about 16600 English feet; whilst on the southern declivity of the Himalaya the snowline sinks to 2030 toises, or about 13000 English feet.

But for this remarkable distribution of temperature in the upper strata of the atmosphere, the mountain plain of Western Thibet would be uninhabitable to the millions who dwell there. (Compare my Examination of the Limit of Perpetual Snow on the two declivities of the Himalaya, in the Asie Centrale, T. ii. p. 435-437; T. ili. p. $281-826$, 
and in Kosmos, Engl. ed. vol. i. note 403 ; S. 483 of the original.)

A letter which I have just received from India from Dr. Joseph Hooker, who is engaged in meteorological and geological researches, as well as those connected with the geography of plants, says: "Mr. Hodgson, who we regard here as the geographer best acquainted with the hypsometric relations of the snow ranges, completely recognises the correctness of your statement in the third part of the Asie Centrale, respecting the reason of the inequality in the height of the limit of perpetual snow on the northern and southern declivities of the Himalaya. In the 'trans Sutlej region' in $36^{\circ}$ lat. we often saw the snow limit only commence at an altitude of 20000 English feet, while in the passes south of the Brahmaputra, between Assam and Burman, in $27^{\circ}$ lat., where the most southern Asiatic snowy mountains are situated, the limit of perpetual snow sinks to 15000 English feet." I believe we ought to distinguish between the extreme and the mean heights, but in both we see manifested in the clearest manner the formerly contested differences between the Thibetian and the Indian declivities.

My statements respecting the mean height of the Snow-line in the Himalaya. (Asie Centrale, tom. iii. p. 326.)

Paris feet. Eng. feet.

Northern declivity 15600...16626 Northern declivity 18764...20000

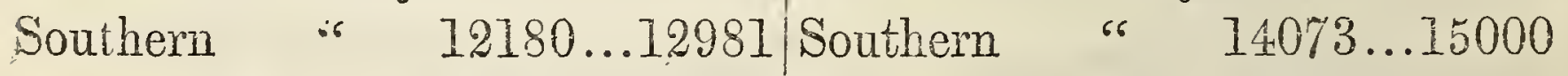
Difference $\overline{3420} \overline{3645} \quad$ Difference $\overline{4691} \overline{5000}$

The local differences vary still more, as may be seen from 
the list of extremes given in my Asie Centrale, T. iii. p. 295. Alexander Gerard saw the snow limit ascend, on the Thibetian declivity of the Himalaya, to 19200 Parisian feet (20465 English); and on the southern Indian declivity, Jacquemont once saw it, north of Cursali on the Jumnotri, even as low as 10800 Parisian (11,510 English) feet.

\section{(11) p. 6.- "A brown Pastoral Race, the Hiongnu."}

The Hiongnu (Hiong-nou), who Deguignes, and with him many historians, long considered to be the Huns, inhabited that vast region of I'artary which is bounded on the east by Uo-leang-ho (the present Mantschu dominion), on the south by the Chinese wall, on the west by the U-siun territory, and on the north by the country of the Eleuthes. But the Hiongnu belong to the Turkish, and the Huns to the Finnish or Uralian race. The northern Huns, a rude pastoral people, unacquainted with agriculture, were dark brown (sunburnt); the southern Huns or Hajatelah, (called by the Byzantines Euthalites or Nepthalites, and dwelling along the eastern shore of the Caspian), had a fairer complexion. The latter cultivated the ground, and possessed towns. They are often called the white, or fair Huns, and d'Herbelot even declares them to be IndoScythians. On Punu, the Leader or Tanju of the Hums, and on the great drought and famine which, about 46 A.D., caused a part of the nation to migrate northwards, (see Deguignes, Histoire gén. des Huns, des Tures, dc., 1756 , T. i. pt. i. p. 217 ; pt. ii. p. 111, 125, 223, 44\%.) All the accounts of the Huns taken from the above-mentioned 
celebrated work have been subjected to a learned and strict examination by Klaproth. According to the result of this research the Hiongnu belong to the widely diffused Turkish races of the Altai and Tangnu Mountains. The name Hiongnu, even in the third century before the Christian era, was a general name for the Ti, Thu-kiu or Turks, in the north and north-west of China. The southern Hiongnu over. came the Chinese, and in conjunction with them destroyed the empire of the northern Hiongnu. These latter fled to the west, and this flight seems to have given the first impulse to the migration of nations in Middle Asia. The Huns, who were long confounded with the Hiongnu, (as the Uigures with the Ugures and the Hungarians), belonged, according to Klaproth, to the Finnish race of the Ural mountains between Europe and Asia, a race which was variously mingled with Germans, Turks, and Samoieds. (Klaproth, Asia Polyglotta, p. 183 and 211 ; Tableaux Historiques de l'Asie, p. 102 and 109.) The Huns (Oivvou) are first named by Dionysius Perigetes, a writer who was able to obtain more accurate information respecting the interior of Asia, because, as a learned man born at Charax on the Arabian Gulf, Augustus had sent him back to the East to accompany thither his adopted son Caius Agrippa. Ptolemy, a century later, writes the word (Xovvou) with a strong aspiration, which, as St. Martin observes, is found again in the geographical name of Chunigard.

$$
\text { (12) p. 7.- "No carved Stone." }
$$

On the banks of the Orinoco near Caicara where the 
forest region joins the plain, we have indeed found representations of the sun, and figures of animals, cut on the rocks: but in the Llanos themselves no traces of these rude memorials of earlier inhabitants have been diacovered. It is to be regretted that we have not received any more complete and certain information respecting a monument which was sent to France to Count Maurepas, and which, according to Kalm, had been found by $M$. de Verandrier in the Prairies of Canada 900 miles west of Montreal, in the course of an expedition intended to reach the Pacific. (Kalm's Reise, 'Th. iii. S. 416.) This traveller found in the middle of the plain enormous masses of stone, placed in an upright position by the hand of man, and on one of them was something which was taken to be a Tartar inscription. (Archæologia: or Miscellaneous Tracts, published by the Society of Antiquaries of London, vol. viii., 1787, p. 304.) How is it that so important a monument has remained unexamined? Can it really have contained alphabetical writing? or is it not far more probably a pictorial history, like the supposed Phœnician inscription on the bank of the Taunton River? I consider it, however, very probable that these plains were once traversed by civilised nations: pyramidal sepulchral mounds, and entrenchments of extreordinary length, found in various places between the Rucky Mountains and the Alleghanies, and on which Squier and Davis (in the "Ancient Monuments of the Mississipi Valley") are now throwing a new light, appear to confirm this supposition. (Relation Hist., T. iii. p. 155.) Verandrier had been sent on his expedition by the Chevalier de Beauharnois, 
the French Governor-general of Canada, in 1746. Several Jesuits in the city of Quebec assured Kalm that they had themselves had the supposed inscription in their hands: it was engraved upon a small tablet which had been let into a pillar of cut stone, in which position it was found. I have asked several of my friends in France to search out this monument, in case it should really be in existence in the collection of Count Maurepas, but without success. I find older, but equally doubtful, statements as to the existence of alphabetical inscriptions belonging to the primitive nations of America, in Pedro de Cieça de Leon, Chronica del Peru, P. i. cap. 87 (losa con letras en los edificios de Vinaque); in Garcia, Origen de los Indios, 1607, lib. iii. cap. 5, p. 258; and in Columbus's Journal of his first voyage, in Navarrete, Viages de los Espanoles, T. i. p. 67. M. de Verandrier moreover affirmed, (and earlier travellers had also thought they had observed the same thing), that in the prairies of Western Canada, throughout entire days' journeys, traces of the ploughshare were discoverable; but the total ignorance of the primitive nations of America with regard to this agricultural implement, the want of draft cattle, and the great extent of ground over which the supposed furrows are found,-all lead ine to conjecture that this singular appearance of a ploughed field has been produced by some effect of water on the surface of the earth.

$$
\text { (13) p. 7.- "Like an arm of the Sea." }
$$

The great Steppe, which extends from east to west from 
the morith of the Orinoco to the snowy mountains of Merida, turns to the south in the 8th degree of latitude, filling the space between the eastern declivity of the high mountains of New Granada, and the Orinoco, the course of which is, in this part, from south to north. This latter portion of the Llanos, which is watered by the Meta, the Vichada, the Zama, and the Guaviare, conrects the valley of the Amazons with the ralley of the Lower Orinoco. The rord Paramo, which I often employ in these pages, signifies in Spanish America all those mountainous regions which are elevated from 1800 to 2200 toises above the lerel of the sea (11500 to 14000 English feet in round nurnbers), and in which an ungenial, rough, and misty climate prevails. Hail and snow fall daily for several hours in the upper Paramos, and furnish a beneficial supply of moisture to the alpine plants; a supply not arising from a large absolute quantity of aqueous rapour in these high regions, but from the frequency of showers, (hail and snow being so termed as $\pi$ ell as rain), produced by the rapidly changing currents of air, and the variations of the electric tension. The arborescent regetation of these regions is low and spreading, consisting chiefly of large flotrering laurels and myrtle-leared alpine shrubs, whose knotty branches are adorned with fresh and evergreen foliage. Escallona tubai, Escallonia myrtilloides, Chuquiragua insignis, Aralias, Weinmannias, Frezieras, Gualtherias, and Andromeda reticulata, may be regarded as representatives of the physiognomy of this regetation. To the south of the town of Santa Fé de Bogota is the Paramo de la Suma Paz; a lonely mountain 
group, in which, according to Indian tradition, vast treasures are buried. The torrent which flows under the remarkable natural bridge of the rocky ravine of Icononzo rises in this Paramo. In my Latin memoir entitled "De distributione geographica Plantarum secundem cœli temperiem et altitudinem montium, 1817," I have sought to characterise those mountain regions: "Altitudine 1700-1900 hexapod. Asperrimæ solitudines, quæ a colonis hispanis uno nomine Paramos appellantur, tempestatum vicissitudinibus mire obnoxiæ, ad quas solutæ et emollitæ defluunt nives; ventorum flatibus ac nimborum grandinisque jactu tumultuosa regio, quæ æque per diem et per noctes riget, solis nubila et tristi luce fere nunquam calefacta. Habitantur in hac ipsa altitudine sat magnæ civitates, ut Micuipampa Peruvianorum, ubi thermometrum centes. meridie inter $5^{\circ}$ et $8^{\circ}$, noctu $-0^{\circ} .4$ consistere vidi; Huancavelica, propter cinnabaris venas celebrata, ubi altitudine 1835 hexap. fere totum per annum temperies mensis Martii Parisiis." (Humboldt de distrib. geogr. Plant, p. 104.)

(14) p. 8.-"The Andes and the eastern mountains send forth detached spurs which advance towards each other."

The vast region situated between the eastern coast of South America and the eastern declivity of the Andes is narrowed by two mountain masses, which partially divide from each other the three valleys or plains of the Lower Orinoco, of the Amazons, and of the River Plate. The 
most northern mountains, called the group of the Parime, are opposite to the Andes of Cundinamarca which projest far to the east, and assume in the 66th and 68th degrees of longitude the form of high mountains, comnected by the narrow ridge of Pacaraima with the granite hills of French Guiana. On the map of Columbia constructed by me from my own astronomical observations, this comnection is clearly marked. The Caribs, who penetrated from the missions of the Caroni to the plains of the Rio Branco, and as far as the Brazilian boundary, crossed in the journey the ridges of Pacaraima and Quimiropaca. The second mountain mass, which divides the valley of the Amazons from the River Plate, is the Brazilian group. In the province of Chiquitos (west of the Parecis range of hills), it approaches the promontory of Santa Cruz de la Sierra. As neither the group of the Parime which causes the great cataracts of the Orinoco, nor the Brazilian group of mountains, are absolutely connected with the Andes, the plains of Venezuela have a direct connection with those of Patagonia. (See my geognostical view of South America, in Relat. Hist. T. iii. p. 188-244.)

$$
\text { (15) p. 8.- "Troops of dogs." }
$$

European dogs have become wild in the grassy plains or Pampas of Buenos Ayres. They live in society, and in hollows in which they hide their young. If the society becomes too numerous, some families detach themselves and form new colonies. The European dog, which has become wild, barks as loud as the original American hairy race. 
Garcilaso relates, that before the arrival of the Spaniards the Peruvians had dogs, "perros gozques." He calls the native dog, Allco: it is called at present in the Quichua language, to distinguish him from the European dog, "Puna-allco," "Indian dog" (dog of the inhabitants of the country). The hairy Runa-allco seems to be a mere variety of the shepherd's dog. He is small, with long hair, (usually of an ochry yellow, with white and brown spots, ) and with upright sharp-pointed ears. He barks a great deal, but seldom bites the natives, however disposed to be mischievous to the whites. When the Inca Pachacutec, in his religious wars with the Indians of Xauxa and Huanca (the present valley of Huancaya and Jauja), conquered them, and converted them forcibly to the worship of the sun, he found them paying divine honours to dogs. Priests blew on the skulls of dogs, and the worshippers ate their flesh. (Garcilaso de la Vega, Commentarios Reales, P. i. p. 184.) This veneration of dogs in the valley of Huancaya is probably the reason why skulls and even entire mummies of dogs have been found in the Huacas, or Perurian graves belonging to the earliest epoch. Von Tschudi, the author of an excellent Fauna Peruviana, has examined these skulls, and believes them to belong to a peculiar species of dog which he call. Canis ingæ, and which is different from the European doo. The Huancas are still called derisively by the inhabitants of other provinces, "dogeaters." Among the natives of the Rocky Mountains, cooked dog's flesh is set before strangers as a feast of honour. Near Fort Laramie, (one of the stations of the Hudson's 
Eay Company for the fur trade with the Sioux Indians), Captain Frémont attended a feast of this description. (Trémont's Exploring Expedition, 1845, p. 42.)

The Perurian dogs had a singular part to play in eclipses of the moon: they were beaten until the eclipse was over. The Mexican Techichi, a variety of the common dog, which latter was called in Anahuac Chichi, was completely dumb. Techichi signifies literally stone-dog, from the Aztec, Tetl, a stone. The Techichi was eaten according to the old Chinese fashion. The Spaniards found this food, before the introduction of European cattle, so indispensable, that almost the whole race was gradually extirpated. (Clavigero, Storia antica del Messico, 1780, T. i. p. 73.) Buffon confounds the Techichi with the Koupara of Guiana. (T. xv. p. 155.) The latter is identical with the Procyon or Ursus cancrivorus, the Raton crabier, or crab-eating Aquaraguaza of the Patagonim coast. (Azara sur les quadrupèdes du Paraguay, T. i. p. 315.) Linnæus, on the other hand, confounds the dumb variety of dogs with the Mexican Itzcuintepotzotli, a kind of dog still only imperfectly described, said to be distinguished by a short tail, a very small head, and a large hump on the back. The name signifies humped-dog, and is formed from the Aztec, itzcuintli (another word for dog), and tepotzotli, humped, a humpback. I was particularly struck in America, and especially in Quito and generally in Peru, with the great number of black dog's without hair, called by Buffon "chiens turcs" (Canis ægyptius, Linn.) Even among the Indians this variety is common, but it is generally despised 
and ill-treated. All European breeds of dogs perpetuate themselves very well in South America, and if the dogs there are not so handsome as those in Europe, the reason is partly want of care, and partly that the handsomest varieties (such as fine greyhounds and the Danish spotted breed) have never been introduced there.

Herr von Tschudi makes the singular remark, that in the Cordilleras, at elevations of 13000 feet, tender races of dogs and the European domestic cat are exposed to a particular kind of mortal disease. "Innumerable attempts have been made to keep cats as domestic animals in the town of the Cerro de Pasco, 132.28 French (or 14100 English) feet above the level of the sea, but such attempts have failed, both cats and dogs dying at the end of a few days in fits, in which the cats were taken at first with convulsive movements, then tried to climb the walls, fell back exhausted and motionless, and died. In Yauli I had several opportunities of observing this chorea-like disease; it seems to be a consequence of the absence of sufficient atmospnerıc pressure." In the Spanish colonies, the hairless dog was looked upon as of Chinese origin, and called Perro Chinesco, or Chino. The race was supposed to have corne from Canton or from Manila: according to Klaproth, it has certainly been extremely common in China since very early times. Among the animals indigenous to Mexico there was an entirely hairless, dog-like, but very large wolf, called Xoloitzcuintli (from the Mexican xolo or xolotl, servant or slave). On American dogs, see Smith Barton's Fragments of the Natural History of Pennsylvania, P.i. p. 34. 
The result of 'Tschudi's researches on the American indigenous races of dogs is the following. There are two kinds almost specifically different: 1 . The Canis caraibicus of Lesson, quite without hair, except a small bunch of white hair on the forehead and at the point of the tail, of a slate grey colour, and silent; it was found by Columbus in the Antilles, by Cortes in Mexico, and by Pizarro in Peru, where it suffers from the cold of the Cordilleras, but is still abundant in the warmer parts of the country, under the name of perros chinos. 2. The Canis inga, with pointed nose and pointed ears; this kind barks: it is now employed in the care of cattle, and shews many varieties of colours, from being crossed with European breeds. The Canis inge follows man to the high regions of the Cordilleras. In ancient Peruvian graves his skeleton is sometimes found resting at the feet of the human mummy. We know how often the carvers of monuments in our own middle ages employed the figure of a dog in this position, as an emblem of fidelity. (J. J. v. Tschudi, Untersuchungen uiber die Fauna Peruana, S. 247-251.) At the rery begiming of the Spanish conquests European dogs became wild in the islands of San Domingo and Cuba. (Garcilaso, P. i. 1723, p. 326.) In the prairies between the Meta, the Arauca, and the Apure, roiceless dogs, (perros mudos,) were eaten in the 10th century. Aloiso de Herrara, who, in 1535, undertook an expedition to the Orinoco, says the natives called them "Majos" or "Auries." A well-informed traveller, Giesecke, found the same non-barking variety of dog in Greenland. The Esquimaux dogrs pass their lives entirely 
in the open air; at night they scrape holes for themselves in the snow; they howl like wolves, in accompaniment with a dog that sits in the middle of the circle and sets them off. In Mexico the dogs were subjected to an operation to make them fatter and better eating. On the borders of the province of Durango, and farther to the north on the slave lake, the natives, furmerly at least, conveyed their tents of buffalo skins on the backs of large dogs when changing their place of residence with the change of seasnn. All these troits resemble the customs of the inhabitants of eastern Asia. (Humboldt, Essai polit. T. ii. p. 448 ; Relation hist. T. ii. p. 625.)

(16) p. 8.- "Like the greater part of the Desert of Sahara, the Llanos are in the torrid zone."

Significant denominations,-particularly such as refer to the form in relief of the earth's surface, and which have arisen at a period when there was only very uncertain information respecting the countries in question and their hypsometric relations,-have led to various and longcontinued geographical errors. The ancient denomination of the "Greater and Lesser Atlas" (Ptol. Geogr. lib: ii. cap. 1) has exercised the prejudicial influence here alluded to. No doubt the snow-covered western summits of the Atlas in the territory of Morocco may be regarded as the Great Atlas of Ptolemy; but where is the limit of the Little Atlas? Is the division into two Atlas chains, which the conservative tendencies of geographers have preserved for 1700 years, to be still maintained in the territory of Algiers, and even between Tunis and Tlemse? Are we to seek between the 
coast and the interior for parallel chains constituting a greater and a lesser Atlas? All travellers familiar with geognostical views, who have visited Algeria since it has been taken possession of by the French, contest the meaning conveyed by the generally received nomenclature. Among the parallel chains, that of Jurjura is generally supposed to be the highest of those which have been measured; but the well-informed Fournel, (long Ingenieur en chef des Mines de l'Algérie), affirms that the mountains of Aurès, near Batnah, which were still found covered with snow at the end of March, are higher. Fournel denies the existence of a Little and a Great Atlas, as I do that of a Little and a Great Altai (Asie Centrale, T. i. p. 247-252). There is only one Atlas, formerly called Dyris by the Mauritanians, and "this name is to be applied to the "foldings," ("rides") or succession of crests which form the division between the waters flowing to the Mediterranean, and those which flow towards the Sahara lowland. The strike or direction of the Eastern Mauritanian portion of the Atlas is from east to west; that of the elevated Atlas of Morocco from north-east to south-west. The latter rises into summits which, according to Renou, (Exploration Scientifique de l'Alg'érie de 1840 à 1842, publiée par ordre du Gouvernement, Sciences Hist. et Geogr. T. viii. 1846, p. 364 and 373), attain an elevation of 10,700 Fr. (11400 Eng.) feet; exceeding, therefore, the height of Etna. A singularly formed highland of an alimost square shape, (Sahab el Marga), bounded on the south by higher elevations, is situated in $33^{\circ}$ lat. From thence towards the sea to 
the west, about a degree south of Mogador, the Atlas declines in height: this south-westernmost part bears the name of Idrar-N-Deren.

The northern Mauritanian boundaries of the widely extended low region of the Sahara, as well as its southern limits towards the fertile Soudan, are still but little known. If we take on a mean estimation the parallels of $16 \frac{1}{2}^{\circ}$ and $32 \frac{1}{2}^{\circ}$ as the outside limits, we obtain for the Desert, including its Oases, an area of more than 118500 square German geographical miles; or between nine and ten times the area of Germany, and almost three times that of the Mediterranean exclusive of the Black Sea. From the best and most recent intelligence, for which we are indebted to the French Colonel Daumas and MM. Fournel, Renou, and Carette, we learn that the desert of Sahara is composed of several detached basins, and that the number and the population of the fertile Oases is very much greater than had been imagined from the awfully desert character of the route between Insalah and Timbuctoo, and that from Mourzouk in Fezzan, to Bilma, Tirtuma, and Lake Tschad. It is now generally affirmed that the sand covers only the smaller portion of the great lowland. A similar opinion had been previously propounded by the acutely observant Ehrenberg, my Siberian travelling companion, from what he had himself seen (Exploration Scientifique de l'Algérie, Hist. et Geogr. T. ii. p. 332). Of larger wild animals, only gazelles, wild asses, and ostriches are to be met with. "Le lion du désert," says M. Carette, (Explor. de l'Alg. T. ii. p. 126-129; T. vii. p. 94 and 97), "est un mythe popularisé par les artistes et les poètes. II 
n'existe que dans leur imagination. Cet animal ne sort pas de sa montagne où il trouve de quoi se loger, s'abreuver et se nourrir. Quand on parle aux habitans du désert de ces bêtes féroces que les Européens leur donnent pour compagnons, ils repondent avec un imperturbable sang froid, il y a donc chez vous des lions qui boivent de l'air et broutent des feuilles? Chez nous il faut aux lions de l'eau courante et de la chair vive. Aussi des lions ne paraissent dans le Zahara que là où il $\mathrm{y}$ a des collines boisées et de l'eau. Nous ne craignons que la vipère (lefa) et d'innombrables essaims de moustiques, ces derniers là où il $\mathrm{y}$ a quelque humidité."

Whereas Dr. Oudney, in the course of the long journey from Tripoli to Lake Tschad, estimated the elevation of the southern Sahara at 1637 English feet, to which German gengraphers have even rentured to add an additional thousand feet, the Ingenieur Fournel has, by careful barometric measurements based on corresponding observations, made it tolerably probable that a part of the northern desert is below the level of the sea. That portion of the desert which is now called "le Zahara d'Algérie" advances to the chains of hills of Metlili and el-Gaous, where the northernmost of all the Oases, - that of el-Kantara, fruitful in dates,-is situated. This low basin, which touches the parallel of $34^{\circ}$ lat., receives the radiant heat of a stratum of chalk, (full of the shells of Inoceramus), inclined at an angle of $65^{\circ}$ towards the south (Fournel sur les Gisemens de Muriate de Soude en Algérie, p. 6 in the Annales des Mines, 4me Série, T. ix., 1846, p. 546). "Arrivés a Biscara," (Biskra), says Fournel, "un horizon indéfini 
comme celui de la mer se déroulait devant nous." Between Biscara and Sidi Ocba the ground is only 228 (243 Eng.) feet above the level of the sea. The inclination increases considerably towards the south. In another work, (Asie Centrale, T. ii. p. 320), where I have brought together everything relating to the depression of some portions of continents below the level of the sea, I have already noticed that according to Le Père the "bitter lakes" on the isthmus of Suez, when they have a little water,-and, according to General Andréossy, the Natron lakes of Fayoum,-are also lower than the level of the Mediterranean.

Among other manuscript notices of M. Fournel, I possess a vertical geological profile, which gives all the inflexions and inclinations of the strata, representing a section of the surface the whole way from Philippeville on the coast to the Desert of Sahara, at a spot not far from the Oasis of Biscara. The direction of the line on which the barometric measurements were taken is south $20^{\circ}$ west; but the elevations determined are projected, as in my Mexican profiles, on a different plane,-a north-south one. Ascending uninterruptedly from Constantine, at an elevation of 332 toises (2122 Eng. feet), the culminating point is found between Batnah and Tizur, at an elevation of only 560 oises ( 3580 Eng. feet). In the part of the desert situated between Biscara' and Tuggurt, Fournel has had a series of Artesian wells dug with success (Comptes Rendus de l'Acad. des Sciences, t. xx. 1845, p. 170, 882, and 1305). We learn from the old accounts of Shaw, that the inhabitants of the country knew of a subterranean supply of water, and 
relate fabulous tales of a "sea under the earth (bahr tôht el-erd)." Fresh waters flowing between clay and marl strata of the old cretaceous and other sedimentary deposits, under the action of hydrostatic pressure form gushing fountains when the strata are pierced (Shaw, Voyages dans plusieurs parties de la Berbérie, t. i. p. 169; Rennell, Africa, Append. p. Ixxxy). That fresh water in this part of the world should often be found near beds of rock salt, need not surprise geologists acquainted with mines, since Europe offers many analogous phenomena.

The riches of the desert in rock-salt, and the fact of rock-salt having been used in building, have been known since the time of Herodotus. The salt zone of the Sahara (zone salifère du désert), is the southermmost of three zones, stretching across Northern Africa from south-west to northeast, and believed to be connected with the beds or deposits of rock-salt of Sicily and Palestine, described by Friedrich Hoffman and by Robinson. (Fournel, sur les Gisements de Muriate de Soude en Algérie, p. 28-41; Karsten über das Vorkommen des Kochsalzes auf der Oberfläche der Erde, 1846, S. 497, 648, and 741.) The trade in salt with Soudan, and the possibility of cultivating dates in the Oases, formed by depressions caused probably by falls or subsidences of the earth in the gypsum beds of the tertiary cretaceous or keuper promotions, have alike contributed to enliven the Desert, at least to some extent, by human intercourse. The high temperature of the air, which makes the day's march so oppressive, renders the coldness of the nights, (of which Denham complained so often in the African Desert, and Sir Alexander Burnes in the Asiatic), 
so much the more striking. Melloni, (Memoria sull' abassamento di temperatura durante le notti placide e serene, 1847 , p. 55), ascribes this cold, produced doubtless by the radiation from the ground, less to the great purity and serenity of the sky, (irrigiamento calorifico per la grande serenità di cielo nell' immensa e deserta pianura dell' Africa centrale), than to the profound calm, the nightly absence of all movement in the atmosphere. (Consult also, respecting African meteorology, Aimé in the Exploration de l’Algérie, Physique génerale, T. ii., 1846, p. 147.)

The southern declivity of the Atlas of Morocco sends to the Sahara, in lat. $32^{\circ}$, a river, the Quad-Dra (Wady-Dra), which for the greater part of the year is nearly dry, and which Renou (Explor. de l'Alg. Hist. et Geogr., T. viii. p. 65-78) considers to be a sixth longer than the Rhine. It flows at first from north to south, until, in lat. $29^{\circ} \mathrm{N}$. and long. $5^{\circ} \mathrm{W}$., it turns almost at right angles to its former course, runs to the west, and, after passing through the great fresh water Lake of Debaid, enters the sea at Cape Nun, in lat. $28^{\circ} 46^{\prime} \mathrm{N}$. and long. $11^{\circ} 08^{\prime} \mathrm{W}$. This region, which was so celebrated formerly in the history of the Portuguese discoveries of the 15th century, and was afterwards wrapped in profound geographical obscurity, is now called on the coast "the country of the Sheikh Beirouk," (a chief independent of the Emperor of Morocco.) It was explored in the months of July and August 1840, by Captain Count Bouet-Villaumez of the French Navy, by order of his government. From the official Reports and Surveys which have been communicated to me in manuscript, it appears evident that the mouth of the 
Quad.Dra is at present very much stopped up with sand, having an open channel of only about 190 English feet wide. A somewhat more easterly channel in the same mouth is that of the still very little known Saguiel el-Hamra, which comes from the south, and is supposed to have a course of at least 600 geographical miles. One is astonished at the length of these deep, but commonly dry river beds. They are ancient furrows, such as I have seen in the Peruvian desert at the foot of the Cordilleras, between those mountains and the coast of the Pacific. In Bouet's manuscript "Relation de l'Expédition de la Malouine," the mountains which rise to the north of Cape Nun are estimated at the great elevation of 2800 metres (9185 English feet).

Cape Nun is usually supposed to have been discovered in 1433, by the Knight Gilianez, acting under the command of the celebrated Infante Henry Duke of Viseo, and founder of the Academy of Sagres, which was presided over by the pilot and cosmographer Mestre Jacomè of Majorca; but the Portulano Mediceo, the work of a Genoese Navigator in 1351, already contains the name of Cavo di Non. The passage round this Cape was then as much dreaded as that of Cape Horn has since been, although it is $23^{\prime}$ north of the parallel of Teneriffe, and could be reached in a few days' voyage from Cadiz. The Portuguese proverb, "quem passa o Cabo di Num, ou tornarà ou nāo," could not deter the Infante, whose heraldic French motto, "talent de bien faire," expressed his noble, enterprising, and vigorous character. The name of the Cape, in which a play of words on the negative particle has long been supposed, does not appear to me to have had a Portuguese origin. Ptolemy 
placed on the north-west coast of Africa a river Nuius, in the Latin version Nunii Ostia. Edrisi speaks of a town, Nul, or Wadi Nun, somewhat more to the south, and three days' journey in the interior: Leo Africanus calls it Belad de Non. Long before the Portuguese squadron of Gilianez, other European navigators had advanced much bcyond, or to the southward of, this Cape. The Catalan, Don Jayme Ferrer, in 1346, as we learn from the Atlas Catalan published by Buchon at Paris, had advanced as far as the Gold River, (Rio do Ouro), in lat. $23^{\circ} 56^{\prime}$; and Normans, at the end of the 14th century, as far as Sierra Leone in lat. $8^{\circ} 30^{\prime}$. The merit of having been the first to cross the equator on the western coast of Africa belongs, however, like that of so many other memorable achievements, to the Portuguese.

\section{(17) p. 8.- "As a grassy plain, resembling many of the Steppes of Central Asia."}

The Llanos of Caraccas and of the Rio Apure and the Meta, over which roam large herds of cattle, are, in the strictest sense of the term, "grassy plains." Their prevalent vegetation, belonging to the two families of Cyperaceæ and Gramineæ, consists of various species of Paspalum, P. leptostachyum and P. lenticulare; of Kyllingia, $K$ : monocephala (Rottb.), K. odorata; of Panicum, P. granuliferum, P. micranthum; of Antephora; Aristida; Vilfa; and Anthistiria, A. reflexa, and A. foliosa. Only here and there are found, interspersed among the Gramineæ, a few herbaceous dicotyledonous plants, consisting of two very low-growing species of Mimosa, (Sensitive Plant), Mimosa 
intermedia, and Mimosa dormiens, which are great favourites with the wild horses and cattle. The natives give to this group of plants, which close their delicate feathery leaves on being touched, the expressive name of Dormiderassleepy plants. For many square miles not a tree is seen; but where solitary trees are found, they are, in moist places, the Mauritia Palm; in arid districts, a Proteacea; described by Bonpland and myself, the Rhopala complicata (Chaparro bobo), which Wildenow regarded as an Embothrium; also the highly useful Palma de Corija, or de Sombrero; and our Corypha inermis, an umbrella palm allied to Chamærops, which is used to cover the roofs of huts. How far more varied is the aspect of the Asiatic plains! Throughout a large portion of the Kirghis and Calmuck Steppes, which I have traversed from the Don, the Caspian, and the Orenburg Ural river the Jaik, to the Obi and the Upper Irtysh near Lake Dsaisang, through a space of 40 degrees of longitude, I have never seen, as in the Llanos, the Pampas, and the Prairies, an horizon like that of the ocean, where the vault of heaven appears to rest on the unbroken plain. At the utmost this appearance presented itself in one direction, or towards one quarter of the heavens. The Asiatic Steppes are often crossed by ranges of hills, or clothed with coniferous woods or forests. Even in the most fruitful pastures the regetation is by no means limited to grasses; there is a great variety of herbaceous plants and shrubs. In spring-time small snow-white and red-flowering rosaceæ and amygdaleæ (Spiræa, Cratægus, Prunus spinosa, and Amygdalus nana) present a smiling aspect. I have already mentioned the tall and luxuriant 
Synantheræ (Saussurea amara, S. salsa, Artemisias, and Centaureas), and of leguminous plants, species of Astragalus, Cytisus, and Caragana. Crown Imperials, (Fritillaria ruthenica, and F. meleagroides), Cypripedias, and tulips, rejoice the eye by the bright variety of their colours.

A contrast to the pleasing vegetation of these Asiatic plains is presented by the desolate salt Steppes, particularly by the part of the Barabinski Steppe which is at the foot of the Altai mountains, and by the Steppes between Barnaul and the Serpent Mountain and the country on the east of the Caspian. Here Chenopodias, some species of Salsola and A triplex, Salicornias and Halimocnemis crassifolia, (each species growing "socially"), form patches of vegetation on the muddy ground. See Göbel's Journey in the Steppes of the South of Russia (Reise in die Steppe des südlichen Russlands, 1838, Th. ii. S. 244 and 301). Of the 500 phanerogamous species which Claus and Göbel collected in the Steppes, the Syrantheræ, the Chenopodeæ, and the Cruciferæ, were more numerous than the grasses; the latter being only $\frac{1}{11}$ of the whole, and the former $\frac{1}{7}$ th and $\frac{1}{9}$ th. In Germany, from the mixture of hill and plain districts, the Glumaceæ (i.e. the Gramineæ, Cyperaceæ, and Juncaceæ collectively), form $\frac{1}{7}$ th ; the Synantheræ or Compositæ $\frac{1}{8}$ th ; and the Cruciferæ $\frac{1}{18}$ th of all our German phanerogamia. In the most northern parts of the flat Siberian lowlands, the fine map of Admiral Wrangell shews that the extreme northern limit of tree and shrub vegetation (Coniferæ and Amentaceæ) is, in the portion towards the Behring's Straits side, in $67 \frac{1}{4}^{\circ}$ lat.; and more to the west, towards the banks of the Lena, in $71^{\circ}$, which is the parallel of the north cape of Lapland. 
The plains which border the Icy Sea are the domain of cryptogamous plants. They are called Tundras (Tuntur in Finnish): they are swampy districts extending farther than the eye can reach, partly covered with a thick carpet of Sphagnum palustre and other mosses, and partly with a dry snow-white covering of Cenomyce rangiferina (Rein-deer moss), Stereocaulon paschale, and other lichens. Admiral Wrangell, in describing his perilous expedition to the new Siberian islands so rich in fossil wood, says: "These Tundras accompanied me to the extreme arctic coast. Their soil has been frozen for thousands of years. In the dreary uniformity of landscape, the eye of the traveller, surrounded by rein-deer moss, dwells with pleasure on the smallest patch of green turf showing itself now and then on a moist spot."

(18) p. 8.- "The causes which lessen both heat and dryness in the New World."

I have tried to bring together in a brief and compendious manner the various causes which produce greater moisture and a less degree of heat in America; it will of course be understood that the question respects the general hygrometric state of the atmosphere, and the temperature of the New Continent as a whole. Single districts, such as the island of Margarita, the Coasts of Cumana and Coro, are as hot and as dry as any part of Africa. It must also be remarked that the maximum of heat at certain hours of a summer's day has been found, on a series of years, to be almost equal at very different parts of the earth's surface, on the Neva, the Senegal, the Ganges, and the Orinoco; being approximately between 
$27^{\circ}$ and $32^{\circ}$ Reaumur $\left(93^{\circ}\right.$ and $104^{\circ}$ Fahrenheit), and generally not higher,- - providing the observation be made in the shade, at a distance from all solid bodies which could radiate heat. to the thermometer, not in an air filled with hot particles of dust or sand, and not with spirit thermometers, which absorb the light. It is probably to fine grains of sand floating in the air, and forming centres of radiant heat, that we must ascribe the dreadful temperature of $40^{\circ}$ to $44^{\circ} .8$ Reaumur (122. to $133^{\circ}$ Fah.) in the shade, to which my unhappy friend Ritchie, who perished there, and Captain Lyon, were exposed for weeks in the Oasis of Mourzouk. The most remarkable instance of very high temperature, in an air probably free from dust, has been recorded by an observer who knew well how to place and to correct all his instruments with the greatest degree of accuracy. Rüppell found $37^{\circ} .6$ Reaumur, (110 .6 Fahrenheit,) at Ambukol in Abyssinia, with a clouded sky, strong south-west wind, and an approaching thunderstorm. The mean annual temperature of the tropics, or of the proper climate of palms, is, on land, between $20^{\circ} .5$ and $23^{\circ} .8$ Reaumur (or $78^{\circ} .2$ and $85^{\circ} .5$ Fahrenheit) without any considerable difference between the observations collected in Senegal, Pondichery, and Surinam. (Humboldt, Mémoire sur les lignes isothermes, 1817, p. 54. Asie Centrale, T. iii. Mahlmann; Table iv.)

The great coolness, I might almost say cold, which prevails for a considerable part of the year within the tropics on the coast of Peru, causing the thermometer to sink to $12^{\circ}$ Reaumur (59 $9^{\circ}$ Fahrenheit), is, as I have noticed elsewhere, by no means to be ascribed to the vicinity of the snow- 
covered Andes, but rather to the fogs (garua) which veil the solar disk, and to a cold sea current which, commencing in the antarctic regions and coming from the south-west, strikes the coast of Chili near Valdivia and Conçeption, and thence streams rapidly along the coast to the northward, as far as Cape Parina. On the coast, near Lima, the temperature of the Pacific is $12^{\circ} .5$ Reaumur $\left(60^{\circ} .2\right.$ Fahr.), whilst in the same latitude out of the current it is $21^{\circ} \mathrm{R}$. (79 2 Fahr.) It is singular that so striking a fact should have remained unnoticed until my visit to the shores of the Pacific, in October 1802.

The variations of temperature of different regions depend in a great degree on the character of the bottom of the "aerial ocean," or on the nature of the floor or base, whether land or sea, continental or oceanic, on which the atmosphere rests. Seas, often traversed by currents of warmer or colder water, (oceanic rivers), have an effect very different from that of continental masses, whether unbroken or articulated, or of islands, which latter may be regarded as shallows in the aerial ocean, and which, notwithstanding their small dimensions, exert, orten to a great distance, a notable influence on the climate of the sea. In continental masses we must distinguish between sandy deserts devoid of vegetation, savannahs or grassy plains, and forest-covered districts. In Upper Egypt and in South America, Nouet in the former, and myself in the latter, found respectively at noon the temperature of the ground composed of granitic sand $54^{\circ} .2$ and $48^{\circ} .4$ Reaumur ( $154^{\circ}$ and $141^{\circ}$ Fahr.) Many careful observations in Paris have given, according to Arago, $40^{\circ}$ and $42^{\circ}$ Reaumur, $122^{\circ}$ and $126^{\circ} .5$ Fahrenheit. (Asie 
Centrale, T. iii. p. 176.) The Savannahs, which between the Missouri and the Mississipi are called Prairies, and which appear in South America as the Llanos of Venezuela and the Pampas of Buenos Ayres, are corered with small monocotyledonous plants of the family of Cyperacex, and with grasses of which the thin pointed stalks or ears, and the delicate lanceolate leaves or blades, radiate towards the unclouded sky, and possess an extraordinary power of "emission." Wells and Daniell (Meteor. Essays, 1827, p. 230 and 278) have even seen in our latitude, where the atmosphere has so much less transparency, the thermometer sink $6^{\circ} .5$ or $8^{\circ}$ of Reaumur (14.5 or $18^{\circ}$ Fahrenheit), on being placed on the grass. Melloni, in a memoir, "Sull abassamento di temperatura durante le notti placide e serene," 1847, p. 47 and 53, has shewn how in a calm state of the atmosphere, which is a necessary condition of strong radiation and of the formation of dew, the cooling of the grassy surface is also promoted by the particles of air which are already cooled sinking to the ground as being the heaviest. In the vicinity of the equator, under the clouded sky of the Upper Orinoco, the Rio Negro, and the Amazons River, the plains are clothed with dense primeval forests; but to the north and south of this wooded region there extend from the zone of palms and lofty dicotyledonous trees, in the northern hemisphere, the Llanos of the Lower Orinoco the Meta and the Guaviare, and in the southern hemisphere the Pampas of the Rio de la Plata and of Patagonia. The space thus occupied by Savannahs or grassy plains in South America is at least nine times as great as the area of France. The wooded region acts in a threefold marner in diminish- 
ing the temperature. by cooling shade, by evaporation, and by radiation. Forests, - which in our temperate zone consist of trees living together in "society," $i$. e., many individuals of one, or of a few kinds, of the families of Coniferæ or Amentaceæ, oaks, beeches, and birches, but in the tropics, of an immense variety of trees living separately or "unsocially,"-protect the ground from the direct rays of the sun, evaporate fluids elaborated by the trees themselves, and cool the strata of air in immediate contact with them by the radiation of heat from their appendicular organs or leaves. The latter are far from being all parallel with each other; they are, on the contrary, variously inclined to the horizon, and, according to the law developed by Leslie and Fourier, the influence of this inclination upon the quantity of heat emitted by radiation is such, that the power of radiation (pouvoir rayonnant) of a measured surface $a$, having a given oblique direction, is equal to the "pouvoir rayonnant" which would belong to a surface of the size of $a$, projected on a horizontal plane. Now in the initial condition of radiation, of all the leaves which form the summit of a tree and partly cover each other, those are first cooled which are directed without any intervening screen towaris the unclouded sky. The cooling result (or the exhaustion of heat by emission) will be the more considerable the greater the thimness of the leaves. A second stratum of leaves has its upper surface turned to the under surface of the first stratum, and will give out more heat by radiation towards that stratum than it can receive by radiation from it. The result of this unequal exchange will thus be a loss of temperature for the second stratum 
of leaves also A similar operation will continue from stratum to stratum until all the leaves of the tree, by greater or less radiation as modified by their diversity of position, have passed into a state of stable equilibrium of which the law can be deduced by mathematical analysis. In this manner, in the long and clear nights of the equinoctial zone, the forest air contained in the intervals between the strata of leaves becomes cooled by the process of radiation; and by reason of the great quantity of its thin appendicular organs or leaves, a tree, the horizontal section of whose summit would measure for example 2000 square feet, would act in diminishing the temperature of the air equivalently to a space of bare or turf-covered ground several thousand times greater than 2000 square feet (Asie Centrale, T. iii. p. 195-205). I have sought thus to develope in detail the complicated effects which make up the total action of extensive forests upon the atmosphere, because they have been so often touched upon in reference to the important question concerning the climates of ancient Germany and Gaul.

As in the old continent European civilization has had its principal seats on a western coast, it could not but be early remarked that, under equal degrees of latitude, the opposite eastern coast of the United States was several degrees colder in mean annual temperature than Europe, which is, as it were, a projecting western peninsula to Asia, as Brittany is to the rest of France. But in this remark it was forgotten that these differences decrease from the higher to the lower latitudes in such manner that they almost entirely disappear from $30^{\circ}$ downwards. For the 
west coast of the new continent, exact thermometric observations are still almost entirely wanting; but the mildness of the winters in New California shews that the west coasts of America and Europe, under the same parallels of latitude, probably differ little from each other in mean annual temperature. The subjoined table shows what are the corresponding mean annual temperatures, in the same geographical latitudes, of the west coast of Europe and the east coast of the New Continent.

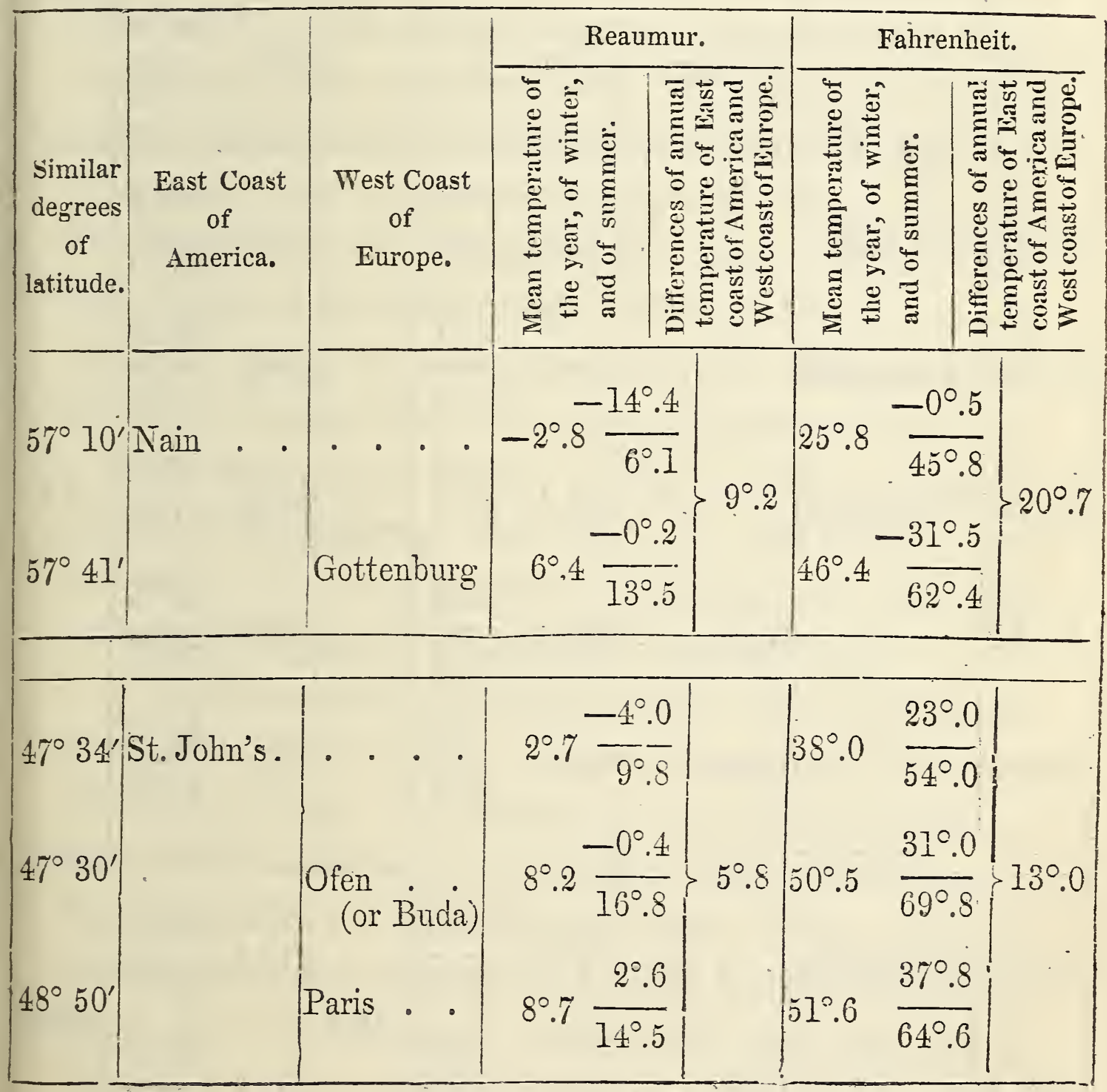

VOL. I. 


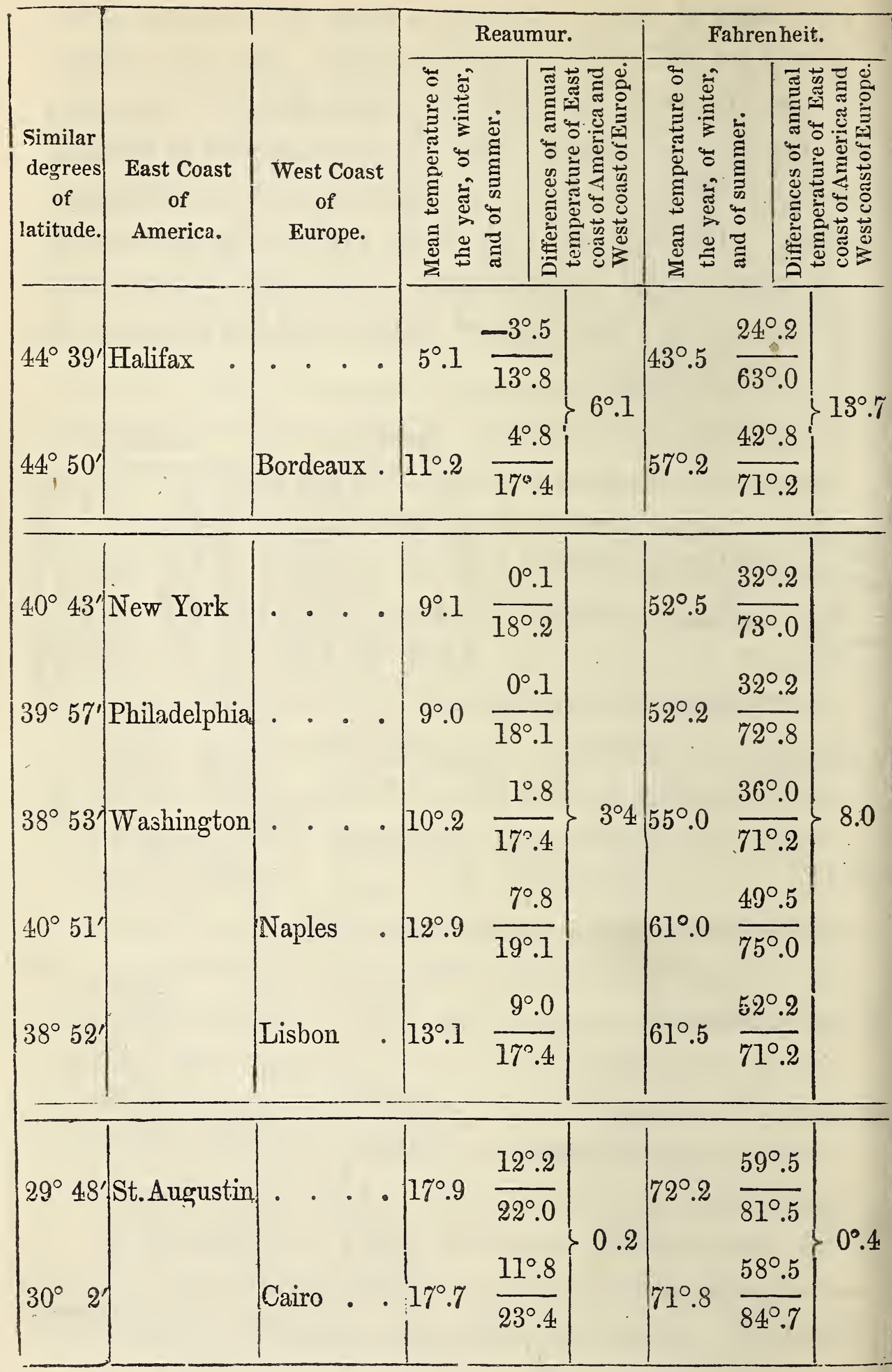


In the column of temperatures in the preceding table the first number represents the temperature of the year; that which stands in place of a numerator the mean. winter temperature; and that which stands in the place of a denominator the mean summer temperature. Besides the great difference of mean annual temperature, there is also $a$ striking difference between the two coasts in respect to the distribution of that temperature into the different seasons of the year, and it is this distribution which is most influential both on our feelings and on the processes of vegetation. Dove remarks generally, that the summer temperature of America is lower under equal degrees of latituce than that of Europe: (Temperatur tafeln nebst Bemerkıngen über die Verbreitung der Wärme auf der Oberfläche der Erde, 1848, S. 95.) The climate of St. Petersburgh, (or to speak more correctly the mean annual temperature of that city which is in lat. $59^{\circ} 56^{\prime}$ ), is found on the east coast of America in lat. $47 \frac{1}{2}^{\circ}$, or $12 \frac{1}{2}^{\circ}$ more to the south; in like manner we find the climate of Konigsberg, (lat. $54^{\circ} 43^{\prime}$ ), at Halifax, (lat. $44^{\circ} 39^{\prime}$ ). The temperature of Toulouse, (lat. $43^{\circ} 36^{\prime}$ ). corresponds to that of Washington (lat. $38^{\circ} 53^{\prime}$ ).

It would be very hazardous to lay down any general statements respecting the temperature in the territory of the United States of America, as we must distinguish in that territory three regions:-1, the Atlantic States east of the Alleghanies; 2, the Western States in the wide basin between the Alleghanies and the Rocky Mountains, through which flow the Mississipi, the Ohio, the Arkansas, and the Missouri; 3, the high plains between the Rocky Mountains, 
and the Maritime Alps of New California through which the Oregon or Columbia River finds a passage. Since the highly honourable establishment, by John Calhoun, of uninterrupted observations of temperature, made on an uniform plan at 35 military posts, and reduced to daily, monthly, and annual means, we have arrived at more just climatic views than those which were so generally received in the time of Jefferson, Barton, and Volney. These meteorological stations or observatories extend from the point of Florida and Thompson's Island, (Key West), lat. 24. 33', to the Council Bluffs on the Missouri; and if we reckon amongst them Fort Vancouver, lat: $45^{\circ} 37^{\prime}$, they include differences of longitude of $40^{\circ}$.

It cannot be affirmed that, on the whole, the mean annual temperature of the second or middle region is higher than that of the first or Atlantic region. The further advance of certain plants towards the north, on the west of the Alleghany mountains, depends partly on the nature of those plants, and partly on the different distribution of the same annual quantity of heat. The wide valley of the Mississipi enjoys at its northern and southern extremities the warming influence of the Canadian Lakes, and of the Mexican Gulf stream. The five lakes, (Superior, Michigan, Huron, Erie, and Ontario), occupy a space of 92,000 English square miles. The climate is much milder and more equable in the neighbourhood of the lakes; for example, at Niagara, (lat. $43^{\circ} 15^{\prime}$ ), the mean winter temperature is only half a degree of Reaumur ( $1^{\circ} .2$ Fahrenheit) below the freezing point, while at a distance from the lakes, in lat $44^{\circ} 53^{\prime}$, at the 
confluence of the river St. Peter's with the Mississipi, the mean winter temperature of Fort Snelling is- $7^{\circ} .2$ Reaumur, or $15^{\circ} .9$ Fahrenheit (see Samuel Forry's excellent Memoir on "the Climate of the United States," 1842, p. 37, 39, and 102.) At this distance from the Canadian Lakes, (whose surface is from 500 to 600 - 530 to 640 Englishfeet above the level of the sea, whilst the bottom of the lakes Michigan and Huron is about five hundred feet below it), recent observations have shewn the climate of the country to possess a proper continental character, i. e., hotter summers and colder winter's. "It is proved," says Forry, "by our thermometrical data, that the climate west of the Alleghany Chain is more excessive than that of the Atlantic side." At Fort Gibson, on the Arkansas River which falls into the Mississipi in lat. $35^{\circ} 47^{\prime}$, with a mean annual temperature hardly equal to that of Gibraltar, the thermometer in the shade, and without any reflected heat from the ground, has been seen, in August 1834, to rise to $37^{\circ} .7$ Reauszur, or $117^{\circ}$ Fahrenheit.

The statement so often repeated, although unsupported by any thermometric measurements, that since the first European settlements in New England, Pennsylvania, and Virginia, the eradication of many forests on both sides of the Alleghanies had rendered the climate more equable, ( $i$. e., milder in winter and cooler in summer), is now generally doubted or disbelieved. Series of trustworthy thermometric observations in the United States hardly extend so far back as 78 years. We see in the Philadelphia observations, 
that from 1771 to 1824, the mean annual temperature has hardly increased $1^{\circ} .2$ Reaumur, (or $2^{\circ} .8$ Fahrenheit), - a difference which is attributed to the increased size of the town, to its greater population, and to the numerous steamengines. The difference may possibly be merely accidental, for I find in the same period an increase of mean winter cold, amounting to $0^{\circ} .9$ Reaumur, or $2^{\circ}$ Fahrenheit; the three other seasons had become somewhat warmer. Threeand-thirty years' observations at Salem in Massachusetts shew no alteration at all: the annual means oscillate, within a degree of Fahrenheit, about the mean of the whole number of years; and the winters of Salem, instead of having become milder, as supposed from the destruction of the forests in the course of the thirty-three years, have become colder by $1^{\circ} .8$ Reaumur, or $4^{\circ}$ Fahrenheit. (Forry, p. 97, 101, and 10\%.)

As the east coast of the United States is comparable in respect to mean annual temperature in equal latitudes to the Siberian and Chinese coasts of the old continent, so also the west coasts of Europe and America have been very properly compared together. I will only take a few examples from the western region on the shores of the Pacific, for two of which (Sitka in Russian America, and Fort George, in the same latitudes respectively as Gottenburg and Geneva) I am indebted to Admiral Lütke's voyage of circumnavigation. Iluluk and Danzig are nearly on the same parallel, and although the mean ternperature of Iluluk, owing to its insular climate and to a cold sea- 
current, is somewhat lower than that of Danzig, yet the winter temperature of the American station is milder than that of the port on the Baltic.

\begin{tabular}{|c|c|c|c|c|}
\hline Sitka . . . & $57^{\circ} 3^{\prime}$ & $135^{\circ} 16^{\prime} \mathrm{W}$. & $5^{\circ} .6 \frac{0^{\circ} .6}{10^{\circ} .2}$ & $44^{\circ} .5 \frac{33^{\circ} .4}{55^{\circ} .0}$ \\
Gottenburg. . & $57^{\circ} 41^{\prime}$ & $11^{\circ} 59^{\prime} \mathrm{E}$. & $6^{\circ} .4 \frac{-0^{\circ} .2}{13^{\circ} .5}$ & $46^{\circ} .4 \frac{31^{\circ} .5}{62^{\circ} .4}$ \\
Fort George . & $46^{\circ} 18^{\prime}$ & $122^{\circ} 58^{\prime} \mathrm{W}$. & $8^{\circ} .1 \frac{2^{\circ} .6}{12^{\circ} .4}$ & $50^{\circ} .3 \frac{37^{\circ} .9}{60^{\circ} .0}$ \\
Genera. . . & $46^{\circ} 12^{\prime}$ & $($ Alt. $1298 \mathrm{E} . \mathrm{ft})$. & $7^{\circ} .9 \frac{0^{\circ} .7}{14^{\circ} .0}$ & $49^{\circ} .8 \frac{33^{\circ} .6}{63^{\circ} .5}$ \\
Kherson. . . & $46^{\circ} 38^{\prime}$ & $32^{\circ} 39^{\prime} \mathrm{E}$. & $9^{\circ} .4 \frac{-3^{\circ} .1}{17^{\circ} .3}$ & $53^{\circ} .2 \frac{25^{\circ} .0}{71^{\circ} .0}$ \\
\hline
\end{tabular}

Snow is hardly ever seen on the banks of the Oregon or Columbia river, and ice on the river lasts only a very few days. The lowest temperature which Mr. Ball once observed there in the winter of 1833 was $6 \frac{1}{2}^{\circ}$ of Reaumur below the freezing point, or $17.4^{\circ}$ Fahrenheit (Message from the President of the United States to Congress, 1844, p. 160 ; and Forry, Clim. of the U. States, p. 49, 67, and 73). A cursory glance at the summer and winter temperatures above given, shews that on and near the west coast, a true insular climate prevails. The winter cold is less than in the western parts of the old continent, and the summers are much cooler. The most striking contrast is presented 
by comparing the mouth of the Oregon with Forts Snelling and Howard, and the Council Bluffs, in the interior of the Mississipi and Missouri basin (Lat. $44^{\circ}-46^{\circ}$ ), where, to speak in the language of Buffon, we find an excessive, or true continental climate, - a winter cold, on single days, of $-28^{\circ} .4$ and $-30^{\circ} .6$ Reaumur $\left(-32^{\circ}\right.$ and $-37^{\circ}$ Fahr.), followed by mean summer temperatures of $16^{\circ} .8$ and $17^{\circ} .5$ Reaumur ( $69^{\circ}$ and $71^{\circ} .4$ Fahr.)

\section{(19) p. 10.-"As if America had emerged later from the chaotic watery covering."}

An acute enquirer into nature, Benjamin Smith Barton, said long since with great truth, (Fragments of the Natural History of Pennsylvania, P. i. p. 4), "I cannot but deem it a puerile supposition, unsupported by the evidence of nature, that a great part of America has probably later emerged from the bosom of the ocean than the other continents." The same subject was touched on by myself in a memoir on the primitive nations of America (Neue Berlinische Monatschrift, Bd.xv. 1806, S. 190). "Writers generally and justly praised have repeated but too often that America is in every sense of the word a New Continent. Her luxuriance of vegetation, the abundant waters of her enormous rivers, the unrepose of her powerful volcanoes, all (say they) proclaim that the still trembling earth, from the face of which the waters have not yet dried off, is here nearer to the chaotic primordial state than in the Old Continent. Such ideas appeared to me, long before I. commenced my travels, alike unphilosophical and con- 
trary to generally acknowledged physical laws. Fantastic images of terrestrial youth, and unrepose associated on the one hand,-and on the other, those of increasing dryness, and inertia in maturer age,-could only have presented themselves to minds more inclined to draw ingenious or striking contrasts between the two hemispheres, than to strive to comprehend, in one general view, the construction of the entire globe. Are we to regard the south of Italy as more modern than its northern portions, because the former is almost incessantly disquieted by earthquakes and volcanic eruptions? Besides, what small phenomena are the volcanoes and earthquakes of the present day, in comparison with those revolutions of nature which the geologist must suppose to have accompanied, in the chaotic state of the earth, the elevation, solidification, disruptions, and cleavings of the mountain masses? Diversity of causes must produce diversity in the operations of natural forces, in countries remote as well as near. Perhaps the volcanoes of the new continent, (of which I still reckon above 28 in a state of activity), have only continued to burn longer than others, because the lofty mountain ridges, on which they have broken forth in rows or series above long subterranean fissures, are nearer to the sea, and because this proximity seems, with a few exceptions, to affect the energy of the subterranean fires in some way not yet sufficiently explained. Besides, both earthquakes and fire-emitting mountains have periods of activity alternating with periods of repose. "At the present moment," (I wrote thus 42 years ago !) "physical disquiet and political calm reign in the New 
Continent, while in the Old the desolating strife of nations disturbs the enjoyment of the repose of nature. Perhaps a time is coming when, in this singular contrast between physical and moral forces, the two sides of the Atlantic will change parts. Volcanoes are quiescent for centuries before they burst forth anew; and the idea that in the so-called older countries, a certain peace must prevail in nature, is founded on a mere play of the imagination. There exists no reason for assuming one entire side of our planet to be older or newer than the other. Islands are indeed raised from the bed of the ocean by volcanic action, and gradually heightened by coral animals, as the Azores and many low flat islands of the Pacific; and these may indeed be said to be newer than many Plutonic formations of the European central chain. A small district of the earth, surrounded, like Bohemia and Kashmeer, (and like many of the vallies in the Moon), by annular mountains, may, by partial inundations, be long covered with water; and after the flowing off of this lake or inland sea, the ground on which vegetation begins gradually to establish itself might be said, figuratively, to be of recent origin. Islands have become connected with each other by the elevation of fresh masses of land; and parts of the previously dry land have been submerged by the subsidence of the oscillating ground; but submersions so general as to embrace a hemisphere, can, from hydrostatic laws, only be imagined as extending at the same time over all parts of the earth. The sea cannot permanently overflow the boundless plains of the Orinoco and the Amazons, without also over- 
whelming the plains adjoining the Baltic. The sequence and identity of the sedimentary strata, and of the organic remains of plants and animals belonging to the ancient world enclosed in those strata, shew that several great depositions have taken place almost simultaneously over the entire globe." (For the fossil vegetable remains in the coal formation in North America and in Europe, compare Adolph Brongniart, Prodrome d'une Hist. des Végétaux Fossiles, p. 179; and Charles Lyell's Travels in North America, vol. ii. p. 20).

\section{${ }^{(20)}$ p. 10.- "The Southern Hemsphere is cooler and} moister than our Northern half of the globe."

Chili, Buenos Ayres, and the southern parts of Brazil and Peru, have all, as a result of the narrowness of the continent of South America as it tapers towards the south, a true "insular climate; or a climate of cool summers and mild winters. As far as the 48th or 50th parallel of latitude this character of the Southern Hemisphere may be regarded as an advantage, but farther on towards the Antarctic Pole, South America gradually becomes an inhospitable wilderness. The difference of latitude of the southern terminating points of Australia, (including Van Diemen Island), of Africa, and of America, - gives to each of these continents a peculiar character. The Straits of Magellan are between the 53d and 54th degrees of latitude, and yet in December and January, when the sun is 18 hours above the horizon, the temperature sinks 
to $4^{\circ}$ Reaumur, or $41^{\circ}$ Fahrenheit. Snow falls almost daily, and the highest atmospheric temperature observed by Churruca (1788) in December, (the summer of those regions), was not above $9^{\circ} \mathrm{R}$, or $52^{\circ} .2 \mathrm{Fahr}$. The Cabo Pilar, whose towering rock, though only 218 toises, or 1394. English feet high, may be regarded as the southern termination of the chain of the Andes, is almost in the same latitude as Berlin. (Relacion del Viage al Estrecho de Magallanes, apendice, 1793, p. 76.)

While in the Northern Hemisphere all the continents attain a sort of mean limit towards the Pole, coinciding pretty regularly with the parallel of $70^{\circ}$, the terminating points in the Southern Hemisphere,-of America, in the deeply indented and intersected Tierra del Fuego, - of Australia, - and of Africa, - are respectively $34^{\circ}, 46 \frac{1}{2}^{\circ}$, and $56^{\circ}$ distant from the south pole. The temperature of the very unequal extents of ocean, which divide these southern points from the icy pole, contributes very materially to modify their climates. The areas of dry land in the Northern and Southern Hemispheres are to each other in the proportion of 3 to 1 . But this inferiority in extent of continental masses in the Southern Hemisphere, as compared with the Northern, belongs much more to the temperate than to the torrid zone. In the temperate zones of the Northern and Southern Hemispheres, the ratio is as 13 to 1 ; in the torrid zones as 5 to 4 . The great inequality in the distribution of the dry land exercises a very sensible influence on the strength of the ascending aerial 
current which turns towards the southern pole, and on the temperature of the Southern Hemisphere. Some of the noblest forms of tropical vegetation, for example the tree-ferns, advance south of the equator as far as the parallels of $46^{\circ}$, and of even $53^{\circ}$; whereas north of the equator they are not found beyond the tropic of Cancer. (Robert Brown, Appendix to Flinders' Voyage, p. 575 and 584; Humboldt, de distributione geographica Plantarum, p. 81.85.) Tree-ferns thrive extremely well at Hobart Town in Van Diemen Island, (lat $42^{\circ} 53^{\prime}$ ), where the mean amnual temperature is $9^{\circ}$ Reaumur, or $52^{\circ} .2$ Fahrenheit, and is therefore $1^{\circ} .6$ Reaumur, or $3^{\circ} .6$ Fahrenheit, less than that of Toulon. Rome is almost a degree of latitude farther from the equator than Hobart Town, and has an anmul temperature of $12^{\circ} .3$ R., or $59^{\circ} .8$ Fahr.; - a minter temperature of $6^{\circ} .5$ R., or $46^{\circ} .4$ Fahr., - and a summer temperature of $24^{\circ} \mathrm{R}$., or $86^{\circ}$ Fahr.; these three values being in Hobart Town $8^{\circ} .9,4^{\circ} .5$, and $13^{\circ} .8 \mathrm{R}$., or $52^{\circ} .0,42^{\circ} .2$, and $63^{\circ}$. Fahr. In Dusky Bay, New Zealand, tree-ferns grow in S. lat. $46^{\circ} 8^{\prime}$, and in the Auckland and Campbell Islands, even in $53^{\circ} \mathrm{S}$. lat. (Jos. Hooker, Flora Antarctica, 1844, p. 107.)

In the Archipelago of Tierra del Fuego,- - where, in the same latitude as Dublin, the mean winter temperature is $0^{\circ} .4$ Reaumur, ( $33^{\circ}$ Fah.) and the mean summer temperature only $S^{\circ}$ R., or $50^{\circ}$ Fahr.,-Captain King found the "vegetation thriving most luxuriantly in large roody-stemmed trees of Fuchsia and Veronica"; while this vigour of regetation, which, especially on the western coast of America 
in $38^{\circ}$ and $40^{\circ}$ of south latitude, is so picturesquely described by Charles Darwin, suddenly disappears south of Cape Horn, on the rocks of the Southern Orkney and Shetland Islands, and of the Sandwich Archipelago. These Islands, but scantily covered with grass, moss, and lichens, "Terres de Désolation," as the French navigators call them, are still far north of the Antarctic Circle; whereas in the Northern Hemisphere in $70^{\circ}$ of latitude, at the extremity of Scandinavia, fir-trees attain a height of between 60 and 70 English feet. (Compare Darwin in the "Journal of Researches," 1845, p. 244, with King in vol. i. of the Narrative of the Voyages of the Adventure and Beagle, p. 577.) If we compare Tierra del Fuego, and particularly Port Famine in the Straits of Magellan in lat. $53^{\circ} 38^{\prime}$, with Berlin, which is one degree nearer the equator, we find for

Berlin $6^{\circ} 8, \frac{-0^{\circ} .5}{13^{\circ} .9}$ R., $47^{\circ} .2, \frac{30^{\circ} .8}{63^{\circ} .2}$ Fahr.; and for Port Famine $4^{\circ} .7, \frac{1^{\circ} .2}{8^{\circ} .0}$ R., $42^{\circ} .6, \frac{34^{\circ} .8}{50^{\circ} .0}$ Fahr.

I subjoin in one view the few well-assured temperature data which we at present possess, for the lands of the temperate zone in the Southern Hemisphere, and which may be compared with the temperatures of the Northern Hemisphere, in most parts of which the distribution into summer heat and winter cold is so different and so much less equable. I employ the convenient method of notation before used and explained in pages 129-131. 


\begin{tabular}{|c|c|c|c|}
\hline \multirow{2}{*}{ Place. } & \multirow{2}{*}{$\begin{array}{l}\text { South } \\
\text { Latitude. }\end{array}$} & \multicolumn{2}{|c|}{$\begin{array}{l}\text { Mean Annual, Winter, and } \\
\text { Sumner Temperature. }\end{array}$} \\
\hline & & Keaumur. & Fahrenheit. \\
\hline $\begin{array}{l}\text { Sidney and Paramatta } \\
\text { (New Holland.) }\end{array}$ & $33^{\circ} .50^{\prime}$ & $14^{\circ} .5 \frac{10^{\circ} .0}{20^{\circ} .2}$ & $64^{0} .5 \frac{54^{\circ} .5}{77^{\circ} .5}$ \\
\hline Cape Town (Africa.) & $33^{\circ} .55^{\prime}$ & $15^{\circ} .0 \frac{11^{\circ} .8}{15^{0} .3}$ & $65^{\circ} .7 \frac{58^{\circ} 5}{73^{\circ} .3}$ \\
\hline Buenos Ayres . . & $34^{\circ} .17^{\prime}$ & $13^{\circ} .5 \frac{9^{\circ} .1}{18^{\circ} .2}$ & $62^{\circ} .4 \frac{52^{\circ} .5}{73^{\circ} .0}$ \\
\hline Monte Video • • . & $34^{\circ} .54^{\prime}$ & $15^{\circ} .5{\frac{11^{\circ} .3}{20^{\circ} .2}}^{(?)}$ & $66^{\circ} .8 \frac{57^{\circ} .3}{77^{\circ} .5}$ \\
\hline $\begin{array}{l}\text { Hobart Town (Van } \\
\text { Diemen Island.) }\end{array}$ & $42^{\circ} .45^{\prime}$ & $9^{\circ} .1 \frac{4^{\circ} .5}{13^{\circ} .8}$ & $52^{\circ} .5 \frac{42^{\circ} .2}{63^{\circ} .0}$ \\
\hline $\begin{array}{l}\text { Port Famine (Straits } \\
\text { of Magellan.) }\end{array}$ & $53^{\circ} .38^{\prime}$ & $4.7 \frac{10.2}{8^{0} .0}$ & $42^{\circ} \cdot 6 \frac{34^{\circ} .8}{50^{\circ} .0}$ \\
\hline
\end{tabular}

(21) p. 11.- "A connected Sea of Sand."

As the Heaths formed of socially growing Ericer, which stretch from the mouth of the Scheldt to that of the Elbe and from the point of Jutland to the Harz, may be regarded as one connected tract of vegetation, - so the seas of sand may be traced through Africa and Asia, from Cape Blanco to beyond the Indus, or through an extent of 5600 geographical miles. Herodotus's Sandy Region interrupted by Oases, called by the Arabs the Desert of Sahara, traverses almost the whole of Africa, which it intersects 
like a dried-up arm of the sea. The valley of the Nile is the eastern limit of the Lybian Desert. Beyond the Isthmus of Suez, beyond the porphyritic, syenitic, and basaltic rocks of Sinai, begins the Desert mountain plateau of Nedjid, which occupies the whole of the interior of the Arabian Peninsula, and is bounded to the west and south by the fertile and happier coast lands of Hedjaz and Hadhramaut. The Euphrates bounds the Arabian and Syrian Deserts towards the east. Immense seas of sand, (bejaban), cross Persia from the Caspian to the Indian Sea. Among them are the salt and soda Deserts of Kerman, Seistan, Beloochistan, and Mekran. The latter is separated from the Desert of Moultan by the Indus.

\section{${ }^{22}$ ) p. 11.- "The western part of the Atlas."}

The question respecting the position of the ancient Atlas has heen much discussed in modern times, but the oldest Phenician legends have been confounded in this discussion with the later fables of the Greeks and the Romans. A man who combined deep philological with thorough mathematical and astronomical knowledge, Professor Ideler, (the father,) was the first person who explained and dispelled the confusion of ideas which had previously existed on this subject. I permit myself to introduce here the remarks that clear-sighted and highly-informed writer has communicated to me on this important subject.

"At a very early period of the world the Phœnicians ventured beyond the Straits of Gibraltar. They built Gades and Tartessus on the Spanish, and Lixus and several other 
tomns on the Mauritanian coasts of the Atlantic. They sailed along those coasts northwards to the Cassiterides where they obtained tin, and to the Prussian coast from whence they brought amber; and southwards, past Madeira, to the Cape de Verde Islands. They visited, among other places, the Canaries, and were struck by the appearance of the lofty Peak of Teneriffe, enhanced by its rising immediately from the sea. Through the colonies which they sent to Greece, and especially through that which came under Cadmus to Bootia, the notice of this mountain rising high above the region of clouds, and of the "Fortunate Islands," adorned with fruits of every kind, and especially with the golden orange, spread into Greece. Here the tradition was propagated by the songs of the bards, and thus reached Homer. He speaks in the Odyssey (i. 52) of an "Atlas who knows all the depths of the sea, and who supposts the great pillars which divide heaven and earth from each other." $\mathrm{He}$ speaks, too, in the Miad, of the Elysian fields, which he describes as a lovely land in the west. (Il. iv. 561.) Hesiod expresses himself in a similar manuer respecting Atlas, who he makes a neighbour of the nymphs the daughters of Hesperus. (Theog. V.517.) He calls the Elysian fields, which he places at the western limit of the earth, the islands of the Blest. (Op. et dies, v. 167.) Later poets have added further embellishments to these myths of Atlas, of the Hesperides, their golden apples, and the Islands of the Blest, assigned as the dwelling-place of the virtuous after death; and have combined with them the expeditions of the Tyrian god of trade, Melicertes (the Grecian Hercules). 
"The Greeks only began at a very late date to rival the Phœnicians and Carthaginians in navigation. They visited the coasts of the Atlantic it is true, but never appear to have penetrated far into the ocean. I doubt whether they ever saw the Canaries and the Peak of Teneriffe. They believed that Atlas, which their poets and legends described as a very high mountain placed at the western limit of the earth, must be sought on the west coast of Africa. It was placed there also by their later geographers, Strabo, Ptolemy, and others. As there is not any single mountain distinguished by its elevation in north-western Africa, the true situation of Mount Atlas has been a subject of perplexity; and it has been sought, sometimes on the coast, sometimes in the interior, sometimes near the Mediterranean, and sometimes further towards the south. It became the custom (in the first century of our era, when the Roman arms penetrated into the interior of Mauritania and Numidia, to give the name of Atlas to the African chain of mountains. which runs from west to east almost parallel with the coast of the Mediterranean. Pliny and Solinus were, however, very sensible that the descriptions of Mount Atlas given by the Greek and Roman poets were not applicable to this long mountain chain; and they therefore thought it necessary to transfer the Atlas, of which they gave a picturesque description in accordance with the poetic legends, to the terra incognita of Central Africa. According to what has been said, the Atlas of Homer and Hesiod can only be the Peak of Teneriffe; and the Atlas of the Greek and Roman geographers must be in Northern Africa." 
I will only add the following remarks to this instructive discussion by Professor Ideler. According to Pliny and Solinus, Atlas rises from a sandy plain (e medio arenarum); and elephants (which certainly were never known in Tenerifie) feed on its declivity. What we now term Atlas is a long ridge. How came the Romans to recognise in this long ridge the isolated conical mountain of Herodotus? Nay not the reason be found in the optical delusion by which erery mountain chain seen in profile, in the prolongation of its direction, has the appearance of a narrow cone? I have often seen in this manner, from the sea, the ends of long chains or ridges, which might be taken for isolated mountains. According to Höst the Atlas is corered near Morocco with perpetual snow, which implies an elevation of above 1800 toises, or 11510 English feet. It is also remarkable that, according to Pliny, the "Barbarians," i.e. the ancient Mauritanians, called the Atlas "Dyris." The chain of the Atlas is still called by the Arabs Daran, a word which has almost the same consonants as Dyris. Hornius, on the other hand (de Originibus Americanorum, p. 195), thinks that he recognises the word Dyris in the Guanche name of the Peak of Teneriffe, Aya-Dyrma. On the connection between purely mythical ideas and geographical traditions, and on the way in which the Titan Atlas gare occasion to the image of a mountain supporting the hearens, beyond the Pillars of Hercules, see Letromne's "Essai sur les Idées cosmographiques qui se rattachent au nom d'Atlas," in Férussac's Bulletin universel des Sciences, Mars 18:31, p. 10. 
Considering that our present (it is true, very limited) geological knowledge of the mountainous parts of North Africa does not make us acquainted with any trace of volcanic eruptions within historic times, it is very remarkable to find among the ancients so many indications of a belief in the existence of this class of phenomena, in the Western Atlas, and in the neighbouring west coast of the continent. The streams of fire, so often mentioned in Hanno's ship-journal, may indeed have only been strips of burning grass, or signal fires kindled by the wild inhabitants of the coasts to give to each other notice of the danger threatened by the appearance of the hostile vessels. The lofty flame-enlightened summit of the "chariot of the gods" $(\theta \varepsilon \tilde{\omega} \nu$ ó $\chi \eta \mu a)$, may recall obscurely the Peak of Teneriffe; but farther on Hanno describes a singular conformation of ground. He finds in the Gulf near the Western Horn, a large island, and in it a salt lake which again contains a smaller island. South of the bay of the Gorilla Apes, the same conformation is repeated. Is this a description of coral productions, of "lagoon islands, (Atolls)" or volcanic "crater lakes" in the middle of which a cone has been upheaved? The Triton lake was not in the neighbourhood of the lesser Syrtis, but near the Atlantic coast. (Asie Cent. T. i. p. 179.) The lake disappeared in consequence of earthquakes which were accompanied by great outbursts of fire. Diodorus (Lib. iii. 53, 55) says expressly,

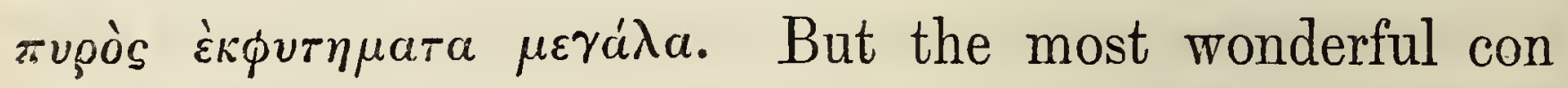
formation is ascribed to the "hollow Atlas" in a passage hitherto little noticed, occurring in one of the philosophic 
Dialexes of Maximus Tyrius. This Platonic philosopher lived in Rome, under Commodus. The situation of his Atlas is "on the continent, where the Western Lybians inhabit a projecting peninsula. The mountain has in it towards the sea a semicircular deep abyss. The precipices are so steep that they cannot be descended; the abyss below is filled with trees, and "one looks down upon their summits, and on the fruits which they bear, as if one was looking into a well." (Maximus Tyrius, viii., 7, ed. Markland.) The description is so graphic and so individually marked, that it doubtless conveys the recollections impressed by a real prospect.

${ }^{(23)}$ p. 11.- "The Mountains of the Moon, Djebel al Komr."

The Mountains of the Moon of Ptolemy (Lib. iv. cap. 9, ( $\sigma \varepsilon \lambda \eta \dot{\eta} \nu \eta$ öoos) form on our older maps an immense uninterrupted mountain zone, traversing Africa from east to west. The existence of these mountains appears certain; but their extent, their distance from the Equator, and their general direction, are ail unsolved problems. I have already alluded in another work, (Cosmos, vol. ii. p. 191, and note 297, Engl. ed.) to the manner in which a closer acquaintance with Indian languages, and with the ancient Persian idiom, the Zend, teaches us that part of the geographical nomenclature of Ptolemy forms an historic monument of the commercial connection of the west with the most distant regions of Southern Asia and Eastern Africa. The same direction of ideas shews itself in a question very recently 
brought forward. It is asked, whether the great geographer and astronomer of Pelusium meant in the name of "Mountains of the Monn," as in that of the "Island of Barley" (Jabadiu, Java), merely to give the Greek translation of a native name;-whether (as is most probable) El Istachri, Edrisi, Ibn-al-Vardi, and other early Arabian geographers, only transferred the nomenclature of Ptolemy into their own language; - or whether they were misled by similarity in the sound of the words and the manner of writing. In the notes to the translation of Abd-Allatif's celebrated description of Figypt, my great instructor, Silvestre de Sacy, (êd. de 1810, p. 7 and 353,) says expressly: "On traduit ordinairement le nom de ces montagnes que Léon Africain regarde comme les sources du Nil, par montagnes de la lune, et j'ai suivi cet usage. Je ne sais si les Arabes ont pris originairement cette dénomination de Ptolémée. On peut croire qu'ils entendent effectivement aujourd'hui le mot, sens de la lune en le prononçant 'Kamar'; je ne crois pas cependant que çait été l'opinion des anciens écrivains arabes qui prononcent, comme le prouve Makrizi, Komr. Aboulféda rejette positivement l'opinion de ceux qui prononcent kamar, et qui dérivent ce nom de celui de la lune. Comme le mot komr, considéré comme pluriel de,, a_, signifie un objet d'une couleur verdâtre on d'un blanc sale, suivant l'auteur du Kamous, il paroit que quelques écrivains ont cru que cette montagne tiroit son nom de sa couleur."

The jearned Reinaud, in his recent excellent translation of Abulfeda (T. ii., P.i., p. 81-82), considers it probable that the Ptolemaic interpretation of the name, by "Mountains 
of the Moon" (" $\circ \eta \eta \sigma \varepsilon \lambda \eta v a \tilde{\iota} a)$, was that originally adopted by the Arabian writers. He remarks that in the Moschtarek of Yakut, and in Ibn-Said, the mountains are written alKomr, and that Yakut writes in the same way the name of the island of Zendj (Zanguebar). The Abyssinian traveller Beke, in his learned critical memoir on the Nile and its tributaries (Journal of the Royal Geographical Society of London, vol. xvii. 1847, p. 74-76), seeks to prove that Ptolemy had merely formed his $\sigma \varepsilon \lambda \eta \nu \eta s$ goos from a native name, for which he was indebted to intelligence received through the medium of the extensive commercial intercourse which prevailed. He says, "Ptolemy 'nnew that the Nile rises in the mountainous country of Moezi; and in the languages which extend over a great portion of South Africa (for example, in the languages of Congc, Monjou, and Mozambique), the word Moezi signifies the inoon. A great south-western country was called MonoMuezi, or Mani-Moezi, i. e. the land of the king of Moezi (of the king of the Moon country), for in the same family of languages in which Moezi or Muezi signifies the Moon, Mono or Mani signifies a king. Alvarez, in the Viaggio nella Ethiopia (Ramusio, vol. i., p. 249,) speaks of the 'regno di Manicongo,' the kingdom of the king of Congo." Beke's opponent, Ayrton, seeks the origin of the White Nile (Bahr el Abiad), not as do Arnaud, Werne, and Beke, near the equator, or even south of it (and in $29^{\circ} \mathrm{E}$. long. from Paris, or $31^{\circ} 22^{\prime}$ from Greenwich), but with Antoine d'Abbadie far to the north-east, in the Godjeb and Gibbe of Eneara (Iniara); therefore in the high mountains of 
Habesch, in $7^{\circ} 20^{\prime} \mathrm{N}$. latitude, and $33^{\circ} \mathrm{E}$. long. from Paris, or $35^{\circ} 22^{\prime}$ from Greenwich. He conjectures that the Arabs, from a similarity of sound, may have interpreted the native name Gamaro belonging to the Abyssinian mountains, in the south-west of Gaka in which the Godjeb (or White Nile?) has its source, to mean Moon Mountains (Djebel al-Kamar); so that Ptolemy himself, familiar with the intercourse between Abyssinia and the Indian Ocean, may have taken the Semitic version, given by early Arab immigrants. (Compare Ayrton in the Journal of the Royal Geogr. Soc. vol. xviii. 1848, p. 53, 55, and 59-63, with Fred. Werne's instructive expedition for the discovery of the sources of the Nile, Exped. zur Entd. der Nil-Quellen, 1848, S. 534-536.

The lively interest which has again been excited in England for the discovery of the most southern sources of the Nile, induced the above-named Abyssiniun traveller, Charles Beke, at the recent meeting of the British Association for the Advancement of Science, held at Swansea; August 1848, to develope more in detail his ideas respecting the connection between the Mountains of the Moon and the Mountains of Habesch. He says:- "The Abyssinian elevated plain, generally above 8000 feet high, extends towards the south to nearly $9^{\circ}$ or $10^{\circ} \mathrm{N}$. latitude. The eastern declivity of the highlands has to the inhabitants of the coast the appearance of a mountain chain. The plateau at its southern extremity passes into the Mountains of the Moon, which run, not east and west, but parallel to the coast, or from NNE. to SSW.; extending, 
from $10^{\circ} \mathrm{N}$. to $5^{\circ} \mathrm{S}$. latitude. The sources of the White Nile are situated in the Mono-Moezi country, probably in $2 \frac{1}{9}^{\circ} \mathrm{S}$, not far from where the river Sabaki, on the eastern side of the Mountains of the Moon, falls into the Indian Ocean near Melindeh, north of Mombaza. Last autumn (1:4:T) the two Abyssinian missionaries Rebmann and Krapf were still on the coast of Mombaza. They have established in the vicinity, among the Wakamba tribe, a missionary station called Rabbay Empie, which promises to be very useful also for geographical discovery. Families belonging to the Wakamba tribe have advanced to the west five or six hundred miles into the interior of the country, as far as the upper course of the river Lusidji, the great lake Nyassi or Zambeze ( $5^{\circ} \mathrm{S}$. lat.?), and the sources of the Nile which are not far distant. An expedition to these sources, which Herr Friedrich Bialloblotzky, of Hanover, is preparing to undertake, (by the advice of Beke), is to set out from Mombaza. The Nile coming from the west referred to by the ancients is probably the Bahr-el-Ghazal, or Keilah, which falls into the Nile in $9^{\circ} \mathrm{N}$. lat., above the mouth of the Godjeb or Sobat."

Russegger's scientific expedition, - which by Mehemet Ali's desire was sent to the gold-washings of Fazokl on the Blue (Green) Nile, Bahr-el-Azrek, in 1837 and 1838, - had made the existence of the "Mountains of the Moon" appear very doubtful. The Blue Nile, the Astapus of Ptolemy, issuing from the lake of Coloe (now called lake Tzana) winds from amongst the colossal Abyssinian mountains; but towards the south-west an extensive low 
tract of country appears. The three exploring expeditions sent by the Egyptian government, (one in November $18 \overline{8} 9$ from Chartum to the confluence of the Blue and the White Nile, under the command of Selim Bimbashi; another in the autumn of 1840, which was accompanied by the French engineers Arnaud, Sabatier, and Thibaud; and a third in August 1841), first unveiled the high mountains which, between the parallels of $6^{\circ}-4^{\circ}$, and probably still farther to the south, run at first from west to east, and afterwards from north-west to south-east, and approach the left bank of the Bahr-el-Abiad. The second of Mehemed Ali's expeditions first saw the mountain chain, according to Werne's account, in lat. $11 \frac{1}{3}^{\circ}$, where Gebel Abul and Gebel Kutak rise to 3400 (3623 Eng.) feet. The high land continued and approached nearer to the river more to the south, between $4 \frac{3}{4}^{\circ}$ lat., to the parallel of the island of Tschenker in $4^{\circ} 4^{\prime}$, where the expedition of Commander Selim and Feizulla Effendi terminated. The shallow river makes its way between rocks, and detached mountains rise again in the country of Bari to 3000 (3197. Eng.) feet. These probably belong to the Mountains of the Moon as represented in our most recent maps, although they are not indeed mountains covered with perpetual snow such as Ptolemy had described (lib. iv. cap. 9). The limit of perpetual snow in these latitudes would not certainly be found below an elevation of 14500 (15450 Eng.) feet. Perhaps Ptolemy transferred to the country of the sources of the White Nile the knowledge which he may have had of the high mountains of Habesch, which are nearer to 
Upper Egypt and to the Red Sea. In Godiam, Kaffa, Miecha, and Sami, the Abyssinian mountains rise to 10000 and 14000 (10657 and 14920 Eng.) feet, according to exact measurements; not according to Bruce, who gives the elevation of Chartum exceedingly wide of the truth, i. e., 4730 (5041 Eng.) feet, instead of 1430 (1524 Eng.) feet! Ruippell, one of the most accurate observers of the present day, found Abba Jaret, in $13^{\circ} 10^{\prime}$ of latitude, only 66 (70 Eng.) feet lower than Mont Blanc. (Compare Rüppell, Reise in Abyssinien, Bd. i. S. 414, and Bd. ï. S. 443). Rüppell found, adjoining the Buahat, an elevated plain 1:3080 (13939 Eng.) feet above the Red Sea, barely covered with a small quantity of fresh fallen snow (Humboldt, Asie Centrale, T. iii. p. 272). The celebrated inscription of Adulis, which Niebuhr considers to be somewhat later than Juba and than Augustus, also speaks of Abyssinian snow "that reaches to the knees." This is, I believe, the earliest mention in antiquity of snow within the tropics (Asie Centrale, T. iii. p. 235); as the Paropanisus is $12^{\circ}$ of latitude north of the northern limit of the torrid zone.

Zimmermann's map of the countries about the Upper Nile sherrs the dividing line which determines the basin of the Great River, and separates it on the south-east from the domain of the rivers which flow into the Indian Ocean;that is to say, from the Doara, which enters the sea north of Magadoxo; from the Teb, which has its embouchure on the Amber coast, near Ogda; and from the Goschop, whose abundant stream is formed by the confluence of 
the Gibu and the Zebi, and which he distinguishes from the Godjeb, rendered celebrated since 1839 by Antoine d'Abbadie, the missionary Krapf, and Beke. These results of the travels of Beke, Krapf, Isenberg, Russeger, Rüppell, Abbadie, and Werne, brought together and shewn in the most comprehensive and convenient manner by Zimmermann, were hailed by me on their appearance in 1843 with the most lively joy, as expressed in a letter to Carl Ritter. "If," I wrote to him, " a life prolonged to an advanced period brings with it several inconveniences to the individual, and perhaps some even to those who live with him, there is a compensation in the delight of being able to compare older states of knowledge with that which now exists, and to see great advances in knowledge grow and develope themselves under our eyes in departments where all had long slumbered in inactivity, with the exception, perhaps, of attempts by hypercriticism to render previous acquisitions doubtful. This enjoyment has from time to time fallen to our share, yours and mine, in our geographical studies, and this particularly in reference to those very parts of the world which formerly could only be treated of with timid hesitating uncertainty. The conformation of a continent depends in its leading traits on several plastic relations which are usually among the latest to be discovered and unravelled. A new and excellent work of our friend Carl Zimmermann, on the upper country of the Nile and the eastern parts of central Africa, has again brought these considerations very vividly before me. His new map shews in the clearest manner to the eye, by 
means of a particular method of shading, what is still unknown, and what, by the courage and perseverance of travellers of all nations, - among whom our own countrymen happily hold an important place, - has been already disclosed to us. It is a valuable service, and one which opens the way for farther advances and more comprehensive inferences, when persons, thoroughly acquainted with the existing, often widely scattered, materials,-men who do not merely draw and compile, but compare, select, and, whereever it is possible, check and control the routes of travellers by astronomical determinations of position, - undertake to represent graphically the results of the elements of knowledge possessed at the time. Those who have themselves given to the world so much as you have done, have an especial right to expect much; since their combinations have largely augmented the number of connecting points; jet I believe that when you executed your great work on Africa in 1822 you could hardly have expected so many accessions as we have now received." The knowledge acquired is, indeed, often only that of rivers, their direction, their branches, and the various synonyms by which they are called in dialects belonging to different families of languages; but rivers reveal to us by their course the form of the surface of the earth, and are at once the nourishers of vegetation, the channels of intercourse between men, and pregnant with unknown influences on the future.

The northerly course of the White Nile, and the southeasterly course of the great Goschop, world indicate that a 
swelling of the ground separates the domains or basins of these rivers. We know, indeed, but imperfectly, how such a swelling or elevation may be connected with the mountains of Habesch, and in what manner it may be continued southward beyond the equator. Probably, and this is also the opinion of my friend Carl Ritter, the Lupata mountains, which, according to the excellent Wilhelm Peters, extend to $25^{\circ}$ S. latitude, are connected with the elevated parts of the Earth's surface on the north side of the equator, (or with the Abyssinian mountains), by the mountains of the Moon. The word "Lupata," we learn from the last-named African traveller, is used in the language of Tette as an adjective, meaning "closed." The chain of mountains would thus be called the "closed" or "barred." "The Lupata chain, of Portuguese writers," says Peters, "is about 90 legoas or leagues from the mouth of the Zambeze, and is only about two thousand feet high. The direction of this mountain rampart is north and south, but with occasional bends alternately to the east and to the west. It is sometimes interrupted by plains. Along the whole of the Zanzibar coast, the traders into the interior speak of this long but not very elevated ridge, which extends from $6^{\circ}$ to $26^{\circ} \mathrm{S}$. latitude, as far as the Factory of Lourenzo-Marques, on the Rio de Espiritu Santo (in the Bay da Lagoa, or Delagoa Bay of the English). The farther the Lupata chain advances towards the south, the nearer it approaches the coast, from which it is only fifteen legoas distant at LourenzoMarques." 
$\left.{ }^{24}\right)$ p. 12.- "Caused by the great revolving current."

In the northern part of the Atlantic, between Europe, North Africa, and the New Continent, the waters of the ocean are driven round in a true revolving current, or circle. This general current,-which, from its cause, might be called a "Rotation Current,"-moves between the tropics, as is well known, with the trade wind, from east to west. It accelerates the passage of ships sailing from the Canaries to South America, and makes it almost impossible to sail "up stream," or in a direct line from Cartagena de Indias to Cumana. This set to the rest, attributed to the trade winds, receives, however, in the Caribbean Sea, the accession of a much stronger movement, originating in a very remote cause, which was discovered as early as 1560 by Sir Humphrey Gilbert, (Hakluyt, Voyages, vol. iii. p. 14), and developed with greater certainty by Rennell in 1832. The Mosambique current, flowing from north to south between Madagascar and the east coast of Africa, sets on the Lagullas Bank, turns on the north side of it round the south point of Africa, and adrances with much force up the western coast of the Continent to a little beyond the equator near the Island of St. Thomas. It gives at the same time a north-westerly direction to a part of the water of the South Atlantic, causing it to strike Cape St. Augustin, and to follow the coast of Guiana to beyond the mouth of the Orinoco, the Boca del Drago, and the coast of Paria. (Rennell, Investigation of the Currents of the Atlantic Ocean, 1832, p. 96 and 136.) The New Continent, from 
the Isthmus of Panama to the northern part of Mexico, opposes a barrier to the farther continuance of this movement of the waters, and thus the current is constrained to assume a northerly course off Veragua, and thence to follow the windings of the coast of Costa Rica, Mosquito, Campeachy, and Tabasco. The waters which enter the Mexican Gulf between Cape Catoche of Yucatan and Cape San Antonio of Cuba, after completing a great rotatory movement or circuit, by Vera. Cruz, Tamiagua, the mouth of the Rio Bravo del Norte, and that of the Mississipi, force their way northwards through the Bahama Channel, and re-issue into the open ocean. Here they form the wellknown "Gulf Stream," a current or river of warm and rapidly moving water, flowing in an oblique or diagonal direction carrying it farther and farther from the North American coast. Ships from Europe bound for this coast, when uncertain in respect to their longitude, are enabled by this oblique direction of the current to direct their course, as soon as they reach the Gulf Stream, by observations of latitude only. The position of this great current was first indicated with accuracy by Franklin, Williams, and Pownall.

From the 4lst degree of latitude, the river of warm water, which has been gradually diminishing in rapidity and increasing in breadth, turns suddenly to the east. It almost touches the southern edge of the great Newfoundland bank, where I found the greatest amount of difference between the temperature of the warm water of the Gulf stream, and that of the waters resting on the banks and subjected thereby to a cooling process. Before the stream 
reaches the westernmost of the Azores it divides into two branches, one of which, at least at certain seasons, advances towards Ireland and Norway, and the other towards the Canaries and the West Coast of Africa. This Atlantic rotatory movement, (described by me in more detail in the first volume of my Voyage to the Equinoctial Regions), explains the possibility of trunks of South American and West Indian trees being carried, in spite of the trade winds, to the coasts of the Canary Islands, and stranded there. I have made many experiments on the temperature of the Gulf Stream in the vicinity of the Banks of Newfoundland. The Stream brings the warmer water of lower latitudes into more northern regions with much rapidity, and I have thus found its temperature two or three degrees of Reaumur $\left(5^{\circ}\right.$ to $7^{\circ}$ Fah.) higher than that of the adjacent unmoved masses of mater, which form as it were the banks of the warm oceanic river.

The flying fish of the tropics (Exocetus volitans) accompanies the warm water of the Gulf Stream far into the temperate zone. Floating sea-weed (Fucus natans), chiefly taken up by the stream in the Gulf of Mexico, shews when a ship is entering the current, and the arrangement of the branches of the sea-meed shews the direction of the movement of the water. 'The mainmast of the English ship of war, the Tilbury, destroyed by fire on the coast of San Domingo, was carried by the Gulf Stream to the north coast of Scotland. Even casks filled with palm oil, the remains of the cargo of a ship wrecked off Cape Lopez on the coast VOL. I. 
of Africa, were carried in the same manner to Scotland*, after having twice traversed the whole breadth of the Atlantic; once from east to west with the equitorial current hetween $2^{\circ}$ and $12^{\circ} \mathrm{N}$. lat., and once from west to east by the aid of the Gulf Stream, between $45^{\circ}$ and $55^{\circ}$ N. lat. Rennell, in p. 347 of the "Investigation of Currents," relates the voyage of a bottle with papers enclosed, thrown overboard by the English ship Newcastle on the 20th of January, 1819, in lat. $38^{\circ} 52^{\prime}$, and long. $63^{\circ} 58^{\prime}$, which was picked up on the 2nd of June, 1820 , at the Rosses, (near the Island of Arran), on the west coast of Treland. A short time before my arrival at Teneriffe a stem of South American cedar (Cedrela odorata), well covered with lichens, had been cast ashore in the harbour of Santa Cruz.

Effects of the Gulf Stream in stranding on the Islands of Fayal, Flores, and Corvo in the Azores, bamboos, artificially cut pieces of wood, trunks of an unknown species of Pine from Mexico and the West Indian Islands, and corpses of men of unknown race with unusually broad faces, contributed to the discovery of America, by confirming Columbus in his belief of the existence to the westward of Asiatic countries and islands at no impassable

[* The circumstance referred to was even more remarkable. Casks of palm oil, part of the cargo of the ship wrecked near Cape Lopez, were conveyed by the current to Finmarken, and stranded near the North Cape. Vide Editor's note in the English translation of "Cosmos," vol. i. p. xcvii.]-Tr. 
distance. The great discoverer even heard from the lips of settlers near the Cape de la Verga in the Azores, of some, "who, in sailing westward, had met decked or corered boats, manned by persons of strange and foreign appearance, and built apparently in such a manner that they could not founder,-almadias con casa movediza que nunca se hunden." There is highly credible and well-confirmed testimony to the fact, much as it has long been doubted, of natives of America, (probably Esquimaux from Greenland or Labrador), carried by currents or driven by storms from the North West, having actually crossed the Atlantic in their canoes and reached our shores. James Wallace, in his "Account of the Islands of Orkney, (1700, p. 60)," relates, that in 1682 a Greenlander was seen in his boat off the South Point of the Island of Eda by several persons, who did not succeed in bringing him to shore. In 16s4, a Greenland fisherman appeared in his boat off the Island of Nestram. In the church at Barra there was suspended an Esquimaux boat, driven thither by currents and tempests. The inhabitants of the Orkneys call Greenlanders so appearing among them Finns or "Finnmen."

In Cardinal Bembo's History of Venice, I find a narrative to the effect that in 1508 a French ship captured near the English coast a small boat, with seren persons of a strange and foreign appearance. The description suits extremely well with Esquimaux, (homines erant septem mediocri statura, colore subobscuro, lato et patente vultu, cicatriceque una riolacea signato.) No one understood their language. Their clothing was composed of fish shins 
sewn together. On their heads they wore "coronam e culmo pictam, septem quasi auriculis intextam." They ate raw flesh, and drank blood as we would wine. Six of the men died during the passage of the vessel, on board which they had been taken; but the seventh, a youth, was presented to the king of France, who was then at Orleans. (Bembo, Historia Veneta, ed. 1718, lib. vii. p. 257).

The appearance of men called Indians on the western coasts of Germany, under the Othos, and under Frederic Barbarossa, in the 10th and 12th centuries, and even, as is related by Cornelius Nepos, (ed. Van Staveren, cur. Bardili, T. ii., 1820, p. 356), Pomponius Mela, (lib. iii. cap. 5, $\S 8$ ), and Pliny, (Hist. Nat., T. ii. p. 67), when Quintus Metellus Celer was Pro-consul in Gaul, may be explained by similar effects of currents and northwest winds of long continuance. A king of the Boii, others say of the Suevi, gave the shipwrecked dark-coloured men to Metellus Celer. Gomara, in his Historia Gen. de las Indias, (Saragossa, 1553, fol. vii.), refers to this account, and considers the Indians spoken of in it to have been natives of Labrador. "Si ya no fuesen de Tierra del Labrador, y los tuviesen, los Romanos por Indianos engañados en el color." The appearance of Esquimaux on the northern coasts of Europe may be believed to have occurred more often in earlier times, because we know, from the researches of Rask and Finn Magnusen, that in the 11th and 12th centuries this race extended in considerable numbers, under the name of the Skrälinges of Labrador, even as far south as the "good Vinland;" i. e., the coast of Massa- 
chusets and Connecticut. (Kosmos, Bd. ii. S. 270 ; English ed. p. 234 ; Examen critique de l'Hist. de la Géographie, T. ii. p. $247-278$.)

As the winter cold of the most northern parts of Scandinavia is softened by the influence of the Gulf Stream, by which American tropical fruits (cocoa nuts, and seeds of the Mimosa scandens and the Anacardium occidentale) are cast upon the shore beyond the 62nd degree of latitude, so does Iceland also occasionally enjoy the beneficial influence of the extension of the warm waters of the Gulf Stream far to the northward. The coasts of Iceland as well as those of the Färoe Islands, receive a great deal of driftwood, which, coming formerly in greater abundance, was cut into beams and planks and used for building timber. Fruits of tropical plants, collected on the coast of Iceland, between Raufarhavn and Vapnafiord, testify the morement of the waters from the southward. (Sartorius von Waltershausen, physisch-geographische Skizze von Island, 1847 , S. 22.35.)

(25) p. 12.-Neither Lecideas nor other Lichens."

In northern countries, the earth, if left bare, soon becomes corered with Bæomyces roseus, Cenomyce rangiferinus, Lecidea muscorum, L. icmadophila, and similar Cryptogamex, which prepare the way for the growth of grasses and herbaceous plants. In the tropics, where mosses and lichens only abound in shady places, some species of succulent plants take their place. 
(26) p. 13.- "The care of animals yielding milk,....... The ruins of the Aztec fortress."

The two kinds of cattle alluded to, and subsequently spoken of,-the Bos americanus and Bos moschatus,-are peculiar to the American continent. But the natives-

Queis neque mos, neque cultus erat, nec jungere tauros. Virgil, Ann. i. 316.

-drink the fresh blood, not the milk, of these animals. Single exceptions have indeed been found, but only among tribes who at the same time cultivated maize. I have before remarked, (p. 54), that Gomara speaks of a people in the north-west of Mexico who possessed herds of tame bisons, and derived from these animals clothing, meat, and drink. The drink may have been the blood, (Prescott, Conquest of Mexico, vol. iii. p. 416) for, as I have more than once remarked, the dislike to milk, or at least the absence of its use, appears, before the arrival of Europeans, to have been, generally speaking, a feature common to all the natives of the New Continent,-and one which they possess in common with the inhabitants of China and Cochin China, who yet were near neighbours to true pastoral nations. The herds of tame lamas, found in the highlands of Quito, Peru, and Chili, belonged to a settled population, who cultivated the ground and did not follow a nomadic life. Pedro de Cieça de Leon, (Chronica del Peru, Sevilla, 1553 , cap. 110, p. 264) seems to imply, though certainly as a rare and exceptional case, that in the Peruvian mountain plateau of Collao lamas were used for drawing the 
plough. (Compare Gay, Zoologia de Chile, Mamiferos, 1847, p. 154.) The usual custom in Peru was to plough with men only. (See the Inca Garcilaso's Commentarios reales, P. i. lib. v. cap. 2, p. 133; and Prescott, Hist. of the Conquest of Peru, 1847, vol. i. p. 136.) Mr. Barton has made it appear probable that, among some of the tribes of Western Canada, the buffalo was from early times made an object of care for the sake of its flesh and skin. (Fragments of the Nat. Hist. of Pennsylvania, P. i. p. 4.) In Peru and Quito the lama is now nowhere found in a state of original wildness. I was told by the natives that the lamas on the western declivity of the Chimborazo had become wild when the ancient residence of the rulers of Quito "Lican" was laid in ashes. In the same manner the oxen in the Ceja de la Montaña, in Middle Peru, have become perfectly wild: they are a small and daring race, and often attack the Indians. The natives call them Vacas del Monte, or Vacas cimarronas. (Tschudi, Fauna Peruana, S. 256.) Cuvier's opinion, that the lama had descended from the still wild Guanaco, has been unfortunately still further disseminated by the meritorious traveller Meyen, (Reise um die Erde, Th. iii. S. 64), but has been completely refuted by ron Tschudi.

The Lama, the Paco or Alpaca, and the Guanaco, are three originally distinct species of animals. (Tschudi, S. 228 and 237.) The Guanaco (Huanacu in the Quichua language) is the largest of the three; and the Alpaca, measured from the ground to the crown of the head, the smallest. The lama is next to the guanaco in stature. Herds of lamas, when they are as numerous as I have seen 
them in the high plateau between Quito and Riobamba, are a great ornament to the landscape. The Moromoro of Chili appears to be a mere variety of the lama. Vicunas, Guanacoes, and Alpacas, still live wild at elevations of from 13000 to 16000 feet above the level of the sea. The two latter species are sometimes met with tamed, but the guanaco only rarely. The alpaca does not bear the warmer climate of the lower elevations so well as the lama. Since the introduction of the more useful horses, mules, and asses, (the latter acquire great spirit and beauty within the tropics), the custom of rearing and using the lama and the alpaca as beasts of burden, in the mountains and among the mines, has much decreased. But the wool, of such different qualities in respect to fineness, is still an important article in the industry of the inhabitants of the mountains. In Chili the wild and the tamed guanaco are distinguished by separate names; the wild being called Luan, and the tame Chilihueque. The wide dissemination of the wild guanaco, from the Peruvian Cordilleras to Tierra del Fuego, sometimes in herds of 500 , has been favoured by the circumstance that these animals can swim with great ease from island to island, so that the Patagonian fiords offer no obstacle to their wanderings. (See the pleasing descriptions by Darwin in his Journal, 1845, p. 66.)

South of the Gila River, which, together with the Rio Colorado, enters the Californian Gulf or Mar de Cortes, stand, in the solitude of the Steppe, the enigmatical ruins of the Aztec Palace, called by the Spaniards las Casas grandes. When the Aztecs, about the year 1160, came from the un- 
known laud of Aztlan to Anahuac, they settled themselves for a time on the banks of the Gila. The Franciscan monks, Garces and Font, are the latest travellers who have visited the Casas grandes, and they did so in 1773. They stated the ruins to extend orer above a square German mile (16 English square miles). The whole plain is strewed with fragments of painted pottery. The principal palace, (if a house built of unburnt clay can be so designated), is 447 English feet long and 27\% English feet broad. (See a rare work printed in Mexico, and entitled Cronica seráfica y apostólica del Colegio de Propaganda Fide de la Santa Cruz de Querétaro por Fr. Juan Domingo Arricivita).

The Tayé of California, as drawn by Father Venegas, appears to differ little from the Ovis musimon of the Old Continent. The same animal is also seen on the "Stony Mountains," near the sources of the Peace River. Very different from it, on the other hand, is the small white and black spotted goat-like creature which feeds near the Missouri and Arkansas rivers. The synonymy of Antilope furcifer, A. tememazama of Smith, and Oris montana, is still very undetermined.

${ }^{(27}$ P. 14.- "The cultivation of farinaceous grasses."

The original habitat of the farinaceous grasses is wrapped in the same obscurity as that of the domestic animals which have accompanied man since his earliest migrations. The German word for corn, "Getraide," has been ingeniously derived by Jacob Grimm from the old German gitragidi, getregede. "It is as it were the tame fruit (fruges, frumen- 
tum), which has come into the hands of man; as we speak of tame animals in opposition to wild ones." (Jacob Grimm, Gesch. der deutschen Sprache, 1848, Th. i. S. 62.) It is certainly a very striking phenomenon, to find on one side of our planet nations to whom flour or meal from small-eared grasses (Hordeaceæ and Avenaceæ), and the use of milk, were completely unknown, while the nations of almost all parts of the other hemisphere cultivate the Cerealia, and rear milk-yielding animals. The cultivation of different kinds of grasses may be said to afford a characteristic distinction between the two parts of the world. In the New Continent, from $52^{\circ}$ north to $46^{\circ}$ south latitude, we see only one species cultivated, viz. maize. In the Old Continent, on the other hand, we find every where, from the earliest times of history, the fruits of Ceres, wheat, barley, spelt or red wheat, and oats. That wheat grew wild in the Leontine fields, as well as in several other places in Sicily, was a belief entertained by ancient nations, and is mentioned. by Diodorus Siculus. (Lib. v. p. 199 and 232, Wessel.) Ceres was found in the alpine meadow of Enna; and Diodorus fables that "the inhabitants of the Atlantis were unacquainted with the fruits of Ceres, because they had separated from the rest of mankind before those fruits had been shewn to mortals." Sprengel has collected several interesting passages which lead him to think it probable that the greater part of our European kinds of grain were originally wild in the northern parts of Persia and India, namely, summer wheat in the country of the Musicanes, a province in Northern India (Strabo, xv. 1017); barley ("anti- 
quissimum frumentum," as Pliny calls it, and which is also the only cereal with which the Guanches of the Canaries were acquainted), according to Moses of Chorene (Geogr, Armen. ed. Whiston, 1736, p. 360), on the Araxes or Kur in Georgia, and according to Marco Polo in Balascham in Northern India (Ramusio, vol. ii. p. 10) ; and spelt or red wheat, near Hamadan. But these passages, as has been shewn by my keen-sighted friend and teacher Link, in an instructive critical memoir (Abhandl. de Berl. Akad. 1816, S. 123), still leave much uncertainty. I also early regarded the existence of originally wild kinds of grain in Asia as extremely doubtful, and riewed such as might have been seen there as having become wild. (Essai sur la Géograplie des Plantes, 1805, p. 28.) Reinhold Forster, who before his voyage with Captain Cook, made by order of the Empress Catherine an expedition into Southern Russia for purposes of natural history, reported that the twostalked summer barley (Hordeum distichon), grew wild near the junction of the Samara and the Volga. At the end of the month of September, 1829, Ehrenberg and myself, on our journey from Orenburg and Uralsk to Saratow and the Caspian, also herborised on the banks of the Samara. We were, indeed, struck with the quantity of wheat and rye plants growing in what might be called a wild state in the uncultivated ground, but the plants did not appear to us to differ from the ordinary cultivated ones. Ehrenberg received from M. Carelin a kind of rye, Secale fragile, gathered on the Kirgis Steppe, and which Marschall von Bieberstein regarded for a time as the original or mother plant of our 
cultivated rye, Secale cereale. Although Olivier and Michaux speak of spelt (Triticum spelta) as growing wild at Hamadan in Persia, Achill Richard does not consider that Michaux's herbarium bears out this statement. Greater confidence is due to the most recent accounts obtained by the unwearied zeal of a highly-informed traveller, Professor Carl Koch. He found much rye (Secale cereale, var. $\beta$, pectinata) in the Pontic Mountains, at elevations of upwards of five or six thousand feet, in places where within the memory of the inhabitants no grain of the kind had ever been cultivated. Koch remarks, that the circumstance is "the more important because with us this grain never pro. pagates itself spontaneously." In the Schirwan parts of the Caucasus, Koch collected a kind of barley which he calls "Hordeum spontaneum," and considers to be the originally wild "Hordeum zeocriton" of Linnæus. (Carl Koch Beitrage zur Flora des Orients, Heft i. S. 139 and 142.)

A negro slave of the great Cortes was the first who cultivated wheat in New Spain. He had found three grains of it amongst the rice which had been brought from Spain for provision for the army. In the Franciscan convent at Quito, I saw preserved as a relic the earthen vessel which had contained the first wheat sowed there by the Franciscan monk Fray Jodoco Rixi, a native of Ghent in Flanders. The first sowing had been made in front of the convent, on what is now the Plazuela de San Francisco, after cutting down the forest which then extended from the foot of the volcano of Pichincha to the spot in question. The monks, who I often visited during my stay at Quito, begged 
me to explain to them the inscription on the earthen vessel, which they thought must contain some mystic reference to the wheat. I read the motto, which was in the old German dialect, and was - "Whoso drinks from me let him not forget his God." I too felt with the monks that this old German drinking vessel was a truly venerable relic. Would that there had been preserved every where in the New Continent the names, not of those who made the earth desolate by bloody conquests, but of those who first intrusted to it these its fruits so early associated with the civilisation of mankind in the Old Continent! In respect generally to the names of the kinds of grain, as bearing on the original affinities of different languages, a high authority has remarked, that "such indications are much more rare in the case of different kinds of grain, and on subjects of agriculture, than on those connected with the care of cattle: herdsmen when dispersed had still much in common, whereas the subsequent cultivators of the soil had to create new words. But the fact that in comparison with the Sanscrit, Romans and Greeks appear nearly on a par with the Germans and Slavonians, argues in favour of the very early contemporaneous emigration of the two latter. Yet the Indian "java" (Frumentum hordeum), compared with the Lithuanian "jarrai," and the Finnish "jywa," offers a singular exception." (Jac. Grimm, Gesch. der deutschen Sprache, Th. i. S. 69.)

$\left.{ }^{28}\right)$ p. 14._- Keeping by preference to the cooler mountain regions."

Throughout Mexico and Peru the traces of a great degree 
of civilisation are confined to the elevated plateaux. We have seen on the Andes the ruins of palaces and baths at heights between 1600 and 1800 toises (10230 and 11510 English feet). It can only have been men of a northern race, who, migrating from the north towards the south, could find delight in such a climate.

\section{(29) p. 15.- "The history of the peopling of Japan."}

The probability of the western nations of the New Continent having had communication with the east of Asia long before the arrival of the Spaniards, was I think shewn by me in a work on the monuments of the native inhabitants of America (Vues des Cordillères et Monumens des peuples indigenes de l'Amérique). I inferred this probability from a comparison of the Mexican and Thibeto-Japanese calendars, - from the correct orientation of the steps of the pyramidal elevations towards the different quarters of the heavens,and from the ancient myths and traditions of the four ages or four epochs of destruction of the world, and the dispersion of mankind after a great flood of waters. The accounts published since my work, in England, France, and the United States, describing the wonderful bas reliefs, almost in the Indian style, in the ruins of Guatimala and Yucatan, have given to these analogies a still higher value. (Compare Antonio del Rio, Description of the Ruins of an Ancient City discovered near Palenque, 1822, translated from the original manuscript report by Cabrera (del Rio's exploration took place in 1787), p. 9, tab. 12-14; with Stephens, Incidents of Travel in Yucatan, 1843, vol. i. pp. 391 and 429-434; vol. ii. pp. 21, 54, 56, 317, 323; 
with the magnificent volume of Catherwood, "Views of ancient Monuments in Central America, Chiapas, and Yucatan," 1844; and lastly, with Prescott's "Conquest of Mexico," vol. iii. App. p. 360.)

The architectural remains in the peninsula of Yucatan shew, still more than those of Palenque, a degree of civilisation and art which excites our astonishment. They are situated between Valladolid, Merida, and Campeachy, chiefly in the western part of the country. But the monuments in the island of Cozumel (more properly Cuzamil), east of Yucatan, were the first which were seen by the Spaniards in the expedition of Juan de Grijalva, 1518, and that of Cortes in 1519, and the report of them did much to spread over Europe a high idea of ancient Mexican civilisation. The most important ruins of the peninsula of Yucatan, which unfortunately have not yet been thoroughly measured and drawn by architects, are the Casa del Gobernador of Uxmal, the Teocallis and vaulted constructions at Kabah, the ruins of Labnah with domed columns, those of Zayi wilh columns very nearly of the Doric order, and those of Chiche with large ornamented pilasters. An old manuscript written in the Maya language by a Christian Indian, and which is still in the hands of the Gefe politico of Peto, Don Juan Pio Perez, gives the different epochs ("Katunes" of 52 years) in which the Toltecs settled in different parts of the peninsula. From these data Perez infers that the monuments or buildings of Chiche go back to the close of the fourth century of our era, while those of Uxmal belong to the middle of the tenth century. But the accuracy of these 
conclusions is subject to much uncertainty. (Stephens, Incidents of Travel in Yucatan, vol. i. p. 439; and vol. ij. p. 278.)

I regard the existence of ancient connections between the inhabitants of western America and eastern Asia as more than probable, but by what routes, or with what Asiatic nations, the communications took place, cannot at present be decided. A small number of individuals of the educated priestly caste might perhaps be sufficient to bring about great alterations in the civil and social state of western America. The stories formerly narrated of Chinese expeditions to the New Continent really apply only to voyages to Fusang or Japan. On the other hand, Japanese and Sian-Pi from the Corea may have been driven by storms to the American coast, and landed there. We know as matter of history that Bonzes and other adventurers sailed over the eastern Chinese seas in search of some medicine which should entirely prevent death. Under Tschin-schikuang-ti, 209 years before our era, 300 young couples, young men and young women, were sent to Japan, and instead of returning to China they settled at Nipon (Klaproth, Tableaux historiques de l'Asie, 1824, p. 79 ; Nouveau Journal Asiatique, T. x. 1832, p. 335; Humboldt, Examen critique, T. ii. p. 62-67). May not similar expeditions have been driven by storms or other accidents to the Aleutian islands, to Alashka, or to New California? As the western coasts of the American continent trend from NW. to SE., and the eastern coasts of Asia in the opposite direction, or from NE. to SW., the distance between the two continents 
in $45^{\circ}$ of latitude, or in the temperate zone which is most farourable to mental derelopment, is too considerable to admit of the probability of such an accidental settlement taking place in that latitude. We must, then, assume the first landiug to have been made in the inhospitable climate of from $55^{\circ}$ to $65^{\circ}$, and that the civilisation thus introduced, like the general movement of population in America, has proceeded by successive stations from north to south (Humboldt, Relat. historique, t. iii. p. 155-160). The remains of ships from Cathay, i. e., from Japan or China, were supposed to have been found on the coasts of the northern Dorado, (called Quivira and Cibora) at the begimning of the 16th century (Gomara, Hist. general de las Indias, p. 117).

Our knomledge of the languages of America is still too limited, considering their great variety, for us as ret entirely to relinquish the hope of some day discovering an idiom which may have been spoken, with certain modifications, at once in the interior of South America and in that of Asia; or which may at least indicate an ancient affinity. Such a discovery would certainly be one of the most brilliant which can be expected in reference to the history of mankind. But analogies of language only deserve confidence when the enquirer, not resting in or dwelling on resemblances of sound in the roots, traces the analogies into the organic structure, the grammatical forms, and into all which in languages shews itself as the product of the human intellect and character. 
(30) p. 15.- "Many other forms of animals."

Whole herds of the Cervus mexicanus wander over the Caraccas Steppes: the young stag is spotted, and resembles in appearance the roe-deer of Europe. We saw among them many entirely white,-a singular circumstance in the torrid zone. The Cervus mexicanus is not found at greater elevations on the mountain-slopes of the Andes under the equator than from 700 to 800 toises (44.76 to 5115 Eng. feet); but a larger, and also often white, stag, - which I could hardly distinguish from the European by any specific characters, - is met with up to 2000 toises (12789 Eng. feet). The Cavia capybara, called in the province of Caraccas "chiguire," is an unfortunate animal; being pursued in the water by the crocodile, and on the plain by the tiger or jaguar. It runs so badly that we could often catch it with our hands. Its extremities are smoked for hams, but their taste is very disagreeable from the smell of musk; and on the Orinoco we willingly ate monkey hams in preference. The beautifully marked animals which have so disagreable an odour are the Viverra mapurito, Viverra zorilla, and Viverra vittata.

\section{(31) p. 16.- The Guaranis, and the fan-palm, Mauritia."}

The small coast tribe or nation of the Guaranis, (called in British Guiana the Warraws or Guaranos, and by the Caribs U-ara-u), inhabit not only the marshy Delta and 
river network of the Orinoco, and particularly the banks of the Manamo Grande and the Caño Macareo, but also extend, with little variation in their modes of life, along the sea coast between the mouths of the Essequibo and the Boca de Navios of the Orinoco. (Compare my Relation historique, T. i. p. 492 , T. ii. p. 653 and 703 , with Richard Schomburgk's "Reisen in Britisch Guiana," Th. i. 1847, S. 62, 120, 173, and 191). According to the testimony of the last-named excellent explorer and observer, there are still 1700 Warraus or Guaranis living in the district of Cumaca, and along the banks of the Barima river, which empties itself into the gulf of the Boca de Navios. The manners and customs of the tribes living in the Delta of the Orinoco mere already known to the great historical writer Cardinal Bembo, the contemporary of Columbus, Amerigo Vespucci, and Alonzo de Hojeda. He says, "quibusdam in locis propter paludes incolæ dorus in arboribus ædificant" (Historiæ Venetæ, 1551, p. 88). It is more probable that Bembo is alluding to the Guaranis at the mouth of the Orinoco, than to the natives near the mouth of the Gulph of Macaraibo, where Alonzo de Hojeda, in August 1499, when he was accompanied by Vespucci and Juan de la Cosa, also found a population having their residence "fondata sopra l' acqua come Venezia" (Riccardi's Text in my Examen crit. t. iv. p. 496). In Vespucci's account of his voyage (in which we find the first indication of the etymology of the term Province of Venezuela, Little Venice, for Province of Caraccas), he 
only speaks of houses raised upon foundation pillars, not of habitations in the trees.

Sir Walter Raleigh offers a later evidence of high authority; he says expressly, in his description of Guiana, that on his second voyage in 1595, when in the mouth of the Orinoco, he saw the "fires" of the Tivitives and the Oua-raa-etes (so he calls the Guaranis) "high up in the trees" (Raleigh, Discov. of Guiana, 1596, p. 90). The fire is represented in a drawing in the Latin edition : "brevis et admiranda descriptio regni Guianæ," (Norib. 1599) tab. 4. Raleigh was also the first who brought to England the fruit of the Mauritia-palm, which he very justly compared, on account of its scales, to a fir cone. The Padre José Gumilla, who twice visited the Guaranis as a missionary, says, indeed, that this people had their habitation in the palmares (palm groves) of the morasses; but he only mentions dwelling's raised upon high pillars, and not scaffoldings attached to trees still in a growing state; (Gumilla, Historia natural, civil, y geografica de las Naciones situadas en las riveras del Rio Orinoco, nueva imp. 1791, p. 143, 145, and 163). Hillhouse and Sir Robert Schomburgk, (Journal of the Royal Geographical Society, vol. xii. 1842, p. 175; and Description of the Murichi or Ita Palm, read at the Meeting of the British Association held at Cambridge, June 1845; printed in Simond's Colonial Magazine), are of opinion that both Bembo and Raleigh, (the former speaking from the reports of others, the latter as an eyewitness), were deceived by the high tops of the palm-trees 
being lit up at night by the flames of fires beneath, so that those who sailed by thought the habitations themselves were attached to the trees. "Me do not deny that in order to escape the attacks of the musquitos, the Indian sometimes suspends his hammock from the tops of trees; on such occasions, however, no fires are made under the hammock." (Compare also Sir Robert Schomburgk's New Edition of Raleigh's Discovery of Guiana, 1848, p. 50.)

According to Martius, the fine Palm Moriche, Mauritia flexuosa, Quitere, or Ita palm, (Bernau, Missionary Labours in British Guiana, 1847, p. 34 and 44), belongs, as well as Calamus, to the group of Lepidocaryeæ or Coryphineæ. Linnæus has described it very imperfectly, as he erroneously considers it to be leafless. The trunk grows as high as 26 feet, but it probably requires from 120 to 150 years to reach this height. The Mauritia extends high up on the declivity of the Duida, north of the Esmeralda mission, where I have found it in great beauty. It forms in moist places fine groups of a fresh shining verdure, which reminds us of that of our Alder groves. The trees preserve the moisture of the ground by their shade, and hence the Indians say that the Mauritia draws the water round its roots by a mysterious attraction. By a somewhat similar theory they adrise that serpents should not be killed; because the destruction of the serpents and the drying up of the pools or lagunas accompany each other: thus the untutored child of nature confounds cause and effect. Gumilla terms the Mauritia flexuosa of the Guaranis the tree of life, arbol de la vida. It grows in the mountains of Ronaima, 
east of the sources of the Orinoco, as high as 4000 (4263 Eng.) feet. On the unvisited banks of the Rio Atabapo, in the interior of Guiana, we discovered a new species of Mauritia with prickly stems, our Mauritia aculeata; (Humboldt, Bonpland and Kunth, Nova Genera et Species Plantarum, t. i. p. 310).

(32) p. 16.- "An American Stylites."

The founder of the sect of the Stylites, the fanatical pillar-saint Simeon Sisanites, the son of a Syrian herdsman, is said to have passed thirty-seven years in religious contemplation on the summits of five successive pillars, each higher than the preceding. The last pillar was 40 ells high. He died in the year 461. For seven hundred years there continued to be men who imitated this manner of life, and were called "sancti columnares" (pillar saints). Even in Germany, in the Diocese of Treves, it was proposed to erect such aerial cloisters, but the Bishops opposed the undertaking (Mosheim, Institut. Hist.Eccles. 1755, p. 215.)

(33) p. 17.- "Towns on the banks of the streams which flow through the Steppe."

Families who live not by agriculture but by the care of cattle, have congregated in the middle of the Steppe in small towns, which, in the cultivated parts of Europe, would hardly be regarded as villages. Such are Calabozo, in $8^{\circ} 56^{\prime} 14^{\prime \prime} \mathrm{N}$. lat. and $67^{\circ} 42^{\prime}$ long. according to my observations, Villa del Pao, lat $8^{\circ} 38^{\prime} 1^{\prime \prime}$, long. $66^{\circ} 57^{\prime}$, S. Sebastian, and others. 
${ }^{(34)}$ p. 17.- "Conical-shaped clouds."

The singular phenomenon of these "sand spouts," something analogous to which may occasionally be seen on a small scale in Europe where four roads meet,-is particularly characteristic of the Peruvian Sand Desert between Amotape and Coquimbo. Such a dense cloud of sand or dust may prove dangerous to the traveller who does not cautiously avoid its approach. It is also worthy of notice that these partial conflicting currents of air only arise when the air generally is perfectly calm. The aerial ocean. resembles the sea in this respect, for in the latter also the small currents which are often heard to ripple audibly, (filets de courant), are only perceptible in a dead calm (calme plat).

\section{$\left.{ }^{(35}\right)$ p. 18.-"Increases the suffocating heat."}

I have observed in the Llanos de Apure, at the Guadalupe cattle farm, the thermometer rise from $27^{\circ}$ to $29^{\circ}$ Reaumur ( $92^{\circ} .7$ to $97^{\circ} .2$ Fahr.) whenever the hot wind began to blow from the Desert, which at such times was covered either with sand or with short withered turf. In the middle of the sand-cloud the temperature was for some minutes $35^{\circ} \mathrm{R}$. $\left(111^{\circ} \mathrm{F}\right.$.). The dry sand in the village of San Fernando de Apure had a temperature of $42^{\circ} \mathrm{R}$. (126 $6^{\circ}$ Fahr.)

${ }^{(36}$ ) p. 18.- "The illusive image of a cool rippling watery mirror."

The well-known phenomenon of the mirage is called in 
Sanscrit the "thirst of the gazelle." (See my Relation historique, T. i. pp. 296 and 625 ; T. ii. p. 161.) All objects appear to hover in the air, and are at the same time seen reflected in the lower stratum of air. At such times the entire desert assumes the aspect of the wave-covered surface of a wide spread lake. Palm trees, cattle, and camels, sometimes appear inverted on the horizon. In the French expedition to Egypt, the soldiers, parched with thirst, were often brought by this optical illusion into a state of desperation. This phenomenon has been remarked in all quarters of the globe. The ancients were acquainted with the remarkable refraction of the rays of light in the Lybian Desert. I find mention made in Diod. Sic. lib. iii. p. 184, Rhod. (p. 219, Wessel), of extraordinary illusive images, an African Fata Morgana, with most extravagant explanations of the supposed conglomeration of the particles of air.

\section{(37) p. 19.—"The Melon-Cactus."}

The Cactus melo cactus is often 10 to 12 inches in diameter, and has usually 14 ribs. The natural group of Cactaceæ, the whole family of Nopaleæ of Jussieu, belong exclusively to the New Continent. The cactuses assume a great variety of shapes : ribbed and melon-like (Melo cacti) ; articulated or jointed (Opuntix); forming upright columns or pillars (Cerei); serpentine and creeping (Rhipsalides); or provided with leaves (Pereskiæ). Many extend high up the sides of the mountains. Near the foot of the Chimborazo, in the elevated sandy plain around Riobamba, I have found a new kind of Pitahaya, the Cactus sepium, even at a height 
of 10,000 (10,660 Eng.) feet. (Humboldt, Bonpland, and Kunth, Synopsis Plantarum æquinoct. Orbis novi, T. iii. p. 370).

\section{(38) p. 19.-"The scene in the Steppe is suddenly changed."}

I have endeavoured to depict the coming in of the rainy season, and the signs by which it is announced. The usual deep dark azure of the sky in the tropics arises from the more complete solution of the vapour contained in the atmosphere. The cyanometer indicates a paler blue as soon as the vapours begin to be precipitated. The dark spot or patch in the constellation of the Southern Cross gradually becomes indistinct as the transparency of the atmosphere diminishes, and this alteration announces the near approach of rain. The brightness of the Magellanic clouds, (Nubecula major and minor), gradually vanishes in a similar manner. The fixed stars, which before shone like planets with a steady, tranquil, and not trembling light, now scintillate even in the zenith, where the vapours are least. (See Arago, in my Relation hist. T. i. p. 623). All these appearances are the results of the increased quantity of vapour diffused in the atmosphere.

(39) p. 20.- "Awakened from a torpid state by the first fall of rain."

Extreme dryness produces in plants and animals the same phenomena as does the withdrawal of the stimulus of heat. Many tropical trees and plants shed their leaves during the dry 
season. The crocodiles and other amphibious animals hide themselves in the mud, where they lie apparently dead, like animals in a state of hybernation or plunged into winter sleep by cold. (See my Relation historique, T. ii. pp. 192 and 626.)

${ }^{40}$ ) p. 20.- "The aspect of a vast inland sea."

Nowhere are these inundations more extensive than in the network of rivers formed by the Apure, the Arachuna, Pajara, Arauca, and Cabuliare. Large vessels sail across the country over the Steppe for 40 or 50 miles.

\section{${ }^{41}$ p. 21.- "To the mountain platean of Antisana."}

The great mountain plain or plateau surrounding the volcano of Antisana is 2107 toises (13473 English feet), above the level of the sea. The atmospheric pressure at this elevation is so small that the wild cattle, when hunted with dogs, bleed from the nose and mouth.

\section{(42) p. 22.- "Bera and Rastro."}

I have described the capture of the Gymnoti in detail in another place. (Observations de Zoologie et d'Anatomie comparée, vol. i. p. 83-87; and Relation historique, T. ii. p. 173-190). M. Gay Lussac and I found the experiment without a circuit succeed perfectly.with a living Gymnotus, which was still very vigorous when brought to Paris. The discharge is solely dependent on the will of the animal. 
We did not see any spark, but other physicists hare done so on several occasions.

\section{(43) p. 23.-"Awakened by the contact of moist dissimilar particles."}

In all parts of organic bodies dissimilar substances are in contact with each other: in ail, solids are associated. mith fluids. Thus, wherever there is organization and life, there is also electric tension or the play of the voltaic pile, as the experiments of Nobili and Matteucci, and especially the latest admirable labours of Emil du Bois, teach us. The last named physicist has succeeded in "manifesting the presence of the electric muscular current in living and wholly uninjured animal bodies:" he shews that "the human body, through the medium of a copper wire, can cause a magnetic needle at a distance to be deflected at pleasure, first in one and then in the opposite direction." (Untersuchungen über thierische Electricetät, von Emil du Bois-Reymond, 1848, Bd. i. S. xv.) I have witnessed these morements produced at pleasure, and have had the gratification of seeing thereby great and unexpected light thrown on phenomena to which I had laboriously and hopefully deroted several years of my youth.

\section{("4) p. 23.- "Osiris and Typhon."}

On the conflict between two races of men; the Arabian pastoral people in Lower Egypt, and the agricultural race in Upper Egypt who were in a more adranced state of cirilisation, on the fair-hained Prince Baby or Typhon, who founded 
Pelusium, and on the dark-complexioned Dionysos or Osiris, see Zoëga's ancient, and now for the most part abandoned views, in his great work "De Origine et Usu Obeliscorum," p. 577.

${ }^{45}$ ) p. 24.- "The boundary of a partial European cultivation."

In the Capitania general de Caracas, as generally every where on the eastern shores of America, the cultivation introduced by Europeans, and their presence and influence, are limited to a narrow strip of country along the coast. In Nexico, New Granada, and Quito, on the other hand, European civilisation has penetrated deep into the interior of the country, and advanced up the ridges of the Cordilleras. There existed in these last-named regions a considerable degree of settled and civilised life previous to the arrival of the Spaniards ; and they have followed this civilisation wherever they found it, regardless whether its seat was near or at a distance from the sea coast. They retained and enlarged the ancient cities, of which they either mutilated the old significant Indian names, or gave them new names, as, for example, of Christian saints.

(46) p. 24.- "Massive leaden-coloured granite rocks."

In the Orinoco, and more especially at the Cataracts of Maypures and Atures, all blocks of granite, and even white pieces of quartz, whenever they are touched by the water of the river, acquire a greyish-black coating which scarcely penetrates a hundredth of a line below the surface of the rock. 
The appearance produced is that of basalt, or fossils coloured with graphite. The crust appears to contain manganese and carbon; I say appears, for the phenomenon has not yet been thoroughly examined. Something similar was remarked by Rozier on the syenite rocks of the Nile, near Syene and Philæ; by the unfortunate Captain Tuckey on the rocky banks of the Congo; and by Sir Robert Schomburgh on the Berbice. (Reisen in Guiana und am Orinoko, S. 212.) On the Orinoco these leaden-coloured rocks are considered to give out pernicious exhalations when wet; and their proximity is believed to produce fevers. (Rel. hist. T. ii. p. 299-304.) In the Rio Negro, and generally in the South American rivers which have "black waters," "aguas negras," or waters of a coffee-brown or yellow tint, no such effects take place. No black colour is imparted to the granite rocks by the waters; that is to say, they do not act upon the stone so as to form from its constituent particles a black or leaden-coloured crust.

\section{(47) p. 24.-"The rain-announcing howtings of the bearded apes."}

The melancholy howlings of the small apes, Simia seniculus, Simia beelzebub, \&c., are heard some hours before the rain commences: it is as if the tempest were heard raging at a distance. The intensity of the noise produced by such small animals can only be explained by their number; seventy or eighty being often lodged in a single tree. On the organs of voice of these animals, see my anatomical treatise in the first chapter of my Recueil d'Observations de Zoologie, vol. i. p. 18. 


\section{(48) p. 24.— "Often covered with birds."}

The crocodiles lie so motionless that I have seen flamingos (Phonicopterus) resting on their heads; the body at the same time being covered with aquatic birds, like the trunk of a tree.

\section{(49) p. 24.-"Down his swelling throat."}

The saliva with which the boa covers his prey hastens the process of decomposition; the muscular flesh thus becomes softened into such a gelatinous state, that he can force entire limbs of larger, and bodies of smaller, animals down his throat without division. The Creoles call this gigantic serpent from these circumstances, "Tragavenado," which means "Stag swallower:" they tell fabulous stories of snakes being seen with the antlers of a stag (which it was impossible to swallow) sticking in their throats. I have several times seen the boa swimming in the Orinoco, and in the smaller forest streams, the Tuamini, the Temi and the Atabapo. It holds its head above the water like a dog. Its skin is finely spotted. It is said to attain a length of 48 feet; but the largest skins which have as yet been brought to Europe and carefully measured do not exceed 21 to 23 feet. The South American boa (which is a Python) differs from the East Indian. On the Ethiopian boa, sce Diodor. lib. iii. p. 204, ed. Wesseling.

$\left.{ }^{50}\right)$ p. 25.— "Using ants, gums, and earth as food."

It was a very prevalent report on the coasts of Cumana, New Barcelona, and Caraccas, visited by the Franciscan 
monks of Guiana on their return from the missions, that there were men on the banks of the Orinoco who ate earth. When, in returning from the Rio Negro, $\pi$ e descended the Orinoco in thirty-six days, we passed the day of the 6th of June, 1s00, in the Mission inhabited by the earth-eating Otomacs. This little village is called La Concepcion de Uruana, and is very picturesquely situated at the foot of a granite rock. I found its geographical position to be $7^{\circ} 8^{\prime} 3^{\prime \prime} \mathrm{N}$. lat., and $67^{\circ} 18^{\prime} \mathrm{W}$. long. from Greenwich. The earth which the Otomacs eat is a soft unctuóus clay; a true potter's clay, of a yellowish-grey colour due to a little oxide of iron. They seek for it in particular spots on the banks of the Orinoco and the Meta, and select it with care. They distinguish the taste of one kind of earth from that of another, and do not consider all clays as equally agreeable to eat. They knead the earth into balls of about five or six inches diameter, which they burn or roast by a weak fire until the outside assumes a reddish tint. The balls are remoistened when about to be eaten. These Indians are generally wild uncultivated beings, and altogether averse to any kind of tillage. It is a proverb even among the most distant of the nations living on the Orinoco, when speaking of anything very unclean, to say that it is "so dirty, that the Otomacs eat it."

As long as the waters of the Orinoco and the Meta are low these Indians live on fish and river tortoises. They kill the fish with arrows when at the surface of the water, a pursuit in which we have often admired their great dexterity. During the periodical swelling of the rivers the taking 
of fish ceases, for it is as difficult to fish in deep river water as in the deep sea. It is in this interval, which is of two or three months' duration, that the Otomacs swallow great quantities of earth. We have found considerable stores of it in their huts, the clay balls being piled together in pyramidal heaps. The very intelligent monk, Fray Ramon Bueno, a native of Madrid (who lived twelve years among these Indians), assured us that one of them would eat from three quarters of a pound to a pound and a quarter in a day. According to the accounts which the Otomacs themselves give, this earth forms their principal subsistence during the rainy season, though they eat at the same time occasionally, when they can obtain it, a lizard, a small fish, or a fern root. They have such a predilection for the clay, that even in the dry season, when they can obtain plenty of fish, they eat a little earth after their meals every day as a kind of dainty. These men have a dark copper-brown complexion, and unpleasing Tartar features. They are fat, but not large-bellied. The Franciscan monk who lived among them as a misssionary, assured us that he could perceive no alteration in their health during the earth-eating season.

The simple facts are therefore as follows :-The Indians eat large quantities of earth without injury to their health; and they themselves regard the earth so eaten as an alimentary substance, i.e. they feel themselves satisfied by eating it, and that for a considerable time; and they attribute this to the earth or clay, and not to the other scanty articles of subsistence which they now and then obtain in addition. If you 
inquire from an Otomac about his winter provision, (in tropical South America the rainy season is usually called winter), he points to the heap of clay balls stored in his hut. But these simple facts by no means determine the questions, whether the clay be really an alimentary substance? Whether earths be capable of assimilation? or whether they merely serve to appease hunger by distending the stomach? I cannot pretend to decide these questions. (Rel. hist. T. ii. p. 618-620.) It is curious that the usually credulous and uncritical Father Gumilla positively denies the earth-eating as such. (Historia del Rio Orinoco, nueva impr. 1791, T. i. p. 179.) He affirms that the balls of clay had maizemeal and crocodile-fat mixed with them. But the missionary, Fray Ramon Bueno, and our friend and travelling companion, the lay brother Fray Juan Gonzalez, who mas lost at sea off the Coast of Africa with part of our collections, both assured us that the Otomacs never mir crocodile fat with the clay; and of the meal said to be mixed with it we heard absolutely nothing during our stay in Uruana. The earth which we brought back with us, and which Vauquelin analysed, is thoroughly pure and unmired. May Gumilla, by a confusion of things wholly distinct, have been alluding to the preparation of bread from the long pod of a kind of Inga, which is previously buried in the earth in order to hasten the commencement of the first stage of decay? That the health of the Otomacs should not suffer from eating so much earth appears to me particularly remarkable. Hare they become accustomed to it in the course of several generations?

FOL. I. 
In all tropical countries, human beings shew an extraordinary and almost irresistible desire to swallow earth; and not alkaline earths, which they might be supposed to crave to neutralize acid, but unctuous and strong-smelling clays. It is often necessary to confine children to prevent them from running out to eat earth immediately after a fall of rain. I have observed with astonishment the Indian women in the village of Banco on the Magdalena River, whilstengaged in shaping earthen vessels on the potter's wheel, put great lumps of clay into their mouths. The same thing was remarked at an earlier period by Gili. (Saggio di Storia Americana, T. ii. p. 311.) Wolves also eat earth, and especially clay, in winter. It would be important to examine carefully the excrements of animals and men that eat earth. With the exception of the Otomacs, individuals of all other races who indulge for any length of time the strange desire of earth-eating have their health injured by it. At the mission of San Borja, we saw the child of an Indian woman, who, his mother said, would hardly eat anything but earth. He was, however, wasted nearly to a skeleton.

Why is it that in the temperate and cold zones this morbid craving for eating earth is so much more rare, and is almost entirely confined, when it is met with, to children and pregnant women; while in the tropics it would appear to be indigenous in all quarters of the globe? In Guinea the negroes eat a yellowish earth, which they call Caouac. When brought as slaves to the West Indies, they try to obtain a similar earth, and affirm that in their own country 
the habit never did them any harm. In the American Islands they were made ill by it, and it was forbidden in consequence; but a kind of earth (un tuf rouge jaunâtre) was, in 1751, sold secretly in the market in Martinique. "Les negres de Guinée disent que dans leur pays ils mangent habituellement une certaine terre, dont le goût leur plait, sans en être incommodés. Ceux qui sont dans l'abus de manger du Caouac en sont si friands qu'il n'y a pas de châtiment qui puisse les empêcher de dérorer de la terre." (Thibault de Chanvalon, Voyage à la Martinique, p. 85.) In the Island of Java, between Sarabaya and Samarang, Labillardière saw small square reddish-coloured cakes exposed for sale in the villages. The natives called them tana ampo (tanah, in Malay and Javanese, signifies earth). On examination and enquiry he found that the cakes consisted of reddish clay, and that they were eaten. (Voyage à la Récherche de la Pérouse, T. ii. p. 322.) The edible clay of Samarang has recently been sent to Berlin by Mohnike, in 1847, in the shape of rolled tubes, like cinnamon, and has been examined by Ehrenberg. It is a fresh-water formation deposited on limestone, and consisting of microscopic Polygastrica, Gaillonella, Naviculas, and Phytolitharia. (Bericht über die Verhandl. der Akad. d. Wiss. zu Berlin, aus dem J. 1848, S. 222-225.) The inhabitants of New Caledonia, to appease their hunger, eat pieces as big as the fist of friable steatite, which Vauquelin found to contain in addition no inconsiderable quantity of copper. (Voyage à la Récherche de la Pérouse, T. ii. p. 205.) In Popayan, and several parts of Peru, calcareous earth is sold in the 
streets as an eatable for the Indians; it is used with Coca (the leaves of the Erythroxylon peruvianum.) Thus we find the practice of eating earth diffused throughout the torrid zone, among indolent races inhabiting the finest and most fertile parts of the globe. But accounts have also come from the North, through Berzelius and Retzius, according to which, hundreds of cartloads of earth containing Infusoria are said to be annually consumed by the country people, in the most remote parts of Sweden, as breadmeal, and even more from fancy (like the smoking of tobacco) than from necessity! In Finland this kind of earth is occasionally mixed with the bread. It consists of empty shells of animalculæ, so small and soft that they do not crunch perceptibly between the teeth; it fills the stomach, but gives no real nourishment. In periods of war, chronicles and documents preserved in archives often give intimation of earths containing infusoria having been eaten; speaking of them under the vague and general name of "mountain meal." It was thus during the Thirty Years' War in Pomerania (at Camin); in the Lausitz (at Muskau); and in the territory of Dessau (at Klieken); and subsequently in 1719 and 1733 at the fortress of Wittenberg. (See Ehrenberg über das unsichtbar wirkende organische Leben, 1842, S. 41.)

$\left.{ }^{51}\right)$ p. 25.- "Figures graven on the rock."

In the interior of South America, between the $2 d$ and 4th degrees of North latitude, a forest-covered plain is enclosed by four rivers, the Orinoco, the Atabapo, the Rio 
Negro, and the Cassiquiare. In this district are found rocks of granite and of syenite, covered, like those of Caicara and Uruana, with colossal symbolical figures of crocodiles and tigers, and drawings of household utensils, and of the sun and moon. At the present time this remote corner of the earth is entirely without human inhabitants, throughout an extent of more than 8000 square geographical miles. The tribes nearest to its boundaries are wandering naked savages, in the lowest stage of human existence, and far removed from any thoughts of carving hieroglyphics on rocks. One may trace in South America an entire zone, extending through more than eight degrees of longitude, of rocks so ornamented; viz. from the Rupuniri, Essequibo, and the mountains of Pacaraima, to the banks of the Orinoco and of the Yupura. These carvings may belong to very different epochs, for Sir Robert Schomburgk even found on the Rio Negro representations of a Spanish galiot (Reisen in Guiana und am Orinoko, übersetzt von Otto Schomburgk, 1841, S. 500), which must have been of a later date than the beginning of the 16th century; and this in a wilderness where the natives were probably as rude then as at the present time. But it must not be forgotten that, as. I have elsewhere noticed, nations of very different descent, when in a similar uncivilized state, having the same disposition to simplify and generalise outlines, and being impelled by inherent mental dispositions to form rhythmical repetitions and series, may be led to produce similar signs and symbols. (Compare Relation hist. T. ii. p. 589, and Martius úber die Physionomie des Pflanzenreichs in Brasilien, 1824, S. 14.) 
At the Meeting of the Society of Antiquaries of London, on the 17th of November, 1836, there was read a memoir by Sir Robert Schomburgk "On the Religious Traditions of the Macusi Indians, who inhabit the Upper Mahu and a part of the Pacaraima Mountains;" a nation, consequently; who for a century (since the journey of the adventurous Hortsmann, have not changed their residence. Sir Robert Schomburgk says: "The Macusis believe that the sole survivor of a general deluge repeopled the earth by changing stones into human beings." This myth (the fruit of the lively imagination of these nations, and which reminds us of Deucalion and Pyrrha), shews itself in a somewhat altered form among the Tamanaks of the Orinoco. When asked how mankind survived the great flood, the "age of waters" of the Mexicans, they reply without any hesitation, that 'one man and one woman took refuge on the high mountain of Tamanacu, on the banks of the Asiveru, and that they then threw over their heads and behind their backs the fruits of the Mauritia-palm, from the kernels of which sprang men and women who repeopled the earth.' Some miles from Encaramada, there rises, in the middle of the savannah, the rock Tepu-Mereme, or the painted rock. It shews several figures of animals and symbolical outlines which resemble much those observed by us at some distance above Encara-' mada, near Caycara, in $7^{\circ} 5^{\prime}$ to $7^{\circ} 40^{\prime}$ lat. and $66^{\circ} 28^{\prime}$ to $67^{\circ} 23^{\prime} \mathrm{W}$. long. from Greenwich. Rocks thus marked are found between the Cassiquiare and the Atabapo (in $2^{\circ} 5^{\prime}$ to $3^{\circ} 20^{\prime}$ lat.), and what is particularly remarkable, 560 geographical miles farther to the East in the solitudes of the Parime. This last fact is placed beyond a 
doubt by the journal of Nicholas Hortsman, of which I have seen a copy in the handwriting of the celebrated D'Anville. That simple and modest traveller wrote down every day, on the spot, what had appeared to him most worthy of notice, and he deserves perhaps the more credence because, being full of dissatisfaction at having failed to discover the objects of his researches, the Lake of Dorado, with lumps of gold and a diamond mine, he looked with a certain degree of contempt on whatever fell in his way. He found, on the 16th of April, 1749, on the banks of the Rupunuri, at the spot where the river winding between the Macarana mountains forms several small cascades, and before arriving in the district immediately round Lake Amucu, "rocks covered with figures,"-or as he says in Portuguese, "de varias letras." We were shown at the rock of Culimacari, on the banks of the Cassiquiare, signs which were called characters, arranged in lines, - but they were only ill-shaped figures of heavenly bodies, boa-serpents, and the utensils employed in preparing manioc-meal. I have never found among these painted rocks (piedras pintadas) any symmetrical arrangement or any regular even-spaced characters. I am therefore disposed to think that the word "letras" in Hortsmann's journal must not be taken in the strictest sense.

Schomburgk was not so fortunate as to rediscover the rock seen by Hortsmann, but he has seen and described others on the banks of the Essequibo, near the cascade of Warraputa. "This cascade," he says, "is celebrated not only for its height but also for the quantity of figures cut on the rock, which have great resemblance to those which I have seen in the Island of St. John, one of the Virgin 
Islands, and which I consider to be, without doubt, the work of the Caribs, by whom that part of the Antilles was formerly inhabited. I made the utmost efforts to detach portions of the rock which contained the inscription, and which I desired to take with me; but the stone was too hard, and fever had taken away my strength. Neither promises nor threats could prevail on the Indians to give a single blow with a hammer to these rocks, - the venerable monuments of the superior mental cultivation of their predecessors. They regard them as the work of the Great Spirit, and the different tribes who we met with, though living at a great distance, were nevertheless acquainted with them. Terror was painted on the faces of my Indian companions, who appeared to expect every moment that the fire of heaven would fall on my head. I saw clearly that my endeavours would be fruitless, and I contented myself with bringing away a complete drawing of these memorials." The last determination was certainly the best, and the editor of the English Journal, to my great satisfaction, adds a note to the effect that it is to be wished that no one else may be more successful than Mr. Schomburgk, and that no future traveller from civilized countries may do anything towards the destruction of these monuments of the unprotected Indians.

The symbolical signs seen by Robert Schomburgk in the Valley of the Essequibo, near the rapids of Waraputa, (Richard Schomburgk, Reisen in Britisch-Guiana, Th. i. S. 320), were remarked by him to bear a great resemblance to genuine Carib ones in one of the small Virgin Islands (St. John's); but notwithstanding the wide 
extent of the invasions of the Caribs, and the ancient power of this fine race, I cannot believe that all the rock engravings, - which, as I have said, form an immense belt traversing a great part of South America from west to east, - are to be regarded as their work. I am inclined rather to view these remains as traces of an ancient civilisation,-belonging, perhaps, to an epoch when the tribes whom we now distinguish by various appellations were still unknown. Even the reneration everywhere testified by the Indians of the present day for these rude sculptures of their predecessors, shews that they have no idea of the execution of similar works. There is another circumstance which should be mentioned: between Encaramada and Caycara, on the banks of the Orinoco, a number of these hieroglyphical figures are sculptured on the face of precipices at a height which could now be reached only by means of extraordinarily high scaffolding. If one asks the natives how these figures can have been cut, they answer, laughing, as if it were a fact of which none but a white man could be ignorant, that "in the days of the great waters their father's went in canoes at that height." Thus a geological fancy is made to afford an answer to the problem presented by a civilisation which has long passed away.

Let me be permitted to introduce here a remark which I borrow from a letter addressed to me by the distinguished traveller, Sir Robert Schomburgk. "The hieroglyphical figures are more widely extended than you had perhaps supposed. During my expedition, which had 
for its object the examination of the Corentyn River, I not only observed some colossal figures on the rock of Timeri $\left(4 \frac{1}{2}^{\circ} \mathrm{N}\right.$. lat. and $57 \frac{1}{2}^{\circ} \mathrm{W}$. long.), but I also discovered similar ones near the great cataracts of the Corentyn, in $4^{\circ} 21^{\prime} 30^{\prime \prime} \mathrm{N}$. lat. and $57^{\circ} 55^{\prime} 30^{\prime \prime} \mathrm{W}$. long. These figures are executed with much greater care than any which I discovered in Guiana. Their size is about ten feet, and they appear to represent human figures. The head-dress is extremely remarkable; it encompasses the head, spreading out considerably in breadth, and is not unlike the halos represented in paintings as surrounding the heads of Saints and Sacred Persons. I have left my drawings of these figures in the colony, but I hope some day to be able to lay them all before the public. I saw ruder figures on the Cuyuwini, a river which empties itself into the Essequibo in latitude $2^{\circ} 16^{\prime} \mathrm{N}$., entering it from the north-west; and I have since seen similar figures on the Essequibo itself in $1^{\circ} 40^{\prime} \mathrm{N}$. lat. These figures extend, therefore, as ascertained by actual observation, from $7^{\circ} 10^{\prime}$ to $1^{\circ} 40^{\prime} \mathrm{N}$. lat.; and from $57^{\circ} 30^{\prime}$ to $66^{\circ} 30^{\prime} \mathrm{W}$. long. Thus the zone of pictured rocks extends, so far as it has been at present examined, over a space of 192000 square geographical miles, comprising the basins of the Corentyn, the Essequibo, and the Orinoco; a circumstance from which we may form some inferences respecting the former amount of population in this part of the continent."

Other remarkable remains of a degree of civilisation which no longer exists, are the granite vases with graceful labyrinthine ornaments, and the earthen masks resembling Roman 
ones, which have been discovered on the Mosquito coast, among wild Indians. (Archæologia Britan. vol. v. 17.79, p. 318-324; and vol. vi. 1782, p. 107.) I have had them engraved in the "Picturesque Atlas" which accompanies the historical portion of my Travels to the Equinoctial Regions. Antiquaries are astonished at the similarity of these ornaments (resembling a well-known Grecian form), to those of the Palace of Mitla, near Oaxaca, in Mexico. In looking at Peruvian carvings, I have never remarked any figures of the large-nosed race of men, so frequently represented in the basreliefs of Palenque in Guatimala, and in the Aztec paintings. Klaproth remembered having seen individuals with similar large noses among the Chalcas, a northern Mogul tribe. It is well known that many tribes of the North American red or copper-coloured Indians have fine aquiline noses; and that this is an essential physiognomic distinction between them and the present inhabitants of Mexico, New Granada, Quito, and Peru. Are the large-eyed, comparatively fair-complexioned people, spoken of by Marchand as having been seen in $54^{\circ}$ and $58^{\circ}$ lat. on the north-west coast of America, descended from an Alano-Gothic race, the Usiuni of the interior of Asia?

${ }^{(52)}$ p. 25.- "Apparently weaponless, and yet prepared for murder."

The Otomacs often poison the thumb-nail with Curare. A mere scratch of the nail is deadly if the curare mixes with the blood. We obtained specimens of the climbing plant, from the juice of which the curare is prepared, at 
Esmeralda on the Upper Orinoco, but unfortunately we did not find it in blossom. Judging by its physiognomy it appears to be related to Strychnos (Rel. hist. T. ii. p. 547556). Since the notice in the work referred to of the curare or ourari (previously mentioned by Raleigh, both as a plant and as a poison), the brothers Robert and Richard Schomburgk have done much towards making us accurately acquainted with the nature and preparation of this substance, of which I was the first to bring a considerable quantity to Europe. Richard Schomburgk found the plant in blossom in Guiana on the banks of the Pomeroon and the Sururu in the territory of the Caribs, who are not, however, acquainted with the manner of preparing the poison. His instructive work (Reisen in Britisch-Guiana, Th. i. S. 441461), contains the chemical analysis of the juice of the Strychnos toxifera, which, notwithstanding its name and its organic structure, does not contain, according to Boussingault, any trace of strychnine. Virchou and Münter's interesting physiological experiments make it probable that the curare or ourari poison does not kill by mere external absorption, but only when absorbed by living animal substance of which the continuity has been severed (i.e. which has been wounded slightly); that it does not belong to the class of tetanic poisons; and that its particular effect is to take away the power of voluntary muscular movement, whilst the involuntary functions of the heart and intestines still continue. Compare, also, the older chemical analysis of Boussingault, in the Annales de Chimie et de Physique, T. xxxix. 1828, p. 24-3\% 
THE

\section{CATARACTS OF THE ORINOCO.}




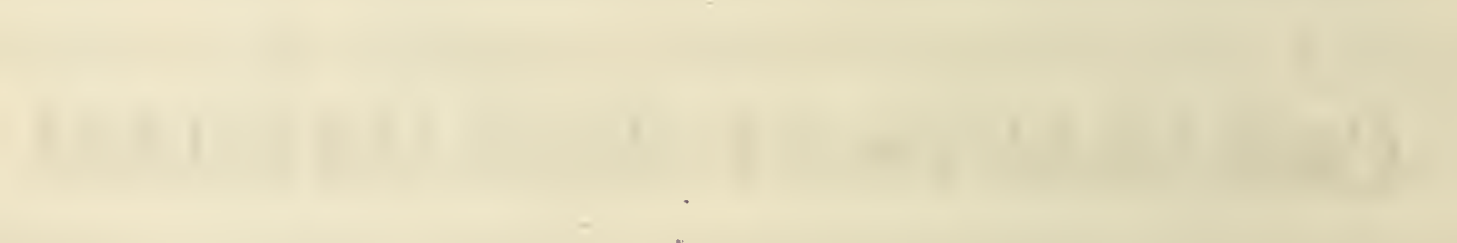


THE

\section{CATARACTS OF THE ORINOCO.}

Is the preceding section, which was made the subject of an academical lecture, I sought to depict those boundless plains which, according to the varying modification of their natural characters induced by climatic relations, appear to us sometimes as Deserts devoid of regetation, and sometimes as Steppes, or widely-extended grassy plains or Prairies. In so doing I contrasted the Llanos of the southern part of the New Continent with the dreadful seas of sand which form the African Deserts; and these again with the Steppes of Central Asia, the habitation of world-assailing pastoral nations, who at a former period, when pressed hitherward from the East, spread barbarism and devastation over the earth.

If on that occasion, (in 1806, I rentured to combine widely distributed portions of the earth's surface in a single picture of nature, and to entertain a public assembly with images whose colouring was in unison with the mournful disposition of our minds at that epoch, I will now, limiting myself to a narrower circle of phenomena, sketch the more cheerful picture of river scenery composed of foaming rapids and rich luxuriant vegetation. I propose to describe in particular two scenes of nature in the wildernesses of Guiana, -the celebrated Cataracts of the Orinoco, Atures and 
Maypures,-which, previous to my visit, few Europeans had ever seen.

The impression left on our minds by the aspect of nature is frequently determined, less even by the peculiar character of the strictly terrestrial portion of the scene, than by the light thrown on mountain or plain, either by a sky of azure purity, or by one veiled by lowering clouds; and in the same manner descriptions of nature act upon us more powerfully or more feebly, according as they are more or less in harmony with the requirements of our feelings. For it is the inward mirror of the sensitive mind which reflects the true and living image of the natural world. All that determines the character of a landscape,-the outline of the mountains, which, in the far-vanishing distance, bound the horizon,-the dark shade of the pine forests, - the sylvan torrent rushing between overhanging cliffs to its fall,--all are in antecedent mysterious communion with the inner feelings and life of man.

On this communion rests the nobler portion of the enjoyment which nature affords. Nowhere does she penetrate us more deeply with the feeling of her grandeur, nowhere does she speak to us with a more powerful voice, than in the tropical world, under the "Indian sky," as, in the early middle ages, the climate of the torrid zone was called. If, therefore, I venture again to occupy this Assembly with a description of those regions, I do so in the hope that the peculiar charm which belongs to them will not be unfelt. The remembrance of a distant richly endowed land, - the aspect of a free and vigorous rege- 
tation,-refreshes and strengthens the mind; in the same manner as our spirits, when oppressed with the actual present, love to escape awhile, and to delight themselves with the earlier youthful age of mankind, and with the manifestations of its simple grandeur.

Favouring winds and currents bear the voyager westward across the peaceful Ocean arm, ${ }^{1}$ ) which fills the wide valley between the New Continent and western Africa. Before the American shore rises from the liquid plain, he hears the tumult of contending, mutually opposing, and inter-crossing waves. The mariner unacquainted with the region would surmise the vicinity of shoals, or a wonderful outbreak of fresh springs in the middle of the ocean, $\left({ }^{2}\right)$ like those in the neighbourhood of Cuba. On approaching nearer to the granitic coast of Guiana, he becomes sensible that he has entered the wide embouchure of a mighty river, which issues forth like a shoreless lake and covers the ocean around with fresh water. The green, and on the shallows the milk-white, tint of the fresh water contrasts with the indigo-blue colour of the sea, and marks with sharp outlines the limits of the river waves.

The name Orinoco, given to the river by its first discoverers, and which probably originated in some confusion of language, is unknown in the interior of the country. Nations in a rude state designate by proper geographical names only such objects as can be confounded with each other. The Orinoco, the Amazons, and the Magdalena rivers, are called simply "The River," or "The Great River," or "The Great Water ;" whilst those who dwell on their

VOL. I. 
banks distinguish even the smallest streams by particular names.

The current produced by the Orinoco, between the mainland and the Island of Trinidad with its asphaltic lake, is so strong, that ships with all sail set, and with a favourable breeze, can with difficulty make way against it. This deserted and dreaded part of the sea is called the Bay of Sadness (Golfo Triste); the entrance forms the Dragon's Mouth (Boca del Drago). Here detached cliffs rise like towers above the foaming floods, and seem still to indicate the ancient site of a rocky bulwark ( 3 , which, before it was broken by the force of the current, united the island of Trinidad with the coast of Paria.

The aspect of this region first convinced the great discoverer of the New World of the existence of an American continent. Familiar with nature, he inferred that so immense a body of fresh water could only be collected in a long course, and "that the land which supplied it must be a continent, not an island." As, according to Arrian, the companions of Alexander, after crossing the snow-covered Paropanisus, $\left({ }^{4}\right)$ on reaching the Indus imagined, from the presence of crocodiles, that they recognised in that river a branch of the Nile; so Columbus, unaware of the similarity of physiognomy which characterises the various productions of the climate of Palms, readily supposed this new continent to be the eastern coast of the far-projecting continent of Asia. The mild coolness of the evening air, the ethereal purity of the starry firmament, the balsamic fragrance of the flowers wafted to him by the land breeze,-all led him (as 
Herrara tells us in the Decades) (5), to deem that he had approached the garden of Eden, the sacred dwelling-place of the first parents of the human race. The Orinoco appeared to him to be one of the four rivers descending from Paradise, to divide and water the earth newly decked with regetation. This poetic passage from the journal of Columbus's voyage, or rather from a letter written from Hayti, in October 1498, to Ferdinand and Isabella, has a peculiar psychological interest. It teaches us anew that the creative imagination of the poet exists in the Discoverer as in every form of human greatness.

In considering the quantity of water which the Orinoco bears to the Atlantic, the question arises-. Which of the great South American Rivers, - the Orinoco, the Amazons, or the River Plate, -is the largest? The question, however, thus put is not a determinate one, the idea of size in this case not being altogether definite. The River Plate has the widest embouchure, being 92 geographical miles across; but, like the British rivers, its length is comparatively small. Even at Buenos Ayres its depth is already so inconsiderable as to impede navigation. The Amazons is the longest of all rivers: its course from its origin in the Lake of Lauricocha to its mouth is 2880 geographical miles. But its breadth in the province of Jaen de Bracamoros, near the cataract of Rentama, as measured by me at the foot of the picturesque mountain of Patachuma, hardly equals that of the Rhine at Mayence.

The Orinoco is narrower at its mouth than either the River Plate or the Amazons; and its length, according to 
positions astronomically determined by me, only amounts to 1120 geographical miles. But, on the other hand, far in the interior of Guiana, 560 miles from its mouth, I still found its breadth, when full, 16200 Parisian (17265 Eng.) feet. The periodical swelling of the river annually raises its level at this part of its course from 30 to 36 feet above its lowest level. Sufficient materials for an accurate comparison of the enormous rivers which intersect the continent of South America are still wanting. For such a comparison it would be needful to know in each case the profile of the river-bed, and the velocity of the water, which differs very greatly in different parts of the same stream.

If, in the Delta enclosed by its variously divided and still unexplored arms, -in the regularity of its periodical rise and fall,-and in the number and size of its crocodiles, - the Orinoco shews points of resemblance to the Nile, there is this further analogy between the two rivers, that after long rushing rapidly through many windings between wood-fringed shores formed by granitic and syenitic rocks and mountains, during the remainder of their course they slowly roll their waters to the sea, between treeless banks, over an almost horizontal bed. An arm of the Nile (the Green Nile, Bahr-el-Azrek) flows from the celebrated mountain-lake near Gondar, in the Abyssinian Gojam Alps, to Syene and Elephantis, through the mountains of Shangalla and Sennaar. In a similar manner the Orinoco rises on the southern declivity of the mountain chain which, in the 4th and 5th parallel of North latitude, extends westward from French Guiana towards the Andes of New 
Granada. The sources of the Orinoco $\left(^{6}\right)$ have never been visited by any European, or even by any natives who have been in communication with Europeans.

In ascending the Upper Orinoco in the summer of 1800 , we passed the Mission of Esmeralda, and reached the mouths of the Sodomoni and the Guapo. Here rises high above the clouds the massive summit of the Yeonnamari or Duida, a grand and picturesque mountain which presents to the spectator one of the finest scenes of nature which the tropical world has to offer. Its altitude, according to my trigonometrical measurement, is 8278 (8823 Eng.) feet above the level of the sea. The southern slope of the mountain presents a treeless grassy surface, and the humid evening air is filled far and wide with the fragrance of the ripe ananas. The stalks of the pine apples, swelling with rich juice, rise between the lowly herbs of the meadow, and the golden fruit is seen shining at a distance from under its leafy crown of bluish-green. Where mountain springs or rivulets break forth from the turfy covering, the scene is further adorned by groups of tall fan-palms, whose foliage never feels the influence of a cool breeze.

On the east of the Duida mountain a dense thicket of wild Cacao groves begins, and amidst these are found trees of the celebrated Bertholletia excelsa, the most vigorous of the productions of the tropical world (7). Here the Indians collect the materials for their blow-pipes, colossal grassstalks having joints above 18 feet long from knot to knot. ( $\left.{ }^{8}\right)$ Some Franciscan monks have penetrated as far as the mouth of the Chiguire, where the river is already so narrow that 
the natives have thrown across it, near the waterfall of the Guaharibes, a suspension bridge formed of the twining stems of climbing plants. The Guaicas, a race of comparatively light complexion but of small stature, armed with poisoned arrows, forbid any farther advance towards the east.

All, therefore, that has been put forward respecting the lake origin of the Orinoco is fabulous $\left({ }^{9}\right)$. We seek in vain in nature for the Laguna of $\mathrm{El}$ Dorado, which is still marked in Arrowsmith's maps as an inland sea 80 geographical miles in length. Has the little reedy lake of Amucu, from which the Pirara (a branch of the Mahu) flows, given rise to this fable? But the swamp in which the lake of Amucu is situated is four degrees of longitude to the east of the district in which the sources of the Orinoco must be sought.

It was an ancient custom of dogmatising geographers to make all the larger rivers of the world originate in considerable lakes. To the lake forming the supposed origin of the Orinoco was transferred the site of the island of Pumacena, a rock of micaceous slate, the glitter of which, in the 16th century, played, in the fable of $\mathrm{El} \mathrm{Dorado,}$ a memorable, and to deceived humanity often a fatal part. It is the belief of the natives, that the Magellanic clouds of the southern hemisphere, and even the fine nebulæ in the constellation of the ship Argo, are a reflection of the metallic brilliancy of the silver mountains of the Parime.

'The Orinoco is one of those rivers which, after many windings, seem to return back towards the region in which 
they took their rise. After following a westerly and then a northerly course, it runs again to the east, so that its mouth is almost in the same meridian as its source. From the Chiguire and the Gehette as far as the Guaviare the Orinoco flows to the west, as if it would carry its waters to the Pacific. It is in this part of its course that it sends out towards the south a remarkable arm, the Cassiquiare, but little known in Europe, which unites with the Rio Negro, (called by the natives the Guainia), and offers perhaps the only example of a bifurcation forming in the very interior of a continent a natural connection between two great rivers and their basins.

The nature of the ground, and the junction of the Guaviare and Atabapo with the Orinoco, cause the latter to turn suddenly towards the north. In the absence of correct geographical knowledge, the Guaviare flowing in from the west was long regarded as the true origin of the Orinoco. The doubts raised by an eminent geographer, M. Buache, since 1797, as to the probability of a connection with the Amazons, have I hope been entirely refuted by my expedition. In an uninterrupted navigation of 920 geographical miles I passed through the singular network of rivers, from the Rio Negro, by the Cassiquiare, into the Orinoco; traversing in this manner the interior of the Continent, from the Brazilian boundary to the coast of Caraccas.

In the upper portion of the basin of the Orinoco and its tributaries, between the 3rd and 4th degrees of north latitude, nature has several times repeated the enigmatical phenomenon of the so-called "black waters." The Atabapo, 
whose banks are adorned with Carolinias and arborescent Melastomas, and the Temi, Tuamini, and Guainia, are all rivers of a coffee-brown colour. In the shade of the palm groves this colour seems almost to pass into ink-black. When placed in transparent vessels, the water appears of a golden yellow. The image of the Southern Constellations is reflected with wonderful clearness in these black streams. Where their waters flow gently, they afford to the observer, when taking astronomical observations with reflecting instruments, a most excellent artificial horizon. A cooler atmosphere, less torment from stinging mosquitoes, greater salubrity, and the absence of crocodiles (fish, however, are also wanting), mark the region of these black rivers. They probably owe their peculiar colour to a solution of carburetted hydrogen, to the luxuriance of the tropical vegetation, and to the quantity of plants and herbs on the ground over which they flow. On the western declivity of the Chimborazo, towards the coast of the Pacific, I remarked that the flooded waters of the Rio de Guayaquil gradually assumed a golden yellow or almost coffee-brown colour, when covering the meadows for some weeks.

In the vicinity of the mouths of the Guaviare and Atabapo grows the Piriguao, $\left({ }^{10}\right)$ one of the noblest of palm trees, whose smooth and polished trunk, between 60 and 70 feet high, is adorned with a delicate flag-like foliage curled at the margins. I know no palm which bears such large and beautifully coloured fruits. They resemble peaches, and are tinged with yellow mingled with a roseate crimson. Seventy or eighty of them form enormous pendulous bunches, of 
which each tree annually ripens three. This fine tree might be called the peach palm. The fleshy fruits are from the luxuriance of regetation most often devoid of seeds, and offer to the natives a nutritious farinaceous food which, like plantains and potatoes, can be prepared in a variety of ways.

Hitherto, or as far as the mouth of the Guaviare, the Orinoco flows along the southern declivity of the Sierra de Parime; and from its southern bank the vast forestcovered plain of the Amazons River stretches far beyond the equator, even to the 15 th degree of south latitude. When the Orinoco turns suddenly to the north near San Fernando de Atabapo, it breaks through a part of the mountain chain along the base of which it had previously flowed; and this is the site of the great waterfalls of Atures and Maypures. The river bed is here everywhere hemmed in by colossal masses of rock, and divided as it were into separate reservoirs by natural dikes.

In front of the entrance of the Meta there stands in the middle of a mighty whirlpool an isolated cliff, to which the natives have given the very appropriate name of the "rock of patience;" because when the waters are low it sometimes costs those who are ascending the river two days to pass it. Here the Orinoco, eating deep into the land, forms picturesque rocky bays. Opposite to the Indian mission of Carichana the traveller is surprised by the singular prospect which presents itself to his view. His eye is involuntarily riveted on an abrupt granitic rock, el Mogote de Cocuyza, a cube with vertically precipitous sides, above 200 feet high and bearing on its upper surface a forest of trees of rich and varied 
foliage. Resembling a Cyclopean monument in its simple grandeur, this mass of rock rises high above the tops of the surrounding palms, its sharp outlines appearing in strong relief against the deep azure of the sky, and its summit uplifting high in air a forest above the forest.

In descending the Orinoco from this point, still within the range of the Carichana mission, we arrive at the part of the river where the stream has forced for itself a way through the narrow pass of Baraguan. Here we recognise everywhere traces of chaotic devastation. To the north, (towards Uruana and Encaramada), masses of granite of extraordinazily notched and serrated outline and grotesque aspect shine with dazzling whiteness high above the thickets from amidst which they rise.

It is in this region, after receiving the Apure, that the Orinoco leaves the granitic chain of mountains and flows eastward to the Atlantic, dividing the impenetrable forests of Guiana from the grassy plains on which the vault of heaven seems everywhere to rest as on the horizon of the ocean. Thus the elevated cluster of the Parime mountains, which occupies the entire space between the sources of the Jao and the Caura, is surrounded on three sides, to the South, to the West, and to the North, by the Orinoco. Below Carichana the course of the river is uninterrupted by rocks or rapids to its mouth, excepting at the whirlpool of the Boca del Infierno (Hell's mouth) near Muitaco, where, however, the rocks which occasion the rapid do not extend across the entire bed of the river as at Atures and Maypures. In these lower parts of the river in the vicinity of the sea, the only danger feared by 
the boatmen is that of encountering the great natural rafts, consisting of trees torn from the banks by the swelling of the river, against which canoes are often wrecked during the night. These rafts, covered like meadows with flowering water plants, remind the spectator of the floating gardens of the Mexican lakes.

After this rapid review of the course of the Orinoco, and of its general relations to the surrounding country, I pass to the description of the Falls of Maypures and Atures.

Between the sources of the rivers Sipapo and Ventuari a granite ridge projects from the elevated mountain group of Cunavami, and advances far to the west towards the mountains of Uniama. Four streams, which may be said to mark the limits of the cataracts of Maypures, descend from this ridge; two, the Sipapo and the Sanariapo, on the eastern side of the Orinoco; and two, the Cameji and the Toparo, on its western side. Near the Missionary village of Maypures the mountains retire and form a wide bay open to the south-west.

The foaming stream flows at the present time at the foot of the eastern mountain declivity, and far to the west we recognise the ancient bank now forsaken by the water. A grass-covered plain, only about thirty feet above the present highest level of the river, extends between the two chains of hills. The Jesuits have built upon it a small church formed of the trunks of palm trees.

The geological aspect of the district, the shapes of the rocks of Keri and Oco, which have so much the character of islands, the water-worn hollows in the first named of these rocks, situated at exactly the same height as the cavities in the opposite island of Uivitari, all testify that the Orinoco 
once filled the whole of this now dry gulf or bay. Probably the waters formed a wide lake as long as the northern dike was able to withstand their pressure. When it gave way, the prairie now inhabited by the Guareke Indians must have been the first part which appeared above the waters; which may subsequently, perhaps, have long continued to surround the rocks of Keri and Oco, which rising like mountain fortresses from the ancient bed of the river, present a picturesque aspect. As the waters gradually diminished they withdrew altogether to the foot of the eastern hills, where the river now flows.

This conjecture is confirmed by several circumstances. The Orinoco, like the Nile near Philæ and Syene, has the property of imparting a black colour to the reddish white masses of granite which it has bathed for thousands of years. As far as the waters reach, one may remark on the rocky shore the leaden-coloured coating described in page $189:$ its presence, and the hollows before mentioned, mark the ancient. height of the waters of the Orinoco.

In the rock of Keri, in the islands of the Cataracts, in the gneiss hills of Cumadaminari above the island of Tomo, and lastly at the mouth of the Jao, we trace these black-coloured hollows at elevations of 150 to 180 (160 to 192 English) feet above the present height of the river. Their existence teaches us a fact of which we may also observe indications in the river beds of Europe; viz. that the streams whose magnitude now excites our astonishment are only the feeble remains of the immense masses of water belonging to an earlier age of the world.

These simple remarks and inferences have not escaped 
even the rude natives of Guiana. The Indians everywhere called our attention to the traces of the former height of the waters. There is in a grassy plain near Uruana an isolated granite rock, on which, according to the report of trustworthy witnesses, there are at a height of more than eighty feet drawings of the sun and moon, and of many animals, particularly crocodiles and boas, engraven or arranged almost in rows or lines. Without artificial aid it would now be impossible to ascend this perpendicular precipice, which deserves to be carefully examined by future travellers. The hieroglyphical rock engravings on the morntains of Uruana and Encaramada are equally remarkable in respect to situation.

If one asks the natives how these figures can have been cut in the rocks, they answer that it was done when the waters were so high that their fathers' boats were only a little lower than the drawings. Those rude memorials of human art would in such case have belonged to the same age as a state of the waters implying a distribution of land and water very different from that which now prevails, and belonging to an earlier condition of the earth's surface; which must not, however, be confounded with that in which the earlier vegetation which adorned our planet, the gigantic bodies of extinct land animals, and the oceanic creatures of a more chaotic state, became entombed in the indurating crust of globe.

At the northernmost extremity of the cataracts, attention is excited by what are called the natural drawings or pictures of the Sun and Moon. The rock Keri, to which I have 
several times referred, has received its name from a white spot which is conspicuous from a great distance, and in which the Indians have thought they recognised a remarkable similarity to the disk of the full moon. I was not myself able to climb the steep precipice, but the white mark in question is probably a large knot of quartz formed by a cluster of veins in the greyish-black granite.

Opposite to the Keri rock, on the twin mountain of the island of Uivitari, which has a basaltic appearance, the Indians shew with mysterious admiration a similar disk which they venerate as the image of the Sun, Camosi. Perhaps the geographical position of the two rocks may have contributed to these denominations, as the Keri (or Moon Rock) is turned to the West, and the Camosi to the East. Some etymologists have thought they recognised in the American word Camosi a similarity to Camosh, the name of the Sun in one of the Phonician dialects, and to Apollo Chomeus, or Beelphegor and Ammon.

Unlike the grander falls of Niagara (which are 140 French or 150 English feet high) the "Cataracts of Maypures" are not formed by the single precipitous descent of a vast mass of waters, nor are they "narrows" or passes through which the river rushes with accelerated velocity, as in the Pongo of Manseriche in the River of the Amazons. The Cataracts of Maypures consist of a countless number of little cascades succeeding each other like steps. The "Raudal" (the name given by the Spaniards to this species of cataract) is formed by numerous islands and rocks which so restrict the bed of the river, that out of a breadth of 8000 
(8526 E.) feet there often only remains an open channel of twenty feet in width. The eastern side is now much more inaccessible and dangerous than the western.

At the confluence of the Cameji with the Orinoco, goods are unladen in order that the empty canoe, or, as it is here called, the Piragua, may be conveyed by Indians well acquainted with the Raudal to the mouth of the Toparo, where the danger is considered to be past. Where the separate rocks or steps (each of which is designated by a particular name) are not much above two or three feet high, the natives, if descending the stream, venture, remaining them. selves in the canoe, to let it go down the falls: if they are ascending the stream they leave the boat, swim forward, and when after many unsuccessful attempts they have succeeded in casting a rope round the points of rock which rise above the broken water, they draw up their ressel, which is often either overset or entirely filled with water in the course of these laborious proceedings.

Sometimes, and it is the only case which gives the natives any uneasiness, the canoe is dashed in pieces against the rocks; the men have then to disengage themselves with bleeding bodies from the wreck and from the whirling force of the torrent, and to gain the shore by swimming. Where the rocky steps are very high and extend across the entire bed of the river, the light boat is brought to land and drawn along the bank by means of branches of trees placed under it as rollers.

The most celebrated and difficult steps, those of Purimarimi and Manimi, are between nime and ten feet high. I 
found with astonishment by barometric measurements, (geodesical levelling being out of the question from the inaccessibility of the locality, its highly insalubrious atmosphere, and the swarms of mosquitoes which fill the air), that the whole fall of the Raudal from the mouth of the Cameji to that of the Toparo hardly amounts to 28 or 30 feet (30 or 32 English). I say, "I found with astonishment;" for this shews that the dreadful noise and wild dashing and foaming of the river are the results of the narrowing of its bed by countless rocks and islands, and of the counter currents produced by the form and situation of the masses of rock. The best ocular demonstration of the small height of the whole fall is obtained by descending from the village of Maypures to the bed of the river by the rock of Manimi.

From this point a wonderful prospect is enjoyed. A foaming surface of four miles in length presents itself at once to the eye: iron-black masses of rock resembling ruins and battlemented towers rise frowning from the waters. Rocks and islands are adorned with the luxuriant vegetation of the tropical forest; a perpetual mist hovers over the waters, and the summits of the lofty palms pierce through the cloud of spray and vapour. When the rays of the glowing evening sun are refracted in these humid exhalations a magic optical effect begins. Coloured bows shine; vanish, and reappear; and the ethereal jmage is swayed to and fro by the breath of the sportive breeze. During the long rainy season the streaming waters bring down islands of vegetable mould, and thus the naked rocks are studded with bright flower-beds adorned with Melastomas and 
Droseras, and with small silver-leaved mimosas and ferns. These spots recal to the recollection of the European those blocks of granite decked with flowers which rise solitary amidst the glaciers of Saroy, and are called by the dwellers in the Alps "Jardins," or "Courtils."

In the blue distance the eye rests on the mountain chain of Cunavami, a long extended ridge which terminates abruptly in a truncated cone. We saw the latter, (Calitamini is its Indian name), glowing at sunset as if in roseate flames. This appearance returns daily: no one has ever been near the jnountain to detect the precise cause of this brightness, which may perhaps proceed from a reflecting surface produced by the decomposition of talc or mica slate.

During the five days which we passed in the neighbourhood of the cataracts, it was striking to hear the thunder of the rushing torrents sound three times louder by night than by day. In all European waterfalls the same phenomenon is remarked. What can be its cause in a wilderness where there is nothing to interrupt the repose of nature? Perhaps the currents of heated ascending air by causing irregular density in the elastic medium impede the propagation of sound during the day, by the disturbance they may occasion in the waves of sound; whereas during the nocturnal cooling of the earth's surface the upward currents cease.

The Indians called our attention to ancient tracks of wheels. They speak with admiration of the horned animals, (oxen), which in the times of the Jesuit missions used to draw the canoes on wheeled supports, along the left bank of the Oriuoco, from the mouth of the Cameji to that of the 
Toparo. The lading was not then removed from the boats, nor were the latter worn and injured as they now are by being constantly stranded upon the rocks and dragged over their rough suriace.

The topographical plan of the district sketched by me shews the facilities which the nature of the ground offers for the opening of a canal from the Cameji to the Toparo, which would form a navigable side arm to the river, the dangerous portion of which would be thus avoided. I proposed its execution to the Governor-General of Venezuela.

The Raudal of Atures closely resembles that of Maypures; like it, it is a cluster of islands between which the river forces its way for ten or twelve thousand yards; a forest of palms rising from the midst of the foaming waters. The most celebrated "Steps" of this Raudal are situated between the islands of Avaguri and Javariveni, between Suripamana and Uirapuri.

When M. Bonpland and I returned from the banks of the Rio Negro, we ventured to pass the latter or lower half of the Raudal of Atures with the loaded canoe, often leaving it for the rocky dikes which connect one island with another. Gometimes the waters rush over these dikes, and sometimes they fall with a hollow thundering sound into cavities, and flowing for a time through subterranean channels, leave large pieces of the bed of the river dry. Here the golden Pipra rupicola makes its nest; it is one of the most beautiful of tropical birds, with a double moveable crest of feathers, and is as pugnacious as the East Indian domestic cock. 
In the Raudal of Canucari the rocky dike or weir consists of piled-up granite spheres. We crept into the interior of a grotto the damp walls of which were corered with conferræ and shining Byssus, and where the river rushed high above our heads with deafening noise.

We had accidentally more time than we desired for the enjoyment of this grand scene of nature. The Indians had left us in the middle of the cataract, proposing to take the canoe round a long narrow island below which we were to re-embark. The waited an hour and a half under a heavy tempestuous rain; night was coming on, and we sought in rain for shelter between the masses of granite. The little monkeys, which we had carried with us for months in wicker cages, by their mournful cries attracted crocodiles whose size and leaden-grey colour shered their great age. I should not here notice an occurrence so usual in the Orinoco, if the Indians had not assured us that no crocodiles were ever seen in the cataracts; and in dependence on this assurance we had even rentured repeatedly to bathe in this part of the river. Meanwhile our anxiety lest we might be forced to pass the long tropical night in the middle of the Raudal, wet through and deafened by the thundering noise of the falling maters, increased every moment; until at last the Indians reappeared with our canoe. From the low state of the waters they had found the steps by which they had intended to lot themselves domn inaccessible, and had been forced to seek among the labyrinth of chamels for a more practicable passage.

Near the southern entrance of the Raudal of Atures, on 
the right bank of the river, is the cave of Ataruipe, which is widely celebrated among the Indians. The grand and melancholy character of the scenery around fits it for the burying-place of a deceased nation. We climbed with difficulty, and not without danger of falling to a great depth below, a steep and perfectly bare granite precipice. It would be hardly possible to keep one's footing on the smooth surface, if it were not for large crystals of feldspar, which, resisting "weathering," project as much as an inch from the face of the rock.

On reaching the summit the traveller beholds a wide, diversified, and striking prospect. From the foaming riverbed rise wood-crowned hills, while beyond the western shore of the Orinoco the eye rests on the boundless grassy plain of the Meta, uninterrupted save where at one part of the horizon the Mountain of Uniama rises like a threatening cloud. Such is the distance; the nearer prospect is desolate, and closely hemmed in by high and barren rocks. All is motionless save where the vulture or the hoarse goatsucker hover solitarily in mid-air, or, as they wing their flight through the deep-sunk ravine, their silent shadows are seen gliding along the face of the bare rocky precipice until they vanish from the eye.

This precipitous valley is bounded by mountains on whose rounded summits are enormous detached granite spheres of more than 40 to 50 feet diameter : they appear to touch the base on which they rest only in a single point, as if the slightest movement, such as that of a faint earthquake shock, must cause them to roll down. 
The farther part of the valley is densely wooded, and it is in this shady portion that the cave of Ataruipe is situated. It is not properly speaking a cave, but rather a vaulted roof formed by a far over-hanging cliff, the cavity having apparently been formed by the waters when at their ancient level. This place is the vault or cemetery of an extinct nation. ( $\left.{ }^{11}\right)$ We counted about 600 well-preserved skeletons placed in as many baskets woven from the stalks of palm leaves. These baskets, which the Indians call "mapires," are shaped like square sacks, differing in size according to the age of the deceased. Even new-born children had each its own mapire. The skeletons are so perfect that not a bone or a joint is manting.

The bones had been prepared in three different ways; some bleached, some coloured red with onoto, the pigment of the Bixa Orellana; and some like mummies closely enveloped in sweet-smelling resin and plantain leaves.

The Indiaris assured us that the custom had been to bury the fresh corpses for some months in damp earth, which gradually consumed the flesh; they were then dug up, and any remaining flesh scraped away with sharp stones. This the Indians said was still the practice of several tribes in Guiana. Besides the mapires or baskets we found urns of half burnt clay which appeared to contain the bones of entire families. The larger of these urns were about three feet high and nearly six feet long, of a pleasing oval form and greenish colour, having handles shaped like snakes and crocodiles, and meandering or labyrinthine ornaments round the upper margin. These ornaments are quite similar to 
those which cover the walls of the Mexican Palace at Mitla. They are found in all countries and climates, and in the most different stages of human cultivation,-among the Greeks and Romans, as well as on the shields of the natives of Tahiti and other islands of the South Sea,-wherever the eye is gratified by the rhythmical recurrence of regular forms. These similarities, as I have elsewhere remarked in more detail, are rather to be ascribed to psychological causes, or to such as belong inherently to our mental constitution, than to be viewed as evidences of kindred descent or ancient intercourse between different nations.

Our interpreters could give us no certain information as to the age of these vessels; that of the skeletons appeared for the most part not to exceed a century. It is reported among the Guareca Indians, that the brave Atures, being pressed upon by cannibal Caribs, withdrew to the rocks of the Cataracts; a melancholy refuge and dwelling-place, in which the distressed tribe finally perished, and with them their language. In the most inaccessible parts of the Raudal there are cavities and recesses which have served like the cave of Ataruipe as burying-places. It is even probable that the last family of the Atures may not have been long deceased, for (a singular fact,) there is still in Maypures an old parrot of whom the natives affirm that he is not understood because he speaks the Ature language.

We left the cave at nightfall, after having collected, to the great displeasure of our Indian guides, several skulls and the entire skeleton of a man. One of these skulls has been figured by Blumenbach in his excellent craniological work; 
but the skeleton (together with a large part of our natural history collections, especially the entomological) was lost in a shipwreck on the coast of Africa, in which our friend and former travelling companion, the young Franciscan monk Juan Gonzalez, perished.

As if with a presentiment of this painful loss, we turned our steps in a thoughtful and melancholy mood from this burying-place of a race deceased. It was one of those clear and cool nights so frequent in the tropics. The moon, encircled with coloured rings, stood high in the zenith illuminating the margin of the mist which lay with well-defined cloud-like outlines on the surface of the foaming river. Countless insects poured their red phosphoric light on the herb-covered ground, which glowed with living fire as if the starry canopy of heaven had sunk domn upon the turf. Climbing Bignonias, fragrant Vanillas, and yellow-flowering Banisterias, adorned the entrance of the cave; and the summits of the palms rnstled above the graves.

Thus perish the generations of men! Thus do the name and the traces of nations fade and disappear! Yet when each blossom of man's intellect withers,- when in the storms of time the memorials of his art moulder and decay, -an ever new life springs forth from the bosom of the earth; maternal Nature unfolds unceasingly her germs, her flowers, and her fruits; regardless though man with his passions and his crimes treads under foot her ripening harvest. 



\section{ANNOTATIONS AND ADDITIONS.}

(1) p. 209.- "Across the peaceful ocean arm, which fills the wide valley between the American shore and Western Africa."

The Atlantic Ocean, from the 23d degree of South to the 70th degree of North latitude, has the form of an excavated longitudinal valley, in which the salient and re-entering angles are opposite to each other. I first developed this idea in my "Essai d'un Tableau géologique de l’Amérique méridionale," printed in the Journal de Physique, T. liii. p. 61. (Geognostische Skizze von Südamerika, in Gilbert's Annalen der Physik, Bd. xvi. 1804, S. 394-449.) From the Canaries, and especially from the 21st degree of North latitude and the 23d degree of West longitude, to the North-East coast of South America, the surface of the sea is usually so calm, and the waves so gentle, that an open boat might navigate in safety.

(2) p. 209.- "A wonderfu outbreak of fresh springs in the middle of the ocean."

On the southern coast of the island of Cuba, south-west of the Port of Batabano in the gulf of Xagur, a few miles from the coast, springs of fresh water gush from the bed of the ocean probably under the influence of hydrostatic pres- 
sure, and rise through the midst of the salt water. They issue forth with such force that boats are cautious in approaching this locality, which has an ill repute on account of the high cross sea thus caused. Trading vessels sailing along the coast and not disposed to land, sometimes visit these springs to take in a supply of fresh water, which is thus obtained in the open sea. The greater the depth from which the water is taken, the fresher it is found to be. The "river cow," Trichecus manati, which does not remain habitually in salt water, is often killed here. This remarkable phenomenon of fresh springs issuing from the sea has been most carefully examined by a friend of mine, Don Francisco Lemaur, who made a trigonometrical survey of the Bay of Xagua. I have been farther to the South in the group of islands called the Jardines del Rey, (the King's Gardens), making astronomical observations for latitude and longitude; but I have never been at Xagua itself.

(3) p. 210.- "The ancient site of u rocky bulwark."

Columbus, whose unwearied spirit of observation exerted itself in every direction, propounds in his letters to the Spanish monarchs a geognostical hypothesis respecting the forms of the larger Antilles. Having his mind deeply impressed with the strength of the East and West Equinoctial current, he ascribes to it the breaking up of the group of the smaller West Indian islands, and the singularly lengthened configuration of the southern coasts of Porto Rico, Haiti, Cuba, and Jamaica, which all follow almost exactly the direction of 
parallels of latitude. On his third voyage (from the end of May 1498 to the end of November 1500), in which, from the Boca del Drago to the Island of Margarita, and afterwards from that island to Haiti, he felt the whole force of the Equinoctial current, "that movement of the waters which is in accordance or conformity with the movement of the hearens-movimiento de los cielos," he says expressly that the Island of Trinidad had been torn from the mainland by the violence of the current. He alludes to a chart which he sends to the monarchs,_a "pintura de la tierra" by himself, which is often referred to in the celebrated lawsuit against Don Diego Colon respecting the rights of the Admiral. "Es la carta de marear y figura que hizo el Almirante señalando los rumbos y vientos por los quales vino á Paria, que dicen parte del Asia", (Navarrete Viages y Descubrimientos que hiciéron por mar los Españoles, T. i. p. 253 and 260 ; T. iii. p. 539 and 587.)

(4) p. 210.- "Over the snow-covered Paropanisus."

Diodorus's descriptions of the Paropanisus (Diodor. Sicul. lib. xvii. p. 553, Rhodom.) might almost pass for a description of the Andes of Peru. The Army passed through in. habited places where snow fell daily!

\section{(5) p. 211.- "Herrara in the Decades."}

Historia general de las Indias occidentales, Dec. i. lib iii. cap. 12 (ed. 1601, p. 106]; Juan Bautista Muñoz, Historia del Nuevo Mundo, lib. vi. c. 31, p. 301 ; Humboldt, Examen Crit. T. iii p. 111. 
(6) p. 213.- "The Sources of the Orinoco have never been visited by any European."

Thus I wrote respecting these sources in the year 1807, in the first edition of the "Ansichten der Natur," and I have to repeat the same statement after an interval of 41 years. The travels of the brothers Robert and Richard Schomburgk, so important for all departments of natural knowledge and geography, have afforded us thorough investigations of other and more interesting facts; but the problem of the situation of the sources of the Orinoco has been only approximately solved by Sir Robert Schomburgk. It was from the West that M. Bonpland and myself adranced as far as Esmeralda, or the confluence of the Orinoco and the Guapo; and I was able to describe with certainty, by the aid of well-assured information, the upper course of the Orinoco to above the mouth of the Gehette, and to the small Waterfall (Raudal) de los Guaharibos. It was from the East that Robert Schomburgk, advancing from the mountains of the Majonkong Inians, (the altitude of the inhabited portions of which he estimated by the boiling point of water at $3300 \mathrm{~F}$., or $3517 \mathrm{E}$. feet), came to the Orinoco by the Padamo River, which the Majonkongs and Guinaus (Guaynas?) call Paramu (Reisen in Guiana, 1841, S. 448). In my Atlas I had estimated the osition of the confiuence of the Padamo with the Orinoco at N. lat. $3^{\circ} 12^{\prime}$, and W. long. $65^{\circ} 46^{\prime}$ : Robert Schomburgk found it by direct observation, lat. $2^{\circ} 53^{\prime}$, long. $65^{\circ} 48^{\prime}$. The eading object of this traveller's arduous journey was not the pursuit of natural history, but the solution of the prize ques- 
tion proposed by the Royal Geographical Society of London in November 1834, - viz. the connection of the coast of British Guiana with the easternmost point which I had reached on the Upper Orinoco. After many difficulties and much suffering, the desired objectwas completely attained. Robert Schomburgk arrived with his instruments on the 2.2d of February, 1839, at Esmeralda. His determinations of the latitude and longitude of the place agreed more closely with mine than I had expected would be the case (S. xviii. and 471). Here let us allow the observer to speak for himself:- "I want words to describe the feelings which overpowered me as I sprang to shore. My aim was attained; my observations, began on the coast of Guiana, were brought into connection with those of Humboldt at Esmeralda: I frankly own, that in the course of this enterprise, at a time when almost all my physical powers had well nigh deserted me, and when I was surrounded by dangers and difficulties of no common nature, it was only by the recognition which I hoped for from him, that I had been encouraged to press onward with unalterable determination towards the goal which I had now reached. The emaciated figures of my Indians and faithful guides told more plainly than any words could do, what difficulties we had had to surmount, and had surmounted." After expressions so kind towards myself, I must be permitted to subjoin the following passage, extracted from my Preface to the German Edition of Robert Schomburgk's Account of his Travels, published in 1841.

"Immediately after my return from Mexico, I notified 
the direction and the routes which should be followed to explore the unknown portion of the South American Continent between the sources of the Orinoco, the mountain chain of Pacaraima, and the sea-shore near Essequibo. These wishes, which I expressed so strongly in my Rélation Historique, have at last, after the lapse of almost half a century, been for the greater part fulfilled. Besides the joy of having lived to see so important an extension of our geographical knowledge, I have had that of seeing it attained by means of a courageous and well-conducted enterprise, requiring the most devoted perseverance, executed by a young man with whom I feel united by the double bond of similarity of pursuits and efforts, and of our common country. Motives such as these have alone been sufficient to overcome the distaste which I entertain, perhaps without reason, to introductory prefaces by another hand than that of the author of the work. But in this case I could not consent to forego the opportunity of expressing, thus publicly, my heartfelt esteem for the accomplished traveller who, in pursuit of an object deriving all its interest from the mind,- - namely, in the self-imposed task of penetrating from East to West, from the Valley of the Essequibo to Esmeralda, - succeeded, after five years of efforts and of sufferings (which $I$ can in part appreciate from my own experience), in reaching the goal which he had proposed to himself. Courage for the momentary execution of a hazardous action is more easily met with, and implies less of inward strength, than does the resolution to endure patiently long-continued physical sufferings, incurred 
in the pursuit of some deeply-felt mental interest, and still to determine to go forward, undismayed by the certainty of having to retrace the same painful route, and to support the same privations in returning with enfeebled porrers. Serenity of mind, almost the first requisite for an undertaking in inhospitable regions, passionate love for some class of scientific labour, (be it in natural history, astronomy, hypsometrics, magnetism, or aught else,) and a pure feeling for the enjoyment which nature in her freedom is ready to impart, are elements which, when they meet together in an individual, ensure the attainment of valuable results from a great and important journey."

In discussing the question respecting the sources of the Orinoco, I will begin with the conjectures which I had myself formed on the subject. The dangerous route travelled in 1739 by the surgeon Nicolas Hortsmann, of Hildesheim; in 1775 by the Spaniard Don Antonio Santos, and his friend Nicolas Rodriguez; in 1793 by the Lientenant-Colonel of the 1st Regiment of the Lime of Para, Don Francisco Jose Rodriguez Barata; and (according to manuscript papers, for which I am indebted to the former Portuguese Ambassador in Paris, Chevalier de Brito) by several English and Dutch settlers, who in 1811 went from Surinam to Para by the Portage of the Rupunuri and by the Rio Branco ;-divides the terra incognita of the Parime into tro unequal portions, and serves to limit the situation of a very important point in the geography of those regions-viz. the sources of the Orinoco, which it is no longer possible to remove to an uncertain disance to the East, without interfering thereby with what we 
know of the course of the Rio Branco, which flows from north to south through the basin of the Upper Orinoco; while that river itself, in this part of its course, pursues for the most part an East and West direction. From political reasons, the Brazilians, since the beginning of the present century, have testified a lively interest in the extensive plains east of the Rio Branco. See the mernoir which I drew up at the request of the Portuguese court in 1817, "sur la fixation des limites des Guyanes Française et Portuguaise" (Schoell, Archives historiques et politiques, ou Recueil de Pièces officielles, Memoires, \&.c. T. i. 1818, p. 48-58). Viewing the position of Santa Rosa on the Uraricapara, the course of which appears to have been determined with tolerable accuracy by Portuguese engineers, the sources of the Orinoco cannot be looked for east of the meridian of $65 \frac{1}{2}^{\circ}$ from Paris, $\left(63^{\circ} .8^{\prime} \mathrm{W}\right.$. long. from Greenwich). This being the eastern limit beyond which they cannot be placed, and considering the state of the river at the Raudal de los Guaharibos (above Caño Chiguire, in the country of the surprisingly fair-skinned Guaycas Indians, and 52' East of the great Cerro Duida), it appears to me probable that the upper part of the Orinoco does not really extend, at the utmost, beyond the meridian of $66 \frac{1}{2}^{\circ}$ from Paris $\left(64^{\circ} .08^{\prime} \mathrm{W}\right.$. from Greenwich.) This point is according to my combinations $4^{\circ} .12$ West of the little lake of Amucu, which was reached by Sir Robert Schomburgk.

I next subjoin the conjectures of that gentleman, having given the earlier ones formed by myself. According to his view, the course of the upper Orinoco to the east of Esme- 
ralda is directed from South-east to North-west; my estimations of latitude for the mouths of the Padamo and the Gehette appearing to be respectively 19 and $36^{\prime}$ too small. Robert Schomburgk supposes the sources of the Orinoco to be in lat. $2^{\circ} .30^{\prime}$ (S. 460); and the fine "Map of Guayana, to illustrate the route of R. H. Schomburgk," which accompanies the splendid English work entitled "Views in the Interior of Guiana," places the sources of the Orinoco in $67^{\circ} .18^{\prime}$ (W. from Paris), $i . e .1^{\circ} .6^{\prime}$ west of Esmeralda, and only $48^{\prime}$ of longitude nearer to the Atlantic than I had thought admissible. From astronomical combinations Schomburgk has placed the morntain of Maravaca, which is upwards of nine thousand feet high, in lat. $3^{\circ} .4 I^{\prime}$ and long. $65^{\circ} .38^{\prime}$ Near the mouth of the Padamo or Paramú the Orinoco was scarcely three hundred yards wide; and more to the west, where it spreads to a breadth of from four to six hundred yards, it was so shallow and so full of sandbanks that the Expedition were obliged to dig channels, the river bed being only fifteen inches deep. Fresh water Dolphins were still to be seen everywhere in large numbers; a phenomenon which the zoologists of the 18th century would not have been prepared to expect in the Orinoco and the Ganges.

(7) p. 213.- "The most vigorous of the productions of the tropical world."

The Bertholletia excelsa (Juvia), of the family of Myrtacex (and placed in Richard Schomburgk's proposed division of Lecythideæ), was first described by Bonpland and myself in VOL I. 
the "Plantes équinoxiales," T. i. 1808, p. 122, tab. 36. This gigantic and magnificent tree offers, in the perfect formation of its cocoa-like, round, thick, woody fruit enclosing the three-cornered and also woody seed-vessels, the most remarkable example of high organic development. The Bertholletia grows in the forests of the Upper Orinoco between the Padamo and the Ccamu, near the mountain of Mapaya, and also between the rivers Amaguaca and Gehette. (Ruélation historique, T. ii. p. 474, 496, 558-562.)

(8) p. 213.- "Grass stalks having joints above eighteen feet long from knot to knot."

Robert Schomburgk, when visiting the small mountainous country of the Majonkongs, on his way to Esmeralda, was so fortunate as to determine the species of Arundinaria which furnishes the material for the blowpipes or tubes through which the Indians discharge their arrows. He says of this plant: "It grows in large tufts like the Bambusa; the first joint rises without a knot to a height of from 16 to 17 feet before it begins to put forth leaves. The entire height of the Arundinaria, as it grows at the foot of the great mountain of Maravaca, is from 30 to 40 feet, with a thickness of scarcely half an inch diameter. The top is always inclined. This kind of grass is peculiar to the sandstone mountains between the Ventuari, the Paramu (Padamo), and the Mavaca. The Indian name is Curata, and hence, from the excellence of these far-famed blow tubes of great. length, the Majonkongs and Guinaus of these 
districts hare been given the names of the Curata nation." (Reisen in Guiana und am Orinoco, S. 451.)

(9) P. 214.- "Fabulous lake-origin of the Orinoco."

The lakes of these regions (some of which have had their real size much esaggerated by theoretical geographers, while the existence of others is purely imaginary), may be divided into two groups. The first of these groups comprises the lakes, whether real or imaginary, placed between Esmeralda (the easternmost mission on the upper Orinoco), and the Rio Branco; and the second those assumed to exist in the district between the Rio Branco and French, Dutch, and British Guiana. This general view, of which travellers should never lose sight, shers that the question of whether there is yet a Lake Parime east of the Rio Branco, other than the Lake Amucu, seen by Hortsmann, Santos, Colonel Barata, and Schomburgk, has nothing whatever to do with the problem of the sources of the Orinoco. As the name of my friend the former Director of the Hydrographic Office at Madrid, Don Felipe Bauza, is deservedly of great weight in geography, the impartiality which ought to preside over every scientific investigation makes me feel it a duty to recall that this learned man was inclined to the view, that there must be lakes west of the Rio Branco and not far from the sources of the Orinoco. He wrote to me from London, a short time before his death: "I wish you were here, that I might converse with you on the subject of the geography of the upper Orinoco, which has occupied you 
so much. I have been so fortunate as to rescue from entire destruction the papers of the General of Marine, Don José Solano, father of the Solano who perished in so melancholy a manner at Cadiz. These documents relate to the boundary division between the Spaniards and the Portuguese, with which the elder Solano had been charged, in conjunction with Chef d'Escadron Yturriaga and Don Vicente Doz, since 1754. In all these plans and sketches I see a Laguna Parime, represented sometimes as the source of the Orinoco, and sometimes quite detached from that river. Are we, then, to admit the existence of another lake north-east of Esmeralda?"

Löffling, the celebrated pupil of Linnæus, came to Cumana as the botanist of the boundary expedition above alluded to. After traversing the missions on the Piritu and the Caroni he died on the 22d of February, 1756, at the mission of Santa Eulalia de Murucuri, a little to the south of the confluence of the Orinoco and the Caroni. The documents of which Bauza speaks are the same as those on which the great map of De la Cruz Olmedilla is based. They constitute the type of all the maps which appeared in England, France, and Germany up to the close of the last century; and they also served for the two maps drawn in 1756 by Peter Caulin, the historian of Solano's expedition, and by an unskilful compiler, M. de Surville, Keeper of the Archives of the Secretary of State's office at Madrid. The discordance between these maps shews the little dependence which can be placed on the surveys of the expedition; besides which, Caulin's acute remarks lead us to perceive 
the circumstances which gave occasion to the fiction of the Lake Parime; and Surville's map, which accompanies his work, not unly restores this lake under the name of the White Sea and of the Nar Dorado, but also adds another lake, from which, partly through lateral outlets, the Orinoco, the Siapa, and the Ocamo issue. I was able to satisfy myself on the spot of the fact, well known in the missions, that Don José Solano went indeed beyond the cataracts of Atures and Maypures, but not beyond the confluence of the Guaviare and the Orinoco, in lat. $4^{\circ} .3^{\prime}$ and long. $68^{\circ} .09^{\prime}$; that the instruments of the Boundary Expedition were not carried either to the Isthmus of the Pimichin and the Rio Negro, or to the Cassiquiare; and that even on the Upper Orinoco they were not taken above the mouth of the Atabapo. This extensive country, in which previous to my journey no exact observations had been attempted, had been traversed since the time of Solano only by a few soldiers sent in search of discoreries; and Don Apolinario de la Fuente (whose journals I obtained from the archives of the province of Quiros), had collected, without critical discrimination, from the lying tales told by Indians, whatever could flatter the credulity of the governor Centurion. No member of the Expedition had seen any lake, and Don Apolinario had not advanced farther than the Cerro Yumariquin and the Gehette.

Having now established throughout the extensive district, to which it is desired to direct the inquiring zeal of travellers, a dividing line bounding the basin of the Rio Branco, it still remains to remark, that for a century past no advance has 
taken place in our geographical knowledge of the country west of this valley between $61 \frac{1}{2}^{\circ}$ and $65 \frac{1}{2}^{\circ} \mathrm{W}$. longitude. The attempts repeatedly made by the Government of Spanish Guiana, since the expeditions of Iturria and Solano, to reach and to pass the Pacaraima mountains, have only produced very inconsiderable results. When the Spaniards, in travelling to the missions of the Catalonian Capuchin monks of Barceloneta at the confluence of the Caroni and the Rio Paragua, ascended the latter river, in going southward, to its junction with the Paraguamusi, they founded at the site of the latter junction the mission of Guirion, which at first received the pompous name of Ciudad de Guirion. I place it in about $4 \frac{1}{2}^{\circ}$ of North latitude. From thence the governor Centurion, stimulated by the exaggerated accounts given by two Indian chiefs, Paranacare and Arimuicapi, of the powerful nation of the Ipurucotos, to search for el Dorado, prosecuted what were then called spiritual conquests still farther, and founded beyond the Pacaraima mountains the two villages of Santa Rosa and San Bautista de Caudacacla; the former on the higher eastern bank of the Uraricapara, a tributary of the Uraricuera which in the narrative of Rodriguez I find called Rio Curaricara; and the latter six or seven German (24 or 28 English) geographical miles farther to the east south-east. The astronomer of the Portuguese Boundary Commission, Don Antonio Pires de Sylva Pontes Leme, captain of a frigate, and the captain of engineers, Don Ricardo Franco d'Almeida de Serra, who between 1787 and 1804 surveyed with the greatest care the whole course of the Rio Branco and its upper branches, call the western. 
most part of the Uraricapara "the Valley of Inundation." They place the Spanish mission of Santa Rosa in $3^{\circ} .46^{\prime} \mathrm{N}$. lat., and point out the route which leads from thence northward across the chain of mountains to the Caño Anocapra, an affluent of the Paraguamusi, by means of which one passes from the basin of the Rio Branco to that of the Caroni. Two maps of these Portuguese officers, which contain the whole details of the trigonometrical survey of the windings of the Rio Branco, the Uraricuera, the Tacuta, and the Mahu, have been kindly communicated to Colonel Lapie and myself by the Count of Iinhares. These valuable unpublished documents, of which I have made use, are in the hands of the learned geographer who began a considerable time ago to have them engraved at his own expense. The Portuguese sometimes give the name of Rio Parime to the whole of the Rio Branco, and sometimes confine that denomination to one branch or tributary, the Uraricuera, below the Caño Mayari and above the old mission of San Antonio. As the words Paragua and Parime signify water, great water, lake, or sea, it is not surprising to find them so often repeated among nations at a distance from each other, the Omaguas on the Upper Marañon, the Western Guaranis, and the Caribs. In all parts of the world, as I have already remarked, the largest rivers are called by those who dwell on their banks "the River," without any distinct and peculiar appellation. Paragua, the name of a branch of the Caroni, is alsc the name given by the natives to the Upper Orinoco. The name Orinucu is Tamanaki; and Diego de Ordaz first heard it pronounced in 1531, when he 
ascended the river to the mouth of the Meta. Besides the "Valley of Inundation," above spoken of, we find other large lakes or expanses of water between the Rio Xumuru and the Parime. One of these belongs to the Tacutu river, and the other to the Uraricuera. Even at the foot of the Pacaraima monntains the rivers are subject to great pericdical overflows; and the Lake of Amucu, which will be spoken of more in the sequel, imparts a similar character to the country at the commencement of the plains. The Spanish missions of Santa Rosa and San Bautista de Caudacacla or Cayacaya, founded in the years 1770 and 1773 by the Governor Don Manuel Centurion, were destroyed before the close of the century, and since that period no fresh attempt has been made to penetrate from the basin of the Caroni to the southern declivity of the Pacaraima mountains.

The territory east of the valley of the Rio Branco has of late years been the subject of some successful examination. Mr. Hillhouse navigated the Massaruni as far as the bay of Caranang, from whence, he says, a path would have conducted the traveller in two days to the sources of the Massaruni, and in three days to streams flowing into the Rio Branco. In regard to the windings of the great river Massaruni, described by Mr. Hilihouse, that gentleman remarks, in a letter written to me from Demerara (January 1, 1831), that "the Massaruni beginning from its source flows first to the West, then to the North for one degree of latitude, afterwards almost 200 English miles to the East, and finally North and N.N.E. to its junction with the Essequibo." As Mr. Hillhouse was unable to reach 
the southern declivity of the Pacarima chain, he was not acquainted with the Amucu Lake: he says himself, in his printed account, that "from the information he had gained from the Accaouais, who constantly traverse all the country between the shore and the Amazons river, he had become satisfied that there is no lake at all in these districts." This statement occasioned me some surprise, as it was in direct contradiction to the views which I had formed respecting the Lake of Amucu, from which the Caño Pirara flows according to the narratives of Hortsmann, Santos, aud Rodriquez, whose accounts inspired me with the more confidence because they agree entirely with the recent Portuguese manuscript. maps. Finally, after five years of expectation, Sir Robert Schomburgk's journey has dispelled all doubts.

"It is difficult to believe," says Mr. Hillhouse, in his interesting memoir on the Massaruni, "that the report of a great inland water is entirely without foundation. It seems to me possible that the following circumstances may have given occasion to the belief in the existence of the fabulous lake of the Parime. At some distance from the fallen rocks of Teboco the waters of the Massaruni appear to the eye as motionless as the tranquil surface of a lake. If at a more or less remote epoch the horizontal stratum of granite at Teboco had been perfectly compact and unbroken, the waters must have stood at least fifty feet above their present level, and there would thus have been formed an immense lake, ten or twelve English miles broad and 1500 to 2000 English miles long." (Nouvelles Annales des Voyages, 1836, Sept. p. 316.) It is not solely the vast extent of this supposed 
inundation which prevents me from accepting this explanation. I have seen plains (the Llanos), where during the rainy season the overflowing of the affluents of the Orinoco annually cover with water a space of 400 German geographical square miles (equal to 6400 English geographical square miles). At such times the labyrinth of branches between the Apure, the Arauca, the Capanaparo, and the Sinaruco (see Maps 17 and 18 of my Geographical and Physical Atlas), can no longer be traced, for the separate courses are obliterated, and all appears one vast lake. But the fable of the Dorado of the Parime, and of the White Sea or Lake of the Parime, belongs historically, as I endeavoured to shew in another work thirty years ago, to an entirely different part of Guiana, namely, to the country south of the Pacaraima mountains; and originated in the shining appearance of the micaceous rocks of the Ucucuamo, the name of the Rio Parime (Rio Branco), the overflowings of the tributaries of that river, and especially the existence of the Lake of Amucu, which is in the vicinity of the Rio Rupunuwini or Rupunuri, and is connected through the Pirara with the Rio Parime.

I have seen with pleasure that the travels of Sir Robert Schomburgk have fully confirmed these early views. The part of his map which gives the course of the Essequibo and the Rupunuri is entirely new and of great geographical importance. It places the Pacaraima chain in $3^{\circ} 52^{\prime}$ to $4^{\circ}$ North latitude ( $\mathrm{I}$ had given it $4^{\circ}$ to $4^{\circ} 10^{\prime}$ ), and makes it reach the confluence of the Essequibo and the Rupunuri, in $3^{\circ} 57^{\prime} \mathrm{N}$. lat. and $60^{\circ} 23^{\prime} \mathrm{W}$. long. from Paris (5 $8^{\circ} 01^{\prime}$ from Greenwich). I had placed this spot 
half a degree too far to the north. Sir Robert Schomburgk calls the last named river Rupununi, according to the pronunciation of the Macusis; he gives as synonymes of Rupuniri, Rupunuwini and Opununy, the Carib tribes in these districts having much difficulty in articulating the sound of the letter $r$. The situation of Lake Amucu and its relations to the Mahu (Maou) and Tacutu (Tacnto) are quite in accordance with my map of Columbia in 1825. We agree equally well respecting the latitude of the lake, which I gave $3^{\circ} 35^{\prime}$, and which he finds to be $3^{\circ} 33^{\prime}$; but the Caño Pirara, (Pirarara) which connects the Lake of Amucu with the Rio Branco, flows from it to the north, instead of to the west as I had supposed. The Sibarana of my map, of which Hortsmann places the source near a fine mine of rock-crystal, a little to the north of the Cerro Ucucuamo, is the Siparuni of Schomburgk's map. His Waa-Ekuru is the Tavaricuru of the Portuguese geographer Pontes Leme; it is the tributary of the Rupunuri, which approaches nearest to the Lake of Amucu.

The following remarks from the narrative of Robert Schomburgk throw some light on the subject before us. "The Lake of Amucu," says this tiaveller, " is incontestably the nucleus of the Lake of Parime and the supposed White Sea. When we visited it in December and January its length scarcely amounted to a mile, and its surface was half covered with reeds." (This remark is found as early as in D'Anville's map, in 1748.) "The Pirara issues from the lake west north-west of the Indian village of Pirara, and falls into the Maou or Mahu. The last named river, from such 
information as I was able to gather, rises on the north side of the Pacaraima mountains, the easternmost part of which only attains a height of 1500 French (in round numbers 1600 English) feet. The sources of the Mahu are on a plateau, from whence it descends in a fine waterfall called Corona. We were about to visit this fall when on the third day of our excursion to the mountains the sickness of one of my companions obliged us to return to the station near Lake Amucu. The Mahu has "black" or coffee-brown water, and its current is more rapid than that of the Rupunuri. In the mountains through which it makes its way it is about 60 yards broad, and its environs are remarkably picturesque. This valley, as well as the banks of the Buroburo which flows into the Siparuni, are inhabited by the Macusis. In April the whole of the savannahs are overflowed, and present the peculiar phenomenon of the waters belonging to different river basins being intermixed and united. The enormous extent of this temporary inundation may not improbably have given occasion to the story of the Lake of Parime. During the rainy season there is formed in the interior of the country a water communication between the Essequibo, the Rio Branco, and Gran Para. Some groups of trees, which rise like oases on the sand hills of the savannahs, assume at the time of the inundation the character of islands scattered over the extensive lake; they are, no doubt, the Ipomucena Islands of Don Antonio Santos."

In D'Anville's manuscripts, which his heirs have kindly permitted me to examine, I find that the surgeon Hortsmann, of Hildesheim, who described these countries with great care, 
saw a second Alpine lake, which he places two dars' journey above the confluence of the Mahu with the Rio Parime (Tacutu?). It is a lake of black water on the top of a mountain. He distinguishes it clearly from the Lake of Amucu, which he describes as "corered with reeds." The narratives of Hortsmann and Santos are as far as the Portuguese manuscript maps of the Bureau de la Marine at Rio Janeiro from indicating or admitting a constant connection between the Rupunuri and the Lake of Amucu. In D'Anville's maps the rivers are better drawn in the first edition of his South America, published in 1748, than in the more widely circulated edition of 1760. Schomburgk's travels have completely established this general independence of the basins of the Rupunuri and the Essequibo; but he remarks that during the rainy season the Rio Waa-Ekuru, a tributary of the Rupunuri, is in connection with the Caño Pirara. Such is the state of these river basins, which are, as it were, still imperfectly developed, and are almost entirely without separating ridges.

The Rupunuri and the village of Anai (lat. $3^{\circ} 56^{\prime}$, long. $\left.58^{\circ} 34^{\prime}\right)$, are at present recognised as the political boundary between the British and the Brazilian territories in these uncultivated regions. Sir Robert Schomburgk makes his chronologically determined longitude of the Lake of Amucu depend on the mean of several lunar distances (East and West) measured by him during his stay at Anai, where he was detained some time by severe illness. His longitudes for these points of the Parime are in general a degree more easterly than the longitudes of my map of Columbia. I am far from throwing any doubt on the observations of lunar 
distances taken at Anai, and would only remark that their calculation is important if it is desired to carry the comparison from the Lake of Amucu to Esmeralda, which I found in long. $63^{\circ} 23^{\prime} 19^{\prime \prime} \mathrm{W}$. from Paris (66 $21^{\prime} 19^{\prime \prime}$ Gr.)

We see, then, the great Mar de la Parima,-which was so difficult to displace from our maps that, after my return from America, it was still set down as having a lerigth of 160 English geographical miles,-reduced by the result of modern researches to the little Lake of Amucu, of two or three miles circumference. The illusions cherished for nearly two centuries (several hundred lives were lost in the last Spanish expedition for the discovery of el Dorado, in 1775), have thus finally terminated, leaving some results of geographical knowledge as their fruit. In 1512, thousands of soldiers perished in the expedition undertaken by Ponce de Leon for the discovery of the "Fountain of Youth," supposed to exist in one of the Bahama Islands called Bimini, and which is not to be found on our maps. This Expedition led to the conquest of Florida, and to the knowledge of the great current of the Gulf Stream, which issues forth through the Bahama channel. The thirst for treasures, and the desire of renovated youth, stimulated with nearly equal force the passions and cupidity of the nations of Europe.

(10) p. 216.-"The Piriguas, one of the noblest of palm trees."

Compare Humboldt, Bonpland, and Kunth, Nova Genera Plant. æquinoct. T. i. p. 315. 
(11) p. 229.- " The vault or cemetery of an extinct nation."

During the period of my stay in the forests of the Orinoco, these caves of bones were examined by order of the Court. The Missionary of the Cataracts had been unjustly accused of having discovered in the caves treasures which had been hidden there by the Jesuits previous to their flight. 



\title{
THE NOCTURNAL LIFE OP ANTMALS
}

\author{
IN THE
}

\section{PRIMEVAL FOREST.}





\title{
THE NOCTURNAL LIFE OF ANIMALS
}

\author{
IN THE
}

\section{PRIMEVAL FOREST.}

IF the vivid appreciation and sentiment of nature which differ so greatly in nations of different descent, and if the natural character and aspect of the countries which those nations now inhabit, or which have been the scene of their earlier wanderings or abode, have rendered different languages more or less rich in well defined and characteristic expressions denoting the forms of mountains, the state of vegetation, the appearance of the atmosphere, and the contour and grouping of the clouds, it is also true that long use, and perhaps their arbitrary employment by literary men, have diverted many such words from their original meaning. Terms have been gradually regarded as synonymous which ought to have been preserved distinct; and thus languages have lost part of the vigour and the grace, as well as the fidelity, which they might otherwise have been capable of imparting to descriptions of natural scenery and of the characteristic physiognomy of a landscape. With the view of shewing how much an intimate acquaintance and contact with nature, and the wants and necessities of a laborious nomade life, may increase the riches of a 
language, I would recall the numerous characteristic appellations which may be used in Arabic ( ${ }^{1}$ ) and in Persian to distinguish plains, steppes, and deserts, according as they are quite bare, covered with sand, broken by tabular masses of rock, or interspersed with patches of pasturage, or with long tracts occupied by social plants. Scarcely less striking is it to observe in the old Castilian idiom $\left({ }^{2}\right)$ the many expressions afforded for describing the physiognomy of mountain-masses, and more particularly for designating those features which, recurring in every zone of the earth's surface, announce from afar to the attentive beholder the nature of the rock. As the declivities of the Andes, of Peru, Chili, and Mexico, and the mountainous parts of the Canaries, the Antilles and the Philippines, are all inhabited by men of Spanish descent, and as these are the parts of the earth where, (with the exception, perhaps, of the Himalaya and the Thibetian Highlands), the manner of ife of the inhabitants is most affected by and dependent on the form of the earth's surface, so all the expressions which the language of the mother country afforded for denoting the forms of mountains in trachytic, basaltic, and porphyritic districts, as well as in those where schists, limestones, and sandstone are the prevailing rocks, have been happily preserved in daily use. Under such influences even newly formed words become part of the common treasure. Speech is emriched and animated by everything that tends to and promotes truth to nature, whether in rendering the impressions received through the senses from the contemplation of the external world, or in 
expressing thoughts, emotions, or sentiments winich have their sources in the inner depths of our being.

In descriptions of natural objects or scenery, both in the manner of vieming the phenomena, and in the choice of the expressions employed to describe them, this trath to nature must ever be kept in view as the guiding aim : its attainment will be at once most easily and most effectually secured by simplicity in the narration of what we have ourselves beheld or experienced, and by limiting and individualising the locality with which the narrative is comnected. Generalisation of physical views, and the statement of general results, belong rather to the "study" of the Cosmos," which, indeed, must ever continue to be to us a science of Induction; but the animated description of organic forms (plants and animals) in their local and picturesque relations to the varied surface of the earth (as a small fragment of the whole terrestrial life) affords materials torrards the study of the Cosmos, and also tends to advance it by the stimulus or impulse imparted to the mind when artistic treatment is applied to phenomena of nature on a great scale.

Among such phenomena must certainly be classed the vast forest region which, in the tropical portion of South America, fills the great connected basins of the Orinoco and the Amazons. If the name of primeval forest, or "Urwald," which has of late years been so prodigally bestowed, is to be given to any forests on the face of the earth, none can claim it perhaps so strictly as the region of which we are speaking. The term "Urwall,". 
primitive or primeval forest, as well as Urseit and Urvolk, primitive age, primitive nation,-are words of rather indefinite meaning, and, for the most part, only relative import. If this name is to be given to every wild forest full of a thick growth of trees on which Man has never laid a destroying hand, then the phenomenon is one which belongs to many parts of the temperate and cold zones. But if the character of the "Urwald" is that of a forest so truly impenetrable, that it is impossible to clear with an axe any passage between trees of eight or twelve feet diameter for more than a few paces, then such forests belong exclusively to the tropical regions. Nor is it by any means, as is often supposed in Europe, only the interlacing "lianes" or climbers which make it impossible to penetrate the forest; the "lianes" often form only a very small portion of the underwood. The chief obstacle is presented by an undergrowth of plants filling up every interval in a zone where all vegetation has a tendency to become ligneous. An impatient desire for the fulfilment of a long cherished wish may sometimes have led travellers who have only just landed in a tropical country, or perhaps island, to imagine that although still in the immediate vicinity of the sea-shore they had entered the precincts of a primeval forest, or "Urwald," such as I have described as impenetrable. In this they deceived themselves; it is not every tropical forest which is entitled to an appellation which I have scarcely ever used in the narrative of my travels; although I believe that of all investigators of nature now living, Bonpland, Martius, 
Poppig, Robert and Richard Schomburgk, and myself, are those who have spent the longest period of time in primeval forests in the interior of a great continent.

Rich as is the Spanish language, (as I have already remarked), in appellations of distinct and definite meaning in the description of nature, yet the same word "Monte" is employed for mountain and forest, for cerro, (montaña) and for selva. In an inquiry into the true breadth and greatest easterly extension of the chain of the Andes, I have shewed how this two-fold signification of the word "monte" led to the introduction, in a fine and extensively circulated English map of South America, of high mountain ranges, where, in reality, only plains exist. When the Spanish map of La Cruz Olmedilla, which has served as the foundation of so many other maps, shewed "Montes de Cacao," (3) "cacao woods," Cordilleras were made to rise although the cacao seeks only the lowest and hottest localities.

If we comprehend in one general view the wooded region which includes the whole of the interior of South America, from the grassy steppes of Venezuela (los Llanos de Caracas) to the Pampas of Buenos Ayres, or from $\delta^{\circ}$ North to $19^{\circ}$ South latitude, we shall perceive that this connected forest of the tropical zone has an extent unequalled in any other portion of the earth's surface. Its area is about twelve times that of Germany. Traversed in all directions by systems of rivers, in which the minor and tributary streams sometimes exceed our Rhine or our Danube in the abundance of their waters, it owes 
the wonderful luxuriance of the growth of its trees to the combined influence of great moisture and high temperature. In the temperate zone, and especially in Europe and Northern Asia, forests may be named from particular genera or species, which, growing together as social plants, (plantæ sociales) form separate and distinct woods. In the northern forests of Oaks, Pines, and Birches, and in the eastern forests of Limes or Linden trees, usually only one species of Amentaceæ, Coniferæ, or Tiliaceæ, prevails or is predominant; sometimes a single species of Needle-trees is intermingled with the foliage of trees of other classes. Tropical forests, on the other hand, decked with thousands of flowers, are strangers to such uniformity of association; the exceeding variety of their flora renders it vain to ask of what trees the primeval forest consists. A countless number of families are here crowded together, and even in small spaces individuals of the same species are rarely associated. Each day, and at each change of place, new forms present themselvés to the traveller, who, however, often finds that he cannot reach the blossoms of trees whose leaves and ramifications had previously arrested his attention.

The rivers, with their countless lateral arms, afford the only routes by which the country can be traversed. Between the Orinoco, the Cassiquiare, and the Rio Negro, astronomical observations, and where these were wanting, determinations by compass of the direction of the rivers, respectively shewed us that two lonely mission villages might be only a few miles apart, and yet that the monks when they 
wished to visit each other could only do so by spending a day and a half in following the windings of small streams, in canoes hollowed out of the trunks of trees. A striking evidence of the impenetrability of particular parts of the forest is afforded by a trait related by an Indian of the habits of the large American tiger, or panther-like jaguar. While in the Llanos of Varinas and the Meta, and in the Pampas of Buenos Ayres, the introduction of European cattle, horses, and mules has enabled the beasts of prey to find an abundant subsistence, - so that since the first discovery of America their numbers have increased exceedingly in those extended and treeless grassy steppes, - their congeners in the dense forests around the sources of the Orinoco lead a very different and far less easy life. In a birouac near the junction of the Cassiquiare with the Orinoco we had had the misfortune of losing a large dog, to which we were much attached, as the most faithful and affectionate companion of our wanderings. Being still uncertain whether he had been actually killed by the tigers, a faint hope of recovering him induced us, in returning from the mission of Esmeralda through the swarms of musquitoes by which it is infested, to spend another night at the spot where we had so long sought him in vain. We heard the cries of the jaguar, probably the very individual which we suspected of the deed, extremely near to us; and as the clouded sky made astronomical observations impossible, we passed part of the night in making our interpreter (lenguaraz) repeat to us the accounts given by our native boat's crew of the tigers of the country. 
The "black jaguar" was, they said, not unfrequently found there; it is the largest and most bloodthirsty variety, with black spots scarceiy distinguishable on its deep darkbrown skin. It lives at the foot of the mountains of Maraguaca and Unturan. One of the Indians of the Durimund tribe then related to us that jaguars are often led, by their love of wandering and by their rapacity, to lose themselves in such impenetrable parts of the forest that they can no longer hunt along the ground, and live instead in the trees, where they are the terror of the families of monkeys and of the prehensile-tailed viverra, the Cercoleptes. I borrow these notices from journals written at the time in German, and which were not entirely exhausted in the Narrative of my Travels, which I published in the French language. They contain a detailed description of the nocturnal life, or perhaps I might rather say the nocturnal voices, of the wild animals in the forests of the torrid zone; which appears to me particularly suited to form part of a work bearing the title of the present volumes. That which is written down on the spot, either in the immediate presence of the phenomena, or soon after the reception of the impressions which they produce, may at least lay claim to more life and freshness than can be expected in recollections.

Descending from West to East the Rio Apure, the overflowings of whose waters and the inundations produced by them were noticed in the chapter on Steppes and Deserts, we arrived at its junction with the Orinoco. It was the season of low water, and the average breadth of the Apure was only a little more than twelve hundred English feet, yet I found 
the Orinoco at the confluence of the two rivers, not far from the granite rock of Curiquima, where I was able to measure a base line, still uptards of 11430 French (12180 English) feet wide. Yet this point, $i$. e. the Rock of Curiquima, is four hundred geographical miles in a straight line from the sea and from the Delta of the Orinoco. Part of the plains watered by the Apure and the Pagara are inhabited by tribes of the Yaruros and Achaguas, who, as they persist in maintaining their independence, are called sarages in the mission villages established by the monks: their manners, however, are scarcely more rude than those of the Indians of the rillages, - who, although baptized and living " under the bell" (baxo la compana), are still almost entirely untaught and uninstructed.

On learing the Island del Diamante, in which Zambos who speak Spanish cultivate sugar-canes, we entered on scenes of nature characterized by wildness and grandeur. The air was filled with countless flocks of flamingoes (Phœnicopterus) and other water birds, which appeared against the blue sky like a dark cloud with continually varying outlines. The river had here narrowed to between 900 and 1000 feet, and flowing in a perfectly straight line formed a kind of canal enclosed on either side by dense wood. The margin of the forest presents at this part a singular appearance. In front of the almost impenetrable wall of giant trunks of Cæsalpinia, Cedrela, and Desmanthus, there rises from the sandy river beach, with the greatest regularity, a low hedge of Sauso, only four feet high, consisting of a small shrub, Hermesia castaneifolia, which forms a new 
genus $\left({ }^{4}\right)$ of the family of Euphorbiacex. Some slender thorny palms, called by the Spaniards Piritu and Coroso (perhaps species of Martinezia and Bactris), stand next; and the whole resembles a close, well-pruned garden hedge, having only occasional openings at considerable distances from each other, which have doubtless been made by the larger four-footed beasts of the forest to gain easy access to the river. One sees, more especially in the early morning and at sunset, the American tiger or jaguar, the tapir, and the peccary, lead their young through these openings to the river to drink. When startled by the passing canoe, they do not attempt to regain the forest by breaking forcibly through the hedge which has been described, but one has the pleasure of seeing these wild animals stalk leisurely along between the river and the hedge for four or five hundred paces, until they have reached the nearest opening, when they disappear through it. In the course of an almost uninterrupted river navigation of 1520 geographical miles on the Orinoco to near its sources, on the Cassiquiare, and on the Rio Negro,-and during which we were confined for seventy-four days to a small canoe,-we enjoyed the repetition of the same spectacle at several different points, and I may add; always with new delight. There came down together, to drink, to bathe, or to fish, groups consisting of the most different classes of animals, the larger mammalia, being associated with many coloured herons, palamedeas, and proudly-stepping curassow and cashew birds (Crax Alector and C. Pauxi). "Es como en el Paraiso ;" it is here as in Paradise, said, with a pious air, our 
steersman, an old Indian who had been brought up in the house of an ecclesiastic. The peace of the golden age was, however, far from prevailing among the animals of this American paradise, which carefully watched and avoided each other. The Capybara, a Cavy three or four feet long; (a magnified repetition of the Brazilian Cavy, Cavia aguti), is devoured in the river by the rrocodiles, and on shore by the tiger. It runs so indifferently that we were several times able to catch individuals from among the numerous herds which presented themselves.

Pelow the mission of Santa Barbara de Arichuna we passed the night as usual, under the open sky, on a sandy flat on the bank of the Rio Apure closely bordered by the impenetrable forest. It was not without difficulty that we succeeded in finding dry wood to kindle the fire with which it is always customary in that country to surround a bivouac, in order to guard against the attacks of the jaguar. The night was humid, mild, and moonlight. Several crocodiles approached the shore; I think I have observed these animals to be attracted by fire, like our cray-fish and many other inhabitants of the water. The oars of our boat were placed upright and carefully driven into the ground, to form poles from which our hammocks could be suspended. Deep stillness prevailed; only from time to time we heard the blowing of the fresh-water dolphins $\left(^{5}\right)$ which are peculiar to the Orinoco net-work of rivers (and, according to Colebrooke, to the Ganges as far as Benares), which followed each other in long lines.

Soun after 11 o'clock such a disturbance began to be 
heard in the adjoining forest, that for the remainder of the night all sleep was impossible. The wild cries of animals appeared to rage throughout the forest. Among the many voices which resounded together, the Indians could only recognise those which, after short pauses in the general uproar, were first heard singly. There was the monotonous howling of the aluates (the howling monkeys); the plaintive, soft, and almost flute-like tones of the small sapajous; the snorting grumblings of the striped nocturnal monkey $\left({ }^{6}\right)$ (the Nyctipithicus trivirgatus, which I was the first to describe); the interrupted cries of the great tiger, the cuguar or maneless American lion, the peccary, the sloth, and a host of parrots, of parraquas, and other pheasant-like birds. When the tigers came near the edge of the forest, our dog, which had before barked incessantly, came howling to seek refuge under our hammocks. Sometimes the cry of the tiger was heard to proceed from amidst the high branches of a tree, and was in such case always accompanied by the plaintive piping of the monkeys, who were seeking to escape from the unwonted pursuit.

If one asks the Indians why this incessant noise and disturbance arises on particular nights, they answer, with a smile, that "the animals are rejoicing in the bright moonlight, and keeping the feast of the full moon." To me it appeared that the scene had probably originated in some accidental combat, and that hence the disturbance had spread to other animals, and thus the noise had increased more and more. The jaguar pursues the peccaries and tapirs, and these, pressing against each other in their flight, 
break through the interwoven tree-like shrubs which impede their escape; the apes on the tops of the trees, being frightened by the crash, join their cries to those of the larger animals; this arouses the tribes of birds, who build their nests in communities, and thus the whole animal world becomes in a state of commotion. Longer experience taught us that it is by no means always the celebration of the brightness of the moon which disturbs the repose of the woods: we witnessed the same occurrence repeatedly, and found that the voices were loudest during volent falls of rain, or when, with loud peals of thunder, the flashing lightning illuminated the deep recesses of the forest. The good-natured Franciscan monk, who, although he had been suffering for several months from ferer, accompanied us through the Cataracts of Atures and Maypures to San Carlos on the Rio Negro, and to the Brazilian boundary, used to say, when fearful on the closing in of night that there might be a thunder-storm, "May Heaven grant a quiet night both to us and to the wild beasts of the forest!"

Scenes, such as those I have just described, were wonderfully contrasted with the stillness which prevails within the tropics during the noontide hours of a day of more than usual heat. I borrow from the same journal the recollections of a day at the Narrows of Baraguan. At this part of its course the Orinoco forces for itself a passage through the western portion of the Parime Mountains. What is called at this remarkable pass a "Narrow" (Angostura del Baraguan), is still a bed or water-basin of 890 toises (5690 English feet) in breadth. On the naked rocks which formed 
the shores we saw only, besides an old withered stem of Aubletia (Apeiba tiburba), and a new Apocinea (Allamanda salicifolia), a few silvery croton shrubs. A thermometer observed in the shade, but brought within a few inches of the towering mass of granite rock, rose to above $40^{\circ}$ Reaumur (122 Fah.) All distant objects had wave-like undulating outlines, the effect of mirage; not a breath of air stirred the fine dust-like sand. The sun was in the zenith, and the flood of light which he poured down upon the river, and which, from a slight rippling movement of the waters, flashed sparkling back, rendered still more sensible the red haze which veiled the distance. All the naked rocks and boulders around were covered with a countless number of large thick-scaled iguanas, gecko-lizards, and variously spotted salamanders. Motionless, with uplifted heads and open mouths, they appeared to inhale the burning air with ecstacy. At such times the larger animals seek shelter in the recesses of the forest, and the birds hide themselves under the thick foliage of the trees, or in the clefts of the rocks; but if, in this apparent entire stillness of nature, one listens for the faintest tones which an attentive ear can seize, there is perceived an all-pervading rustling sound, a humming and fluttering of insects close to the ground, and in the lower strata of the atmosphere. Every thing announces a world of organic activity and life. In every bush, in the cracked bark of the trees, in the earth undermined by hymenopterous insects, life stirs audibly. It is, as it were, one of the many voices of Nature, heard only by the seusitive and reverent ear of her true votaries. 


\section{ANNOTATIONS AND ADDITIONS.}

\section{(1) p. 260.-"Characteristic names in Arabic and Persian."}

More than twenty different terms might be cited as used by Arabs in speaking of steppes, (tanufah), to denote deserts without water, entirely bare, eovered with siliceous sand, or interspersed with spots affording some pasture: (sahara, kafr, mikfar, tih, and mehme.) Sahl, is a low plain; dakkah, a desolate elevated plain. In Persian, "beyaban" signifies the arid sandy desert,-as do the Mogul "gobi," and the Chinese "han-hai," and "scha-mo." "Yaila" is a steppe covered rather with grasses or herbage than with herbaceous plants; so are also the Mogul "küdah," and the Turkish "tala," or "tschol," and the Chinese "huang." "Deshti-reft" is an elevated plain devoid of vegetation. (Humboldt, Relation hist. T. ii. p. 158.)

(2) p. 260.- "In the old Castilian idiom."

Pico, picacho, mogote, cucurucho, espigon, loma tendida, mesa, panecillo, farallon, tablon, peña, peñon, peñasco, peñoleria, roca partida, laxa, cerro, sierra, serrania, cordillera, monte, montaña, montañuela, cadena de montes; los altos, malpais, reventazon, bufa, \&c.

VOL. I. 
(3) p. 263.- "Where the map had exhibited Montes de Cacao."

On the range of hills which had been converted into the lofty Andes de Cuchao, see my Rel. hist. T. iii. p. 238.

\section{(4) p. 268.- "Hermesia."}

The genus Hermesia, the Sauso, has been described by Bonpland, and figured in our Plantes equinoxiales, T. i. p. 162, tab. xlvi.

\section{(5) p. 269.-"The fresh-water dolphin."}

These are not sea-dolphins, ascending the rivers for a great distance, as is done by some species of Pleuronectes (flat fish, which always have both eyes on one side of the body) ; for example, the Limande (Pleuronectes Limanda), which comes up the Loire to Orleans. Some sea forms of fish, as dolphins and skates, are repeated in the great rivers of both continents. The fresh-water dolphin of the Apure and the Orinoco differs specifically from the Delphinus gangeticus, as well as from all sea-dolphins. See my Rel. hist. T. ii. pp. 223, 239, 406-413.

(6) p. 270.- "The striped nocturnal monkey."

This is the Douroucouli, or Cusi-cusi of the Cassiquiare, described by me as Simia trivirgata in my Recueil d'Observations de Zoologie et $a^{9}$ Anatomie comparée, T. i. p.306311, tab. xxviii., the plate being taken from a drawing made by myself from the living animal. We subsequently 
saw this nocturnal monkey living in the menagerie of the Jardin des Plantes at Paris. (See the work above cited, T. ii. p. 340.) Spix also found this remarkable little animal on the Amazons river, and called it Nyctipithecus vociferans.

Potsdam, June 1849. 



\section{HYPSOMETRIC ADDENDA.}

I ay indebted to Mr. Pentland (whose scientific labours have thrown so much light on the geology and geography of Bolivia) for the following determinations, which he communicated to me in a letter written from Paris, in October 1848, after the publication of his great map :-

Nevado of Sorata, or Ancohuma.

South Peak.....15 $15^{\circ}$ j $1^{\prime} 33^{\prime \prime}$

North Peak.....15 $45^{\prime} 18^{\prime \prime}$

Illimani.

South Peak.....16 $16^{\circ} 38^{\prime} 52^{\prime \prime}$

Middle Peak ...16 $36^{\circ} 38^{\prime} 26^{\prime \prime}$

North Peak.....16 $36^{\circ} 50^{\prime \prime}$
Long, from

Greenwich.

$68^{\circ} 33^{\prime} 55^{\prime \prime}$

$68^{\circ} 33^{\prime}$ ว $2^{\prime \prime}$

$67^{\circ} 49^{\prime} 18^{\prime \prime}$

$67^{\circ} 49^{\prime} 17^{\prime \prime}$

$67^{\circ} 49^{\prime} 39^{\prime \prime}$
Height in English Feet.

21286

21043

21145

21094

21060

The heights (with the exception of the unimportant difference of a few feet in the South Peak of Mlimani) are the same as those given in the map of the Lake of Titicaca. A sketch of the last-named mountain (Illimani), as it shews itself in all its majesty from $\mathrm{La}$ Paz, has been given by $\mathrm{Mr}_{\mathrm{r}}$. Pentland in the Journal of the Royal Geographical Society, Vol. V. (1835), p. 77. This was five years after the publieation of the first measurements in the Annuaire du Bureau des Longitudes for 1830, p. 323, which results I myself 
hastened to make known in Germany. (Hertha, Zeitschrift für Erd und Völkerkunde, von Berghaus, Bd. xiii. 1829, S. 3-29.) The Nevado de Sorata is to the east of the village Sorata, or Esquibel : it is called in the Ymarra language, according to Pentland, Ancomani, Itampu, and Illhampu. We recognise in "Illimani," the Ymarra word "illi," snow.

If, however, in the eastern chain of Bolivia the Sorata was long assumed 3718 French, or 3952 English feet, and the Tllimani 2675 French, or 2851 English, feet too high, there are in the western chain of the same country, according to Pentland's map of Titicaca (1848), four peaks to the east of Arica and between lat. $18^{\circ} 7^{\prime}$ and $18^{\circ} 25^{\prime}$, all of which are higher than Chimborazo, which is 21422 English or 20100 French feet. These four peaks are-

Pomarape . . . . 21700 English feet, or 20360 French feet. Gualateiri . . . . 21960 " " 20604 " " Parinacota • . . . 22030 " " 20670 " " Sahama . . . . 22350 " " 20971 " "

Berghaus has applied to the eastern and western chains of the Andes of Bolivia the investigation published by me in the Annales des Sciences Naturelles, T. iv. 1825, p. 225-253, of the proportion (very different in different mountain chains), which the general height of the ridge, the crest, or kamm (the mean height of the passes), bears to the highest summits or culminating points. He finds, following Pentland's map, the mean height of the passes in the eastern chain 12672 French, or 13502 English feet; and in the 
western chain 13602 French, or 14896 English feet. The culminating points are 19972 and 20971 French, 21286 and 22350 English feet; consequently the ratio of the height of the ridge to that of the culminating point is, in the eastern chain, as $1: 1.57$, and in the westem chain as 1 : 1.54. (Berghaus, Zeitschrift für Erdkunde, Band. is. S. 322-326). This ratio, which is, as it were, the measure of the subterranean elevating force, is very similar to that which exists in the Pyrenees, but very different from the Alps, where the mean height of the passes is less as compared with Mont Blanc. The ratios are, in the Pyrenees, $=1: 1.43$, and in the Alps, =1:2.09.

But, according to Fitz Roy and Darwin, the height of the Sahama is still surpassed by 796 French, or 850 English feet, by that of the volcano of Aconcagua, on the north east of Valparaiso, in Chili, in S. lat. $32^{\circ} 39^{\prime}$. The officers of the Adventure and Beagle, in Fitz Roy's Expedition, found, in August 1835, the summit of Acongagua between 23000 and 23400 English feet. If we take it at 23200 (equal to 21767 Paris feet), this volcano would be 1667 French, or 1777 English, feet higher than the Chimborazo. (Fitz Roy, Voyages of the Adventure and Beagle, 1839, Vol. ii. p. 481 ; Darrin, Journal of Researches, 1845, pp. 223 and 291.) According to more recent calculations, the height of Acongagua is given as 22431 French, or 23907 English feet. (Mary Somerville, Physical Geogr. 1849, Vol. ii. p. 425.)

Our knowledge of the systems of mountains which, north of the parallels of $30^{\circ}$ and $31^{\circ} \mathrm{N}$. lat., are called the Rocky 
Mountains and the Sierra Nevada of California, has received most important additions, geologically, botanically, hypsometrically, and geographically by astronomical determinations of position, from the excellent works of Charles Frémont (Geographical Memoir upon Upper California, an illustration of his Map of Oregon and California, 1848) ; of Dr. Wislizenus (Memoir of a Tour to Northern Mexico, connected with Col. Doniphan's Expedition, 1848); and of Lieutenants Abert and Peck (Expedition on the Upper Arkansas, 1845; and Examination of New Mexico in 1846 and 1847.) There prevails throughout these different North American works a true scientific spirit, which is deserving of the greatest commendation. The remarkable elevated plain, which rises to an uninterrupted height of four or five thousand French (4260 and 5330 English) feet, between the Rocky Mountains and the Sierra Nevada of California, of which I have spoken in p. 44, and which is called the Great Basin, forms an inland closed river basin, and has hot springs and salt lakes. None of its rivers,Bear River, Carson River, and Humboldt River,-find their way to the sea. The Lake, which I was led by combinations and inferences to represent, in the great Map of Mexico drawn by me in 1804, under the name of Lake Timpanogos, is the great Salt Lake of Frémont's Map : it is sixty geographical miles long from north to south, and ten broad; and it communicates, with the fresh water lake of Utah, which is situated at a higher level, and receives the Timpanogos or Timpanaozu River, which enters it from the eastward, in lat. $4.0^{\circ} 13^{\prime}$. The circumstance of the Timpano- 
gos Lake of my map not having been placed by me sufficiently far to the north and west, is to be attributed to the entire want, at that time, of any astronomical determinations of the position of Santa Fé, in New Mexico. The error amounts, for the western margin of the lake, to almost 50 minutes of arc; a difference of absolute longitude which will appear less surprising, if it is remembered that my itinerary map of Guanaxuato could only be based for 15 degrees of latitude on compass surveys, or compass directions, for which I was indebted to Don Pedro de Rivera. (Humboldt, Essai polit. sur la Nourelle Espagne, T. i. pp. 127-136.) These directions being differently combined by my early deceased fellow-labourer, Herr Friesen, and myself, gave him as the result of his combinations $107^{\circ} 58$ from Paris as the longitude of Santa Fé, and to me as the result of mine, $107^{\circ} 13^{\prime}$. According to actual astronomical determinations since obtained, the true longitude appears to be $108^{\circ} 22^{\prime} \mathrm{W}$. of Paris, or $106^{\circ} 00^{\prime} \mathrm{W}$. of Greenwich. The relative position of the beds of fossil salt-found in "thick strata of red clay," on the south east of the islandstudded Great Salt Lake (my Laguna de Timpanogos), and not far from the present Fort Mormon and the Utah Lakewas given with perfect correctness in my large map of Mexico. I may refer on this point to the latest evidence of the traveller who made the first well-assured determinations of geographical position in that district:-" The mineral or rock salt, of which a specimen is placed in Congress Library, was found in the place marked by Humboldt in his map of 
New Spain (northern half), as derived from the journal of the missionary Father Escalante, who attempted (1777) to penetrate the unknown country from Santa Fé of New Mexico to Monterey of the Pacific Ocean. South-east of the Lake Timpanogos is the chain of the Wha-satch Mountains; and in this, at the place where Humboldt has written Montagnes de sel gemme, this mineral is found." (Frémont, Geogr. Mem. of Upper California, 1848, pp. 8 and 67; compare Humboldt, Essai politique, T. ii. p. 261.)

A great historical interest attaches to this part of the highland, and more particularly to the country round the Lake of Timpanogos, which is perhaps the same with the Lake of Teguayo, the ancestral seat of the Aztecs. In their migration from Aztlan to Tula, and to the Valley of Tenochtitlan (Mexico), this people made three halting places or stations, at which the ruins of the Casas grandes are still to be seen. The first sojourn of the Aztecs was at the Lake of Teguayo, the second on the Rio Gila, and the third not far from the Presidio de Llanos. Lieutenant Abert found on the banks of the Gila the same immense number of fragments of pottery ornamented with painting, and scattered over a considerable tract of ground, which had astonished the missionaries Francisco Garces and Pedro Fonte in that locality. These remains of the products of human skill are supposed to indicate the existence of a former higher civilisation in these now solitary regions. Remains of buildings in the singular style of architecture of the Aztecs, and of their houses of seven stories, are also found far to the east. 
ward of the Rio Grande del Norte; for example, in Taos. (Compare Abert's Examination of New Mexico, in the Documents of Congress, No. 41, pp. 4.89 and 581-605, with my Essai pol. T. ii. pp. 241-244.) The Sierra Nevada of California is parallel to the Coast of the Pacific; but between the latitudes of $34^{\circ}$ and $41^{\circ}$, between San Buenarentura and the Bay of Trinidad, there runs, on the West of the Sierra Nevada, another (smaller) coast chain, of which Monte del Diablo, 3448 French, 3674 English feet high, is the culminating point. In the narrow valley, between this coast chain and the great Sierra Nevada, flow from the south the Rio de San Joaquin, and from the north the Rio del Sacramento, on the banks of which, in rich alluvial soil, are the rich gold-washings now so much resorted to.

I have already referred, p. 43, to a hypsometric levelling, and to barometric measurements made from the junction of the Kanzas River with the Missouri to the Pacific, or throughout the immense extent of 28 degrees of longitude. Dr. Wislizenus has now successfully continued the levelling began by me from the city of Mexico, in the Equinoctial Zone, to the North as far as Santa Fé del Nuevo Mexico, in lat. $35^{\circ} 38^{\prime}$. It will be seen, perhaps, with surprise, that the elevated plain which forms the broad crest of the Mexican Andes is far from sinking down, as had long been supposed, to an inconsiderable height. I give here for the first time, according to the measurements which we at present possess, the elevations of several points, forming a line of levelling from the city of Mexico to Santa Fé, which latter 
town is less than four German (sixteen English) geographical miles from the Rio del Norte.

French Feet. Eng. Feet. Observer.

\begin{tabular}{|c|c|c|c|c|c|c|c|c|}
\hline Mexico • . & . & . & . & 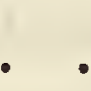 & & 7008 & 7490 & Ht. \\
\hline Tula . . . & . & . & . & . & . & 6318 & 6733 & Ht. \\
\hline San Juan del Rio & . & . & & . & : & 6090 & 6490 & Ht. \\
\hline Queretaro . & . & . & . & . & & 5970 & 6363 & Ht. \\
\hline Celaya. . & . & . & . & . & & 5646 & 6017 & Ht. \\
\hline Salamanca & . & . & . & . & . & 5406 & 5761 & Ht. \\
\hline Guanaxuato . & . & . & . & . & . & 64.14 & 6836 & Ht. \\
\hline Silao . . . & . & . & . & . & . & 5546 & 5910 & $\mathrm{Br}$ \\
\hline Villa de Leon & . & . & . & . & . & 5755 & 6133 & Br. \\
\hline Lagos . . . & . & . & . & . & . & 5983 & 6376 & $\mathrm{Br}$ \\
\hline Aguas Calientes & . & . & . & . & & 5875 & 6261 & $\mathrm{Br}$ \\
\hline San Luis Potosi & . & . & . & & & 5714 & 6090 & $\mathrm{Br}$ \\
\hline Zacatecas. . & . & . & . & . & & 7544 & 8040 & $\mathrm{Br}$ \\
\hline Fresnillo . . & . & . & . & & & 6797 & 7244 & $\mathrm{Br}$ \\
\hline Durango . & . & . & . & . & & 6426 & 6848 & (Oteiza) \\
\hline Parras. . & . & . & . & & & 4678 & 4985 & Ws. \\
\hline Saltillo . & : & - & . & & & 4917 & 5240 & Ws. \\
\hline El Bolson de Mar & & & & & & $\left\{\begin{array}{l}3600 \text { to } \\
4200\end{array}\right.$ & $\left.\begin{array}{c}3837 \text { to } \\
4476\end{array}\right\}$ & Ws. \\
\hline Chihuahua . & , & - & . & & & 4352 & 4638 & Ws. \\
\hline Cosiquiriachi . & . & . . & & & & 5886 & 6273 & Ws. \\
\hline $\begin{array}{l}\text { Passo del Norte, } \\
\text { Norte } .\end{array}$ & & & & & & 3557 & 3812 & Ws. \\
\hline Santa Fé del Nue & & & & & & 6612 & 7047 & Ws. \\
\hline
\end{tabular}

The letters Ws., Br., and Ht., are placed to distinguish the barometric measurements of Dr. Wislizenus, Oberbergrath Burkart, and my own. Wislizenus has appended to his valuable memoir three vertical sections of the surface of the ground: one from Santa Fé to Chihuahua by Passo del 
Norte; one from Chihuahua to Reynosa by Parras; and one from Fort Independence (a little to the east of the Confluence of the Missouri and the Kanzas River) to Santa Fé. The calculation is founded on daily corresponding observations of the barometer, made by Engelmann at St. Louis, and by Lilly at New Orleans. If we consider that the difference of latitude between Santa Fé and Mexico is $16^{\circ}$, and that thus (apart from deviations from a straight line) the distance in the north and south direction is above 960 geographical miles, we are led to inquire whether there be in any other part of the whole globe a similar conformation of the Earth, equal in extent and elevation (between 5000 and 7000 French, or 5330 and 7460 English feet above the level of the sea) to the highland of which I have just given the levelling, and yet over which four-wheeled waggons can travel as they do from Mexico to Santa Fé. It is formed by the broad, undulating, flattened crest of the chain of the Mesican Andes, and is not the swelling of a valley between two mountain chains, as is the case in some other remarkable elevations of plain or undulating sufacein the Northern Hemisphere, in the "Great Basin" between the Rocky Mountains and the Sierra Nevada of California,in the Southern Hemisphere, in the high plain of the lake of Titicaca, between the eastern and western chains of the Andes of Bolivia,-and in Asia, in the highlands of Thibet, between the Himalaya and the Kuen-lün. 



\section{GENERAL SUMMARI}

OF THE

CONTENTS OF THE FIRST VOLUME. 



\section{GENERAI SUMMARY}

\section{OF THE \\ CONTENTS OF VOL. I.}

Preface to the First Edition-p. vii. to p. ir.

Preface to the Second and Third Editions-p. xi. to p. IV.

Note by the Translator-p. xrii.

Steppes and Deserts-p. 1 to p. 26.

Coast chain and mountain valleys of Caraccas. Lake of Tacarigua. Contrast in respect to the luxuriance of regetation between those districts and the treeless plains. The steppe regarded as the bottom of a Mediterranean Sea; broken strata a little higher than the rest of the plain called "banks." General phenomena of extensire plains; the Heaths of Europe, the Pampas and Llanos of South America, the African Deserts, and the Steppes of Northern Asia. Different characters of the regetable covering of the surface. Animal life. Pastoral nations, and their invasive migrations. $1-6$

Description of the South American plains and prairies - their extent and climate; the latter dependent on the outline of the coasts, and on the hypsometric conformation of the New Continent. Comparison with the plains and deserts of Africa . . . . 7-13

Original absence of pastoral life in America. Food furnished by the Mauritia palm; the Guaranis' huts raised on trees . 13-17 
Since the discovery of America the Llanos have become more habitable, Extraordinary increase in the number of wild cattle, horses, asses, and mules. Description of the season of extreme dryness, and of the rainy season. Appearance of the surface of the ground and of the sky. Life of the animals - their sufferings, their conflicts; power of adaptation with which certain animals and plants are endowed. Jaguars, crocodiles, and electric fishes. Unequal conflict between Gymnoti and horses

$17-23$

Retrospective glance at the countries surrounding the Steppes and Deserts. Forest wildernesses of the Orinoco and the Amazons. Indian tribes separated by the wonderful diversity of their languages and differences of their habits; their lardships, and frequent variance between the different tribes. Figures graven on the rocks show that these solitudes were once the seat of a degree of civilisation which has now disappeared

Scientific Elucidations and Additions-p. 27 to p. 204.

The island-studded lake of Tacarigua ; its relations to the neighbouring mountain chains. Geological description. Progress of cultivation and of European civilisation. Varieties of the sugar-cane. Cacao plantations. Great fertility of soil associated within the tropics with insalubrity of atmosphere.

$27-33$

"Banks" or broken strata. General horizontality of the surface. Subsidences of the surface . . . . . . 33-35

Resemblance of the distant steppe to the ocean. Naked stony crust. Tabular masses of syenite; whether prejudicial to health $36-37$

General views respecting the mountain systems of North and South America, embracing the most recent information. Chains running in a south-west and north-east direction in Brazil and in the 
Atlantic portion of the United States of North America. The low prorince of Chiquitos; small swellings of the ground constitute the division between the waters of the Guaporé and Aguapebi in $15^{\circ}$ and $17^{\circ} \mathrm{S}$. lat., and between the river basins of the Orinoco and the Rio Negro in $2^{\circ}$ and $3^{\circ} \mathrm{N}$. lat. . . . 37-39

Continuation of the chain of the Andes north of the isthmus of Panama (through the Aztec country, where Popocatepetl, 16626 French, or 17720 English feet high, has very recently been again ascended by Captain Stone) in the Sierra de las Grullas and the Rocky Mountains. Excellent scientific investigations of Captain Frémont. The longest barometric levelling erer made, showing a profile or rertical section of the earth's surface through a space of $28^{\circ}$ of longitude. Culminating point of the route from the coast of the Atlantic to the Pacific. "South Pass," south of the Wind River Mountains. Swelling of the ground in the Great Basin. Long contested existence of the Timpanogos Lake. Coast Chain, Maritime Alps, or Sierra Nevada of California. Volcanic eruptions. Falls of the Columbia .

General considerations on the contrasts shown by the spaces included between the central chain (the Rocky Mountains) and the diverging chains on the east and west (the Alleghanies and the Sierra Nevada of California); hypsometric characters of the low eastern space, which is only from 400 to 600 French, or 426 to 639 English feet above the level of the sea, and of the arid uninhabited plain 5000 or 6000 (5330 to 6400 English) feet abore the same level, called the Great Basin. Sources of the Mississipi in the Lake of Istaca according to Nicollet's highly meritorious researches. Buffalo country; Gomara's assertion of buffaloes having been formerly tamed in the northern part of Mexico . . . . 50-55

Retrospective view of the chain of the Andes from the Rocks of 
Diego Ramirez to Behring's Strait. Long circulated errors respecting the heights of mountains in the eastern chain of the Andes of Bolivia, especially the Sorata and the Illimani. Four summits of the western chain of Bolivia, which, according to Pentiand's latest determinations, are higher than the Chimborazo, but are not equal in height to the still active volcano of Acongagua measured by Fitz-Roy

$55-58$

The African mountains of Harudsch-el-Abiad. Oases

West winds on the coast of the Sahara. Accumulation of sea-weed; position of the great bank of Fucus from the time of Scylax of Caryanda to that of Columbus, and to the present day . $\quad 60-67$

Tibbos and Tuaricks. The camel and its distribution . 67-71

Mountain systems of the interior of Asia between Northern Siberia and India. Erroneous belief in the existence of a single great elevated plain called "Plateau de la Tartarie" . . 71-75

Chinese literature a rich source of orographic knowledge. Series of elevations of different highlands. Desert of Gobi. Probable mean height of Thibet. . . . . . . . 75-85

Review of the mountain systems of the interior of Asia. Chains running in the direction of the meridian; the Ural, which separates the low part of Europe from the low part of Asia, or divides into two portions the Scythian Europe of Pherecydes of Syros and of Herodotus; Bolor; Khingan and the Chinese chains, which, near the great bend in the direction of the Thibetian and AssamoBurmese river Dzangbo-tschu, run north and south. The elevations which, between $66^{\circ}$ and $77^{\circ} \mathrm{E}$. long. from Greenwich, follow the direction of meridians from Cape Comorin to the Icy Sea, alternate 
like reins or dikes in which there are faults or displacements; thus the Ghauts, the Soliman Chain, the Paralasa, the Bolor, and the Ural, succeed each other from south to north: the Bolor gare occasion among the ancients to the idea of the Imaus, which Agathodæmon supposed to be prolonged to the north into the low basin of the lower Irtysch. Parallel chains ruming east and west; the Altai; Thian-schan, with its actire rolcanoes at a distance of I52S geographical miles from the Icy Sea at the mouth of the Obi, and of 1512 geographical miles from the Indian Sea at the mouth of the Ganges; the Kuen-lün, recognised by Eratosthenes, Marinus of Tyre, Ptolemy, and Cosmas Indicopleustes, as the longest axis of eleration in the Old World, runs between $35 \frac{1}{2}$ and $36^{\circ}$ of latitude in the direction of the diaphragm of Dicearchus. Himalaya. The Kuen-lün, considered as an axis of eleration, may be traced from the wall of China near Lung-tscheu through the somewhat more northerly chains of Nan-schan and Kilian-schan, through the mountain knot near the Lake called the "Starry Sea," through the Hindu-Coosh (the Parapanisus and Indian Caucasus of the ancients), and through the chain of Demanend and the Persian Elbourz, to Taurus in Lycia. Near the intersection of the Kuenliun and the Bolor the correspondence of the direction of the ares of elevation (east and west in the Kuen-lün and the Hindu-Coosh, whereas that of the Himalaya is south-east and north-west) shows that the Hindu-Coosh is a continuation of the Kuen-lum, and not of the Fimalaja. The point where the direction of the Himalaja changes to south-east and north-west from haring been east and west, is about the 79 th degree of east longitude from Paris ( $81^{\circ} 22^{\prime}$ Greenwich). Next to the Dhawalagiri, it is not, as has been hitherto supposed, the Jarrahir which is the highest summit of the Himalasa ; that rank belonging, according to the most recent intelligence received from Dr. Joseph Hooker, to a mountain situated between Boutan and Nepaul in the meridian of Sikkim, the Kinchinjinga: the western summit of this mountain, which has been measured 
by Colonel Wangh, director of the trigonometrical survey of India, is 28178 feet, and its eastern summit 27826 feet high, according to the Journal of the Asiatic Society of Bengal, Nov. 1848 :-The mountain which is now supposed to be higher than the Dhawalagiri is figured on the frontispiece of the magnificent work of Joseph Hooker entitled "The Rhododendrons of Sikkim-Himalaya, 1849." -Determination of the lower limits of the snow-line on the northern and southern declivities of the Himalaya; its height being on an average 3400 to 4600 French, or 3620 to 4900 English feet higher on the northern face. New data on the subject from Hodgson. Without this remarkable distribution of temperature in the upper strata of the atmosphere, the mountain plains of Western Thibet would be uninhabitable to the millions of human beings who now dwell there.

$85-101$

The Hiong-nu, regarded by Deguignes and Johannes Müller as a tribe of Huns, appear rather to have been one of the widely scattered tribes of the Turks of the Altai and Tang-nu mountains. The Huns, whose name was known to Dionysius Perigetes, and who are noticed by Ptolemy as Chuns (whence the later appellation of Chunigard given to a country!), are a Finnish race of the Ural mountains .

. 101-102

Figures of the sun and of animals, and other signs carved on rocks in the Sierra Parime, as well as in North America, have often been supposed to be writing . . . . . 102-104

Description of the cold mountain elevations between 11000 and 13000 (or 11720 and 13850 English) feet, which are distinguished by the appellation of Paramos; character of their vegetation. 104-106

Notices of the two groups of mountains (Pacaraima Mountains, and 
the Sierra de Chiquitos) which separate the three plains of the Lower Orinoco, the Amazons, and the Rio de la Plata . 106-107

On the dogs of South America; both the aboriginal race and the descendants of European dogs which have become wild. Sufferings of cats when taken to elerations exceeding 13000 (13850 Eng.) feet.

. $107-112$

The low tract of the Sahara, and its relations to the Atlas Mountains, according to the latest information given by Daumas, Carette, and Renou. The barometric measurements of Fournel make it appear very probable that part of the North African desert is lower than the level of the sea. Oasis of Biscara; abundance of fossil salt in zones or bands running from south-west to north-east. Causes of the nocturnal cold in the desert according to Melloni . 112-118

Notices of the River Wady Dra (1-6th longer than the Rhine, and dry a large portion of the year), and of the country of Sheikh Beirouk, a chief independent of the Emperor of Morocco, from manuscript communications of the Naval Captain Count BouetVillaumez. The mountains north of Cape Noun (a name used by Edresi, in which, since the 15th century, an allusion to the negative particle has been erroneously sought) attain 8600 (9166 English) feet of elevation.

. $118-120$

The vegetation of the tropical American Llanos consisting of grasses, compared with the vegetation of the North Asiatic Steppes consisting of herbaceous plants. In the last-named Steppes, and especially the more fertile among them, a pleasing effect is produced in spring by small snow-white and red-flowering Rosaceæ, Amjgdaleæ, species of Astragalus, Crown Imperials, Cypripedias, and Tulips. Contrast with the desolate salt Steppes full of Chenopodiaceæ, species of Salsola and Atriplex. Considerations on the 
relative numbers of the prevailing families of plants. The plains adjoining the Icy Sea, north of the limit determined by Admiral Wrangel as that of the growth of Coniferæ and Amentaceæ, are the domain of cryptogamous plants. Aspect and physiognomy of the Tundras, where the soil, which is perpetually frozen, is covered either with a thick coating of Sphagnum and other mosses, or with the snow-white Cenomyce and Stereocaulon paschale . 120-123

Principal causes of the very different distribution of temperature in the European and American Continents. Direction and curvature of the isothermal lines, or lines of equal temperature, for the entire year, for the winter, and for the summer . . . 123-136

Are there any grounds for believing that America emerged later than the Old Continent from the chaotic watery covering? . 136-139

Thermic comparison of the Northern and Southern Hemispheres in high latitudes

Apparent connection of the African sea of sand with those of Persia, Kerman, Beloochistan, and the interior of Asia. On the western part of Mount Atlas, and the connection of purely mythical ideas with geographical traditions. Indistinct allusions to igneous eruptions. Triton. Lake. Crater-like forms of a locality south of Hanno's "Bay of the Gorilla Apes." Singular description of the "hollow Atlas" from the Dialexes of Marinus Tyrius . 143-149

Notices respecting the Mountains of the Moon (Djebel al-Komr) in the interior of Africa by Reinaud, Beke, and Ayrton. Werne's instructive notice of the second expedition undertaken by the orders of Mehemet Ali. The Abyssinian mountains, which rise, according to Rüppell, almost to the height of Mont Blanc. The most ancient notice of snow between the tropics contained in the Inscrip. 
tion of Adulis, which is somewhat more modern than Juba. High mountains which, between $6^{\circ}$ and $4^{\circ}$ of north latitude, and still more to the south, approach the Bahr el-Abiad. A considerable swelling of the ground divides the White Nile from the basin of the Goschop. Line of separation between the waters which flow to the Mediterranean and those which flow to the Indian Ocean according to Carl Zimmermanm's map. Lupata Chain according to the instructive researches of Wilhelm Peters . . 149-158

Oceanic currents. In the northern part of the Atlantic Ocean the waters are impelled in a true revolving current. That the first impulse which causes the Gulf Stream is to be sought at the southern extremity of Africa, was already known to Sir Humphry Gilbert in 1560. Influence of the Gulf Stream on the climate of Scandinavia. How it contributed to the discovery of America. Instances of Esquimaux who, aided by the returning eastward flowing portion of the warm Gulf Stream, and by north-west winds, arrived on the coasts of Europe. Such a case related by Cornelius Nepos and Pomponius Mela (of Indians given by a king of the Boil to Quintus Metellus Celer, Proconsul of Gaul); others in the time of the Othos and of Frederic Barbarossa, of Columbus and of Cardinal Bembo. Again, in the years 1682 and 1684 natives of Greenland appeared in the Orkneys . . . . 159-165

Operation of lichens and other Cryptogamia in the cold and temperate zones in preparing the way for the more rapid establishment of larger phænogamous plants. Within the tropics lichens are often replaced in this respect by succulent plants. Milk-yielding animals of the New Continent; the Lama, the Alpaca, the Guanaco. $165-169$

Cultivation of farinaceous grasses $.169-173$ 
The coast nation of the Guaranis (Warraus), and the Mauritia palm of the coasts, according to the accounts given by Bembo in the Historiæ Venetæ, and those of Raleigh, Hillhouse, and Robert and Richard Schomburgk .

Phenomena which long-continued drought produces in the Steppe; sand-spouts, hot winds (Mirage); awakening of crocodiles and tortoises from long summer sleep . . . . . 182-190

Otomacs. General considerations on the practice of earth-eating among particular nations or tribes. Clays and earths containing Infusoria . . . . . . . . . 190-196

Figures graven on rocks throughout a zone running from east to west, and extending from the Rupunuri, Essequibo, and the Pacaraima Mountains, to Caycara and the wildernesses of the Cassiquiare. Earliest notice (April 1749) of these traces of former civilization in the manuscript account of the travels of the surgeon Nicolas Hortsmann of Hildesheim, found among D'Anville's papers. $196-203$

The vegetable poison Curare or Ourari . $203-204$

\section{Cataracts of the Orinoco-p. 207 to p. 231.}

The Orinoco; general view of its course. Ideas excited in Columbus on seeing its embouchure. Its unknown sources are east of the Mountain of Duida and the groves of Bertholletia. Causes of the principal bends of the river.

. $207-219$

The falls or rapids; Raudal of Maypures enclosed by four streams. Former state of the district. Island-like form of the rocks Keri and Oco. Grandeur of the view obtained on descending the hill of Manimi, where a foaming river-surface of four miles in extent presents itself at once to the eye. Iron-black masses of rock rise like 
castles from the bed of the river; the summits of the lofty palm trees pierce through the cloud of spray and vapour a 219-226

Raudal of Atures; numerous islands; rocky dikes connecting one island with another, and the resort of pugnacious golden Pipras. Parts of the bed of the river at the cataracts are dry, from the waters having found a passage by subterranean channels. We visited the rocks at the closing in of night and during storm and heavy rain. Unsuspected proximity of crocodiles . . 226-227

Celebrated cave of Ataruipe, the sepulchral vault of an extinct nation

Scientific Elucidations and Additions-p. 233 to p. 255.

The river-cow (Trichecus manati) lives in the sea at the place where, in the Gulf of Xagua, on the south coast of the Island of Cuba, springs of fresh water break forth . . . . .233-234

Geographical discussion on the sources of the Orinoco . 236-241

The Bertholletia, a Lecythidea, a remarkable example of highly developed organization. Stem of an Arundinarea sixteen to seventeen feet long from knot to knot. . . . . . 241-243

On the myth or fable of the Lake of Parime . . . 243-254

The Nocturnal Life of Animals in the Primeval Forest-p. 259 to p. 272.

Difference between languages in respect to their richness in welldefined expressions for characterising natural phenomena, such as the state of regetation, the forms of plants, the outlines and grouping of clouds, the appearance of the surface of the ground, and the forms of rocks and mountains. Loss which languages suffer by the disuse of such words, or by their signification becoming impaired. 
The misinterpretation of a Spanish word, "Monte," has caused the undue extension or introduction of mountains in maps. Primeval Forest; frequent abuse of the term. Absence of the uniformity which is produced by the association of the same kinds of trees, characteristic of tropical forests. Causes of the impenetrability of forests between the tropics; the twining plants, Lianes, often form only a small portion of the Underwood.

. $259-266$

Appearance of the Rio Apure in the lower part of its course. Margin of the forest fenced like a garden by a low hedge of Sauso (Hermesia). The wild animals of the forest lead their young to the river through small openings in this hedge. Flocks of large waterhogs or Cavies (Capybara). Fresh-water dolphins 266-269

Wild cries of animals resound throughout the forest. Cause of the nocturnal uproar. . . . • . . . 269-271

Contrast with the stillness which reigns during the noon-tide hours on days of more than usual heat in the torrid zone. Description of the narrows of the Orinoco at Baraguan. Humming and fluttering of insects. Life stirs audibly in every bush, in the clefts of the bark of trees, and in the earth undermined and furrowed by Hymenopterous insects . . . . . . 271-272

Scientific Elucidations and Additions-p. 273 to p. 275.

Characteristic terms in Arabic and Persian descriptive of the surface of the ground (Steppes, grassy plains, deserts, \&c.) Richness of the old Castilian idiom in words expressive of the form of mountains. Fresh-water skates and dolphins. In the great rivers of both continents some organic sea-forms are repeated. American nocturnal monkeys, the three-striped Douroucouli of the Cassiquiare. 


\section{Hypsometric Addenda-p. 277 to p. 285.}

Pentland's measurements in the eastern mountain chain of Bolivia. Height of the volcano of Aconcagua according to Fitzroy and Darwin. Western mountain chain of Bolivia . . 277-279

Mourtain systems of North America. Rocky Mountains and the Snotry Chain (Sierra Nevada) of California. Laguna de Timpanogos.

$$
279-283
$$

Hypsometrical profile of the Highland of Mexico from the city of Mexico to Santa Fé . . . . . 283-285

END OF TOL. I. 



\section{ASPECTS OF NATURE,}

$I N$

DIFFERENT LANDS AND DIFFERENT CLINATES;

TITH

Srientitic 遇luciotions.

\section{ALEXANDER VON HUMBOLDT.}

TRANSLATED BY MRS. SABINE.

IN TWO VOLUMES.

VOL. II.

\section{LONDON:}

PRINTED FOR

LONGMAN, BROWN, GREEN, AND LONGMANS,

JOHN MURRAY, ALBEMARLE STREET. 
Wilson and Ogilvy, Skinner Street, Snowhill, London. 


\section{CONTENTS OF VOL. II.}

Phisiogrom of Pintits . . . . . . . 3

Annotations and Additions . . . . . . 33

Postscript on the Physiognomic Classification of Plants . 205

On the Structure and Mode of Action of Volcanos, is Different Parts of the Globe . . . . 214

Annotations and Additions . . . . . 243

The Vital Force, or the Rhodiax Genius . . . 251

Note. . . . . . . 259

The Plateau of Caxamarca, the Axcient Capital of the Irca Atahualtea, and the First View of the Pacific Ocean, from the Crest of the Andes . . . $26 \%$ Amnotations and Additions . . . . . 303

General Summary of the Contexts of the Second Volume . 327

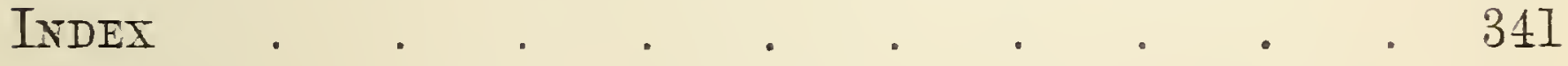





\section{PHYSIOGNOMY OF PLANTS.}





\section{ASPECTS OF NATURE}

IN

DIFFERENT LANDS AND DIFFERENT CLIMATES.

\section{PHYSIOGNOMY OF PLANTS.}

WHEN the active curiosity of man is engaged in interrogating Nature, or when his imagination dwells on the wide fields of organic creation, among the multifarious impressions which his mind receives, perhaps none is so strong and profound as that of the universal profusion with which life is everywhere distributed. Even on the polar ice the air resounds with the cries or songs of birds, and with the hum of insects. Nor is it only the lower dense and vaporous strata of the atmosphere which are thus filled with life, but also the higher and more ethereal regions. Whenever Mont Blanc or the summits of the Cordilleras have been ascended, living creatures have been found there. On the Chimborazo, ( $\left.{ }^{1}\right)$ eight thousand feet higher than Etna, we found butterflies and other winged insects, borne by ascending currents of air to those almost unapproachable solitudes, which man, led by 
a restless curiosity or unappeasable thirst of knowledge, treads with adventurous but cautious steps: like him strangers in those elevated regions, their presence shows us that the more flexible organization of animal creation can subsist far beyond the limits at which vegetation ceases. The condor, $\left({ }^{2}\right)$ the giant of the Vulture tribe, often soared over our heads above all the summits of the Andes, at an altitude higher than would be the Peak of Teneriffe if piled on the snow-covered crests of the Pyrenees. The rapacity of this powerful bird attracts him to these regions, whence his far-seeing eye may discern the objects of his pursuit, the soft-wooled Vicunas, which, wandering in herds, frequent, like the Chamois, the mountain pastures adjacent to the regions of perpetual snow.

But if the unassisted eye sees life distributed throughout the atmosphere, when armed with the microscope we discover far other marvels. Rotiferæ, Brachionæ, and a multitude of microscopic animalculæ, are carried up by the winds from the surface of evaporating waters. These minute creatures, motionless and apparently dead, are borne to and fro in the air until the falling dews bring them back to the surface of the earth, dissolve the film or envelope which encloses their transparent rotating bodies, $\left.{ }^{3}\right)$ and, probably. by means of the oxygen which all waters contain, breathe new irritability into their dormant organs.

According to Ehrenberg's brilliant discovery, the yellow sand or dust which falls like rain on the Atlantic near the Cape de Verde Islands, and is occasionally carried even to Italy and Middle Europe, consists of a multitude of siliceous- 
shelled microscopic animals. Perhaps many of them float for years in the upper strata of the atmosphere, until they are brought down by vertical currents or in accompaniment with the superior current of the trade-winds, still susceptible of revivification, and multiplying their species by spontaneous division in conformity with the particular laws of their organisation.

But, besides creatures fully formed, the atmosphere contains innumerable germs of future life, such as the eggs of insects and the seeds of plants, the latter provided with light hairy or feathery appendages, by means of which they are wafted through the air during long antumnal wanderings. Even the fertilizing dust or pollen from the anthers of the male flowers, in species in which the sexes are separated, is carried over land and sea, by winds and by the agency of winged insects, $\left({ }^{4}\right)$ to the solitary female plant on other shores. Thus wherever the glance of the inquirer into Nature penetrates, he sees the continual dissemination of life, either fully formed or in the germ.

If the aereal ocean in which we are submerged, and above the surface of which we cannot rise, be indispensable to the existence of organised beings, they also require a more substantial aliment, which they can find only at the bottom of this gaseous ocean. This bottom is of two kinds; the smaller portion consisting of dry land in immediate contact with the external atmosphere, and the larger portion consisting of water, which may perhaps have been formed thousands of years ago by electric agencies from gaseous substances, and which is now incessantly undergoing decom- 
position in the laboratories of Nature, in the clouds and in the pulsating vessels of animals and plants. Organic forms also descend deep below the surface of the earth, wherever rain or surface water can percolate either by natural cavities or by mines or other excavations made by man: the subterranean cryptogamic Flora was an object of my scientific research in the early part of my life. Thermal springs of very high temperature nourish small Hydropores, Confervæ, and Oscillatoria. At Bear Lake, near the Arctic Circle, Richardson saw the ground, which continues frozen throughout the summer at a depth of twenty inches, covered with flowering plants.

We do not yet know where life is most abundant,whether on continents or in the unfathomed depths of the ocean. Through the excellent work of Ehrenberg, "Über das Verhalten des kleinsten Lebens," we have seen the sphere of organic life extend, and its horizon widen before our eyes, both in the tropical parts of the ocean and in the fixed or floating masses of ice of the Antarctic seas. Siliceousshelled Polygastrica, and even Coscinodiscæ, with their green ovaries, have been found alive enveloped in masses of ice only twelve degrees from the Pole; the small black Glacier flea (Desoria glacialis) and Podurellæ inhabit the narrow tubular holes examined by Agassiz in the Swiss glaciers. Ehrenberg has shown that on several microscopic Infusoria (Synedra, Cocconeis) others live as parasites, and that in the Gallionellæ such is their prodigious power of development, or capability of division, that in the space of four days an animalcule invisible to the naked eye can form 
two cubic feet of the Bilin polishing slate. In the sea, gelatinous worms, living or dead, shine like stars, $\left(^{5}\right)$ and by their phosphoric light change the surface of the wide ocean into a sea of fire. Ineffaceable is the impression made on my mind by the calm nights of the torrid zone, on the waters of the Pacific. I still see the dark azure of the firmament, the constellation of the Ship near the zenith, and that of the Cross declining towards the horizon, shedding through the perfumed air their soft and planetary lustre; while bright furrows of flashing light marked the track of the dolphins through the midst of the foaming waves:

Not only the ocean, but also the waters of our marshes, hide from us an innumerable multitude of strange forms. The naked eye can with difficulty distinguish the Cyclidias, the Euglenes, and the host of Naids divisible by branches like the Lemna or Duckweed, of which they seek the shade. Other creatures inhabit receptacles where the light cannot penetrate, and an atmosphere variously composed, but differing from that which we breathe: such are the spotted Ascaris, which lives beneath the skin of the earthworm; the Leucophra, of a bright silvery colour, in the interior of the shore Naid; and a Pentastoma, which inhabits the large pulmonary cells of the rattlesnake of the tropics. (6) There are animalculæ in the blood of frogs and of salmon, and even, according to Nordmann, in the fluids of the eyes of fishes and in the gills of the Bleak. Thus the most hidden recesses of creation teem with life. We propose in these pages to direct our attention to the vegetable world, on the existence of which that of animals is dependent. Plants are inces- 
santly engaged in disposing into order towards subsequent organization the raw materials of which the earth is composed : it is their office, by their vital forces or powers, to prepare those substances which, after undergoing a thousand modifications, are gradually converted to nobler purposes in the formation of nervous tissues. In directing our consideration towards the various families of plants, we shall at the same time glance at the multitude of animated beings to which they afford nutriment and protection.

The carpet of flowers and of verdure spread over the naked crust of our planet is unequally woven; it is thicker where the sun rises high in the ever cloudless heavens, and thinner towards the poles, in the less happy climes where returning frosts often destroy the opening buds of spring, or the ripening fruits of autumn. Everywhere, however, man finds some plants to minister to his support and enjoyment. If new lands are formed, the organic forces are ever ready to cover the naked rock with life. Sometimes, as at an early period among the Greek Islands, volcanic forces suddenly elevate above the surface of the boiling waves a rock covered with Scoriæ: sometimes, by a long-continued and more tranquil series of phenomena, the collective labours of united Lithophytes (7) raise their cellular dwellings on the crests of submarine mountains, until, after thousands of years, the structure reaches the level of the ocean, when the creatures which have formed it die, leaving a low flat coral island. How are the seeds of plants brought so immediately to these new shores? by wandering birds, or by the winds and waves of 
the ocean? The distance from other coasts makes it difflcult to determine this question; but, no sooner is the rock of the nerrly raised islands in direct contact with the atmosphere, than there is formed on its surface, in our northern countries, a soft silky net-work, appearing to the naked eye as coloured spots and patches. Some of these patches are bordered by single or double raised lines running round their margins; other patches are crossed by similar lines traversing them in various directions. Gradually the light colour of the patches becomes darker, the bright yellow which was visible at a distance changes to brown, and the bluish gray of the Leprarias becomes a dusty black. The edges of neighbouring patches approach and run into each other; and on the dark ground thus formed there appear other lichens, of a circular shape and dazzling whiteness. Thus an organic film or covering establishes itself by successive layers; and as mankind, in forming settled communities, pass through different stages of civilisation, so is the gradual propagation and extension of plants connected with determinate physical laws. Lichens form the first covering of the naked rock, where afterwards lofty forest trees rear their airy summits. The successive growth of mosses, grasses, herbaceous plants, and shrubs or bushes, occupies the intervening period of long but undetermined duration. The part which lichens and mosses perform in the northern countries is effected within the tropics by Portulacas, Gomphrenas, and other low and succulent shore plants. The history of the vegetable covering of our planet, and its gradual propagation over the desert crust of the 
earth, has its epochs, as well as that of the migrations of. the animal world.

Yet although organic life is everywhere diffused, and the organic powers are incessantly at work in reconnecting with each other the elements set free by death or dissolution, the abundance and variety of organised beings, and the rapidity with which they are renewed, differ in different climates. In the cold zones, the activity of organic life undergoes a temporary suspension during a portion of the year by frost ; fluidity is an essential condition of life or vital action, and animals and plants, with the exception of mosses and other cryptogamia, are in those regions buried for several months of each year in winter sleep. Over a large part of the earth, therefore, there could only be developed organic forms capable of supporting either a considerable diminution of heat, or, being without leaves, a long interruption of the vital functions. Thus we see variety and grace of form, mixture of colours, and generally the perpetually youthful energy and vigour of organic life, increase as we approach the tropics. This increase can be denied only by those who have never quitted Europe, or who have neglected the study of physical geography. When, leaving our oak forests, we traverse the Alps or the Pyrenees, and enter Italy or Spain, or when we direct our attention to some of the African shores of the Mediterranean, we might easily be led to draw the erroneous inference that hot countries are marked by the absence of trees. But those who do so, forget that the South of Europe wore a different aspect on the first arrival of Pelasgian or Carthaginian colonies; they forget that an 
ancient civilisation causes the forests to recede more and more, and that the wants and restless activity of large communities of men gradually despoil the face of the earth of the refreshing shades which still rejoice the eye in Northern and Middle Europe, and which, even more than any historic documents, prove the recent date and youthful age of our civilization. The great catastrophe which occasioned the formation of the Mediterranean, when the swollen waters of what was previously an immense lake burst through the barriers of the Dardanelles and of the Pillars of Hercules, appears to have stripped the adjacent countries of a large portion of their coating of regetable mould. The traditions of Samothrace, ( ${ }^{8}$ ) handed down to us by Grecian writers, appear to indicate the recentness of the epoch of the ravages caused by this great change. In all the countries which surround the Mediterranean, and which are characterised by beds of the tertiary and cretaceous periods (nummulitic limestone and neocomian rocks), great part of the surface of the earth consists of naked rock. One especial cause of the picturesque beauty of Italian scenery is the contrast thus afforded between the bare rock, and the islands if I may so call them of luxuriant regetation scattered over its surface. Wherever the rock is less intersected with fissures, so that it retains water at the surface, and where it is covered with vegetable mould, there, as on the enchanting shores of the Lake of Albano, Italy has her oak forests, with glades as deeply embowered and verdure as fresh as those which re admire in the North of Europe. 
The deserts to the south of the Atlas, and the immense plains or steppes of South America, must be regarded as only local phenomena. The latter, the South American steppes, are clothed, in the rainy season at least, with grass, and with low-growing almost herbaceous mimosas. The African deserts are, indeed, at all seasons devoid of regetation; seas of sand, surrounded by forest shores clothed with perpetual verdure. A few scattered fan-palms alone recall to the wanderer's recollection that these awful solitudes belong to the domain of the same animated terrestrial creation. which is elsewhere so rich and so varied. The fantastic play of the mirage, occasioned by the effects of radiant heat, sometimes causes these palm trees to appear divided from the ground and hovering above its surface, and sometimes shews their inverted image reflected in strata of air undulating like the waves of the sea. On the west of the great Peruvian chain of the Andes, on the coasts of the Pacific, I have passed entire weeks in traversing similar deserts destitute of water.

The origin of extensive arid tracts destitute of plants, in the midst of countries rich in luxuriant vegetation, is a geognostical problem which has hitherto been but little considered, but which has doubtless depended on ancient revolutions of nature, such as inundations or great volcanic changes. When once a region has lost the covering of plants with which it was invested, if the sands are loose and mobile and are destitute of springs, and if the heated atmosphere, forming constantly ascending currents, prevents precipitation taking place from clouds $\left({ }^{9}\right)$, thou- 
sands of years may elapse ere organic life can pass from the verdant shores to the interior of the sandy sea, and repossess itself of the domain from which it had been banished.

Those, therefore, who can view nature with a comprehensive glance and apart from local phenomena, may see from the poles to the equator organic life and vigour gradually augment with the augmentation of vivifying heat, But, in the course of this progressive increase there are reserved to each zone its own peculiar beauties; to the tropics, variety and grandeur of vegetable forms; to the north, the aspect of its meadows and green pastures, and the periodic reawakening of nature at the first breath of the mild air of spring. Each zone, besides its own peculiar advantages, has its own distinctive character. Primeval laws of organisation, notwithstanding a certain degree of freedom in the abnormal development of single parts, bind all animal and vegetable forms to fixed ever-recurring types. As we recognise in distinct organic beings a determinate physiognomy, and as descriptive botany and zoology, in the restricted sense of the terms, consist in a detailed analysis of animal and vegetable forms, so each region of the earth has a natural physiognomy peculiar to itself. The idea indicated by the painter by expressions such as "Swiss nature," "Italian sky," \&c., rests on a partial perception of this local character in the aspect of nature. The azure of the sky, the lights and shadows, the haze resting on the distance, the forms of animals, the succulency of the plants and herbage, the brightness of the foliage, the outline 
of the mountains, are all elements which determine the total impression characteristic of each district or region. It is true that in every zone the same kinds of rocks, trachyte, basalt, porphyritic schists, and dolomite, form groups having the same physiognomy and aspect. The greenstone precipices of South America and Mexico resemble those of the Fichtel-Gebirge of Germany, just as among animals the form of the Allco, or native race of dogs of the New Continent, corresponds perfectly with that of the European race. For the inorganic crust of the globe shews itself independent of climatic influences; whether it be that differences of climate depending on differences of latitude were more recent than the formation of the rocks, or that the mass of the earth in solidifying and parting with its heat regulated its own temperature, $\left({ }^{10}\right)$ instead of receiving it from without. Thus all the kinds of rock with which we are acquainted may be met with in all parts of the globe, and everywhere affect the same characteristic forms. Everywhere basalt rises in twin mountains and truncated cones; everywhere the porphyritic trap appears in grotesquely arranged masses, and granite in rounded summits. Also similar forms of trees-pines and oaks-adorn the declivities of the mountains of Sweden, and those of the most southern part of Mexico. (11) Yet, notwithstanding these correspondences of form, and this similarity of outline in the component parts of the picture, their grouping gives to the whole the greatest difference of character.

Mineralogy is not more distinct from geology than is the individual description of natural objects from a general 
description of the physiognomy of nature. George Forster, in the narrative of his voyages, and in his other publications, -Goethe, in the descriptions of nature which so many of his immortal works contain,-Buffon, Bernardin de St. Pierre, and Chateaubriand, have traced with inimitable truth of description the character of some of the zones into which the earth is divided. Not only do such descriptions afford us mental enjoyment of a high order, but the knowledge of the character which nature assumes in different regions is moreover intimately connected with the history of man, and of his civilisation. For although the commencement of this civilisation is not solely determined by physical relations, yet the direction which it takes, the national character, and the more grave or gay dispositions of men, are dependent in a very high degree on climatic influences. How powerfully have the skies of Greece acted on its inhabitants! The nations settled in the fair and happy regions bounded by the Euphrates, the Halys, and the Egean Sea, also early attained amenity of manners and delicacy of sentiment. When in the middle ages religious enthusiasm suddenly re-opened the saered East to the nations of Europe who were sinking back into barbarism, our ancestors in returning to their homes brought with them gentler manners, acquired in those delightful valleys. The poetry of the Greeks, and the ruder songs of the primitive northern nations, owe great part of their peculiar character to the aspect of the plants and animals seen by the bard, to the mountains and valleys which surrounded him, and to the air which he breathed. And to recall more familiar objects, who does not 
feel himself differently affected in the dark shade of the beech, on hills crowned with scattered fir-trees, or on the turfy pasture, where the wind rustles in the trembling foliage of the birch? These trees of our native land have often suggested or recalled to our minds images and thoughts, either of a melancholy, of a grave and elevating, or of a cheerful character. The influence of the physical on the moral world, - that reciprocal and mysterious action and reaction of the material and the immaterial,-gives to the study of nature, when regarded from higher points of view, a peculiar charm, still too little recognised.

But if the characteristic aspect of different portions of the earth's surface depends conjointly on all external phenomena, - if the contours of the mountains, the physiognomy. of plants and animals, the azure of the sky, the form of the clouds, and the transparency of the atmosphere, all combine in forming that general impression which is the result of the whole, yet it cannot be denied that the vegetable covering with which the whole earth is adorned is the principal element in the impression. Animal forms are deficient in mass, and the individual power of motion which animals possess, as well as often the smallness of their size, withdraw them from our sight. The vegetable forms, on the contrary, produce a greater effect by their magnitude and by their constant presence. The age of trees is marked by their size, and the union of age with the manifestation of constantly renewed vigour is a charm peculiar to the vegetable kingdom. The gigantic Dragon-tree of Orotava, (12) (as sacred in the eyes of the inhabitants of the Canaries as 
the olive-tree in the Citadel of Athens, or the Elm of Ephesus), the diameter of which I found, when I visited those Islands, to be more than 16 feet, had the same colossal size, when the French adventurers, the Béthencourts, conquered these gardens of the Hesperides in the beginning of the fifteenth century; yet it still flourishes, as if in perpetual youth, bearing flowers and fruit. A tropical forest of $\mathrm{Hy}$ menæas and Cæsalpinieæ may perhaps present to us a monument of more than a thousand years' standing.

If we embrace in one general view the different species of phænogamous plants at present contained in herbariums, the number of which may now be estimated at considerably above 80000 , (13) we shall recognise in this prodigious multitude certain leading forms to which many others may be referred. In determining these leading forms or types, on the individual beauty, the distribution, and the grouping of which the physiognomy of the vegetation of a country depends, we must not follow the march of systems of botany, in which from other motives the parts chiefly regarded are the smaller organs of propagation, the flowers and the fruit; we must, on the contrary, consider solely that which by.its mass stamps a peculiar character on the total impression produced, or on the aspect of the country. Among the leading forms of vegetation to which $I$ allude, there are, indeed, some which coincide with families belonging to the "natural systems" of botanists. Such are the forms of Bananas, Palms, Casuarineæ, and Coniferæ. But the botanic systematist divides many groups which the physiognomist is obliged to unite. When plants or trees present themVOL. II. 
selves in masses, the outlines and distribution of the leaves and the form of the stems and of the branches are blended together. The painter (and here the artist's delicate tact and appreciation of nature are demanded) can distinguish in the middle distance and background of a landscape groves of palms or pines from beech woods, but he cannot distinguish the latter from woods consisting of other deciduous forest trees.

Above sixteen different forms of vegetation are principally concerned in determining the aspect or physiognomy of Nature. I mention only those which I have observed in the course of my travels both in the New and Old Continents, where during many years I have attentively examined the vegetation of the regions comprised between the 60th degree of North and the 12th degree of South latitude. The number of these forms will no doubt be considerably augmented when travellers shall have penetrated farther into the interior of Continents, and discovered new genera of plants. In the South-eastern part of Asia, the interior of Africa and of New Holland, and in South America from the river of the Amazons to the province of Chiquitos, the vegetation is still entirely unknown to us. How if at some future time a country should be discovered in which ligneous fungi, Cenomyce rangiferina, or mosses, should form tall trees? The Neckera dendroides, a German species of moss, is in fact arborescent; and bamboos (which are arborescent grasses) and the tree ferns of the tropics, which are often higher than our lime-trees and alders, now present to the European a sight as surprising as would be that 
of a forest of tree mosses to its discoverer. The absolute size and the degree of development attained by organic forms of the same family (whether plants or animals), depend on laws which are still unknown to us. In each of the great divisions of the animal kingdom, insects, crustacea, reptiles, birds, fishes, or mammalia, the size of the body oscillates between certain extreme limits. But these limits, which have been established by observation as far as it has yet gone, may be corrected by the discovery of species with which we are still unacquainted.

In land animals the higher temperatures of the low latitudes appear to have favoured organic development. The small and slender form of our lizards is exchanged in the south for the gigantic, heary, and cuirassed bodies of crocodiles. In the formidable tiger, lion, and jaguar, we see repeated, on a larger scale, the form of the common cat, one of the smallest of our domestic animals. If we penetrate into the interior of the earth, and search the cemeteries in which the plants and animals of the ancient world lie entombed, the fossil remains which we discover not only announce a distribution inconsistent with our present climates, -they also disclose to us gigantic forms that contrast no less with those which now surround us, than does the simple heroism of the Greeks with the character of human greatness in modern times. Has the temperature of our planet undergome considerable changes,-possibly of periodical recurrence? If the proportion between land and sea, and eren the height of the aerial ocean and its pressure, (14) have not always been the same, the physiog- 
nomy of nature, and the dimensions and forms of organised beings, must also have been subjected to various alterations. Huge Pachydermata, Mastodons, Owen's Mylodon robustus, and the Colossochelys, a land-tortoise above six feet high, have existed, and in the vegetable kingdom there have been forests composed of gigantic Lepidodendra, cactus-like Stigmarias, and numerous kinds of Cycadeæ. Unable to depict fully according to its present features the physiognomy of our planet in this its later age, I will only venture to attempt to indicate the characters which principally distinguish those vegetable groups which appear to me to be most strongly marked by physiognomic differences. However favoured by the richness and flexibility of our native language, it is still an arduous and hazardous undertaking when we attempt to trace in words that which belongs rather to the imitative art of the painter. I feel also the necessity of avoiding as much as possible the wearisome impression almost inseparable from all lengthened enumerations.

We will begin with palms, ( ${ }^{15}$ ) the loftiest and noblest of all vegetable forms, that to which the prize of beauty has been assigned by the concurrent voice of nations in all ages; for the earliest civilisation of mankind belonged to countries bordering on the region of palms, and to parts of Asia where they abound. Their lofty, slender, ringed, and, in some cases, prickly stems, terminate in aspiring and shining either fanlike or pinnated foliage. The leaves are frequently curled, like those of some gramineæ. Smooth polished stems of palms carefully measured by me had attained 192 English feet in height. In receding from 
the equator and approaching the temperate zone, palms diminish in height and beauty. The indigenous regetation of Europe only comprises a single representative of this form of plants, the sea-coast Dwarf-palm or Chamærops, which, in Spain and Italy, extends as far north as the 44 th parallel of latitude. The true climate of palms has a mean annual temperature of $20^{\circ} .5-22^{\circ}$ Reaumur $\left(78^{\circ} .2-81^{\circ} .5 \mathrm{Fahr}\right)$. The Date, which is much inferior in beauty to several other genera, has been brought from Africa to the south of Europe, where it lives, but can scarcely be said to flourish, in a mean temperature not exceeding $12^{\circ}-13^{\circ} .5$ Reaumur $\left(59^{\circ}-62^{\circ} .4\right.$ Fahr $)$. Stems of palms and fossil bones of elephants are found buried beneath the surface of the earth in northern countries, in positions which make it appear probable that their presence is not to be accounted for by their having been drifted thither from the tropics, and we are led to infer that in the course of the great revolutions which our planet has undergone, great changes of climate, and of the physiognomy of nature as dependent on climate, have taken place.

In all parts of the globe the palm form is accompanied by that of Plantains or Bananas; the Scitamineæ and Musaceæ of botanists, Heliconia, Amomum, and Strelitzia. In this form, the stems, which are low, succulent, and almost herbaceous, are surmounted by long, silky, delicately-veined leaves of a thin loose texture, and bright and beautiful verdure. Groves of plantains and bananas form the ornament of moist places 
in the equatorial regions. It is on their fruits that the subsistence of a large part of the inhabitants of the torrid zone chiefly depends, and, like the farinaceous cereals of the north, they have followed man from the infancy of his civilisation (16). The aboriginal site of this nutritious plant is placed by some Asiatic fables or traditions on the banks of the Euphrates, and by others, with more probability, at the foot of the Himalaya. Grecian fables named the fields of Enna as the happy native land of the cereals; and if in northern climes, where corn is cultivated in immense unbroken fields, their monotonous aspect adds but little to the beauty of the landscape, the inhabitant of the tropics, on the other hand, in rearing groves of plantains wherever he fixes his habitation, contributes to the adornment of the earth's surface by the extension of one of the most noble and beautiful forms of the vegetable world.

The form of Malvaceæ (17) and Bombaceæ, represented by Ceiba, Cavanillesia, and the Mexican hand-tree Cheirostemon, has enormously thick trunks; large, soft, woolly leaves, either heart-shaped or indented; and superb flowers frequently of a purple or crimson hue. It is to this group of plants that the Baobab, or monkey bread-tree, (Adansonia digitata), belongs, which, with a very moderate elevation, has a diameter of 32 English feet, and is probably the largest and most ancient organic monument on our planet. In Italy the Malvacea already begin to impart to the vegetation a peculiar southern character.

The delicately pinnated foliage of the Mimosa form ( ${ }^{18}$ ), of which Acacia, Desmanthus, Gleditschia, Porleria, and 
Tamarindus are important members, is entirely wanting in our temperate zone in the old continent, though found in the United States, where, in corresponding latitudes, vegetation is more varied and more vigorous than in Europe. The umbrella-like arrangement of the branches, resembling that seen in the stone pine of Italy, is very frequent among the Mimosas. The deep blue of the tropic sky seen through their finely divided foliage has an extremely picturesque effect.

The Heath form (19) belongs more especially to the old world, and particularly to the African continent and islands: taking for our guides physiognomic character and general aspect, we may class under it the Epacrideæ and Diosmex, many Proteacex, and those Australian Acacias which have mere leaf-stalks instead of leaves (phyllodias). This form has some points of similarity with that of needle trees, and the partial resemblance enhances the effect of the pleasing contrast which, when these two are placed together, is afforded by the abundant bell-shaped blossoms of the heaths. Arborescent heaths, like some other African plants, extend to the northern shores of the Mediterranean : they adorn Italy, and the cistus-covered grounds of the south of Spain. The declivity of the Peak of Teneriffe is the locality where I have seen them growing with the greatest luxuriance. In the countries adjoining the Baltic, and farther to the north, the aspect of this form of plants is unwelcome, as announcing sterility. Our heaths, Erica (Calluna) vulgaris, Erica tetralix, E. carnea, and E. cinerea, are social plants, and for centuries agricultural nations have combated their 
advance with little success. It is remarkable that the extensive genus which is the leading representative of this form appears to be almost limited to one side of our planet. Of the 300 known species of Erica only one has been discovered across the whole extent of the New Continent, from Pensylvania and Labrador to Nootka and Alashka.

The Cactus form, $\left({ }^{20}\right)$ on the other hand, is almost exclusively American. Sometimes spherical, sometimes articulated or jointed, and sometimes assuming the shape of tall upright polygonal columns resembling the pipes of an organ, this group presents the most striking contrast to those of Liliaceæ and Bananas. It comprises some of the plants to which Bernardin de St. Pierre has applied the term of "vegetable fountains in the desert." In the waterless plains of South America the animals suffering from thirst seek the meloncactus, a spherical plant half buried in the dry sand, and encased in formidable prickles, but of which the interior abounds in refreshing juice. The stems of the columnar cactus rise to a height of 30 or 32 feet; they are often covered with lichens, and, dividing into candelabra-like branches, resemble, in physiognomy, some of the Euphorbias of Africa.

While the above-mentioned plants flourish in deserts almost devoid of other vegetation, the Orchideæ ${ }^{21}$ ) enliven the clefts of the wildest rocks, and the trunks of tropical trees blackened by excess of heat. This form (to which the Vanilla belongs) is distinguished by its bright green succulent leaves, and by its flowers of many colours and strange and curious shape, sometimes resembling that of 
winged insects, and sometimes that of the birds which are attracted by the perfume of the honey vessels. Such is their number and variety that, to mention only a limited district, the entire life of a painter would be too short for the delineation of all the magnificent Orchideæ which adorn the recesses of the deep valleys of the Andes of Peru.

The Casuarina form $\left({ }^{22}\right)$, leafless, like almost all species of Cactus, consists of trees with branches resembling the stalks of our Equisetums. It is found only in the islands of the Pacific and in India, but traces of the same singular rather than beautiful type are seen in other parts of the world. Plumier's Equisetum altissimum, Forskül's Ephedra aphylla from the north of Africa, the Peruvian Colletias, and the Siberian Calligonum pallasia, are nearly allied to the Casuarina form.

As the Banana form shews the greatest expansion, so the greatest contraction of the leaf-ressels is shewn in Casuarinas, and in the form of Needle trees ( ${ }^{23}$ ) (Coniferæ). Pines, Thuias, and Cypresses, belong to this form, which prevails in northern regions, and is comparatively rare within the tropics: in Dammara and Salisburia the leaves, though they may still be termed needle-shaped, are broader. In the colder latitudes the never-failing verdure of this form of trees cheers the desolate winter landsciape, and tells to the inhabitants of those regions that when snow and ice cover the ground the inward life of plants, like the Promethean fire, is never extinct upon our planet.

Like mosses and lichens in our latitudes, and like orchidex in the tropical zone, plants of the Pothos form (24) clothe 
parasitically the trunks of aged and decaying forest trees: succulent herbaceous stalks support large leaves, sometimes sagittate, sometimes either digitate or elongate, but always with thick veins. The flowers of the Aroider are cased in hooded spathes or sheaths, and in some of them when they expand a sensible increase of vital heat is perceived. Stemless, they put forth aerial roots. Pothos, Dracontium, Caladium, and Arum, all belong to this form, which prevails chiefly in the tropical world. On the Spanish and Italian shores of the Mediterranean, Arums combine with the succulent Tussilago, the Acanthus, and Thistles which are almost arborescent, to indicate the increasing luxuriance of southern vegetation.

Next to the last-mentioned form of which the Pothos and Arum are representatives, I place a form with which, in the hoitest parts of South America, it is frequently associated, - that of the tropical twining rope-plants, or Lianes, (25) which display in those regions, in Paullinias, Banisterias, Bignonias, and Passifloras, the utmost vigour of vegetation. It is represented to us in the temperate latitudes by our twining hops, and by our grape vines. On the banks of the Orinoco the leafless branches of the Bauhinias are often between 40 and 50 feet long: sometimes they hang down perpendicularly from the high top of the Swietenia, and sometimes they are stretched obliquely like the cordage of a ship : the tiger-cats climb up and descerid by them with wonderful agility.

In strong contrast with the extremeflexibility and fresh lightcoloured verdure of the climbing plants, of which we have just 
been speaking, are the rigid self-supporting growth and bluish hue of the form of Aloes, (26) which, instead of pliant stems and branches of enormous length, are either without stems altogether, or have branchless stems. The leaves, which are succulent, thick, and fieshy, and terminate in long points, radiate from a centre and form a closely crowded tuft. The tall-stemmed aloes are not found in close cluster's or thickets like other social or gregarious plants or trees; they stand singly in arid plains, and impart thereby to the tropical regions in which they are found a peculiar, melancholy, and I would almost venture to call it, African character. Taking for our guides resemblance in physiognomy, and influence on the impression produced by the landscape, Te place together under the head of the Aloe form, (from among the Bromeliacex) the Pitcaimias, which in the chain of the Andes grow out of clefts in the rocks; the great Poumetia pyramidata, (the Atschupalla of the elevated plains of New Granada); the American Aloe, (Agave); Bromelia aranas and B. karatas; from among the Euphorbiaceæ the rare species which have thick short candelabra-like divided stems; from the family of Asphodeleæ the African Aloe and the Dragon tree, (Dracæna draco) ; and lastly, from among the Liliaceæ, the tall flowering Yucca.

If the Aloe form is characterised by an almost mournful repose and immobility, the form of Graminex, (27) especially the physiognomy of arborescent grasses, is characterised, on the contrary, by an expression of cheerfulness and of airy grace and tremulous lightness, combined with lofty stature. Both in the East and West Indies groves of Bamboo form 
shaded over-arching walks or avenues. The smooth polished and often lightly-waving and bending stems of these tropical grasses are taller than our alders and oaks. The form of Graminex begins even in Italy, in the Arundo donax, to rise from the ground, and to determine by height as well as mass the natural character and aspect of the country.

The form of Ferns, (28) as well as that of Grasses, becomes ennobled in the hotter parts of the globe. Arborescent ferns, when they reach a height of above 40 feet, have something of a palm-like appearance; but their stems are less slender, shorter, and more rough and scaly than those of palms. Their foliage is more delicate, of a thinner and more translucent texture, and the minutely indented margins of the fronds are finely and sharply cut. Tree ferns belong almost entirely to the tropical zone, but in that zone they seek by preference the more tempered heat of a moderate elevation above the level of the sea, and mountains two or three thousand feet high may be regarded as their principal seat. In South America the arborescent ferns are usually found associated with the tree which has conferred such benefits on mankind by its fever-healing bark. Both indicate by their presence the happy region where reigns a soft perpetual spring.

I will next name the form of Liliaceeous plants, (29) (Amaryllis, Ixia, Gladiolus, Pancratium) with their flag-like leaves and superb blossoms, of which Southern Africa is the principal country; also the Willow form $\left({ }^{30}\right)$, which is indigenous in all parts of the globe, and is represented in the elevated plains of Quito, (not in the shape of the leaves but 
in that of the ramification), by Schinus Molle; Myrtacex ( ${ }^{31}$ ), (Metrosideros, Eucalyptus, Escallonia myrtilloides); Melastomacex ( $\left.{ }^{32}\right)$, and the Laurel form (33).

It would be an enterprise worthy of a great artist to study the aspect and character of all these regetable groups, not merely in hot-houses or in the descriptions of botanists, but in their native grandeur in the tropical zone. How interesting and instructive to the landscape painter ${ }^{(34)}$ would be a work which should present to the eye, first separately and then in combination and contrast, the leading forms which have been here enumerated! How picturesque is the aspect of tree-ferns spreading their delicate fronds above the laurel-oaks of Mexico; or groups of plantains overshadowed by arborescent grasses (Guaduas and Bamboos)! It is the artist's privilege, having studied these groups, to analyse them: and thus in his hands the grand and beautiful form of nature which he would pourtray resolves itself, (if I may venture on the expression) like the written works of men, into a few simple elements.

It is under the burning rays of a tropical sun that vegetation displays its most majestic forms. In the cold north the bark of trees is covered with lichens and mosses, whilst between the tropics the Cymbidium and fragrant Vanilla enliven the trunks of the Anacardias, and of the gigantic fig trees. The fresh verdure of the Pothos leaves, and of the Dracontias, contrasts with the many-coloured flowers of the Orchidex. Climbing Bauhinias, Passifloras, and yellow flowering Banisterias, twine round the trunks of the forest trees. Delicate blossoms spring from the roots of the Theobroma, and from 
the thick and rough bark of the Crescentias and the Gustavia. (35) In the midst of this profusion of flowers and fruits, and in the luxuriant intertwinings of the climbing plants, the naturalist often finds it difficult to discover to which stem the different leaves and flowers really belong. A single tree adorned with Paullinias, Bignonias, and Dendrobium, forms a group of plants which, if disentangled and separated from each other, would cover a considerable space of ground.

In the tropics vegetation is generally of a fresher verdure, more luxuriant and succulent, and adorned with larger and more shining leaves than in our northern climates. The "social" plants, which often impart so uniform and monotonous a character to European countries, are almost entirely absent in the Equatorial regions. Trees almost as lofty as our oaks are adorned with flowers as large and as beautiful as our lilies. On the shady banks of the Rio Magdalena in South America, there grows a climbing Aristolochia bearing flowers four feet in circumference, which the Indian boys draw over their heads in sport, and wear as hats or helmets. $\left({ }^{36}\right)$ In the islands of the Indian Archipelago the flower of the Rafflesia is nearly three feet in diameter, and weighs above fourteen pounds.

The great elevation attained in several tropical countries not only by single mountains but even by extensive districts, enables the inhabitants of the torrid zone-surrounded by palms, bananas, and the other beautiful forms proper to those latitudes-to behold also those vegetable forms which, demanding a cooler temperature, would seem to belong to 
other zones. Elevation above the level of the sea gives this cooler temperature even in the hottest parts of the earth; and Cypresses, Pines, Oaks, Berberries and Alders, (nearly allied to our own) cover the mountainous districts and elevated plains of Southern Mexico and the chain of the Andes at the Equator. Thus it is given to man in those regions to behold without quitting his native land all the forms of vegetation dispersed orer the globe, and all the shining worlds which stud the heavenly vault from pole to pole. (37)

These and many other of the enjoyments which Nature affords are wanting to the nations of the North. Many constellatious, and many vegetable forms, -and of the latter, those which are most beautiful, (palms, tree ferns, plantains, arborescent grasses, and the finely-divided feathery foliage of the Mimosas), - remain for ever unknown to them. Individual plants languishing in our hot-houses can give but a very faint idea of the majestic vegetation of the tropical zone. But the high cultivation of our languages, the glowing fancy of the poet, and the imitative art of the painter, open to us sources whence flow abundant compensations, and from whence our imagination can derive the living image of that more vigorous nature which other climes display. In the frigid North, in the midst of the barren heath, the solitary student can appropriate mentally all that has been discovered in the most distant regions, and can create within himself a world free and imperishable as the spirit by which it is conceived. 



\section{ANNOTATIONS AND ADDITIONS.}

\section{(1) p. 3.- "On the Chimborazo, eight thousand feet higher than Etna."}

Small singing birds, and even butterflies, are found at sea at great distances from the coast, (as I have several times had opportunities of observing in the Pacific), being carried there by the force of the wind when storms come off the land. In the same involuntary manner insects are transported into the upper regions of the atmosphere, 16000 or 19000 feet above the plains. The heated crust of the earth occasions an ascending vertical current of air, by which light bodies are borne upwards. M. Boussingault, an excellent chemist who, as Professor at the newly instituted Mining Academy at Santa Fé de Bogota, visited the Gneiss Mountains of Caraccas, in ascending to the summit of the Silla witnessed, together with his companion Don Mariano de Rivero, a phenomenon affording a remarkable ocular demonstration of the fact of a vertically ascending current. They saw in the middle of the day, about noon, whitish shining bodies rise from the valley of Caraccas to the summit of the Silla, which is 5400 (5755 E.) feet high, and then sink down towards the neighbouring sea coast. These movements continued uninterruptedly for the 
space of an hour, and the objects, which at first were mistaken for a flock of small birds, proved to be small agglomerations of straws or blades of grass. Boussingault sent me some of the straws, which were immediately recognised by Professor Kunth for a species of Vilfa, a genus which, together with Agrostis, is very abundant in the provinces of Caraccas and Cumana: it was the Vilfa tenacissima of our Synopsis Plantarum æquinoctialium Orbis Novi, T. i. p. 205. Saussure found butterflies on Mont Blanc, as did Ramond in the solitudes which surround the summit of the Mont Perdu. When Bonpland, Carlos Montufar, and myself, reached, on the 23d of June, 1802, on the eastern declivity of the Chimborazo, the height of 18096 (19286 E.) feet-a height at which the barometer sank to 13 inches $11 \frac{1}{5}$ lines (14.850 English inches), we saw winged insects fluttering around us. We could see that they were Dipteras, resembling flies, but on a sharp ridge of rock (cuchilla) often only ten inches wide, between steeply descending masses of snow, it was impossible to catch the insects. The height at which we saw them was nearly the same at which the uncovered trachytic rock, piercing through the eternal snows, gave to our view, in Lecidea geographica, the last traces of vegetation. The insects were flying at a height of about 2850 toises (18225 E. feet), or about $2600 \mathrm{E}$. feet higher than Mont Blanc. Somewhat lower down, at about 2600 toises (10626 E. feet), also therefore within the region of perpetual snow, Bonpland had seen yellow butterflies flying very near the ground. According to our present knowledge the Mam- 
malia which live nearest to the region of perpetual snow are in the Swiss Alps, the Marmot which sleeps through the winter, and a very small field-mouse (Hypudæus nivalis), described by Martins, which on the Faulhorn lays up a store of the roots of phænogamous alpine plants almost under the snow. (Actes de la Société Helvétique, 184:3, p. 324.) The beautiful Chinchilla, of which the bright and silky fur is so much prized, is often supposed by Europeans to be an inhabitant of the high mountain regions of Chili: this, however, is an error; the Chinchilla laniger (Gray) only lives in the mild temperature of the lower zone, and is not found farther south than the parallel of $35^{\circ}$. (Claudio Gay, Historia fisica y politica de Chile, Zoologia, 1844, p. 91.)

While on our European Alps, Lecideas, Parmelias, and Umbilicarias form only a fer coloured patches on the rocks which are not completely covered with snow, in the Andes, beautiful flowering phænogamous plants, first described by us, live at elevations of thirteen to fourteen thousand feet (13700 to nearly 15000 E.) We found there woolly species of Culcitium and Espeletia (C. nivale, C. rufescens, and C. reflexum, E. grandiflora, and E. argentea), Sida pichinchensis, Ranunculus nubigenus, R. Gusmanni with red or orange-colouredblossoms, the small moss-like umbelliferous plant Myrrbis andicola, and Fragosa arctioides. On the declivity of the Chimborazo the Saxifraga boussingaulti, described by Adolph Brongniart, grows bejond the limit of perpetual snow on loose boulders of rock, at 14796 (15770 E.) feet above the level of the sea, not at 17000, as stated 
in two estimable English journals. (Compare my Asie Centrale, T. iii. p. 262, with Hooker, Journal of Botany, vol. i. 1834, p. 327, and Edinburgh New Philosophical Journal, vol. xvii. 1834, p. 380.) The Saxifrage discovered by Boussingault is certainly, up to the present time, the highest known phænogamous plant on the surface of the earth.

The perpendicular height of the Chimborazo is, according to my trigonometrical measurement, 3350 toises (21422 E. feet.) (Recueil d'Observ. Astron., vol. i., Introd. p. Ixxii.) This result is intermediate between those given by French and Spanish academicians. The differences depend not on different assumptions for refraction, but on differences in the reduction of the measured base lines to the level of the sea. In the Andes this reduction could only be made by the barometer, and thus every measurement called a trigonometric measurement is also a barometric one, of which the result differs according to the first term in the formula employed. If in chains of mountains of great mass, such as the Andes, we insist on determining the greater part of the whole altitude trigonometrically, measuring from a low and distant point in the plain or nearly at the level of the sea, we can only obtain very small angles of altitude. On the other hand, not only is it difficult to find a convenient base among mountains, but also every step increases the portion of the height which must be determined barometrically. These difficulties have to be encountered by every traveller who selects, among the elevated plains which surround the Andes, the station at which he may execute his geodesical measurements. My measure- 
ment of the Chimborazo was made from the plain of Tapia, which is covered with pumice. It is situated to the west of the Rio Chambo, and its elevation, as determined by the barometer, is 1482 toises (9497 E. feet.) The Llanos de Luisa, and still more the plain of Sisgun, which is 1900 toises (12150 E. feet) high, would have given greater angles of altitude; I had prepared everything for making the measurement at the latter station when thick clouds concealed the summit of Chimborazo.

Those who are engaged in investigations on languages may not be unwilling to find here some conjectures respecting the etymology of the widely celebrated name of Chimborazo. Chimbo is the name of the Corregimiento or District in which the mountain of Chimborazo is situated. La Condamine (Voyage à l'Equateur, 1751, p. 184) deduces Chimbo from "chimpani," "to pass over a river." Chimbo-raço signifies, according to him, "la neige de l'autre bord," because at the village of Chimbo one crosses a stream in full view of the enormous snow-clad mountain. (In the Quichua language "chimpa" signifies the "other, or farther, side;" and chimpani signifies to pass or cross over a river, a bridge, \&c.) Several natives of the province of Quito have assured me that Chimborazo signifies merely "the snow of Chimbo." We find the same termination in Carguai-razo. But razo appears to be a provincial word. The Jesuit Holguin, (whose excellent "Vocabulario de la Lengua general de todo el Peru llamada Lengua Qquichua o del Inca," printed at Lima in 1608, is in my possession,) knows nothing of the word "razo." The genuine word 
for snow is "ritti." On the other hand, my learned friend Professor Buschmann remarks that in the Chinchaysuyo dialect (spoken north of Cuzco up to Quito and Pasto, raju (the $j$ apparently guttural) signifies snow; see the word in Juan de Figueredo's notice of Chinchaysuyo words appended to Diego de Torres Rubio, Arte, y Vocabulario de la Lengua Quichua, reimpr. en Lima, 1754; fol. 222, b. For the two first syllables of the name of the mountain, and for the village of Chimbo, (as chimpa and chimpani suit badly on account of the $a$ ), we may find a definite signification by means of the Quichua word: chimpu, an expression used for a coloured thread or fringe (señal de lana, hilo ó borlilla de colores), - for the red of the sky (arreboles), - and for a halo round the sun or moon. One may try to derive the name of the mountain directly from this word, without the intervention of the village or district. In any case, and whatever the etymology of Chimborazo may be, it must be written in Peruvian Chimporazo, as we know that the Peruvians have no $b$.

But what if the name of this giant mountain should have nothing in common with the language of the Incas, but should have descended from a more remote antiquity? According to the generally received tradition, it was not long before the arrival of the Spaniards that the Inca or Quichua language was introduced into the kingdom of Quito, where the Puruay language, which has now entirely perished, had previously prevailed. Other names of mountains, Pichincha, Tlinissa, and Cotopaxi, have no signification at all in the language of the Incas, and are therefore certainly older. 
than the introduction of the worship of the sun and the court language of the rulers of Cuzco. In all parts of the world the names of mountains and rivers are among the most ancient and most certain monuments or memorials of languages; and my brother Wilhelm von Humboldt has employed these names with great sagacity in his researches on the former diffusion of Iberian nations. A singular and unexpected statement has been put forward in recent years (Velasco Historia de Quito, T. i. p. 185) to the effect that "the Incas Tupac Yupanqui and Huarna Capac were astonished to find at their first conquest of Quito a dialect of the Quichua language already in use among the natives." Prescott, however, appears to regard this statement as doubtful. (Hist. of the Conquest of Peru, Vol. i. p. 115.)

If the Pass of St. Gothard, Mount Athos, or the Rigi, were placed on the summit of the Chimborazo, it would form an elevation equal to that now ascribed to the Dhawalagiri in the Himalaya. The geologist who rises to more general views connected with the interior of the earth, regards, not indeed the direction, but the relative height of the rocky ridges which we term mountain chains, as a phenomenon of so little import, that he would not be astonished if there should one day be discovered between the Himalaya and the Altai, summits which should surpass the Dhawaligiri and the Djawahir as much as these surpass the Chimborazo. (See my Vues des Cordillères et Monumens des peuples indigènes de l'Amérique, T. i. p. 116; and my Notice on two attempts to ascend the Chimborazo, in 1802 and 1831, in Schumacher's Jahrbuch 
for 1847, S. 176.) The great height to which the snow line on the northern side of the Himalaya is raised in summer, by the influence of the heat returned by radiation from the high plains of the interior of Asia, renders those mountains, although situated in 29 to $30 \frac{1}{2}$ degrees of latitude, as accessible as the Peruvian Andes within the tropics. Captain Gerard has attained on the Tarhigang an elevation as great, and perhaps (as is maintained in the Critical Researches on Philosophy and Geography) 117 English feet greater than that reached by me on the Chimborazo. Unfortunately, as I have shewn more at large in another place, these mountain journies beyond the limits of perpetual snow (however they may engage the curiosity of the public) are of only very inconsiderable scientific use.

(2) p. 4.- "The Condor, the giant of the Vulture tribe."

In my Recueil d'Observations de Zoologie et d'Anatomie comparée, vol. i. pp. 26-45, I have given the natural history of the Condor, which, before my journey to the equatorial regions, had been much misrepresented. (The name of the bird is properly Cuntur in the Inca language; in Chili, in the Araucan, Manque; Sarcoramphus Condor of Duméril.) I made and had engraved a drawing of the head from the living bird, and of the size of nature. Next to the Condor, the Lämmergeier of Switzerland, and the Falco destructor of Daudin, probably the Falco Harpyia of Linnæus, are the largest flying birds.

The region which may be regarded as the ordinary haunt of the Condor begins at the height of Etna, and comprises 
atmospheric strata from ten to eighteen thousand (about 10600 to 19000 English) feet above the level of the sea. Humming birds, which make summer excursions as far as $61^{\circ} \mathrm{N}$. latitude on the north-west coast of America on the one hand, and the Tierra del Fuego on the other, have been seen by Von Tschudi (Fauna Peruana, Ornithol. p. 12) in Puna as high as 13700 (14600 English) feet. There is a pleasure in comparing the largest and the smallest of the feathered inhabitants of the air. Of the Condors, the largest individuals found in the chain of the Andes round Quito measured, with extended wings, 14 (nearly 15 English) feet, and the smallest 8 ( $8 \frac{1}{2}$ English) feet. From these dimensions, and from the visual angle at which the hird often appeared vertically above our heads, we are enabled to infer the enormous height to which the Condor soars when the sky is serene. A visual angle of $4^{\prime}$, for example, gives a perpendicular height above the eje of 6876 (73.30 English) feet. The cave (Machay) of Antisana, which is opposite the mountain of Chussulongo, and from whence we measured the height of the soaring bird, is 14958 (15942 English) feet above the surface of the Pacific. This would give the absolute height attained by the Condor at fully 21894 (23270 English) feet; an elevation at which the barometer would hardly reach 12 French inches, but which yet does not surpass the highest summits of the Himalaya. It is a remarkable physiological phenomenon, that the same bird, which can fly round in circles for hours in regions of an atmosphere so rarified, should sometimes suddenly descend, as on the western declivity of the Volcano of Pichincha, to 
the sea-shore, thus passing rapidly through all gradations of climate. The membranous air-bags of the Condor, if filled in the lower regions of the atmosphere, must undergo extraordinary distension at altitudes of more than 23000 English feet. Ulloa, more than a century ago, expressed his astonishment that the vulture of the Andes could soar in regions where the atmospheric pressure is less than 14 French inches, (Voyage de l'Amérique meridionale, T. ii. p. 2, 1752; Observations astronomiques et physiques, p. 110). It was then believed, in analogy with experiments under the airpump, that no animal could live in so low a pressure. I have myself, as I have already noticed, seen the barometer sink on the Chimborazo to 13 French inches 11.2 lines (14.850 English inches). Man, indeed, at such elevations, if wearied by muscular exertion, finds himself in a state of very painful exhaustion; but the Condor seems to perform. the functions of respiration with equal facility under presw sures of 30 and 13 English inches. It is apparently of all living creatures on our planet the one which can remove at pleasure to the greatest distance from the surface of the earth; I say at pleasure, for minute insects and siliceousshelled infusoria are carried by the ascending current to possibly still greater elevations. The Condor probably flies higher than the altitude found as above by computation. I remember on the Cotopaxi, in the pumice plain of Suniguaicu, 13578 (14470 English) feet above the sea, to have seen the bird soaring at a height at which he appeared only as a small black speck. What is the smallest angle under which feebly illuminated objects can be discerned? Their form, (linear 
extension) has a great influence on the minimum of this angle. The transparency of the mountain atmosphere at the equator is such that, in the province of Quito, as I have elsewhere noticed, the white mantle or Poncho of a horseman was distinguished with the naked eye at a horizontal distance of 84132 (89665 English) feet; therefore under a visual angle of 13 seconds. It was my friend Bonpland, whom, from the pleasant country seat of the Marques de Selvalegre, we saw moving along the face of a black precipice on the Volcano of Pichincha. Lightning conductors, being long thin objects, are seen, as has already been remarked by Arago, from the greatest distances, and under the smallest angles.

The accounts of the habits of the Condor in the mountainous districts of Quito and Peru, given by me in a monograph on this powerful bird, have been confirmed by a later traveller, Gay, who has explored the whole of Chili, and has described that country in an excellent work entitled Historia fisica y politica de Chile. The Condor, which, like the Lamas, Vicunas, Alpacas, and Guanacos, does not extend beyond the equator into New Granada, is found as far south as the Straits of Magellan. In Chili, as in the mountain plains of Quito, the Condors, which at other times live either solitarily or in pairs, assemble in flocks to attack lambs and calves, or to carry off young Guanacos (Guanacillos). The ravages annually committed among the herds of sheep, goats, and cattle, as well as among the wild Vicunas, Alpacas, and Guanacos of the Andes, are very considerable. The inhabitants of Chili assert that, in cap- 
tivity, the Condor can support forty days' hunger; when free, his voracity is excessive, and, vulture-like, is directed by preference to dead flesh.

The mode of capture of Condors in Peru by means of palisades, as described by me, is practised with equal success in Chili. When the bird has gorged himself with flesh, he cannot rise into the air without first running for some little distance with his wings half expanded. A dead ox, in which decomposition is beginning to take place, is strongly fenced round, leaving within the fence only a small space, in which the Condors attracted by the prey are crowded together. When they have gorged themselves with food, the palisades not permitting them to obtain a start by running, they become, as remarked above, unable to rise, and are either killed with clubs by the country people, or taken alive by the lasso. On the first declaration of the political independence of Chili, the Condor appeared on the coinage as the symbol of strength. (Claudio Gay, Historia fisica y politica de Chile, publicada bajo los auspicios del Supremo Gobierno; Zoologia, pp. 194-198.)

Far more useful than the Condor in the great economy of Nature, in the removal of putrefying animal substances and in thus purifying the air in the neighbourhood of human habitations, are the different species of Gallinazos, of which the number of individuals is much greater. In tropical America I have sometimes seen as many as 70 or 80 assembled at once round a dead animal; and I am able, as an eye-witness, to confirm the fact long since stated, but which has recently been doubted by ornithologists, of the whole 
assembly of these birds in such cases taking flight on the appearance of a single king-vulture, who yet is no larger than the Gallinazos. No combat ever takes place; but the Gallinazos (the tro species of which, Cathartes urubu and C. aura, have been confounded with each other by an unfortunately fluctuating nomenclature) appear to be terrified by the sudden appearance and courageous demeanour of the richly coloured Sarcoramphus papa. As the ancient Egyptians protected the bird which rendered them similar services towards the purification of their atmosphere, so in Peru the careless or wanton killing of the Gallinazos is punished with a fine, which in some torns amounts, according to Gay, to 300 piastres for each bird. It is a remarkable circumstance, stated so long ago as by Don Felix de Azara, that these species of vultures, if taken young and reared, will so accustom themselves to the person who feeds them, that they will follow him on a joumey for many miles, flying after the waggon in which he travels orer the Pampas.

\section{(3) p. 4.-"Their rotating bodies."}

Fontana, in his excellent work "Über das Viperngift," Bd. i. S. 62, relates that he succeeded, in the course of two hours, by means of a drop of water, in bringing to life a rotifera which had lain for two years and a half dried up and motionless. On the action and effect of water, see my "Versuche über die gereizte Muskel-und Nervenfaser," Bd. ii. S. 250 .

What has been called the revivification of Rotiferæ, since observations have been more exact and have had to undergo 
stricter criticism, has been the subject of much animated discussion. Baker affirmed that he had resuscitated, in 1771, paste-eels which Needham had given him in 1744 ! Franz Bauer saw his Vibrio tritici, which had been dried up for four years, move again on being moistened. An extremely careful and experienced observer, Doyère, in his Mémoire sur les Tardigrades, et sur leur propriété de revenir à la vie (1842), draws from his own fine experiments the following conclusions:-Rotiferæ come to life, $i$. e. pass from a motionless state to a state of motion, after having been exposed to temperatures of $19^{\circ} .2$ Reaumur below, and $36^{\circ}$ Reaumur above, the freezing point; $i$. e. from $11^{\circ} .2$ to $113^{\circ} .0$ Fah. They preserve the capability of apparent revivification, in dry sand, up to $56^{\circ} .4 \mathrm{R}$. (158 .9 Fah.); but they lose it, and cannot be excited afresh, if heated in moist sand to $44^{\circ}$ only ( $131^{\circ} .0$ Fah.) Doyère, $p, 119$. The possibility of revivification or reanimation is not prevented by their being placed for twenty-eight days in barometer tubes in vacuo, or even by the application of chloride of lime or sulphuric acid (pp. 130-133). Doyère has also seen the rotiferæ come to life again very slowly after being dried without sand (desséchés à nu), which Spallanzani had denied (pp. 117 and 129). "Toute dessiccation faite à la température ordinaire pourroit souffrir des objections auxquelles l'emploi du vide sec n'eût peut-être pas complètement repondu: mais en voyant les Tardigrades périr irrévocablement à une température de $44^{\circ}$, si leurs tissus sont pénétrés d'eau, tandis que desséchés ils supportent sans périr une chaleur qu'on peut évaluer à $96^{\circ}$ 
Reaumur, on doit être disposé à admettre que la revivification n'a dans l'animal d'autre condition que l'intégrité de composition et de connexions organiques." In the same way, in the regetable kingdom, the sporules of cryptogamia, which Kunth compares to the propagation of certain phænogamous plants by buds (bulbillæ), retain their germinating power in the highest temperatures. According to the most recent experiments of Payen, the sporules of a minute fungus (Oidium aurantiacum), which covers the crumb of bread with a reddish feathery coating, do not lose their power of germination by being exposed for half an hour in closed tubes to a temperature of from $67^{\circ}$ to $78^{\circ}$ Reaumur (182 .75 to $207^{\circ} .5 \mathrm{Fah}$.), before being strewed on fresh perfectly unspoilt dough. May not the newly discovered monad (Monas prodigiosa), which causes blood-like spots on mealy substances, have been mingled with this fungus?

Ehrenberg, in his great work on Infusoria (S. 492-496), has given the most complete history of all the investigations which have taken place on what is called the revivification of rotiferæ. He believes that, in spite of all the means of desiccation employed, the organization-fluid still remains in the apparently dead animal. He contests the hypothesis of "latent life ;" death, he says, is not "life latent, but the want of life."

We have evidence of the diminution, if not of the entire disappearance or suspension of organic functions, in the hybernation or winter sleep both of warm and cold-blooded animals, in the dormice, marmots, sand martins (Hirundo riparia) according to Cuvier (Règne animal, 1829, T. i. p. 
396), frogs and toads. Frogs, awakened from winter-sleep by warmth, can support an eight tirnes' longer stay under water without being drowned, than frogs in the breeding season. It would seem as if the functions of the lungs in respiration, for some time after their excitability had been suspended, required a less degree of activity. The circumstance of the sand-martin sometimes burying itself in a morass is a phenomenon which, while it seems not to admit of doubt, is the more surprising, as in birds respiration is so extremely energetic, that, according to Lavoisier's experiments, two small sparrows, in their ordinary state, decomposed, in the same space of time, as much atmospheric air as a porpoise. (Lavoisier, Mémoires de Chimie, T. i. p, 119.) The winter-sleep of the swallow in question (the Hirundo riparia) is not supposed to belong to the entire species, but only to have been observed in some individuals. (Milne Edwards, Elémens de Zoologie, 1834, p. 54.3.)

As in the cold zone the deprivation of heat causes some animals to fall into winter-sleep, so the hot tropical countries afford an analogous phænomenon, which has not been sufficiently attended to, and to which I have applied the name of summer-sieep. (Relation historique, T. ii. pp. 192 and 626.) Drought and continuous high temperatures act like the cold of winter in diminishing excitability. In Madagascar, (which, with the exception of a very small portion at its southern extremity, is entirely within the tropical zone,) as Bruguière had before observed, the hedgehog-like Tenrecs (Centenes, Illiger), one species of which (C. ecaudatus) 
has been introduced into the Isle of France, sleep during great heat. Desjardins makes, it is true, the objection that the time of their slumber is the winter season of the southern hemisphere; but in a country in which the mean temperature of the coldest month is $3^{\circ}$ Reaumur $\left(6^{\circ} .75\right.$ Fah.) above that of the hottest month in Paris, this circumstance cannot change the three months" "summer-sleep" of the Tenrec in Madagascar and at Port Louis, into what we understand by a winter-sleep, or state of hybernation.

In the hot and dry season, the crocodile in the Llanos of Venezuela, the land and water tortoises of the Orinoco, the huge boa, and several smaller kinds of serpents, become torpid and motionless, and lie incrusted in the indurated soil. The missionary Gili relates that the natives, in seeking for the slumbering Terekai (land tortoises), which they find lying at a depth of sixteen or serenteen inches in dried mud, are sometimes bitten by serpents which become suddenly aroused, and which had buried themselves at the same time as the tortoise. An excellent observer, Dr. Peters, who has just returned from the East Coast of Africa, writes thus to me on the subject:- "During my short stay at Madagascar I could obtain no certain information respecting the Tenrec; but, on the other hand, I know that in the East of Africa, where I lived for several years, different kinds of tortoises (Pentonys and Trionchydias) pass months during the dry season of this tropical country inclosed in the dry hard earth, and without food. The Lepidosiren also, in places where the stramps are dried up, remains coiled up VOL. II. 
and motionless, encased in indurated earth, from May to December."

Thus we find an annual enfeeblement of certain vital functions in many and very different classes of animals, and, what is particularly striking, without the same phenomena being presented by other living creatures nearly allied to them, and belonging to the same family. The northern glutton (Gulo), though allied to the badger (Meles), does not like him sleep during the winter; whereas, according to Cuvier's remark, "a Myoxus (dormouse) of Senegal (Myoxus coupeii), which could never have known wintersleep in his tropical home, being brought to Europe fell asleep the first year on the setting in of winter." This torpidity or enfeeblement of the vital functions and vital activity passes through several gradations, according as it extends to the processes of nutrition, respiration, and muscular motion, or to depression of the activity of the brain and nervous system. The winter-sleep of the solitary bears and of the badger is not accompanied by any rigidity, and hence the reawakening of these animals is so easy, and, as was often related to me in Siberia, so dangerous to the hunters and country people. The first recognition of the gradation and connection of these phenomena leads us up to what has been called the "vita minima" of the microscopic organisms, which, occasionally with green ovaries and undergoing the process of spontaneous division, fall from the clouds in the Atlantic sand-rain. The apparent revivification of rotiferæ, as well as of the siliceous-shelled infusoria, is only the renewal of long-enfeebled vital functions,- 
a state of vitality which was never entirely extinct, and which is fanned into a fresh flame, or excited anew, by the appropriate stimulus. Physiological phenomena can only be comprehended by being traced throughout the entire series of analogous modifications.

\section{(4) p. 5.—" Winged insects."}

Formerly the fertilization of flowers in which the sexes are separated was ascribed principally to the action of the wind: it has been shown by Kölreuter, and with great ingenuity by Sprengel, that bees, wasps, and a host of smaller winged insects, are the chief agents. I say the chief agents, because to assert that no fertilization is possible without the intervention of these little animals appears to me not to be in conformity with nature, as indeed has been shown in detail by Willdenow. (Grundriss der Kräuterkunde, 4te Aufl., Berl. 1805, S. 405-412.) On the other hand, Dichogamy, coloured spots or marks indicating honeyvessels (maculæ indicantes), and fertilization by insects, are, in much the greater number of cases, inseparably associated. (Compare Auguste de St. Hilaire, Leçons de Botanique, 1840, p. 565-571.)

The statement which has been often repeated since Spallanzani, that the diøcious common hemp (Cannabis sativa) yields perfect seeds without the neighbourhood of pollen-bearing vessels, has been refuted by later experiments. When seeds have been obtained, anthers in a rudimentary state, capable of furnishing some grains of fertilizing dust, have been discovered near the ovarium. Such hermaphro- 
ditism is frequent in the entire family of Urticeæ, but a peculiar and still unexplained phenomenon has been presented in the forcing-houses at Kew by a small New Holland shrub, the Coelebogyne of Smith. This phænogamous plant produces in England perfect seeds without trace of male organs, or the hybridising introduction of the pollen of other species. An ingenious botanist, Adrien de Jussieu, in his "Cours Elementaire de Botanique," 1840, p. 463, expresses himself on the subject as follows:-Un genre d'Euphorbiacées (?) assez nouvellement décrit mais cultivé depuis plusieurs années dans les serres d'Angleterre, le Colebogyne, y a plusieurs fois fructifié, et ses graines étaient évidemment parfaites, puisque non seulement on y a observé un embryon bien constitué, mais qu'en le semant cet embryon s'est développé en une plante semblable. Or les fleurs sont dioïques; on ne connait et ne possède pas (en Angleterre) de pieds mâles, et les recherches les plus minutieuses, faites par les meilleurs observateurs, r’ont pu jusqu'ici faire découvrir la moindre trace d'anthères ou seulement de pollen. L'embryon ne venait donc pas de ce pollen, qui manque entièrement: il a dû se former de toute pièce dans l'ovule."

In order to obtain a fresh confirmation or elucidation of this highly important and isolated phenomenon, I addressed myself not long since to my young friend Dr. Joseph Hooker, who, after making the Antarctic voyage with Sir James Ross, has now joined the great Thibeto-Himalayan expedition. Dr. Hooker wrote to me in reply, on his arrival at Alexandria near the end of December 184\%, before embarking at Suez: "Our Colebogyne still flowers with my father at Kew as well 
as in the Gardens of the Horticultural Society. It ripens its seeds regularly: I have examined it repeatedly very closely and carefully, and have never been able to discover a penetration of pollen-tubes either in the style or ovarium. In my herbarium the male blossoms are in small catkins."

(5) p. 7.- "Shine like stars."

The luminosity of the ocean is one of those superb natural phenomena which continue to excite our admiration eren when we have seen them recur every night for months. The sea is phosphorescent in every zone; but those who have not witnessed the phenomenon within the tropics, and especially in the Pacific, have only an imperfect idea of the grand and majestic spectacle which it affords. When a man-of-war, impelled by a fresh breeze, cuts the foaming waves, the royager standing at the ship's side feels as if he could never be satisfied with gazing on the spectacle which presents itself to his view. Every time that in the rolling of the ressel her side emerges from the water, blue or reddish streams of light appear to dart upwards like lashes of lightning from her keel. Nor can I describe the splendour of the appearance presented on a dark night in the tropic seas by the sports of a troop of porpoises. As they cut through the foaming wares, following each other in long winding lines, one sees their mazy track marked by intense and sparkling light. In the Gulf of Cariaco, between Cumana and the Peninsula of Maniquarez, I hare stood for hours enjoying this spectacle.

Le Gentil and the elder Forster attributed the fiashing to the electric friction excited by the ship in moving through 
the water, but the present state of our knowledge does not permit us to receive this as a valid explanation. (Joh. Reinh. Forster's Bemerkungen auf seiner Reise um die Welt, 1783, S. 57 ; Le Gentil, Voyage dans les Mers de l'Inde, 1779, T. i. p. 685-698.)

Perhaps there are few natural subjects of observation which have been so long and so much debated as the luminosity of the waters of the sea. What we know with certainty on the subject may be reduced to the following simple facts. There are several luminous animals which, when alive, give out at pleasure a faint phosphoric light: this light is, in most instances, rather bluish, as in Nereis noctiluca, Medusa pelagica var. $\beta$ (Forskäl, Fauna Agyptiaco-arabica, s. Descriptiones animalium quæ in itinere orientali observavit, 1775, p. 109), and in the Monophora noctiluca, discovered in Baudin's expedition, (Bory de St.-Vincent, Voyage dans les Iles des Mers d'Afrique, 1804, T. i. p. 107, pl. vi.) The luminous appearance of the sea is due partly to living animals, such as are spoken of above, and partly to organic fibres and membranes derived from the destruction of these living torch-bearers. The first of these causes is undoubtedly the most usual and most extensive. In proportion as travellers engaged in the investigation of natural phenomena have become more zealous in their researches, and more experienced in the use of excellent microscopes, we have seen in our zoological systems the groups of Mollusca and Infusoria, which become luminous either at pleasure or when excited by external stimulus, increase more and more.

The luminosity of the sea, so far as it is produced by 
living organic beings, is principally due, in the class of Zoophytes, to the Acalephæ (the families of Medusa and Cyanea), to some Mollusca, and to a countless host of Infusoria. Among the small Acalephæ, the Mammaria scintillans offers the beautiful spectacle of, as it were, the starry firmament reflected by the surface of the sea. This little creature, when full grown, hardly equals in size the head of a pin. Michaelis, at Kiel, was the first to show that there are luminous siliceous-shelled infusoria: he observed the flashing light of the Peridinium (a ciliated animalcule), of the cuirassed Monad the Prorocentrum micans, and of a rotifera to which he gave the name of Synchata baltica. (Michaelis über das Leuchten der Ostsee bei Kiel, 1830, S. 17.) The same Synchata baltica was subsequently discovered by Focke in the Lagunes of Venice. My distinguished friend and Siberian travelling companion, Ehrenberg, has succeeded in keeping luminous infusoria from the Baltic alive for almost two months in Berlin. He shewed them to me in 1832 with a microscope in a drop of sea-water: placed in the dark I saw their flashes of light. The largest of these little infusoria were 1-8th, and the smallest from 1-48th to 1-96th of a Paris line in length (a Paris line is about nine-hundredths of an English inch): after they were exhausted, and had ceased to send forth sparkles of light, the flashing was renewed on their being stimulated by the addition of acids or of a little alcohol to the sea.water.

By repeatedly filtering water taken up fresh from the sea, Ehrenberg succeeded in obtaining a fluid in which a greater number of these luminous creatures were concentrated. 
(Abhandlungen der Akad. der Wiss. zu Berlin aus dem J. 1833, S. 307 ; 1834, S. 537-575; 1838, S. 45 and 258.) This acute observer has found in the organs of the Photocaris, which emits flashes of light either at pleasure or when irritated or stimulated, a cellular structure with large cells and gelatinous interior resembling the electric organs of the Gymnotus and the Torpedo. "When the Photocaris is irritated, one sees in each cirrus a kindling and flickering of separate sparks, which gradually increase in intensity until the whole cirrus is illuminated; until at last the living fire runs also over the back of the small Nereis-like animal, so that it appears in the microscope like a thread of sulphur burning with a greenish-yellow light. It is a circumstance very deserving of attention, that in the Oceania (Thaumantias) hemisphærica the number and situation of the sparks correspond exactly with the thickened base of the larger cirri or organs which alternate with them. The exhibition of this wreath of fire is a vital act, and the whole development of light is an organic vital process which in the Infusoria shows itself as an instantaneous spark of light, and is repeated after short intervals of repose." (Ehrenberg über das Leuchten des Meeres, 1856, S. 110, 158, 160, and 163.)

According to these suppositions, the luminous creatures of the ocean show the existence of a magneto-electric lightevolving process in other classes of animals than fishes, insects, Mollusca, and Acalephr. Is the secretion of the luminous fluid which is effused in some luminous creatures, and which continues to shine for some time without any farther infuence of the living animal (for example, in 
Lampyrides and Elaterides, in the German and Italian glowworms, and in the South American Cucujo which lives on the sugar-cane), only a consequence of the first electric discharge, or is it simply dependent on chemical mixture? The shining of insects surrounded by air has doubtless other physiological causes than those which occasion the luminosity of inhabitants of the water, fishes, Medusæ, and Infusoria. The small Infusoria of the ocean, being surrounded by strata of salt water which is a good conducting fluid, must be capable of an enormous electric tension of their light-flashing organs to enable them to shine so intensely in the water. They strike like Torpedos, Gymnoti, and the Tremola of the Nile, through the stratum of water; while electric fishes, in connexion with the galvanic circuit, decompose water and impart magnetism to steel bars, as I showed more than half a century ago (Versuche über die gereizte Muskel- und Nervenfaser, Bd. i. S. 438-441, and see also Obs. de Zoologie et d'Anatomie comparée, vol. i. p. 84); and as John Davy has since confirmed (Phil. Trans. for 1834, Part ii. p. 545-547), do not pass a flash through the smallest intervening stratum.

The considerations which have been developed make it probable that it is one and the same process which operates in the smallest living organic creatures, so minute that they are not perceived by the naked eye,-in the combats of the serpent-like gymnoti,-in flashing luminous infusoria which raise the phosphorescence of the sea to such a degree of brilliancy; -as well as in the thundercloud, and in the auroral, terrestrial, or polar light (silent 
magnetic lightnings), which, as the result of an increased tension in the interior of the globe, are announced for hours beforehand by the suddenly altered movements of the magnetic needle. (See my letter to the Editor of the Annalen der Physik und Chemie, Bd. xxxvii. 1836, S. 24.2-244).

Sometimes one cannot even with high magnifying powers discern any animalcules in the luminous water; and yet, whenever the wave strikes and breaks in foam against a hard body, a light is seen to flash. In such case the cause of the phenomenon probably consists in the decaying animal fibres, which are disseminated in immense abundance throughout the body of water. If this luminous water is filtered through fine and closely woven cloths, these little fibres and membranes are separated in the shape of shining points. When we bathed at Cumana in the waters of the Gulf of Cariaco, and afterwards lingered awhile on the solitary beach in the mild evening air without our clothes, parts of our bodies continued luminous from the shining organic particles which had adhered to the skin, and the light only became extinct at the end of some minutes. Considering the enormous quantity of animal life in all tropical seas, it is, perhaps, not surprising that the sea water should be luminous, even where no visible organic particles can be detached from it. From the almost infinite subdivision of the masses of dead Dagysæ and Medusæ, the sea may perhaps be looked on as a gelatinous fluid, which as such is luminous, distasteful to, and undrinkable by man, and capable of affording nourishment to many fish. If 
one rubs a board with part of a Medusa hysocella, the part so rubbed regains its luminosity on friction with a dry finger. On my passage to South America I sometimes placed a Medusa on a tin plate. When I struck another metallic substance against the plate, the slightest vibrations of the tin were sufficient to cause the light. What is the manner in which in this case the blow and the vibrations act? Is the temperature momentarily augmented? Are new surfaces exposed? or does the blow press out a fluid, such as phosphuretted hydrogen, which may burn on coming into contact with the oxygen of the atmosphere or of the air held in solution by the sea-water. This light-exciting influence of a shock or blow is particularly remarkable in a "cross sea," i. e. when waves coming from opposite directions meet and clash.

I have seen the sea within the tropics appear Juminous in the most different states of weathier; but the light was most brilliant when a storm was near, or with a sultry atmosphere and a vaporous thickly-clouded sky. Heat and cold appear to have little influence on the phenomenon, for on the Banks of Newfoundland the phosphorescence is often very bright during the coldest winter weather. Sometimes under apparently similar external circumstances the sea will be highly luminous one night and not at all so the following night. Does the atmosphere influence the disengagement of light, or do all these differences depend on the accident of the observer sailing through a part of the sea more or less abundantly impregnated with gelatinous animal substances? Perhaps it is only in certain states of the 
atmosphere that the light-evolving animalculæ come in large numbers to the surface of the sea. It has been asked why the fresh water of our marshes, which is filled with polypi, is never seen to become luminous. Both in animals and plants, a particular mixture of organic particles appears to be required in order to favour the production of light. Willow-wood is oftener found to be luminous than oak-wood. In England experiments have succeeded in making saltwater shine by pouring into it the liquor from pickled herrings. It is easy to shew by galvanic experiments that in living animals the evolution of light depends on an irritation of the nerves. I have seen an Elater noctilucus which was dying emit strong flashes of light when I touched the ganglion of his fore leg with zinc and silver. Medusæ sometimes shew increased brightness at the moment of completing the galvanic circuit. (Humboldt, Relat. Hist. T. i. p. 79 and 533.).

Respecting the wonderful development of mass and power of increase in Infusoria, see Ehrenberg, Infus. S. xiii. 291 and 512. He observes that "the galaxy of the minutest organisms passes through the genera of Vibrio and Bacterium and that of Monas, (in the latter they are often only $\frac{1}{3000}$ of a line,) S. xix. and 244 .

(6) p.7.- "Which inhabits the large pulmonary cells of the rattle-snake of the tropics."

This animal, which I formerly called an Echinorhynchus or even a Porocephalus, appears on closer investigation, and according to the better founded judgment of Rudolphi, to 
belong to the division of the Pentastomes. (Rudolphi, Entozoorum Synopsis, p. 124 and 434.) It inhabits the ventral cavities and wide-celled lungs of a species of Crotalus which lives in Cumana, sometimes in the interior of houses, where it pursues the mice. Ascaris lumbrici (Gözen's Eingeweidewürmer, Tab. iv. Fig. 10,) lives under the skin of the common earthworm, and is the smallest of all the species of Ascaris. Leucophra nodulata, Gleichen's pearl-animalcule, has been observed by Otto Friedrich Müller in the interior of the reddish Nais littoralis. (Müller, Zoologia danica, Fasc. II. Tab. Inxx. a-e.). Probably these microscopic animals are again inhahited by others. All are surrounded by air poor in oxrgen and variously mixed with hydrogen and carbonic acid. Whether any animal can live in pure nitrogen is very doubtful. It might formerly have been believed to be the case with Fischer's Cistidicola farionis, because according to Fourcroy's experiments the swimming bladders of fish appeared to contain an air entirely deprived of oxygen. Erman's experience and my own shew, however, that fresh-water fishes never contain pure nitrogen in their swimming bladders. (Humboldt et Provençal, sur la respiration des Poissons, in the Recueil d'Observ. de Zoologie, Vol. ii. p. 194-216.) In sea-fish as much as 0.80 of oxygen has been found, and according to Biot the purity of the air would appear to depend on the depth at which the fish live. (Mémoires de Physique et de Chimie de la Societé d'Arcueil, T. i. 1807, p. 252-281.) 
(7) p. 8. " The collected labours of united Lithophytes."

Following Linnæus and Ellis, the calcareous zoophytes,among which Madrepores, Meandrinæ, Astreæ, and Pocilloporæ, especially, produce wall-like coral-reefs,-are inhabited by living creatures which were long believed to be allied to the Nereids belonging to Cuvier's Annelidæ. The anatomy of these gelatinous little creatures has been elucidated by the ingenious and extensive researches of Cavolini, Savigny, and Ehrenberg. We have learnt that in order to understand the entire organization of what are called the rockbuilding coral animals, the scaffolding which survives them, $i . e$. , the layers of lime, which in the form of thin delicate plates or lamellæ are elaborated by vital functions, must not be regarded as something extraneous to the soft membranes of the food-receiving animal.

Besides the more extended knowledge of the wonderful formation of the animated coral stocks, there have been gradually established more accurate views respecting the influence exercised by corals on other departments of Nature, - on the elevation of groups of low islands above the level of the sea,-on the migrations of land-plants and the successive extension of the domains of particular Floras, and, lastly, in some parts of the ocean, on the diffusion of races of men, and the spread of particular languages.

As minute organic creatures living in society, corals do indeed perform an important part in the general economy of Nature, although they do not, as was begun to be believed at the time of Cook's voyages, enlarge continents and build 
up islands from fathomless depths of the ocean. They excite the liveliest interest, whether considered as subjects of physiology and of the study of the gradation of animal forms, or whether they are regarded in reference to their influence on the geography of plants and on the geological relations of the crust of the Earth. According to the great views of Leopold von Buch, the whole formation of the Jura consists of "large raised coral-banks of the ancient world surrounding the ancient mountain chains at a certain distance."

In Ehrenberg's Classification, (Abhandlungen der Akad. der Wiss. zu Berlin aus dem, J. 1832, S. 393-432) Coralanimals, (often improperly called, in English works, Coralinsects) are divided into two great classes : the singlemouthed Anthozoa, which are either free or capable of detaching themselves, being the animal-corals, Zoocorallia; and those in which the attachment is permanent and plantlike, being the Phyto-corals. To the first order, the Zoocorallia, belong the Hydras or Arm-polypi of Trembley, the Actiniæ decked with beautiful colours, and the mushroomcorals; to the second order or Phyto-corals belong the Madrepores, the Astræids, and the Ocellinæ. The Polypi of the second order are those which, by the cellular wavedefying ramparts which they construct, are the principal subject of the present note. These ramparts consist of an aggregate of coral trunks, which, however, do not instantly lose their common vitality as does a forest tree when cut down.

Every coral-trunk is a whole which has arisen by a formation of buds taking place according to certain laws, the 
parts of which the whole consists forming a number of organically distinct individuals. In the group of Phytocorals these individuals cannot detach themselves at pleasure, but remain united with each other by thin plates of carbonate of lime. It is not, therefore, by any means the case that each trunk of coral has a central point of common vitality or life. (See Ehrenberg's Memoir above referred to, S. 419.) The propagation of coral-animals takes place, in the one order, by eggs or by spontaneous division; and in the other order, by the formation of buds. It is the latter mode of propagation which, in the development of individuals, is the most rich in variety of form.

Coral-reefs, (according to the definition of Dioscorides, sea-plants, a forest of stone-trees, Lithodendra), are of three kinds; - coast reefs, called by the English "shore or fringing reefs," which are immediately connected with the coasts of continents or islands, as almost all the coral banks of the Red Sea seen during an eighteen months' examination by Ehrenberg and Hemprich;- "barrier-reefs," "encircling-reefs," as the great Australian barrier-reef on the north-east coast of New Holland, extending from Sandy Cape to the dreaded Torres Strait; and as the encircling-reefs surrounding the islands of Vanikoro (between the Santa Cruz group and the New Hebrides) and Poupynete (one of the Carolinas;-and lastly, coral banks enclosing lagoons, forming "Atolls" or "Lagoon-islands." This highly natural division and nomenclature have been introduced by Charles Darwin, and are intimately connected with the explanation which that ingenious and 
excellent investigator of nature has given of the gradual production of these wonderful forms. As on the one hand Carolini, Ehrenberg, and Sarigny hare perfected the scientific anatomical knowledge of the organisation of coralanimals, so on the other hand the geographical and geological relations of coral.islands have been investigated and elucidated, first by Reinhold and George Forster in Cook's Second Voyage, and subsequently, after a long interval, by Chamisso, Péron, Quoy and Gaimard, Flinders, Lütke, Beechey, Darwin, d'Urville, and Lottin.

The coral-animals and their stony cellular structures or. scafiolding belong principally to the trarm tropical seas, and the reefs are found more frequently in the Southern than in the Northern Hemisphere. The Atolls or Lagoon Islands are cromded together in what has been called the Coral-Sea, off the north-east coast of New Holland, including New Caledonia, the Salomon's Islands, and the Louisiade Archipelago; in the group of the Low islands (Low Archipelago), eighty in number; in the Fidji, Ellice, and Gilbert groups; and in the Indian Ocean, on the north-east of Madagascar, under the name of the Atoll-group of Saya de Malha.

The great Chagos bank, of which the structure and rocks of dead coral have been thoroughly examined by Captain Moresby and by Powell, is so much the more interesting, because we may regard it as a continuation of the more northerly Laccadives and Maldives. I have already called. attention elsewhere (Asie Centrale, T. i. p. 218), to the importance of the succession of these Atolls, running exactly in the direction of a meridian and continued as far as $7^{\circ}$ 
south latitude, to the general system of mountains and the configuration of the earth's surface in Central Asia. They form a kind of continuation to the great rampart-like mountain elevations of the Ghauts and the more northern chain of Bolor, to which correspond in the trans-Gangetic Peninsula the North and South Chains which are intersected near the great bend of the Thibetian Tzang-bo River by several transverse mountain systems running east and west. In this eastern peninsula are situated the chains of Cochin China, Siam, and Malacca which are parallel with each other, as well as those of Ava and Arracan which all, after courses of unequal length, terminate in the Gulfs or Bays of Siam, Martaban, and Bengal. The Bay of Bengal appears like an arrested attempt of nature to form an inland sea. A deep invasion of the ocean, between the simple western system of the Ghauts, and the eastern very complex trans-Gangetic system of mountains, has swallowed up a large portion of the low lands on the eastern side, but met with an obstacle more difficult to overcome in the existence of the extensive high plateau of Mysore.

Such an invasion of the ocean has occasioned two almost pyramidal peninsulas of very different dimensions, and differently proportioned in breadth and length; and the continuations of two mountain systems (both running in the direction of the meridian, $i . e$, the mountain system of Malacca on the east, and the Ghauts of Malabar on the west), shew themselves in submarine chains of mountains or symmetrical series of islands, on the one side in the Andaman and Nicobar Islands which are very poor 
in corals, and on the other side in the three longextended groups or series of Atolls of the Laccadives, the Maldives, and Chagos. The latter series, called by navigators the Chagos-bank, forms a lagoon encircled by a narrow and already much broken, and in great measure submerged, coral reef. The longer and shorter diameters of this lagoon, or its length and breadth, are respectively 90 and 70 geographical miles. Whilst the enclosed lagoon is only from seventeen to forty fathoms deep, the depth of water at a small distance from the outer margin of the coral, (which appears to be gradually sinking), is such, that at half a mile no bottom was found in sounding with a line of 190 fathoms, and, at a somewhat greater distance, none with 210 fathoms. (Darwin, Structure of Coral Reefs, p. 39, 111, and 183.) At the coral lagoon called Keeling-Atoll, Captain Fitz-Roy, at a distance of only two thousand yards from the reef, found no soundings with 1200 fathoms.

"The corals which, in the Red Sea, form thick wall-like masses, are species of Meandrina, Astræa, Faria, Madrepora (Porites), Pocillopora (hemprichii), Millepora, and Heteropora. The latter are among the most massive, although they are somernat branched. The corals which lie deepest below the surface of the water in this locality, and which, being magnified by the refraction of the rays of light, appear to the eve like the domes or cupolas of a cathedral or other large building, belong, so far as we were enabled to judge, to Meandrina and Astræa." (Ehrenberg, manuscript notices.) It is necessary to distinguish between separate and in part 
free and detached polypifers, and those which form wall-like structures and rocks.

If we are struck with the great accumulation of building polypifers in some regions of the globe, it is not less surprising to remark the entire absence of their structures in other and often nearly adjoining regions. These differences must be determined by causes which have not yet been thoroughly investigated; such as currents, local temperature of the water, and abundance or deficiency of appropriate food. That certain thin-branched corals, with less deposit of lime on the side opposite to the opening of the mouth, prefer the repose of the interior of the lagoon, is not to be denied; but this preference for the unagitated water must not, as has too often been done (Annales des Sciences Naturelles, 1825, T. vi. p. 277), be regarded as a property belonging to the entire class. According to Ehrenberg's experience in the Red Sea, that of Chamisso in the Atolls of the Marshall Islands east of the Caroline group, the observations of Captain Bird Allen in the West Indies, and those of Capt. Moresby in the Maldives, living Madrepores, Millepores, and species of Astræa and of Meandrina, can support the most violent action of the waves, - "a tremendous surf," (Darwin, Coral Reefs, pp. 63-65), and even appear to prefer the most stormy exposure. The living organic forces or powers regulating the cellular structure, which with age acquires the hardness of rock, resist with wonderful success the mechanical forces acting in the shock of the agitated water.

In the Pacific, the Galapágos Islands, and the whole 
Western Coast of America, are entirely without coral reefs, although so near to the many Atolls of the Low Islands, and the Archipelago of the Marquesas. This absence of corals might perhaps be ascribed to the presence of colder water, since we know that the coasts of Chili and Peru are washed by a cold current coming from the south and turning to the westward off Punta Parina, the temperature of which I found, in 1802, to be only $12^{\circ} .5$ Reaumur $\left(60^{\circ} .2\right.$ Fah. $)$, while the undisturbed adjacent masses of water were from $22^{\circ}$ to $23^{\circ}$ Reaumur ( $81^{\circ} .5$ to $83^{\circ} .8$ Fah.) ; and there are also among the Galapagos small currents running betreen the islands, having a temperature of only $11^{\circ} .7$ Reaumur ( $58^{\circ} .2$ Fah.) But these lower temperatures do not extend farther to the north along the shores of the Pacific, and are not found upon the coasts of Guayaquil, Guatimala, and Mexico; nor does a low temperature prevail at the Cape de Verd Islands on the West Coast of Africa, or at the small islands of St. Paul (St. Paul's rocks), or at St. Helena, Ascension, or San Fernando Noronha,which yet are all without coral reefs.

While this absence of coral reefs appears to characterise the western coasts of Africa, America, and Australia, on the other hand such reeffs abound on the eastern coasts of tropical America, of Africa, on the coasts of Zanzibar and Australia, and on that of New South Wales. The coral banks which I have chiefly had opportunities of obserring are those of the interior of the Gulf of Mexico, and those to the south of the Island of Cuba, in what are called the "Gardens of the King and Queen" (Jardines y Jardinillos 
del Rey y de la Reyna). It was Columbus himself who, on his second voyage, in May 1494, gave that name to this little group of islands, because the agreeable mixture of the silver-leaved arborescent Tournefortia gnapholoides, flowering species of Dolichos, Avicennia nitida, and mangrove hedges, gave to the coral islands the appearance of a group of floating gardens. "Son Cayos verdes y graciosos llenos de arboledas," says the Admiral. On the passage from Batabano to Trinidad de Cuba, I remained several days in these, gardens, situated to the east of the larger island, called the Isla de Pinos, which is rich in mahogany trees: my stay was for the purpose of determining the longitude of the different keys (Cayos). The Cayo Flamenco, Cayo Bonito, Cayo de Diego Perez, and Cayo de piedras, are coral islands rising only from eight to fourteen inches above the level of the sea. The upper edge of the reef does not consist simply of blocks of dead coral; it is rather a true conglomerate, in which angular pieces of coral, cemented together with grains of quartz, are embedded. In the Cayo. de piedras I saw such embedded pieces of coral measuring as much as three cubic feet. Several of the small West Indian coral islands have fresh water, a phenomenon which, wherever it presents itself, (for example, at Radak in the Pacific; see Chamisso in Kotzebue's Entdeckungs-Reise, Bd. iii. S. 108), is deserving of examination, as it has sometimes been ascribed to hydrostatic pressure operating from a distant coast, (as at Venice, and in the Bay of Xagua east of Batabano), and sometimes to the filtration of rain water. (See my Essai politique sur l'Ile de Cuba, 'T. ii. p. 137.) 
The living gelatinous investment of the stony calcareous part of the coral attracts fish, and even turtles, who seek it as food. In the time of Columbus the now unfrequented locality of the Jardines del Rey was enlivened by a singular kind of fishery, in which the inhabitants of the coasts of the Island af Cuba engaged, and in which they availed themselves of the serrices of a small fish. They employed in the capture of turtle the Remora, once said to detain ships (probably the Echeneis Naucrates), called in Spanish "Reres," or" rerersed, because at first sight his back and abdomen are mistaken for each other. The remora attaches itself to the turtle by suction throngh the interstices of the indented and moreable cartilaginous plates which corer the head of the latter, and "would rather," says Columbus, "allow itself to be cut in pieces than lose its hold." The natives, therefore, attach a line, formed of palm fibres, to the tail of the little fish, and after it has fastened itself to the turtle draw both out of the water together. Martin Anghiera, the learned secretary of Charles V., says, "Nostrates piscem reversum appellant, quod rersus venatur. Non aliter ac nos canibus gallicis per æquora campi lepores insectamur, illi (incolæ Cubæ insulæ) venatorio pisce pisces alios capiebant." (Petr. Martyr, Oceanica, 1532, Dec. I. p. 9; Go. mara, Hist. de las Indias, 1553, fol. xiv.) Te learn by Dampier and Commerson that this piscatorial artifice, the employing a sucking-fish to catch other inhabitants of the water, is much practised on the East Coast of Africa, at Cape Natal and on the Mozambique Chamnel, and also in the Island of Madagascar. (Lacépède, Hist. nat. des Pois- 
sons, T. i. p. 55.) The same necessities combine with a knowledge of the habits of animals to induce the same artifices and modes of capture among nations who are entirely unconnected with each other.

Although, as we have already remarked, the zone included between 22 or 24 degrees of latitude on either side of the equator, appears to be the true region of the calcareous saxigenous lithophytes which raise wall-like structures, yet coral reefs are also found, favoured it is supposed by the warm current of the Gulf-stream, in lat. $32^{\circ} 23^{\prime}$, at the Bermudas, where they have been extremely well described by Lieutenant Nelson. (Transactions of the Geological Society, 2d Series, 1837, Vol. V. Pt. i. p. 103.) In the southern hemisphere, corals, (Millepores and Cellepores), are found singly as far south as Chiloe, the Archipelago of Chonos, and Tierra de Fuego, in $53^{\circ}$ lat.; and Retepores are even found in lat. $72 \frac{1}{2}^{\circ}$.

Since the second voyage of Captain Cook there have been many defenders of the hypothesis put forward by him as well as by Reinhold and George Forster, according to which the low coral islands of the Pacific have been built up by living creatures from the depths of the bottom of the sea. The distinguished investigators of nature, Quoy and Gaimard, who accompanied Captain Freycinet in his voyage round the world in the frigate Uranie, were the first who ventured, in 1823, to express themselves with great boldness and freedom in opposition to the views of the two Forsters (father and son), of Flinders, and of Péron. (Annales des Sciences Naturelles, T. vi., 1825, p. 273.) 
"En appelant l'attention des naturalistes sur les animalcules des coraux, nous espérons démontrer que tout ce qu'on a. dit ou cru observer jusqu'à ce jour relativement aux im. menses travaux qu'il sont susceptibles d'exécuter, estle plus sourent inexact et toujours excessivement exagéré. Nous pensons que les coraux, loin d'élever des profondeurs de l'océan des murs perpendiculaires, ne forment que des couches ou des encroûtemens de quelques toises d'èpaisseur." Quoy and Gaimard also propounded (p. 289) the conjecture that the Atolls, (coral walls enclosing a lagoon), probably orred their origin to submarine volcanic craters. Their estimate of the depth below the surface of the sea at which the animals which form the coral reefs (the species of Astræa, for example) could live, was doubtless too small,

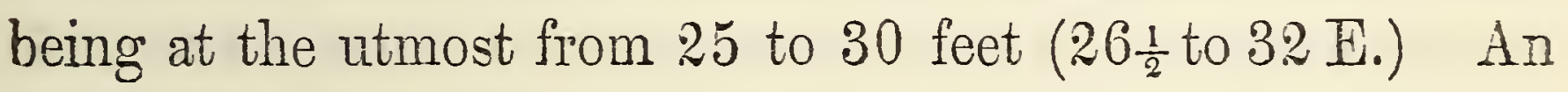
investigator and lover of nature who has added to his own many and valuable observations a comparison with those of others in all parts of the globe, Charles Darwin, places with greater certainty the depth of the region of living corals at 20 to 30 fathoms. (Darwin, Journal, 1845, p. 467; and the same writer's Structure of Coral Reefs, p. 84-87; and Sir Robert Schomburgk, Hist. of Barbadoes, 1848, p. 636.) This is also the depth at which Professor Edward Forbes found the greatest number of corals in the Egean Sea : it is his "fourth region" of marine animals in his very ingenious memoir on the "Provinces of Depth" and the geographical distribution of Mollusca at vertical distances from the surface. (Report on Egean Invertebrata in the Report of the 13th Meeting of the British Association, held at Cork in 1843, pp. 151 and 161.) The depths at which corals 
live would seem, however, to be very different in different species, and especially in the more delicate ones which do not form such large masses.

Sir James Ross, in his Antarctic Expedition, brought up corals with the sounding lead from great depths, and entrusted them to Mr. Stokes and Professor Forbes for more thorough examination. On the west of Victoria Land, near Coulman Island, in S. lat. $72^{\circ} 31^{\prime}$, at a depth of 270 fathoms, Retepora cellulosa, a species of Hornera, and Prymnoa Rossii, were found quite fresh and living. Prymnoa Rossii is very analogous to a species found on the coast of Norway. (See Ross, Voyage of Discovery in the Southern and Antaretic Regions, vol. i. pp. 334 and 337.) In a similar manner in the high northern regions the whalers have brought up Umbellaria grænlandica, living, from depths of 236 fathoms. (Ehrenberg, in the Abhandl. der Berl. Akad. aus dem J. 1832, S. 430.) We find similar relations of species and situation among sponges, which, indeed, are now considered to belong rather to plants than to zoophytes. On the coasts of Asia Minor the common sponge is found by those engaged in the fishery at depths varying from 5 to 30 fathoms; whereas a very small species of the same genus is not found at a less depth than 180 fathoms. (Forbes and Spratt, Travels in Lycia, 184\%, Vol. ii. p. 124.) It is difficult to divine the reason which prevents Madrepores, Meandrina, Astræa, and the entire group of tropical Phyto-corals which raise large cellular calcareous structures, from living in strata of water at a considerable depth below the surface of the sea. The diminution of temperature in descending takes place but slowly; 
that of light almost equally so; and the existence of numerous Infusoria at great depths shews that the polypifers would not want for food.

In opposition to the hitherto generally received opinion of the entire absence of organic life in the Dead Sea, it is deserving of notice that my friend and fellow labourer, $M$. Valenciennes, has received through the Marquis Charles de l'Escalopier, and also the French consul Botta, fine specimens of Porites elongata from the Dead Sea. This fact is the more interesting because this species is not found in the Mediterranean, but belongs to the Red Sea, which, according to Valenciennes, has but fer organic forms in common with the Mediterranean. I have before remarked that in France a sea fish, a species of Pleuronectes, advances far up the rivers into the interior of the country, thus becoming accustomed to gill-respiration in fresh water' so we find that the coral-animal above spoken of, the Porites elongata of Lamarck, has a not less remarkable flexibility of organisation, since it lives in the Dead Sea, which is orer-saturated with salt, and in the open ocean near the Seychelle Islands. (See my Asie Centrale, T. ii. p. 517.)

According to the most recent chemical nnalyses made by the younger Silliman, the genus Porites, as well as many other cellular polypifers, (Madrepores, Andræas, and Meandrinas of Ceylon and the Bermudas), contain, besides 92-95 per cent. of carbonate of lime and magnesia, some fluoric and phosphoric acids. (See p. 124-131 of "Structure and Classification of Zoophytes," by James Dana, Geologist of the United States' Exploring Expedition, under the command 
of Captain Wilkes.) The presence of fluorine in the solid parts of polypifers reminds us of the fluorate of lime in the bones of fishes, according to the experiments of Morechini and Gay Lussac at Rome. Silex is only found mixed in very small quantity with fluorate and phosphate of lime in coral stocks; but a coral-animal allied to the Horn-coral, Gray's Hyalonema, has an axis of pure fibres of silex resembling a queue or braided tress of hair. Professor Forchhammer, who has been lately engaged in a thorough analysis of the sea-water from the most different parts of the globe, finds the quantity of lime in the Caribbean Sea remarkably small, being only 247 parts in ten thousand, while in the Categat it amounts to 371 parts in ten thousand. He is disposed to attribute this difference to the many coral-banks among the West Indian Islands, which appropriate the lime, and lower the per centage remaining in the sea-water. (Report of the 16th Meeting of the British Association for the Advancement of Science, held in 1846, p. 91.)

Charles Darwin has developed in a very ingenious manner the probable genetic connection between fringing or shorereefs, island-encircling reefs, and lagoon-islands, $i$.e., narrow ring-shaped reefs enclosing interior lagoons. According to his views these three varieties of form are dependent on the oscillating condition of the bottom of the sea, or on periodic elevations and subsidences. The hypothesis which has been several times put forward, according to which the closed ring or annular form of the coral-reefs in Atolls or Lagoon Islands marks the configuration of a submarine volcano, the structure having been raised on the margin of the 
crater, is opposed by their great dimensions, the diameters of many of them being 30,40 , and sometimes even 60 geographical miles. Our fire-emitting mountains have no such craters; and if we would compare the lagoon, with its submerged interior and narrow enclosing reef, to one of the annular mountains of the moon, we must not forget that those lunar mountains are not volcanoes, but wall-surrounded districts. According to Darwin, the process of formation is the following:- $\mathrm{He}$ supposes a mountainous island surrounded by a coral-reef, (a "fringing reef" attached to the shore), to undergo subsidence: the "fringing reef" which subsides with the island is continually restored to its level by the tendency of the coral-animals to regain the surface of the sea, and becomes thus, as the island gradually sinks and is reduced in size, first an "encircling reef" at some distance from the included islet, and subsequently, when the latter has entirely disappeared, an atoll. According to this view, in which islands are regarded as the culminating points of a submerged land, the relative positions of the different coral islands would disclose to us that which we could hardly learn by the sounding line, concerning the configuration of the land which was above the surface of the sea at an earlier epoch. The entire elucidation of this attractive subject, (to the connection of which with the migrations of plants and the diffusion of races of men attention was called at the commencement of the present note), can only be hoped for when inquirers shall have succeeded in obtaining greater knowledge than is now possessed of the depth and the nature of the rocks on which the lomest strata of the dead corals rest. 


\section{(8) p. 11._"Traditions of Samothrace."}

Diodorus has preserved to us this remarkable tradition, the probability of which renders it in the eyes of the geologist almost equivalent to a historical certainty. The Island of Samothrace, formerly called also Æthiopea, Dardania, Leucania or Leucosia in the Scholiast to Apollonius Rhodius, and which was a seat of the ancient mysteries of the Cabiri, was inhabited by the remains of an ancient nation, several words of whose language were preserved to a later period in the ceremonies accompanying sacrifices. The situation of this island, opposite to the Thracian Hebrus and near the Dardanelles, renders it not surprising that a more detailed tradition of the catastrophe of the breaking forth of the waters of the Euxine should have been preserved there. Rites were performed at altars supposed to mark the limits of the irruption of the waves; and in Samothrace as well as in Bootia, a belief in the periodically recurring destruction of mankind, (a belief which was also found among the Mexicans in the form of a myth of four destructions of the world), was connected with historical recollections of particular inundations. (Otfr. Müller Geschichten Hellenischer Stärnme und Städte, Bd. i. S. 65 and 119.) According to Diodorus, the Samothracians related that the Black Sea had once been an inland lake, but that, being swollen by the rivers which flow into it, it had broken through, first the strait of the Bosphorus, and afterwards that of the Hellespont; and this long before the inundations spoken of by other nations. (Diod. Sicul. lib. v. cap. 47, p. 369, Wesseling.) These ancient revolutions 
of nature have been treated of in a special work by Dureau de la Malle, and all the information possessed on the subject has been collected in Carl von Hoff's important work, entitled Geschichte der natürlichen Veränderungen der Erdoberfläche, Th. i. 1822, S. 105-162; and in Creuzer's Symbolik, 2te Aufl. Th. ii. S. 285, 318, and 301. A reflex, as it were, of the traditions of Samothrace appears in the "Sluice theory" of Strato of Lampsacus, according to which the swelling of the waters of the Euxine first opened the passage of the Dardanelles, and afterwards caused the outlet through the pillars of Hercules. Strabo has preserved to us in the first book of his Geography, among critical extracts from the works of Eratosthenes, a remarkable fragment of the lost writings of Strato, presenting views which extend to almost the entire circumference of he Mediterranean.

"Strato of Lampsacus," says Strabo (Lib. i. p. 49 and 50, Casarib.), "is eren more disposed than the Lydian Xanthus," (who had described impressions of shells at a distance from the sea) "to expound the causes of the things which we see. He asserts that the Euxine had formerly no outlet at Byzantium, but the sea becoming swollen by the rivers which ran into it, had by its pressure opened the passage through which the waters flow into the Propontis and the Hellespont. He also says that the same thing has happened to our Sea (the Mediterranean);" "for here, too, when the sea had become swollen by the rivers, (which in flowing into it had left dry their marshy banks), it forced for itself a passage through the isthmus of land comnecting the 
Pillars. The proofs which Strato gives of this are, first that there is still a bank under water running from Europe to Libya, shewing that the outer and inner seas were formerly divided; and next that the Euxine is the shallowest, the Cretan, Sicilian, and Sardoic Seas being on the contrary very deep; the reason being that the Euxine has been filled with mud by the many and large rivers flowing into it from the North, while the other seas continued. deep. The Euxine is also the freshest, and the waters flow towards the parts where the bottom of the sea is lowest. Hence he inferred that the whole of the Euxine would finally be choked with mud if the rivers were to continue to flow into it: and this is already in some degree the case on the west side of the Euxine towards Salmydessus (the Thracian Apollonia), and at what are called by mariners the "Breasts" off the mouth of the Ister and along the shore of the Scythian Desert. Perhaps the Temple of Ammon (in Lybia) may once have stood on the sea-shore, and causes such as these may explain why it is now far inland. This Strato thought might account for the celebrity of the Oracle, which would be less surprising if it had been on the sea-shore; whereas its great distance from the coast made its present renown inexplicable. Egypt, too, had been formerly overflowed by the sea as far as the marshes of Pelusium, Mount Casius, and Lake Serbonis; for, on digging beneath the surface, beds of sea-sand and shells are found; shewing that the country was formerly overflowed, and the whole district round Mount Casius and Gerrha was a marshy sea which joined the gulf 
of the Red Sea. When our Sea (the Mediterranean) retreated, the land was uncovered; still, however, leaving the Lake of Serbonis: subsequently this lake also broke through its bounds and the water flowed off, so that the lake became a swamp. The banks of Lake Mœris are also more like sea than river banks." An erroneously corrected reading introduced by Grosskurd on account of a passage in Strabo, Lib. xvii. p. 809, Cas., gives instead of Moris "the Lake Halmyris:" but this latter lake was situated not far from the mouth of the Danube.

The sluice-theory of Strato led Eratosthenes of Cyrene (the most celebrated of the series of librarians of Alesandria, but less happy than Archimedes in writing on floating bodies), to examine the problem of the equality of level of all external seas, $i$. e., seas surrounding the Continents. (Strabo, Lib. i. p. 51-56; Lib. ii. p. 104, Casaub). The varied outlines of the northern shores of the Mediterranean, and the articulated form of the peninsulas and islands, had given occasion to the geognostical myth of the ancient land of Lyctonia. The supposed mode of origin of the smaller Syrtis and of the Triton Lake (Diod. iii. 53-55) as well as that of the whole Western Atlas (Maximus Tyrius, viii. 7) were drawn in to form part of an imaginary scheme of igneous eruptions and earthquakes. (See my Examen crit. de l'hist. de la Géographie, Vol. i. p. 179 ; T. iii. p. 136.) I hare recently touched more in detail on this subject (Kosmos, Bd. ii. S. 153; Engl. ed. p. 118-119) in a passage which I permit myself to subjoin :-

"A more richly varied and broken outline gives to the VOL. II. 
northern shore of the Mediterranean an advantage over the southern or Lybian shore, which according to Strabo was remarked by Eratosthenes. The three great peninsulas, the Iberian, the Italian, and the Hellenic, with their sinuous and deeply indented shores, form, in combination with the neighbouring islands and opposite coasts, many straits and isthmuses. The configuration of the continent and the islands, the latter either severed from the main or volcanically elevated in lines, as if over long fissures, early led to geognostical views respecting eruptions, terrestrial revolutions, and overpourings of the swollen higher seas into those which were lower. The Euxine, the Dardanelles, the Straits of Gades, and the Mediterranean with its many islands, were well fitted to give rise to the view of such a system of sluices. The Orphic Argonaut, who probably wrote in Christian times, wove antique legends into his song; he describes the breaking up of the ancient Lyktonia into several islands, when 'the dark-haired Poseidon, being wroth with Father Kronion, smote Lyktonia with the golden trident.' Similar phantasies, which indeed may often have arisen from imperfect knowledge of geographical circumstances, proceeded from the Alexandrian school, where erudition abounded, and a strong predilection was felt for antique legends. It is not necessary to determine here whether the myth of the Atlantis broken into fragments should be regarded as a distant and western reflex of that of Lyktonia (as I think I have elsewhere shewn to be probable), or whether, as Otfried Müller considers, "the destruction of Lyktonia (Leuconia) refers to 
the Samothracian tradition of a great flood which had changed the form of that district."

\section{(9) p. 12.- "Prevents precipitation taking place from clouds."}

The vertically-ascending current of the atmosphere is a principal cause of many most important meteorological phenomena. When a desert or a sandy plain partly or entirely destitute of plants is bounded by a chain of high mountains, we see the sea breeze drive the dense clouds over the desert without any precipitation taking place before they have reached the mountain-ridge. This phenomenon was formerly explained in a very inappropriate manner by a supposed superior attraction exercised by the mountains on the clouds. The true reason of the phenomenon appears to consist in the ascending column of warm air which rises from the sandy plain, and prevents the vesicles of vapour from being dissolved. The more complete the absence of vegetation, and the more the sand is heated, the greater is the height of the clouds, and the less can any fall of rain take place. When the clouds reach the mountains these causes cease to operate; the play of the vertically-ascending atmospheric current is feebler, the clouds sink lower, and dissolve in rain in a cooler stratum of air. Thus, in deserts, the want of rain, and the absence of vegetation, act and react upon each other. It does not rain, because the naked sandy surface having no vegetable covering, becomes more powerfully heated by the solar rays, and thus radiates more heat; and the absence of rain forbids the desert being converted 
into a steppe or grassy plain, because without water no organic development is possible.

(10) p. 14.-" The mass of the earth in solidifying and parting with its heat."

If, according to the hypothesis of the Neptunists, now long since obsolete, the so-called primitive rocks were precipitated from a fluid, the transition of the crust of the earth from a fluid to a solid state must have been accompanied by an enormous disengagement of heat, which would in turn have caused fresh evaporation and fresh precipitations. The later these precipitations, the more rapid, tumultuous, and uncrystalline they would have been. Such a sudden disengagement of heat might cause local augmentations of temperature independent of the height of the pole or the latitude of the place, and independent of the position of the earth's axis ; and the temperatures thus caused would influence the distribution of plants. The same sudden disengagement of heat might also occasion a species of porosity, of which there seem to be indications in many enigmatical geological phenomena in sedimentary rocks. I have developed these conjectures in detail in a small memoir "über ursprungliche Porosität." (See my work entitled Versuche über die chemische Zersetzung des Luftkreises, 1799, S. 177; and Moll's Jahrbuicher der Berg- und Hüttenkunde, 1797, S. 234.) According to the newer views which I now entertain, the shattered and fissured earth, with her molten interior, may long have maintained a high temperature on her oxydised surface, independently of position in respect to the sun 
and of latitude. Would not the climate of Germany be wonderfully altered, and that perhaps for centuries, if there were opened a fissure a thousand fathoms in depth, reaching from the shores of the Adriatic to the Baltic? If in the present condition of our planet, the stable equilibrium of temperature, first calculated by Fourier in his Théorie analytique de la chaleur, has been almost completely restored by radiation from the earth into space; and if the external atmosphere now only communicates with the molteninterior through the inconsicierable openings of a few rolcanoes, -in the earlier state of things numerous clefts and fissures, produced by the frequently recurring corrugations of the rocky strata of the globe, emitted streams of heated air which mingled with the atmosphere and were entirely independent of latitude. Every planet must thus in its earliest condition have for a time determined its own temperature, which afterwards becomes dependent on the position relatively to the central body, the Sun. The surface of the Moon also shows traces of this reaction of the interior upon the crust.

\section{(11) p. 14.-"The mountain declivities of the southern part of Mexico."}

The greenstone in globular concretions of the mountain district of Guanasuato is quite similar to that of the Francovian Fichtel-Gebirge. Both form grotesquely shaped summits, which pierce through and cover the transition argillaceous schists. In the same manner, pearl stone, porphyritic schists, trachyte, and pitch-stone porphyry, constitute rocks similar in form in the Mexican mountains near Cinapecuaro and Moran, in Hungary, in Bohemia, and in Northern Asia. 


\section{(12) p. 16._"The dragon-tree of Orotava."}

This colossal dragon-tree, Dracæna draco, stands in the garden of Dr. Franqui in the small town of Oratava, the ancient Taoro, one of the most delightful spots in the world. In June 1799, when we ascended the Peak of Teneriffe, we measured the circumference of the tree, and found it nearly 48 English feet. Our measurement was taken several feet above the root. Lower down, and nearer to the ground, Le Dru made it nearly 79 English feet. Sir George Staunton found the diameter still as much as 12 feet at the height of 10 feet above the ground. The height of the tree is not much above 69 English feet. According to tradition, this tree was venerated by the Guanches (as was the ash-tree of Ephesus by the Greeks, or as the Lydian plane-tree which Xerxes decked with ornaments, and the sacred Banyan-tree of Ceylon), and at the time of the first expedition of the Béthencourts in 1402, it was already as thick and as hollow as it now is. Remembering that the Dracæua grows extremely slowly, we are led to infer the high antiquity of the tree of Orotava. Bertholet, in his description of Teneriffe, says, "En comparant les jeunes Dragonniers, voisins de l'arbre gigantesque, les calculs qu'on fait sur l'age de ce dernier effraient l'imagination." (Nova Acta Acad. Leop. Carol. Naturæ Curiosorum, T. xiii. 1827, p. 781.) The dragon-tree has been cultivated in the Canaries, and in Madeira and Porto Santo, from the earliest times ; and an accurate observer, Leop sld von Buch, has even found it wild in Teneriffe, near Igueste. Its original country, therefore, is not India, as had long been believed; nor does its appear- 
ance in the Canaries contradict the opinion of those who regard the Guanches as haring been an isolated Atlantic nation without intercourse with African or Asiatic nations. The form of the Dracænas is repeated at the southern extremity of Africa, in the Isle of Bourbon, and in New Zealand. In all these distant regions species of the genus in question are found, but none have been met with in the New Continent, where its form is 'replaced by that of the Yucca. Dracæna borealis of Aiton is a true Convallaria, and has all the "habitus" of that genus. (Humboldt, Rel. hist. T.i. p. 118 and 639.) I have given a representation of the dragou-tree of Orotara, taken from a drawing made by $\mathrm{F}$. d'Ozonne in 1776, in the last plate of the Picturesque Atlas of $\mathrm{my}$ American journey. (Vues des Cordillères et Monumens des Peuples indigènes de l'Amérique, Pl. lxix.) I found d'Ozonne's drawing among the manuscripts left by the celebrated Borda, in the still unprinted travelling journal entrusted to me by the Dépôt de la Marine, and from which I borrowed important astronomically-determined geographical, as well as barometric and trigonometric notices. (Rel. hist. T. i. p. 282.) The measurement of the dragon-tree of the Villa Franqui was made on Borda's first voyage with Pingré, in 1771 ; not in his second voyage, in 1776, with Varela. It is affirmed that in the early times of the Norman and Spanish Conquests, in the 15 th century, Mass was said at a small altar erected in the hollow trunk of the tree. Unfortunately the dragon-tree of Orotavalost one side of its top in the storm of the 21st of July, 1819. There is a fine and large English copperplate engraving which represents the present state of the tree with remarkable truth to nature. 
The monumental character of these colossal living vegetable forms, and the kind of reverence which has been felt for them among all nations, have occasioned in modern times the bestowäl of greater care in the numerical determination of their age and the size of their trunks. The results of these inquiries have led the author of the important treatise, "De la longévité des Arbres," the elder Decandolle, Endlicher, Unger, and other able botanists, to consider it not improbable that the age of several individual trees which are still alive goes back to the earliest historical periods, if not of Egypt, at least of Greece and Italy. It is said in the Bibliothèque Universelle de Genève, 1831, T. Ixvii. p. 50 :- "Plusieurs exemples semblent confirmer l'idée qu'il existe encore sur le globe des arbres d'une antiquité prodigieuse, et peut-être témoins de ses dernières révolutions physiques. Lorsqu'on regarde un arbre comme un agrégat d'autant d'individus soudés ensemble qu'il s'est développé de bourgeons à sa surface, on ne peut pas s'étonner si, de nouveaux bourgeons s'ajoutant sans cesse. aux anciens, l'agrégat qui en résulte n'a point de terme nécessaire à son existence." In the same manner Agardh says:- "If in trees there are produced in each solar year new parts, so that the older hardened parts are replaced by new ones capable of conducting sap, we see herein a type of growth limited only by external causes." He ascribes the shortness of the life of herbs, or of such plants as are not trees, "to the preponderance of the production of flowers and fruit over the formation of leaves." Unfruitfulness is to a plant a prolongation of life. Endlicher cites the example of a plant of Medicago sativa, var. $\beta$ versicolor, 
which, bearing no fruit, lived eighty years. (Grundzüge der Botanik, 1843, S. 1003).

With the dragon trees, which, notwithstanding the gigantic development of their closed vassular bundles, must by reason of their floral parts be placed in the same natural family with asparagus and garden onions, we must asso. ciate the Adansonia (monkey bread-tree, Baobab,) as being certainly among the largest and oldest inhabitants of our planet. In the very first voyages of discovery of the Catalans and Portuguese, the navigators were accustomed to cut their names on these trro species of trees, not merely to gratify the desire of handing down their names, but also to serve as marks or signs of possession, and of whaterer rights nations claim on the ground of being the first discoverers. The Portuguese navigators often used as their "marco" or token of possession the French motto of the Infant Don Henrique the Discoverer. Manuel de Faria y Sousa says in his Asia Portuguesa (T. i. cap. 2, pp. 14 and 18):-"Era uso de los primeros Naregantes de dexar inscrito el Motto del Infante, talent de bien faire, en la corteza de los arboles." (Compare also Barros, Asia, Dec. I. liv. ii. cap. 2, T. i. p. 148; Lisboa, 1778.)

The above-named motto cut on the bark of two trees by Portuguese navigators in 1435 , twentyaeight years therefore before the death of the Infante, is curiously connected in the history of discoveries with the elucidations to which the comparison of Tespucci's fourth voyage with that of Gonzalo Coelho, in 1503, has given rise. Vespucci relates that Coelho's admiral's ship was wrecked on an island 
which has been sometimes supposed to be San Fernando Noronha, sometimes the Peñedo de San Pedro, and sometimes the problematical Island of St. Matthew. This lastnamed island was discovered by Garcia Jofre de Loaysa on the 15 th of October, 1525 , in $2 \frac{1}{2}^{\circ} \mathrm{S}$. lat., in the meridian of Cape Palmas, almost in the Gulf of Guinea. He remained thére eighteen days at anchor, found crosses, as well as orange trees which had been planted and had become wild, and on two trunks of trees inscriptions dating back ninety vears. (Navarrete, T. v. pp. 8, 247, and 4.01.) I have examined the questions presented by this account more in detail in my inquiries into the trustworthiness of Amerigo Vespucci. (Examen critique de l'hist. de lic Geographie, T. v. pp. 129-132.)

The oldest description of the Baobab (Adansonia digitata), is that given by the Venetian Aloysius Cadamosto (the real name was Alvise da Ca da Mosto), in 1454. He found at the mouth of the Senegal, trunks of which he estimated the circumierence at seventeen fathoms, or 102 feet, (Ramusio, Vol.i. p. 109) : he might have compared them with Dragon trees which he had seen before. Perrottet says in his "Flore de Sénégambie" (p. 76), that he had seen monkey bread-trees which, with a height of only about 70 or 80 feet, had a diameter of 32 English feet. The same dimensions had been given by Adanson, in the account of his voyage in 1748; the largest trunks which he himself saw (in 1749) in one of the small Magdalena 1slands near Cape de Verd, and in the vicinity of the mouth of the Senegal River, were from 26 to $28 \frac{1}{2}$ English feet in diameter, with a beight of little more than 70 feet, and a top about 180 feet broad; 
but he adds at the same time, that other travellers had found trunks of nearly 32 English feet diameter. French and Dutch sailors had cut their names on the trees seen by Adanson in letters half a foot long; the dates added to the names shewed these inscriptions to be all of the 16 th cenltury, except one which belonged to the 15th. (In Adanson's "Familles des Plantes", 1763, P. I. pp. ccxv.ccrviii., it stands as the 14th century, but this is doubtless an error of inadrertence.) From the depth of the inscriptions, which were covered with new lavers of rood, and from the comparison of the thickness of different trunks of the same species in which the relative age of the trees was known, Adanson computed the probable age of the larger trees, and found for a diameter. of 32 English feet 5150 years. (Voyage au S'̇negal, 1757, p. 66.) He prudently adds (I do not alter his curious orthography):- "Le calcul de l'aje de chake couche n'a pas d'exactitude géometrike." In the village of Grand Galarques, also in Senegambia, the negroes have ornamented the entrance of a hollow Baobab tree with sculptures cut out of the still fresh wood; the interior serves for holding meetings in which their interests are debated. Such a hall of assembly reminds one of the hollow or care (specus) of the plane tree in Lycia, in which Lucinius Mutianus, who had previously been consul, feasted with twenty-one guests. Plino (xii. 3) assigns to such a cavity in a hollow tree the somewhat large allowance of a breadth of eighty Roman feet. The Baobab was seen by Réné Caillié in the Valley of the Niger near Jenne, by Caillaud in Nubia, and by Wilhelm Peters along the whole eastern coast of Africa (where 
it is called Mulapa, i. e. Nlapa-tree, more properly Mutinlapa) as far as Lourenzo Marques, almost to $26^{\circ}$ of $\mathrm{S}$. lat. Although Cadamosto said in the 15 th century " eminentia non quadrat magnitudini," and although Golberry (Fragmens d'un Voyage en Afrique, T. ii. p. 92) found in the "Vallée des deux Gagnacks" trunks which, with 36 English feet diameter near the roots, were only 64 English feet high, yet this great disproportion between height and thickness must not be regarded as general. The learned traveller Peters remarks that "very old trees lose height by the gradual decay of the top, while they continue to increase in girth. On the East Coast of Africa one sees not unfrequently trunks of little more than ten feet diameter reach a height of 69 English feet."

If, according to what has been said, the bold estimations of Adanson and Perottet assign to the Adansonias measured by them an age of from 5150 to 6000 years, which would make them contemporaneous with the epoch of the building of the Pyramids or even with that of Menes, a period when the constellation of the Southern Cross was still visible in Northern Germany (Kosmos, Bd. iii. S. 402 and 487; Eng. ed. p. 29:3, and note 146), on the other hand, the more secure estimations made from the annual rings of trees in our northern temperate zone, and from the ratio which has been found to subsist between the thickness of the layer of wood and the time of growth, give us shorter periods. Decandolle finds as the result of his inquiries, that of all European species of trees the yew is that which attains the greatest age. He assigns to the yew (Taxus baccata) of 
Braborne, in the county of Kent, thirty centuries; to the Scotch yew of Fortingal, from twenty-five to trenty-six; and to those of Crowhurst in Surrey, and Ripon in York. shire, respectively, fourteen and a half and twelve centuries. (Decandolle, de la longévité dês arbres, p. 65.) Endlicher remarks that the age of another yew tree, in the Churchyard of Grasford, in North Wales, which measures 52. English feet in circumference below the branches, is estimated at 1400 jears, and that of a yew in Derbyshire at 2096 years. In Lithuania lime trees have been cut down which were 87 English feet in circumference, and in which 815 annual rings have been counted." (Endlicher, Grundzüge der Botanik, S. 399.) In the temperate zone of the southern hemisphere some species of Eucalyptus attain an enormous girth, and as they also reach to a great stature (above 230 Paris, 245 English, feet), they are singularly contrasted with our yer trees, whose great dimension is in thickness only. Mr. Backhouse found in Emu Bay, on the coast of Van Diemen Land, trunks of Eucalyptus which measured 70 English feet round the trunk near the ground, and five feet higher up 50 English feet. (Gould, Birds of Australia, Vol. I. Introd. p. xT.)

It is not, as is commonly stated, Malpighi, but the ingenious Michel Montaigne, who has the merit of haring been the first, in 1581, in his Voyage in Italie, to notice the relation of the annual rings to the age of the tree. (Adrien de Jussieu, Cours élémentaire de Botanique, 1840, p. 6.1.) A skilful artist, engaged in the preparation of astronomical instruments, had called the attention of Mon- 
taigne to the annual rings; and he also maintained that the rings were narrower on the north side of the tree. Jean Jacques Rousseau had the same belief; and his Emile, if he loses himself in a forest, is to direct himself by the indications afforded by the relative thickness of the layers of wood. More recent observations on the anatomy of plants teach us, however, that both the acceleration and also the retardation or intermission of growth, or the varying production of circles of ligneous fascicies (annual deposits) from the Cambium cells, depend on influences which are wholly distinct from the quarter of the heavens towards which one side of the amnual rings is turned. (Kunth, Lehrbuch der Botanik, 1847, T. i. S. 146 and 164; Lindley, Introduction to Bo.tany, 2d edition, p. 75.)

Trees which in individual cases attain a diameter of more than twenty feet, and an age extending to many centuries, belong to the most different natural families. I may name here Baobabs, Dragon-trees, some species of Eucalyptus, Taxodium disticum (Rich.), Pinus Lambertiana (Douglas), Hymenæa courbaril, Cæsalpinieæ, Bombax, Swietenia mahagoni, the Banyan tree (Ficus religiosa), Liriodendron tulipifera? Platanus orientalis, and our Limes, Oaks, and Yews. The celebrated Taxodium distichon, the Ahuahuete of the Mexicans, (Cupressus disticha Linn., Schubertia disticha Mirbel), at Santa Maria del Tule, in the state of Oaxaca, has not a diameter of 57 , as Decandolle says, but of exactly 38 French ( $40 \frac{1}{2}$ English) feet. (Mühlenpfordt, Versuch einer getreuen Schilderung der Republik Mexico, Bd. i. S. 153.) The two fine Ahuahuetes near Chapoltepec, 
which I have often seen, and which are probably the surviving remnants of an ancient garden or pleasure-ground of Montezuma, measure, (according to Burkart's aecount of his travels, Bd. i. S. 268, a work which otherwise contains much information), only 36 and 38 English feet in circumference; not in diameter, as has often been erroneously asserted. The Buddhists in Ceylon venerate the gigantic trunk of the sacred fig-tree of Anourahdepoura. The Indian fig-tree or Banyan, of which the branches take root round the parent stem, forming, as Onesicritus well described, a leafy canopy resembling a many-pillared tent, often attain a thickness of 28 ( $29 \frac{1}{2}$ English) feet diameter. (Lassen, Indische Alterthumskunde, Bd. i. S. 260.) On the Bombax ceiba, see early notices of the time of Columbus, in Bembo's Historiæ Venetæ, 1551, fol. 83.

Among oak-trees, of those which have been accurately measured, the largest in Europe is no doubt that near the town of Saintes, in the Departement de la Charente Inférieure, on the road to Cozes. This tree, which is 60 (64 English) feet high, has a diameter of 27 feet $8 \frac{1}{2}$ inches (29 $\frac{1}{2}$ English feet) near the ground: $21 \frac{1}{2}$ (almost 23 English) feet fire feet higher up; and where the great boughs commence 6 Parisian feet (6 feet 5 inches English.) In the dead part of the trunk a little chamber has been arranged, from 10 feet 8 inches to 12 feet 9 inches wide, and 9 feet 8 inches high (all English measure), with a semi-circular bench cut out of the fresh wood. A window gives light to the interior, so that the sides of the chamber (which is closed with a door) are clothed with ferms and 
lichens, giving it a pleasing appearance. Judging by the size of a small piece of wood which has been cut out above the door, and in which the marks of 200 annular rings have been counted, the oak of Saintes would be between 1800 and 2000 years old. (Annales de la Société d'Agriculture de la Rochelle, 1843, p. 380.)

In the wild rose-tree of the crypt of the Cathedral of Hildesheim, said to be a thousand years old, it is the root only, and not the stem, which is eight centuries old, according to accurate information derived from ancient and trustworthy original documents, for the knowledge of which I am indebted to the kindness of Stadtgerichts-Assessor Römer. A legend connects the rose-tree with a vow made by the first founder of the cathedral, Ludwig the Pious; and an original document of the 11th century says, "that when Bishop Hezilo rebuilt the cathedral which had been burnt down, he enclosed the roots of the rose-tree with a vault which still exists, raised upon this vault the crypt, which was re-consecrated in 1061, and spread out the branches of the rose-tree upon the walls." The stem now living is $26 \frac{1}{2}$ feet high and about two mches thick, and the outspread branches cover about 32 feet of the external wall of the eastern crypt; it is doubtless of considerable antiquity, and well deserving of the celebrity which it has gained throughout Germany.

If extraordinary development in point of size is to be regarded as a proof of long continued organic life, particular attention is due to one of the thalassophytes of the sub-marine vegetable world, $i$. e., to the Fucus giganteus, 
or Macrocystis pyrifera of Agardh. According to Captain Cook and George Forster, this sea-plant attains a length of 360 English feet; surpassing, therefore, the height of the loftiest Coniferæ, even that of the Sequoia gigantea, Endl., or Taxodium sempervirens, Hook and Arnott, which grows in California. (Darwin, Journal of Researches into Natural History, 1845, p. 239 ; and Captain Fitz-Roy in the Narrative of the Voyages of the Adventure and Beagle, vol. ii. p. 363.) Macrocystis pyrifera is found from $64^{\circ}$ south to $45^{\circ}$ north latitude, as far as San Francisco on the northwest coast of America; and Joseph Hooker believes it to extend as far as Kamtschatka. In the Antarctic seas it is even seen floating among the pack-ice. (Joseph Hooker, Botany of the Antarctic Voyage under the command of Sir James Ross, 1844, pp. 7, 1, and 178; Camille Montagne, Botanique cryptogame du Voyage de la Bonite, 1846, p. 36.). The immense length to which the bands or ribbands and the cords or lines of the cellular tissue of the Macrocystis attain, appears to be limited only by accidental injuries.

(13) p. 17.- "Species of phrenogamous plants already contained in herbariums."

We must carefully distinguish between three different questions: How many species of plants are described in printed works? how many have been discovered, $i$. e. are contained in herbariums, though without being described? how many are probably existing on the globe? Murray's edition of the Linnean system contains, including crypto-

TOL. II。 
gamia, only 10042 species. Willdenow, in his edition of the Species Plantarum, between the years 1797 and 1807, had already described 17457 phænogamous species, (from Monandria to Polygamia diœcia.) If we add 3000 cryptogamous species, we obtain the number which Willdenow mentions, viz. 20000 species. More recent researches have shown how much this estimation of the number of species described and contained in herbariums falls short of the truth. Robert Brown counted above 37000 phænogamous plants. (General Remarks on the Botany of Terra Australis, p. 4.) I afterwards attempted to give the geographical distribution (in different parts of the earth already explored), of 44000 phænogamous and cryptogamous plants. (Humboldt, de distributione geographica Plantarum, p. 23.) Decandolle found, in comparing Persoon's Enchiridium with his Universal System in 12 several families, that the writings of botanists and European herbariums taken together might be assumed to contain upwards of 56000 species of plants. (Essai élementaire de Géographie botanique, p. 62.) If we consider how many species have since that period been described by travellers,-(my expedition alone furnished 3600 of the 5800 collected species of the equinoctial zone),-and if we remember that in all the botanical gardens taken together there are certainly above 25000 phænogamous plants cultivated, we shall easily perceive how much Decandolle's number falls short of the truth. Completely unacquainted as we still are with the larger portions of the interior of South America,-(Mato-Grosso, Paraguay, the eastern declivity of the Andes, Santa Cruz 
de la Sierra, and all the countries between the Orinoco, the Rio Negro, the Amazons, and Puruz), - of Africa, Madagascar, Borneo, and Central and Eastern Asia,- the thought rises involuntarily in the mind that we may not yet know the third, or probably even the fifth part of the plants existing on the earth! Drège has collected 7092 species of phænogamous plants in South Africa alone. (See Meyer's pflanzen geographische Documente, S. 5 and 12.) He believes that the Flora of that district consists of more than 11000 phænogamous species, while on a surface of equal area (12000 German, or 192000 English square geographical miles) von Koch has described in Germany or Switzerland 3300, and Decandolle in France 3645 species of phænogamous plants. I would also recall that even now new Genera, (some even consisting of tall forest trees), are being discovered in the small West Indian Islands which have been visited by Europeans for three centuries, and in the vicinity of large commercial towns. These considerations, which I propose to develop in further detail at the close of the present annotation, make it probable that the actual number of species exceeds that spoken of in the old myth of the Zend-Avesta, which says that "the Primeval Creating Power called forth from the blood of the sacred bull 120000 different forms of plants!" If, then, we cannot look for any direct scientific solution of the question of how many forms of the vegetable kingdom,including leafless Cryptogamia (water Algæ, funguses, and lichens), Characeæ, liver-worts, mosses, Marsilaceæ, Lycopodiaceæ, and ferns, - exist on the dry land and in the ocean 
in the present state of the organic life of our globe, we may yet attempt an approximate method by which we may find some probable "lowest limits" or numerical minima. Since 1815, I have sought, in arithmetical considerations relating to the geography of plants, to examine first the ratios which the number of species in the different natural families bear to the entire mass of the phænogamous vegetation in countries where the latter is sufficiently well known. Robert Brown, the greatest botanist among our cotemporaries, had previously determined the numerical proportions of the leading divisions of the vegetable kingdom; of Acotyledons (Agamæ, Cryptogamic or cellular plants) to Cotyledons (Phanerogamic or vascular plants), and of Monocotyledonous (Endogenous) to Dicotyledonous (Exogenous) plants. He finds the ratio of Monocotyledons to Dicotyledons in the tropical zone as $1: 5$, and in the cold zones of the parallels of $60^{\circ} \mathrm{N}$. and $55^{\circ} \mathrm{S}$. latitude, as $1: 2 \frac{1}{2}$. (Robert Brown, General Remarks on the Botany of Terra Australis, in Flinders' Voyage, vol. ii. p. 338.) The absolute number of species in the three leading divisions of the vegetable kingdom are compared together in that work according to the method there laid down. I was the first to pass from these leading divisions to the divisions of the several families, and to consider the ratio which the number of species of each family bears to the entire mass of phænogamous plants belonging to a zone of the earth's surface. (Compare my memoir entitled "De distributione geographica Plantarum secundum cœli temperiem et altitudinem montium, 1817, p. 24-44; and the farther development of the subject of these numerical 
relations given by me in the Dictionmaire des Sciences naturelles, T. xriii. 1820, p. 422-4:36; and in the Amales de Chimie et de Physique, T. xri. 1821, p. 267-292.)

The numerical relations of the forms of plants, and the laws observed in their geographical distribution, may be considered in two rery different ways. If plants are studied in their arrangement according to natural families, without regard to their geographical distribution, it is asked, What are the fundamental forms or types of organisation to which the greatest number of species correspond? Are there on the entire surface of the earth more Glumacex than Compositæ? Do these two orders make up between them onefourth part of the whole number of phronogamous plants? What is the proportion of Monocotyledons to Dicotyledons? These are questions of General Phytology, or of the science which investigates the organsation of plants and their mutual comnection, or the present state of the entire vegetable world.

If, on the other hand, the species of plants which have been grouped according to the analogy of their structure are considered, not abstractedly, but according to their climatic relations, or according to their distribution over the surface of the earth, we have questions offering quite another and distinct interest. We then examine that are the families which prevail more in proportion to other Phanerogama in the torrid zone than towards the polar circle? Are Compositæ more numerous, either in the same geographical latitudes or on the same isothermal lines, in the New than in the Old Continent? Do the forms which gradually lose 
their predominance in advancing from the equator towards the poles follow a similar law of decrease in ascending mountains situated in the equatorial regions? Do the proportions of particular families to the whole mass of Phanerogamæ differ in the temperate zones, and on equal isothermal lines, north and south of the equator? These questions belong properly to the Geography of Plants, and connect themselves with the most important problems of meteorology and terrestrial physics. The character of a landscape or country is also in a high degree dependent on the predominance of particular families of plants, which render it either desolate or adorned, smiling or majestic. Grasses forming extensive savannahs, Palms and other trees affording food, or social Coniferæ forming forests, have powerfully influenced nations in respect to their material condition, to their manners, to their mental dispositions, and to the more or less rapid development of their prosperity.

In studying the geographical distribution of forms, we may consider species, genera, and natural families, separately. In social plants, a single species often covers extensive tracts of country; as in northern regions forests of Pines or Firs and extensive heaths (ericeta), in Spain cistus-covered grounds, and in tropical America assemblages of the same species of Cactus, Croton, Brathys, or Bambusa Guadua. It is interesting to examine these relations more closely, and to view in one case the great multiplicity of individuals, and in another the variety of organic development. We may inquire what species produces the greatest number of individuals in a particular zone, or we may ask 
which are the families to which, in different climates, the greatest number of species belong. In a high northern region, where the Compositæ and the Ferns are to the sum of all the phrnogamous plants in the ratio of $1: 13$ and $1: 25$ (i.e. where these ratios are found by dividing the sum total of all the Phanerogamæ by the number of species belonging to the family of Composite or to that of Filices or Ferns), it may nevertheless happen that a single species of fern covers ten times more ground than do all the species of Compositæ taken together. In this case Ferms predominate orer Compositæ by their mass, or by the number of individuals belonging to the same species of Pteris or Polypodium; but they do not so predominate if we only compare the number of the different specific forms of Filices and Compositæ with the sum of all the phænogamous plants. Since, then, multiplication of plants does not follow the same law in all species, - that is to say, all species do not produce the same number of individuals, - therefore the quotients given by dividing the sum of the phænogamous plants by the number of species belonging to one family, do not suffice by themselves to determine the character of the landscape, or the physiognomy which Nature assumes in different regions of the earth. If the attention of the travelling botanist is engaged by the frequent repetition of the same species, their mass, and the uniformity of regetation thus produced, it is even more arrested by the rarity or infrequency of several other species which are valuable to mankind. In tropical regions, where the Rubiaceæ, Myrtaceæ, Leguminosæ, or Terebinthaceæ, form forests, one is 
astonished to find the trees of Cinchona, particular species of Swietenia (Mahogany), Hæmatoxylon, Styrax, and balsamic Myroxylum, so sparingly distributed. We had occasion, on the declivities of the high plains of Bogota and Popayan, and in the country round Loxa, in descending towards the unhealthy valley of the Catamayo and to the Amazons River, to remark the manner in which the trees which furnish the precious fever-bark (species of Cinchona) are found singly and at considerable distances from each other. The China Hunters, Cazadores de Cascarilla (the name given at Loxa to the Indians and Mestizoes who collect each year the most efficacious of all fever-barks, that of the Cinchona Condaminea, among the lonely mountains of Caxanuma, Uritusinga, and Rumisitana), climb, not without peril, to the summits of the loftiest forest trees in order to gain a wide prospect, and to discern the solitarily scattered slender aspiring trunks of the trees of which they are in search, and which they recognise by the shining reddish tint of their large leaves. The mean temperature of this important forest region, situated in $4^{\circ}$ to $4 \frac{1}{2}^{\circ} \mathrm{S}$. lat. and at an elevation of about 6400 to 8000 English feet, is from $12 \frac{1^{\circ}}{2}$ to $16^{\circ}$ Réaumur $\left(60^{\circ} \cdot 2\right.$ to $68^{\circ} \mathrm{F}$ ahr.) (Humboldt and Bonpland, Plantes équinoxiales, T. i. p. 33, tab. 10.)

In considering the distribution of species, we may also proceed, without regard to the multiplication of individuals, to the masses which they form or the space which they occupy, and may simply compare together the absolute number of species belonging to a particular family in each country. This is the mode of comparison which Decandolle has 
employed in the work entitled Regni vegetabilis Systema naturale (T. i. p. 128, 396, 439, 464, and 510), and Kunth has carried it out in regard to the whole number of species of Compositæ at present known (abore 3300). It does not show which is the predominant family either in the number of species or in the quantity of individuals as compared with other families; it merely tells how many of the species of one and the same family are indigenous in each country or each quarter of the world. The results of this method are on the whole more exact, because they are obtained by the careful study of single families without the necessity of being acquainted with the whole number of the phanerogamæ belonging to each country. The most varied forms of Ferns, for example, are found betreen the tropics; it is there, in the tempered heat of moist and shaded places in mountainous islands, that each genus presents the largest number of species: this variety of species in each genus diminishes in passing from the tropical to the temperate zone, and decreases stili farther in approaching nearer to the pole. Nevertheless, as in the cold zone-in Lapland, for example-those plants succeed best which can best resist the cold, so the species of Ferns, although the absolute number is less than in France or Germany, are yet relatively more numerous than in those countries; $i$. e. their number bears a greater proportion to the sum total of all the phanerogamous plants of the country. These proportions or ratios, given as abovementioned by quotients, are in France and Germany $\frac{1}{73}$ and $\frac{1}{71}$, and in Lapland $\frac{1}{25}$. I published numerical ratios of 
this kind,-( $i . e$. the entire quantity of phænogamous plants in each of the different Floras divided by the number of species in each family) - in my Prolegomenis de distributione geographica Plantarum, in 1817; and in the Memoir on the distribution of plants over the Earth's surface, subsequently published in the French language, I corrected my previously published numbers by Robert Brown's great works. In advancing from the Equator to the Poles, the ratios taken in this manner vary considerably from the numbers which would be obtained from a comparison of the absolute number of species belonging to each family. We often find the value of the fraction increase by the decrease of the denominator, while yet the absolute number of species has diminished. In the method by fractions, which I have followed as more instructive in reference to the geography of plants, there are two variables; for in proceeding from one isothermal line, or one zone of equal temperature, to another, we do not see the sum total of all the phanerogamæ change in the same proportion as does the number of species belonging to a particular family.

We may, if we please, pass from the consideration of species to that of divisions formed in the natural system of botany according to an ideal series of abstractions, and direct our attention to Genera, to Families, and even to the still higher, i. e. more comprehensive, Classes. There are some genera, and éven some entire families, which belong exclusively to particular zones of the Earth's surface ; and this not only because they can only flourish under a particular 
combination of climatic conditions, but also because both the localities in which they originated, and their migrations, have been limited. It is otherwise with the greater number of genera and of families, which have their representatives in all regions of the globe, and at all latitudes of elevation. The earliest investigations into the distribution of vegetable forms related solely to genera; we find them in a valuable work of Treviranus, in his Biology (Bd. ii. S. 47,63, 83, and 129). This method is, horrever, less fitted to afford general results than that which compares either the number of species of each family, or the great leading divisions (of Acotyledons, Monocotyledons, and Dicotyledons) with the sum of all the phanerogamæ. We find that in the cold zones the variety of forms does not lecrease so much if estimated by genera as if estimated by species; in other words, we find relatively more genera and fewer species. (Decandolle, Théorie élémentaire de la Botanique, p. 190 ; Humboldt, Nova genera et species Plantarum, T. i. pp. xvii. and 1.) It is almost the same in the case of high mountains whose summits support single members of a large number of genera, which we should have been à priori inclined to regard as belonging exclusively to the vegetation of the plains.

I have thought it desirable to indicate the different points of view from which the laws of the geographical distribution of plants may be considered. It is by confounding these different points of view that apparent contradictions are found, which are unjustly attributed to uncertainties of observation. (Jahrbiicher der Gewächskunde, Bd. i. Berlin, 1818, S. 18, 21, 30.) When such expressions as the following are made use of - "This form, or this 
family, diminishes as the cold zones are approached;it has its true home in such or such a latitude;-it is a southern form;-it predominates in the temperate zone;" care should always be taken to state expressly whether the writer is speaking of the absolute number of species, and its increase or decrease with the change of latitude; or whether he means that the family in question prevails over other families of plants as compared with the entire number of phanerogamæ of which a Flora consists. The impression of prevalence as conveyed by the eye depends on relative quantity.

Terrestrial physics have their numerical elements, as has the System of the Universe, or Celestial Physics, and by the united labours of botanical travellers we may expect to arrive gradually at a true knowledge of the laws which determine the geographical and climatic distribution of vegetable forms. I have already remarked that in the temperate zone the Compositæ (Synanthereæ), and the Glumaceæ (including under this latter name the three families of Grasses, Cyperoidæ and Juncaceæ), make up the fourth part of all phænogamous plants. The following numerical ratios are the results of my investigations for 7 great families of the vegetable kingdom in the same temperate zone.

Glumaceæ $\quad \frac{1}{8} \quad$ (Grasses alone $\frac{1}{12}$ )

Compositæ $\frac{1}{8}$

Leguminosæ $\frac{1}{18}$

Labiatæ $\frac{1}{24}$

Umbelliferæ $\frac{1}{40}$

Amentaceæ (Cupuliferæ, Betulineæ, and Salicineæ) $\frac{1}{45}$

Cruciferæ $\quad \frac{1}{19}$ 
The forms of organic being's are in reciprocal dependence on each other. In the unity of nature these forms limit each other according to laws which are probably attached to periods of long duration. If on any particular part of the globe we know with accuracy the number of species of one of the great families of Glumacex, Leguminosæ, or Compositæ, we mar with a tolerable degree of probability form approximative inferences, both as to the sum of all the phanerogame of the country, and also as to the number of species belonging to the rest of the leading families of plants. The number of Cyperoidæ determines that of Composita, and the number of Compositæ that of Leguminosæ; they even enable us to judge in what classes or orders the Floras of countries are still incomplete, and teach us, if we are on our guard against confounding together very different systems of regetation, what harvest. may still remain to be reaped in the several families.

The comparison of the numerical ratios of families in different already well explored zones, has conducted me to the recoguition of laws according to which, in proceeding from the equator to the poles, the vegetable forms constituting a natural family decrease or increase as compared with the whole mass of phanerogamæ belonging to each zone. We hare here to regard not only the direction of the change (whether an increase or a decrease), but also its rapidity or measure. The see the denominator of the fraction which expresses the ratio increase or decrease: let us take as our example the beautiful family of Leguminosæ, which decreases in going from the equinoctial zone towards the North Pole. If we find its proportion or ratio for the 
torrid zone (from $0^{\circ}$ to $10^{\circ}$ of latitude) at $\frac{1}{10}$, we obtain for the part of the temperate zone which is between $45^{\circ}$ and $52^{\circ}$ latitude $\frac{1}{18}$, and for the frigid zone (lat. $67^{\circ}$ to $70^{\circ}$ ) only $\frac{1}{3} \frac{1}{5}$. The direction followed by the great family of Leguminosæ (increase on approaching the equator), is also that of the Rubiaceæ, the Euphorbiaceæ, and especially the Malvaceæ. On the contrary, the Grasses and Juncaceæ (the latter still more than the former), diminish in approaching the equator, as do also the Ericeæ and Amentaceæ. The Compositæ, Labiatæ, Umbelliferæ, and Cruciferæ, decrease in proceeding from the temperate zone, either towards the pole or towards the equator, the Umbelliferæ and Cruciferæ decreasing most rapidly in the last-named direction; while at the same time in the temperate zone the Cruciferæ are three times more numerous in Europe than in the United States of North America. On reaching Greenland the Labiatæ have entirely disappeared with the exception of one, and the Umbelliferæ with the exception of two species; the entire number of phænogamous species, still amounting; according to Hornemann, to 315 species.

It must be remarked at the same time that the development of plants of different families, and the distribution of vegetable forms, does not depend exclusively on geographical, or even on isothermal latitude; the quotients are not always on the same isothermal line in the temperate zone, for example, in the plains of North America and those of the Old Continent. Within the tropics there is a very sensible difference between America, India, and the West Coast of Africa. The distribution of organic beings over the surface of the earth does not depend wholly on thermic or climatic 
relations, which are of themselves very complicated, but also on geological causes almost unknown to us, belonging to the original state of the earth, and to catastrophes which have not affected all parts of our planet simultaneously. The large pachydermatous animals are at the present time nanting in the New Continent, while we still find them in analogous climates in Asia and Africa. These differences ought not to deter us from endeavouring to search out the concealed laws of nature, but should rather stimulate us to the study of them through all their intricacies.

The numerical laws of the families of plants, the often striking agreement of the numbers expressing their ratios, where yet the species of which the families consist are for the most part different, conduct us into the mysterious obscurity which envelopes all that is connected with the fixing of organic types in the species of plants and animals, or with their original formation or creation. I will take as examples two adjoining countries which have both been thoroughly explored-France and Germany. In France, many species of Grasses, Umbelliferæ and Cruciferæ, Compositæ, Leguminosæ, and Labiatæ, are wanting which are common in Germany; and yet the numerical ratios of these six great families are almost identical in the two countries, as will be seen by the subjoined comparison.

Fanilies.

Gramineæ.

Umbelliferæ.

Cruciferæ.

Compositæ.

Leguminosæ.

Labiatæ.
Germany.

$\frac{1}{13}$

$\frac{1}{22}$

$\frac{1}{18}$

$\frac{1}{8}$

$\frac{1}{13}$

$\frac{1}{26}$
France.

$\frac{1}{13}$

$\frac{1}{21}$

$\frac{1}{19}$

$\frac{1}{7}$

$\frac{1}{16}$

$\frac{1}{21}$ 
This agreement in the number of species in each family compared to the whole number of phænogamous species in the Floras of France and Germany, would not by any means exist if the German species which are missing in France were not replaced there by other types belonging to the same families. Those who are fond of imagining gradual transformations of species, and suppose the different kinds of parrots proper to two islands not far removed from each other to present examples of such a change, will be inclined to attribute the remarkable similarity between the two columns of figures which have just been given, to a migration of species, which, having been the same at first, have been altered gradually by the long-continued action of climatic causes during thousands of years, so that their identity being lost they appear to replace each other. But why is it that our common heather (Calluna vulgaris), why is it that our oaks have never advanced to the eastward of the Ural Mountains, and so passed from Europe to Northern Asia? Why is there no species of the genus Rosa in the Southern Hemisphere, and why are there scarcely any Calceolarias in the Northern Hemisphere? The necessary conditions of temperature are insufficient to explain this. Thermic relations alone cannot, any more than the hypothesis of migrations of plants radiating from certain central points, explain the present distribution of fixed organic forms. Thermic relations are hardly sufficient to explain the limits beyond which individual species do not pass, either in latitude towards the pole at the level of the sea, or in vertical elevation towards the summits of mountains. The cycle of vegetation in each species, however different its duration may be, 
requires, in order to be successfully passed through, a certain minimum of temperature. (Playfair, in the Transactions of the Royal Society of Edinburgh, vol. v. 1805, p. 202; Humboldt, on the sum of the degrees of temperature required for the cycle of vegetation in the Cerealia, in Mem. sur les lignes isothermes, p. 96 ; Boussingault, Economie rurale, T. ii. p. 659, 663, and 667; Alphonse Decandolle sur les causes qui limitent les espèces végétales, 1847, p. 8.) But all the conditions necessary for the existence of a plant, either as diffused naturally or by cultivation,-conditions of latitude or minimum distance from the pole, and of elevation or maximum height above the level of the sea, - are farther complicated by the difficulty of determining the commencement of the thermic cycle of regetation, and by the influence which the unequal distribution of the same quantity of heat into groups of successive days and nights exercises on the excitability, the progressive development, and the whole vital process; to all this must be farther added hygrometric influences and those of atmospheric electricity.

My investigations respecting the numerical laws of the distribution of forms may possibly be applied at some future day with advantage to the different classes of Rotiferæ in the animal creation. The rich collections at the Museum d'Histoire Naturelle in the Jardin des Plantes at Paris, already contained, in 1820, (acccording to approximate estimations) above 56000 phænogamous and cryptogamous plants in herbariums, 44000 insects (a number doubtless too small, though given me by Latreille), 2500 species of

VOL. II. 
fish, 700 reptiles, 4000 birds, and 500 mammalia. Europe has about 80 species of indigenous mammalia, 400 birds, and 30 reptiles. In the Northern temperate zone, therefore, the species of birds are five times nore numerous than those of mammalia, as there are in Europe five times as many Compositæ as there are Amentaceæ and Coniferæ, and five times as manyLeguminosæ as there are Orchideæ andEuphorbiaceæ. In the southern hemisphere the ratio of mammalia is in tolerably striking agreement, being as 1. to $4 \cdot 3$. Birds, and still more reptiles, increase in the number of species in approaching the torrid zone more than the mammalia. Cuvier's researches might lead us to believe that the proportion was different in the earlier state of things, and that many more mammalia had perished by revolutions of Nature than birds. Latreille has shewn what groups of insects increase towards the pole, and what towards the equator. Hiliger has given the countries of 3800 species of birds according to the quarters of the globe : it would have been much more instructive if the same thing had been done according to zones. We should find little difficulty in comprehending how on a given space of the earth's surface the individuals of a class of plants or animals limit each other's numbers, or how, after long continued contest and many fiuctuations caused by the requirements of nourishment and mode of life, a state of equilibrium should be at last established; but the causes which have limited not the number of individuals of a form, but the forms themselves, in a particular space, and founded their typical diversity, are placed beneath the impenetrable veil which still conceals 
from our eyes all that relates to the manner of the first creation and commencement of organic beings.

If, then, we would attempt to solve the question spoken of in the early part of this dissertation, by giving in an approximate manner the numerical limit, (le nombre limite of French mathematicians), which the whole phanerogamæ now existing on the surface of the earth cannot be supposed to fall short of, we may perhaps find our safest guide in a comparison of the numerical ratios (which, as we have seen, may be assumed to exist between the different families of plants), with the number of species contained in herbariums and cultivated in our great botanic gardens. I have said that in 1820 the number of species contained in the herbariums of the Jardin des Plantes at Paris was already estimated at 56000. I do not permit myself to conjecture the amount which the herbariums of England may contain; but the great Paris herbarium, which was formed with much personal sacrifice by Benjamin Delessert, and given by him for free and general use, was stated at his death to contain $\$ 6000$ species; a number almost equal to that which, as late as 1835, was conjecturally assigned by Lindley as that of all the species existing on the whole earth. (Lindley, Introduction to Botany, 2d edit. p. 504.) Few herbariums have been reckoned with care, after a complete and strict separation and withdrawal of all mere varieties. Not a few plants contained in smaller collections are still wanting in the greater herbariums which are supposed to be general or complete. Dr. Klotzsch estimates the present entire number of phænogamous plants in the great 
Royal Herbarium at Schöneberg, near Berlin, of which he is the curator, at 74000 species.

Loudon's useful work, Hortus Britannicus, gives an approximate view of all the species which are, or at no remote time have been, cultivated in British gardens: the edition of 1832 enumerates, including indigenous plants, exactly 26660 phænogamous species. We must not confound with this large number of plants which have grown or been cultivated at any time and in any part of the whole British Islands, the number of living plants which can be shewn at any single moment of time in any single botanic garden. In this last-named respect the Botanic Garden of Berlin has long been regarded as one of the richest in Europe. The fame of its extraordinary riches rested formerly only on uncertain and approximate estimations, and, as my fellowlabourer and friend of many years' standing, Professor Kunth, has justly remarked (in manuscript notices communicated to the Gartenbau-Verein in December 1846), "no real enumeration or computation could be made until a systematic catalogue, based on a rigorous examination of species, had been prepared. Such an enumeration has given rather above 14060 species: if we deduct from this number 375 cultivated Ferns, we have remaining 13685 phænogamous species; among which we find 1600 Compositæ, 1150 Leguminosæ, 428 Labiatæ, 370 Umbelliferæ, 460 Orchideæ, 60 Palms, and 600 Grasses and Cyperaceæ. If we compare with these numbers those of the species already described in recent works,-Compositæ (Decandolle and Walpers) about 10000 ; Leguminosæ, 8070 ; Lạbiatæ 
(Bentham), 2190; Umbelliferæ, 1620; Grasses, 3544; and Cyperaceæ (Kunth, Enumeratio Plantarum), 2000 ;we shall perceive that the Berlin Botanic Garden cultivates, of the very large families (Compositæ, Leguminosæ, and Grasses), only 1-7th, 1-8th, and 1-9th; - and of the small families (Labiatæ and Umbelliferæ), about 1-5th, or 1-4th, of described species. If, then, we estimate the number of all the different phænogamous plants cultivated at one time in all the botanic gardens of Europe at 20000, we find that the cultivated speciesoappear to be about the eighth part of those which are already either described or preserved in herbariums, and that these must nearly amount to 160000 . This estimate need not be thought excessive, since of many of the larger families, (for example, Guttiferæ, Malpighiaceæ, Melastomex, Myrtacex, and Rubiacex), hardly a hundredth part are found in our garden." If we take the number given by Loudon in his Hortus Britannicus (26660 species) as a basis, we shall find, (according to the justly drawn succession of inferences of Professor Kunth, in the manuscript notices from which I have borrowed the above), the estimate of 160000 species rise to 213000 ; and even this is still very moderate, for Heynhold's Nomenclator botanicus hortensis (1846) even rates the phænogamous species then cultivated at 35600 ; whereas I have employedLoudon's number for 1832, viz. 26660. On the whole it would appear from what has been said,-and the conclusion is at first sight a sufficiently striking one,一that at present there are almost more known species of phænogamous plants (with which we are 
acquainted by gardens, descriptions, or herbariums), than there are known insects. According to the average of the statements which I have received from several of our most distinguished entomologists whom I have had the opportunity of consulting, the number of insects at present described, or contained in collections without being described, may be taken at between 150000 and 170000 species. The rich Berlin collection does not contain less than 90000 species, among which are about 32000 Coleoptera. A very large number of plants have been collected in distant parts of the globe, without the insects which live on them or near them being brought at the same time. If, however, we limit the estimates of numbers to a single part of the world, and that the one which has been the best explored in respect to both plants and insects, viz. Europe, we find a very different proportion; for while we can hardly enumerate between seven and eight thousand European phænogamous plants, more than three tumes that number of Europear insects are already known. According to the interesting. communications of my friend Dohrn at Stettin, 8700 insects have already been collected from the rich Fauna of that vicinity, (and many micro-Lepidopteræ are still wanting), while the phrnogamous plants of the same district scarcely exceed 1000. The Insect Fauna of Great Britain is estimated at 11600 species. Such a preponderance of animal forms need the less surprise us, since large classes of insects subsist solely on animal substances, and others on agamous vegetation (funguses, and even those which are subterren- 
nean). Bombyx pini alone (the spider which infests the Scotch fir, and is the most destructive of all forest insects), is visited, according to Ratzeburg, by thirty-five parasitical Ichneumonides.

If these considerations have led us to the proportion borme by the species of plants cultivated in gardens to the entire amount of those which are already either described or preserved in herbariums, we have still to consider the proportion borne by the latter to what we conjecture to be the whole number of forms existing upon the earth at the present time; i.e. to test the assumed minimum of such forms by the relative numbers of species in the different families, therefore, by uncertain multipliers. Such a test, however, gives for the lowest limit or minimum number results so low as to lead us to perceive that even in the great families, - our knowledge of which has been of late most strikingly enriched by the descriptions of botanists, -we are still acquainted with only a small part of existing plants. The Repertorium of Talpers completes Decandolle's Prodromus of 1825, up to 1846: we find in it, in the family of Leguminosæ, 8068 species. Tre may assume the ratio, or relative numerical proportion of this family to all phanogamous plants, to be $\frac{1}{21}$ - as we find it $\frac{1}{10}$ within the tropics, $\frac{1}{18}$ in the middle temperate, and $\frac{1}{35}$ in the cold northern zone. The described Leguminosæ rould thus lead us to assume only 169400 existing phænogamous species on the whole surface of the earth, whereas, as we have shewn, the Composita indicate more than 160000 already known species. The discordance is instructive, and 
may be further elucidated and illustrated by the following analogous considerations.

The major part of the Compositæ, of which Linnæus knew only 785 species and which has now grown to 12000 , appear to belong to the Old Continent: at least Decandolle described only 3590 American, whilst the European, Asiatic, and African species amounted to 5093. This apparent richness in Compositæ is, however, illusive, and considerable only in appearance; the ratio or quotient of the family, $\left(\frac{1}{15}\right.$ between the tropics, $\frac{1}{7}$ in the temperate zone, and $\frac{1}{13}$ in the cold zone), shews that even more species of Compositre than Leguminosæ must hitherto have escaped the researches of travellers; for a multiplication by 12 would give us only the improbably low number of 144000 Phænogamous species. The families of Grasses and Cyperaceæ give still lower results, because comparatively still fewer of their species have been described and collected. We have only to cast our eyes on the map of South America, remembering the wide extent of territory occupied by grassy plains, not only in Venezuela and on the banks of the Apure and the Meta, but also to the south of the forest-covered regions of the Amazons, in Chaco, Eastern Tucuman, and the Pampas of Buenos Ayres and Patagonia, bearing in mind that of all these extensive regions the greater part have never been explored by botanists, and the remainder only imperfectly and incompletely so. Northern and Central Asia offer an almost equal extent of Steppes, but in which, however, dicotyledonous herbaceous plants are more largely mingled with the Graminex. If we had sufficient grounds for be- 
lieving that we are now acquainted with half the phænogamous plaits on the globe, and if we took the number of known species only at one or other of the before-mentioned numbers of 160000 or 213000 , we should still have to take the number of grasses (the general proportion of which appears to be $\frac{1}{12}$ ), in the first case at least at 26000 , and in the second case at 35000 different species, which would give respectively in the two cases only either $\frac{1}{8}$ or $\frac{1}{10}$ part as known.

The assumption that we already know half the existing species of phænogamous plants is farther opposed by the following considerations. Several thousand species of Monocotyledons and Dycotyledons, and among them tall trees,-(I refer here to my own Expedition), - have been discovered in regions, considerable portions of which had been previously examined by distinguished botanists. The portions of the great continents which have never even been trodden by botanical observers considerably ex. ceed in area those which have been traversed by such travellers, even in a superficial manner. The greatest variety of phænogamous regetation, $i . e$. the greatest number of species on a given area, is found between the tropics, and in the sub-tropical zones. This last-mentioned consideration renders it so much the more important to remember how almost entirely unacquainted we are, on the New Continent, north of the equator, with the Floras of Oaxaca, Yucatan, Guatimala, Nicaragua, the Isthmus of Panama, Choco, Antioquia, and the Prorincia de los Pastos; -and south of the equator, with the Floras of the vast 
forest region between the Ucayale, the Rio de la Madera, and the Tocantin (three great tributaries of the Amazons), and with those of Paraguay and the Provincia de los Missiones. In Africa, except in respect to the coasts, we know nothing of the vegetation from $15^{\circ}$ north to $20^{\circ}$ south latitude; in Asia we are unacquainted with the Floras of the south and south-east of Arabia, where the highlands rise to about 6400 English feet above the level of the sea,-of the countries between the Thian-schan, the Kuenlün, and the Himalaya, all the west part of China, and the greater part of the countries beyond the Ganges. Still more unknown to the botanist wre the interior of Borneo, New Guinea, and part of Australia. Farther to the south the number of species undergoes a wonderful diminution, as Joseph Hooker has well and ably shewn from his own observation in his Antarctic Flora. The three islands of which New Zealand consists extend from $34 \frac{1}{2}^{\circ}$ to $47 \frac{1}{4}^{\circ} \mathrm{S}$. latitude, and as they contain, moreover, snowy mountains of above 8850 English feet elevation, they must include considerable diversity of climate. The Northern Island has been examined with tolerable completeness from the voyage of Banks and Solander to Lesson and the Brothers Cunningham and Colenso, and yet in more than 70 years we have only become acquainted with less than 700 phænogamous species. (Dieffenbach, Travels in New Zealand, 1843, vol. i. p. 419.) The paucity of vegetable corresponds to the paucity of animal species. Joseph Hooker, in his Flora Antarctica, p. 73-75, remarks that "the botany of the densely wooded regions of the Southern Islands of the New Zealand group 
and of Fuegia is much more meagre not only than that of similarly clothed regions of Europe, but of islands many degrees nearer to the Northern pole than these are to the Southern one. Iceland, for instance, which is from 8 to 10 degrees farther from the equator than the Auckland and the Campbell Islands, contains certainly five times as many flowering plants. In the Antarctic Flora, under the in= fluence of a cool and moist, but singularly equable climate, great uniformity, arising from paucity of species, is associated with great luxuriance of regetation. This striking uniformity prevails both at different levels, (the species found on the plains appearing also on the slopes of the mountains), and orer vast extents of country, from the south of Chili to Patagonia, and even to Tierra del Fuego, or from lat. $45^{\circ}$ to $56^{\circ}$. Compare, on the other hand, in the nor thern temperate region, the Flora of the South of France, in the latitude of the Chonos Archipelago on the coast of Chili, with the Flora of Argyleshire in Scotland in the latitude of Cape Horn, and how great a difference of species is found; while in the Snuthern Hemisphere the same types of regetation pass through many degrees of latitude. Lastly, on Walden Island, in lat. $80 \frac{1}{2}^{\circ} \mathrm{N}$., or not ten degrees from the North Pole of the earth, ten species of flowering plants have been collected, while in the southernmost islet of the South Shetlands, though only in lat. $63^{\circ} \mathrm{S}$, only a solitary grass mas found." These considerations on the distribution of plants confirm the belief that the great mass of still unobserved, uncollected, and undescribed flowering plants must be sought for in tropical 
countries, and in the latitudes from $12^{\circ}$ to $15^{\circ}$ distant from the tropics.

It has appeared to me not unimportant to show the imperfect state of our knowledge in this still little cultivated department of arithmetical botany, and to propound numerical questions in a more distinct and determinate manner than could have been previously done. In all conjectures respecting numerical relations we must seek first for the possibility of deducing the lower or minimum limits; as in a question treated of by me elsewhere, on the proportion of coined gold and silver to the quantity of the precious metal fabricated in other ways; or as in the questions of how many stars, from the 10th to the 12th magnitude, are dispersed over the sky, and how. many of the smallest telescopic stars the Milky Way may contain. (John Herschel, Results of Astron. Observ. at the Cape of Good Hope, 1847, p. 381.) We may consider it as establiṣhed, that if it were possible to know completely and thoroughly by observation all the species belonging to one of the great families of phanerogamous or flowering plants, we should learn thereby at the same time, approximatively, the entire sum of all such plants (including all the families). As, therefore, by the progressive exploration of new countries we progressively and gradually exhaust the remaining unknown species of any of the great families, the previously assigned lowest limit rises gradually higher, and since the forms reciprocally limit each other in conformity with still undiscoveredlaws of universal organisation, we approach continually nearer to the solution of the great numerical problem of 
organic life. But is the number of organic forms itself a constant number? Do new regetable forms spring from the ground after long periods of time, while others become more and more rare, and at last disappear? Geology, by means of her historical monuments of ancient terrestrial life, answers to the latter portion of this question affirmatively. "In the Ancient World," to use the remark of an eminent naturalist, Link (Abhandl. der Akad. der Wiss. zu Berlin aus dem Jahr 1846, S. 322), "we see characters, now apparently remote and widely separated from each other, associated or crowded together in wondrous forms, as if a greater development and separation awaited a later age in the history of our planet."

\section{(14) p. 19.- "If the height of the aerial ocean and its pressure have not always been the same."}

The pressure of the atmosphere has a decided influence on the form and life of plants. From the abundance and importance of their leafy organs provided with porous openings, plants live principally in and through their surfaces; and hence their dependence on the surrounding medium. Animals are dependent rather on in. ternal impulses and stimuli; they originate and maintain their own temperature, and, by means of muscular movement, their own electric currents, and the chemical vital processes which depend on and react upon those currents. A species of skin-respiration is an active and important vital function in plants, and this respiration, in so far as it consists in evaporation, inhalation, and exhala. 
tion of fluids, is dependent on the pressure of the atmosphere. Therefore it is that alpine plants are more aromatic, and are hairy and covered with numerous pores. (See my work über die gereizte Muskel-und Nervenfaser, Bd. ii. S. 142-145.) For according to Zoonomic experience, organs become more abundant and more perfect in proportion to the facility with which the conditions necessary. for the exercise of their functions are fulfilled,-as I have elsewhere shown. In alpine plants the disturbance of their skinrespiration occasioned by increased atmospheric pressure makes it very difficult for such plants to flourish in the low grounds.

The question whether the mean pressure of the aerial ocean which surrounds our globe has always been the same is quite undecided: we do not even know accurately whether the mean height of the barometer has continued the same at the same place for a century past. According to Poleni's and Toaldo's observations, the pressure would have seemed to vary. The correctness of these observations. has long been doubted, but the recent researches of Carlini. render it almost probable that the mean height of the barometer is diminishing in Milan. Perhaps the phenomenon is a very local one, and dependent on variations in descending atmospheric currents.

\section{(15) p. 20.—" Palms."}

It is remarkable that of this majestic form of plants, (some of which rise to more than twice the height of the Royal Palace at Berlin, and to which the Indian 
Amarasinha gave the characteristic appellation of "Kings among the Grasses"), - up to the time of the death of Linnæus only 15 species were described. The Peruvian travellers Ruiz and Pavon added to these 8 more species. Bonpland and I, in passing orer a more extensire range of country from $12^{\circ} \mathrm{S}$. lat. to $21^{\circ} \mathrm{N}$. lat., described $20 \mathrm{new}$ species of palms, and distinguished as many more, but without being able to obtain complete specimens of their flowers. (Humboldt de distrib. geogr. Plantarum, p. 2.25233.) At the present time, 44 years after my return from Mexico, there are from the Old and New World, including the East Indian species brought by Griffith, above 440 regularly described species. The Enumeratio Plantarum of my friend Kunth, published in 1841, had already 356 species.

A few, but only a few species of palms, are, like our Coniferæ, Quercineæ, and Betrilineæ, social plants: such are the Mauritia flexuosa, and two species of Chamrrops, one of which, the Chamærops humilis, occupies extensire tracts of ground near the Mouth of the Ebro and in Valencia; and the other, C. mocini, discorered by us on the Mexican shore of the Pacific and entirely without prickles, is also a social plant. While some kinds of palms, including Chæmerops and Cocos, are littoral or shore-loving trees, there is in the tropics a peculiar group of mountain palms, which if I am not mistaken was entirely unknown previous to my South American travels. Almost all species of the family of palms grow on the plains or low grounds in a mean temperature of between $22^{\circ}$ and $24^{\circ}$ Reaumur 
$\left(81^{\circ} .5\right.$ and $86^{\circ}$, Fahr.) ; rarely ascending so high as 1900 English feet on the declivities of the Andes: but in the mountain palms to which I have alluded, the beautiful Wax-palm (Ceroxylon andicola), the Palmeto of Azufral at the Pass of Quindiu (Oreodoxa frigida), and the reed-like Kunthia montana (Caña de la Vibora) of Pasto, attain elevations between 6400 and 9600 English feet above the level of the sea, where the thermometer often sinks at night as low as $4^{\circ} .8$ and $6^{\circ}$ of Reaumur ( $42^{\circ} .8$ and $45 .^{\circ} 5$, Fahr.), and - the mean temperature scarcely amounts to $11^{\circ}$ Reaumur, or $56^{\circ} .8$ Fahrenheit. These Alpine Palms grow among Nut trees, yew-leaved species of Podocarpus and Oaks (Quercus granatensis). I have determined by exact barometrical measurement the upper and lower limits of the range of the WaxPalm. We first began to find it on the eastern declivity of Andes of Quindiu, at the height of 7440 (about 7930 English) feet above the level of the sea, and it extended upwards as far as the Garita del Paramo and los Volcancitos, or to 9100 (almost 9700 English) feet: several years after my departure from the country the distinguished botanist Don Jose Caldas, who had been long our companion amidst the mountains of New Granada, and who afterwards fell a victim to Spanish party hatred, found three species of palms growing in the Paramo de Guanacos very near the limits of perpetual snow ; therefore probably at an elevation of more than 13000 (13855 English) feet. (Semanario de Santa Fé de Bogotá, 1809, No. 21, p. 163.) Even beyond the tropics, in the latitude of $28^{\circ} \mathrm{North}$, the Chamærops mar- 
tiana reaches on the sub-Himalayan mountains a height of 5000 English feet. (Wallich, Plantæ Asiaticæ, Vol. iii. Tab. 211.)

If we look for the extreme geographical limits of palms, (which are also the extreme climatic limits in all the species which inhabit localities but little raised above the level of the sea), we see some, as the date-palm, the Chamærops humilis, C. palmetto, and the Areca sapida of New Zealand, advance far into the temperate zones of either hemisphere, into regions where the mean temperature of the year hardly equals $11^{\circ} .2$ and $12^{\circ} .5$ Reaumur $\left(57^{\circ} .2\right.$, and $60^{\circ} .2$ Fahrenheit). If we form a series of cultivated plants or trees, placed in order of succession according to the degree of heat they require, and beginning with the maximum, we have Cacao, Indigo, Plantains, Coffee, Cotton, Date-palms, Orange and Lemon Trees, Olives, Sweet Chestnuts, and Vines. In Europe, date-palms (introduced, not indigenous) grow mingled with Chamærops humilis in the parallels of $43 \frac{1}{2}^{\circ}$ and $44^{\circ}$, as on the Genoese Rivera del Ponente, near Bordighera, between Monaco and San Stefano, where there is an assernblage of more than 4000 palm-stems; and in Dalmatia round Spalatro. It is remarkable that Chamærops humilis is abundant both at Nice and in Sardinia, and yet is not found in the island of Corsica which lies between those localities. In the New Continent, the Chamærops palmetto, which is sometimes above 40 English feet high, only advances as far North as $34^{\circ}$ latitude, a difference sufficiently explained by the inflexions of the isothermal lines. In the Southern hemi- 
sphere, in New Holland, palms, of which there are very few, (six or seven species), only advance to $34^{\circ}$ of latitude (see Robert Brown's general remarks on the Botany of Terra Australis, p. 45) ; and in New Zealand, where Sir Joseph Banks first saw an Areca palm, they reach the 38th parallel. In Africa, which, quite contrary to the ancient and still widely prevailing belief, is poor in species of palms, only one palm, the Hyphæne coriacea, advances to Port Natal in $30^{\circ}$ latitude. The continent of South America presents almost the same limits in respect to latitude. On the eastern side of the Andes, in the Pampas of Buenos Ayres and in the Cis-Plata province, palms extend, according to Auguste de St.-Hilaire, to $34^{\circ}$ and $35^{\circ} \mathrm{S}$. latitude. This is also the latitude to which on the western side of the Andes the Coco de Chile (our Jubæa spectabilis?), the only Chilian palm, extends, according to Claude Gay, being as far as the banks of the Rio Maule. (See also Darwin's Journal, edition of 1845, p. 244 and 256).

I will here introduce some detached remarks which I wrote in March, 1801, on board the ship in which we were sailing from the palmy shores of the mouth of the Rio Sinu, west of Darien, to Cartagena de las Indias.

"We have now, in the course of the two years which we have spent in South America, seen 27 different species of palms. How many must Commerson, Thunberg, Banks, Solander, the two Forsters, Adanson, and Sonnerat, have observed in their distant voyages! Yet, at the present moment, when I write these lines, our systems of botany do not include more than from 14 to 18 systematically 
described species. In truth, the difficulty of procuring the flowers of palms is greater than can readily be imagined. We have felt it so much the more from having especially directed our attention to Palms, Grasses, Cyperaceæ, Juncacex, Cryptogamous Plants, and such other objects as have been least studied hitherto. Most species of palms flower only once a year, in the neighbourhood of the Equator in the months of Jonuary and February. But how often is it impossible for travellers to be precisely at that season in places where palms are principally found. In many species of palms the flowers last only so few days that one almost always arrives too late, and finds the fertilization completed and the male blossoms gone. Frequently only three or four species of palms are found in areas of 2000 square German geographical miles (3200 English geographical square miles). How is it possible during the short flowering season to visit the different places where palms abound: the Missions on the Rin Caroni, the Morichales at the mouth of the Orinoco, the valley of Caura and Erevato, the banks of the Atabapo and the Rio Negro, and the side of the Duida Mountain? Add to this the difficulty of reaching the flowers, when, in the dense forests, or on the swampy river banks, (as on the Temi and Tuamini), one sees them hanging from stems above 60 feet high, and armed with formidable spines. A traveller, when preparing to leave Europe on an expedition in which natural history is one of his leading objects, flatters himself with the thoughts of shears or curved blades fastened to long poles, with which he imagines he will be able to reach and cut down whatever he desires; he 
dreams, too, of native boys, who, with a cord fastened to their two feet, are to climb up the highest trees at his bidding. But, alas! very few of these fancies are ever realised; the great height of the blossoms renders the poles useless; and in the missions established on the banks of the rivers of Guiana, the traveller finds himself among Indians whose poverty, stoicism, and uncultivated state, renders them so rich, and so free from wants of every kind, that neither money nor other presents that can be made to them will induce them to turn three steps out of their path. This insurmountable apathy is the more provoking to a European, because he sees the same people climb with inconceivable agility wherever their own fancies lead them; for example, when they wish to catch a parrot, or an iguana, or a monkey, which having been wounded by their arrows saves himself from falling by holding on to the branches with his prehensile tail. Even at the Havannah we met with a similar disappointment. We were there in the month of January, and saw all the trees of the Palma Real (our Oreodoxa Regia), in the immediate vicinity of the eity and on the public walks, adorned with snow-white blossoms. For several days we offered the negro boys whom we met in the streets of Regla and Guanavacoa two piastres for a single bunch of the blossoms which we wanted, but in vain! Between the tropics men are indisposed to laborious exertion, unless compelled by constraint or by extreme destitution. The botanists and artists of the Royal Spanish Commission for researches in Natural History, under the direction of Count Jaruco y Mopor (Estevez, Boldo, Guio, 
and Echeveria),-acknowledged to us that during several years they had not been able to obtain these flowers for examination. These difficulties sufficiently explain what would have been incomprehensible to me before my voyage, namely, that although during our two years' stay up to the present time, we have, indeed, discovered more than 20 different species of palms, we have as yet been only able to describe systematically 12. "How interesting a work might be produced by a traveller in South America who should occupy himself exclusively with the study of palms, and should make drawings of the spathe, spadix, inflorescence, and fruit, all of the size of nature!" (I wrote this many years before the Brazilian travels of Martius and Spix, and the admirable and excellent work of Martius on Palms.) "There is considerable unformity in the shape of the leaves of palms; they are generally either pinnate (feathery, or divided like the plume of a feather); -or else palmate or palmo-digitate (of a fan-like form); the leaf-stalk (petiolus), is in some species without spines, in others sharply toothed (serrato-spinosus). The form of the leaf in Caryota urens and Martinezia caryotifolia, (which we saw on the banks of the Orinoco and Atabapo, and again in the Andes, at the pass of Quindiu, 3000 Fr. (3197 English) feet above the level of the sea), is exceptional and almost unique among palms, as is the form of the leaf of the Gingko among trees. The port and physiognomy of palms have a grandeur of character very difficult to convey by words. The stem, shaft, or caudex, is generally simple and undivided, but in extremely rare exceptions divides into branches in the 
manner of the Dracænas, as in Cucifera thebaica (the Doumpalm), and Hyphæne coriacea. It is sometimes disproportionately thick (as in Corozo del Sinu, our Alfonsia oleifera); sometimes feeble as a reed (as in Piritu, Kunthia montana, and the Mexican Corypha nana); sometimes swelling towards the base (as in Cocos); sometimes smooth, and sometimes scaly (Palma de covija o de sombrero, in the Llanos); sometimes armed with spines (as Corozo de Cumana and Macanilla de Caripe), the long spines being distributed with much regularity in concentric rings."

"Characteristic differences are also furnished in some species by roots which, springing from the stem at about a foot or a foot and a half above the ground, either raise the stem as it were upon a scaffolding, or surround it with thick buttresses. I have seen Viverras, and even very small monkeys, pass underneath this kind of scaffolding formed by the roots of the Caryota. Often the shaft or stem is swollen only in the middle, being more slender above and below, as in the Palma Real of the Island of Cuba. The leaves are sometimes of a dark and shining green (as in the Mauritia and the Cocoa nut palm); sometimes of a silvery white on the under side (as in the slender Fan-palm, Corypha miraguama, which we found in the Harbour of Trinidad de Cuba). Sometimes the middle of the fan or palmate leaf is ornamented with concentric yellowish or bluish stripes like a peacock's tail; as in the thorny Mauritia which Bonpland discovered on the banks of the Rio Atabapo."

"The direction of the leaves is a character not less important than their form and colour. The leaflets (foliola), are 
sometimes arranged like the teeth of a comb, set on in the same plane, and close to each other, and having a very rigid parenchyma (as in Cocos, and in Phœnix the genus to which the Date belongs); whence the fine play of light from the sun-beams falling on the upper surface of the leaves (which is of a fresher verdure in Cocos, and of a more dead and asliy hue in the date palm); sometimes the leaves are flag-like, of a thimner and more flexible texture, and curl towards the extremities (as in Jagua, Palma Real del Sinu, Palma Real de Cuba, and Piritu dell' Orinoco). The peculiarly majestic character of palms is given not only by their lofty stems, but also in a very high degree by the direction of their leaves. It is part of the beauty of any particular species of palms that its leaves should possess this aspiring character; and not only in youth, as is the case in the Date-palm, but also throughout the duration of the life of the tree. The more upright the direction of the leaves, or, in other words, the more acute the angles which they form with the upper part or continuation of the stem, the grander and more imposing is the general character and physiognomy of the tree. How different are the character and aspect given by the drooping leaves of the Palma de covija del Orinoco y de los Llanos de Calabozo (Corypha tectorum); the more nearly horizontal or at least less upright leaves of the Date and Cocoa-nut palms; and the aspiring heavenward pointing branches of the Jagua, the Cucurito, and the Pirijao !

Nature has lavished every beauty of form on the Jagua palm, which, intermingled with the Cucurito or Vadgihai, 
(85 to 106 English feet high), adorns the cataracts of Atures and Maypures, and is occasionally found also on the lonely banks of the Cassiquiare. The smooth slender stems of the Jagua, rising to between 64 and 75 English feet, appear above the dense mass of foliage of other kinds of trees from amidst which they spring like raised colonnades, their airy summits contrasting beautifully with the thickly-leaved species of Ceiba, and with the forest of Laurineæ, Calophyllum, and different species of Amyris which surround them. The leaves of the Jagua, which are few in number (scarcely so many as seven or eight), are sixteen or seventeen feet long, and rise almost vertically into the air ; their extremities are curled like plumes; the ultimate divisions or leaflets, having only a thin grass-like parenchyma, flutter lightly and airily round the slowly balancing central leaf-stalks. In all palms the inflorescence springs from the trunk itself, and below the place where the leaves originate; but the manner in which this takes place modifies the physiognomic character. In a few species only (as the Corozo del Sinu), the spathe (or sheath enclosing the flowers and fruits), rises vertically, and the fruits stand erect, forming a kind of thyrsus, like the fruits of the Bromelia: in most species of palms the spathes (which are sometimes smooth and sometimes rough and armed with formidable spines) are pendent; in a few species the male flowers are of a dazzling whiteness, and in such cases the flower-covered spadix, when fully developed, shines from afar. In most species of palms the male flowers are yellowish, closely crowded, and appear almost withered when they disengage themselves from the spathe. 
"In Palms with pinnate foliage, the leaf-stalks either proceed (as in the Cocoa-nut, the Date, and the Palma Real del Sinu) from the dry, rough, woody part of the stem; or, as in the Palma Real de la Havana (Oreodoxa regia) seen and admired by Columbus, there rises upon the rough part of the stem a grass-green, smooth, thinner shaft, like a column placed upon a column, and from this the leafstalks spring. In fan-palms, "foliis palmatis," the leafy crown (as in the Moriche and the Palma sombrero de la Havana) often rests on a previous bed of dry leaves, a circumstance which gives to the tree a sombre and melancholy appearance. In some umbrella-palms the crown consists of very few leaves, which rise upwards, carried on very slender petioles or foot-stalks (as in Miraguama).

"The form and colour of the fruits of Palms also offer much more variety than is commonly believed in Europe. Mauritia flexuosa bears egg-shaped fruits, whose scaly, brown, and shining surface, gives them something of the appearance of young fir-cones. What a difference between the enormous triangular cocoa-nut, the soft fleshy berries of the date, and the small hard fruits of the Corozo! But among the fruits of palms none equal in beauty those of the Pirijao (Pihiguao of S. Fernando de Atabapo and S. Balthasar); they are egg-shaped, mealy, and usually without seeds, two or three inches thick, and of a golden colour, which on one side is overspread with crimson; and these richly coloured fruits, crowded together in a bunch, like grapes, are pendent from the summits of majestic palm 
trees." I have already spoken in the first volume of the present work, p. 216, of these beautiful fruits, of which there are seventy or eighty in a bunch, and which can be prepared as food in a variety of ways, like plantains and potatoes.

In some species of Palms the flower sheath, or spathe surrounding the spadix and the flowers, opens suddenly with an audible sound. Richard Schomburgk (Reisen in Britisch Guiana, Th. i. S. 55) has like myself observed this phenomenon in the flowering of the Oreodoxa oleracea. This first opening of the flowers of Palms accompanied by sound recalls the vernal Dithyrambus of Pindar, and the moment when, in Argive Nemea, "the first opening shoot of the cate-palm proclaims the arrival of balmy spring." (Kosmos, Bd. ii. S. 10 ; Eng. ed. p. 10.)

Three vegetable forms of peculiar beauty are proper to the tropical zone in all parts of the globe; Palms, Plantains or Bananas, and Arborescent Ferns. It is where heat and moisture are combined that vegetation is most vigorous, and its forms most varied; and hence South America excels the rest of the tropical world in the nurnber and beauty of her species of Palms. In Asia this form of vegetation is more rare, perhaps because a considerable part of the Indian continent which was situated immediately under the equinoctial line has been broken up and covered by the sea in the course of former geological revolutions. We know scarcely anything of the palm trees of Africa between the Bight of Benin and the Coast of Ajan; and, generally 
speaking, we are only acquainted, as has been already remarked, with a very small number of species of Palms belonging to that quarter of the globe.

Palms afford, next to Coniferæ and species of Eucalyptus belonging to the family of Myrtacex, examples of the greatest loftiness of stature attained by any of the members of the regetable kingdom. Of the Cabbage Palm (Areca oleracea), stems have been seen from 150 to 160 French (160 to 170 English) feet high. (Aug. de Saint-Hilaire, Morphologie régétale, 1840, p. 176.) The Wax-palm, our Ceroxylon andicola, discorered by us on the Andes between Ibague and Carthago, on the Montaña de Quindiu, attains the immense height of 160 to 180 French (170 to 192 English) feet. I was able to measure with exactness the prostrate trunks which had been cut down aud were lying in the forest. Next to the Wax-palm, Oreodoxa Sancona, which we found in flower near Roldanilla in the Cauca Tallev, and which affords a very hard and excellent building rood, appeared to me to be the tallest of American palms. The circumstance that notrithstanding the enormous quantity of fruits produced by a single Palm tree, the number of individuals of each species which are found in a wild state is not very considerable, can only be explained by the frequently abortive development of the fruits (and consequent absence of seeds), and by the voracity of their numerous assailants, belonging to all classes of the animal world. Yet although $I$ have said that the wild individuals are not very numerous, there are in the basin of the Orinoco entire tribes of men who live for several months of the year on the fruits 
of palms. "In palmetis, Pihiguao consitis, singuli trunci quotannis fere 400 fructus ferunt pomiformes, triturnque est verbum inter Fratres S. Francisci, ad ripas Orinoci et Gauiniæ degentes, mire pinguescere Indorum corpora, quoties uberem Palmæ fructum fundant." (Humboldt, de Distrib. geogr. Plant. p. 240.)

\section{${ }^{16}$ ) p. 22.- "Since the earliest infancy of human civilisation."}

In all tropical countries we find the cultivation of the Banana or. Plantain established from the earliest times with which tradition or history make us acquainted. It is certain that in the course of the last few centuries African slaves have brought new varieties to America, but it is equally certain that Plantains were cultivated in the new world before its discovery by Columbus. The Guaikeri Indians at Cumana assured us that on the Coast of Paria, near the Golfo Triste, when the fruits were allowed to remain on the tree till ripe, the plantain sometimes produced seeds which would germinate; and in this manner plantains are occasionally found growing wild in the recesses of the forest, from ripe seeds conveyed thither by birds. Perfectly formed seeds have also sometimes been found in plantain fruits at Bordones, near Cumana. (Compare my Essai sur la Géographie des Plantes, p. 29; and my Relat. hist. T. i. pp. 104 and 587, T. ii. pp. 355 and 367.)

I have already remarked elsewhere (Kosmos, Bd. ii. S. 191; English edition, p. 156), that Onesicritus and the other companions of Alexander, while they make no 
allusion to the tall arborescent ferns, speak of the fanleaved umbrella palm, and of the delicate and always fresh verdure of the cultivated plantains or bananas. Among the Sanscrit names given by Amarasinha for the plantain or banana (the Musa of botanists) there are bhanu-phala (suifruit), varana-buscha, and moko. Phala signifies fruit in general. Lassen explains the words of Pliny (xii. 6), "arbori nomen palæ, pomo arienæ" thus: "The Roman mistook the word pala, fruit, for the name of the tree; and varana (in the mouth of a Greek ouarana) became transformed into ariena. The Arabic mauza may have been formed from moko, and hence our Musa. Bhanu-fruit is not far from banana-fruit." (Compare Lassen, Indische Alterthumskunde, Bd.i. S. 262, with my Essai politique sur la Nouvelle Espagne, T. ii. p. 382, and Rel. hist. T. i. p. 491.)

\section{(17) p. 22.-"The form of Malvacec."}

Larger malvaceous forms begin to appear as soon as we have crossed the Alps; at Nice and in Dalmatia, Lavatera arborea; and in Liguria, Lavatera olbia. The dimensions of the Baobab, monkey-bread tree, have been mentioned above, (Vol. ii. p. 90.) To this form are attached the also botanically allied families of the Byttneriaceæ (Sterculia, Hermannia, and the large-leaved Theobroma Cacao, in which the flowers spring from the bark both of the trunk and the roots); the Bombaceæ (Adansonia, Helicteres, and Cheirustemon); and lastly the Tiliaceæ (Sparmannia Africana.) I may name more particularly as superb representatives of the Mallow-form, our Cavanillesia platanifolia, of 
Turbaco near Carthagena in South America, and the celebrated Ochroma-like Hand-tree, the Macpalxochiquahuitl of the Mexicans, (from macpalli, the flat hand), Arbol de las Manitas of the Spaniards, our Cheirostemon platanoides; in which the long curved anthers project beyond the fine purple blossom, causing it to resemble a hand or claw. Throughout the Mexican States this one highly ancient tree is the only existing individual of this extraordinary race : it is supposed to be a stranger, planted about five centuries ago by the kings of Toluca. I found the height above the sea where the Arbol de las Manitas stands to be 8280 French (8824 English) feet. Why is there only a single individual, and from whence did the kings of Toluca procure either the young tree or the seed? It seems no less difficult to account for Montezuma not having possessed it in his botanical gardens of Huaxtepec, Chapoltepec, and Iztapalapan, of which Hernandez, the surgeon of Philip II., was still able to avail himself, and of which some traces remain even to the present day; and it seems strange that it should not have found a place among the representations of objects of natural history which Nezahualcoyotl, king of Tezcuco, caused to be drawn half a century before the arrival of the Spaniards. It is asserted that the Hand-tree exists in a wild state in the forests of Guatimala. (Humboldt and Bonpland, Plantes équinoxiales, T. i. p. 82, pl. 24; Essai polit. sur la Nouv. Esp., T. i. p. 98.) At the equator we have seen two Malvaceæ, Sida Phyllanthos (Cavan), and Sida pichinchensis, ascend, on the mountain of Antisana and the Volcano Rucu-Pichincha, to the great elevations of 12600 
and 14136 French (13430 and 15066 English) feet. (See our Plantes équin., T. ii. p. 113, pl. 116.) Only the Saxifraga boussingaulti (Brongn.) reaches, on the slope of the Chimborazo, an altitude sis or seven hundred feet higher.

\section{(18) p. 22.-"The Mimosa form."}

The finely feathered or pinnated leares of Mimosas, Acacias, Schrankias, and species of Desmanthus, are most truly forms of tropical regetation. Yet there are some representations of this form berond the tropics; in the northern hemisphere in the Old Continent I can indeed cite but one, and that only in Asia, and a low-growing shrub, the Acacia Stephaniana, according to Kunth's more recent investi. gations a species of the genus Prosopis. It is a social plant, corering the arid plains of the province of Shirwan, on the Kur (Cyrus), as far as the ancient Araxes. Olivier also found it near Bagdad. It is the Acacia foliis bipimatis mentioned by Busbaum, and extends as far north as $42^{\circ}$ of latitude. (Tableau des Provinces situées sur la Cóte occidentale de la. Mer Caspienne, entre les fleures Terek et Kour, 1798, pp. 58 and 120.) In Africa the Acacia gummifera of Willdenow advances as far as Mogador, or to $32^{\circ}$ north latitude.

On the New Continent, the banks of the Mississipi and the Temnessee, as well as the savannahs of Illinois, are adorned with Acacia glandulosa (Michaux), and A. brachyloba (Tilld). Michaux found the Schrankia uncinata extend northwards from Florida into Virginia, or to $37^{\circ} \mathrm{N}$. latitude. Gleditschia tricanthos is found, according to Barton, on the 
east side of the Alleghany mountains, as far north as the 38th parallel, and on the west side even as far as the 41st parallel. Gleditschia monosperma ceases two degrees farther to the south. These are the limits of the Mimosa form in the northern hemisphere. In the southern hemisphere we find beyond the tropic of Capricorn simple leaved Acacias as far as Vau Diemen Island; and even the Acacia cávenia, described by Claude Gay, grows in Chili between the 30th and 37 th degrees of south latitude. (Molina, Storia Naturale del Chili, 1782, p. 174.) Chili has no true Mimosa, but it has three species of Acacia. Even in the north part of Chili the Acacia cavenia only grows to a height of twelve or thirteen feet; and in the south, near the sea coast, it hardly rises a foot above the ground. In South America, north of the equator, the most excitable Mimosas were (next to Mimosa pudica), M. dormiens, M. somnians, and M. somniculosa. Theophrastus (iv. 3) and Pliny (xiii. 10) mention the irritability of the African sensitive plant; but I find the first description of the South American sensitive plants (Dormideras) in Herrera, Decad. II. lib. iii. cap. 4. The plant first attracted the attention of the Spaniards in 1518, in the savannahs on the isthmus near Nombre de Dios: "parece como cosa sensible ;" and it was said that the leaves ("de echura de una pluma de pajaros") only contracted on being touched with the finger, and not if touched with a piece of wood. In the small swamps which surround the town of Mompox on the Magdalena, we discovered a beautiful aquatic Mimosacea (Desmanthus lacustris). It is figured in our Plantes équinoxiales, T. i. 
p. 55, pl. 16. In the Andes of Casamarca we found two Alpine Mimosea (Mimosia montana and Acacia revoluta), 8500 and 9000 French (about 9060 and 9590 English) feet above the surface of the Pacific.

Hitherto no true Mimosa (in the sense established by Willdenow), or even Inga, has been found in the temperate zone. Of all Acacias, the Oriental Acacia julibrissin, which Forskal has confounded with Mimosa arborea, is that which supports the greatest degree of cold. In the botanic garden of Padua there is in the open air a tree of this species with a stem of considerable thickness, although the mean temperature of Padua is below 10. 5 Reanmur ( $55^{\circ} .6$ Fahr.)

$$
\text { (19) p. 23.-" Heaths." }
$$

In these physiognomic considerations we by no means comprise under the name of Heaths the whole of the natural family of Ericacex, which on account of the similarity and analogy of the floral parts includes Rhododendron, Befaria, Gaultheria, Escallonia, \&c. We confine ourselves to the highly accordant and characteristic form of the species of Erica, including Calluna (Erica) Vulgaris, L., the common heather.

While, in Europe, Erica carnea, E. tetralix, E. cinerea, and Calluna vulgaris, cover large tracts of ground from the plains of Germany, France, and England to the extremity of Norway, South Africa offers the most varied assemblage of species. Only one species which is indigenous in the southern hemisphere at the Cape of Good Hope, Erica umbellata, is found in the northern hemisphere, i. e. in the 
North of Africa, in Spain, and Portugal. Erica vagans and E. arborea also belong to the two opposite coasts of the Mediterranean : the first is found in North Africa, near Marseilles, in Sicily, Dalmatia, and even in England; the second in Spain, Italy, Istria, and in the Canaries." (Klotsch on the Geographical Distribution of species of Erica with persistent corollas, MSS.) The common heather, Calluna vulgaris, is a social plant covering large tracts from the mouth of the Scheldt to the western declivity of the Ural. Beyond the Ural, oaks and heaths cease together: both are entirely wanting in the whole of Northern Asia, and throughout Siberia to the shores of the Pacific Ocean. Gmelin (Flora Sibirica, T. iv. p. 129) and Pallas (Flora Rossica, T. i. Pars 2, p. 53) have expressed their astonishment at this disappearance of the Calluna vulgaris, - a dism appearance which, on the eastern declivity of the Ural Mountains, is even more sudden and decided than might be inferred from the expressions of the last-named great naturalist. Pallas says merely: "ultra Uralense jugum sensim deficit, vix in Isetensibus campis rarissime apparet, et ulteriori Sibiriæ plane deest.". Chamisso, Adolph Erman, and Heinrich Kittlitz, have found Andromedas indeed in Kamtschatka, and on the North West coast of America, but no Calluna. The accurate knowledge which we now possess of the mean temperature of several parts of Northern Asia, as well as of the distribution of the annual temperature into the different seasons of the year, affords no sort of explanation of the cessation of heather to the east of the Ural Mountains. Joseph Hooker, in a note to his Flora Antarc- 
tica, has treated and contrasted with great sagacity and clearness two very different phenomena which the distribution of plants presents to us: on the one hand, "uniformity of surface accompanied by a similarity of vegetation;" and on the other hand, "instances of a sudden change in the regetation unaccompanied by any diversity of geological or other features." (Joseph Hooker, Botany of the Antarctic Voyage of the Erebus and Terror, 1844, p. 210.) Is there any species of Erica in Central Asia? The plant spoken of by Saunders in Turner's Travels to Thibet (Phil. Trans. Vol. Ixxix. p. 86), as having been found in the Highlands of Nepaul (together with other European plants, Vaccinium myrtillus and V. oxjcoccus) and described by him as Erica vulgaris, is believed by Robert Brown to have been an Andromeda, probably Andromeda fastigiata of Wallich. No less striking is the absence of Calluna vulgaris, and of all the species of Erica throughout all parts of the Continent of America, while the Calluna is found in the Azores and in Iceland. It has not hitherto been seen in Greenland, but was discovered a few years ago in Newfoundland. The natural family of the Ericaceæ is also almost entirely wanting in Australia, where it is replaced by Epacrideæ. Limnæus described only 102 species of the genus Erica; according to Klotzsch's examination, this genus really contains, after a careful exclusion of all mere varieties, 440 true species.

$$
\text { (20) p. 24.-"The Cactus form." }
$$

If we take the natural family of the Opuntiacere separated 
from the Grossulariacex (the species of Ribes), and, viewed as it is by Kunth (Handbuch der Botanik, S. 609), we may well regard it as belonging exclusively to America. I am aware that Roxburgh, in the Flora Indica (inedita), cites two species of Cactus as belonging to South Eastern Asia;Cactus indicus and C. chinensis. Both are widely disseminated, and are found in a wild state (whether they were originally wild or have become so), and are distinct from Cactus opuntia and C. coccinellifer; but it is remarkable that the Indian plant (Cactus indicus) has no ancient Sanscrit name. Cactus chinensis has been introduced in St. Helena as a cultivated plant. Now that a more general interest has at length been awakened on the subject of the original distribution of plants, future investigation will dispel the doubts which have been felt in several quarters respecting the existence of true Asiatic Opuntiaceæ. In the animal kingdom particular forms are found to occur singly. Tapirs were long regarded as a form exclusively. characteristic of the New Continent; and yet the American tapir has been found as it were repeated in that of Malacca (Tapirus indicus, Cuv.)

Although the species of Cactus belong, generally speaking; more properly to the tropical regions, yet some are indigenous in the temperate zone, as on the Missouri and in Louisiana, Cactus missuriensis and C. vivipara; and Back saw with astonishment the shores of Rainy Lake, in north lat. $48^{\circ} 40^{\prime}$, covered with C. opuntia. South of the equator the species of Cactus do not extend beyond the Rio Itata, in lat. $36^{\circ}$, and the Rio Biobio, in lat. $37^{\circ} 15^{\prime}$. In the 
part of the Andes which is situated between the tropics, I have seen species of Cactus (C. sepium, C. chlorocarpus, C. bonplandii) growing on elevated plains nine or ten thousand (French) feet (about 9590 and 10660 English) above the level of the sea; but a still more alpine character is shewn in latitudes belonging to the temperate zone, in Chili, by the Opuntia ovallei, which has yellow flowers and a creeping stem. The upper and lower limits beyond which this plant does not extend have been accurately determined by barometric measurement by the learned botanist Claude Gay : it has never been found lower than 6330 French (6746 English) feet, and it reaches and even passes the limits of perpetual snow, having been found on uncovered masses of rock rising from amongst the snows. The last small plants were collected on spots situated 12820 French (13663 English) feet above the level of the sea. (Claudio Gay, Flora Chilensis, 1848, p. 30.) Some species of Echino-cactus are also true alpine plants in Chili. A counterpart to the fine-haired Cactus senilis is found in the thick-wooled Cereus lanatus, called by the natives Piscol, which has handsome red fruit. We found it in Peru, near Guancabamba, when on our journey to the Amazons river. The dimensions of the different kinds of Cactacer (a group on which the Prince of Salm-Dyck has been the first to throw great light) offer great variety and contrasts. Echinocactus wislizeni, which is 4 feet high and 7 feet in circumference ( 4 feet 3 inches and 7 feet 5 inches English); is still only the third in size, being surpassed by E. ingens 
(Zuce.) and by E. platyceras (Lem.) (Wislizenus, Tour to Northern Mexico, 1848, p. 97.) The Echinocactus stainesii reaches from 2 to $2 \frac{1}{2}$ feet diameter; E. visnago, from Mexico, upwards of 4 English feet high, is above 3 English feet diameter, and weighs from 700 to 2000 lbs.: while Cactus nanus, which we found near Sondorillo, in the province of Jaen, is so small that, being only slightly rooted in the sand, it gets between the toes of dogs. The Melocactuses, which are full of juice in the dryest seasons like the Ravenala of Madagascar (forest-leaf in the language of the country, from rave, raven, a leaf, and ala, the Javanese halas, a forest), are vegetable fountains; and the manner in which the horses and mules stamp them open with their hoofs, at the risk of injury from the spines, has been already mentioned (Vol. I. p. 19). Since the last quarter of a century Cactus opuntia has extended itself in a remarkable manner into Northern Afric. syria, Greece, and the whole of the South of Europe; even penetrating, in Africa, from the coasts far into the interior of the country, and associating itself with the indigenous plants.

When one has been accustomed to see Cactuses only in our hothouses, one is astonished at the degree of density and hardness which the ligneous fibres attain in old cactus stems. The Indians know that cactus wood is incorruptible, and excellent for oars and for the thresholds of doors. There is hardly anything in vegetable physiognomy which makes so singular and ineffaceable an impression on a newly arrived person, as the sight of an arid plain thickly. 
covered, like those near Cumana, New Barcelona, and Coro, and in the province of Jaen de Bracamoros, with columnar and candelabra-like divided cactus stems.

\section{(21) p. 24.-"Orchidece."}

The almost animal shape of blossoms of Orchidex is particularly striking in the celebrated Torito of South America (our Anguloa grandiflora); in the Mosquito (our Restrepia antennifera); in the Flor del Espiritu Santo (also an Anguloa, according to Floræ Peruvianæ Prodrom. p. 118, tab. 26); in the ant-like flower of the Chiloglottis cormuta (Hooker, Flora antarctica, p. 69); in the Mexican Bletia speciosa; and in the highly curious host of our European species of Ophrys: O. muscifera, O. apifera, O. aranifera, O. arachnites, \&c. A predilection for this superbly flowering group of plants has so increased, that the number cultivated in Europe by the brothers Loddiges in 1848 has been estimated at 2360 species; while in 1843 it was rather more than 1650, and in 1813 only 115. What a rich mine of still unknown superb flowering Orchidex the interior of Africa must contain, if it is well watered! Lindley, in his fine work entitled "The Genera and Species of Orchideous Plants," described in 1840 precisely 1980 species; at the end of the year 1848 Klotzsch reckoned 3545 species.

While in the temperate and cold zones there are only "terrestrial" Orchidex, i.e. growing on and close to the ground, tropical countries possess both forms, i. e. the "terrestrial" and the "parasitic," which grow on trunks of trees. To the first-named of these two divisions belong the tropical genera 
Neottia, Cranichis, and most of the Habenarias. We have also found both forms growing as alpine plants on the slopes of the chain of the Andes of New Granada and Quito : of the parasitical Orchideæ (Epidendreæ), Masdevallia uniflora (at 9600 French, or about 10230 English feet); Cyrtochilum flexuosum (at 9480 French, or about 10100 English teet) ; and Dendrobium aggregatum (8900 French, or about 9480 English feet): and of the terrestrial Orchideæ, the Altensteinia paleacea, near Lloa Chiquito, at the foot of the Volcano of Pichincha. Claude Gay thinks that the Orchideæ said to have been seen growing on trees in the Island of Juan Fernandez, and even in. Chiloe, were probably in reality only parasitical Pourretias, which extend at least as far south as $40^{\circ} \mathrm{S}$. lat. In New Zealand we find that the tropical form of Orchideæ hanging from trees extends even to $45^{\circ} \mathrm{S}$. lat. The Orchideæ of Auckland's and Campbell's Islands, however (Chiloglottis, Thelymitra, and Acianthus), grow on the ground in moss. In the animal kingdom, one tropical form at least advances much farther to the south. In Macquarie Island, in lat. $54^{\circ} 39^{\prime}$, nearer to the South Pole therefore than Dantsic is to the North Pole, there is a native parrot. (See also the section Orchidex in my work de Distrib. geogr. Plant., pp. 241-247.)

\section{(22) p. 25.- "The Casuarinea."}

Acacias which have phyllodias instead of leaves, some Myrtaceæ (Eucalyptus, Metrosideros, Melaleuca, and Leptospermum), and Casuarinas, give a uniform character to the vegetation of Australia and Tasmania (Van Diemen Island). 
Casuarinas with their leafless, thin, string-like, articulated branches, having the joints provided with membranous denticulated sheaths, have been compared by travellers, according to the particular species which fell under their observation, either to arborescent Equisetaceæ (Horsetails) or to our Scotch firs. (See Darmin, Journal of Researches, p. 449.) Near the coast of Peru the aspect of small thickets of Col. letia and Ephedra also produced on my mind a singular impression of leaflessness. Casuarina quadrivalvis advances, according to Labillardière, to $43^{\circ} \mathrm{S}$. lat. in Tasmania. The sad-looking Casuarina form is not unknown in India and on the east coast of Africa.

\section{${ }^{(23)}$ p. 25.- "Needle-leaved trees."}

The family of Coniferæ holds so important a place by the number of individuals, by their geographical distribution, and by the vast tracts of country in the northern temperate zone corered with trees of the same species living in society, that we are almost surprised at the small number of species of which it consists, -even including members which belong to it in essential respects, but deviate from it in a degree by the shape of their leaves and their manner of growth (Dammara, Ephedra, and Gnetum, of Java and New Guinea). The number of known Coniferæ is not quite equal to three-fourths of the number of described species of palms; and there are more known Aroideæ than Coniferæ. Zuccarini, in his Beiträgen zur Morphologie der Coniferen (Abhandl. der mathem. physikal. Classe der Akademie der Wiss. zu München, Bd. iii. S. 752, 18:37-1843), reckons 216 species, 
of which 1.55 belong to the northern and 51 to the southern hemisphere. Since my researches these proportionate numbers must be modified, as, including the. species of Pinus, Cupressus, Ephedra, and Podocarpus, found by Bonpland and myself in the tropical parts of Peru, Quito, New Granada, and Mexico, the number of species between the tropics rises to 42 . The most recent and excellent work of Endlicher, Synopsis Coniferarum, 1847, contains 312 species now living, and 178 fossil species found in the coal measures, the bunter-sandstone, the keuper, and the Jurassic formations. The vegetation of the ancient world offers to us more particularly forms which, by their simultaneous affinity with several different families of the present vegetable world, remind us that many intermediate links have perished. Coniferæ abounded in the ancient world: their remains, belonging to an early epoch, are fornd especially in association with Palms and Cycader; but in the latest beds of lignite we also find pines and firs associated as now with Cupuliferæ, maples, and poplars. (Kosmos, Bd. i. S. 295-298, and 468-470; Engl. edit. p. 271-274, and lxxxix.)

If the earth's surface did not rise to considerable elevations within the tropics, the highly characteristic form of needle-leaved trees would be almost unknown to the inhabitants of the equatorial zone. In common with Bonpland I have laboured much in the determination of the exact lower and upper limits of the region of Coniferæ and of oaks in the Mexican highlands. The heights at which both begin to grow (los Pinales y Encinales, Pineta et Querceta) 
are hailed with joy by those who come from the sea-coast, as indicating a climate where, so far as experience has hitherto shewn, the deadly malady of the black vomit (Vomito prieto, a form of yellow fever) does not reach. The lower limit of oaks, and more particularly of the Quercus xalapensis (one of the 22 Mexican species of oak first described by us), is on the road from Vera Cruz to the eity of Mexico, a little below the Venta del Encero, 2860 (3048 E.) feet above the sea. On the western side of the highlands between the city of Mexico and the Pacific, the limit is rather lower down, for oaks begin to be found near a hut called Venta de la Moxonera, between Acapulco and Chilpanzingo, at an absolute elevation of 2328 (2480 E.) feet. I found a similar difference in the height of the lower limit of pine woods on the two sides of the continent. On the Pacific side, in the Alto de los Caxones north of Quaxiniquilapa, we found this limit for Pinus Montezumæ (Lamb.), which we at first took for Pinus occidentalis (Swartz), at an elevation of 34.80 (3709 E.) feet; while towards Vera Cruz, on the Cuesta del Soldado, pines are first met with at a height of 5610 ( 5980 E.) feet. Therefore both the kinds of trees spoken of above, oaks and pines, descend lower on the side of the Pacific than they do on the side of the Antillean sea. In ascending the Cofre di Perote, I found the upper limit of the oaks 9715 (10354 E.) feet, and that of the Pinis Montezumæ at 12138 (12936 E.) feet above the sea, or almost 2000 (2132 E.) feet higher than the summit of Etna. Considerable quantities of snow had fallen at this elevation in the month of February. 
The more considerable the heights at which the Mexican Coniferæ are first met with, the more striking it appears to find in the Island of Cuba (where, indeed, on the borders of the torrid zone, northern breezes sometimes cool the atmosphere down to $6 \frac{1}{2}^{\circ}$ Reaumur, $46^{\circ} .6$ Fah.), another species of pine (P. occidentalis of Swartz), growing in the plains or on the low hills of the Isla de Pinos, intermixed with palms and mahogany trees (Swietenias). Columbus mentions a small pine wood (Pinal) in the journal of his first vojage (Diario del 25 de Nov. 1492), near Cayo de Moya, on the north-east of the Island of Cuba. In Hayti also, Pinus occidentalis descends from the mountains to the sea-shore, near Cape Samana. The trunks of these Pines, carried by the Gulf-stream to the Islands of Graciosa and Fayal in the Azores, were among the chief indications from which the great discoverer inferred the existence of unknown lands to the west. (See my Examen crit., T. ii. p. 246-259.) Is it true that in Jamaica, notwithstanding the height of its mountains, Pinus occidentalis is entirely wanting? We may also ask what is the species of Pinus found on the eastern coast of Guatimala, as P. tenuifolia (Benth.) probably belongs only to the mountains near Chinanta?

If we cast a general glance on the species which form the upper limits of arborescent vegetation in the northern hemisphere, from the frigid zone to the equator, we find, beginning with Lapland, that according to Wahlenberg, on the Sulitelma Mountain (lat. 68 $8^{\circ}$ ) it is not needle-trees which form the upper limit, but that birches (Betula alba) extend much higher up than Pinus sylvestris;-whilst in the tem- 
perate zone, in the Alps (lat. $45_{\frac{3}{4}}^{\circ}$ ), Pinus picea (Du Roi) advances highest, leaving the birches behind; and in the Pyrenees (lat. $42 \frac{1}{2}^{\circ}$ ), Pinus uncinata (Ram.) and P. sylrestris var. rubra: within the tropics, in lat. $19^{\circ}-20^{\circ}$, in Mexico, Pinus Montezumæ leares far behind Alnus toluccensis, Quercus spicata, and Q. crassipes; while in the snow mountains of Quito at the equator, Escallonia myrtilloides, Aralia aricennifolia, and Drymis winteri, take the lead. The last-named tree, which is identical with Drymis granatensis (Mut.) and Wintera aromatica (Murray), presents, as Joseph Hooker has shewn (Flora Antarctica, p. 229), the striking. example of the uninterrupted extension of the same species of tree from the most southerm part of Tierra del Fuego and Hermit Island, where it was discovered by Drake's Expedition in 157\%, to the northern highlands of Mexico; or through a rainge of 86 degrees of latitude, or 5160 geographical miles. Where it is not birches (as in the far north), but needle trees (as in the Swiss Alps and the Pyrenees), which form the limit of arborescent regetation on the highest mountains, we find above them, still nearer to the snowy summits which the gracefully enwreath with their bright garlands, in Europe and Western Asia, the Alp roses, the Rhododendra,- which are replaced on the Silla de Caracas and in the Perurian Paramo de Saraguru by the purple flowers of another genus of Ericacex, the beautiful race of Befarias. In Lapland the needle-trees are immediately followed by Rhododendron laponicum; in the Swiss Alps by Rhododendron ferrugineum and R. hirsutum; in the $\mathrm{Py}$ renees by the $R$. ferrugineum only; and in the Caracasus by 
R. caucasicum. Decandolle found the Rhododendron ferrugineum growing singly in the Jura (in the Creux de Vent) at the moderate altitude of 3100 to 3500 (3304 to $37.30 \mathrm{E}$.) feet, 5600 (5968 E.) feet lower down than its proper elevation. If we desire to trace the last zone of vegetation nearest to the snow line in the tropics, we must name, from our own observations, in the Mexican part of the tropical. zone, Cnicus nivalis and Chelone gentianoides; in the cold mountain regions of New Granada, the woolly Espeletia grandiflora, E. corymbosa and E. argentea; and in the Andes of Quito, Culcitium rufescens, C. ledifolium, and C. nivale,-yellow flowering Compositæ which replace in the last-named mountains the somewhat more northerly Espeletias of New Granada, to which they bear a strong: physiognomic resemblance. This replacement, the repetition of resembling or almost similar forms. in countries separated either by seas or by extensive tracts of land, is a wonderful law of nature which appears to prevail even in regard to some of the rarest forms of vegetation. In Robert Brown's family of the Rafflesieæ, separated from the Cytinea, the two Hydnoras described by Thunberg and Drege' in South Africa ( $H$. africana and $H$. triceps) have their counterpart in South America in Hydnora americana (Hooker).

Far above the region of alpine plants, grasses, and liehens, and even above the limit of perpetual snow, the botanist sees with astonishment, both in the temperate and tropical zones, isolated phænogamous plants occur now and then sporadically on rocks which remain free from the general 
surrounding snowy covering, and which may possibly be warmed by heat ascending through open fissures. I have already spoken of the Saxifraga boussingaulti, which is found on the Chimborazo at an elevation of 14800 (15773 E.) feet; in the Swiss Alps, Silene acaulis has been seen at a height of 10680 (11380 E.) feet, being in the first-named case 600 (640 E.) feet, and in the second 2460 (2620 E.) feet above the limit of the snows, that limit being taken as it was in the two cases respectively at the time when the plants were found.

In our European Coniferæ, the Red and White Pine shew great and remarkable differences in respect to their distribution. While in the Swiss Alps the Red Pine (Pinus picea, $\mathrm{Du}$ Roi, foliis compresso-tetragonis; unfortunately called by Linnæus, and by most of the botanists of the present day, Pinus abies!) forms the upper limit of arborescent vegetation at a mean height of 5520 (5883 English) feet, only an occasional low growing mountain-alder (Alnus viridis, Dec., Betula viridis, Vill.) advancing now and then still nearer to the snow-line; the White Pine (Pinus abies, Du Roi, Pinus picea, Linn., foliis planis, pectinatodistichis, emarginatis) ceases, according to Wahlenberg, more than a thousand feet lower down. The Red Pine does not appear at all in the South of Europe, in Spain, the Appennines, and Greece ; even on the northern slope of the Pyrenees it is seen only, as Ramond remarks, at great elevations, and is entirely wanting in the Caucasus. The Red Pine advances in Scandinavia farther to the north than the White Pine, of which last-named tree there is in Greece 
(on Mounts Parnassus, Taygetus, and (Eta) a long needled variety (foliis apice integris, breviter mucronatis), the Abies Apollinis of Link. (Linnæa, Bd. xv. 1841, S. 529; and Endlicher, Synopsis Coniferarum, p. 96.)

On the Himalaya the Coniferæ are distinguished by the great thickness and height of their trunks, and by the length of their leaves. The Deodwara Cedar, Pinus deodara (Roxb.),-(properly, in Sanscrit, dêwa-dâru, timber of the Gods), -which is from 12 to $13 \frac{1}{2}$ feet thick, is the great ornament of the mountains. It grows in Nepaul to 11000 (11720 E.) feet above the level of the sea. More than 2000 years ago the Deodara supplied the materials for the fleet of Nearchus on the Hydaspes (the present Behut). In the valley of Dudegaon, north of the copper mines of Dhunpour in Nepaul, Dr. Hoffmeister, so early lost to science, found the Pinus longifolia of Royle (the Tschelu Pine) growing among tall stems of the Chamærops martiana of Wallich. (Hoffmeister's Briefe aus Indien wahrend der. Expedition des Prinzen Waldemar von Preussen, 1847, S. 351.) Such an intermixture of pineta and palmata had excited the surprise of the companions of Columbus in the New Continent, as a friend and cotemporary of the Admiral, Petrus Martyr Anghiera, has informed us. (Dec. iii. lib. 10, p. 68.) I saw myself this intermixture of pines and palms for the first time on the road from Acapulco to Chilpanzingo. The Himalaya, like the Mexican highlands, has, besides Pines and Cedars, also the forms of Cypresses (Cupressus torulosa (Don), of Yews (Taxus wallichiana, Zuccar.), of Podocarpus (P. nereifolia, Robert Brown), and of 
Juniper (Juniperus squamata, Don., and J. excelsa, Bieberst; Juniperus excelsa is also found at Schipke in Thibet, in Asia Minor, in Syria, and in the Greek Islands). Thuja, Taxodium, Larix, and Araucaria, are forms found in the New Continent, but wanting in the Himalaya.

Besides the 20 species of Pines which we already know from Mexico, the United States of North America, which in their present extent reach to the Shores of the Pacific, have 45 described species, while Europe has only 15 . There is a similar difference in respect to Oaks : i.e. greater variety of forms in the New Continent which extends continuously through a greater extent of latitude. The recent very exact researches of Siebold and Zuccarini have, however, completely refuted the previous belief, that many European species of Pines extend also across the whole of Northern Asia to the Islands of Japan, and even grow there, interspersed, as Thunberg has stated, with genuime Mexican species, the Weymouth Pine, Pinus Strobus of Linnæus. What Thunberg took for European Pines are wholly different and distinct species. Thunberg's Red Pine (Pinus abies, Limn.) is P. polita, (Sieb.) and is often planted near Buddhistic temples; his common Scotch Fir (Pinus sylvestris) is $\mathrm{P}$. Massoniana (Lamb.) ; his P. cembra (the German and Siberian pine with eatable seeds) is $\mathrm{P}$. parvifiora (Sieb.) ; his common Larch (P. larix) is P. leptolepis (Sieb.); and his supposed Taxus baccata, the fruits of which are eaten by Japanese courtiers in case of long-protracted court ceremonials, (Thunberg, Flora Japonica, p. 275), constitutes a distinct genus, and is the Cephalotaxus drupacea of Siebold. VOL. II. 
The Islands of Japan, notwithstanding the vicinity of the Continent of Asia, have a very distinct character of vegetation. Thunberg's supposed Japanese Weymouth Pine, (Pinus Strobus) which would offer an important phenomenon, is only a planted tree, and is besides quite distinct from the American species of Pine. It is Pinus korajensis (Sieb.), and has been brought to Nipon from the peninsula of Corea, and from Kamtschatka.

Of the 114 species of the Genus Pinus with which we are at present acquainted, not one belongs to the Southern Hemisphere, for the Pinus merkusii described by Junghuhn and De Vriese belongs to the part of the Island of Sumatra which is north of the Equator, to the district of the Battas; and Pinus insularis (Endl.) although it was at first given in Loudon's Arboretum as P. timoriensis, really belongs to the Philippines. Besides the Genus Pinus, the Southern hemisphere, according to the present state of our now happily advancing knowledge of the geography of plants, is entirely without species of Cupressus, Salisburia (Gingko), Cunninghamia (Pinus lanceolota, Lamb.) Thuja, (one of the species of which, Th. gigantea, Nutt., found on the banks of the Columbia, has a height of above 180 Eng. feet), Juniperus, and Taxodium (Mirbel's Schubertia). I include the last-named genus with the less hesitation, as a Cape of Good Hope plant (Sprengel's Schubertia capensis) is no Taxodium, but constitutes a genus of itself, Widringtonia, (Endl.) in quite a different division of the family of Coniferæ.

This absence, from the Southern Hemisphere, of true Abietineæ, Juniperineæ, Cupressineæ, and all the Taxodineæ, as 
well as of Torreya, Salisburia adiantifolia, and Cephalotaxus from among the Taxineæ, recalls forcibly the obscurity which still prevails in the conditions which have determined the original distribution of vegetable forms, a distribution which cannot be sufficiently and satisfactorily explained solely by similarity or diversity of soil, thermic relations, or meteorological phenomena. I remarked long ago that the Southern Hemisphere for example has many plants belonging to the natural family of Rosacer, but not a single species of the genus Rosa. We learn from Claude Gay that the Rosa chilensis described by Meyen is only a wild variety of the Rosa centifolia (Linn.), which has been for thousands of years a European plant. Such wild varieties, (i. e. varieties which have become wild) occupy large tracts of ground in Chili, near Valdivia and Osormo. (Gay, Flora Chilensis, p. 340.$)$

In the tropical region of the Northern hemisphere we also found only one single native rose, our Rosa montezunn, in the Mexican highlands near Moran, at an elevation of 8760 (9336 Engl.) feet. It is one of the singular phenomena in the distribution of plants, that Chili, which has Palms, Pourretias, and many species of Cactus, has no Agave; although A. americana grows luxuriantly in Roussillon, near Nice, near Botzen and in Istria, having probably been introduced from the New Continent since the end of the 16th century, and in America itself forms a continuous tract of regetation from Northern Mexico across the isthmus of Panama to the Southern part of Peru. I have long believed that Calceolarias were limited like Roses exclusively to one side of the Equator; of the 22 species which we 
brought back with us, not one was collected to the north of Quito and the Volcano of Pichincha; but my friend Professor Kunth remarks that Calceolaria perfoliata, which Boussingault and Captain Hall found at Quito, advances to New Granada, and that this species, as well as C. integrifolia of Santa Fé de Bogotá, were given by Mutis to the great Linnæus.

The species of Pinus which are so frequent in the tropical Antilles and in the tropical mountains of Mexico do not pass the isthmus of Panama, and are not found in the equally mountainous parts of the tropical portion of South America, and in the high plains of New Granada, Pasto, and Quito. I have been both in the plains and on the mountains from the Rio Sinu, near the isthmus of Panama, to $12^{\circ} \mathrm{S}$. lat.; and in this tract of almost 1600 geographical miles the only forms of needle-trees which I saw were a Taxus-like species of Podocarpus with stems 60 (64 Eng.) feet high (Podocarpus taxifolia), growing in the Pass of Quindiu and in the Paramo de Saraguru, in $4^{\circ} 26^{\prime}$ north, and $3^{\circ} 40^{\prime}$ 'south latitude; and an Ephedra (E. americana) near Guallabamba, north of Quito.

Among the Coniferæ there are common to the northern and southern hemispheres the genera Taxus, Gnetum, Ephedra, and Podocarpus. The last-named genus was distinguished from Pinus long before L'Heritier by Columbus himself, who wrote on the 25th of November, 1492: "Pinales en la Serrania de Haiti que no llevan piñas, pero frutos que parecen azeytunos del Axarafe de Sevilla." (See my Examen crit. T. iii. p. 24.) There are species of Taxus from the Cape of Good Hope to $61^{\circ} \mathrm{N}$. lat. in Scandinavia, 
or through more than 95 degrees of latitude; Podocarpus and Ephedra extend almost as far. In Cupuliferæ, the species of oak which we are accustomed to regard as a northern form do not indeed pass beyond the equator in South America, but in the Indian Archipelago they re-appear in the southern hemisphere in the Island of Java. To the southern hemisphere belong exclusively ten genera of Coniferæ, of which I will name here only the principal: Araucaria, Dammara (Agathis Sal.), Frenela (with eighteen New Holland species), Dacrydium, and Lybocedrus, which is found both in New Zealand and at the Straits of Magrellan. New Zealand has one species of the genus Dammara (D. australis) and no Araucaria. In New Holland in singular contrast the case is opposite.

Among tree vegetation, it is $i_{-}$'he form of needle-trees that Nature presents to us the greatest extension in length (longitudinal axis): I say among tree regetation, because, as we have already remarked, among oceanic Algæ, Macrocystis pyrifera, which is found between the coast of California and $68^{\circ} \mathrm{S}$. lat., often attains from 370 to 400 (about 400 to 430 Eng.) feet in length. Of Coniferæ, (setting aside the sis Araucarias of Brazil, Chili, New Holland, Norfolk Island, and New Caledonia), the loftiest are those which belong to the northern temperate zone. As in the family of Palms we found the most gigantic, the Ceroxylon andicola, above 180 French (192 English) feet high, in the temperate mountain climate of the Andes, so the loftiest Coniferæ belong, in the northern hemisphere, to the temperate north-west coast of America and to the Rocky Mountains 
(lat. $40^{\circ}-52^{\circ}$ ); and in the southern hemisphere to New Zealand, Tasmania or Van Diemen Island, the south of Chili and Patagonia (between $43^{\circ}$ and $50^{\circ}$ latitude). The most gigantic forms belong to the genera of Pinus, Sequoia (Endl.), Araucaria, and Dacrydium. I propose to name only those species which not only attain but often exceed 200 French feet (213 Eng.) In order to afford a standard of comparison, it should be remarked that in Europe the tallest Red and White Pines, the latter especially, attain about 150 or 160 (160-170 Eng.) feet; that, for example, in Silesia the Pine of the Lampersdorf Forest near Frankenstein enjoys great celebrity, although, with a circumference of 17 English feet, its height is only 153 Prussian, or 148 French, or 158 English feet. (Compare Ratzeburg, Furstreisen, 1844, S. 287.)

Pinus grandis (Douglas) in New California attains 224 English feet.

Pinus frémontiana (Endl.), also in New California, probably attains the same stature as the preceding. (Torrey and Frémont, Report of the Exploring Expedition to the Rocky Mountains in 1844, p. 319.)

Dacrydium cupressinum (Solander), from New Zealand, 213 English feet.

Pinus lambertiana (Dougl.,, in North-west America, 224-235 English feet.

Araucaria excelsa (R. Brown), the Cupressus columnaris of Forster, in Norfolk Island and the surrounding rocky islets, 181-224 English feet. 'The six species of Araucaria 
which have become known to us hitherto, fall, according to Endlicher, into two groups:

a. The American group (Brazil and Chili) : A. brasiliensis (Rich.), between $15^{\circ}$ and $25^{\circ} \mathrm{S}$. lat.; and A. imbricata (Pavon), between $35^{\circ}$ and $50^{\circ} \mathrm{S}$. lat., the latter growing to 234-260 English feet.

b. The Australian group: A. bidwilli (Hook.) and A. cunninghami (Ait.) on the east side of New Holland; A. excelsa on Norfolk Island, and A. cookii (R. Brown) in New Caledonia. Corda, Presl. Göppert, and Endlicher, have already discovered five species of Araucarias belonging to the ancient world in the lias, in chalk, and in beds of lignite (Endlicher, Coniferæ fossiles, p. 301.)

Pinus Douglasii (Sabine), in the valleys of the Rocky Mountains and on the banks of the Columbia River (north lat. $43^{\circ}-52^{\circ}$ ). The meritorious Scotch botanist from whom this tree is named perished in 1833 by a dreadful death in collecting plants in the Sandwich Islands, where he had arrived from New California. He fell inadvertently into a pit in which a fierce bull belonging to the cattle which have become wild had previously fallen, and was gored and trampled to death. By exact measurement a stem of Pinus Douglasii was $57 \frac{1}{2}$ English feet in girth at 3 feet above the ground, and its height was 245 English feet. (See Journal of the Royal Institution, 1826, p. 325.)

Pinus trigona (Rafinesque), on the western declivity of the Rocky Mountains, described in Lewis and Clarke's Travels to the Source of the Missouri River and across the American Continent to the Pacific Ocean (1804-1806), 1814, p. 456. This gigantic Fir was measured with great care; the 
trunks were often 38 to 45 English feet in girth, 6 feet above the ground: one tree was 300 English feet high, and the first 192 feet were without any division into branches.

Pinus Strobus grows in the eastern parts of the United States of North America, especially on the east of the Mississipi ; but it is found again in the Rocky Mountains from the sources of the Columbia to Mount Hood, or from $43^{\circ}$ to $54^{\circ} \mathrm{N}$. lat. It is called in Europe the Weymouth Pine and in North America the White Pine: its ordinary height does not exceed 160 to $192 \mathrm{Eng}$. feet, but several trees of 250 to $266 \mathrm{Eng}$. feet have been seen in New Hampshire. (Dwight, Travels, Vol. i. p. 36 ; and Emerson's Report on the Trees and Shrubs growing naturally in the Forests of Massachusetts, 1846, p. 60-66.)

Sequoia gigantea (Endl.), Condylocarpus (Sal.) from New California; like Pinus trigona, about 300 English feet high.

The nature of the soil, and the circumstances of heat and moisture on which the nourishment of plants depend, no doubt influence the degree to which they flourish, and the increase in the number of individuals in a species; but the gigantic height attained by the trunks of a few among the many other nearly allied species of the same genus, depends not on soil or climate; but, in the vegetable as well as in the animal kingdom, on a specific organisation and inherent natural disposition. I will cite as the greatest contrast to the Araucaria imbricata of Chili, the Pinus Douglasii of the Columbia River, and the Sequoia gigantea of New California, which is from 245 to 300 Eng. 
feet in height,-not a plant taken from among a regetation stunted by cold either of latitude or elevation, as is the case with the small Willow-tree, two inches in height, (Salix arctica),-but a small phænogamous plant belonging to the fine climate of the southern tropic in the Brazilian province of Goyaz. The moss-like Tristicha hypnoïdes, from the monocotyledonous family of the Podostemex, hardly reaches the height of 3 lines ( $\frac{2 \pi}{100}$ ths, or less than three-tenths of an English inch.) "En traversant le Rio Claro dans la Province de Goyaz," says an excellent observer, Auguste de St.-Hilaire, "j'aperçus sur une pierre une plante dont la tige n'aroit pas plus de trois lignes de haut et que je pris d'abord pour une mousse. C'étoit cependant une plante phanérogame, le Tristicha hypnoïdes, pourvue d'organes sexuels comme nos chênes et les arbres gigantesques qui à l'entour élevaient leur cimes majestueuses." (Auguste de St.-Hilaire, Morphologie Végétale, 1840, p. 98.)

Besides the height of their stems, the length, breadth, and position of the leaves and fruit, the form of the ramification aspiring or horizontal, and spreading out like a canopy or umbrella,-the gradations of colour, from a fresh green or silvery grey to a blackish-brown, all give to Coniferæ a peculiar physiognomy and character. The needles of Douglas's Pinus lambertiana from North-west America are five French inches long; those of Pinus excelsa of Wallich, on the southern declivity of the Himalaya, near Katmandoo, seven French inches; and those of P. longifolia (Roxb.), from the mountains of Kashmeer, above a French foot long. In one 
and the same species the length of the leaves or needles varies in the most striking manner from the influence of soil, air, and elevation above the level of the sea. In travelling in an east and west direction through eighty degrees of longitude (above 3040 geographical miles), from the mouth of the Scheldt through Europe and the north of Asia to Bogoslowsk in the northern Ural and Barnaul beyond the Obi, I have found differences in the length of the needles of our common Fir (Pinus sylvestris) so great, that sometimes a traveller may be misled by the shortness and rigidity of the leaves, to think that he has discovered a new species allied to the Mountain Pine, P. rotundata (Link), P. uncinata (Ram.) Link has justly remarked (Linnæa, Bd. xv. 1841, S. 489) that such instances may be regarded as transitions to Ledebour's P. sibirica of the Altai.

In the Mexican highlands I have looked with particular pleasure on the delicate cheerful green of the Ahuahuete, Taxodium distichum (Rich.), Cupressus disticha (Linn.), which, however, is much given to shedding its leaves. In this tropical region the above-mentioned tree, (of which the Aztec name signifies water-drum, from atl, water, and huehuetl, a drum, the trunk swelling to a great thickness), flourishes 5400 and 7200 (5755 and 7673 English) feet above the level of the sea, while in the United States of North America it is found in the low grounds of the cypress swamps of Louisiana, in the $43 \mathrm{~d}$ parallel. In the Southern States of North America the Taxodium distichum (Cyprès chauve) reaches, as in the Mexican highlands, the height of 120 (128 English) feet, and the 
enormous thickness of 30 to 37 ( 32 to 39 English) feet, in diameter measured near the ground. (Emerson, Report on the Forests, pp. 49 and 101). The roots present the striking phenomenon of woody excrescences which project from 3 to $4 \frac{\mathrm{I}}{2}$ feet above the earth, and are conical and rounded, and sometimes tabular. Travellers have compared these excrescences in places where they are very numerous to the grave tablets in a Jewish burying-ground. Auguste de St. Hilaire remarks with much acuteness :- "Ces excroissances du Cyprès chauve, ressemblant à des bornes, peuvent être regardées comme des exostoses, et comme elles vivent dans l'air, il s'en échapperoit sans doute des bourgeons adventifs, si la nature du tissu des plantes conifères ne s'opposoit au développement des germes cachés qui donnent naissance à ces sortes de bourgeons." (Morphologie végétale, p. 91). A singularly enduring power of vitality in the roots of trees of this family is shown by a phenomenon which has excited the attention of vegetable physiologists, and appears to be of only very rare occurrence in other dicotyledonous trees. The remaining stumps of White Pines which have been cut down continue for several years to make fresh layers of wood, and to increase in thickness, without putting forth new shoots, leaves, or branches. Göppert believes that this only takes place by means of root nourishment received by the stump from a neighbouring living tree of the same species; the roots of the living individual which has branches and leaves having become organically united with those of the cut tree by their having grown together. (Göppert, Beobachtungen über das sogenannte Umwallen 
der Tännen-stöcke, 1842, S. 12). Kunth, in his excellent new "Lehrbuch der Botanik," objects to this explanation of a phenomenon which was known, imperfectly, so early as Theophrastus. (Hist. Plant. lib. iii. cap. 7, pp. 59 and 60, Schneider.) He considers the case to be analogous to what takes place when metal-plates, nails, carved letters, and even the antlers of stags, become enclosed in the wood of a growing tree. "The cambium, $i . e$. the viscid secretion out of which new elementary organs are constructed either of woody or cellular tissue, continues, without reference to the buds (and quite apart from them), to deposit new layers of wood on the outermost layer of the ligneous substance." ("Th. i. S. 143 and 166.)

The relations which have been alluded to, between elevation above the level of the sea and geographical and thermallatitude, manifest themselves often when we compare the tree vegetation of the tropical part of the chain of the Andes with the vegetation of the north-west coast of America, or with that of the shores of the Canadian Lakes. Darwin and Claude Gay have made the same remark in the Southern Hemisphere, in advancing from the high plains of Chili to Eastern Patagonia and Tierra del Fuego, where they found Drymis winteri and forests of Fagus antarctica and Fagus forsteri forming a uniform covering throughout long continuous lines running from north to south and descending to the low grounds. We find even in Europe small deviations (dependent on local causes which have not yet been sufficiently examined), from the law of constant ratio as regards stations or habitat of plants between elevation above the sea and 
geographical latitude. I mould recall the limits, in respect to elevation, of the birch and the common fir in a part of the Sriss Alps, on the Grimsel. The fir (Pinus sylvestris) extends to 5940, and the birch (Betula alba) to 6480 French (6330 and 6906 English) feet; above the birches there is a higher line of Pinus cembra, whose upper limit is 6890 (7343 English) feet. Here, therefore, we have the birch intervening between two zones of Coniferæ. According to the excellent observations of Leopold Von Buch, and the recent ones of Martins, who also visited Spitzbergen, the folloming geographical limits were found in Lapland:Pinus sylvestris extends to $70^{\circ}$; Betula alba to $70^{\circ} 40^{\prime}$; and Betula nana quite up to $71^{\circ}$; Pinus cembra is altogether wanting in Lapland. (Compare Unger über den Einfluss des Bodens auf die Vertheilung der Gewächse, S. 200; Lindblom, Adnot. in geographicam plantarum intra Sueciam distributionem, p. 89 ; Martins, in the Annales des Sciences naturelles, T. xriii. 1842, p. 195).

If the length and arrangement of the needle-shaped leaves go far to determine the physiognomic character of Coniferæ, this character is still more influenced by the specific differences in the breadth of the needles, and the degree of development of the parenchyma of the appendicular organs. Several species of Ephedra may be called almost leafless; but in Taxus, Araucaria, Dammara (Agathis), and the Salisburia adiantifolia of Smith (Gingko biloba, Linn.), the surfaces of the leaves become gradually broader. I have here placed the genera in morphological succession. The specific names first chosen by botanists 
testify in favour of such a succession. The Dammara orientalis of Borneo and Java, often above ten feet in diameter, was first called loranthifolia; and Dammara australis (Lamb.) of New Zealand, which is 140 (149 English) feet high, was first called zamæfolia. In both these species of trees the leaves are not needles, but "folia alterna oblongo-lanceolata, opposita, in arbore adultiore sæpe alterna, enervia, striata." The under surface of the leaves is thickly set with porous openings. This passage or transition of the appendicular system from the greatest contraction to a broadleaved surface, like all progression from simple to compound, has at once a morphological and a physiognomic interest (Link, Urwelt, Th. I. 1834, S. 201-211). The shortstalked, broad, cleft leaf of the Salisburia (Kämpfer's Gingko) has also its breathing pores only on the under side of the leaf. The original native country of this tree is unknown to us. By the connection and intercourse of Buddhistic communities it early passed from the templegardens of China to those of Japan.

In travelling from a port on the Pacific to Mexico, on our way to Europe, I witnessed the singular and painful impression which the first sight of a pine forest near Chilpanzingo made on one of our companions, who, born at Quito under the equinoctial line, had never seen needle trees, or trees with "folia acerosa." It seemed to him as if the trees were leafless; and he thought that as we were travelling towards the cold North, he already recognised in this extreme contraction of the vegetable organs the chilling and impoverishing influence of the pole. The traveller 
whose impressions I here describe, whose name neither my friend Bonpland or myself can pronounce without regret, was Don Carlos Montufar (son of the Marquis of Selvalegre), an excellent young man, whose noble and ardent love of freedom led him a few years later, in the war of independence of the Spanish Colonies, to meet courageously a violent death, of which the dishonour did not fall on him.

(24) p. 26.- "The Pothos-form, Aroidec."

Caladium and Pothos are exclusively forms of the tropical world; the species of Arum belong more to the temperate zone. Arum italicum, A. dracunculus, and A. tenuifolium, extend to Istria and Friuli. No Pothos has yet been discovered in Africa. India has some species of this genus (Pothos scandens and P. pinnata) which are less beautiful in their physiognomy, and less luxuriant in their growth, than the American species. We discovered a beautiful and truly arborescent member of the group of Aroideæ (Caladium arboreum) having stems from 16 to 21 English feet high, not far from the convent of Caripe, to the East of Cumanas. A very curious Caladium (Culcasia scandens) has been discovered by Beaurois in the kingdom of Benin. (Palisot de Beaurois, Flore d'Orare et de Benin, T. i. 1804, p. 4, pl. iii.) In the Pothos-form the parenchyma is sometimes so much extended that the surface of the leaf is interrupted by holes as in Calla pertusa (Kunth), and Dracontium pertusum (Jacquin), which we collected in the woods round Cumana. The Aroidex first led attention to the remarkable 
phenomenon of the fever-heat, which in certain plants is sensible by the thermometer during the development of their inflorescence, and which is connected with a great and temporary increase of the absorption of oxygen from the atmosphere. Lamarck remarked in 1789 this increase of temperature at the time of flowering in Arum italicum. According to Hubert and Bory de St. Vincent the vital heat of Arum cordifolium in the Isle of France was found to rise to $35^{\circ}$ and $39^{\circ}$ Reaumur, (110 .6 and $119^{\circ} .6$ Fahr.) while the temperature of the surrounding air was only $15^{\circ} .2 \mathrm{R}$. $\left(66^{\circ} .2 \mathrm{~F}\right.$.) Even in Europe, Becquerel and Breschet found as much as $17 \frac{1}{2}^{\circ}$ difference, Reaumur (39 .4 Fahr.) Dutrochet remarked a paroxysm, an alternate decrease and increase of vital heat, which appeared to reach a double maximum in the day. Théodore de Saussure observed analogous augmentations of temperature, though to a less amount, only from $0^{\circ} .5$ to $0^{\circ} .8$ of Reaumur's scale $\left(1^{\circ} .15\right.$ to $1^{\circ} .8 \mathrm{Fahr}$.), in plants belonging to other families; for example, in Bignonia radicans and Cucurbita pepo. In the latter plant the use of a very sensitive thermoscope shews that the increase of temperature is greater in the male than in the female plant. Dutrochet, who previous to his early death made such meritorious researches in physics and in vegetable physiology, found by means of thermo-magnetic multiplicators (Comptes rendus de l'Institut, T. viii. 1839 , p. 454, T. ix. p. 614 and 781) an increase of vital heat from $0^{\circ} .1$ to $0^{\circ} .3$ Reaumur, $\left(0^{\circ} .25\right.$ to $0^{\circ} .67$ Fahr.) in several young plants (Euphorbia lathyris, Lilium candidum, Papaver somniferum), and even among funguses in several species of Agaricus and Lycoperdon. 
This vital heat disappeared at night, but was not prevented by placing the plants in the dark during the day-time.

A yet more striking physiognomic contrast than that of Casuarineæ, Needle trees, and the almost leafless Peruvian Colletias, with Aroideæ, is presented by the comparison of those types of the greatest contraction of the leafy organs with the Nymphæaceæ and Nelumboneæ. Te find in these as in the Aroidex, leaves, in which the cellular tissue forming their surface is extended to an extreme degree, supported on long fleshy succulent leaf-stalks; as in Nymphæa alba; N. Iutea; $\mathbf{N}$. thermalis (once called N. lotus, from the hot spring of Pezce near Groswardein, in Hungary); the species of Nelumbo; Euryale amazonica of Pöppig; and the Victoria Regina discovered in 18.37 by Sir Robert Schomburgk in the River Berbice in British Guiana, and which is allied to the prickly Euryale, although, according to Lindley, a rery different genus. The round leares of this magnificent water plant are six feet in diameter, and are surrounded by turned up margins 3 to 5 inches high, light green inside, and bright crimson outside. The agreeably perfumed flotrers, twenty or thirty blossoms of which may be seen at the same time within a small space, are white and rose coloured, 15 inches in diameter, and have many hundred petals. (Rob. Schomburgk, Reisen in Guiana und am Orinoko, 1841, S. 233.) Pöppig also gives to the leaves of his Euryale amazonica which he found near Tefe, as much as 5 feet 8 inches French, or 6 English feet, diameter. (Pöppiğ, Reise in Chile, Peru und auf dem Amazonenstrome, Bd. ii. 1836, S. 432.) If Euryale and TOL. II. 
Victoria are the genera which present the greatest extension in all dimensions of the parenchyma of the leaves, the greatest known dimensions of a flower belong to a parasitical Cytinea, the Rafflesia Arnoldi (R. Brown), discovered by Dr. Arnold in Sumatra, in 1818: it has a stemless flower of three English feet diameter, surrounded by large leaf-like scales. Fungus-like, it has an animal smell, resembling beef.

$$
\begin{gathered}
\text { p. 26.- "Lianes, rope-plants, ('Bush ropes:' } \\
\text { in Spanish, Vejuccos.") }
\end{gathered}
$$

According to Kunth's division of the Bauhiniex, the true genus Bauhinia belongs to the New Continent: the African Bauhinia, B. rufescens, (Lam.) is a Pauletia (Cav.) a genus of which we found some new species in South America. So also the Banisterias, from among the Malpighiaceæ, are properly an American form; although two species are natives of India, and one species, Banisteria leona, described by Cavanilles, is a native of Western Africa. Within the tropics and in the Southern Hemisphere we find among the most different families of plants the twining rope-like climbers which in those regions render the forests at once so impenetrable to man, and on the other hand so accessible and habitable to the Quadrumanæ (or Monkeys) and to the Cercoleptes and the small tiger-cats. The rapid ascent to the tops of lofty trees, the passage from tree to tree, and even the crossing of streams by whole herds or troops of gregarious animals, are all greatly facilitated by these twining plants or Lianes.

In the South of Europe and in North America, Hops 
from among the Urticex, and the species of Vitis from among the Ampelidex, belong to the class of twining climbers, and between the tropics we find climbing Grasses or Graminex. We have seen in the plains of Bugota, in the pass of Quindiu, in the Andes, and in the Quina-producing forests of Loxa, a Bambusacea allied to Nastus, our Chusquea scandens, twine round massive and lofty trunks of trees adorned at the same time with flowering Orchidex. The Bambusa scandens (Tjankorreh), which Blume found in Java, belongs probably either to the genus Nastus or to that of Chusquea, the Carrizo of the Spanish settlers. Twining plants appear to me to be entirely absent in the Pine-woods of Mexico, but in New Zealand, besides the Ripogonum parviflorum of Robert Brown, (a climber belonging to the Smilacex which renders the forests almost impenetrable), the sweet-smelling Freycinetia Banksii, which belongs to the Pandanex, twines round a gigantic Podocarpus 220 English feet high, the P. dacryoides (Rich), called in the native language Kakikatea. (Dieffenbach, Travels in New Zealand, 1843, Vol. i. p. 426.)

With climbing Gramineæ and Pandaneæ are contrasted by their beautiful and many-coloured blossoms the Passifloras (among which, hotrever, we even found an arborescent selfsupporting species, Passiflora glanca, growing in the Andes of Popayan, at an eleration of 9840 French (10487 English) feet); 一the Bignoniaceæ, Mutisias, Alströmerias, Urvilleæ, and Aristolochias. Among the latter our Aristolochia cordata has a crimson-coloured flower of 17 English inches diameter! "flores gigantei, pueris mitræ instar inservientes." Many of these twining plants have a peculiar physiognomy and 
appearance produced by the square shape of their stems, by flattenings not caused by any external pressure, and by riband-like wavings to and fro. Cross sections of Bignonias and Banisterias shew cruciform or mosaic figures produced by the mutual pressure and interpenetration of the stems which twine around each other. (See very accurate drawings in Adrien de Jussieu's Cours de Botanique, p. 77-79, fig. 105-108.)

\section{(26) p. 27.- "The form of Aloës."}

To this group of plants, characterised by so great a similarity of physiognomy, belong; Yucca aloifolia, which extends as far north as Florida and South Carolina; Y. angustifolia (Nutt.) which advances as far as the banks of the Missouri; Aletris arborea; the Dragon-tree of the Canaries and two other Dræcænas from New Zealand; arborescent Euphorbias; Aloë dichotoma (Linn.) (formerly the genus Rhipidodendrum of Willdenow); and the celebrated Koker-boom of Southern Africa with a trunk twenty-one feet high and above four feet thick, and a top of 400 (426 Engl.) feet in circumference. (Patterson, Reisen in das Land der Hottentotten und der Kaffern, 1790, S. 55.) The forms which I have thus brought together belong to very different families: to the Liliaceæ, Asphodeleæ, Pandaneæ, Amaryllideæ, and Euphorbiaceæ; all, however, with the exception of the last, belonging to the great division of the Monocotyledones. A Pandanea, Phytelephas macrocarpa (Ruiz, which we found in New Granada on the banks of the Magdalena, with its pinnated leavos, 
quite resembles in appearance a small palm-tree. This Phytelephas, of which the Indian name is Tagua, is besides, as Kunth remarks, the only one of the Pandanex found (according to our present knowledge) in the New Continent. The singular Agave-like and at the same time very tall-stemmed Doryanthes excelsa of New South Wales, which was first described by the acutely observing Correa de Serra, is an Amaryllidea, like our low-growing Narcissuses and Jonquils.

In the Candelabra shape of plants of the Aloë form, we must not confound the branches of an arborescent stem with flower-stalks. It is the latter which in the American Aloë (Agave Americana, Maguey de Cocuyza, which is entirely wanting in Chili) as well as in the Yucca acaulis, (Maguey de Cocuy) presents in the rapid and gigantic derelopment of the inflorescence a candelabrum-like arrangement of the flowers which, as is well known, is but too transient a phenomenon. In some arborescent Euphorbias, on the other hand, the physiognomic effect is given by the branches and their division, or by ramification properly so called. Lichtenstein, in his "Reisen im südlichen Africa" (Th. i. S. 370), gives a vivid description of the impression made upon him by the appearance of a Euphorbia officinarum which he found in the "Chamtoos Rivier," in the Colony of the Cape of Good Hope; the form of the tree was so symmetrical that the candelabrum-like arrangement was regularly repeated on a smaller scale in each of the subdivisions of the larger branches up to 32 English feet high. All the branches were armed with sharp spines. 
Palms, Yuccas, Aloes, tall-stemmed Ferns, some Aralias, and the Theophrasta where I have seen it growing luxuriantly, different as they are in the structure of their flowers, yet offer to the eye in the nakedness (absence of branches) of their stems, and in the ornamental character of their tops or crowns, a certain degree of physiognomic resemblance.

The Melanoselinum decipiens (Hofm.), which is sometimes upwards of 10 or 12 feet high, and which has been introduced into our gardens from Madeira, bèlongs to a peculiar group of arborescent umbelliferous plants to which Araliaceæ are otherwise allied, and with which other plants which will doubtless be discovered in course of time will be associated. Ferula, Heracleum, and Thapsia, do indeed attain a considerable height, but they are still herbaceous plants. Melanoselinum is still almostentirelyalone as an umbelliferous tree; Bupleurum (Tenonia) fruticosum (Linn.) of the shores of the Mediterranean; Bubon galbanum of the Cape, and. Crithmum maritimum of our sea-shores, are only shrubs. On the other hand, the tropical zone, in which, according to the old and very just remark of Adanson, Umbelliferæ and Cruciferæ are almost entirely wanting in the plains, presented to us on the high ridges of the American Andes the smallest and most dwarf-like of all umbelliferous plants. Among 38 species of plants which we collected at elevations where the mean temperature is below $10^{\circ}$ Reaumur ( $54^{\circ} .5$ Fah.), there vegetate almost like mosses, and as if they made part of the rock and of the often frozen earth, at an elevation of 12600 (13430 English) feet above the level of the 
sea, Myrrhis andicola, Fragosa arctioïdes, and Pectophytum pedunculare, intermingled with which there is an equally dwarfed Alpine Draba. The only umbelliferous plants growing in the low grounds within the tropics observed by us in the New Continent were two species of Hydrocotyle (H. umbellata and H. leptostachya) between Havannah and Batabano; therefore at the extreme limits of the torrid Zone.

\section{(27) p. 27.-"The form of Graminece."}

The group of arborescent grasses which Kunth, in his able treatise on the plants collected by Bonpland and myself, has combined under the name of Bambusacex, is among the most beautiful adornments of the tropical world. (Bambu, also called Mambu, is a word in the Malay language, but appears according to Buschmann to be of doubtful origin, as the usual Malay expression is buluh, in Java and Madagascar wuluh, voulu.) The number of genera and species which form this group has been extraordinarily augmented by the "zeal of botanists. It is now recognised that the genus Bambusa is entirely wanting in the New Continent, to which on the other hand Guadua, from 50 to 60 French or about 53 to 64 English feet high, discovered by us, and Chusquea, exclusively belong; that Arundinaria (Rich) is common to both continents, although the species are different; that Bambusa and Beesha (Rheed.) are found in India and the Indian Archipelago, and Nastus in the Island of Bourbon, and in Madagascar. With the exception of the tall-climbing Chusquea the forms which have been named may be said to replace each other morpholo- 
gically in the different parts of the world. In the northern hemisphere, in the valley of the Mississipi, the traveller is gratified, long before reaching the tropics, with the sight of a form of bamboo, the Arundinaria macrosperma, formerly called also Miegia, and Ludolfia. In the Southern Hemisphere Gay has discovered a Bambusacea, (a still undescribed species of Chusquea, 21 English feet high, which does not climb, but is arborescent and self-supporting) growing in southern Chili between the parallels of $37^{\circ}$ and $42^{\circ} \mathrm{S}$. latitude; where, intermixed with Drymis chilensis, a uniform forest covering of Fagus obliqua prevails.

While in India the Bambusa flowers so abundantly that in Mysore and Orissa the seeds are mixed with honey and eaten like rice, (Buchanan, Journey through Mysore, Vol. ii. p. 341, and Stirling in the Asiat Res. Vol. xv. p. 205) in South America the Guadua flowers so rarely, that in four years we were only twice able to procure blossoms; once on the unfrequented banks of the Cassiquiare, (the arm which connects the Orinoco with the Rio Negro and the Amazons River, and once in the province of Popayan between Buga and Quilichao. It is. striking to see plants in particular localities grow with the greatest vigour without producing flowers: it is thus with European olive trees which have been planted for centuries between the tropics near Quito, 9000 (about 9590 English) feet above the level of the sea, and also in the Isle of France with Walnut-trees, Hazel-nuts, and, as at Quito, olive trees (Olea europea): see Bojer, Hortus Mauritianus, 1837, p. 291. 
As some of the Bambusacex (arborescent grasses) adrance into the temperate zone, so within the tropics they do not suffer from the temperate climate of the mountains. They certainly grow more luxuriantly as social plants from the sea coast to the height of about 2560 English feet; for example, in the province de las Esmeraldas, west of the Volcano of Pichincha, where Guadua angustifolia (Bambusa Guadua in our Plantes équinoxiales, T. i. Tab. xx.) produces in its interior much of the siliceous Tabaschir (Sanscrit tvakkschira, ox-milk). In the pass of Quindiu me saw the Guadua growing at an elevation which we found by barometric measurement to be 5400 (5755 English) feet above the level of the Pacific. Nastus borbonicus is called by Bory de St. Vincent a true Alpine plant; he states that it does not descend lower on the declivity of the Volcano in the Island of Bourbon than 3600 (3837 English) feet. This recurrence or repetition as it were at great elevations of the forms characteristic of the hot plains, recalls the mountain group of palms before pointed out by me (Kunthia Montana, Ceroxylon andicola, and Oreodoxa frigida), and a grove or thicket of Musaceæ sixteen English feet high (Heliconia, perhaps Maranta), which I found growing isolated at an elevation of 6600 (7034 English) feet, on the Silla de Caraccas. (Rélation hist. T. i. p. 605-606.) As, with the exception of a few isolated herbaceous dicotyledones, grasses form the highest zone of phænogamous vegetation round the snowy summits of lofty mountains, so also, in advancing in a horizontal direction towards either pole of the Earth, the phænogamous vegetation terminates with grasses. 
To my young friend Joseph Hooker, who, but just returned with Sir James Ross from the frozen antarctic regions, is now exploring the Thibetian portion of the Hima-. laya, the geography of plants is indebted not only for a great mass of important materials, but also for excellent general deductions. He calls attention to the circumstance that phænogamous flowering plants (grasses) approach $17 \frac{1}{2}^{\circ}$ nearer to the Northern than to the Southern pole. In the Falkland Islands near the thick masses of Tussack grass (Dactylis cæspitosa, Forster, according to Kunth a Festuca), and in Tierra del Fuego or Fuegia, under the shade of the birch-leaved Fagus antarctica, there grows the same Trisetum subspicatum which extends over the whole range of the Peruvian Cordilleras, and over the Rocky Mountains to. Melville Island, Greenland, and Iceland, and which is also found in the Swiss and Tyrolese Alps, in the Altai mountains, in Kamtschatka, and in Campbell Island, south of New Zealand; therefore, from $54^{\circ}$ South to $74 \frac{1}{2}^{\circ}$ North latitude, or through $128 \frac{1}{2}^{\circ}$ of latitude. "Few grasses," says Joseph Hooker, in his Flora Antarctica, p. 97, "have so wide a range as Trisetum subspicatum, (Beauv.) nor am I acquainted with any other Arctic species which is equally an inhabitant of the opposite polar regions." The South Shetland Islands, which are divided by Bransfield Strait from D'Urville's Terre de Louis Philippe and the Volcano of Haddington Peak, situated in $64^{\circ} 12^{\prime}$ South latitude and 7046 English feet high, have been very recently visited by a Botanist from the United States of North America, Dr. Eights. He found there (probably in $62^{\circ}$ or 
$62 \frac{1}{4}^{\circ}$, S. latitude) a small grass, Aira antarctica (Hooker, Icon. Plant. Vol. ii. Tab. 150) which is "the most antarctic flowering plant hitherto discovered."

In Deception Island, of the same group, S. lat. $62^{\circ} 50^{\prime}$, lichens only are found, and not a single species of grass; and so also farther to the south-east, in Cockburn Island (lat. $\left.64^{\circ} 12^{\prime}\right)$, near Palmer's Land, there were only found Lecanoras, Lecideas, and fire Mosses, among which was our German Bryum argenteum: "this seems to be the ultima Thule of antarctic vegetation." Farther to the south, landcryptogamic, as well as phænogamic, vegetation is entirely wanting. In the great bay formed by Tictoria Land, on a small island which lies opposite to Mount Herschel (S. lat. $71^{\circ} 49^{\prime}$ ), and in Franklin Island, 92 geographical miles North of the great volcano Mount Erebus, 12400 English feet high (latitude $76^{\circ} 7^{\prime}$ South), Hooker found not a single trace of vegetable life. It is quite different in respect to the extension even of the forms of higher vegetable organisation in the high northern latitudes. Phænogamous plants there approach $18 \frac{1}{2}^{\circ}$ nearer to the pole than in the southern hemisphere: Walden Island (N. lat. $80 \frac{1}{2}^{\circ}$ ) has still ten species. The antarctic phænogamous regetation is also poorer in species at corresponding distances from the pole (Iceland has five times as many flowering plants as the southern group of Auckland and Campbell Islands), but this less varied antarctic vegetation is from climatic reasons more luxuriant and succulent. (Compare Hooker, Flora antarctica, p. vii., 74, and 215, with Sir James Ross, Voyage in the Southern and Antarctic Regions, 1839-1843, Vol. ii.

p. $335-342$. 


\section{(28) p. 28.-“Ferns."}

If, with a naturalist deeply versed in the knowledge of the Agamæ, Dr. Klotzsch, we estimate the whole number of cryptogamic species hitherto described at 19000, this gives to Fungi 8000 (of which the Agarici constitute 1-8th); Lichens, according to J. von Flotow of Hirschberg, and Hampe of Blankenburg, at least 1400 ; Algæ 2580; Mosses and Liver-worts, according to Carl Miuller of Halle, and Dr. Gottsche of Hamburgh, 3800; and Ferns 3250. We are indebted for this last important result to the thorough investigation of all that is known concerning this group of plants by Professor Kunze of Leipsic. It is remarkable that of the entire number of described Filices the family of Polypodiaceæ, alone, comprises 2165 species; while other forms, even Lycopodiaceæ and Hymenophyllaceæ, only count 350 and 200. There are, therefore, almost as many described ferns as described grasses.

It is remarkable that in the ancient classic writers, Theophrastus, Dioscorides, and Pliny, no notice occurs of the beautiful form of arborescent ferns; while from information derived from the companions of Alexander, Aristobulus, Megasthenes, and Nearchus, mention is made of Bamboos "quæ fissis internodiis lembi vice vectitabant navigantes ;" of the Indian trees "quarum folia non minora clypeo sunt;" of the fig-tree of which the branches take root round the parent stem; and of Palms "tantæ proceritatis, ut sagittis superjici nequeant." (Humboldt, de Distributione geogr. Plantarum, p. 178 and 213.) I find the first description of tree-ferns in Oviedo's Historia de las Indias, 1535, fol. xc. 
This experienced traveller, who had been placed by Ferdinand the Catholic as director of the gold-washings in Hayti, says : "Among the many ferns there are some which I reckon among trees, for they are as thick and as tall as pines (Helechos que yo cuento por arboles, tan gruesos como grandes pinos y muy altos). They grow chiefly in the mountains and where there is much water." The height is exag'gerated. In the dense forests round Caripe even our Cyathea speciosa only attains a height of 30 to 35 ( 32 to 37 English) feet; and an excellent observer, Ernst Dieffenbach, in the northernmost of the three islands of $\mathrm{New}$ Zealand saw no stems of Cyathea dealbata of more than 40

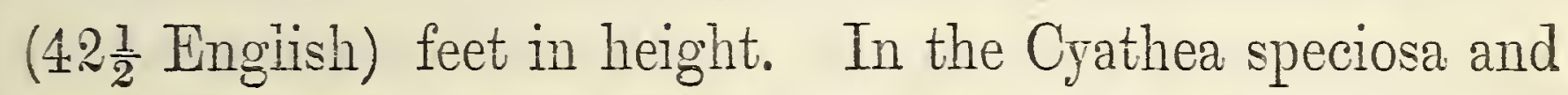
the Meniscium of the Chaymas missions we observed, in the midst of the shadiest primeval forest, in very luxuriantly growing individuals, the scaly stems covered with a shining carbonaceous powder. It seemed like a singular decomposition of the fibrous parts of the old frond stalks. (Humboldt, Rel. hist. T. i. p. 43\%.)

Between the tropics, where, on the declivities of the Cordilleras, climates are placed successively in stages one above another, the proper zone of the tree-ferns is between three and five thousand feet (about 3200 and 5330 English) above the level of the sea. In South America and in the Mexican highlands they seldom descend lower towards the plains than 1200 (about 1280 Eng.) feet. The mean temperature of this happy zone falls between $17^{\circ}$ and $14^{\circ} .5$ Reaumur ( $70^{\circ} .2$ and $64^{\circ} .6$ Fahr.) This region enters the lowest stratum of clouds, or that which floats next above the 
sea and the plains ; and hence, besides great equality of temperature, it also enjoys uninterruptedly a high degree of humidity. (Robert Brown, in Appendix to Expedition to Congo, p. 423.) The inhabitants, who are of Spanish descent, call this zone "tierra templada de los helechos." The Arabic word for fern is feledschun, $f$ being changed into $h$ in helechos according to Spanish custom: perhaps the Arabic feledschun is connected with "faladscha," "it divides;" in allusion to the finely divided margins of fern leaves or fronds. (Abu Zacaria Ebn el Awam, Libro de Agricultura, traducido por J. A. Banqueri, T. ii. Madr. 1802, p. 736.)

The conditions of mild temperature and an atmosphere nearly saturated with vapour, together with great equability of climate in respect to both temperature and moisture, are fulfilled on the declivities of the mountains, in the valleys of the Andes, and above all in the mild and humid atmosphere of the southern hemisphere, where arborescent ferns extend not only to New Zealand and Van Diemen Island (Tasmania), but even to the Straits of Magellan and to Campbell Islands, or to a latitude almost corresponding to that of Berlin in the northern hemisphere. Of tree-ferns, Dicksonia squarrosa grows vigorously in $46^{\circ}$ South latitude, in Dusky Bay (New Zealand); D. antarctica of Labillardière in Tasmania; a Thyrsopteris in Juan Fernandez; an undescribed Dicksonia with stems from 12 to 15 (nearly 13 to 16 English) feet in the south of Chili, not far from Valdivia; and a Lomaria of rather less height in the Straits of Magellan. Campbell Island is still nearer to the south pole, in $52 \frac{1}{2}^{\circ}$ lat., and even there the stem of the Aspidium venustum rises to 
4 feet ( 4 feet 3 inches, English) before the fronds branch off.

The climatic relations under which Ferns in general flourish, are manifested in the numerical laws of their quotients of distribution taken in the manner alluded to in an earlier part of the present volume. In the low plains of the great continents within the tropics, the quotient for ferns is, according to Robert Brown, and according to late researches, 1-20th of all the species of phænogamous plants growing in the same region; in the mountainous parts of the great continents in the same latitudes it is from 1-8th to 1-6th. But a very different ratio is found in the small islands dispersed over the wide ocean. The proportion of ferms to the whole number of Phanerogamæ increases there in such a manner that in the groups of islands between the tropics in the Pacific the ferns equal a fourth,-and in the solitary far detached islands in the Atlantic Ocean, St. Helena, and Ascension, - almost equal the half of the entire phænogamous vegetation. (See an excellent memoir of D'Urville entitled Distribution géographique des Fougères sur la surface du Globe, in the Annales des Sciences Nat. T. vi. 1825, p. 51 , 66 , and 73). From the tropics (where in the great continents D'Urville estimates the ratio generally at $1: 20$ ) we see the relative frequency of ferns decrease rapidly in the temperate zone. The quotients are : for North America and for the British Islands $\frac{1}{35}$, for France $\frac{1}{58}$, for Germany $\frac{1}{52}$, for the dry parts of the south of Italy $\frac{1}{\tau^{4}}$, and for Greece $\frac{1}{84}$. Towards the colder regions of the north we see the relative 
frequency increase again rapidly; that is to say, the number of species of ferns decreases much more slowly than does the number of species of phænogamous plants. At the same time, the luxuriance, abundance, and mass of individuals in each species augments the illusive impression of absolute numbers. According to Wahlenberg's and Hornemann's Catalogues the relative numbers of Filices are, for Lapland $\frac{1}{25}$, for Iceland $\frac{1}{18}$, and for Greenland $\frac{1}{12}$.

Such, according to the present state of our knowledge, are the natural laws manifested in the distribution of the pleasing form of Ferns. But it would seem as if in the family of Ferns, which has so long been regarded as a cryptogamic family, we had quite recently arrived on the traces of another natural law, a morphological one of propagation. Count Leszczyc-Suminski, who happily unites the gift of microscopic examination with distinguished artistic talent, has discovered in the prothallium of ferns an organisation by which fructification is effected. He distinguishes a bisexual arrangement in the ovule-like cell on the middle of the theca, and in the ciliated antheridia or spiral threads before examined by Nägeli. The fertilisation is supposed to take place not by pollen tubes but by the moveable ciliated spiral threads. (Suminski zur Entwickelungs-geschichte der Farrnkräuter, 1848, S. 10-14.) According to this view, Ferns, as Ehrenberg expresses it (Monatl. Berichte der Akad. zu Berlin, Januar 1848, S. 20), would be produced by a microscopic fertilisation taking place on the prothallium as a receptacle; and throughout the whole remainder of their often arborescent 
development they would be flowerless and fruitless plants, forming buds or bulbs; the spores or sori on the under side of the frond not being seeds but flower buds.

$$
\text { (29) p. 28.- "Litiacece." }
$$

The principal seat of this form is Africa, where it is both most varied and most abundant, and where these beautifully flowering plants are assembled in masses and determine the aspect and character of the country. The New Continent does, indeed, also possess superb Alstromeriæ and species of Pancratium, Hæmanthus, and Crinum (we augmented the first-named of these genera by nine, and the second by three species); but these American Liliacex grow dispersed, and are less social than our European Iridex.

$$
\text { (30) p. 28.- "Willow Form." }
$$

Of the leading representative of this form, the Willow itself, 150 different species are already known. They are spread over the northerm hemisphere from the Equator to Lapland. They appear to increase in number and diversity of form between the 46 th and 70 th degrees of north latitude, and especially in the part of north of Europe where the configuration of the land has been so strikingly indented by early geological changes. Of Willows as tropical plants I am acquainted with ten or twelre species, which, like the willows of the southern hemisphere, are deserving of particular attention. As Nature seems as it were to take pleasure in multiplying certain forms of animals, for example Anatidæ (Lamellirostres) and Columbæ, in all the zones of the earth; 
so are Willows, the different species of Pines, and Oaks, no less widely disseminated: the latter (oaks) being always alike in their fruit, though much diversified in the forms of their leaves. In Willows, the similarity of the foliage, of the ramification, and of the whole physiognomic appearance, in the most different climates, is unusually great, - -almost greater than even in Coniferæ. In the southern part of the temperate zone of the northern hemisphere the number of species of willows decreases considerably, yet (according to the Flora atlantica of Desfontaines) Tunis has still a species of its own resembling Salix caprea; and Egypt reckons, according to Forskäl, five species, from the catkins of whose male flowers a medicine much employed in the East, Moie chalaf (aqua salicis) is obtained by distillation. The Willow which I saw in the Canaries is also, according to Leopold von Buch and Christian Smith, a peculiar species, common however to that group and to the Island of Madeira, - S. canariensis. Wallich's Catalogue of the plants of Nepaul and of the Himalaya cites from the Indian sub-tropical zone thirteen species, partly described by Don, Roxburgh, and Lindley. Japan has its indigenous willows, one of which, S. japonica (Thunb.) is also found as a mountain plant in Nepaul.

Previous to my expedition, the Indian Salix tetrasperma was the only known intertropical species, so far as I am aware. We collected seven new species, three of which were from the elevated plains of Mexico, and were found to extend to an elevation of 8000 (about 8500 English) feet above the level of the sea. At still greater elevations,-for example, on the mountain plains situated between 12000 
and 14000 feet, (about 12790 and 14920 English,) which we often visited, - we did not find, either in the Andes of Mexico or in those of Quito and Peru, any thing which could recall the small creeping alpine willows of the Pyrenees, the Alps, and Lapland (S. herbacea, S. lanata, and S. reticulata). In Spitzbergen, where the meteorological conditions have much analogy with those of the Swiss and Scandinavian snow-mountains, Martins described two dwarf willows, of which the small woody stems and branches creep on the ground, and which lie so concealed in the turf-bogs that their small leaves are only discovered with difficulty under the moss. The species found by me in Peru in $4^{\circ} 12^{\prime} \mathrm{S}$. latitude, near Loxa, at the entrance of the forests where the best Cinchona bark is collected, and described by Willdenow as Salix humboldtiana, is the one which is most widely distributed in the western part of South America. A sea-shore species, S. falcata, which we found on the sandy coast of the Pacific, near Truxillo, is, according to Kunth, probably only a variety of the above; and possibly the fine and often pyramidal willow which accompanied us along the banks of the Magdalena, from Mahates to Bojorque, and which, according to the report of the natives, had only extended so far within a few years, may also be identical with Salix humboldtiana. At the confluence of the Rio Opon with the Magdalena, we found all the islands covered with willows, many of which had stems 64 English feet high, but only 8 to 10 inches in diameter. (Humboldt and Kunth, Nova Gen. Plant. T. ii. p. 22, tab. 99.) Lindley has made us acquainted with a species of Salix from Senegal, and there- 
fore in the African equinoctial zone. (Lindley, Introduction to the Natural System of Botany, p. 99.) Blume also found two species of Salix near the equator, in Java: one wild and indigenous, S. tetrasperma; and another cultivated, S. sieboldiana. From the southern temperate zone I know only two willows described by Thunberg, (S. hirsuta and S. mucronata); they grow by the side of Protea argentea (which has itself very much the physiognomy of a willow), on the banks of the Orange River, and their leaves and young shoots form the food of the hippopotamus. Willows are entirely wanting in Australia and the neighbouring islands.

\section{(31) p. 29._-"Myrtacea."}

An elegant form, with stiff, shining, thickly set, generally unindented, small leaves, studded with pellucid dots. Myrtacer give a peculiar character to three districts of the earth's surface,- the South of Europe, particularly the calcareous and trachytic islands which rise above the surface of the Mediterranean;- - the continent of New Holland, adorned with Eucalyptus, Metrosideros, and Leptospermum;-and an intertropical region, part of which is low, and part from nine to ten thousand feet high (about 9590 to 10660 English), in the Andes of South America. This mountain district, called in Quito the district of the Paramos, is entirely covered with trees which have a myrtlelike aspect and character, even though they may not all belong to the natural family of Myrtaceæ. Here, at the above-named elevation, grow the Escallonia myrtilloides, 
E. tubar, Simplocos alstonia, some species of Mrrica, and the beautiful Myrtus microphylla which we have figured in the Plantes équinoxiales, T. i. p. 2. , Pl. iv. We found it groming on mica slate, and extending to an elevation of more than ten thousand English feet, on the Paramo de Saraguru, near Vinayacu and Alto de Pulla, which is adorned with so many lovely alpine flowering plants. Myrtus myrsinoides even extends in the Paramo de Guamani up to 10500 (11190 English) feet. Of the 40 species of the Genus Mrrtus which we collected in the equinoctial zone, and of which 37 were undescribed, much the greater part belonged, however, to the plains and lower mountains. From the mild tropical mountain climate of Mexico we brought back only a single species (Myrtus xalapensis); but the Tierra templada, towards the Volcano of Orizaba, must no doubt contain several more. We found M. maritima near Acapulco, quite on the sea-coast of the Pacific.

The Escallonias, -among which E. myrtilloides, E. tubar, and $\mathrm{E}$. floribunda, are the ornament of the Paramos, and by their physiognomy remind the beholder strongly of the myrtle-form, - once constituted, in combination with the European and South American Alp-roses (Rhododendrum and Befaria), and with Clethra, Andromeda, and Gaylussaccia buxifolia, the family of Ericer. Robert Brown (see the Appendix to Franklin's Narrative of a Journey to the Shores of the Polar Sea, 1823, p. 765), has raised them to the rank of a separate family, which Kunth places between Philadelpheæ and Hamamelideæ. 
The Escallonia floribunda offers in its geographical distribution one of the most striking examples, in the habitat of the plant, of proportion between distance from the equator and vertical elevation above the level of the sea. In making this statement I again support myself on the authority of my acute and judicious friend Auguste de St.-Hilaire (Morphologie végétale, 1840, p. 52):-“Messieurs de Humboldt et Bonpland ont découvert dans leur expédition l'Escallonia floribunda à 1400 toises par les $4^{\circ}$ de latitude australe. Je l'ai retrouvé par les $21^{\circ}$ au Brésil dans un pays élevé, mais pourtant infiniment plus bas que les Andes du Pérou : il est commun entre les $24^{\circ} .50^{\prime}$ et les $25^{\circ} .55^{\prime}$ dans les Campos Geræs, enfin je le revois au Rio de la Plata vers les $35^{\circ}$, au niveau même l'océan."

Trees belonging the group of Myrtaceæ,-to which Melaleuca, Metrosideros, and Eucalyptus belong in the sub-division of Leptospermeæ,-produce partially, either where the leaves are replaced by phyllodias (leaf-stalk leaves), or by the peculiar disposition or direction of the leaves relatively to the unswollen leaf-stalk, a distribution of stripes of light and shade unknown in our forests of round-leaved trees. The first botanical travellers who visited New Holland were struck with the singularity of the effect thus produced. Robert Brown was the first to show that this strange appearance arose from the leaf-stalks (the phyllodias of the Acacia longifolia and A. suaveolens) being expanded in a vertical direction, and from the circumstance that the light instead of falling on horizontal surfaces, falls on and passes between vertical ones. (Adrien de Jussieu, Cours de 
Botanique, p. 106, 120, and 700; Darwin, Joumal of Researches, 1845, p. 433). Morphological laws in the development of the leafy organs determine the peculiar character of the effects produced, the outlines of light and shade. "Phyllodias," says Kunth; "can, according to my view, only occur in families which have compound pinnated leaves; and in point of fact they have as yet only been found in Leguminosæ, (in Acacias). In Eucalyptus, Metrosideros, and Melaleuca, the leaves are simple (simplicia), and their edgewise position arises from a half turn or twist of the leaf-stalk (petiolus) ; it should be remarked at the same time that the two surfaces of the leaves are similar." In the comparatively shadeless forests of New Holland the optical effects here alluded to are the more frequent, as two groups of Myrtaceæ and Leguminosæ, species of Eucalyptus and of Acacia, constitute almost the half of all the greyish green trees of which those forests consist. In addition to this, in Melaleuca there are formed between the layers of the inner bark easily detached portions of epidermis which press outwards, and by their whiteness remind the European of our birch bark.

The distribution of Myrtaceæ is very different in the two continents. In the New Continent, and especially in its western portion, it scarcely extends beyond the 26th parallel of north latitude, according to Joseph Hooker (Flora antarctica, p. 12); while in the Southern Hemisphere, according to Claude Gay, there are in Chili 10 species of Myrtus and 22 species of Eugenia, which, intermixed with Proteacex (Embothrium and Lomatia), and with Fagus 
obliqua, form forests. The Myrtaceæ become more abundant beyond $38^{\circ} \mathrm{S}$. lat., -in the Island of Chiloe, where a Metrosideros-like species of Myrtus (Myrtus stipularis) forms almost impenetrable thickets under the name of Tepuales; in Patagonia; and in Fuegia to its extremity in $56 \frac{1}{2}^{\circ} \mathrm{S}$. lat. In the Old Continent they prevail in Europe as far as the 46th parallel of North latitude: in Australia, Tasmania, New Zealand, and the Auckland Islands, they advance to $50 \frac{1}{2}^{\circ}$ South latitude.

\section{(32) p. 29._“Melastomacea."}

This group comprises the genera Melastoma (Fothergilla and Tococa Aubl.) and Rhexia (Meriana and Osbeckia), of which we found, on either side of the equator in tropical America alone, 60 new species. Bonpland has published a superb work on Melastomaceæ, in two volumes, with coloured drawings. Some species of Rhexia and Melastoma ascend in the Andes, as alpine or Paramos shrubs, as high as nine and ten thousand five hundred (about 9600 and 11190 English) feet: among these are Rhexia cernua, R. stricta, Melastoma obscurum, M. aspergillare, and M. lutescens.

\section{(33) p. 29.- Laurel-form."}

To this form belong the genera of Laurus and Persea, the Ocotex so numerous in South America, and (on account of physiognomic resemblance), Calophyllum and the superb aspiring Mammea, from among the Guttiferæ. 
(34) p. 29.- "How interesting and instructive to the landscape painter would be a work which should present to the eye the leading forms of vegetation!"

In order to define somewhat more distinctly what is here only briefly alluded to, I permit myself to introduce some cc nsiderations taken from a sketch of the history of landscape painting, and of a graphical representation of the physiognomy of plants, which I have given in the second volume of Kosmos (Bd. ii. S. 88-90; English edit. vol. ii. p. 86-87).

"All that belongs to the expression of human emotion and to the beauty of the human form, has attained perhaps its highest perfection in the northern temperate zone, under the skies of Italy and Greece. By the combined exercise of imitative art and of creative imagination, the artist has derived the types of historical painting at once from the depths of his own mind, and from the contemplation of other beings of his own race. Landscape painting, though no merely imitative art, has, it may be said, a more material substratum and a more terrestrial domain: it requires a greater mass and variety of distinct impressions, which the mind must receive within itself, fertilize by its own powers, and reproduce visibly as a free work of art. Hence landscape painting must be a result at once of a deep and comprehensive reception of the visible spectacle of external nature, and of this inward process of the mind."

"Nature, in every region of the earth, is indeed a reflex of the whole; the forms of organised being's are repeated 
everywhere in fresh combinations; even in the icy north, herbs covering the earth, large alpine blossoms, and a serene azure sky, cheer a portion of the year. Hitherto landscape painting has pursued amongst us her pleasing task, familiar only with the simpler form of our native floras, but not, therefore, without depth of feeling, or without the treasures of creative imagination. Even in this narrower field, highly gifted painters, the Caracci, Gaspar Poussin, Claude Lorraine, and Ruysdael, have with magic power, by the selection of forms of trees and by effects of light, found scope wherein to call forth some of the most varied and beautiful productions of creative art. The fame of these master-works can never be impaired by those which I venture to hope for hereafter, and to which I could not but point, in order to recall the ancient but deeply-seated bond which unites natural knowledge with poetry and with artistic feeling; for we must ever distinguish in landscape painting, as in every other branch of art, between productions derived from direct observation, and those which spring from the depths of inward feeling and from the power of the idealising mind. The great and beautiful works which owe their origin to this creative power of the mind applied to landscape-painting, belong to the poetry of nature, and like man himself, and the imagination with which he is gifted, are not rivetted to the soil, or confined to any single region. I allude here more particularly to the gradation in the form of trees from Ruysdael and Everdingen, through Claude Lorraine to Poussin and Annibal Caracci. . In the great masters of the art we perceive no trace of local limitation; but an enlargement of 
the visible horizon, and an increased acquaintance with the nobler and grander forms of nature, and with the luxuriant fulness of life in the tropical world, offer the advantage not only of enriching the material substratum of landscape painting, but also of affording a more lively stimulus to less gifted artists, and of thus heightening their powers of production."

(35) p. 30.-" From the rough bark of Crescentias and Gustavia."

In the Crescentia cujete (the Tutuma or Calabash-tree, whose large fruit-shells are so useful to the natives for household purposes), -in the Cynometra, the Theobroma (the Cacao-tree), and the Perigara (the Gustavia of Limnæus), -the delicate flowers break through the half carbonized bark. When children eat the fruit of the Pirigara speciosa (the Chupo), their whole body becomes tinged with yellow; it is a jaundice, which lasts from 24 to 36 hours, and then disappears without the use of medicine.

I have never forgotten the impression which I received of the luxuriant power of regetation in the tropical world, when on entering a Cacao plantation (Caca hual), in the Valles de Aragua, after a damp night, I saw for the first time large blossoms springing from a root of the Theobroma deeply imbedded in black earth. It was one of the most instantaneous manifestations of the activity of the vegetative organic forces. Northern nations speak of the "awakening of Nature at the first breath of the mild air of spring:" Such an expression is singularly contrasted with the imagination of the Stagirite, who recognised in plants forms which 
"lie buried in a tranquil slumber that knows no waking, free from the desires which impel to spontaneous motion." (Aristot. de generat. Animal. V.i. p. 778, and de somno et vigil. cap. 1, p. 4.55, Bekker.)

\section{(36) p. 30.- "Draw over their heads."}

The flowers of our Aristolochia cordata, to which I have already referred in Note 25. The largest flowers in the world, apart from Compositæ (in the Mexican Helianthus annuus), belong to Rafflesia arnoldi, Aristolochia, Datura, Barringtonia, Gustavia, Carolinea, Lecythis, Nymphæa, Nelumbium, Victoria regina, Magnolia, Cactus, and to Orchideous and Liliaceous plants.

(37) p. 31.- "To behold all the shining worlds which stud the heavenly vault from pole to pole."

The finest portion of the southern celestial hemisphere, where shine the constellations of the Centaur, the Ship, and the southern Cross, and where the soft lustre of the Magellanic clouds is seen, remains for ever concealed from the view of the inhabitants of Europe. It is only beneath the equinoctial line that Man enjoys the peculiar privilege of beholding at once all the stars both of the Southern and the Northern heavens. Some of our northern constellations seen from thence appear from their low altitude of a surprising and almost awful magnitude: for example, Ursus major and minor. As the inhabitant of the tropics sees all the stars of the firmament, so also, in regions where plains alternate with deep valleys and lofty mountains, Nature surrounds him with representatives of all the forms of plants. 


\title{
POSTSCRIPT
}

\author{
ON THE
}

PHYSIOGNOMIC CLASSIFICATION OF PLANTS.

Is the preceding sketch of a "Physiognomy of Plants," I have had principally in view three nearly allied subjects :- the absolute diversity of forms; their numerical proportion, $i . e$. their local predominance in the total number of species in phænogamous floras; and their geographic and climatic distribution. If we desire to rise to general views respecting organic forms, the physiognomy of plants, the study of their numerical proportions (or the arithmetic of botany), -and their geography (or the study of their zones of distribution), - cannot, as it appears to me, be separated from each other. In the study of the physiognomy of plants, we ought not to dwell exclusively on the striking contrasts presented by the larger organic forms separately considered, but we should also seek to discern the laws which determine the physiognomy of Nature generally, or the picturesque character of vegetation over the entire surface of the globe, and the impression produced on the mind of the beholder by the grouping of contrasted forms in different zones of latitude and of elevation. It is from this point of view, and with this concentration or combination of objects, that we become 
aware, for the first time; of the close and intimate connection between the subjects which have been treated of in the foregoing pages. We are here conducted into a field which has been as yet but little cultivated. I have ventured to foilow the method first employed with such brilliant results in the Zoological works of Aristotle, and which is especially suited to lay the foundation of scientific confidence,-a method which, whilst it continually aims at generality of conception, seeks, at the same time, to penetrate the specialities of phenomena by the consideration of particular instances.

The enumeration of forms according to physiognomic diversity is, from the nature of the case; not susceptible of any strict classification. Here, as everywhere else, in the consideration of external conformation, there are certain leading forms which present the most striking contrasts: such are the groups of arborescent grasses, plants of the aloë form, the different species of cactus, palms, needletrees, Mimosaceæ, and Musaceæ. Even a few scattered individuals of these groups are sufficient to determine the character of a district, and to produce on a non-scientific but sensitive beholder a permanent impression. Other forms, though perhaps much more numerous and preponderating in mass, may not be calculated either by the outline and arrangement of the foliage, or by the relation of the stem to the branches,-by luxuriant vigour of vegetation,-by cheerful grace,-or, on the other hand, by cheerless contraction of the appendicular organs, to produce any such characteristic impressions.

As, therefore, a "physiognomic classification," or a divi- 
sion into groups from external aspect or "facies," does not admit of being applied to the whole vegetable kingdom, so also, in such a classification, the grounds on which the division is made are quite different from those on which our systems of natural families and of plants (including the whole of the regetable kingdom) have been so happily established. Physiognomic classification grounds her dirisions and the choice of her types on whatever possesses "mass," - such as shape, position and arrangement of leares, their size, and the character and surfaces (shining or dull) of the parenchyma, - therefore, on all that are called more especially the "organs of regetation," $i . e$. those on which the preservation,-the nourishment and development, -of the individual depend; while systematic Botany, on the other hand, grounds the arrangement of natural families on the consideration of the organs of propagation, - those on which the continuation or preservation of the species depends. (Kunth, Lehrbuch der Botanik, 1847, Th. i. S. 511 ; Schleiden, die Pflanze und ihr Leben, 1848, S. 100). It was already taught in the school of Aristotle (Probl. 20, 7), that the production of seed is the ultimate object of the existence and life of the plant. Since Caspar Fried. Wolf (Theoria Generationis, $\S 5-9$ ), and since our great (German) Poet, the process of development in the organs of fructification has become the morphological foundation of all systematic botany.

That study, and the study of the physiognomy of plants, I here repeat, proceed from two different points of view: the first from agreement in the inflorescence or in the delicate 
organs of reproduction; the second from the form of the parts which constitute the axes (i.e. the stems and branches), and the shape of the leaves, dependent principally on the distribution of the vascular fascicles. As, then, the axes and appendicular organs predominate by their volume and mass, they determine and strengthen the impression which we receive; they individualise the physiognomic character of the vegetable form and that of the landscape, or of the region in which any of the more strongly-marked and distinguished types severally occur. The law is here given by agreement and affinity in the marks taken from the vegetative, $i . e$. the nutritive organs. In all European colonies, the inhabitants have taken occasion, from resemblances of physiognomy (of "habitus," "facies"), to bestow the names of European forms upon tropical plants or trees bearing very different flowers and fruits from those from which the names were originally taken. Everywhere, in both hemispheres, northern settlers have thought they found Alders, Poplars, Appleand Olive-trees. They have been misled in most cases by the form of the leaves and the direction of the branches. The illusion has been favoured by the cherished remembrance of the trees and plants of home, and thus European names have been handed down from generation to generation; and in the slave colonies there have been added to them denominations derived from Negro languages.

The contrast so often presented between a striking agreement of physiognomy and the greatest diversity in the inflorescence and fructification,-between the external aspect as determined by the appendicular or leaf-system, and the 
reproductive organs on which the groups of the natural systems of botany are founded, - is a remarkable and surprising phenomenon. Te should have been inclined beforehand to imagine that the shape of what are exclusively termed the vegetative organs (for example, the leaves) would have been less independent of the structure of the organs of reproduction; but in reality such a dependence only shows itself in a small number of families, -in Ferns, Grasses and Cyperaceæ, Paims, Coniferæ, Umbelliferæ, and Aroideæ. · In Leguminosæ the agreement in physiognomic character is scarcely to be recognised until we divide them into the several. groups (Papilionaceæ, Cæsalpinineæ, and Mimoseæ). I may name, of types which, when compared with each other, shew considerable accordance in physiognomy with great difference in the structure of the flowers and fruit, Palms and Cycader, the latter being more nearly allied to Coniferæ; Cuscuta, one of the Convolvulacæ, and the leafless Cassytha, a parasitical Laurinea; Equisetum (belonging to the great division of Cryptogramia), and Ephedra, closely allied to Coniferæ. On the other hand, our common gooseberries and currants (Ribes) are so closely allied by their inflorescence to the Cactus, $i . e$. to the family of Opuntiacer, that it is only quite recently that they have been separated from it! One and the same family (that of Asphodelex) comprises the gigantic Dracæna draco, the common asparagus, and the Aletris with its coloured flowers. Not only do simple and compound leaves often belong to the same family, but they eren occur in the same genus. We found in the high plains of Peru and New Granada, among twelve new species of Weinmannia, five 
with "foliis simplicibus," and the rest with pinnate leaves. The genus Aralia shews still greater independence in the form of the leaves: "folia simplicia, integra, vel lobata, digitata et pinnata." (Compare Kunth, Synopsis Plantarum quas in itinere collegerunt, Al. de Humboldt et Am. Bonpland, T. iii, p. 87 and 360.)

Pinnated leaves appear to me to belong chiefly to families which are in the highest grade of organic devolopment, namely, the Polypetalæ; and among these, in the Perigynic class, to the Leguminosæ, Rosaceæ, Terebinthaceæ, and Juglandeæ; and in the Hypogynic, to the Aurantiaceæ, Cedrelacex, and Sapindacex. The beautiful doublypinnated leaves which form one of the principal ornaments of the torrid zone, are most frequent among the Leguminosæ, in Mimoseæ, also in some Cæsalpinieæ, Coulterias, and Gleditschias; never, as Kunth remarks, in Papilionaceæ. "Folia pinnata" and "folia composita" are never found in Gentianeæ, Rubiaceæ, and Myrtaceæ. In the morphological development presented by the abundance and variety of form in the appendicular organs of Dicotyledones, we can at present discern only a small number of general laws. 
ON THE

STRUCTURE AND MODE OF ACTION

OF

\section{VOLCANOS,}

IN DIFFERENT PARTS OF THE GLOBE. 



\section{STRUCTURE AND MODE OF ACTION}

\section{VOLCANOS,}

IN DIFFERENT PARTS OF THE GLOBE。

[This dissertation was read in a public assembly of the Academy at Berlin, on the 24th of January, 1823.]

WHEN we reflect on the influence which, for some centuries past, the progress of geography and the multiplication of distant voyages and travels have exercised on the study of nature, we are not long in perceiving how different this infuence has been, according as the researches were directed to organic forms on the one hand, or on the other to the study of the inanimate substances of which the earth is composedto the knomledge of rocks, their relative ages, and their origin. Different forms of plants and animals enliven the surface of the earth in every zone, whether the temperature of the atmosphere varies in accordance with the latitude and with the many inflections of the isothermal lines on plains but 
little raised above the level of the sea, or whether it changes rapidly in ascending in an almost vertical direction the steep declivities of mountain-chains. Organic nature gives to each zone of the earth a peculiar physiognomy; but where the solid crust of the earth appears unclothed by vegetation, inorganic nature imparts no such distinctive character. The same kinds of rocks, associated in groups, appear in either hemisphere, from the equator to the poles. In a remote island, surrounded by exotic vegetation, beneath a sky where his accustomed stars no longer shine, the voyager often recognises with joy the argillaceous schists of his birth-place, and the rocks familiar to his eye in his native land.

This absence of any dependence of geological relations on the present constitution of climates does not preclude or even diminish the salutary influence of numerous observations made in distant regions on the advance and progress of geological science, though it imparts to this progress something of a peculiar direction. Every expedition enriches natural history with new species or new genera of plants and animals : there are thus presented to us sometimes forms which connect themselves with previously long known types, and thus permit us to trace and contemplate in its perfection the really regular though apparently broken or interrupted network of organic forms : at other times shapes which appear isolated,-either surviving remnants of extinct genera or orders, or otherwise members of still undiscovered groups, stimulating afresh the spirit of research and expectation. The examination of the solid crust of the globe does not, indeed, unfold to us such diversity and va- 
riety; it presents to us, on the contrary, an agreement in the constituent particles, in the superposition of the different kinds of masses, and in their regular recurrence, which excites the admiration of the geologist. In the chain of the Andes, as in the mountains of middle Europe, one formation appears, as it were, to summon to itself another. Rocks of the same name exhibit the same outlines; basalt and dolerite form twin mountains; dolomite, sandstone, and porphyry, abrupt precipices; and vitreous feldspathic trachyte, high dome-like elevations. In the most distant zones large crystals separate themselves in a similar manner from the compact texture of the primitive mass, as if by an internal development, form groups in association, and appear associated in layers, often announcing the vicinity of new independent formations. Thus in any single system of mountains of considerable extent we see the whole inorganic substances of which the crust of the earth is composed represented, as it were, with more or less distinctness; jet, in order to become completely acquainted with the important phenomena of the composition, the relative age, and mode of origin of rocks, we must compare together observations from the most varied and remote regions. Problems which long perplexed the geologist in his native land in these northern countries, find their solution near the equator. If, as has been already remarked, new zones do not necessarily present to us new kinds of rock (i. e. unknown groupings or associations of simple substances), they, on the other hand, teach us to discern the great and every where equally prevailing laws, according to which the strata of the crust of 
the earth are superposed upon each other, penetrate eack other as veins or dykes, or are upheaved or elevated by elastic forces.

If, then, our geological knowledge is thus promoted by researches embracing extensive parts of the earth's surface, it is not surprising that the particular class of phenomena which form the subject of the present discussion should long have been regarded from a point of view the more restricted as the points of comparison were of difficult, I might almost say arduous and painful, attainment and access. Until the close of the last century all real or supposed knowledge of the structure or form of volcanos, and of the mode of operation of subterranean forces, was taken from two mountains of the South of Europe, Vesuvius and Etna. The former of these being the easiest of access, and its eruptions, as is generally the case in volcanos of small elevation, being most frequent in their occurrence, a hill of minor elevation became the type which regulated all the ideas formed respecting phænomena exhibited on a far larger scale in many vast and distant regions, as in the mighty volcanos arranged in linear series in Mexico, South America, and the Asiatic Islands. Such a proceeding might not unnaturally recall Virgil's shepherd, who thought he beheld in his humble cottage the type of the eternal City, Imperial Rome.

A more careful examination of the whole of the Mediterranean, and especially of those islands and coasts where men awoke to the nobiest intellectual culture, might, however, have dispelled views formed from so limited a consideration of nature. Among the Sporades, trachytic rocks have been 
upraised from the deep bottom of the sea, forming islands resembling that which, in the vicinity of the Azores, appeared thrice periodically, at nearly equal intervals, in three centuries. The Peloponnesus has, between Epidaurus and Trœzene, near Methone, a Monte Nuovo described by Strabo and seen again by Dodwell, which is higher than the Monte Nuoro of the Phlegræan Fields near Baiæ, and perhaps eren higher than the new volcano of Jorullo in the plains of Mesico, which I found surrounded by several thousand small basaltic cones which had been protruded from the earth and were still smoking. In the Mediterranean and its shores, it is not only from the permanent craters of isolated mountains haviug a constant communication with the interior, as Stromboli, Vesuvius, and Etna, that volcanic fires break forth : at Ischia, on the Monte Epomeo, and also, as it would appear by the accounts of the ancients, in the Lelantine plain near Chalcis, lavas have flowed from fissures which have suddenly opened at the surface of the earth. Besides these phænomena, which fall within the historic period, or within the restricted domain of mellassured tradition, and which Carl Ritter will collect and elucidate in his masterly work on Geography, - the shores of the Nediterranean exhibit numerous remains of more ancient rolcanic action. In the south part of France, in Auvergne, we see a separate complete system of volcanos arranged in lines, trachytic domes alternating with cones of eruption, from which streams of lava have flowed in narrow bands. The plain of Lombardy, as level as the surface of the sea, and forming an inner Gulf of the Adriatic, surrounds 
the trachyte of the Euganean Hills, where rise domes of granular trachyte, obsidian, and pearl-stone, masses connected by a common origin, which break through the lower cretaceous rock and nummulitic lime-stone, but have never flowed in narrow streams. Similar evidences of ancient revolutions of nature are found in several parts of the mainland of Greece and in Asia Minor, countries which will one day offer a rich field for geological investigation, when intellectual light shall revisit the seats from which it has radiated to the western world, and when oppressed humanity shall no longer be subject to the barbarism of Turkish rule.

I recall the geographical proximity of these various phænomena, in order to shew that the basin of the Mediterranean, with its series of islands, might have offered to an attentive observer much that has been recently discovered, under various forms, in South America, Teneriffe, and the Aleutian Islands near the polar circle. The objects to be observed were assembled within a moderate distance; yet distant voyages, and the comparison of extensive regions in and out of Europe, have been required for the clear perception and recognition of the resemblance between volcanic phænomena and their dependence on each other.

Our ordinary language, which often gives permanency and apparent authority to the first-formed erroneous views of natural phænomena, but which also often points instinctively to the truth,-our ordinary language, I repeat, applies the term "volcanic" to all eruptions of subterranean fires or molten substances; to columns of smoke and vapour rising from rocks, as at Colares after the great earthquake of Lisbon; 
to "Salses" or mud volcanos, argillaceous cones emitting mud, asphalte, and hydrogen, as at Girgenti in Sicily, and at Turbaco in South America; to the Geysers, hot springs in which, as in those of Iceland, the waters, pressed by elastic vapours, rise in jets to a considerable altitude; and, in general, to all operations of natural forces having their seat in the interior of our planet. In Central America (Guatimala), and in the Philippine Islands, the natives even distinguish formally between water- and fire-volcanos, Volcanes de agua y de fuego, giving the former name to those mountains from which subterranean waters issue from time. to time with violent earthquake shocks and a hollow noise.

Not denying the connexion of the different phenomena which have been referred to, it yet appears desirable to give greater precision to the terms employed in the physical as well as in the mineralogical part of geology, and not to apply the word "volcano" at one moment to a mountain terminating in a permanent igneous opening or fiery crater, and at another to every subterranean cause of volcanic phenomena. In the present state of our planet the most ordinary form of volcanos is indeed in all parts of the globe that of an isolated conical mountain, such as Vesuvius, Etna, the Peak of Teneriffe, Tunguragua, and Cotapaxi. I have myself seen such volcanos varying in size from the smallest hill to an elevation of 18000 (19184 English) feet above the sea. But besides these isolated cones there are also permanent openings or craters, having established channels of communication with the interior of the earth, which are situated on long chains of mountains with serrated 
crests, and not even always on the middle of the ridge, but sometimes at its extremity: such is Pichincha, situated between the Pacific and the city of Quito, and which acquired celebrity in connection with Bouguer's earliest barometric formulæ, and such are the volcanos which rise in the elevated Steppe de los Pastos, itself ten thousand (10657 English) feet high. All these summits, which are of various shapes, consist of trachyte, formerly called Trapporphyry: a granular vesicular rock composed of different kinds of feldspar (Labradorite, Oligoklase, and Albite), augite, hornblende, and sometimes interspersed mica, and even quartz. In cases where the evidence of the first outburst or eruption, or I might say where the ancient structure or scaffolding remain entire, the isolated conical mount is surrounded by an amphitheatre or lofty circular rampart of rocky strata superimposed upon each other. Such walls or ring-formed ramparts are called "craters of elevation," a great and important phenomenon, concerning which a memorable treatise was presented to our Academy five years ago ( $i . e$. in 1818), by the first geologist of our time, Leopold von Buch, from whose writings I have borrowed several of the views contained in the present discussion.

Volcanos which communicate, with the atmosphere through permanent openings, conical basaltic hills, and craterless trachytic domes, sometimes as low as Sarcouy, sometimes as lofty as the Chimborazo, form various groups. Comparative geography shows us sometimes small clusters or distinct systems of mountains, with craters and lava-currents in the Canaries and the Azores, and without craters and without 
lava-currents, properly so-called, in the Eugranean hills and the Siebengebirge near Bonn;-and at other times the same study describes to us volcanos arranged in single or double lines extending through many hundred leagues in length, these lines being either parallel to the direction of a great chain of mountains, as in Guatimala, in Peru, and in Java, or cutting it transversely or at right angles, as in tropical Mexico. In this land of the Aztecs the fire-emitting trachytic mountains are the only ones which attain the elevation of the lofty region of perpetual snow; they are ranged in the direction of a parallel of latitude, and have probably been raised from a fissure 420 English geographical miles long, traversing the continent from the Pacific to the Atlantic Ocean.

These assemblages of volcanos, whether in rounded groups or in double lines, show in the most conclusive manner that the volcanic agencies do not depend on small or restricted causes, in near proximity to the surface of the earth, but that they are great phænomena of deep-seated origin. The whole of the eastern part of the American continent, which is poor in metals, is, in its present state, without fire-emitting mountains, without masses of trachyte, and perhaps even without basalt containing olivine. All the American volcanos are on the side of the continent which is opposite to Asia, in the chain of the Andes which rurs nearly in the direction of a meridian, and extends over a length of 7200 geographical miles.

The whole plateau or high-land of Quito, of which Pichincha, Cotopaxi, and Tunguragua form the summits, 
is to be viewed as a single volcanic furnace. The subterranean fire breaks forth sometimes through one and sometimes through another of these openings, which it has been customary to regard as separate and distinct volcanos. The progressive march of the subterranean fire has been here directed for three centuries from North to South. Even the earthquakes which occasion such dreadful ravages in this part of the world afford remarkable proofs of the existence of subterranean communications, not only between countries where there are no volcanos (a fact which had long been known), but also between fire-emitting openings situated at great distances asunder. Thus in 1797 the volcano of Pasto, east of the Guaytara River, emitted uninterruptedly for three months a lofty column of smoke, which column disappeared at the instant when, at a distance of 240 geographical miles, the great earthquake of Riobamba and the immense eruption of mud called "Moya" took place, causing the death of between thirty and forty thousand persons.

The sudden appearance of the Island of Sabrina near the Azores, on the 30th of January, 1811, was the precursor of the terrible earthquake movements which, much farther to the west, shook almost incessantly, from the month of May 1811 to June 1813, first the West Indian Islands, then the plain of the Ohio and Mississipi, and lastly, the opposite coast of Venezuela or Caraccas. Thirty days after the destruction of the principal city of that province, the long tranquil volcano of the Island of St. Vincent burst forth in an eruption. A remarkable phenomenon accom- 
panied this eruption: at the same moment when the explosion took place, on the 30th of April, 1811, a loud subterranean noise was heard in South America, which spread terror and dismay over a district of 2200 (German) geographical square miles (35200 English geographical square miles). The dwellers on the banks of the Apure near the confluence of the Rio Nula, and the most distant inhabitants of the sea coast of Venezuela, alike compared the sound to that of the discharge of great pieces of ordnance. Now from the confluence of the Nula with the Apure (by which latter river I arrived on the Orinoco) to the volcano of St. Vincent is a distance in a straight line of 628 English geographical miles. The sound, which certainly was not propagated through the air, must have proceeded from a deep-seated subterranean cause; for its intensity was scarcely greater on the sea coast nearest to the volcano where the eruption was taking place, than in the interior of the country, in the basin of the Apure and the Orinoco.

It would be unnecessary to multiply examples by citing other instances which I have collected, but, to recall a phenomenon of European historical importance, I will only farther mention the celebrated earthquake of Lisbon. Simultaneously with that event, on the 1 st of Norember, 1755, not only were the Swiss lakes and the sea near the coast of Sweden violently agitated, but even among the eastern West Indian Islands, Martinique, Antigua, and Barbadoes, where the tide never exceeds thirty inches, the sea suddenly rose more than twenty feet. All these pheno- 
mena show the operation of subterranean forces, acting either dynamically in earthquakes, in the tension and agitation of the crust; or in volcanos, in the production and chemical alteration of substances. They also show that these forces do not act superficially, in the thin outermost crust of the globe, but from great depths in the interior of our planet, through crevices or unfilled veins, affecting simultaneously widely distant points of the earth's surface.

The greater the variety of structure in volcanos, or in the elevations which surround the channel through which the molten masses of the interior of the earth reach its surface, the greater the importance of submitting this structure to strict investigation and measurement. The interest attaching to these measurements, which formed a particular object of my researches in another quarter of the globe, is enhanced by the consideration that at many points the magnitude to be measured is found to be a variable quantity. The philosophical study of nature endeavours, in the vicissitudes of phenomena, to connect the present with the past.

If we desire to investigate either the fact of a periodical return, or the law of progressive variations or changes in phenomena, it is essential to obtain, by means of observations carefully made and connected with determinate epochs, certain fixed points which may afford a base for future numerical comparisons. If we only possessed determinations made once in each period of a thousand years, of the mean temperature of the atmosphere and of the earth in different latitudes, or of the mean height of the barometer at the level of the sea, we should know whether, and in what 
ratio, the temperature of different climates had increased or decreased, or whether the height of the atmosphere had undergone changes. Such points of comparison are also needed for the inclination and declination of the magnetic needle, as well as for the intensity of the magneto-electric forces, on which, within the circle of this Academy, two excellent physicists, Seebeck and Erman, have thrown so much light. As it is an honourable object for the exertions of scientific societies to trace out perseveringly the cosmical variations of temperature, atmospheric pressure, and magnetic direction and intensity, so it is the duty of the geological traveller, in determining the inequalities of the earth's surface, to attend more particularly to the variable height of volcanos. The endearours made by me for this object in the Mexican mountains, in respect to the Volcan de Toluca, the Popocatepetl, the Cofre de Perote or Nauhcampatepet], and the Jorullo, and also the volcano of Pichincha in the Andes of Quito, have been continued since my return to Europe at different epochs on Vesuvius. Where complete trigonometric or barometric measurements are wanting, accurate angles of altitude, taken at points which are exactly determined, may be substituted for them; and for a comparison of determinations made at different epochs, angles of altitude so measured may even be often preferable to the complication of circumstances which more complete operations may involve.

Saussure had measured Mount Vesuvius, in 1773, when the two margins of the crater, the north-western and the southeastern, appeared to him be of equal height. He found their 
height above the level of the sea 609 toises, 3894 English feet. The eruption of 1794 occasioned a breaking down of the margin of the crater on the southern side, and a consequent inequality between the height of the two edges which the most unpractised eye does not fail to distinguish even at a considerable distance. In 1805, Leopold von Buch, GayLussac, and myself, measured the height of Vesuvius three times, and found the northern margin opposite to La Somma, (the Rocca del Palo), exactly as given by Saussure, but the southern margin 75 toises, or 450 French or 479 English feet, lower than he had found it in 1773. The whole elevation of the volcano on the side of Torre del Greco (the side towards which, for the last thirty years, the igneous action has, as it were, been principally directed, ) had at that time diminished one-eighth. The height of the cone of ashes, as compared with the whole height of the mountain, is in Vesuvius as 1 to 3 ; in Pichincha, as 1 to 10 ; and in the Peak of Teneriffe, as 1 to 22. In these three volcanic mountains, the cone of ashes is therefore, relatively speaking, highest in Vesuvius; probably because, being a low volcano, the action has been principally by the summit.

A few months ago (in 1822) I was enabled not only to repeat my former barometric measurements of the height of Vesuvius, but also, during the course of three visits to the summit, to make a more complete determination of all the edges of the crater $\left(^{1}\right)$. These determinations may not be without interest, since they include the long period of great eruptions between $] 805$ and 1822, and constitute perhaps the only known examination and measurement of a volcano 
at different epochs, in which the different parts of the examination are all truly comparable with each other. We learn from it that the margins of craters are a phenomenon of far more permanent character than had been previously inferred from passing observations, and this not only where (as in the Peak of Teneriffe, and in all the volcanos of the chain of the Andes,) they are visibly composed of trachyte, but also elsewhere. According to my last determinations, the north-west edge of Vesuvius has, perhaps, not altered at all since the time of Saussure, an interval of 19 years; and the south-eastern side, on the side towards Bosche Tre Case, which, in 1794, had become 400 French (426 English) feet lower, has since then hardly altered 10 toises $(60$ French or 64 English feet).

If the public journals, in describing great eruptions, often state the shape of Vesuvius to have undergone an entire change, and if these assertions appear to be confirmed by picturesque views sketched at Naples, the cause of the error consists in the outlines of the margin of the crater having been confounded with those of the cones of eruption accidentally formed in the middle of the crater on its fioor or bottom which has been upheaved by vapours. Such a cone of eruption, consisting of loosely heaped-up rapilli and scoriæ, had in the course of the years 1816-1818 gradually risen so as to be seen above the south-eastern margin of the crater; and the eruption of the month of February 1822 augmented it so much, that it eren became from 100 to 110 (about 107 to 117 English) feet higher than the northwestern margin of the crater (the Rocca del Palo). This 
remarkable cone, which it had become customary in Naples to regard as the true summit of the mountain, fell in, with a dreadful noise, in the last eruption, on the night of the $22 d$ of October (1822): so that the floor of the crater, which had been constantly accessible since 1811, is now 750 (almost 800 English) feet lower than the northern, and 200 (213 English) feet lower than the southern edge of the volcano. Variations in the form and relative position of the cones of eruption, - the openings of which ought not to be confounded, as they often are, with the crater of the volcano itself,-give to Vesuvius at different epochs a different appearance, which would enable a person well acquainted with the history of the volcano, on a mere inspection of Hackert's paintings in the palace of Portici, to tell from the outlines of the summit, according as the northern or the southern side of the mountain is represented as the highest, in what year the artist had taken the sketch from which the picture was made.

In the last eruption, in the night of the $23 \mathrm{~d}$ to the 24 th of October, twenty-four hours after the falling in of the great cone of scoriæ which has been mentioned, and when the small but numerous currents of lava had already flowed off, the fiery eruption of ashes and rapilli commenced : it continued without intermission for twelve days, but was greatest in the first four days. During this period the detonations in the interior of the volcano were so violent that the mere concussion of the air, (for no earthquake movement was perceived), rent the ceilings of the rooms in the palace of Portici. In the neighbouring villages of 
Resina, Torre del Greco, Torre del Amnunziata, and Bosche Tre Case, a remarkable phenomenon was witnessed. Throughout the whole of that part of the country the air was so filled with ashes as to cause in the middle of the day profound darkness, lasting for several hours: lanterns were carried in the streets, as has so often been done at Quito during the eruptions of Pichincha. The flight of the inhabitants had never been more general: lava currents are regarded by those who dwell near Vesuvius with less dread than an eruption of ashes, a phenomenon which had never been known to such a degree in modern times; and the obscure tradition of the manner in which the destruction of Herculaneum, Pompeii, and Stabiæ took place, filled the imaginations of men with appalling images.

The hot aqueous vapours which rose from the crater during the eruption and spread themselves in the atmosphere, formed, in cooling, a dense cloud, surrounding the column of fire and ashes, which rose to a height of between rime and ten thousand feet. So sudden a condensation of vapour, and even, as Gay-Lussac has shewn, the formation of the cloud itself, augmented the electric tension. Flashes of forked lightning, issuing from the column of ashes, darted in every direction; and the rolling thunders were distinctly heard, and distinguished from the sounds which proceeded from the interior of the volcano. In no other eruption had the play of the electric forces formed so striking a feature.

On the morning of the 26th of October, a surprising rumour prevailed, to the effect that a torrent of boiling water was gushing from the crater, and pouring down the 
slope of the cone of ashes. The learned and zealous observer of the volcano, Monticelli, soon discovered that this erroneous rumour had arisen from an optical illusion. The supposed torrent of water was in reality a flow of dry ashes, which, being as loose and moveable as shifting sands, issued in large quantities from a crevice in the upper margin of the crater. The cultivated fields had suffered much from a long-continued drought which had preceded the eruption; towards its close the "volcanic thunder-storm" which has been described produced an exceedingly violent and abundant fall of rain. This phenomenon is associated in all climates with the close of a volcanic eruption. As during the eruption the cone of aslies is generally enveloped in cloud, and as it is in its immediate vicinity that the rain is most violent, torrents of mud are seen to descend from it in all directions, which the terrified husbandman imagines to consist of waters which have risen from the interior of the volcano and overflowed the crater; while geologists have erroneously thought they recognised in them either sea-water or muddy products of the volcano, "Eruptions boueuses," or, in the language of some old French systematists, products of an igneo-aqueous liquefaction,

Where, as is generally the case in the Andes, the summit of the volcano rises into the region of perpetual snow, (even attaining, in some cases, an elevation twice as great as that of Etna), the melting of the snows renders such inundations as have been described far more abundant and disastrous. The phenomena in question are meteorologically connected with the eruptions of volcanos, and are variously modified 
by the height of the mountain, the dimensions of that part of it which is always covered with snow, and the extent and degree to which the sides of the cone of cinders become heated; but they are not to be regarded as volcanic phenomena properly so called. Vast cavities also often exist on the slope or at the foot of volcanos which, communicating through many channels with the mountain torrents, form large subterranean lakes or reservoirs of water. Then earthquake shocks, which, in the Andes, usually precede all igneous eruptions, convulse the entire mass of the volcano, these subterranean reservoirs are opened, and there issue from them water, fishes, and tufaceous mud. This is the singular phenomenon which brings to light an otherrise unknown fish, the Pimelodes Cyclopum, called by the inhabitants of the highlands of Quito "Prenadilla," and which I described soon after my return. When, on the night of the 19th of June, 1698, the summit of a mountain situated to the north of Chimborazo, the Carguairazo, above 19000 English feet high, fell in, the country for nearly thirty English geographical square miles round was covered with mud and fishes; and seven years earlier a putrid fever, in the town of Ibarra, was ascribed to a similar eruption of fish from the volcano of Imbaburu.

I recall these facts, because they throw some light on the difference between the eruption of dry ashes and miry inundations of tufa and trass, carrying with them wood, charcoal, and shells. The quantity of ashes emitted by Vesurius in the recent eruption, like every thing connected with volcanos and other great natural phenomena of a character to excite 
terror, has been exceedingly exaggerated in the public papers; and two Neapolitan chemists, Vicenzo Pepe and Giuseppe di Nobili, notwithstanding the statements of Monticelli and Covelli to the contrary, even describe the ashes as containing silver and gold. According to the results of my researches and inquiries, the thickness of the bed of ashes formed by the twelve days' shower was but little above three feet, towards Bosche Tre Case, on the slope of the cone where rapilli were mingled with them; and in the plain, from $15 \frac{1}{2}$ to 19 inches at the utmost. Such measurements ought not to be taken in places where the ashes have been heaped up by the action of wind, like drifted snow or sand, or have accumulated from being carried thither by water. The times are passed for seeking only the marvellous in volcanic phenomena, in the manner of the ancients among whom Ctesias made the ashes of Etna to be conveyed as far as the Indian peninsula. There are in Mexico veins of gold and silver in trachytic porphyry; but in the ashes of Vesuvius which I brought back with me, and which an excellent chemist, Heinrich Rose, has examined at my request, no traces of either gold or silver have been discovered.

Although the above mentioned results, which are quite in accordance with the exact observations of Monticelli, differ much from the accounts which have been current during the short interval which has elapsed, it is nevertheless true that the eruption of ashes from Vesuvius from the 24th to the 28th of last October (1822) is the most memorable of any of which we possess an authentic account, since that which occasioned the death of the elder Pliny. The quantity of 
ashes is, perhaps, three times as great as has ever been seen to fall since volcanic phenomena have been attentively observed in Italy. A stratum of ashes, from 16 to 19 inches thick, appears at first sight insignificant compared with the mass which we find covering Pompeii; but, not to speak of the increase which that mass has probably received by the effects of heavy rains and other causes during the centuries which have since elapsed, and without renewing the animated debate respecting the causes of the destruction of the Campanian towns, and which, on the other side of the Alps, has been carried on with a considerable degree of scepticism, it should here be recalled to recollection that the eruptions of a volcano, at widely separated epochs, do not well admit of comparison, as respects their intensity. All inferences derived from analogy are inadequate where quantitative relations are concerned; as the quantity of lava and ashes, the height of the column of smoke, and the loudness or intensity of the detonations.

From the geographical description of Strabo, and from an opinion given by Vitruvius respecting the volcanic origin of pumice, we perceive that, up to the year of the death of Vespasian, $i . e$. previous to the eruption which orerwhelmed Pompeii, Vesuvius had more the appearance of an extinct volcano than of a Solfatara. When, after long repose, the subterranean forces suddenly opened for themselves new channels, and again broke through the beds of primitive and trachytic rocks, effects must have been produced for which subsequent ones do not furnish a standard. From the wellknown letter in which the younger Pliny informs Tacitus of 
his uncle's death, it may be clearly seen that the renewal of volcanic outbursts, or what might be called the revival of the slumbering volcano, began with an eruption of ashes. The same thing was observed at Jorullo when, in September 1759, the new volcano, breaking through beds of syenite and trachyte, rose suddenly in the plain. The countrypeople took flight on finding their huts strewed with ashes which had been emitted from the everywhere opening ground. In the ordinary periodical manifestations of volcanic activity, on the contrary, the shower of ashes marks the termination of each particular eruption. There is a passage in the letter of the younger Pliny which shews clearly that, at a very early stage of the eruption, the dry ashes which had fallen had reached a thickness of four or five feet, without accumulation from drift or other extraneous cause. He writes, in the course of his narrative, "the court which had to be crossed to reach the room in which Pliny was taking his noon-day repose was so filled with ashes and pumice, that, if he had longer delayed coming forth, he would have found the passage stopped." In an enclosed space like a court, the action of wind in drifting the ashes can scarcely have been very considerable.

I have interrupted my general comparative view of volcanos by a notice of particular observations made on Vesuvius, partly on account of the great interest excited by the recent eruption, and partly on account of those recollections of the catastrophes of Pompeii and Herculaneum, which are almost involuntarily recalled to our minds by the occurrence of any considerable shower of ashes. I have 
recorded in a note the measurements of height made by myself and others on Vesurius and in its vicinity.

We have hitherto been considering the structure and mode of action of those volcanos which have a permanent communication with the interior of the Earth by craters. The summits of such volcanos consist of masses of trachyte and lava upheaved by elastic forces and traversed by veins. The permanency of their action gives us reason to infer great complexity of structure. They have, so to speak, an individual character which remains unaltered for long periods of time. Neighbouring mountains often present the greatest differences in their products: leucitic and feldspathic lavas, obsidian with pumice, and masses of basalt containing olivine. They belong to the most recent terrestrial phænomena, breaking through almost all the sedimentary strata, and their products and lava currents are of later origin than our valleys. Their life, if I may permit myself to employ this figurative mode of expression, depends on the manner and permanence of their communications with the interior of the Farth. They often continue for centuries in a state of repose, are then suddenly rekindled, and end by becoming Solfataras, emitting aqueous, vapours, gases, and acids; sometimes, however, as in the case of the Peak of Teneriffe, we find that their summit has already become a laboratory of regenerated sulphur; while from the sides of the mountain there still issue large torrents of lava, basaltic in the lower part, but towards the upper part, where the pressure is less, (2) presenting the form of obsidian with pumice.

Distinct from these rolcanos provided with permanent 
craters, there is another class of volcanic phenomena more rarely observed, but particularly instructive to the geologist, as they recall the ancient world or the earliest geological revolutions of our planet. Trachytic mountains open suddenly, emit lava and ashes, and clnse again, perhaps never to reopen. Thus it was with the gigantic mountain of Antisana in the chain of the Andes, and with the Monte Epomeo in Ischia in 1302. Sometimes such an outbreak has even taken place in plains: as in the high plateau of Quito, in Iceland at a distance from Mount Hecla, and in Euboea in the Lelantine Fields. Many of the upheaved islands belong to this class of transitory phænomena. In all these cases the communication with the interior of the earth is not permanent, and the action ceases as soon as the cleft or fissure forming a temporary channel closes again. Veins or dykes of basalt, dolerite, and porphyry, which in different parts of the earth traverse almost all formations, and masses of syenite, augitic porphyry, and amygdaloid, which characterise the recent transition and oldest sedimentary rocks, have probably been formed in a similar manner. In the youth of our planet, the substances of the interior being still fluid, penetrated through the everywhere fissured crust of the globe, sometimes becoming solidified in the form of rocky veins or dykes of granular texture, and sometimes spreading out in broad sheets, and resembling superimposed strata. The volcanic products or rocks transmitted to us from the earlier ages of our planet have not flowed in narrow bands like the lavas of the isolated conical volcanos of the present time. The 
mixtures of augite, titaniferous iron, feldspar, and hornblende, may have been the same at different epochs, sometimes approximating more to basalt and sometimes to trachyte; and, (as we learn from the important researches of Mitscherlich, and the analogy of artificial igneous products) chemical substances may have united in definite proportions in a crystalline form: in all cases we recognise that substances similar in composition have arrived at the surface of the earth by very different ways; either simply upheaved, or penetrating through temporary fissures; and that breaking through the older rocks, $(i . e$. the earlier oxydized crust of the globe), they have finally issued as lava currents from conical mountains having a permanent crater. To confound together phenomena so different is to throw the geological study of volcanos and volcanic action back into the obscurity from which, by the aid of numerous comparative observations and researches, it has gradually began to emerge.

The question has often been propounded: What is it that burns in volcanos, - What produces the heat which melts and fuses together earths and metals? Modern chemical science has essayed to answer, that what burns are the earths, the metals, the alkalies themselves; viz. the metalloids of those substances. The solid and already-oxydised crust of the globe separates the surrounding atmosphere, with the oxygen which it contains, from the inflammable unoxydised substances in the interior of our planet: when those metalloids come in contact with the oxygen of the atmosphere there arises disengagement of heat. The great and celebrated chemist who propounded this explanation of vol- 
canic phenomena soon himself relinquished it. Observations made in mines and caverns in all climates, and which in concert with $\mathbf{M}$. Arago $\mathrm{I}$ have collected in a separate memoir, shew that, even at what may be considered a very small depth, the temperature of the Farth is much above the mean temperature of the atmosphere at the same place. A fact so remarkable, and so generally confirmed, connects itself with that which we learn from volcanic phenomena. The depth at which the globe may be regarded as a molten mass has been calculated. The primitive cause of this subterranean heat is, as in all planets, the process of formation itself, the separation of the spherically condensing mass from a cosmical gaseous fluid, and the cooling of the terrestrial strata at different depths by the loss of heat parted with by radiation. All volcanic phenomena are probably the result of a communication either permanent or transient between the interior and exterior of the globe. Elastic vapours press the molten oxydising substances upwards through deep fissures. Volcanos might thus be termed intermitting springs or fountains of earthy substances; $i . e$. of the fluid mixture of metals, alkalis, and earths which solidify into lava currents and flow softly and tranquilly, when being upheaved they find a passage by which to escape. In a similar manner the Ancients represented (according to Plato's Phædon) all volcanic fiery currents as streams flowing from the Pyriphlegethon.

To these considerations and views let me be permitted to add another more bold. May we not find in this internal heat of our globe,-(a heat indicated by thermometric 
experiments on the waters of springs rising from different depths, (3) as well by our observations on volcanos), -a cause which may explain one of the most monderful phænomena with which the study of fosssils has made us acquainted? Tropical forms of animals, and, in the vegetable lingdom, arborescent ferms, palms, and bambusacer, are found buried in the cold regions of the North. Everywhere the ancient world shews a distribution of organic forms at rariance with our present climates. To resolve so important a problem, recourse has been had to several hypotheses; such as the approach of a comet, a change in the obliquity of the Ecliptic, and a different degree of intensity in the solar light. None of these explanations are satisfactory at once to the astronomer, the physicist, and the geologist. For my part I willingly leave the axis of the Earth in its place, and suppose no change in the light of the solar disk (from whose spots a celebrated astronomer was inclined to explain the farourable or unfavourable harvests of particular years); I am disposed to recognise that in each planet there exist, independently of its relations to the central body of the system to which it belongs, and independently of its astronomical position, various causes for the derelopment of heat;-processes of oxydation, precipitations and chemical changes in the capacity of bodies, by increase of electromagnetic intensity, and communications opened between the internal and external portions of the planet.

It may be that in the Ancient World, exhalations of heat issuing forth through the many openings of the deeply 
fissured crust of the globe may have favoured, perhaps for centuries, the growth of palms and tree-ferns and the existence of animals requiring a high temperature, over entire countries where now a very different climate prevails. According to this view of things (a view already indicated by me in a work entitled "Geological Essay. on the Superposition of Rocks in both Hemispheres") the temperature of volcanos would be that of the interior of the earth, and the same cause which, operating through volcanic eruptions, now produces devastating effects, might in primeval ages have clothed the deeply fissured rocks of the newly oxydised earth in every zone with the most luxuriant vegetation.

If, with a view to explain the distribution of tropical forms whose remains are now discovered buried in northern regions, it should be assumed that the long-haired species of Elephant now found enclosed in ice was originally indigenous in cold climates, and that forms resembling the same leading type may, as in the case of lions and lynxes, have been able to live in wholly different climates, still this manner of solving the difficulty presented by fossil remains cannot be extended so as to apply to vegetable productions. From reasons with which the study of vegetable physiology makes us acquainted, Palms, Musaceæ, and arborescent Monocotyledones, are incapable of supporting the deprivation of their appendicular organs which would be caused by the present temperature of our northern regions; and in the geological problem which we have to examine, it appears to 
me difficult to separate regetable and animal remains from each other. The same mode of explanation ought to comprehend both.

I have permitted myself at the conclusion of the present discussion to connect with facts collected in different and widely separated countries some uncertain and hypothetical conjectures. The philosophical study of Nature rises beyond the requirements of a simple description of Nature: it does not consist in a sterile accumulation of isolated facts. It may sometimes be permitted to the active and curious mind of man to stretch forward from the present to the still obscure future; to divine that which cannot yet be clearly known; and thus to take pleasure in the ancient myths of geology reproduced in our own davs in new and varied forms. 



\section{ANNOTATIONS AND ADDITIONS.}

(1) p. 226.- "A more complete determination of the height of all parts of the margin of the crater."

Oltmanns, my astronomical fellow labourer, of whom, alas! science has been early deprived, re-calculated the barometric measurements of Vesuvius referred to in the preceding memoir (of the $22 \mathrm{~d}$ and 25 th of November and of the 1st of December, 1822), and has compared the results with the measurements which have been communicated to me in manuscript by Lord Minto, Visconti, Monticelli, Brioschi, and Poulett Scrope.

\section{A. Rocca del Palo, the highest and northern margin of the Crater}

$$
\text { of Vesurius. }
$$

Saussure, barometric measurement computed in

Toises. Eng. ft.

1773 , probably by Deluc's formula . . . 609 - 3894 Poli, 1794, barometric. . . . . . $606-3875$ Breislak, 1794, barometric (but, like Poli, the formula employed uncertain). . . . . 613 - 3920 Gay-Lussac, Leopold ron Buch, and Humboldt, 1805, barometric, computed by Laplace's formula, as are also all the barometric results which follow . 603 - 3856 Brioschi, 1810, trigonometric . . . . 638 - 4080 Visconti, 1816, trigonometric . . . . 622 - 3977 Lord Minto, 1822, barometric, often repeated . 621 - 3971 
Poulett Scrope, 1822, barometrie, somewhat un-

Toises. Eng. ft. certain from the proportion between the diameters of the tube and cistern being unknown - . $604-3862$ Monticelli and Covelli, 1822. . . . . 624 - 3990 Huinboldt, 1822 . . . . . . . 629 - 4022

Most probable result 317 toises, or 2027 English feet, above the Hermitage; or 625 toises, or 3996 English feet, above the level of the sea.

B. The lowest and southern margin of the crater opposite to Bosche Tre Case.

After the eruption of 1794 this edge became 400 Toises. Eng. ft. (426 Eng.) feet lower than the Rocca del Palo; therefore if we estimate the latter at 625 toises (3996 English feet). . . . . . 559 - 3574 Gay-Lussac, Leopold von Buch, and Humboldt, 1805 , barometric . . . . . . 534 - 3414 Humboldt, 1822, barometric : . . $546-3491$

C. Height of the cone of scoria inside the crater, which fell in on the $22 d$ of October, 1822.

Lord Minto, barometric Toises. Eng. ft. Brioschi, trigonometric, according to different comOr binations either.

Probable final result for the height of the above-mentioned cone of scoriæ 646 toises, or 4130 English feet.

D. Punta Nasone, highest summit of the Somma.

Schuckburoh, 1794, barometric, probably computed Toises. Eng. ft. by his own formula. . . . . . $584-3734$ Humboldt, 1822, barometric, Laplace's formula . 586 - 3747 
E. Plain of the Atrio del Cavallo.

Humboldt, 1822, barometric
F. Foot of the cone of ashes.

Gay-Lussac, Leopold von Buch, and Humboldt,

Toises. Eng. ft.

$403-2577$

1805 , barometric $\cdot \cdot \cdot \cdot \cdot$
G. Hermitage del Salvatore.

Gay-Lussac, Leopold ron Buch, and Humboldt,

Toises. Eng. ft. 1805 , barometric

Lord Minto, 1822, barometric . . . . 307.9 - 1969

Humboldt, 1822, barometric repeated . . . 30s. 7 - 1974

Part of my measurements have been printed in Monticelli's Storia de' fenomeni del Vesurio, avvenuti negli anni 18211823, p. 115 ; but the neglected correction for the height of the mercury in the cistern has somewhat disfigured the results as there published. When it is remembered that the results given in the above table were obtained with barometers of very different constructions, at various hours of the day, with winds from very different quarters, and on the unequally heated declivity of a volcano, in a locality in which the decrease of atmospheric temperature differs greatly from that which is supposed in our barometric formulæ, - the agreement will be found to be as great as could be expected, and quite satisfactory.

My measurements in 1822, at the time of the Congress of Verona, when I accompanied the late King of Prussia to 
Naples, were made with more care and under more favourable circumstances than those of 1805. Differences of height are besides always to be preferred to absolute heights, and these show that since 1794 the difference between the heights of the edges of the crater at the Rocca del Palo and on the side towards Bosco Tre Case has continued almost the same. I found it in 1805 exactly 69 toises (441 English feet), and in 1822 almost 82 toises (524 English feet). A distinguished geologist, Mr Poulett Scrope, found 74 toises (473 English feet), although the absolute heights which he assigns to the two sides of the crater appear to be rather too small. So little variation in a period of twenty-eight years, in which there were such violent commotions in the interior of the crater, is certainly a striking phænomenon.

The height attained by cones of scoriæ rising from the floor of the crater of Vesuvius is also deserving of particular attention. In 1776 Schuckburgh found such a cone 615 toises, or 3932 English feet, above the surface of the Mediterranean : according to the measurements of Lord Minto, (a very accurate observer,) the cone of scoriæ which fell in on the $22 \mathrm{~d}$ of October, 1822, even attained the height of 650 toises, or 4156 English feet. On both occasions, therefore, the height of the cones of scoriæ in the crater surpassed that of the highest part of the margin of the crater. When we compare together the measurements of the Rocca del Palo from 1773 to 1822, we are almost involuntarily led to entertain the bold conjecture that the north margin of the crater has been gradually upraised by subterranean forces. The accordance of the three measurements between 1773 
and 1805 is almost as striking as that of those taken from 1816 to 1822 . In the latter period we cannot doubt the height being from about 621 to 629 toises (3970 to 4022 English feet). Are the measurements made from thirty to forty year's earlier, which gave only 606 to 609 toises (3875 to 3894 English feet), less certain? At some future day, after longer periods shall have elapsed, it will be possible to decide what is due to errors of measurement, and what to an actual rise in the margin of the crater. There cannot be in this case any accumulation of loose materials from above. If the solid trachyte-like lava beds of the Rocca del Palo really become higher, we must assume them to be upheared from below by volcanic forces.

My learned and indefatigable friend Oltmanns has placed all the details of the above measurements before the public, accompanied by a careful critical examination of them, in the Abhandl. der königl. Akademie der Wissenschaften zu Berlin, 1822-1823, S. 3-20. May this investigation be the means of inducing geologists frequently to examine hypsometrically this low and most easily accessible (except Stromboli) of the European volcanos, so that in the course of centuries there may be obtained a frequently checked and accurate account of its periods of development!

(2) p. 235.- "Where the pressure is less."

Compare Leopold von Buch on the Peak of Teneriffe in his Physikalische Beschreibung der canarischen Inseln, 1825, S. 213; and in the Abhandlungen der königl. Akademie zu Berlin, 1820-1821, S. 99. 
(3) p. 239.- "Waters of springs rising from different depths."

Compare Arago in the Annuaire du Bureau des Longitudes pour 1835, p. 234. The increase of temperature is in our latitudes $1^{\circ}$ of Reaumur ( $2^{\circ} .25$ of a degree of Fahrenheit) for every 113 Parisian feet (120.5 English feet), or $1^{\circ}$ Fah. to 53.5 English feet nearly. In the Artesian boring at New Salzwerk (Oeynhausen's Bad), not far from Minden, which is the greatest known depth below the level of the sea, the temperature of the water at $2094 \frac{1}{2}$ Parisian feet

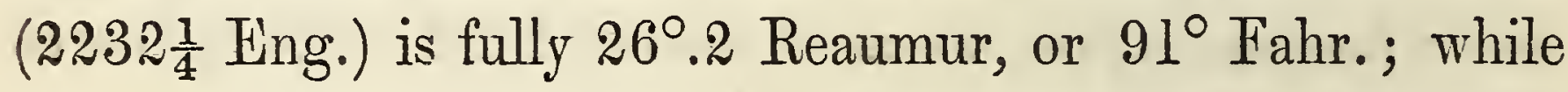
the mean temperature of the air above may be taken at $7^{\circ} .7$ Reaumur, or $49^{\circ} .2$ Fahr. It is very remarkable that in the third century Saint Patricius, Bishop of Pertusa, was led by seeing the hot springs near Carthage to a very just view respecting the cause of such an increase of heat. (Acta S. Patricii, p. 555, ed. Ruinart; Kosmos, Bd. i. S. 231,-English Edition, Vol. i. p. 211.) 
THE

\section{VITAL FORCE;}

OR,

\section{THE, RHODIAN GENIUS.}

[RIRST PRINTED IN 1795.] 



\section{THE VITAL FORCE,}

\section{$\mathrm{OR}$ \\ THE RHODIAN GENIUS.}

The Syracusans, like the Athenians, had their Pœcile, ili which representations of gods and heroes, the works of Grecian and Italian art, adomed the halls, glowing with raried colours. The people resorted thither continually; the young warriors to contemplate the exploits of their ancestor's, the artists to study the works of the great masters. Among the numerous paintings which the active zeal of the Syracusans had collected from the mother country, there was one which, for a century past, had particularly attracted the attention of spectators. Sometimes the Olympian Jove, Cecrops the founder of cities, and the hernic courage of Harmodius and Aristogiton, would want admirers, while men pressed in crowded ranks around the picture of which we speak. Whence this preference? Was it a rescued work of Apelles, or of the school of Callimachus? No; it possessed indeed grace and beauty; but yet neither in the blending of the colours, nor in the character and style of the entire picture, could it be compared with many other paintings in the Pœcile.

The multitude (comprehending therein many classes of 
society), often regard with astonishment and admiration what they do not comprehend: this picture had occupied its place for a hundred years; but though Syracuse contained within the narrow limits enclosed by its walls more of the genius of art than the whole of the remainder of sea-surrounded Sicily, no one had yet divined the hidden meaning of the design. It was even uncertain to what temple the painting had originally belonged, for it had been rescued from a shipwrecked vessel, which was only conjectured from the merchandise it contained to have come from Rhodes.

On the foreground of the picture youths and maidens formed a closely crowded group. They were without clothing and well formed, but at the same time did not exhibit the more noble and graceful proportions admired in the statues of Praxiteles and Alcamenes. Their robust limbs, shewing the traces of laborious efforts, and the purely terrestrial expression of their desires and sorrows, seemed to take from them every thing of a diviner character, and to chain them exclusively to their earthly habitation. Their hair was simply ornamented with leaves and field-flowers. Their arms were outstretched towards each other, as if to indicate their desire of union, but their troubled looks were turned towards a Genius who, surrounded by bright light, hovered in the midst. A butterfly was placed on his shoulder, and in his hand he held on high a lighted torch. The contours of his form were soft and child-like, but his glance was animated by celestial fire : he looked down as a master upon the youths and maidens at his feet. Nothing else that was characteristic could be discovered in the pic- 
ture. Some persons thought they could make out at its foot the letters $\zeta$ and $\varsigma$, from whence (as antiquaries were then no less bold in their conjectures than they now are), they took occasion to infer, in a somewhat forced manner, the name of Zenodorus; thus attributing the work to a painter of the same name as the artist who at a later period cast the Colossus of Rhodes.

The "Rhodian Genius," howerer,-for such was the name given to the picture,- - did not want for commentators and interpreters in Syracuse. Amateurs of the arts, and especially the younger amongst them, on returning from a short visit to Corinth or Athens, would have thought it equivalent to renouncing all pretensions to connoisseurship if they had not been provided with some new explanation. Some regarded the Genius as the personification of Spiritual Love, forbidding the enjuyment of sensual pleasures; others said it was the assertion of the empire of Reason over Desire : the wiser among the critics were silent; and presuming some high though yet undiscovered meaning, examined meanwhile with pleasure the simple composition of the picture.

Still, however, the question remained unsolved. The picture had been copied with various additions and sent to Greece, but not the least light had been thrown on its origin; when at length, at the season of the early rising of the Pleiades, and soon after the reopening of the navigation of the Egean Sea, ships from Rhodes entered the port of Syracuse, bearing a precious collection of statues, altars, candelabras, and paintings, which Dionysius's love of art had caused to be brought together from different parts of Greece. 
Among the paintings was one which was immediately recognised as the companion or pendent of the Rhodian Genius: the dimensions were the same, and the colouring similar, but in a better state of preservation: the Genius was still the central figure, but the butterfly was no longer on his shoulder; his head was drooping, and his torch extinguished and inverted. The youths and maidens pressing around him had met and embraced; their glance, no longer subdued or sad, announced, on the contrary, emancipation from restraint, and the fulfilment of long-cherished desires.

The Syracusan antiquaries were already seeking to modify the explanations they had previously proposed, so as to adapt them to the newly-arrived picture, when Dionysius commanded the latter to be carried to the house of Epicharmus, a philosopher of the Pythagorean school, who dwelt in a remote part of Syracuse called Tyche. Epicharmus rarely presented himself at the court of Dionysius, for although the latter was fond of calling around him the most distinguished men from all the Greek colonial cities, yet the philosopher found that the proximity of princes takes even from men of the greatest intellectual power part of their spirit and their freedom. He devoted himself unceasingly to the study of natural things, their forces or powers, the origin of animals and plants, and the harmonious laws in accordance with which the heavenly bodies, as well as the grains of hail and the flakes of snow, assume their distinctive forms. Oppressed with age, and unable to proceed far without assistance, he caused himself to be conducted daily to the Pocile, and thence to the entrance of the port, where, 
as he said, his eyes received the image of the boundless and the infinite which his spirit ever strove in vain to apprehend. He lived honoured alike by the tyrant, whose presence he avoided, and by the lower classes of the people, whom he met gladly, and often with friendly help.

Exhausted with fatigue, he was reposing on his couch, when the newly-arrived picture was brought to him by the command of Dionysius. Care had been taken to bring, at the same time, a faithful copy of the "Rhodian Genius," and the philosopher desired the two paintings to be placed side by side before him. After having remained for some time with his eyes fixed upon them, and absorbed in thought, he called his scholars together, and spoke to them in the following terms, in a voice which was not without emotion :-

"Withdraw the curtain from the window, that I may enjoy once more the view of the fair earth animated with living beings. During sixty years I have reflected on the internal motive powers of nature, and on the differences of substances: to-day for the first time the picture of the Rhodian Genius leads me to see more clearly that which I had before only obscurely divined. As living beings are im. pelled by natural desires to salutary and fruitful union, so the raw materials of inorganic nature are moved by similar impulses. Even in the reign of primeval night, in the darkness of chaos, elementary principles or substances sought or shunned each other in obedience to indwelling. dispositions of amity or enmity. Thus the fire of heaven follows metal, iron obeys the attraction of the loadstone, 
amber rubbed takes up light substances, earth mixes with earth, salt collects together from the water of the sea, and the acid moisture of the Stypteria ( $\sigma \tau v \pi \tau \eta \rho \iota v \gamma \gamma \rho \alpha$ ), as well as the flocculent salt Trichitis, love the clay of Melos. In inanimate nature all things hasten to unite with each other according to their particular laws. Hence no terrestrial element (and who would dare to inclide light among the number of such elements?) is to be found anywhere in its pure and primitive simple state. Each as soon as formed tends to enter into new combinations, and the art of man is needed to disjoin and present in a separated state substances which you would seek in vain in the interior of the earth, and in the fluid oceans of air or water. In dead inorganic matter, entire inactivity and repose reign so long as the bonds of affinity continue undissolved, so long as no third substance comes to join itself to the others. But even then, the action and disturbance produced are soon again succeeded by unfruitful repose.

"It is otherwise, however, when the same substances are brought together in the bodies of plants and animals. In these the vital force or power reigns supreme, and regardless of the mutual amity or enmity of the atoms recognised by Democritus, commands the union of substances which in inanimate nature shun each other, and separates those which are ever seeking to enter into combination.

"Now come nearer to me, my friends; look with me on the first of the pictures before us, and recognise in the Rhodian Genius, in the expression of youthful energy, in the butterfly on his shoulder, and in the commanding glance of 
his eye, the symbol of vital force animating each individual germ of the organic creation. At his feet are the earthy elements desiring to mix and unite, conformably to their particular tendencies. The Genius, holding aloft his lighted torch with commanding gesture, controls and constrains them, without regard to their ancient rights, to obey his laws.

"Now view with me the new picture which the tyrant has sent to me for explanation: turn your eyes from the image of life to that of death. The butterfly has left its former place and soars upwards; the extinguished torch is reversed, the head of the youth has sunk : the spirit has fled to other spheres, and the vital force is dead. Now the youths and maidens joyfully join hands, the earthy substances resume their ancient rights: they are freed from the chains that bound them, and follow impetuously after long restraint the impulse to union.-Thus inert matter, animated awhile by vital force, passes through an innumerable diversity of forms, and perhaps in the same substance which once enshrined the spirit of Pythagoras, a poor worm may have enjoyed a momentary existence.

"Go, Polycles, and tell Dionysius what thou hast heard;and you my friends, Euryphamos, Lysis, and Scopas, come nearer to me and support me; I feel that in my weakened frame the enfeebled vital power will not long hold in subjection the earthly substances which reclaim their ancient liberty. Lead me once again to the Pœcile, and thence to the sea shore; soon you will collect my ashes." 



\section{NOTE.}

I Have noticed in the Preface to the Second and Third Editions (S. xiii., p. xii. English Trans.) the subject of the republication here of the preceding pages, which were first printed in Schiller's Horen (Jahrg. 1795, St. 5, S. 90-96). They contain the development of a physiological. idea clothed in a semi-mythical garb. In the Latin "Aphorisms from the Chemical Physiology of Plants" appended to my "Subterranean Flora," in 1793,-I had defined the "vital force" as "the unknown cause which prevents the elements from following their original affinities." The first of my aphorisms were as follows:- "Rerum naturam si totam consideres, magnum atque durabile, quod inter elementa intercedit, discrimen perspicies, quorum altera affinitatum legibus obtemperantia, altera, vinculis solutis, varie juncta apparent. Quod quidem discrimen in elementis ipsis eorumque indole neutiquam positum, quum ex sola distributione singulorum petendum esse videatur. Materiam segnem, brutam, inanimam eam rocamus, cujus stamina secundum leges chymice affinitatis mixta sunt. Animata atque organica ea potissimum corpora appellamus, quæ, licet in novas mutari formas perpetuo tendant, vi interna quadam continentur, quominus priscam sibique insitam formam relinquant. 
"Vim internam, quæ chymicæ affinitatis vincula resolvit, atque obstat, quominus elementa corporum libere conjungantur, vitalem vocamus. Itaque nullum certius mortis criterium putredine datur, qua primæ partes vel stamina rerum, antiquis juribus revocatis, affinitatum legibus parent. Corporum inanimorum nulla putredo esse potest." (Vide Aphorismi ex doctrina Physiologiæ chemicæ Plantarum, in Humboldt, Flora Fribergensis subterranea, 1793, p. 133136).

I have placed in the mouth of Epicharmus the above propositions, which were disapproved by the acute Vicq d'Azyr, in his Traité d'Anatomie et de Physiologie, T. i.p. 5, but are now entertained by many distinguished persons among my friends. Reflection and continued. study in the domains of physiology and chemistry have deeply shaken my earlier belief in a peculiar so-called vital force. In 1797, at the close of my work entitled "Versuche über die gereizte Muskel und Nervenfaser, nebst Vermuthungen über den chemischen Process des Lebens in der Thier und Pflanzenwelt" (Bd. ii. S. 430-436), I already declared that I by no means regarded the existence of such peculiar vital forces as demonstrated. Since that time I have no longer called peculiar forces what may possibly only be the operation of the concurrent action of the several long-known substances and their material forces. We may, however deduce from the chemical relations of the elements a safer definition of animate and inanimate substances, than the criteria which are taken from voluntary motion, from the circulation of fluids within solids, from internal appropria- 
tion, and from the fibrous arrangements of the elements. I term that an animated substance "of which the parts being: separated by external agency alter their state of composition after the separation, all other and external relations continuing the same." This definition is merely the enunciation of a fact. The equilibrium of the elements in animated or organic matter is preserved by their being parts of a whole. One organ determines ariother, one gives to another its temperature and tone or disposition, in all which, these, and no other, affinities are operative. Thus in organised beings all is reciprocally means and end. The rapidity with which organic parts, separated from a complete living organism, change their state of combination, differs greatly, according to the degree of their original dependence, and to the nature of the substance. Blood of animals, which varies much in the different classes, suffer's change sooner than the juices of plants. Funguses generally decay sooner than leares of trees, and muscle more easily than the cutis.

Bones, the elementary structure of which has been very recently recognised, hair of animals, mood in plants or trees, the feathery appendages of seeds of plants (Pappus), are not inorganic or without life; but eren in life they approximate to the state in which they are found after their separation from the rest of the organism. The higher the degree of vitality or susceptibility of an animated substance, the more rapidly does organic change in its composition ensue after separation. "The aggregate total of the cells is an organism, and the organism lives so long as the parts are active in subservience to the whole. In oppo- 
sition to lifeless or inorganic, organic nature appears to be self-determining." (Henle, Allgemeine Anatomie, 1841, S. 216-219). The difficulty of satisfactorily referring the vital phenomena of organic life to physical and chemical laws, consists chiefly (almost as in the question of predicting meteorological processes in the atmosphere), in the complication of the phænomena, and in the multiplicity of simultaneously acting forces and of the conditions of their activity.

I have remained faithful in "Kosmos" to the same mode of viewing and representing what are called "Lebenskräfte," vital forces, and vital affinities, (Pulteney, in the Transact. of the Royal Soc. of Edinburgh, vol. xvi. p. 305), the formation-impulse, and the active principle in organisation. I have said, in Kosmos, Bd. i. S. 67, (English Ed. vol. i. p. 62), "The myths of imponderable matter and of vital forces peculiar to each organism have complicated and perplexed the view of nature. Under different conditions and forms of recognition the prodigious mass of our experimental knowledge has progressively accumulated, and is now enlarging with increased rapidity. Investigating reason essays from time to time with varying success to break through ancient forms and symbols, invented to effect the subjection of rebellious matter, as it were, to mechanical constructions." Farther on in the same volume, (p. 339 English, and 367 of the original,) I have said, "In a physical description of the universe, it should still be noticed that the same substances which compose the organic forms of plants and animals are also found in the inorganic crust 
of the globe; and that the same forces or powers which govern inorganic matter are seen to prevail in organic beings likewise, combining and decomposing the various substances, regulating the forms and properties of organic tissues, but acting in these cases under complicated conditions yet unexplained, to which the very vague terms of 'vital phænomena,' 'operations of vital forces,' have been assigned, and which have been systematically grouped, according to analogies more or less happily imagined." (Compare also the critical notices on the assumption of proper or peculiar vital forces in Schleiden's Botanik als inductive Wissenchaft (Botany as an Inductive Science), Th. i. S. 60, and in the recently published excellent Untersuchungen über thierische Elektricität (Researches on Animal Electricity), by Emil du Bois-Reymond, Bd. i. S. xxxiv.-1.) 



\section{PLATEAU OF CAXAMARCA,}

THE

ANCIENT CAPITAL OF THE INCA ATAHUALLPA:

AND

THE FIRST VIEN OF THE PACIFIC OCEAN, FRON THE CREST OF THE ANDES. 

THE

\section{PLATEAU OF CAXAMARCA,}

THE ANCIENT CAPITAL OF THE INCA ATAHUALLPA.

AFTER a residence of an entire year on the crest of the chain of the Andes or Antis ( $\left.{ }^{1}\right)$, between $4^{\circ}$ North and $4^{\circ}$ South Latitude, in the high plains of New Granada, Pastos, and Quito, whose mean elevations range between 8500 and 12800 English feet, we rejoiced in descending gradually through the milder climate of the Quina-yielding forests of Loxa to the plains of the upper part of the course of the Amazons, a terra incognita rich in magnificent vegetation. The small town of Loxa has given its name to the most efficacious of all the species of medicinal Fever-Bark: Quina, or Cascarilla fina de Loxa. It is the precious production of the tree which we have described botanically as Cinchona condaminea, but which, under the erroneous impression that all the kinds of the Quina or fever bark of commerce were furnished by the same species of tree, had previously been called Cinchona officinalis. The Fever Bark was first brought to Europe towards the middle of the seventeenth century, 
either, as Sebastian Badus asserts, to Alcala de Henares in 1632, or to Madrid in 1640, on the arrival of the wife of the Viceroy, the Countess of Chinchon $\left({ }^{2}\right)$, who had been cured of irtermittent fever at Lima, accompanied by her physician, Juan del Vego. The trees which yield the finest quality of Quina de Loxa are found from 8 to 12 miles to the south east of the town, in the mountains of Uritusinga, Villonaco, and Rumisitana, growing on mica-slate and gneiss, at very moderate elevations above the level of the sea, being between 5400 and 7200 (5755 and 7673 English) feet, heights about equal respectively to those of the Hospice on the Grimsel and the Pass of the great St. Bernard. The proper boundaries of the Quina-woods in this quarter are the small rivers Zamora and Cachiyacu.

The tree is cut down in its first flowering season, or in the fourth or seventh year of its age, according as it has sprung from a vigorous root-shoot, or from a seed: we heard with astonishment that at the period of my journey, according to official computations, the collectors of Quina (Cascarilleros and Cazadores de Quina, Quina Hunters),only brought in 110 hundred weight of the Bark of the Cinchona condaminea annually. None of this precious store found its way at that time into commerce; the whole was sent from the port of Payta on the Pacific, round Cape Horn to Cadiz, for the use of the Spanish Court. In order to furnish this small quantity of 11000 Spanish pounds, eight or nine hundred trees were cut down every year. The older and thicker stems have become more and more scarce; 
but the lusuriance of regetation is such that the younger trees which are now resorted to, though only 6 inches in diameter, often attain from 5 s to 64 English feet in height. This beautiful tree, which is adorned with leaves above 5 English inches long and 2 broad, growing in dense woods, seems always to aspire to rise above its neighbour's. As its upper branches wave to and fro in the wind, their red and shining foliage produces a strange and peculiar effect recognisable from a great distance. The mean temperature in the roods where the Cinchona condaminea is found, ranges betrreen $12 \frac{1}{2}^{\circ}$ and $15^{\circ}$ Reaumur $\left(60^{\circ} .2\right.$ and $65^{\circ} .8$ Fahrenheit), which are about the mean annual temperatures of Florence and the Island of Madeira; but the extremes of heat and cold observed at these two stations of the temperate zone are never felt around Loxa. Comparisons between the climates of places, one of which is situated in an elevated tropical plain, and the other in a higher parallel of latitude, can be from their nature but little satisfactory.

In order to descend South-South-East from the mountain knot of Lora to the hot Valley of the Amazons, it is first necessary to pass orer the Paramos of Chulucanas, Guamani and Yamoca, - mountain wildernesses of a peculiar character of which we have already spoken, and to which, in the southern parts of the Andes, the name of Puna (a word belonging to the Quichua language) is giren. They mostly rise above 9500 (10125 English) feet; they are stormy, often enveloped for days in dense mist, or visited by violent and formidable shower's of hail,-consisting not merely of hailstones of different spherical forms, usually a 
good deal flattened by rotation, but also sometimes of less regular forms, the hail having run together into thin plates of ice (papa-cara) which cut the face and hands. At such times I have occasionally seen the thermometer sink to $7^{\circ}$ or $5^{\circ}$ Reaumur, (47. .8 and $43^{\circ} .2 \mathrm{Fahr}$.) and the electric tension of the atmosphere, measured by Volta's electrometer, pass in a few minutes from positive to negative. When the temperature sinks below $5^{\circ}$ Reaumur, ( $43^{\circ} .2$ Fahrenheit) snow falls in large and thinly scattered flakes. The vegetation of the Paramos has a peculiar physiognomy and character, from the absence of trees, the short close branches of the small-leaved myrtlelike shrubs, the large sized and numerous blossoms, and the perpetual freshness of the whole from the constant and abundant supply of moisture. No zone of Alpine vegetation in the temperate or cold parts of the globe can well be compared with that of the Paramos in the tropical Andes.

The impressions produced on the mind by the natural characters of these wildernesses of the Cordilleras are heightened in a remarkable and unexpected manner, from its being in those very regions that we still see admirable remains of the gigantic work, the artificial road of the Incas, which formed a line of communication through all the provinices of the Empire, extending over a length of more than a thousand English geographical miles. We find, placed at nearly equal distances apart, stations consisting of dwelling houses built of well-cut stone; they are a kind of Caravanserai, and are called Tambos and sometimes Inca-pilca (from pircca, the wall?). Some of them are surrounded by a kind of fortification; others were 
constructed for baths with arrangements for conducting hot water; the larger were designed for the use of the family of the Monarch himself. I had previously seen, measured, and drawn with care, buildings of the same kind in a good state of preservation at the foot of the volcano of Cotopaxi, near Callo. Pedro de Cieça, writing in the 16th century, called them "Aposentos de Mulalo." (3) In the pass between Alausi and Loxa, called the Paramo del Assuay, - (a much frequented route across the Ladera de Cadlud, 14568 French or 15526 English feet above the level of the sea, or almost equal to the height of Mont Blanc), -as we were leading our heavily laden mules with great difficulty through the marshy ground on the elevated plain del Pullal, our eyes meanwhile were continually dwelling on the grand remains of the Inca's road, which with a breadth of twentyone English feet ran by our side for above a German mile. It had a deep under-structure, and was paved with well-cut blocks of blackish trap-porphyry. Nothing that I had seen of the remains of Roman roads in Italy, in the South of France, and in Spain, was more imposing than these works of the ancient Peruvians, which are moreover situated, according to my barometric measurements, at an elevation of 12440 (13258 English) feet above the sea, or more than a thousand feet higher than the summit of the Peak of Teneriffe. The ruins of what is called the Palace of the Inca Tupac Yupanqui, and which are known by the name of the "Paredones del Inca," are situated at the same elevation on the Assuay. Proceeding from thence to the southward towards Cuenca, the road leads to the small but well preserved 
fortress of Cañar $\left(^{4}\right)$, belonging probably to the same period, that of Tupac Yupanqui, or to that of his warlike son, Huayna Capac.

We saw still finer remains of the old Peruvian artificial roads on the way between Loxa and the Amazons, at the Baths of the Incas on the Paramo de Chulucanas, not far from Guancabamba, and in the neighbourhood of Ingatambo, at Pomahuaca. These last named remains are at a so much lower elevation, that I found the difference of level between the Inca's Road at Pomahuaca and that on the Paramo del Assuay upwards of 9100 (about 9700 English) feet. The distance in a straight line is by astronomically determined latitudes exactly 184 English geographical miles, and the ascent of the road is 3500 (3730 English) feet greater than the height of the Pass of Mount Cenis above the Lake of Como. There are two great artificial Peruvian paved roads or systems of roads, covered with flat stones, or sometimes even with cemented gravel(5) (Macadamised); one passes through the wide and arid plain between the Pacific Ocean and the chain of the Andes, and the other over the ridges of the Cordilleras. Mile-stones, or stones marking the distances, are often found placed at equal intervals. The road was conducted across rivers and deep ravines by three kinds of bridges, stone, wood, and rope bridges (Puentes de Hamaca or de Maroma), and there were also aqueducts, or arrangements for bringing water to the Tambos, (hostelries or caravanserais) and to the fortresses. Both systems of roads were directed to the central point, Cuzco, the seat of government of the great empire, in $13^{\circ} 31^{\prime}$ South lati- 
tude, and which is placed, according to Pentland's map of Bolivia, 10676 Paris or 11378 English feet above the level of the sea. As the Perurians employed no wheel carriages, and the roads were consequently only designed for the march of troops, for men carrying burdens, and for lightly laden lamas, we find them occasionally interrupted, on account of the steepness of the mountains, by long flights of steps, provided with resting places at suitable intervals. Francisco Pizarro and Diego Almagro, who on their distant expeditions used the military roads of the Incas with so much advantage, found great difficulties ior the Spanish Cavalry at the places where these steps occurred $\left({ }^{6}\right)$. The impediment presented to their march on these occasions was so much the greater, because in the early times of the Conquista, the Spaniards used only horses instead of the carefully treading mule, who in the difficult parts of the mountains seems to deliberate on every step he takes. It was not until a later period that mules were employed.

Sarmiento, who saw the Roads of the Incas whilst they were still in a perfect state of preservation, asks in a "Relacion" which long lay unread, buried in the Library of the Escorial, "how a nation unacquainted with the use of iron could have completed such grand works in so high and rocky a region ("Caminos tan grandes y tan sorervios"), extending from Cuzco to Quito on the one hand, and to the coast of Chili on the other? The Emperor Charles," he adds, "with all his power could not accomplish even a part of what the well-ordered Government of the Incas effected through the obedient people orer whom they ruled."

VOL. II. 
Hernando Pizarro, the most educated and civilised of the three brothers, who for his misdeeds suffered a twenty years' imprisonment at Medina del Campo, and died at last at a hundred years of age " in the odour of sanctity," "en olor de Santidad," exclaims: "in the whole of Christendom there are nowhere such fine roads as those which we here admire." The two important capitals and seats of government of the Incas, Cuzco and Quito, are 1000 English geographical miles apart in a straight line (SS.E., NN.W.), without reckoning the many windings of the way; and including the windings, the distance is estimated by Garcilaso de la Vega and other Conquistadores at "500 leguas." Notwithstanding the great distance, we learn from the wellconfirmed testimony of the Licentiate Polo de Ondegardo, that Huayna Capac, whose father had conquered Quito, caused some of the building materials for the "princely buildings," (the houses of the Incas) in the latter city, to be brought from Cuzco.

When enterprising races inhabit a land where the form of the ground presents to them difficulties on a grand scale which they may encounter and overcome, this contest with nature becomes a means of increasing their strength and power as well as their courage. Under the despotic centralizing system of the Inca-rule, security and rapidity of communication, especially in the morement of troops, became an important necessity of government. Hence the construction of artificial roads on so grand a scale, and hence also the establishment of a highly improved postal system. Among nations in very different stages of culti- 
vation we see the national activity display itself with peculiar predilection in some particular directions, but we can by no means determine the general state of culture of a people from the striking development of such particular and partial activity. Egyptians, Greeks (7), Etruscans, and Romans, Chinese, Japarese, and Hindoos, shew many interesting contrasts in these respects. It is difficult to pronounce what length of time may have been required for the execution of the Perurian roads. The great works in the northerm part of the Empire of the Incas, in the highlands of Quito, must at all events have been completed in less than 30 or 35 years; $i$. e. within the short period intervening between the defeat of the Ruler of "Quitu" and the death of Huayna Capac, but entire obscurity prevails as to the period of the formation of the Southern, and more properly speaking Peruvian, roads.

The mysterious appearance of Manco Capac is usually placed 400 years before the landing of Pizarro in the Island of Puna (1532), therefore towards the middle of the 12 th century, almost 200 years before the foundation of the city of Mexico (Tenochtitlan); some Spanish writers eren reckon, instead of 400,500 and 550 years between Manco Capac and Pizarro. But the history of the empire of Peru only recognises thirteen ruling princes of the Inca-dynasty, a number which, as Prescott very justly remarks, is not sufficient to occupy so long an interval as 550 or even 400 years. Quetzalcoatl, Botschica, and Manco Capac, are the three mythical forms with which the commencements of cirilisation among the Aztecs, the Muyscas (more properly Chib- 
chas), and the Peruvians, are connected. Quetzalcoatl, bearded, clothed in black, a high priest of Tula, subsequently a penance-performing anchorite on a mountain near Tlaxapuchicalco, comes to the highlands of Mexico from the coast of Panuco; therefore from the eastern coast of Anabuac. Botschica, or rather Nemterequeteba ( ${ }^{8}$ ) (a Buddha of the Muyscas), a messenger sent by the Deity, bearded and wearing long garments, arrives in the high plains of Bogota from the grassy steppes east of the chain of the Andes. Before Manco Capac a degree of civilisation already prevailed on the picturesque shores of the Lake of Titicaca. The strong fort of Cuzco, on the hill of Sacsahuaman, was formed on the pattern of the older constructions of Tiahuanaco. In the same manner the Aztecs imitated the pyramidal structures of the Toltecs, and these, those of the Olmecs (Hulmecs); and gradually ascending, we arrive, still on historic ground in Mexico, as far back as the sixth century of our Era. According to Siguenza, the Toltec steppyramid (or Teocalli) of Cholula is a repetition of the form of the Hulmec step-pyramid of Teotihuacan. Thus as we penetrate through each successive stratum of civilisation we arrive at an earlier one; and national self-consciousness not having awoke simultaneously in the two continents, we find in each nation the imaginative mythical domain always immediately preceding the period of historic knowledge.

Notwithstanding the tribute of admiration which the first Conquistadores paid to the roads and aqueducts of the Peruvians, not only did they neglect the repair and preservation of both these classes of useful works, but they even wantonly 
destroyed them; and this still more towards the sea-coast, (for the sake of obtaining fine cut stones for new buildings; and where the want of water consequent on the destruction of the aqueducts has rendered the soil barren), than on the ridges of the Andes, or in the deep-cleft valleys by which the mountain chain is intersected. In the long day's journey from the syenitic rocks of Zaulaca to the Valley of San Felipe (rich in fossils, and situated at the foot of the icy Paramo de Yamoca), we were obliged to wade through the Rio de Guancabamba (which flows into the Amazons), no less than twenty-seven times, on account of the windings of the stream; while we continually saw near us, running in a straight line along the side of a steep precipice, the remains of the high built road of the Incas with its Tambos. The mountain torrent, though only from 120 to 150 English feet broad, was so strong and rapid that, in fording it, our heavily laden mules were often in danger of being swept away by the flood. They carried our manuscripts, our dried plants, and all that we had been collecting for a year past. Under such circumstances one watches from the other side of the stream with very anxious suspense until the long train of eighteen or twenty beasts of burden have passed in safety.

The same Rio de Guancabamba, in the lower part of its course, where it has many falls and rapids, is made to serve in a very singular manner for the conveyance of correspondence with the coast of the Pacific. In order to expedite more quickly the few letters from Truxillo which are intended for the province of Jaen de Bracamoros, a "swimming 
courier," "el correo que nada," as he is called in the country, is employed. This post messenger, who is usually a young Indian, swims in two days from Pomahuaca to Tomependa, first by the Rio de Chamaya (the name given to the lower part of the Rio de Guancabamba), and then by the Amazons. He carefully places the few letters entrusted to him in a large cotton handkerchief, which he winds round his head in the manner of a turban. When he comes to waterfalls he leaves the river, and makes a circuit through the woods. In order to lessen the fatigue of swimming for so long a time, he sometimes throws one arm round a piece of a very light kind of wood (Ceiba, Palo de balsa), of a tree belonging to the family of Bombacer. Sometimes also a friend goes with him to bear him company. The pair have no concern about provisions, as they are always sure of a hospitable reception in any of the scattered huts, which are abundantly surrounded with fruit trees, in the beautiful Huertas de Pucara and Cavico.

Happily the river is free from crocodiles, which, in the upper part of the Amazons, are first met with below the cataracts of Mayasi. These unwieldy and slothful monsters generally prefer the more tranquil waters. According to my measurements the Rio de Chamaya, from the Ford (Paso) de Pucara to the place where it enters the Amazons River below the village of Choros, has a fall (9) of 1668 (1778 English) feet in the short space of 52 English geographical miles. The Governor of the province of Jaen de Bracamoros assured me that letters carried by this singular waterpost were rarely either wetted or lost. Soon after my return 
to Europe from Mexico, I received, in Paris, letters from Tomependa, which had been sent in the manner above described. Several tribes of wild Indians, living on the banks of the Upper Amazons, make their journeys in a similar manner, swimming down the stream sociably in parties. I had the opportunity of seeing in this manner, in the bed of the river, the heads of thirty or forty persons (men, women, and children), of the tribe of the Xibaros, on their arrival at Tomependa. The "Correo que nada" returns by land by the difficult route of the Paramo del Paredon.

On approaching the hot climate of the basin of the Amazons, the eye is cheered by the aspect of a beautiful, and occasionally very luxuriant vegetation. We had never before, not even in the Canaries or on the hot sea coast of Cumana and Caraccas, seen finer orange trees than those of the Huertas de Pucara. They were principally the sweet orange (Citrus aurantium, Risso), and less frequently the bitter or Seville orange (C. vulgaris, Risso). Laden with many thousands of their golden fruits, they astain a height of sixty or sixty-four English feet; and, instead of rounded tops or crowns, have aspiring branches, almost like a laurel or bay tree. Not far from thence, near the Ford of Cavico, we were surprised by a very unexpected sight. We saw a grove of small trees, only about eighteen or nineteen English feet high, which, instead of green, had apparently perfectly red or rose-coloured leaves. It was a new species of Bougainvillæa, a genus first established by the elder Jussieu, from a Brazilian specimen in Commerson's herbarium. The trees were almost entirely without true leares, as what we took 
for leaves at a distance, proved to be thickly crowded bracteas. The appearance was altogether different, in the purity and freshness of the colour, from the autumnal tints which, in many of our forest trees, adorn the woods of the temperate zone at the season of the fall of the leaf. A single species of the South African family of Proteacer, Rhopala ferruginea, descends here from the cold heights of the Paramo de Yamoca to the hot plain of Chamaya. We often found here the Porlieria hygrometrica (belonging to the Zygophylleæ), which, by the closing of the leaflets of its finely pinnated foliage, foretels an impending change of weather, and especially the approach of rain, much better than any of the Mimosaceæ. It very rarely deceived us.

We found at Chamaya rafts (balsas) in readiness to convey us to Tomependa, which we desired to visit for the purpose of determining the difference of longitude between Quito and the mouth of the Chinchipe (a determination of some importance to the geography of South America on account of an old observation of La Condamine). ( ${ }^{10}$ ) We slept as usual under the open sky on the sandy shore (Playa de Guayanchi) at the confluence of the Rio de Chamaya with the Amazons. The next day we embarked on the latter river, and descended it to the Cataracts and Narrows (Pongo in the Quichua language, from puncu, door or gate) of Rentema, where rocks of coarse-grained sandstone (conglomerate) rise like towers, and form a rocky dam across the river. I measured a base line on the flat and sandy shore, and found that at Tomependa the afterwards mighty River of the Amazons is only a little above 1386 English feet across. In the celebrated River Narrow or Pongo of Manseritche, 
between Santiago and San Borja, in a mountain ravine where at some points the overhanging rocks and the canopy of foliage forbid more than a very feeble light to penetrate, and where all the drift wood, consisting of a countless number of trunks of trees, is broken and dashed in pieces, the breadth of the stream is under 160 English feet. The rocks by which all these Pongos or Narrows are formed undergo many changes in the course of centuries. Thus a part of the rocks forming the Pongo de Rentema, spoken of above, had been broken up by a high flood a year before my journey; and there has even been preserved among the inhabitants, by tradition, a lively recollection of the precipitous fall of the then towering masses of rock along the whole of the Pongo, - an event which took place in the early part of the eighteenth century. This fall, and the consequent blocking up of the channel, arrested the flow of the stream; and the inhabitants of the village of Puyaya, situated below the Pongo de Rentema, saw with alarm the wide river-bed entirely dry: but after a few hours the waters again forced their way. Earthquake movements are not supposed to have occasioned this remarkable occurrence. The powerful stream appears to be as it were incessantly engaged in improving its bed, and some idea of the force which it exerts may be formed from the circumstance, that notwithstanding its breadth it is sometimes so swollen as to rise more than 26 English feet in the course of twenty or thirty hours.

We remained for serenteen days in the hot valley of the Upper Marañon or Amazons. In order to pass from thence to the shores of the Pacific, the Andes have to be crossed at 
the point where, between Micuipampa and Caxamarca (in $6^{\circ} 57^{\prime}$ S. lat. and $78^{\circ} 34^{\prime} \mathrm{W}$. long. from Greenwich), they are intersected, according to my observations, by the magnetic equator. Ascending to a still higher elevation among the mountains, the celebrated silver mines of Chota are reached, and from thence with a few interruptions the route descends until the low grounds of Peru are gained; passing intermediately over the ancient Caxamarca, where 316 years ago the most sanguinary drama in the annals of the Spanish Conquista took place, and also over Aroma and Gangamarca. Here, as almost everywhere in the Chain of the Andes and in the Mexican Mountains, the most elevated parts are picturesquely marked by tower-like outbreaks of porphyry (often columnar), and trachyte. Masses of this kind give to the crest of the mountains sometimes a cliff-like and precipitous, and sometimes a dome-shaped character. They have here broken through calcareous rocks, which, both on this and on the northern side of the equator, are largely developed; and which, according to Leopold von Buch's researches, belong to the cretaceous group. Between Guambos and Montan, 12000 French (12790 English) feet above the sea, we found marine fossils ( ${ }^{11}$ ) (Ammonites nearly fifteen English inches in diameter, the large Pecten alatus, oyster shells, Echini, Isocardias, and Exogyra polygona). A species of Cidaris, which, according to Leopold von Buch, cannot be distinguished from that which Brongniart found in the lower part of the chalk series at the Perte du Rhone, was collected by us, both at Tomependa in the basin of the Amazons and at Micuipampa,-stations of which the ele- 
vations differ 9900 (10551 English) feet. In a similar manner, in the Amuich Chain of the Caucasian Daghestan, the cretaceous beds rise from the banks of the Sulak, which are hardly 5:30 English feet above the sea, to a height of fully 9000 (9592 English) feet on the Tschunum; while on the summit of the Schadagh Mountain, 13090 (13950 English) feet high, the Ostrea diluviana (Goldf.) and the same cretaceous beds are again found. Abich's excellent observations in the Caucasus would thus appear to have confirmed in the most brilliant manner Leopold von Buch's geological views on the mountain development of the cretaceous group.

From the lonely grazing farm of Montan surrounded by herds of lamas, we ascended more to the south the eastern declivity of the Cordilleras, and arrived as night was closing in at an elevated plain where the argentiferous mountain of Gualgayoc, the principal site of the celebrated silver mines of Chota, afforded us a remarkable spectacle. The Cerro de Gualgayoc, separated by a deep-cleft ravine or valley (Quebrada) from the limestone mountain of Cormolatsche, is an isolated mass of siliceous rock traversed by a multitude of veins of silver which often meet or intersect, and terminated to the north and west by a deep and almost perpendicular precipice. The highest workings are 1445 (1540 English) feet above the floor of the gallery, the Socabon de Espinachi. The outline of the mountain is broken by numerous towerlike and pyramidal points; the summit bears indeed the name of "Las Puntas," and offers the most decided contrast to the "rounded outlines" which the miners are accustomed to attribute to metalliferous districts generally. "Our moun- 
tain," said a rich possessor of mines with whom we had arrived, "stands there like an enchanted castle (como si fuese un castillo encantado)." The Gualgayoc reminds the beholder in some degree of a cone of dolomite, but still more of the serrated crest of the Monserrat Mountains in Catalonia, which I have also visited, and which were subsequently described in so pleasing a manner by my brother. The silver mountain. Gualgayoc, besides being perforated to its summit by many hundred galleries driven in every direction, presents also natural openings in the mass of the siliceous rock, through which the interisely dark blue sky of these elevated regions is visible to a spectator standing at the foot of the mountain. These openings are popularly called "windows," "las ventanillas de Gualgavoc." Similar "windows" were pointed out to us in the trachytic walls of the volcano of Pichincha, and called by a similar name,"ventanillas de Pichincha." The strangeness of the view presented to us was still farther increased by the numerous small sheds and dwelling-houses, which nestled on the side of the fortress-like mountain wherever a flat surface permitted their erection. The miners carry down the ore in baskets by very steep and dangerous paths to the places where the process of amalgamation is performed.

The value of the silver furnished by the mines in the first thirty years (from 1771 to 1802) amounted probably to considerably above thirty-two millions of piastres. Notwithstanding the hardness of the quartzose rock, the Peruvians, before the arrival of the Spaniards (as ancient galleries and excavations testify), extracted rich argentiferous galena on 
the Cerro de la Lin and on the Chupiquivacu, and gold in Curumayo (where native sulphur is also found in the quartz rock as well as in the Brazilian Itacolumite). We inhabited near the mines the small mountain town of Micuipampa, which is 11140 (11873 English) feet above the level of the sea, and where, though only $6^{\circ} 43^{\prime}$ from the equator, water freezes in the house nightly throughout a large portion of the year. In this desert devoid of vegetation live three or four thousand persons, who are obliged to have all their means of subsistence brought from the warm valleys, as they themselves only rear some kinds of kale and excellent salad. In this wilderness, as in every town in the high mountains of Peru, ennui leads the richer class of persons, who are not on that account more cultivated or more civilised, to pass their time in deep gambling: thus wealth quickly won is still more quickly dissipated. There is much that reminds one of the soldier of Pizarro's troop, who, after the pillage of the temple at Cuzco, complained that he had lost in one night at play "a great piece of the sun" (a gold plate). I observed the thermometer at Micuipampa at 8 in the morning $1^{\circ}$, and at noon $7^{\circ}$ Reaumur ( $34^{\circ} .2$ and $47^{\circ} .8$ Fahrenheit). We found among the thin blades of Ichhu-grass (perhaps our Stipa eriostachya), a beautiful Calceolaria (C. sibthorpioides), which we should not have expected at such an elevation.

Not far from the town of Micuipampa, in a high plain called Llanos or Pampa de Navar, there have been found throughout an area of above an English geographical square mile, immediately under the turf, and as it were intertwined 
with the roots of the alpine grasses, enormous masses of rich red silver ore and threads of pure silver (in remolinos, clavos, and vetas manteadas). Another elevated plain west of the Purgatorio, near the Quebrada de Chiquera, is called "Choropampa" or the "Field of Shells" (churu, in the Quichua language, signifies shells, and particularly small eatable kinds, hostion, mexillon). The name refers to fossils which belong to the cretaceous group, and which are found there in such abundance that they early attracted the attention of the natives. This is the place where there was obtained near the surface a mass of pure gold spun round with threads of silver in the richest manner. Such an occurrence shows how independent many of the ores thrown up from the interior of the earth into fissures or veins, are of the nature of the adjacent rock and of the relative age of the formations broken through. The rock of the Cerro de Gualgayoc and of Fuentestiana has a great deal of water, but in the Purgatorio absolute dryness prevails. I found to my astonishment that notwithstanding the height of the strata above the level of the sea, the temperature of the last named mine was $15^{\circ} .8$ Reaumur ( $67^{\circ} .4$ Fahr.); while in the neighbouring Mina de Guadalupe the water in the mine showed about $9^{\circ}$ Reaumur $\left(52^{\circ} .2\right.$ Fahr. $)$ As in the open air the thermometer only rises to about $4^{\circ}$ Reaumur ( $41^{\circ}$ Fahr.), the miners, whose toil is severe, and who are almost without clothing, call the subterranean heat in the Purgatorio stifling.

The narrow path from Micuipampa to the ancient city of the Incas, Caxamarca, is difficult even for mules. The name 
of the town was originally Cassamarca or Kazamarca, $i . e$. the Frost town; (marca, as signifying a place or locality, belongs to the northern Chinchaysuyo or Chinchaysuyu dialect, while the word in the general Quichua language signifies the stories of houses, and also defences or forts). Our way lay for nive or six hours over a succession of Paramos, where we were exposed almost incessantly to the fury of the wind and to the sharp-edged hail so peculiar to the ridges of the Andes. The height of the route above the level of the sea is generally between nine and ten thousand feet (about 9600 and 10660 Eng.) It afforded me, however", the opportunity of making a magnetic observation of general interest; $i . e$. the determination of the point where the North Inclination of the Needle passes into South Inclination, or where the traveller's route crosses the Magnetic Equator. (12)

On reaching at length the last of these mountain wildernesses, the Paramo de Yanaguanga, the traveller looks down with increased pleasure on the fertile valley of Caxamarca. It affords a charming prospect: a small river winds through the elevated plain, which is of an oval form and about six or seven German geographical square miles in extent (96 or 112 English geographical square miles). The plain resembles that of Bogota: both are probably the bottoms of ancient lakes; but at Caxamarca there is wanting the myth of the wonder-working Botschica or Idacanzas, the high priest of Iraca, who opened for the waters a passage through the rock of Tequendama. Caxamarca is situated 600 (640 Eng.) feet higher than Santa F'e de Bogota, 
therefore almost as high as the city of Quito; but being sheltered by surrounding mountains it enjoys a far milder and more agreeable climate. The soil is extremely fertile, and the plain full of cultivated fields and gardens traversed by avenues of Willows, large flowered red, white, and yellow varieties of Datura, Mimosas, and the beautiful Quinuar-trees (our Polylepsis villosa, a Rosacea allied to Alchemilla and Sanguisorba). Wheat yields on an average in the Pampa de Caxamarca fifteen to twentyfold, but the hopes of a plentiful harvest are sometimes disappointed by night frosts, occasioned by the great radiation of heat towards the unclouded sky through the dry and rarefied mountain air : the frosts are not felt in the roofed houses.

In the northern part of the plain, small porphyritic domes break through the widely extended sandstone strata, and probably once formed islands in the ancient lake before its waters had flowed off. On the summit of one of these domes, the Cerro de Santa Polonia, we enjoyed a pleasing prospect. The ancient residence of Atuhuallpa is surrounded on this side by fruit gardens and by irrigated fields of lucerne (Medicago sativa, "campos de alfalfa"). Columns of smoke are seen at a distance rising from the warm baths of Pultamarca, which are still called Baños del Inca. I found the temperature of these sulphur-springs $55^{\circ} .2$ Reaumur ( $156^{\circ} .2$ Fahrenheit). Atahuallpa spent a part of the year at these baths, where some slight remains of his palace still survive the devastating rage of the Conquistadores. The large and deep basin or reservoir in which, according to tradition, one of the golden chairs in which the Iuca was 
carried had been sunk and has ever since been sought in vain, appeared to me, from the regularity of its circular shape, to have been artificially excavated in the sandstone rock above one of the fissures through which the spring's issue.

Of the fort and palace of Atahuallpa there are also only very slight remains in the town, which is now adomed with some fine churches. The destruction of the ancient buildings has been accelerated by the devouring thirst of gold which led men, before the close of the sisteenth century, in digging for supposed hidden treasures, to overturn walls and carelessly to undermine or weaken the foundations of all the houses. The palace of the Inca was situated on a hill of porphyry which had originally been hollowed at the surface, so that it surrounds the principal dwelling almost like a wall or rampart. A state prison and a municipal building (la Casa del Cabildo) have been erected on a part of the ruins. The most considerable ruins still visible, but which are only from 13 to 16 feet high, are opposite the convent of San Francisco ; they consist, as may be observed in the house of the Cacique, of fine cut blocks of stone two or three feet long, and placed upon each other without cement, as in the Inca-Pilca or strong fortress of Cañar in the high land of Quito.

There is a shaft sunk in the porphyritic rock which once led into subterranean chambers, and a gallery said to extend to the other porphyritic dome before spoken of, that of Santa Polonia. Such arrangements shew an apprehension of the uncertainties of war, and the desire to secure the means of escape. The burying of treasures was an old and very gene- 
rally prevailing Peruvian custom. There may still be found subterranean chambers below many of the private dwellings of Caxamarca.

We were shown steps cut in the rock, and also what is called the Inca's foot-bath (el lavatorio de los pies). The washing of the monarch's feet was accompanied by some inconvenient usages of court etiquette. (13) Minor buildings, designed according to tradition for the servants, are constructed partly like the others of cut stones, and provided with sloped roofs, and partly with well formed bricks alternating with siliceous cement (muros y obra de tapia). In the latter class of constructions there are vaulted recesses, the antiquity of which I long doubted, but, as I now believe, without sufficient grounds.

In the principal building the room is still shown in which the unhappy Atahuallpa was kept a prisoner for nine months (14) from November 1532, and there is pointed out to the traveller the wall on which the captive signified to what height he would fill the room with gold if set free. This height is given very variously, by Xerez in his "Conquista del Peru" which Barcia has preserved for us, by Hernando Pizarro in his letters, and by other writers of the period. The prince said that "gold in bars, plates, and vessels, should be heaped up as high as he could reach with his hand." Xerez assigns to the room a length of 23, and a breadth of 18 English feet. Garcilaso de la Vega, who quitted Peru in his 20th year, in 1560 , estimates the value of the treasure collected from the temples of the sun at Cuzco, Huaylas, Huamachuco, and Pachacamac, up to the 
fateful 29th of August 1553, on which day the Inca was put to death, at 3,838,000 Ducados de Oro (15).

In the chapel of the state prison, to which I have before alluded as built upon the ruins of the Inca's palace, the stone still marked by the indelible stains of blood is shown to the credulous. It is a very thin slab, 13 feet long, placed in front of the altar, and has probably been taken from the porphyry or trachyte of the vicinity. One is not permitted to make any more precise examination by striking off a part of the stone, but the three or four supposed blood spots appear to be natural collections of hornblende or pyroxide in the rock. The Licentiate Fernando Montesinos, who visited Peru scarcely a hundred years after the taking of Caxamarca, even at that early period gave currency to the fahle that Atahuallpa was beheaded in prison, and that stains of blood were still visible on the stone on which the execution had taken place. There is no reason to doubt the fact, confirmed by many eye-witnesses, that the Inca, in order to aroid being burnt alive, consented to be baptised under the name of Juan de Atahuallpa by his fanatic persecutor, the Dominican monk Vicente de Valverde. He was put to death by strangulation (el garrote) publicly, and in the open air. Another tradition relates that a chapel was raised over the spot where Atahuallpa was strangled, and that his body rests beneath the stone; in such case, however, the supposed spots of blood would remain unaccounted for. In reality, however, the corpse was never placed beneath the stone in question. After a mass for the dead, and solemn funereal rites, at which the brothers Pizarro 
were present in mourning habits (!), it was conveyed first to the churchyard of the convent of San Francisco, and afterwards to Quito, Atahuallpa's birthplace. This last transfer was in compliance with the expressed wish of the dying Inca. His personal enemy, the astute Ruminavi ("stoneeye," a name given from the disfigurement of one eye by a wart; "rumi," signifying "stone," and " ñaui," " eye," in the Quichua language), from political motives caused the body to be buried at Quito with solemn obsequies.

We found descendants of the monarch, the family of the Indian Cacique Astorpilco, dwelling in Caxamarca, among the melancholy ruins of ancient departed splendour, and living in great poverty and privation; but patient and uncomplaining. Their descent from Atahuallpa through the female line has never been doubted in Caxamarca, but traces of beard may perhaps indicate some admixture of Spanish blood. Of the sons of the Great (but for a child of the sun somewhat free thinking), ( ${ }^{16}$ ) Huayna Capac, neither of the two who swayed the sceptre before the arrival of the Spaniards, Huascar and Atahuallpa, left behind them acknowledged sons. Huascar became the prisoner of Atahuallpa in the plains of Quipaypan, and was soon afterwards secretly murdered by his order. Neither were there any surviving male descendants of the two remaining brothers of Atahuallpa, the insignificant youth Toparca, who Pizarro caused to be crowned as Inca in the autumn of 1553, and the enterprising Manco Capac, similarly crowned, but who afterwards rebelled again. Atahuallpa left indeed a son, whose christian name was Don Francisco, (but who died very young), and a daughter, 
Doña Angelina, by whom Francisco Pizarro (with whom she led a wild and warlike life), had a son whom he lored fondly, grandchild of the slaughtered monarch. Besides the family of the Cacique Astorpilco, with whom I was acquainted at Caxamarca, the Carguraicos and Titu Buscamayta were pointed out at the period of my visit as belonging to the Inca dynasty; but the Buscamayta family has since become extinct.

The son of the Cacique Astorpilco, a pleasing and friendly youth of seventeen, who accompanied me over the ruins of the palace of his ancestor, while living in extreme poverty, had filled his imagination with images of buried splendour and golden treasures hidden beneath the masses of rubbish upon which we trod. He related to me that one of his more immediate forefathers had bound his wife's eyes, and then conducted her through many labyrinths cut in the rock into the subterranean garden of the Incas. There she saw, skilfully and elaborately imitated, and formed of the purest gold, artificial trees, with leaves and fruit, and birds sitting on the branches; and there too was the much sought for golden travelling chair (una de las andas) of Atahuallipa. The man commanded his wife not to touch any of these enchanted riches, because the long foretold period of the restoration of the empire had not yet arrived, and that whoever should attempt before that time to appropriate aught of them would die that very night. These golden dreams and fancies of the youth were founded on recollections and traditions of former days. These artificial "golden gardens" (Jardines o Huertas de oro) were often 
described by actual eye-witnesses, Cieza de Leon Sarmiento, Garcilaso, and other early historians of the Conquest. They were found beneath the temple of the sun at Cuzco, in Caxamarca, and in the pleasant valley of Yucay, a favourite residence of the monarch's family. 'Where the golden Huertas were not below ground, living plants grew by the side of the artificial ones : among the latter, tall plants and ears of maize (mazorcas) are mentioned as particularly well executed.

The morbid confidence with which the young Astorpilco assured me that below our feet, a little to the right of the spot on which I stood at the moment, there was an artificial large-flowered Datura tree (Guanto), formed of gold wire and gold plates, which spread its branches over the Inca's chair, impressed me deeply but painfully, for it seemed as if these illusive and baseless visions were cherished as consolations in present sufferings. I asked the lad- "Since you and your parents believe so firmly in the existence of this garden, are not you sometimes tempted in your necessities to dig in search of treasures so close at hand?" The boy's answer was so simple, and expressed so fully the quiet resignation characteristic of the aboriginal inhabitants of the country, that I noted it in Spanish in my journal. "Such a desire (tal antojo) does not come to us; father says it would be sinful (que fuese pecado). If we had the golden branches with all their golden fruits our white neighbours would hate and injure us. We have a small field and good wheat (buen trigo)." Few of my readers, I think, will blame me for recalling here the words of the young Astorpilco and his golden visions. 
The belief, so midely current among the natives, that to take possession of buried treasures which belonged to the Incas would be wrong, and would incur punishment and bring misfortune on the entire race, is connected with another belief which prevailed, especially in the 16 th and 17 th centuries, $i$. e. the future restoration of a kingdom of the Incas. Every suppressed nationality looks forward to a day of change, and to a renewal of the old government. The flight of Manco Inca, the brother of Atahuallpa, into the forests of Vilcapampa on the declivity of the eastern Cordillera, and the sojourn of Sayri Tupac and Inca Tupac Amaru in those wildernesses, have left permanent recollections. It was beliered that the dethroned dynasty had settled between the rivers Apurimac and Beni, or still farther to the east in Guiana. The myth of el Dorado and the golden city of Manoa, travelling from the west to the east, increased these dreams, and Raleigh's imagination was so inflamed by them, that he founded an expedition on the hope of "conquering" "the imperial and golden city, placing in it a garrison of three or four thousand English, and levying from the 'Emperor of Guiana,' a descendant of Huayna Capac, and who holds his court with the same magnificence, an anmual tribute of $£ 300,000$ sterling, as the price of his promised restoration to the throne in Cuzco and Caxamarca." Wherever the Peruvian Quichua language has extended, some traces of such expectations of the return of the Inca's sovereignty continue (17) to exist in the minds of many among those of the natives who are possessed of some knowledge of the history of their country. 
We remained for five days in the town of the Inca Atahuallpa, which at that time scarcely reckoned seven or eight thousand inhabitants. Our departure was delayed by the number of mules which were required for the conveyance of our collections, and by the necessity of making a careful choice of the guides who were to conduct us across the chain of the Andes to the entrance of the long but narrow Peruvian sandy desert (Desierto de Sechura). The passage over the Cordillera is from north-east to south-west. Immediately after quitting the plain of Caxamarca, on ascending a height of scarcely 9600 (10230 English) feet, the traveller is struck with the sight of two grotesquely shaped porphyritic summits, Aroma and Cunturcaga (a favourite haunt of the powerful vulture which we commonly call Condor; kacca in the Quichua language signifies "the rock.") These summits consisted of five, six, or sevensided columns, 37 to 42 English feet high, and some of them jointed. The Cerro Aroma is particularly picturesque. By the distribution of its often converging series of columns placed one above another, it resembles a two-storied build. ing, which, moreover, is surmounted by a dome or cupola of non-columnar rock. Such outbursts of porphyry and trachyte are, as I have before remarked, characteristic of the high crests of the Cordilleras, to which they impart a physiognomy quite distinct from that presented by the Swiss Alps, the Pyrenees, and the Siberian Altai.

From Cunturcaga and Aroma we descended by a zig-zag course a steep rocky declivity of 6400 English feet into the deep cleft valley of the Magdalena, the bottom of which 
is still 4260 English feet above the level of the sea. A few wretched huts, surrounded by the same wool or cottontrees (Bombax discolor) which we had first seen on the banks of the Amazons, were called an Indian village. The scanty regetation of the valley bears some resemblance to that of the province of Jaen de Bracamoros, but we missed the red groves of Bougainvillæa. This valley is one of the deepest with which I am acquainted in the chain of the Andes : it is a true transverse valley directed from east to west, deeply cleft, and hemmed in on the two sides by the Altos de Aroma and Guangamarca. In this valley recommences the same quartz formation which we had observed in the Paramo de Yanaguanga, between Micuipampa and Caxamarca, at an elevation of 11720 English feet, and which, on the western declivity of the Cordillera, attains a thickness of several thousand feet, and was long an enigma to me. Since von Buch has shown us that the cretaceous group is also widely extended in the highest chains of the Andes, on either side of the Isthmus of Panama, the quartz formation which we are now considering, which has perhaps been altered in its testure by the action of rolcanic forces, may be considered to belong to the Quadersandstein, intermediate between the upper part of the chalk series, and the Gault and Greensand. On quitting the mild temperature of the Magdalena valley we had to ascend again for three hours the mountain wall of 5120 English feet, opposite to the porphyritic group of the Alto de Aroma. The change of climate in so doing was the more sensible, as we were often enveloped in the course of the ascent in a cold fog. 
The longing desire which we felt to enjoy once more the open view of the sea after eighteen months' constant sojourn in the ever restricted range of the interior of the mountains, had been heightened by repeated disappointments. In looking from the summit of the volcano of Pichincha, over the dense forests of the Provincia de las Esmeraldas, no sea horizon can be clearly distinguished, by reason of the too great distance of the coast and height of the station : it is like looking down from an air-balloon into vacancy. One divines, but one does not distinguish. Subsequently, when between Loxa and Guancabamba we reached the Paramo de Guamini, where there are several ruined buildings of the times of the Incas, and from whence the mule-drivers had confidently assured us that we should see beyond the plain, beyond the low districts of Piura and Lambajeque, the sea itself which we so much desired to behold, a thick mist covered both the plain and the distant sea shore. We saw only variously shaped masses of rock alternately rise like islands above the waving sea of mist, and again disappear, as had been the case in our view from the Peak of Teneriffe. We were exposed to almost the same disappointment in our subsequent transit over the pass of Guangamarca, at the time of which I am now speaking. As we toiled up the mighty mountain side, with our expectations continually on the stretch, our guides, who were not perfectly acquainted with the road, repeatedly promised us that at the end of the hour's march which was nearly concluded, our hopes would be realised. The stratum of mist which enveloped us appeared occasionally to be about 
to disperse, but at such moments our field of view was again restricted by intervening heights.

The desire which we feel to behold certain objects does not depend solely on their grandeur, their beauty, or their importance; it is interwoven in each individual with many accidental impressions of his youth, with early predilection for particular occupations, with an attachment to the remote and distant, and with the love of an active and varied life. The previous improbability of the fulfilment of a wish gives besides to its realisation a peculiar kind of charm. The traveller enjoys by anticipation the first sight of the constellation of the cross, and of the Magellanic clouds circling round the Southern Pole,-of the snow of the Chimborazo, and the column of smoke ascending from the volcano of Quito,- of the first grove of tree-ferms, and of the Pacific Ocean. The days on which such wishes are realised form epochs in life, and produce ineffaceable impressions; exciting feelings of which the vividness seeks not justification by processes of reasoning. With the longing which I felt for the first view of the Pacific from the crests of the Andes, there mingled the interest with which I had listened as a boy to the narrative of the adventurous expedition of Vasco Nuñez de Balboa, (18) the fortunate man who (followed by Francisco Pizarro) first among Europeans beheld from the heights of Quarequa, on the Isthmus of Panama, the eastern part of the Pacific Ocean, - the "South Sea." The reedy shores of the Caspian, at the place where I first saw them, $i$. e. from the Delta formed by the mouths of the Volga, cannot certainly be called pictu. 
resque; yet I viewed them with a gratification heightened almost into delight by the particular interest and pleasure with which, in early childhood, I had looked at the shape of this Asiatic inland sea on maps. That which is thus excited in us (19) by childish impressions, or by accidental circumstances in life, takes at a later period a graver direction, and often becomes a motive for scientific labours and distant enterprises.

When after many undulations of the ground, on the summit of the steep mountain ridge, we finally reached the highest point, the Alto de Guangamarca, the heavens which had long been veiled became suddenly clear : a sharp west wind dispersed the mist, and the deep blue of the sky in the thin mountain air appeared between narrow lines of tise highest cirrous clouds. The whole of the western declivity of the Cordillera by Chorillos and Cascas, covered with large blocks of quartz 13 to 15 English feet long, and the plains of Chala and Molinos as far as the sea shore near Truxillo, lay beneath our eyes in astonishing apparent proximity. We now saw for the first time the Pacific Ocean itself; and we saw it clearly: forming along the line of the shore a large mass from which the light shone reflected, and rising in its immensity to the well-defined, no longer merely conjectured horizon. The joy it inspired, and which was vividly shared by my companions Bonpland and Carlos Montufar, made us forget to open the barometer until we had quitted the Alto de Guangamarca. From our measurement taken soon after, but somewhat lower down, at an isolated cattle-farm called the Hato de Guangamarca, 
the point from which we first saw the sea would be only somewhere between 9380 and 9600 English feet above the level of the sea.

The view of the Pacific was peculiarly impressive to one who like myself owed a part of the formation of his mind and character, and many of the directions which his wishes had assumed, to intercourse with one of the companions of Cook. My schemes of travel were early made known, in their leading outlines at least, to George Forster, when I enjoyed the advantage of making my first visit to England under his guidance, more than half a century ago. Forster's charming descriptions of Otaheite had awakened throughout Northern Europe a general interest (mixed, I might almost say, with romantic longings) for the Islands of the Pacific which had at that time been seen by very few Europeans. I too cherished at the time of which I am speaking the hope of soon landing on them; for the object of my visit to Lima was twofold,- - to observe the transit of Mercury orer the solar disk, and to fulfil an engagement made with Captain Baudin before I left Paris, to join him in a voyage of circumnarigation which was to take place as soon as the Government of the French Republic could furnish the requisite funds.

Whilst we were in the Antilles, North American newspapers announced that the two Corvettes, Le Géographe and Le Naturaliste, would sail round Cape Horn and touch at Callao de Lima. On receiving this intelligence at Havana, where.I then was, after having completed my Orinoco journey, I relinquished my original plan of going through Mexico to 
the Philippines, and hastened to engage a vessel to convey me from the Island of Cuba to Cartagena de Indias. Baudin's Expedition, however, took quite a different route from that which was announced and expected; instead of sailing round Cape Horn, as had been designed when it had been intended that Bonpland and myself should form part of it, it sailed round the Cape of Good Hope. One of the two objects of my Peruvian journey and of our last passage over the Chain of the Andes failed; but on the other hand I had, at the critical moment, the rare good fortune of a perfectly clear day, during a very unfavourable season of the year, on the misty coast of Low Peru. I observed the passage of Mercury over the Sun at Callao, an observation which has become of some importance towards the exact determination of the longitude of Lima $\left({ }^{20}\right)$, and of all the south-western part of the New Continent. Thus in the intricate relations and graver circumstances of life, there may often be found, associated with disappointment, a germ of compensation. 


\section{ANNOTATIONS AND ADDITIONS.}

(1) 1. 267.- On the ridge of the Chain of the Andes or Antis."

The Inca Garcilaso, who was mell acquainted with the language of his country and was fond of dwelling on etymologies, always calls the Chain of the Andes las Montañas de los Antis. He says positively, that the great Mountain chain east of Cuzco derived its name from the tribe of the Antis, and the Prorince of Anti which is to the east of the Capital of the Incas. The Quaternary division of the Peruvian Empire according to the four quarter's of the Hearens, reckoned from Cuzco, borrowed its terminology not from the very circumstantial words taken which signify East, West, North, and South in the Quichua language (intip lluscinanpata, intip yaucunanpata, intip chaututa chayananpata, intip charipunchau chayanampata); but from the names of the Prorinces and of the tribes or races, (Provincias llamadas Anti, Cunti, Chincha y Colla), which are east, west, north, and south of the Centre of the Empire (the city of Cuzco). The four parts of the Inca-theocracy are called accordingly Antisuyu, Cuntisuyu, Chinchasuyu, and Collasuyu. The word suyu signifies "strip," and also "part." Notwithstanding the great distance, Quito be- 
longed to Chinchasuyu; and in proportion as by their religious wars the Incas extended still more widely the prevalence of their faith, their language, and their absolute form of government, these Suyus also acquired larger and unequally increased dimensions. Thus the names of provinces came to be used to express the different quarters of the heavens; "Nombrar aquellos Partidos era lo mismo," says Garcilaso, "que decir al Oriente, ó al Poniente." The Snow Chain of the Antis was thus looked upon as an East chain. "La Provincia Anti da nombre á las Montañas de los Antis. Llamaron la parte ádel Oriente Antisuyu, por la qual tambien llaman Anti á toda aquella gran Cordillera de Sierra Nevada que pasa al Oriente del Peru, por dar á entender, que está al Oriente.” (Commentarios Reales, P. T. p. 47 and 122.) Later writers have tried to deduce the name of the Chain of the Andes from "anta," which signifies "copper" in the Quichua language. This metal was indeed of the greatest importance to a nation whose tools and cutting instruments were made not of iron but of copper mixed with tin; but the name of the "Copper Mountains" can hardly have been extended to so great a chain; and besides, as Professor Buschmann very justly remarks, the word anta retains its terminal $a$ when making part of a compound word: anta, cobre, y antamarca Provincia de Cobre. Moreover, the form and composition of words in the ancient Peruvian language are so simple that there can be no question of the passage of an $a$ into an $i$; and thus "anta" (copper) and "Anti or Ante" (meaning as dictionaries of the country explain "la tierra de los Andes, 
el Indio hombre de los Andes, la Sierra de los Andes;" i. e. the country of the Andes, an inhabitant of the Andes, or the chain of mountains themselves), are and must continue two wholly different and distinct words. There are no means of interpreting the proper name (Anti) by connecting it with any signification or idea; if such connection exist it is buried in the obscurity of the past. Other Composites of Anti besides the above-mentioned Antisuyu are "Anteruna" (the native inhabitant of the Andes), and Anteunccuy or Antionccoy, (sickness of the Andes, mal de los Andes pestifero).

${ }^{2}$ ) p. 268.- "The Countess of Chinchon."

She was the wife of the Viceroy Don Geronimo Fernandez de Cabrera, Bobadilla y Mendoza, Conde de Chinchon, who administered the government of Peru from 1629 to 1639. The cure of the Vice-Queen falls in the year. 1638. A tradition which has obtained currency in Spain, but which I have heard much combated at Loxa, names a Corregidor del Cabildo de Loxa, Juan Lopez de Cañizares, as the person by whom the Quina-bark was first brought to Lima and generally recommended as a remedy. I have heard it asserted in Loxa that the beneficial virtues of the tree were known long before in the mountains, though not generally. Immediately after my return to Europe I expressed the doubts I felt as to the discovery having been made by the natives of the country round Loxa, since even at the present day the Indians of the neighbouring valleys, where intermittent fevers are very prevalent, shun the use of VOL. II. 
bark. (Compare my memoir entitled "über die Chinawälder" in the "Magazin der Gesellschaft naturforschender Freunde" zu Berlin, Jahrg. I. 1807, S. 59.) The story of the natives having learnt the virtues of the Cinchona from the lions who "cure themselves of intermittent fevers by guawing the bark of the China (or Quina) trees,"-(Hist. de l'Acad. des Sciences, année 1738, Paris, 1740, p. 233),-appears to be entirely of European origin, and nothing but a monkish fable. Nothing is known in the New Continent of the "Lion's fever," for the large so-called American Lion (Felis concolor), and the small mountain Lion (Puma) whose footmarks I have seen on the snow, are never tamed and made the subjects of observation; nor are the different species of Felinæ in either continent accustomed to gnaw the bark of trees. The name of Countess's Powder (Pulvis Comitissæ), occasioned by the remedy having been distributed by the Countess of Chinchon, was afterwards changed to that of Cardinal's or Jesuit's powder, because Cardinal de Lugo, Procurator-General of the order of the Jesuits, spread the knowledge of this valuable remedy during a journey through France, and recommended it to Cardinal Mazarin the more urgently, as the brethren of the order were beginning to prosecute a lucrative trade in South American Quina-bark which they obtained through their missionaries. It is hardly necessary to remark, that in the long controversy which ensued respecting the good or bad effects of the fever bark, the protestant physicians sometimes permitted themselves to be influenced by religious intolerance and dislike of the Jesuits. 
(3) p. 271.- "Aposentos de Mulalos."

Respecting these aposentos (dwellings, inns, in the Quichua language tampu, whence the Spanish form tambo), compare Cieça, Chronica del Peru, cap. 41, (ed. de 15.54, p. 108) and my Vues des Cordillères, Pl. xxiv.

(4) p. 27\%.- "The fortress of the Cañar"

Is situated not far from Turche, at an elevation of 9984 (10640 English) feet. I hare given a drawing of it in the Vues des Cordillères, Pl. xvii. (compare also Cieça, cap. 44, P. i. p. 120). Not far from the Fortaleza del Cañar, in the celebrated ravine of the Sun, Inti-Guaycu, (in the Quichua or Qquechhua language, muaycco), is the rock on which the natives think they see a representation of the sun and of an enigmatical sort of bank or bench which is called IngaChungana (Incachuncana), the Inca's play. I have dramn both. See Vues des Cordillères, Pl. xriii. and xix.

(5) p. 272.- "Artificial roads covered with cemented. gravel."

Compare Velasco, Historia de Quito, 1844, T. i. p. 126128, and Prescott, Hist. of the Conquest of Peru, Vol. i. p. $15 \%$

$\left.{ }^{6}\right)$ p. 273.- "Where the road was intermpted by flights. of steps."

Compare Pedro Sancho in Ramusio, Vol. iii. fol. 404, and Extracts from Manuscript Letters of Hernando Pizarro, 
employed by the great historical writer now living at Boston; Prescott, Vol. i. p. 444. "El camino de las sierras es cosa de ver, porque en verdad en tierra tan fragosa en la cristiandad no se han visto tan hermosos caminos, toda la mayor parte de calzada."

(7) p. 275.- "Greeks and Romans shew these contrasts."

"If," says Strabo, (Lib.v. p. 235, Casaub) "the Greeks in building their cities sought for a happy result by aiming especially at beauty and solidity, the Romans on the other hand have regarded particularly, objects which the Greeks left unthought of ;--stone pavements in the streets; aqueducts bringing to the city abundant supplies of water; and provisions for drainage so as to wash away and carry to the Tiber all uncleanliness. They also paved the roads through the country, so that waggons may transport with ease the goods brought by trading ships."

\section{(8) p. 276.—"The messenger of the deity Nemterequeteba."}

The civilisation of ancient Mexico (the Aztec land of Anahuac), and that of the Peruvian theocracy or empire of the Incas, the children of the Sun, have so engrossed attention in Europe, that a third point of comparative light and of dawning civilisation, which existed among the nations inhabiting the mountains of New Granada, was long almost entirely overlooked. I have touched on this subject in some detail in the Vue des Cordillères et Monumens des Peuples Indigènes de l'Amérique (ed. in 8vo.) T. ï. p. 220- 
267. The form of the government of the Muyscas of New Granada reminds us of the constitution of Japan and the relation of the Secular Ruler (Kubo or Seogun at Jeddo) to the sacred personage the Dairi at Miyako. When Gonzalo Ximenez de Quesada advanced to the high table land of Bogota (Bacata, i. e. the extremity of the cultivated fields, probably from the proximity of the mountain wall), he found there three powers or authorities respecting whose reciprocal relations and subordination there remains some uncertainty. The spiritual chief, who was appointed by election, was the high priest of Iraca or Sogamoso (Sugamuxi, the place of the disappearance of Nemterequeteba): the secular rulers or princes were the Zake (Zaque of Hunsa or Tunja), and the Zipa of Funza. In the feudal constitution the last. named prince appears to have been originally subordinate to the Zake.

The Muyscas had a regular mode of computing time, with intercalation for amending the lunar year: they used small circular plates of gold, cast of equal diameter, as money (any traces of which among the highly civilised ancient Egyptians have been sought in vain), and they had temples of the Sun with stone columns, remains of which have very recently been discovered in the Valley of Leiva. (Joaquin Acosta, Compendio historico del Descubrimiento de la Nueva Granada, 1848, p. 188, 196, 206, and 208; Bulletin de la Société de Géographie de Paris, 184\%, p. 114.) The tribe or race of the Muyscas ought properly speaking to be always denoted by the name of Chibchas; as Muysca in the Chibcha language signifies merely "men," "people." 
The origin and elements of the civilisation introduced are attributed to two mystical forms, Bochica (Botschica) and Nemterequeteba which are often confounded together. The first of these is still more mythical than the second; for it was only Botschica who was regarded as divine, and mad? almost equal to the Sun itself. His fair companion Chia or Huythaca occasioned by her magical arts the overflowing of the valley of Bogota, and for so doing was banished by Botschica from the earth, and made to revolve round it for the first time, as the moon. Botschica struck the rock of Tequendama, and gave a passage for the waters to flow off near the field of the Giants (Campo de Gigantes) in which the bones of elephant-like mastodons lie buried at an elevation of 8250 ( 8792 Engl.) feet above the level of the sea. Captain Cochrane (Journal of a Residence in Colombia, 1825, Vol. ii. p. 390) and Mr. John Ranking (Historical Researches on the Conquest of Peru, 1827, p. 397), state that animals of this species are still living in the Andes, and shed their teeth! Nemterequeteba, also called Chinzapogua (enviado de Dios) is a human person, a bearded man, who came from the East, from Pasca, and disappeared at Sogamoso. The foundation of the sanctuary of Iraca is sometimes ascribed to him and sometimes to Botschica, and as the latter is said to have borne also the name of Nemqueteba, the confusion between the two, on ground so unhistoric, is easily accounted for.

My old friend Colonel Acosta, in his instructive work entitled Compendio de la Hist. de la Nueva Granada, p. 185, endeavours to prove by means of the Chibcha language that 
"potatoes (Solanum tuberosum) bear at Usmè the native non-Peruvian name of Yomi, and were found by Quesada already cultivated in the province of Velez as early as 1537 , a period when their introduction from Chili, Peru, and Quito, would seem improbable, and therefore that the plant may be regarded as a native of New Granada." I would remark, however, that the Peruvian invasion and complete possession of Quito took place before 1525, the year of the death of the Inca Huayna Capac. The southern provinces of Quito even fell under the dominion of Tupac Inca Yupanqui at the conclusion of the 15th century (Prescott, Conquest of Peru, Vol. i. p. 332.) In the unfortunately still very obscure history of the first introduction of the potato into Europe, the merit of its introduction is still very generally attributed to Sir John Hawkins, who is supposed to have received it from Santa Fé in 1563 or 1565. It appears more certain that. Sir Walter Raleigh planted the first potatoes on his Irish estate near Youghal, from whence they were taken to Lancashire. Before the conquista, the plantain (Musa), which since the arrival of the Spaniards has been cultivated in all the warmer parts of New Granada, was only found, as Colonel Acosta believes, (p. 205) at Choco. On the name Cundinamarca,-applied by a false erudition to the young republic of New Granada in 1811, a name "full of golden dreams" (sueños dorados), more properly Cundirumarca (not Cunturmarca, Garcilaso, lib. viii. cap. 2), --see also Joaquin Acosta, p. 189. Luis Daza, who joined the small invading army of the Conquistador Sebastian de Belalcazar which came from the south, had heard of a distant country abounding in gold, called 
Cundirumarca, inhabited by the tribe of the Chicas, and whose prince had solicited Atahuallpa at Caxamarca for auxiliary troops. These Chicas have been confounded with the Chibchas or Muyscas of New Granada; and thus the name of the unknown more southern country has been unduly transferred to that territory.

\section{(9) p. 278.-"The fall of the Rio de Chamaya."}

Compare my Recueil d'Observ. Astron., vol. i. p. 304; Nivellement barométrique, No. 236-242. I have given in the Vues des Cordillères, Pl. xxxi. a drawing of the "swimming post," as he binds round his head the handkerchief containing the letters.

(10) p. 280.- "Which, on account of an old observation of La Condamine, was of some importance to the geography of South America."

I desired to connect chronometrically Tomependa, the point at which La Condamine began his voyage, and other places geographically determined by him on the Amazons river, with the town of Quito. La Condamine had been in June 174.3, (59 years before me) at Tomependa, which place I found, by star observations taken for three nights, to be in south lat. $5^{\circ} 31^{\prime} 28^{\prime \prime}$, and west longitude from Paris $80^{\circ} 56^{\prime} 37^{\prime \prime}$ (from Greenwich $78^{\circ} 34^{\prime} 55^{\prime \prime}$ ). Previous to my return to France the longitude of Quito was in error to the full amount of $50 \frac{\mathrm{I}}{2}$ minutes of arc, as Oltmanns has shown by my observations, and by a laborious recalculation of all those previously made. (Humboldt, Recueil d'Observations Astron., vol. ii. p. 309-359): Jupiter's satellites, 
lunar distances, and occultations, give a satisfactory accordance, and all the elements of the calculation are placed before the public. The too easterly longitude of Quito was transferred by La Condamine to Cuenca and the Amazons river. "Je fis," says La Condamine, "mon premier essai de navigation sur un radeau (balsa) en descendant la rivière de Chinchipe jusqu'à Tomependa. Il fallut me contenter d'en déterminer la latitude et de conclure la longitude par les routes. J'y fis mon testament politique en rédigeant l'extrait de mes observations le plus importantes." (Journal du Voyage fait à l'Equateur, 175l, p. 186.)

(11) p. 282.- "At upwards of twelve thousand feet above the sea we found fossil marine shells."

See my Essai géognostique sur le Gisement des Roches, 1823, p. 236 ; and for the first zoological determination of the fossils contained in the cretaceous group in the chain of the Andes, see Léop. de Buch, Pétrifications recueillies en Amérique, par Alex. de Humboldt et Charles Degenhardt, 1839 (in fol.), pp. 2-8, 5, 7, 9, 11, and 18-22. Pentland found fossil shells of the Silurian formation in Bolivia, on the Nevado de Antakäua, at the height of 164000 French (17480 English) feet, (Mary Somerville, Physical Geography, 1849, Vol. i. p. 185).

(12) p. 28\%.- Where the chain of the Andes is intersected by the magnetic equator."

Compare my Rélation hist. du Voyage aux Régions équinoxiales, T. iii. p. 622 ; and Kosmos, Bd. i. S. 191 
and 432 ; where, however, by errors of the press, the longitude is once $48^{\circ} 40^{\prime}$, and afterwards $80^{\circ} 40^{\prime}$, instead of, as it should be, $80^{\circ} 54^{\prime}$ from Paris (or $78^{\circ} 32^{\prime}$ from Greenwich), (English edit. p. 173, and note 159).

(13) p. 290.- "Accompanied by inconvenient ceremonies of Court etiquette."

In conformity with a highly ancient Court ceremonial, A tahuallpa spat not on the ground, but into the hand of one of the principal ladies present; " all," says Garcilaso, "on account of his majesty." El Inca nunca escupia en el suelo, sino en la mano de una Señora mui principal, por Majestad, (Garcilaso, Comment. Reales, P. ii. p. 46).

\section{$\left.{ }^{14}\right)$ p. 290._"Captivity of Atahuallpa."}

A short time before the captive Inca was put to death, he was taken into the open air, in compliance with his request, to see a large comet. The "greenish black comet, nearly as thick as a man," (Garcilaso says, P. ii. p. 44, una cometa verdinegra, poco menos gruesa que el cuerpo de un hombre), seen by Atahuallpa before his death, therefore in July or August 1533, and which he supposed to be the same malignant comet which had appeared at the death of his father, Huayna Capac, is certainly the one observed by Appian (Pingré, Cométographie, T. i. p. 496; and Galle's "Notice of all the Paths of Comets hitherto computed," in "Olber's Leichtester Methode die Bahn eines Cometen zu berechnen," 1847, S. 206), and which, on the 21st of July, standing high in the north, near the constellation of Perseus, 
represented the sword which Perseus holds in his right hand. (Mädler, Astronomie, 1846, S. 307 ; Schnurrer, Die Chronik der Seuchen in Verbindung mit gleichzeitigen Erscheinungen, 1825, Th. ii. S. 82.) Robertson considers the year of Huayna Capac's death uncertain; but, from the researches of Balboa and Velasco, that event appears to have. occurred towards the close of 1525 : thus the statements of Hevelius (Cometographia, p. 844), and of Pingré (T. i. p.485), derive confirmation from the testimony of Garcilaso (P. i. p. 321) and the tradition preserved among the "amautas, que son los filosofos de aquella Republica." I may here introduce the remark, that Oviedo alone, and certainly erroneously, asserts, in the inedited continuation of his Historia de las Indias, that the proper name of the Inca was, not Atahuallpa, but Atabaliva (Prescott, Conquest of Peru, Vol. i. p. 498.)

\section{(15) p. 291._"Ducados de Oro."}

The sum mentioned in the text is that which is stated by Garcilaso de la Vega in the Commentarios reales de los Incas, Parte ii. 1722, pp. 27 and 51. The statements of Padre Blas Valera and of Gomara, Historia de las Indias, 1553, p. 6\%, differ, however, considerably. Compare my Essai politique sur la Nouvelle Espagne (éd. 2), T. iii. p. 424). It is, moreover, no less difficult to determine the value of the Ducado, Castellano, or Peso de Oro. (Essai pol. T. iii. pp. 371 and 377 ; Joaquin Acosta, Descubrimiento de la Nueva Granada, 1848, p. 14.) The modern excellent historical writer, Prescott, has been able to avail 
himself of a manuscript bearing the very promising title, "Acta de Reparticion del Rescate de Atahuallpa." The estimate of the whole Peruvian booty which the brothers Pizarro and Almagro divided amongst themselves at the (I believe) too large value of three and a half millions of pounds sterling, includes doublless the gold of the ransom and that taken from the different temples of the Sun and from the enchanted gardens, (Huertas de Oro). (Prescott, Conquest of Peru, Vol. i. pp. 464-47\%.)

(16) p. 292.- "The great, but, for a Son of the Sun, somewhat free-thinking Huayna Capac."

The nightly absence of the Sun excited in the Inca many philosophical doubts as to the government of the world by that luminary. Padre Blas Valera noted down the remarks of the Inca on the subject of the Sun : "Many maintain that the Sun lives, and is the Maker and Doer of all things (el hacedor de todas las cosas); but whoever would complete any thing must remain by what he is doing. Now many things take place when the Sun is absent; therefore he is not the original cause of all things. It seems also doubtful whether he is living; for though always circling round, he is never weary (no se cansa). If he was living, he would become weary, as we do; and if he was free, he would surely move sometimes into parts of the heavens where we never see him. The Sun is like an animal fastened by a cord so as always to move in the same round, (como una Res atada que siempre hace un mismo cerco); or as an arrow which only goes where it is sent, 
and not where it chooses itself." (Garcilaso, Comment. Reales, P. i. lib. viii. cap. 8, p. 2\%6.) The view taken of the circling round of a hearenly bodr, as if it was fastened to a cord, is rery striking. As Huayna Capac died at Quito in 1525, seven years before the arrival of the Spaniards, he no doubt used, instead of "res atada," the general expression of an "animal" fastened to a cord; but indeed, even in Spanish, "res" is by no.means limited to oxen, but may be applied to any tame cattle. Te cannot examine here how far the Padre may have mingled parts of his own sermons with the heresies of the Inca, with the view of meaning the natives from the official and dynastic worship of the Sun, the religion of the Court. We see in the very conservative State policy, and in the maxims of State and proceedings of the Inca Roca, the conqueror of the province of Charcas, the solicitude which was felt to guard strictly the lower classes of the people from such doubts. This Inca founded schools for the upper classes only, and forbade, under heavy penalties, to teach the common people any thing, "lest they should become presumptuous, and should create disturbances in the State!" (No es lecito que enseñen á los hijos de los Plebeios las Ciencias, porque la gente baja no se eleve y ensoberrezca y manoscabe la Republica; Garcilaso, P. i. p. 276.) Thus the policy of the Inca's theocracy was almost the same as that of the Slave States in the United Free States of North America.

(17) p. 295.- "The restoration of an empire of the Incas." I have treated this subject more fully in another place 
(Relation hist. T. iii. p. 703.705 and 713). Raleigh thought there was in Peru an old prophecy "that from Inglaterra those Ingas should be againe in time to come restored and deliuered from the seruitude of the said conquerors. I am resolued that if there were but a smal army afoote in Guiana marching towards Manoa, the chiefe citie of Inga, he would yield Her Majestie by composition so many hundred thousand pounds yearely, as should both defend all enemies abroad and defray all expences at home, and that he woulde besides pay a garrison of 3000 or 4000 soldiers very royally to defend him against other nations. The Inca wil be brought to tribute with greai gladnes." (Raleigh, "The Discovery of the large, rich, and beautiful Empire of Guiana, performed in 1595," according to the edition published by Sir Robert Schomburgk, 1848, p. 119 and 137.) This scheme of a Restoration promised much that might be very agreeable to both sides, but unfortunately the dynasty who were to be restored, and who were to pay the money, were wanting!

\section{(18) p. 299.- "Of the expedition of Vasco Nuñez de} Balboa."

I have already remarked elsewhere (Examen critique de l'histoire de la Géographie du Nouveau Continent, et des progrès de l'Astronomie nautique aux 15ème et 16ème siècles, T. i. p. 349) that Columbus knew fully ten years before Balboa's expedition the existence of the South Sea and its great proximity to the east coast of Veragua. He was conducted to this knowledge not by theoretical specula- 
tions respecting the configuration of Eastern Asia, but by the local and positive reports of the natives, which he collected on his fourth voyage (May 11, 1502, to November 7, 1504). On this fourth voyage the Admiral went from the coast of Honduras to the Puerto de Mosquitos, the western end of the Tsthmus of Panama. The reports of the natives, and the comments of Columbus on those reports in the "Carta rarissima" of the 7th of July, 1503, were to the effect that "not far from the Rio de Belen the other sea (the South Sea) turns (boxa) to the mouths of the Ganges, so that the countries of the Aurea ( $i . e$. the countries of the Chersonesus aurea of Ptolemy) are situated in relation to the eastern coasts of Veragua, as Tortosa (at the mouth of the Ebro) is to Fuentarrabia (on the Bidassoa) in Biscay, or as Venice in relation to P1sa." Although Balboa first saw the South Sea from the heights of the Sierra de Quarequa on the 25th of September (Petr. Martyr, Epist. dxl. p. 296), yet it was not until several days later that Alonso Martin de Don Benito, who found a way from the mountains of Quarequa to the Gulf of San Miguel, embarked on the South Sea in a canoe. (Joaquin Acosta, Compendio hist. deI Descubrimiento de la Nueva Granada, p. 49.)

As the taking possession of a considerable part of the west coast of the New Continent by the United States of North America, and the report of the abundance of gold in New California (now called Upper California) have rendered more urgent than ever the formation of a communication between the Atlantic States and the regions of the West through the Isthmus of Panama, I feel it my duty to call 
attention once again to the circumstance that the shortest way to the shores of the Pacific, which was shown by the natives to Alonso Martin de Don Benito, is in the eastern part of the Isthmus, and led to the Golfo de San Miguel. We know that Columbus (Vida del Almirante por Don Fernando Colon, cap. 90) sought for an "estrecho de Tierra firmë"; and in the official documents which we possess of the years 1505 and 1507, and especially 1514, mention is made of the desired "opening" (abertura), and of the pass (passo), which should lead directly to the "Indian Land of Spices." Having for more than forty years been occupied with the subject of the means of communication between the two seas, I have constantly, both in my printed works and in the different memoirs which with honourable confidence the Free States of Spanish America have requested me to furnish, urged that the Isthmus should be examined hypsometrically throughout its entire length, and more especially where, in Darien and the inhospitable former Provincia de Biruquete, it joins the continent of South America; and where, between the Atrato and the Bay of Cupica (on the shore of the Pacific), the mountain chain of the Isthmus almost entirely disappears. (See in my Atlas géographique et physique de la Nouvelle Espagne, Pl.iv.; in the Atlas de la Relation historique, Pl. xxii. and xxiii.; Voyage aux Régions équinoxiales du Nouveau Continent, T. iii. p. 117 154; and Essai politique sur le Royaume de la Nouvelle Espagne, T. i. 2de édit. 1825, p. 202-248.)

General Bolivar at my request caused an exact levelling of the Isthmus between Panama and the mouth of the Rio 
Chagres to be made in 1828 and 1829 by Lloyd and Falmarc. (Philosophical Transactions of the Royal Society of London for the year 1830, p. 59-68.) Other measurements have since been executed by accomplished and experienced French engineers, and projects have been formed for canals and railways with locks and tunnels, but always in the direction of a meridian between Portobello and Panama, - or more to the west, towards Chagres and Cruces. Thus the most important points of the eastern and south-eastern part of the Isthmus have remained unexamined on both shores! So long as this part is not examined geographically by means of exact but easily obtained determinations of latitude and of longitude by chronometers, as well as hypsometrically in the conformation of the surface by barometric measurements of elevation,-so long I consider that the statement I have repeatedly made, and which I now repeat in 1849, will still be true; viz. "that it is as yet unproved and quite premature to pronounce that the Isthmus does not admit of the formation of an Oceanic Canal $(i . e$. a canal with fewer locks than the Caledonian Canal) permitting at all seasons the passage of the same sea-going ships between New York and Liverpool on the one hand, and Chili and California on the other."

On the Atlantic side (according to examinations which the Direccion of the Deposito hidrografico of Madrid have entered on their maps since 1809j the Ensenada de Mandinga penetrates so deeply towards the south that it appears to be only four or five German geographical miles, fifteen to an equatorial degree, (i.e.16 or 20 English geographical 
miles), from the coast of the Pacific on the east of Panama. On the Pacific side the isthmus is almost equally indented by the deep Golfo de San Miguel, into which the Rio Tuyra falls, with its tributary river the Chuchunque (Chuchunaque). This last-named stream in the upper part of its course approaches within 16 English geographical miles of the Atlantic side of the isthmus to the west of Cape Tiburon. For more than twenty years I have had inquiries made from me on the subject of the problem of the Isthmus of Panama, by associations desirous of employing considerable pecuniary means : but the simple advice which $I$ have given has never been followed. Every scientifically educated engineer knows that between the tropics, (even without corresponding observations), good barometric measurements (the horary variations being taken into account) afford results which are well assured to less than from 70 to 90 French or 75 to 96 English feet. It would besides be easy to establish for a few months on the two shores two fixed corresponding barometric stations, and to compare repeatedly the portable instruments employed in preliminary levelling; with each other and with those at the fixed stations. Let that part be particularly examined where, near the continent of South America, the separating mountain ridge sinks into hills. Seeing the importance of the subject to the great commerce of the world, the research ought not, as hitherto, to be restricted to a limited field. A great and comprehensive work, which shall include the whole eastern part of the Isthmus,-and which will be equally useful for every possible kind of operation or construction,-for canal, or for 
railway, - can alone decide the much discussed problem either affirmatively or negatively. That will be done at last, which should, and, had my advice been taken, would have been done in the first instance.

(19) p. 300-" That which is awakened in us by childish impressions or by the circumstances of life."

On the incitements to the study of nature, compare Kosmos, Bd. ii. S. 5, (English edit. vol. ii. p. 5).

${ }^{20}$ p. 302. "Of importance for the exact determination of the longitude of Lima."

At the period of my Expedition, the Longitude of Lima was given in the maps published in the Deposito hidro. grafico de Madrid, from the observations of Malaspina, which made it $5 \mathrm{~h} .16 \mathrm{~m} .53 \mathrm{~s}$. from Paris. The transit of Mercury over the Sun's disk on the 9th of Norember, 1802, which I observed at Callao, the Port of Lima, (in the northern Torreon del Fuerte de San Felipe) gave for Callao by the mean of the contact of both limbs $5 \mathrm{~h} .18 \mathrm{~m} .16 \mathrm{~s} .5$, and by the exterior contact only $5 \mathrm{~h} .18 \mathrm{~m} .18 \mathrm{~s} .\left(79^{\circ} 34\right.$ $30^{\prime \prime}$ ). This result (obtained from the Transit of Mercury) is confirmed by those of Lartigue, Duperrey, and Captain FitzRoy in the Expedition of the Adventure and Beagle. Lartigue found Callao 5h. $17 \mathrm{~m}$. 58s., Duperrey $5 \mathrm{~h} .18 \mathrm{~m}$. 16s., and FitzRoy 5h. 18m. 15s. (all West of Paris). As I determined the difference of longitude between Callao and the Convent de San Juan de Dios at Lima by carrying chronometers between them four times, the observation of 
the transit of Mercury gives the longitude of Lima $5 \mathrm{~h} .17 \mathrm{~m}$. 51s. ( $79^{\circ} 27^{\prime} 45^{\prime \prime} \mathrm{W}$. from Paris, or $77^{\circ} 06^{\prime} 03^{\prime \prime} \mathrm{W}$. from Greenwich). Compare my Recueil d'observations astron. Vol. ii. p. 397, 419 and 428, with my Relat. hist. T. ii. p. 592.

Potsdam, June 1849 


\section{GENERAL SUMMARY}

OF THE

CONTENTS OF THE SECOND VOLUME. 



\section{GENERAI SUMMARY}

OF THE

\section{CONTENTS OF VOL. II.}

\section{Physiognomy of Plants-p. 1 to p. 31.}

Unirersal profuse distribution of organic life on the declivities of the highest mountains, on the ocean, and in the atmosphere. Subterranean Flora. Siliceous-shelled Polygastrica in masses of polar ice. Podurellæ in tubular holes in the glaciers of the Alps; the glacier flea (Desoria glacialis). Small organic creatures in the dust which falls like rain in the neighbourhood of the African Desert.

History of the regetable covering of the surface of the globe. Gradual extension of regetation orer the bare rocky crust. Lichens, mosses, and succulent plants. Causes of the present absence of regetation in particular districts . . . . . $8-13$

Each zone has its peculiar character. All animal and vegetable forms attached to fixed and always recurring types. Physiognomy of Nature. Analysis of the general impression produced by the aspect of a country or district. The sereral elements which make up this impression; outlines of the mountains, azure of the sky, and form of the clouds : but principally determined by the regetable covering. Animal organisation far less influential on the landscape from defisiency of mass. The power of locomotion of individuals, and 
frequently their small size, also contribute to lessen their general effect on the landscape .

. $13-16$

Enumeration of the forms of plants which principally determine the physiognomy of Nature, and which decrease or increase from the equator to the poles according to laws which have been made the subject of investigation.

Palms

Plantains or Bananas

$20,21,126-140$ Malvaceæ

Mimosæ .

Ericeæ, or Heath form

Cactus form

Orchideæ.

Casuarineæ

Needle trees

Pothos and Aroideæ.

Lianes, or twining rope plants .

Aloë form

Gramineæ

Ferns

Liliaceæ .

Willow form

Myrtaceæ

Melastomaceæ .

Laurel form

$21,22,140,141$

- 22, $141-143$

$22,23,143-145$

23, 24, 145-147

- 24, 147-151

24, 25, 151, 152

- 25, 152, 153

- $25,153-175$

- $26,175-178$

- 26, 178-180

- $27,180-183$

$27,28,183-187$

- 28, 188-193

- 28,193

- 28, 193-196

- $28,196-200$

- 28,200

- 28,200

Enjoyment derived from the sight of the natural grouping and con- 
trasts of these forms of plants. Importance of the physiognomic study of plants to the landscape painter . . 29-31, 200-203

Scientific Elucidations and Additions-p. 33 to p. 210.

Organic forms, animal and regetable, in the highest mountain regions adjacent to the limit of perpetual snow in the Andes and the Alps; insects carried up involuntarily by ascending currents of air. The Hypudæus nivalis of the Swiss Alps. On the true eleration abore the sea reached by the Chinchilla laniger in Chili . . 33-35

Lecidias and Parmelias on rocks not entirely corered with snow; some phænogamous plants also wander in the Cordilleras beyond the limits of perpetual snow, as the Saxifraga boussingaulti, to 15770 English feet above the lerel of the sea. Groups of phæno. gamous plants extend in the Andes to 13700 and 14920 English feet above the sea; species of Culcitium, Espeletia, and Ranunculus; small umbelliferous plants resembling mosses in appearance; Mrrrhis andicola and Fragosa arctioides.

- 35,36

Measurement of the height of Chimborazo, and etrmology of the name .

On the greatest absolute heights which have yet been reached by any human beings in either continent; in the Cordilleras and the Himalaya, on the Chimborazo and the Tarhigang . . . 40

Habits and haunts of the Condor (Cuntur in the Inca language), and singular mode of capturing these powerful birds in an enclosure fenced by palisades

Useful serrices rendered by the Gallinazos (Cathartes urubu and C. aura) in purifying the air in the neighbourhood of human habitations; these birds sometimes tamed . . . . 44, 45 
On what has been called the revivification of Rotiferæ; views of Ehrenberg and Doyère. According to Payen, germs of Cryptogamia preserve their power of germination even after being exposed to the highest temperatures. . . . . 45-47

Diminution, if not entire suspension, of organic functions in the winter sleep of animals belonging to the higher classes . $\quad 47,48$

Summer sleep of animals in the tropical zone; great dryness acts like winter cold. Tenrecs, crocodiles, tortoises, and the Lepidosiren of Eastern Africa.

Anther dust or pollen; fertilization of flowers. The Colebogyne found to produce perfect seeds in England without any traces of pollen being discovered.

The luminosity of the ocean produced by living luminous animals and by decaying fibres and membranes of animals. Acalephæ and siliceous-shelled luminous Infusoria. Influence on the luminosity of a stimulus applied to the nerves $53-60$

Pentastomes inhabiting the pulmonary cells of the rattle-snake of Cumana 60,61

Rock-building eorals. The scaffolding or solid material which survives the death of the coral animals. More correct views of recent times. Shore reefs, encircling reefs, and lagoon islands. Atolls, or coral walls enclosing a lagoon. The coral islands to the south of Cuba, the Jardines del Rey of Columbus. The living gelatinous investment of the calcareous seaffolding of the coral trunks attracts fish and turtles in search of food. Singular mode of fishing by the aid of the Remora (the Eeheneis naucrates) . . . . 62-72 
Besides much carbonate of lime and magnesia, Madrepores and Astræas also contain some fluoric and phosphoric acids . 75, 76

Oscillatory state of the bottom of the sea according to Darwin 76-79

Traditions of Samothrace. Irruptions of the sea. Mediterranean. Sluice theory of Strato. Myth of Lyktonia, and the "Atlantis broken into fragments" . . . . . 78-83

On the causes which prevent the sinking down of clouds and precipitation taking place from them . . . . . 83-84

Heat disengaged from the crust of the earth while solidifying. Hot currents of air which in the early ages of the earth, from frequent corrugations of the strata and elevations of land, may have been diffused in the atmosphere from temporary fissures . . 84,85

Colossal size and great age of some kinds of trees; Dragon tree of Orotava thirteen, and Adansonia digitata (Baobab) thirty-two English feet in diameter. Characters cut in the bark of the trees in the 15th century. Adanson assigns to some of the Baobab trunks in Senegambia an age of between 5100 and 6000 years . 86-92

Judging by the annular rings, there are yew-trees (Taxus baccata) from 2600 to 3000 years old. Is it true that in the northern temperate zone the part of the tree tumed towards the north has narrower annular rings, as Michel Montaigne affirmed in 1581 ? Species of trees in which individuals attain a size of above twenty. one or twenty-two English feet diameter, and an age of several centuries, belong to the most different natural families . 92-94

Diameter of the Mexican Schubertia disticha of Santa Maria del Tule $40 \frac{1}{2}$ English feet; the sacred Banyan fig-tree of Ceylon almost 30; and the oak at Saintes (Dep. de la Charente Inférieure) 291 English feet. The age of the oak tree estimated from its annular rings at 
from 1800 to 2000 years. The root of the rose tree growing against the crypt of the Cathedral of Hildesheim is 800 years old. A kind of sea-weed, Macrocystis pyrifera, attains a length of 630 English feet, exceeding therefore the height of the loftiest Coniferæ, even that of the Sequoia gigantea . . 94-97

Examination of the probable number of phænogamous plants hitherto described or preserved in herbariums. Relative numbers. Laws discovered in the geographical distribution of plants. Relative numbers of the great divisions of Cryptogamia to Cotyledonous plants, and of Monocotyledonous to Dicotyledonous plants, in the torrid, temperate, and frigid zones. Elements of arithmetical botany. Number of individuals; predominance of social plants. The forms of organic beings are mutually dependent on and limit each other. If we know exactly the number of species of one of the great families of Glumaceæ, Leguminosæ, or Compositæ, at any one part of the globe, we may infer approximatively both the number of species in the remaining families, and the entire number of phænogamous plants in the same district. Application of the numerical ratios to the direction of the isothermal lines. Mysterious original distribution of types. Absence of Roses in the southern, and of Calceolarias in the northern hemisphere. Why has our heather (Calluna vulgaris), and why have our oaks never advanced eastward beyond the Ural Mountains into Asia? The vegetation cycle of each species requires for its successful organic development a certain minimum amount of temperature.

$97-113$

Analogy between the numerical laws of the distribution of animal and of vegetable forms. If there are now cultivated in Europe above 35000 species of phænogamous plants, and if our herbariums probably contain, described and undescribed, from 160000 to 212000 species of phænogamous plants, it is probable that the number of collected insects and collected phænogamous plants are nearly 
equal; whilst we know that certain well-explored districts in Europe have more than three times as many insects as phænogamous plants

$113-119$

Considerations on the probable proportion which the number of known phænogamous plants bears to the entire number existing on the surface of the globe

$119-125$

The different forms of plants successirely noticed. Physiognomy of plants treated in a threefoid manner; viz. as to the absolute diTersity of forms, their local predominance in comparison with the entire number of species in different phænogamous Floras, and their geographical climatic distribution . . . 126-200

Greatest extension in height or of the longitudinal axis in arborescent regetation: examples of 235 to 245 English feet in Pinus lambertiana and P. douglasii; of 266 English feet in P. strobus : of 298 and 300 English feet in Sequoia gigantea and Pinus trigona. All these examples are from the north-west part of the New Continent. Arancaria excelsa of Norfolk Island only attains, according to well-assured measurements, 203 to 223 English feet; and the Mountain Palm of the Cordilleras, Cerosylon andicola, 192 English feet

$165-168$

These gigantic regetable forms contrasted with the stem of two inches high of a willow-tree stunted by cold of latitude or of mountain elevation; and still more remarkably with a phænogamous plant, Tristicha hypnoides, which, when fully dereloped in the plains of a tropical country, is only a quarter of an English inch in height .

169

Bursting forth of blossoms from the rough bark of the Crescentia cujete, the Gustaria augusta, and the roots of the Cacao tree. The largest flowers, Rafflesia arnoldi, Aristolochia cordata, Mag- 
nolia, Helianthus annuus, Victoria regina, Euryale amazonica, \&c.

The different forms of plants determine the character of the landscape as dependent on vegetation in different zones. Physiognomic classification or division into groups according to external "facies" or aspect, entirely different in its principles from the classification according to the system of natural families. The study of the physiognomy of plants is based principally on what are called the vegetative organs, or those on which the preservation of the individual depends; systematic botany grounds the arrangement of natural families on a consideration of the reproductive organs, or those on which the preservation of the species depends $205-210$

On the Structure and Mode of Action of Volcanos in the different Parts of the Earth-p. 211 to p. 241.

Influence of journeys in distant countries on the generalisation of ideas, and the progress of physical geology. Influence of the form of the Nediterranean on the earliest ideas respecting volcanic phenomena. Comparative geology of volcanos. Periodical recurrence of certain natural changes or revolutions which have their origin in the interior of the globe. Relative proportion of the height of volcanos to that of their cones of ashes in Pichincha, the Peak of Teneriffe, and Vesuvius. Changes in the height of the summit of volcanos. Measurements of the height of the margins of the crater of Vesuvius from 1773 to 1822: the author's measurements comprise the period from 1805 to $1822,213-228$

Particular description of the eruption in the night of 23-24 October, 1822. Falling in of a cone of cinders 426 English feet in height, which previously stood in the interior of the crater. The eruption of ashes from the 24th to the 28th of October is the most 
remarkable of which we possess any certain knowlenge since the death of the elder Pliny . . . . 228-235

Difference between volcanos with permanent craters; and the phenomena (very rarely observed within historic times) in which trachytic mountains open suddenly, emit lava and ashes, and reclose again perhaps for ever. The latter class of phenomena are particularly instructive to the geologist, because they recall the earliest revolutions of the oscillating, upheaved, and fissured surface of the globe. They led, in classical antiquity, to the riew of the Pyriphlegethon. Volcanos are intermitting earth springs, indicating a communication (permanent or transient) between the interior and the exterior of our planet; they are the result of a reaction of the still fluid interior against the crust of the earth; it is therefore needless to ask what chemical substance burns, or supplies materials for combustion, in rolcanos.

$235-238$

The primitive cause of subterranean heat is, as in all planets, the process of formation itself, i.e. the forming of the aggregating mass from a cos mical gaseous fluid. Power and influence of the radiation of heat from numerous open fissures and unfilled reins in the ancient world. Climate (or atmospheric temperature) at that period very independent of the geographical latitude, or of the position of the planet in respect to the central body, the sun. Organic forms of the present tropical world buried in the icy regions of the north $238-241$

Scientific Elucidations and Additions-p. 243 to p. 248.

Barometric measurements of Vesuvius. Comparison of the height of different points of the crater of Vesurius . . . 243-247

Increase of temperature with depth, $1^{\circ}$ Reaumur for every 113 Parisian feet, or $1^{\circ}$ of Fahrenheit for every 53.5 English feet. Temperature of the Artesian well at Oejnhausen's Bad (New 
Salzwerk, near Minden), the greatest depth yet reached below the level of the sea. The hot springs near Carthage led Patricius, Bishop of Pertusa, in the 3rd century, to form just conjectures respecting the cause of the increase of temperature in the interior of the earth.

The Vital Force, or the Rhodian Genius-p. 249 to p. 257.

Note to "The Vital Force, or the Rhodian Genius"-p. 259 to p. 263.

The Rhodian Genius, the development of a physiological idea in a mythical garb. Difference of views respecting the hypothesis of peculiar vital forces

The difficulty of satisfactorily reducing the vital phenomena of organisation to physical and chemical laws, is principally founded on the complication of the phenomena, and on the multiplicity of simultaneously acting forces, as well as the varying conditions of the activity of those forces. Definition of the expressions "animate" and "inanimate" substances. Criteria derived from the composition of the elements after a substance has been separated into parts by external agency are the simple enunciation of facts

The Plateau of Caxamarca, the ancient residence of the Inca Atahuallpa, and the first view of the Pacific from the crest of the Andesp. 265 to p. 302.

Quina-producing forests in the valleys of Loxa. First use of the fever-bark in Europe; the Countess of Chinchon, wife of the Viceroy 
Alpine regetation of the Paramos. Remains of ancient Perurian artificial roads; they rise in the Paramo del Assuay almost to the height of the summit of Mont Blane

269-27T

Singular mode of communication by a "swimming post" messenger.

Descent to the Amazons river. Tegetation round Chamaya and Tomependa; Red Groves of Bougainvillæa. Ridges of rock traverse the Amazons. Its breadth at the Pongo de Manseriche less than 160 English feet. The falling in of masses of rock at Rentema left the bed of the river below the falls dry for some hours, to the great alarm of those who lived on the banks . 279-281

Passage across the chain of the Andes at the part where it is intersected by the magnetic equator. Ammonites nearly 15 English inches long, Echini, and Isocardias of the cretaceous group, collected between Guambos and Montan, 12790 English feet above the level of the sea. Rich silver mines of Chota. The picturesquely torrering Cerro de Gualgayoc. Large mass of pure native silver in filaments or wire found in the Pampa de Navar. A fine piece of pure gold, wound round with similar threads of silver, found in the Choropampa (field of shells), so called from the numerous fossils. Outbursts of silver and gold ores amongst the cretaceous rocks. The small mountain town of Micuipampa is 11874 English feet above the level of the sea.

$282-286$

From the mountain wilderness of the Paramo de Yanaguanga the traveller descends into the beautiful valley, or rather plateau, of Caxamarca (the elevation of which is nearly equal to that of the city of Quito). Hot baths of the Incas. Ruins of the Palace of Atahuallpa inhabited by his descendants, the family of Astorpilco, who live there in the greatest porerty. Strong belief of the still remaining subterranean "golden gardens" of the Inca beneath the ruins; such certainly existed in the valles of Yrcas, 
beneath the Temple of the Sun at Cuzco, and at several other points. Conversation with the jouthful son of the Curaca Astorpilco. The room is still shewn in which (1553) the unhappy Atahuallpa was imprisoned for nine months, also the wall on which the Inca indicated the height to which he would fill the room with gold if he should regain his liberty. Manner in which the Inca was put to death on the 29th of August, 1533, and remarks on what are erroneously called "the indelible stains of blood" on a stone slab in front of the altar of the chapel of the state prison, 287-295

Hope of a restoration of the empire of the Incas (which was also entertained by Raleigh) has been preserved among the natives. Cause of this expectation

295

Journey from Caxamarca to the sea-coast. Passage over the Cordillera by the Altos de Guangamarca. Often disappointed hope of enjoying the first view of the Pacific Ocean from the crest of the Andes. This hope at last fulfilled at an elevation of 9380 English feet.

$296-302$

Scientific Elucidations and Additions-p. 303 to p. 324.

On the origin of the name borne by the chain of the Andes 303-305

Wpoch of the introduction of the Quina-bark in Europe

305,306

Remains of the roads of the Incas, and of fortifed dwellings; Apozentos de Mulalo, Fortalezar del Cañar, Inti-Guaycu

307,308

On the ancient civilisation of the Chibchas or Muyscas of New Granada

$308-310$

Potatoes and Plantains, when first cultivated

311

Etymology of the word Cundinamarca, which has been corrupted 
from Cundirumarca, and was used in the first years of republican independence to denote the whole country of New Granada, 311, 312

Chronometric connection of the town of Quito with Tomependa on the upper waters of the Amazons, and with Callao de Lima, the position of which was accurately determined by observations of the transit of Mercury on the 9th day of November, 1802, 312,313

Unpleasant etiquette in the Inca's court. Atahuallpa's captivity: his proposed rainsom

Philosophic doubts of Huayna Capac (according to the report of Padre Blas Valera) respecting the Deity of the Sun. Objections of the Inca-government to the extension of knowledge among the poorer and lower classes of the people . . . . 316,317

Raleigh's project for restoring the dynasty of the Incas under English protection, for which a jearly tribute of several hundred thousand pounds was to be paid . . . . $37 \%, 318$

Earliest evidence obtained by Columbus of the existence of the South Sea or Pacific Ocean. The South Sea first beheld by Vasco Nuñez de Balboa (2oth Sept. 1513), and first navigated by Alonso Martin de Don Benito .

On the possibility of the formation of an oceanic canal (with fewer locks than the Caledonian Canal) through the Isthmus of Panama. Points in which the examination has been neglected $319-323$

Determination of the longitude of Lima . . . 323,324 



\section{N D E X.}

ADANSONia digitata (monkey-bread tree), one of the largest and oldest trees of the globe, ii. 89 .

Allco, the native Peruvian dog, i. 108.

Alöe, ii. 27, 180.

Altai, one of the four parallel mountain chains in Central Asia, i. 86.

American races, connection between the inhabitants of Western America and Eastern Asia probable, but its nature and period uncertain, i. 176.

Andes, etymological considerations connected with the word Andes or Antis, ii. 303.

Animal life, its universal diffusion, ii. 1.

Asia, Central, general review of its mountain systems, i. 85 .

Atlas.-The position of the ancient Atlas discussed, i. 144.

Atahuallpa, site of his ancient palace, ii. 289; his prisou, 290; death, 291;

descendants, 292; notice of the comet which appeared in the year on which the Inca was put to death, 313 .

Banks, slightly elevated portions of the Llanos, called "Banks" by the natives, i. 2,33 .

Boa, swims in the South American rivers, and carries its head above water like a dog, i. 190.

Bogota, the seat of an ancient civilisation of the Muyscas or Chibchas, ii. 309. Cactus, ii. 24, 147.

Camel, i. 68; Ritter's memoir on the diffusion of the camel, present existence in a wild state, i. 70 ; fossil in the Sewalik hills, i. 71.

Casas grandes, ruins of an Aztec palace, i. 168. 
Casuarineæ, ii. 25, 152.

Caxamarca, the ancient capital of the Incas, ii. 267, 287.

Cereals. - Original country of the principal Cereals discussed, i. 169.

Chibchas, ii. 309.

Chimboiazo, conjectures as to the origin of the name, ii. $3 \%$.

Chota, silver mines of, ii. 282.

Cinchona, fever-bark, or quina, ii. 267, 305.

Climate of the eastern or flat portions of South America widely different from that of Africa in the same latitudes, causes of the difference, i. 8, 123; the southern hemisphere cooler and moister than the northern, 139.

Climatic effects of extensive forests, i. 126.

Cœlebogyne, produces perfect seeds without any trace of pollen having been discovered, ii. 51.

Condor.-Discussion of the height in the atmosphere to which the condor ascends, ii. 40.

Coniferæ, or needle trees, ii. 25,175 .

Coral reefs, classified by Darwin, ii. 64; his hypothesis of the origin and growth of coral reess, 76 .

Correo que nada, the "swimming post" in the upper" waters of the Amazons river, ii. $27 \%$.

Curare, plant from which the poison is obtained, i. 203.

Cinrent.-Great revolving current of the Atlantic Ocean discussed, i. 159.

Dogs.-European dogs have become wild in South America, and live in troops in the Pampas, i. 107; native Peruvian dogs, 108; Tschudi's remarks on the indigenous races of dogs in America, 111.

Dragon-tree of Orotava, ii. 16, 85.

Esquimaux, instances recorded of their having been carried across the Atlantic to the shores of Europe, i. 162.

Ferns, ii. 28, 188.

Figured rocks, $i$. e. figures engraven on rocks in an extensive district of South America, i. 196.

Fresh-water springs in the ocean near Cuba, i. 233. 
Fournel, recent contributions to the phrsical geography of Northern Africa, i. 115 .

Frémont, Captain, importance of his geographical memoirs on our lnowledge of the geograpty of North America, i. Br, and generally in Note (j), also i. 280.

Geographical distribution of plants, laws of the, ii. 102.

Gobi, the plateau of, i. 71, 79 .

Graminer, ii. 2\%, 183.

Guaranis, a tribe inhabiting the s2a.coast and rivers near the mouth of the Orinoco, i. $1 \% 8$.

Granite, leaden-coloured rocks of, in the Orinoco, i. 188.

Great basin, the elevated plain so called, between the Rock Mountains and the Sierra Nerada of California, i. 41 ; forms an inland closed riter basin, 280 .

- Gymnotus, description of its capture in South America by means of horses. i. 22 .

Heat in plants dereloped during inflorescence, ii. $1 \%$.

Heaths, ii. 23, 115.

Himalara, oue of the four parallel mountain chains of Central Asia, $\dot{1} .2$.

Hiongur., i. 101.

Hooker, Dr. J., recent determination of the eleration of the Kinchinjinga, one of the highest peats of the Himalara, i. 93 : on the production of perfect seeds by the Colebogrne, ii. bl: remarks on the geographical distribution of plants in Antarctic fluras, ii. 122.

Illimani and Sorata, their height abore the sea recently corrected, $\dot{1} .5 \%, 96$, $27 \%$.

Kashmeer, ralley of, i. 80.

Kinchinjinga, one of the highest peats of the Fimalara, its eleration recently determined, i. 92.

Kuen-litu, one of the four parallel mountain chains in Central Asia, i. $72,90$.

Lama, alpaca, and granaco, three originall distinct species of animals, described, i. 166. 
Iaurels as a characteristic form of vegetation, ii. 28, 200.

Lianes, ii. 26, 178.

Liliacer, ii. 28, 193.

Llanos, their description, $i .7$; climate strongly contrasted with that of the African plains, 8; animals which inhabit them, 15 ; their prevalent vegetation, 120.

Lnminosity of the ocean, ii. 53.

Malvacer, ii. 22.

Maranon, or Amazons, upper valley of, ii. 281.

Mauritia palm, i. 16, 181.

Melastomaceæ, ii. 28, 200.

Mimosere, ii. 22, 14ّ̆.

Mississipi, river, its source correctiy ascertained, i. 52.

Moon, mountains of the, their existence, extent, distance from the Equator, and general direction, discussed, i. 149.

Mountain chains in Asia, in the direction of parallels of latitude, i. 85; those coinciding nearly with meridians, i. 94.

Muyscas, ancient civilisation of the, ii. 308.

Myrtaceæ, ii. 28, 196.

North America, general aspect of its natural features, and considerations on its physical geography, i. 39.

Orchideæ, ii.-24, 151.

Orinoco, i. 207; magnitude of the river compared with that of the rivers Plate and Amazons, 211; its sources yet unvisited, 213; general description of its course, 214; "black waters" of the Upper Orinoco, 215 ; cataracts of Atures and Maypures, 21\%; discussion of questions concerning its sources, 239 ; supposed origin in a lake, 243.

Otomacs, a tribe on the Orinoco who use earth as food, i. 190.

Pacific, the author's gratification at first seeing the Pacific from the Alto de Guangamarca, ii. 300.

Palms, ii. 20, 128. 
Panama.-Communication by canal or railroad across the Isthmus of Panama discussed, ii. 319.

Paramo, a mountainous region in South America so called, i. 105; its climate and regetation, i. 105, ii. 269.

Pastoral life almost unknown to the original inhabitants of America, i. 13.

Plants, physiognomy of, essentially distinct from a botanical arrangement, ii. $14,17,208$; is the principal element in the characteristic aspect of different portions of the earth's surface, 16; about sixteen different forms of plants enumerated, which are chiefly concerned in determining the aspect of Nature, 18; Palms, 20; Plantains or Bananas, 21; Malvaceæ and Bombaceæ, 22; Mimosas, 22; Heaths, 23; Cactuses, 24; Orchideæ, 24; Casuarineæ, 25 ; Coniferæ, 25 ; Pothos, 26; Lianes, 26; Aloes, 27; Grasses, 27; Ferns, 28; Liliaceæ, 28; Willows, 28 ; Myrtaceæ, Melastomaceæ, and Laurineæ, 29; number of species contained in herbariums, 97 ; points of view in which the laws of the geographical distribution of plants may be regarded, 102; conjectures as to the whole number of species on the globe, 119; more than half the number of species are probably yet unknown, 121; heat developed during inflorescence, 175 ; general remarks on a physiognomic classification, 205 .

Pothos, ii. 26, 17 o.

Quina (or fever bark), ii. $26 \%$.

Roads, old Peruvian, of the times of the Incas, ii. 270 .

Rotiferæ, their revivification, ii. 4.5 .

Sahara (African desert) composed of several detached basins, i. 114 .

Sand-spouts a phenomenon characteristic of the Peruvian Sand Desert, i. 183. Sargasso, Mar de; its geographical position discussed, i. 63 ; is the most remarkable assemblage of plants of a single species yet known on the globe, i. 64.

Schomburgk. - Travels of the brothers Robert and Richard Schomburgk important in many respects in regard to the physical geography of Guiana and the bordering countries, i. 178, 197, 236, 250. 
Sleep, summer and winter, of animals, i. 18, 185 ; ii. 48.

Snow, limit of perpetual; inequality of this limit on the northern and southern declivities of the Himalaya, i. 98.

Sorata and Illimani; their heights above the sea recently corrected, i. $5 \%$, 96,277 .

Steppes and Deserts, Characteristics of the European, i. 2 ; African, i. 3 ; Asiatic, i. 4; South American, i. 7 ; analogies and contrasts between the steppes and the ocean, i. 2,35 .

Strato, his sluice theory, ii. 78.

Sugar-cane; of Tahiti, of the West Indies, and of Guiana, i. 31.

Tacarigua, Lake of, i. 1 ; its scenery and vegetation, i. $2 \%$.

Temperature.-Contrast between the temperature of the east coast of America and the west coast of Europe in the same latitudes, i.129; general remarks on the temperature of the United States of America, i. 131. Thian-schan, one of the four parallel mountain chains in Central Asia, i. 72, 82.

Thibet, occupying the valley between the great chains of the Kuen-lün and Himalaya, divided into Upper, Middle, and Little Thibet; its mean elevation and description, i. 81.

Tibbos, i. 67.

Timpanogos, Laguna de, i. 44; is the Great Salt Lake of Frémont, 280.

Traditions of Samothrace, ii. 78.

Trees, age of, ii. 86 ; trees of highest growth, ii. 165 .

Trisetum subspicatum, an inhabitant both of the Arctic and Antarctic Circles, ii. 186 .

Tuaricks, i. 67.

Urwald, or primeval forest, a name too lightly used, i. 261 ; true character of a primeval forest, 262 ; description of the nocturnal life of wild animals in the Urwald, 266.

Vegetation, its propagation and extension over newly formed lands, ii. 8 ; the absence of trees erroneously supposed to characterise hot countries, 10 ; extensive arid tracts in countries otherwise of luxuriant vegetation a 
geological problem which has not been sufficiently considered, 12; characteristic aspect of regetation in the tropics, 30; characteristic regetation of the Alps and Andes at great elerations, $3 \check{.}$

Vesuvius, measurements of height at different periods, ii. 225, 243; particulars of the eruption of 1822,228 .

Vital force, the, or Rhodian Genius, ii. 251.

Volcanos of the Thian-schan chain situated in the interior of Asia far distant from the sea, i. 88 ; structure and mode of action of, ii. 213 ; instances of extensive rolcanic comnection, 221 ; importance of repeating exact measurements of the heights of crater's, 224 .

Willows, ii. $28,193$.

THE END. 

- 





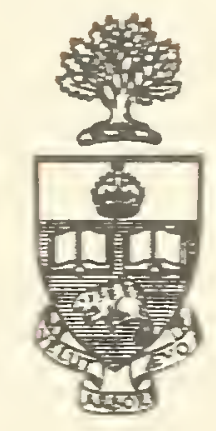

Library

of the

University of Toronto 


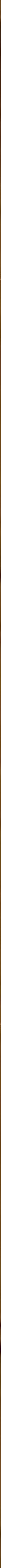

